\title{
CHAPTER I \\ Introduction
}

The elusive state

In 1840 several Dutch envoys were sent to southern Bali to investigate the political situation on the island. Soon it turned out that the Balinese polity was a far cry from the Western model of the state as a sovereign entity with well-defined borders, a bureaucratic administration, and centralized power. But what kind of political system the Balinese actually did have remained a mystery to the envoys. The reports they sent to Batavia reflect their confusion in this respect:

'Since my first arrival here I set myself the task of gaining a picture of the relationships between the rajas [...] the manner of their government, their power etc. The more I learned about it, the more I noticed that I became entangled in a labyrinth of complex family relations and interests. All this became even more complicated by the divergence of information, the content of which varied as one received it from [representatives of various] royal lineage[s] [...] or from someone else. ${ }^{1}$

'Everything here is chimeral, nothing clear-cut; everyday the most blatant contradictions supplant each other.' ${ }^{2}$

Similar problems were faced by nineteenth-century colonial officials elsewhere in Southeast Asia. They, too, had to cope with the complexities of local political systems with which they were not familiar. They were, in other words, not so sure what Southeast Asian 'states' were. At the same time, however, scholars in Europe produced a facile picture of Asian states and empires. Obviously, Asia was 'non-European', but there were (or at least had been) strong states. In this respect the notion of 'oriental despotism' provided a simplistic but persuasive image of Asian empires in the past, characterized by despotic rule over village republics. This model helped to legitimize the colonial conquest of large parts of Asia as well: once the 'despots' were replaced by rational and benevolent colonial rulers, the inhabitants were guaranteed an undisturbed life within the closeness of their traditional villages.

Asian history seemed of little relevance to the new white rulers because 
Asian society was characterized as static. Only in two respects was a degree of historical change thought possible. In the first place there was the cyclical pattern of the rise and fall of dynasties; this, however, was assumed never to produce structural change. Second, whereas Western history became more and more synonymous with the ongoing evolution of Western civilization, the only long-term process that seemed to fit Asian societies was a gradual and unavoidable process of decay. Somewhere in the past there had indeed been 'classical' states in Asia, but they had not been able to reproduce themselves, far less develop into political systems comparable to the achievements of Western statecraft.

The irrelevance of Asian history was further emphasized when colonial control gained ground. Not only the 'classical' Asian states but their history, too, was replaced by colonial rule. Although European historians studied the rise and fall of Asian dynasties, they showed little or no understanding of the kinds of kings and kingship they were looking at. Eventually Asian history was subordinated to the history of European expansion (P. Anderson 1974; Inden 1986; Cohn 1987; Guha 1989).

At the height of the late-colonial state the Dutch scholar J.C. van Leur (1955) confronted prevailing colonial historiography with a new approach to Indonesian history. He rejected the Eurocentric periodization and perspective of colonial historians. Inspired by the works of Max Weber, Van Leur analysed the nature of political systems in Asia in sociological terms and emphasized the connections between economic and social structures, ideologies, and religion. Using 'universal' concepts like patrimonialism and patrimonial bureaucracy, he demonstrated the fragmented nature of Javanese kingdoms. Lacking a stable power monopoly, the royal centre was unable to exert direct control over the whole realm. Instead, the king controlled only a small domain, while the rest of the realm was divided among regional lords who managed to develop a considerable power basis of their own. At most, the king could exert some degree of influence in the territories of these lords, depending on the extent to which they were willing to recognize his authority. 'Government' consisted in this context of a specific mixture of personal relationships between the king and his lords and a degree of bureaucratic administration, while no distinction was made between private and public interests (Weber 1925; Bendix 1962; Wertheim 1964).

It was only after the process of decolonization, when colonial historiography lost its hegemony, that the significance of Van Leur's ideas was widely recognized. His work, and that of another remarkable sociologist, B.J.O. Schrieke (1955-1957), marked a watershed in the study of Indonesian history.

Van Leur's work was, of course, criticized. His insufficient knowledge of 
historical sources and the way he treated Weber's ideal types, as if these concepts represented a historical reality, were major points of criticism (Meilink-Roelofsz 1962; Wertheim 1950). The rather rigid application of Weberian ideal types had particularly far-reaching consequences: ironically, Van Leur's efforts to emphasize the autonomy of Asian history vis-à-vis European influences resulted in an essentially static picture of Indonesian society.

During the 1950s, while Indonesian studies in the Netherlands experienced a period of crisis as a result of decolonization, and elsewhere in the world new centres of research were established, it was W.F. Wertheim at the University of Amsterdam who continued the historical-sociological approach of Indonesian society advocated by Van Leur. Wertheim was more successful in combining the use of sociological concepts with a perceptive understanding of historical change (Wertheim 1959, 1964). ${ }^{3}$ Wertheim's approach was a sound alternative to the simplistic evolutionism prevalent in the 1950s and early 1960s, in which 'modernization' was the key concept and the new nation-state the 'natural' setting for historical research. ${ }^{4}$

Before long, however, historians of Southeast Asia turned away from the nation-state and leaders and institutions operating at the national level, and focused their attention on regional histories. They tried to discover the local foundations and cultural diversity of large political entities like Indonesia. Perhaps even more important was that this approach brought historians closer to what is, after all, the real issue: the people themselves. ${ }^{5}$ Only a local perspective could transform the anonymous masses into actors on the stage of Indonesia's history.

The regional approach not only enabled Southeast Asian historians to fill in many gaps and uncharted areas in the history of the area during the colonial period, they gradually also entered the largely unknown but rich and fascinating world of pre-colonial Southeast Asia. Again, historical research was confronted with the question of the nature of political systems during that period. Instead of the static image of oriental despots on the one

3 In his essay on the Lebak affair - which gave birth to Multatuli's monumental novel Wertheim (1978) illustrates how the conflict between the regent and the assistant resident should be seen in terms of two conflicting systems: one in which patrimonial values dominated and one in which modern bureaucratic norms prevailed.

4 See B. Anderson 1982. In this period culture either remained the exclusive domain of anthropologists or was seen as the equivalent of 'tradition' soon to be overcome by modernization. The historical-sociological approach, characterized by an emphasis on longterm processes in large areas, had problems dealing with aspects of culture as well, as a result of which it had no fruitful interaction with anthropology.

5 In this connection Smail (1961) sounded the call. One of Indonesia's most outstanding historians, Sartono Kartodirdjo, made important contributions to this approach. The regional approach was facilitated by the fact that the organization of colonial archives was to a large extent based on regional-administrative categories. 
hand and village republics on the other, a much more dynamic picture of Southeast Asian politics emerged, emphasizing the interaction between leaders and followers. It turned out that the myriad of vertical personal linkages formed one of the keys to a better understanding of pre-colonial political systems (Reid 1983:6-8, 1988:120-1; Tambiah 1985a:268). ${ }^{6}$ In line with this is the approach by Lucien Hanks (1975), based on his research in Thailand. Hanks sketches a succession of configurations of central leaders and their entourages. The entourage is not a homogeneous group, but consists of individuals, each of whom maintains a reciprocal bond with the leader. Around this entourage there is a wider circle of persons who, via the members of the entourage, may be counted among the leader's followers, albeit less directly. ${ }^{7}$

At about the same time, the image of the village as an autonomous entity was 'shattered' as well (on Java see Onghokham 1975; Breman 1980; Kumar 1980). Instead of an agrarian society without history, a much more diversified and turbulent picture emerged. The village as cornerstone of rural order tended to dissolve and was replaced by phenomena like mobility, migration, landless labourers, slavery, bandits, and perennial warfare among the nobility. Taking into account the predominant role of conflict and violence in everyday life and noting the structural limitations of precolonial polities, Michael Adas has proposed the term 'contest state' to characterize the political arenas of Southeast Asia. ${ }^{8}$

Once the dynamics of Southeast Asia's past had been discovered, and the emphasis had shifted from stable structures to the fluidity of political

6 In his study on South Sulawesi H.Th. Chabot defined the system of lords and followers as 'the whole of the relationships between a higher-placed person and his subordinates [...]. Basic to this system is the awareness that the higher has authority over the lower, an authority which is accepted by the latter and conjoined with the understanding that high and low need each other to enhance their prestige' (1950:102).

7 Hanks's conceptualization should be seen against the background of the so-called 'loose structure' debate concerning the Thai social order, which will not be elaborated on here. I believe that the notions of entourage and circle can be used in the Indonesian context as well (see Errington 1983).

8 'Central in this form of government is rule by a king or emperor who claims a monopoly of power and authority in a given society, but whose effective control is in reality severely restricted by rival power centres among the elite, by weaknesses in administrative organization and institutional commitment on the part of state officials, by poor communications, and by low population-to-land ratios that place a premium on manpower retention and regulation. These politics gave rise to policies in which there was a constant struggle between the ruler and the nobility, between factions of the elite at various levels, and between supra-village elite groups and village notables and peasants for the control of labour and the agricultural production which formed the basis of these predominantly agrarian states. Although the fortunes of the contending parties fluctuated greatly over time, their continuing struggle over revenue control and the inability of any of the parties to dominate the others decisively on a sustained basis suggest the concept of the contest state as a useful way to characterize this form of political organization.' (Adas 1981:218.) 
relationships, it became imperative to re-evaluate the nature of pre-colonial political systems. Although patrimonialism remained a helpful startingpoint, it had by now become very doubtful whether the term patrimonial bureaucracy really helped in understanding the vague and fluid relationships described in recent publications (Tambiah 1985a). One might even wonder whether the term 'state' is still appropriate. After a century of Western academic discourse the image of the state in (Southeast) Asia has changed from despotism, via (patrimonial) fragmentation, into an elusive phenomenon:

'The closer one looks at any given state in traditional Southeast Asia, the more it seems to dissolve before one's eyes. Upon examination, it appears not to be "governed" nor even "administrated" in any systematic way at all, and one is forced to ask just what it is that holds such a "state" together.' (Gesick 1983:1.)

This confusion on the part of Western historians and social scientists is at first sight rather similar to the observations of the Dutch envoys sent to Bali in 1840, quoted at the beginning of this chapter. In order to find a way out of this problem the analytical approach has shifted towards the realm of symbolic action. Instead of looking at Southeast Asian polities in terms of failing governments and imperfect administration, scholars are exploring indigenous notions of hierarchy and circular conceptions of space, which are heavily influenced by Indian concepts (Gesick 1983).

The turn towards symbols involved a renewed interest in questions concerning the nature of kingship and processes of Indianization of Southeast Asia. These questions are especially relevant for Bali, which is widely known as the last island in the Indonesian archipelago where Hinduism survived. Bali became, moreover, inextricably linked with the concept of the 'theatre state' as launched by Clifford Geertz (1980). In his book Geertz proposes a new approach to pre-colonial 'states' in Southeast Asia by emphasizing the central importance of symbolism as expressed in royal rituals. Geertz summarizes his thesis in a powerful metaphor:

'The expressive nature of the Balinese state was apparent through the whole of its known history, for it always pointed not toward tyranny, whose systematic concentration of power it was incompetent to effect, and not even very methodically toward government, which was pursued indifferently and hesitantly, but rather toward spectacle, toward ceremony, toward the public dramatization of the ruling obsessions of Balinese culture: social inequality and status pride. It was a theatre state in which the kings were the impresarios, the priests the directors and the peasants the supporting cast, stage crew and audience. The stupendous cremations, tooth filings, temple dedications, pilgrimages and blood sacrifices, mobilizing hundreds and even thousands of people and great quantities of wealth, were not means to political ends: they were the ends themselves, they were what the state was for. Court ceremonial was the driving force of court politics; and mass ritual 
was not a device to shore up the state, but rather the state, even in its final gasp, was a device for the enactment of mass ritual. Power served pomp, not pomp power.' (Geertz 1980:13.) ${ }^{9}$

Geertz rightly argues that Western thinking about political power has moved in too narrow a framework since Machiavelli, and that royal ritual is far more than mere decoration gilding the 'real' machinations of power (1980:121-36). ${ }^{10}$ Nevertheless, his historical analysis does raise a number of questions.

At the core of the Balinese negara ${ }^{11}$ Geertz places the king and his court in the exemplary centre: 'the court and the capital is at once a microcosm of the supernatural order [...] and the material embodiment of political power [...]. It is the state' (1980:13). Through this construction of an exemplary centre and in observance of royal ritual, the 'state' was given shape, modelled primarily on a supposedly superhuman, cosmic order. Implicitly, Geertz refers here to the theory of Robert Heine-Geldern (1942), which states that the cosmic order was reflected in the earthly order in which the king mediates an equilibrium between macrocosm and microcosm. ${ }^{12}$ On Bali the enduring divine order was reflected, for instance, in the architecture of the royal centre and in ritual. ${ }^{13}$ Geertz's interpretation, however, suggests too close a parallel between the divine order as imagined and the political practice of the people. The latter falls short of the ideal model and the former is open to more than one interpretation. ${ }^{14}$ Another problem is that Geertz makes it look as if the royal elite and the people lived in worlds that were almost wholly separate, even to the extent that 'culture came from the top down, while power welled up from the bottom' (Geertz 1980:85). This would mean that the nobility was preoccupied with the ritual expression of

9 This concept of the theatre state may be seen as a blueprint of 'thick description' (Geertz $1973 \mathrm{~b})$ and an elaboration of his essay 'Religion as a cultural system' (1973a). For a criticism of both, see Lieberson (1984) and Asad (1973).

10 Susan Hoeber-Rudolph supports him in this respect. Referring to symbols and rituals she says: 'We underestimate the power and reality of these forces. It is a lacuna in our historical and theoretical imagination [...]. We must treat the symbolic as a phenomenon' (1987:742). See also Cohen $(1969,1974,1979)$, who argued this from the point of view of political anthropology.

11 Negara (Sanskrit) means city, court, and realm, or, translated more freely, royal centre and its surroundings (Gonda 1973:692; Zoetmulder 1982). On Bali other terms are used as well: jagat ('middle'-high Balinese) and bumi (high Balinese), both meaning 'world' (I Wayan Warna 1978). I will use the term negara, which, since Geertz (1980), has become the most current.

12 Relative to Java this concept was elaborated by Soemersaid Moertono (1968).

13 See Swellengrebel 1960b:36-53; Grader 1970; Stuart-Fox 1982:91.

14 Schulte Nordholt 1981b:475-6; Hobart 1985. Geertz implicitly agrees with the ontological explanation of this model given by Heine-Geldern. Presumably, a 'cosmic conscience' once gave rise to the macrocosm-microcosm relation. The 'ratio' of the model remains obscure (Tambiah 1985a:256-7). 
status differences and the imaginative construction of the divine order, while the people gave shape to daily life in locally organized frameworks characterized by a 'pluralist collectivism' (Geertz 1980:48). Geertz attaches even greater significance to this distinction between nobility and commoners by linking it with the distinctions between theatrical expression and instrumental government, between culture and power, and between religion and politics. Stanley J. Tambiah is right in saying that this sort of approach leaves us with an almost completely disconnected society, where elite and populace can hardly engage in vital interaction (Tambiah 1985b:319; see also Schulte Nordholt 1981b:474). Moreover, the 'power' that upheld the splendour of the theatre state remains an enigma: from where does it emanate, how is it organized, who controls it? ${ }^{15}$ Just as Geertz's distinction between elite and people seems artificial, so also the analytical distinctions between power and pomp, between politics and religion, between 'the cultural forms of the divine king cult and the social paradigms of royal authority' (Geertz 1980:125) seem untenable. ${ }^{16}$

Finally, the concept of the theatre state leaves little room for the conflicts and the violence inherent in Balinese society. ${ }^{17}$ Geertz tends to picture a Balinese king as 'an icon, a figuration of the sacred, in itself sacred' (1980: 108). In so doing he underestimates the part played by central leaders, which was necessarily a very active one. As I will show, the more successful of the Balinese rulers were anything but anonymous objects of ritual; they were clearly leaders who survived by personally commanding the respect of those around them.

\section{Beyond theatre}

At first sight one might wonder whether the concepts of the contest state and the theatre state - the one stressing conflict and violence, the other hierarchy and symbolic order - both apply to the same world of Southeast Asia. But I do not intend to deny the importance of symbols and symbolic action in favour of emphasizing violence and conflict. Instead of choosing between these, I will try to combine the two approaches into a single analytical framework. I believe that conflict and hierarchy, and violence and

15 Walters (1980) noted that the importance of power relationships is generally underestimated by Geertz and those who apply his interpretive approach.

16 In this connection A.M. Hocart's caveat should be taken to heart: 'How can we make any progress in the understanding of cultures, ancient or modern, if we persist in dividing what people join and in joining what they keep apart?' (Hocart 1969:28).

17 Tambiah 1985b:324; Hobart 1985. In a number of places Geertz does prove to be aware of the discrepancy between the ideal order as imagined and the harsh political reality (see for instance 1980:18). But these are unconnected remarks, hardly brought into the purview of his major thesis. 
symbolic order, should not be separated: they can only be understood in their mutual interaction. Such a combined approach aims to conceptualize the pre-colonial polities of South and Southeast Asia as a dynamic totality (Tambiah 1985a, 1987:198-201).

A brief look at recent studies on the way Indian notions of hierarchy and kingship took root in Southeast Asia will help us to gain a better understanding of the dynamic relationship between conflicts and symbolic order, and hence overcome the artificial analytical distinction between power and ritual, or politics and religion. ${ }^{18}$

In a series of lectures Oliver W. Wolters (1982:52) introduced the term 'localization' to indicate the transformation of Indian notions as they took root in foreign soil. ${ }^{19}$ 'Localization' was an active process whereby Indian concepts were adopted and given a new meaning. In the case of Bali, too, notions of Indian origin were interpreted and used by the Balinese to shape their own hierarchical order. This localization, however, did not necessarily make for immutable 'final results' but was open to historical change. ${ }^{20}$

18 Early statements about these processes by N.J. Krom (1931) and G. Coedès (1968) postulated the idea of the 'Hindu colonization' by Indian warriors or traders, who transplanted a superior Indian culture to tribal Southeast Asia by establishing Hindu kingdoms. According to this view, after a period in which these kingdoms flourished, a process of disintegration and decay started and brought the classical Hindu era to an end. This perception was to a large extent influenced by anti-Islamic sentiments among Western scholars. They saw in Hinduism a grand civilization which was destroyed by the rise of Islam, which in its turn represented decay and fanaticism (Schulte Nordholt 1986b; see also Said 1979). Bali was never converted to Islam and nineteenth-century studies describe Balinese culture as predominantly Hindu (Raffles 1817; Crawfurd 1820; Friederich 1849-50). Later, a 'layered cake' model was developed in order to differentiate several levels of Balinese culture, the one superimposed on the other. 'Below' was the 'genuine', nearly 'undisturbed' Balinese culture, which was considered to be Indonesian in character, over which was spread a 'layer' of Hinduism. According to this model both layers persisted in retaining their separate identities (Korn 1932:674-6). Both the thesis of 'Hindu colonization' and the 'layered cake' model are no longer accepted. It was, again, Van Leur (1955), later followed by F.D.K. Bosch (1952, 1960), who advanced the theory that Southeast Asian lords and rulers had invited Indian priests to their courts in order to enhance their status and prestige. From then on a more sophisticated debate started about the nature of what was called the 'Indianization' of Southeast Asia (Mabbett 1977a, 1977b). Recently Hermann Kulke (1990) has proposed the 'convergence hypothesis'. Instead of the one-way traffic of Indian influences to Southeast Asia, he emphasizes the mutual interaction between southern India and Southeast Asia, and argues that in both areas comparable historical processes occurred.

19 See also Bentley 1986; Kulke 1986; Miller 1984. Bosch (1952) discusses in this respect the concept of 'local genius'.

20 Geertz, writing about nineteenth-century Bali, does suggest a fixed result of Indianization. He speaks of an 'essentially constant cultural form, the divine king cult', characteristic of the pre-colonial political order (1980:125). Jean-François Guermonprez (1985) has criticized this view and advanced the hypothesis that the nature of kingship on Bali did undergo change. An older form of kingship - going back to the eleventh and twelfth centuries - may well have been of a deified kind, the king being associated with Siwa. In the seventeenth and eighteenth centuries, however, a transition was made to a more 'secular' type of rule in which the king became primarily a warrior. 
One of the most important Indian notions adopted by Southeast Asian leaders was that of the mandala, translated by Wolters as 'circles of kings' (1982:16). ${ }^{21}$ In a mandala the 'radiation' from the centre determined the diameter of the circle and hence the extent to which a lord could wield power over the environs. This mandala pattern was typical of the precolonial world of Southeast Asia, and Bali was no exception. The creation of such royal circles emanated from strong leaders. These 'men of prowess', as Wolters calls them, subjugated neighbouring competitors and temporarily established a dominant seat of power surrounded by a number of satellites (Wolters 1982:25; Tambiah 1985a:252). Since their leadership was very insecure, these men of prowess sought to confer stability on their power by the expedient of claiming for themselves Indian concepts of royalty. By adopting these concepts they sought to rise above the competitors around them and to create continuity of rule through the establishment of a dynasty.

For the Balinese negara Geertz has elaborated on an important aspect of the relationship between centre and satellites. Not only was the royal seat the strongest one, it also served as an example for the satellites which - as lesser centres in their own right - in turn oriented everything within their orbits to the great exemplary centre, the seat of the king (1980:11-9).

Although these relationships between centre and satellites were rather straightforward in abstraction, they were not at all so in practice. In reality, these relationships were extremely complex and subject to unabated tension. It is important to note that the mandala pattern did not imply the existence of one exclusive royal centre, but a multiplicity of centres each claiming universal authority (Wolters 1982:66-7). ${ }^{22}$ Besides the coexistence of various royal centres, each of the centres had to cope with a fundamental weakness deeply ingrained in the political system, which rendered the contours of the orbits of power impermanent. ${ }^{23}$ Moreover, within the royal centre itself, conflicts were always imminent and ready to threaten the larger hierarchy.

A ruler had to be more than an anonymous icon, the highest expression of the exemplary centre. In line with Michael Adas, Wolters, too, underscores the personal character of hierarchical relationships:

21 See also Tambiah 1985a. Hagesteijn (1989) offers a review of recent studies on this topic with regard to mainland Southeast Asia.

22 See for similar developments in East Java, Van Naerssen 1975 and Kulke 1982. With regard to the multiplicity of royal centres, Kulke (1990) remarks that one should keep in mind that the Indian notions of kingship which took root in Southeast Asia came from southern India, where a comparable fragmented political structure existed.

23 'Mandalas represented a particular and often unstable political situation in a vaguely defined geographical area without fixed boundaries, where smaller forces tended to look in all directions for security. Mandalas would expand and contract in concertina-like fashion. Each one contained several tributary rulers, some of whom would repudiate their vassal status when opportunity arose and try to build up their own networks of vassals.' (Wolters 1982:17.) 
'There was the minimum of bureaucratic procedures and the maximum amount of discussion, for consultation in societies knit together by webs of personal ties was bound to be a prominent feature of public life. Everything depended on man-to-man relations. Needless to say, the ruler had to be known to enjoy prestige in his home base if he wanted to exert influence in the peripheries.' (Wolters 1982:20.)

The weakness of this order lay not only in the incessant danger to the centre in the form of disaffected or rebelling satellites, internal fights, and the loss of allies, but also in the structural limitations inherent in a system dependent on personal relationships. Logistic barriers and especially the many personal 'go-betweens' through whom the centre had to mobilize its resources siphoned off manpower and agricultural surplus to such a degree that only a small part of it was left for the centre. But the centre seemed to have no choice, since fragmentation of manpower and surplus was the only way to reward the many links in the hierarchical chain and thus be assured of loyalty. Paradoxically, it was only through fragmentation that a ruler could keep his realm together.

Seen from this perspective it becomes easier to contextualize questions about hierarchy and symbolic action within a fragmented system characterized by conflict and violence: the contest state formed the arena in which Indian ideas about kingship took root.

In an illuminating attempt to unite the various dimensions of precolonial political systems in Southeast Asia into a conceptual 'totality', S.J. Tambiah $(1976,1985 a)$ has demonstrated that one and the same basic pattern, that of the mandala, recurs on several levels: it is found on the levels of cosmology, geography, politics, administration, and economy. The advantage of this approach is that a political system is analysed as a whole, rather than one-sidedly in terms of either the cosmological and symbolic or the dimension of personal networks. The significance of the mandala pattern lies in the intertwining of these levels.

While Wolters argues that the adoption of Indian notions primarily served powerful men to further enhance their status, Tambiah emphasizes that symbolic order and social action are not separate spheres but rather inform each other within a meaningful whole. These approaches are extremely valuable and I will use them as guidelines throughout this book. But there is still another aspect that needs to be elaborated.

Tambiah's approach resembles the concept of the segmentary state applied in studies of African political systems, which is now gaining ground in Asian studies (Hoeber-Rudolph 1987; Stein 1977, 1980). Aiden Southall has defined the segmentary state as one 'in which the spheres of suzerainty and political sovereignty do not coincide. The former extends widely towards a flexible, changing periphery. The latter is confined to the central, core domain' (1988:52; see also Southall 1956). In the course of this study it 
will become clear that the Balinese negara meets this description. However, I do not intend to use this concept as a handsome anthropological translation of Weber's patrimonial state just in order to make a distinction between the limited power of the royal centre over its core domain and its authority over a wider area. What really matters here is to learn what royal power was all about, why and on what terms ordinary Balinese recognized royal authority, and why they needed their kings. Related to this is the question of the importance of large public rituals, and why so many Balinese participated in these events.

Following Geertz, I will also emphasize the importance of large public rituals, but the context in which I see these events is very different. They did not merely help express status differences of the ruling nobility; much more was at stake: life itself. ${ }^{24}$

What has generally been neglected, or at least underestimated, in studies of pre-colonial political systems is the imminence of death and, hence, the necessity to seek protection. This is not a new theme. The historian Marc Bloch wrote: 'To seek a protector, or to find satisfaction in being one - these are things common to all ages' (1964, I:147). Protection was, however, not confined to the relationship between a king and his subjects or strong lords and their followers in, to put it in Balinese terms, the visible (sekala) world. Protection had wider implications, to which anthropologist Jan van Baal refers: 'No one in search of meaning can ignore suffering and death as basic themes in human life' (1981:316). On Bali, too, life was overshadowed by the imminence of death, and this cannot be ignored in a study of Balinese politics. ${ }^{25}$ Life and death had to do with the invisible world of Bali (niskala) as well, from which threats like earthquakes, eruptions, bad harvests, and recurring epidemics emanated. An important task of royal centres was to provide protection from these threats in order to guarantee the continuation of life. It is in the relationship between the visible and the invisible world of Bali that the negara should be understood. ${ }^{26}$

24 A.M. Hocart has argued that underlying questions regarding states and governments is a far more fundamental issue: 'It is not government that man wants [...]. It is life he wants, and in the effort to live he does one thing after another, till he eventually finds himself governed' (1970:299).

25 For an important study on death and disease in Southeast Asia see Owen 1987.

26 A similar approach is advanced by Wiener 1990 . Only recently I received a copy of the impressive thesis of the late Barbara Lovric (1987b). Reading her work makes me realize how preliminary my study on the Balinese negara actually is. In order to obtain a deeper understanding of Balinese statecraft and forces motivating Balinese politics we need to take representations of life, disease, and death into account. 


\section{Themes}

Central themes in this study are the complexity and the historical dynamics of the negara. I have concentrated on the history of one particular negara in central southern Bali, Mengwi, from the end of the seventeenth century up to the middle of the twentieth. I try to analyse negara Mengwi by composing a collective biography of the ruling dynasty from its beginning through the last years of Dutch colonial rule. ${ }^{27}$ In the course of this story I will address a number of recurring and interrelated themes.

The first theme concerns the relationships between the royal centre and its satellites. The rise of the dynasty and the creation of a royal centre at the beginning of the eighteenth century and the way this centre succeeded in establishing precedence over a number of satellites will be described, with all the concomitant tensions, violent conflicts, and internal shifts of power. Then come the periods of crisis, decline, restoration, and finally the dramatic fall of the royal centre at the end of the nineteenth century.

If the dynasty formed the backbone of the negara, the vital connections with its inhabitants were established through intricate networks involving the entourage of each of the dynastic leaders who, in their turn, had wider circles of followers. The dynamics of and changes in these relationships form the second theme.

Closely related to the lord-follower relationships and the mobilization of manpower is the third theme, which concerns irrigation and the mobilization and distribution of agricultural surplus. I will pay special attention to royal involvement in large-scale irrigation projects, a subject largely overlooked in most studies.

A fourth theme is related to a major source of income for the dynasty: external trade. During the seventeenth and eighteenth centuries Bali was one of the most important sources of slaves in the Archipelago. The slave trade not only provided those in power with wealth, but affected the relationships between lords and commoners as well, since the lord-protectors were also the main exporters of slaves. At the beginning of the nineteenth century slaving declined and was replaced by the export of agricultural products, causing new changes in the negara.

External trade was closely connected with warfare - either to 'produce' slaves or to control major irrigation systems. This leads to a fifth theme, which has to do with the changing relationships between the various negara and the position of each of them within the hierarchical order on Bali as a whole. In this respect, too, incisive changes occurred over time.

27 The dynasty was formed by a noble patrilineal clan consisting of a core lineage, branching out to lesser lineages spread over the area. 
Finally, there was the ritual order overarching the negara, expressed in the structure of the regional temple system, explained by royal priests, and enacted through large-scale public rituals. ${ }^{28} \mathrm{I}$ will argue that through these temples and rituals the dynasty sustained the 'flow of life' of the negara. This complex set of themes, then, shaped the negara.

To speak of pre-colonial Bali in terms of the 'classical' political system may lead to the mistaken conclusion that the island did not witness profound historical change. I will demonstrate that between 1650 and 1900 important changes took place as a result of which nineteenth-century Bali differed considerably from eighteenth-century Bali.

The colonial conquest of southern Bali (1906-1908) brought a series of fundamental changes that affected all the relationships mentioned above. By far the most important change was that Bali was incorporated in the larger framework of the colonial state. Despite the efforts of the colonial administration to isolate Bali from the outside world - to preserve its supposedly traditional character - the very presence of Dutch colonial rule (1906-1942) transformed the island to such an extent that it hardly resembled the Bali of former days. What the innocent visitor to Bali today readily accepts as 'traditional Balinese' is very likely a product of Dutch colonial intervention.

Dutch colonial rule not only affected power relationships at the regional level, but also penetrated into local life where it affected village organization, irrigation, and patterns of landownership. More than ever before, Bali was incorporated into the world economy, and the negative consequences of this reduced thousands of Balinese households to poverty during the Great Depression of the 1930s.

Of major importance in the transition from pre-colonial to colonial times was the fact that a bond was forged between some of the old dynasties and the new colonial government. The interaction between part of the Mengwi nobility and the colonial rulers called into being completely new relationships between members of the old dynasty and the rest of the population. Ruth McVey $(1978: 12,18)$ has remarked that in Southeast Asia in general the presence of the colonial state conferred on those regional lords who participated in government more power than they had ever had before. Consequently, the distance between these lords and the masses widened greatly. What the effects of colonial rule in Mengwi were and to what extent the relationships between the old dynasty and the masses changed will be examined in the last two chapters.

28 Grader (1960b) is one of the few to point out the importance of these regional temples and their mutual relationships. Remarkably, Geertz (1980) pays virtually no attention to this. 


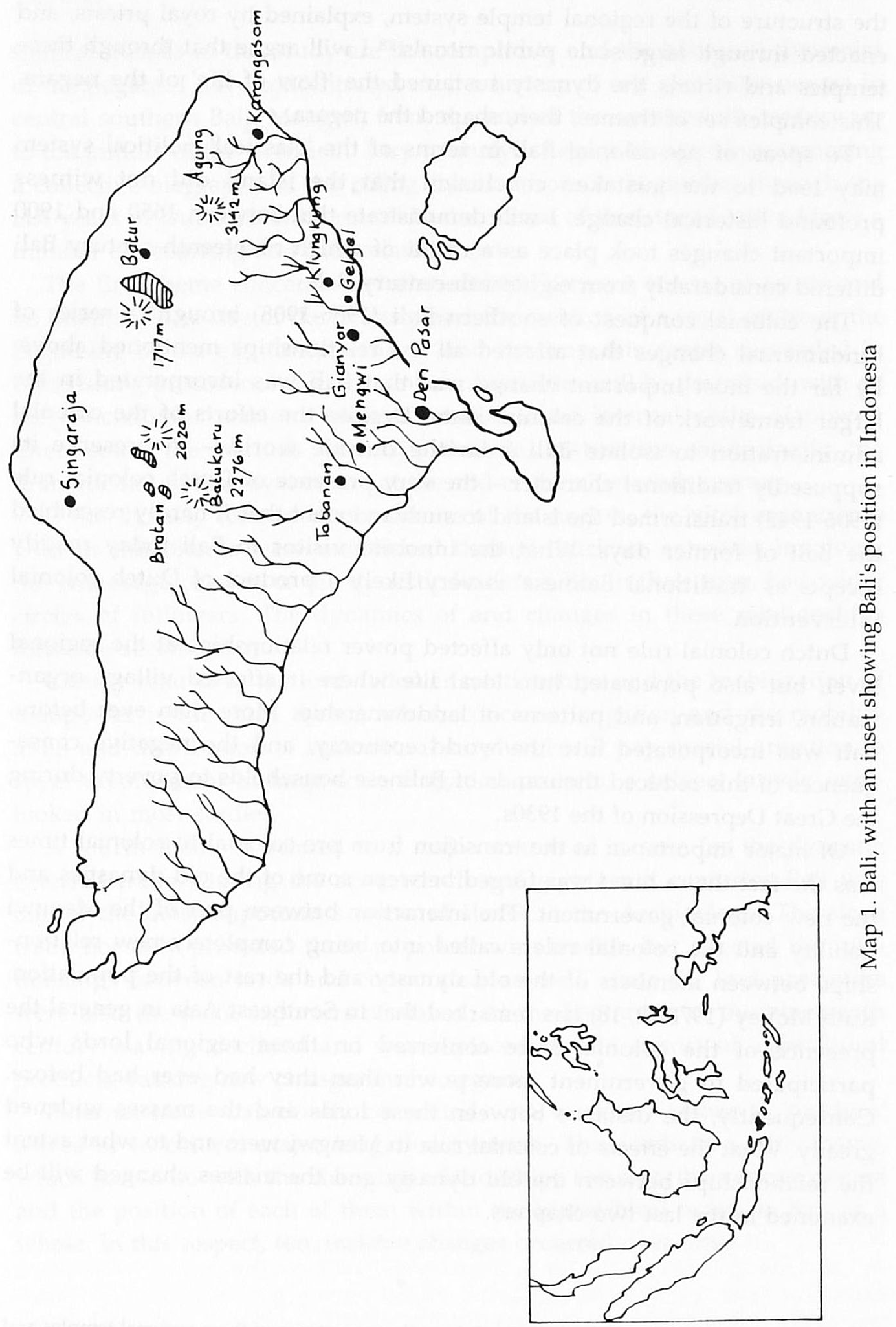


The stage

The setting is southern Bali. To the north are the mountains, to the south the sea. A mountain range begins its climb on the west side; as it traverses the island the peaks grow taller until the range reaches its summit: the Gunung Agung volcano in the east, roof of Bali. Here, and above the other mountains, dwell the gods. The demons who spread misfortune and disease over the land live in the sea. ${ }^{29}$ The wooded mountainsides are steep, descending to about 750 metres above sea level, where they spill onto a wide, alluvial plain sloping gently to the Indian Ocean. About one quarter of the entire island, with over 5,800 square kilometres and just over a million inhabitants in 1930, 30 is covered by sloping, fertile plains. In 1930 over half of the population lived on the southern plain, and to this day it remains the most densely populated area. Surrounded by rice fields and shaded by trees, the people lived in rather compact settlements varying from 1,000 to 6,000 souls, while villages in the sparsely populated mountain areas would have 50 to 500 residents.

The Balinese have a strong sense of direction, as evidenced by words like kaja and kelod. Kaja means 'to the mountains' and refers to anything that is higher; kelod - 'to the sea' - is used to indicate low or lesser places. The mountains and the gods are kaja and the sea with its demons kelod. The Gunung Agung dominates the island, so that in southern Bali the northeast (kaja-kangin) direction is the most significant. This orientation is repeated in nearly every southern Balinese yard. The house temple is in the northeast corner, the kitchen and the pigpen on the south side. In between are the living quarters, consisting of several separate structures placed in a specific order (Tan 1967; Howe 1983).

An important social distinction used in connection with the kaja-kelod axis is that between jero (inside) and jaba (outside). People of noble birth, usually wielding a degree of power, are 'insiders' in relation to commoners, who are 'outside' the centres of power. Seniority and especially descent determine the place in which a person sleeps or sits. 'Insiders' whose position is higher are relatively kaja-kangin, while 'outsiders' are kelod. This illustrates that the importance of the Balinese relative to each other is inscribed in the landscape.

The plain of southern Bali is not continuous; it is traversed by small rivers that cut deep gorges running from north to south and divide the terrain into long, broad bands. Similarly, the kaja-kelod hierarchy is characterized by geographical segmentation. Segmentation characterized the pre-

29 Swellengrebel 1960b:37-40. The distinction between mountains and sea requires refinement: the sea contains benevolent and purifying forces as well (Lovric 1986).

30 Korn 1932:310; by 1983 this number had more than doubled. 


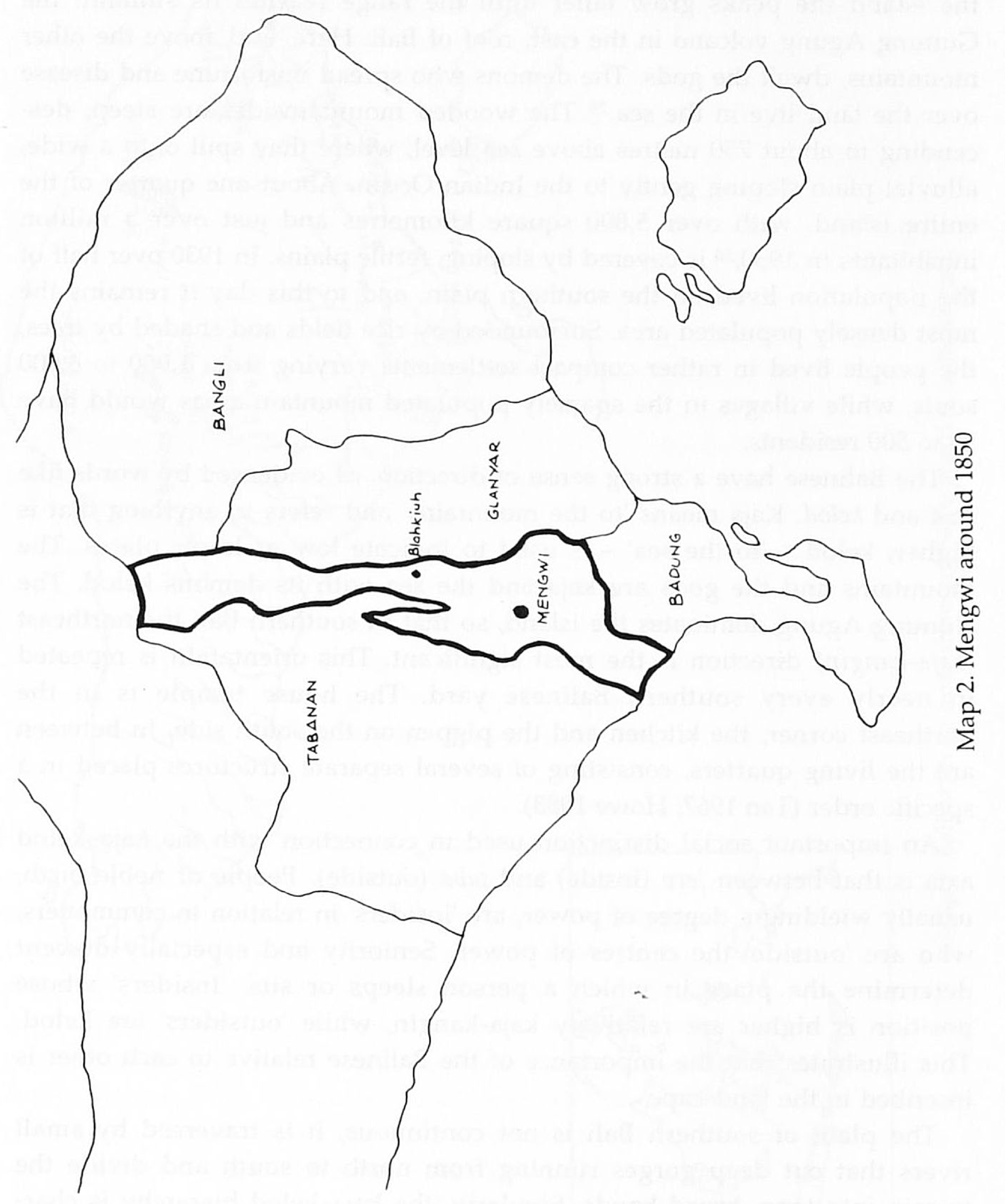


colonial political system as well. Around the middle of the seventeenth century various noble families engaged each other in bitter fights in the relatively small arena of the southern plain. Only a few rose to prominence and succeeded in establishing a dynasty. It is on this stage that the history of the Mengwi dynasty begins. 



\section{CHAPTER II \\ The rise of Mengwi, 1700-1770}

The genealogical narrative of the Mengwi dynasty begins with the rise of the mighty King I Gusti Agung Ngurah Made Agung. ${ }^{1}$ His rule extended far beyond Mengwi to Buleleng in the north, Jembrana in western Bali and even to Blambangan in East Java. Probably around 1733, the king returned from a decisive pitched battle in northern Bali at which he had defeated his most important enemies. ${ }^{2}$ Mengwi's king was powerful and feared by many, but he had a problem: he did not know who his ancestors were and hence did not really know his own identity. He therefore sent for his brahman priest and had him narrate the story of his ancestry.

The first part of the narrative, a question-and-answer dialogue between king and priest, explains that the Mengwi dynasty derives directly from ancient royalty of East Java, which had merged with the great Javanese realm of Majapahit (1292-ca. 1520). During the period that Majapahit flourished, Bali was conquered and a new dynasty, hailing from East Java, established itself in Gelgel in southern Bali. Serving the new king (Dalem) were nobles of lesser status, also from Java. Part of Bali was entrusted to their rule. The most important of these nobles was the patih, the Dalem's right hand and chancellor of the realm. Successive patih all belonged to the Arya Kepakisan clan, and in the hierarchy they held second place, only the Dalem of Gelgel being superior to them. The later lords of Mengwi trace their lineage to this Arya Kepakisan clan. ${ }^{3}$

The narrative makes repeated mention of violent conflict within the Gelgel hierarchy. The most serious crisis arose when one of the patih, Gusti Agung, rebelled against the king and usurped power himself. Some years later, however, he in turn was overcome by nobles who had remained loyal to the Gelgel dynasty. They saw to it that this dynasty was reinstated in near-

1 Babad Mengwi-Blahkiuh a:1. There are different versions of Babad Mengwi. Since 1928 the one mentioned here has been generally accepted as the 'correct', or 'true' version; see IX.1. Gusti Agung Ngurah means 'great ruling lord'; Made refers to the relative order of birth, the second child. The title was the king's ceremonial name, and was also used by later Mengwi kings.

2 I will clarify the identity of the king in section 1.

3 Babad Mengwi-Blahkiuh a:1-14. Arya is an old Javanese noble title. 





by Klungkung, which later became the seat of the most prestigious lord on Bali, the Dewa Agung.

The vanquished patih managed to escape, with his family, to western Bali. The narrative recounts the story of the wanderings, the marriages, and the battles of those years, and especially the strife within the clan from which eventually one dominant lineage emerged. This lineage produced the man who established negara Mengwi. And it is he who, once he had come and conquered, went in search of his ancestry.

Next, the text explains how Mengwi rose from anonymity and became the most important power on Bali during the rule of this first king. ${ }^{4}$ The king achieved this personally, that is to say, by defeating his opponents. Physical prowess, along with the possession of krisses (daggers with a wavy blade), passed down as family heirlooms, constituted the major source of royal power, which soon spread in concentric circles over an ever-expanding domain. Local lords placed themselves under the protection of the king, and a ranking of superordination and subordination gave form to the rising hierarchy. Once the king had established his reputation in successive battles and the lines of his dynasty had fanned out over the domain, he created a new centre in desa Mengwi. This centre consisted of a large puri or 'palace' and the central temple, pura Taman Ayun, where the king's subjects came to worship and pay their taxes. The negara was now established.

The narrative tells us of the conquest of areas outside Mengwi, especially Buleleng to the north. Reconciliation with the dynasty of Gelgel and Klungkung was effected at last. The king of Mengwi recognized the greater status of the Dewa Agung of Klungkung, and the Dewa Agung received the king of Mengwi as his patih 'again', which now meant that the king was below him in status, but more powerful.

Royal authority, however, was not lasting, as the narrative does not fail to point out. Expansion was followed by a period of instability, disloyalty, and dynastic intrigues, rendering central authority ineffective. But in these chaotic years a new, strong leader emerged: Cokorda Munggu, who decisively restored royal authority. During his rule negara Mengwi experienced many years of peace and prosperity. The dynasty's power was at its zenith, and at this point the narrative ends.

The text recounts the rise of the Mengwi dynasty at the beginning of the eighteenth century and continues up to about 1770 . It is this topic and this time span with which the present chapter is concerned. I will trace the

4 After that the text no longer mentions the dialogue between king and priest, which suggests that the remainder of the text was written later. A similar dialogue can be found in Babad Ksatrya (Wiener 1990:148). Use of the dialogue as a literary form is derived from Old Javanese and Indian models. Elsewhere (Schulte Nordholt 1992) I have discussed this babad in more detail. 
formation of the dynasty and the negara, as well as the hierarchy characterizing them both, and the inherent conflicts. This will not be done by attempting to reconstruct in detail the many, often confusing events that took place during the eighteenth century: the sources, mostly Balinese, are too one-sided and too complex for this. ${ }^{5}$ What I will do is to sketch some interrelated developments that have to do with the shaping of the Mengwi dynasty. The first section recounts the rise of the dynasty. Next, I deal with the personal relationships around the king and with the relationships between nobles, followers, and slaves. The third section discusses the weal and woe of the centre versus its satellites. Section four illuminates the relation between the dynasty and irrigation. Finally, the situation around 1750 will be sketched, at which time negara Mengwi flourished and a new centre shaped its hierarchy.

\section{Kris and kawitan, $1700-1733$}

The ruler of Mengwi who went in search of his forebears had a plurality of names. One of these was Cokorda Bima Sakti Blambangan, which in rough translation means His Majesty, Mighty as Bima, of Blambangan. ${ }^{6}$ The name Bima was derived from one of the five Pandawa brothers in the classic Indian epic Mahabarata, parts of which became known, via Java, on Bali (Zoetmulder 1974:68-100). Bima is the hero who descended into the underworld to wrench his parents away and carry them off to heaven (Hinzler 1981:198-204). The name Bima was appropriate for this king of Mengwi in two respects: he, too, was virtually invincible in battle, and he had recovered his ancestors, his kawitan, so that they would receive the homage which was their due. ${ }^{7}$ Kris and kawitan, strife and source, prowess and parentage, are two crucially significant dimensions in the rise of the Mengwi dynasty.

The narrative presents an idealized history in which fact and fiction merge, and is intended to construct a suitable past for the king's power. There are at least three points on which the historical reliability of the text is doubtful. These are, first, the streamlined 'origins' of the Mengwi dynasty, via Gelgel, from ancient East Javanese royalty; second, the manner in which a single lord established the entire kingdom; and third, the way in which

5 For an attempt to reconstruct a historical event around 1700 purely on the basis of Balinese sources, see Hinzler 1986b. The uncertainties prove too numerous to sketch a likely state of affairs.

6 Cokorda literally means Cokor Ida, which is high Balinese for 'His Feet', the lord's lowest members and the highest a subject may name. Sakti means 'in possession of supernatural powers'; compare Javanese sekti (Koentjaraningrat 1980).

7 Kawitan comes from the stem wit - 'middle'-high Balinese - and means 'origin' or 'progenitors' (I Wayan Warna 1978). Although Hinzler does not mention it explicitly, on Bali the story of Bima's journey to the nether world is associated with ancestor worship. 
this king expanded his influence in concentric circles. In this section I discuss these three points.

\section{The genealogical construction}

That the genealogical linkage of Java, Gelgel, and Mengwi is historically accurate is open to serious doubt. It is not at all certain that migrating Javanese nobility settled on Bali after the island was conquered by the Javanese empire of Majapahit in $1343 .{ }^{8}$

The Nagarakertagama mentions the year 1343 (Pigeaud 1960, III:54). None of the various babad of Balinese nobility goes back to generations prior to 1550, leaving a gap of two hundred years unaccounted for (Berg 1938:126-7; Schulte Nordholt 1986b:11). Moreover, Hedi Hinzler (1986a) has demonstrated that the texts dating from the golden age of the Gelgel court - the sixteenth century - do not yet contain references to Gelgel and its alleged Majapahit roots. ${ }^{9}$ Such references are of later date.

It does seem probable that the court at Gelgel was the most important royal centre of Bali during the sixteenth century and up to 1650 . Balinese sources do not mention other centres, and contemporary Dutch reports refer to Gelgel as Bali's only royal centre. The Gelgel court was rife with tension, however, as may be gathered from both the Klungkung narrative Babad Dalem and from Dutch reports from 1633 and 1638. ${ }^{10}$ In 1651 the struggle for power erupted in earnest, 'whereby all the land was in revolt, everyone alike seeking mastery and striving to be king'. ${ }^{11}$

In 1656 someone evidently prevailed; VOC sources mention a 'new king on Bali'. By 1665 a certain 'Gusty Agong' proved to be lord of the 'south side of the Island', and, two years later (1667), he was referred to as 'regent to Gegyl [Gelgel]'. ${ }^{12}$ According to the Balinese texts, Gusti Agung is the title of the man who usurped power in Gelgel; he is said to have acted as patih of the former Dalem of Gelgel. ${ }^{13}$ The Gusti Agung mentioned in VOC docu-

8 The Nagarakertagama mentions the year 1343 (Pigeaud 1960, III:54).

9 Furthermore it is doubtful that Arya Kepakisan, founder of the Mengwi dynasty, ever existed. The authoritative Klungkung narrative Babad Dalem (Kirtya:1252) does not mention him in the list of Javanese nobles who supposedly conquered Bali. There is passing mention that one of the patihs of Gelgel was one of the Treh Kepakisan, that is, a member of the Kepakisan family (Babad Dalem Kirtya:12b). In an official edition of Babad Dalem Arya Kepakisan is indeed mentioned (I Wayan Warna 1986:B) but this seems to be a recent 'correction' by the editors. In the text Raja Purana Basakih (KITLV, Coll. Korn:253) Arya Kepakisan is not mentioned either, although other noble families are.

10 Leupe 1855, 1856; Wessels 1923. The Dalem of Gelgel was old at the time and a son and a grandson both claimed the throne (Leupe 1855:261).

11 Report of a mission of the VOC (Vereenigde Oost-Indische Compagnie, or Dutch East Indies Company) that visited Bali in 1651 (De Jonge IV:24).

12 Generale Missiven III:75; Daghregister 1665:281, 1667:285; see also Creese 1991.

13 Babad Dalem Kirtya:75b; Worsley 1972:168-9; Babad Mengwi-Blahkiuh a:7. 
ments is most likely the person referred to in the Balinese texts as the progenitor of subsequent kings of Mengwi (Babad Mengwi-Blahkiuh a:3).

In 1686 the rule of Gusti Agung in Gelgel came to an end. At this point the next genealogical link is at issue, the one between Gelgel and Mengwi. Balinese sources say that Gusti Agung was defeated by lords who remained loyal to the Gelgel dynasty, but contradictory accounts are given of what happened after that. The Mengwi narrative has it that Gusti Agung managed to escape from Gelgel and, after a period of wandering, established the Mengwi dynasty. But other sources render this implausible. In 1687 a letter arrived at Batavia, written by the Dewa Agung of Klungkung, who introduced himself as the new king of Bali and reported that the rebel Gusti Agung had been killed in Gelgel. ${ }^{14}$ Even so, it might be that sons of the dead patih established negara Mengwi, but in this respect, too, there are stories that run otherwise. One of these even amounts to an alternative version of the Mengwi narrative. In it, the origin of the first ruler of Mengwi is not traced back to the rebelling patih of Gelgel, but to a related but unfriendly branch of the clan. ${ }^{15}$ It is this deviant version which, regarding the eighteenth century, will prove historically more reliable than the text referred to so far.

It appears impossible to present an accurate genealogy of the Mengwi dynasty. The deeper one digs, the more versions come to light. ${ }^{16}$ This is why

14 KITLV, Coll. de Graaf:8a. Gusti Agung 'with some 1200 people [had been] attacked by the enemy and beaten to death in the negorij Gilgil [...] by a certain Loera Batoe Lepang, who commanded the enemy's troops and who also fell in that place'. Four grandchildren of G. Agung were detained at the Klungkung court. Independently of this, another Balinese source reports the same data. According to Babad Bhoemi (KITLV, Coll. Korn:232) the rebel G. Agung was killed in 1686 by Gusti (Batu) Lepang. The Pariagem Taman Bali (:28) also reports the death of G. Agung. The Klungkung genealogies (Sidemen et al. 1983, appendix) mention Dewa Agung Jambe as the new king of Klungkung.

15 Babad Mengwi-Sedang:1. See also Babad Mengwi-Buleleng:1b; KITLV, Coll. Korn:211, Malay note on the descent of Balinese nobility (approx. 1920). It discusses the lineage of Krian Pranawa Diler, who fulfilled a function below that of patih of Gelgel. After a conflict with the patih, Krian Pranawa Diler left for western Bali and one of his descendants established negara Mengwi. It is not known why the babad of Mengwi-Sedang and MengwiBuleleng differ on this vital point. Babad Blahbatuh (Berg 1932; Sugriwa 1975), of a family closely related to the dynasty of Mengwi in the eighteenth century, does not connect the patih of Gelgel and the kings of Mengwi genealogically either. Research into the origin of the kris of the Mengwi kings - I Panglipur - suggests that the Mengwi dynasty did not derive from the patih, but from the lineage of Krian Pranawa Diler, since this is the lineage which in Gelgel was in possession of the kris I Panglipur.

16 Another version has it that the kings of Mengwi are the descendants of a sub-branch of the Gelgel patihs. In Babad Arya Tabanan (1974:41) and Babad Dalem (I Wayan Warna 1986:47) a Gusti Agung Badeng (or Badung) is brought forward who, according to the genealogy of the Mengwi dynasty (ARA, MvK, V26-4-1940-9) was a brother of the revolting patih of Gelgel. De Graaf (1935:19-20) also mentions a G. Agung Badung as one of the powerful lords of Bali in 1691. According to Babad Surapati (:6), however, the king of Mengwi belonged to an entirely different noble family, namely that of Kaba-Kaba, whose domain lay south of 
it is far from evident that there really was a direct genealogical line from an ancient East Javanese empire to the patih of Gelgel and the later dynasty of Mengwi. On the other hand, it is not hard to see why this dynasty was eager to lay claim to such origins: this sort of genealogical adjustment was ubiquitous, anchoring power in a legitimating past (Schrieke 1957:7,275; Henige 1974; Hoeber-Rudolph 1987:741).

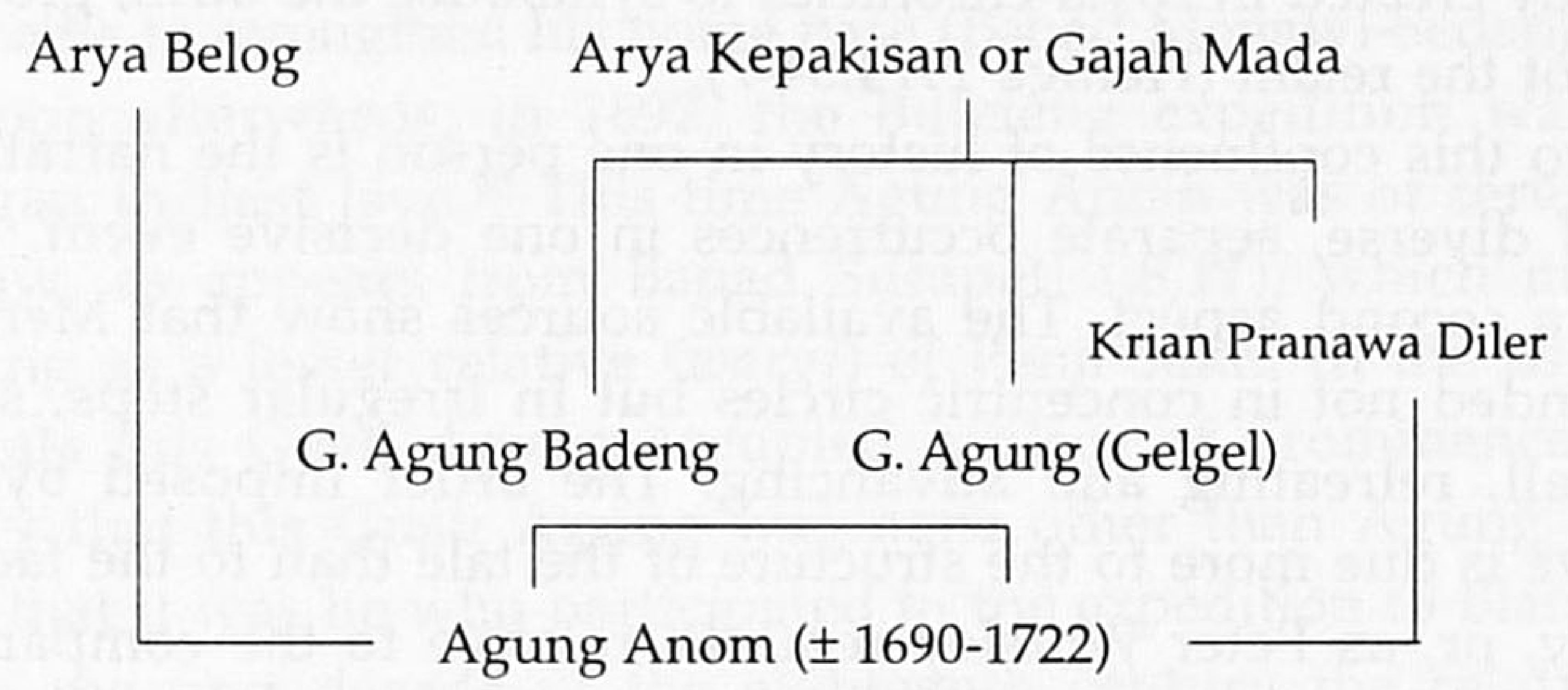

Figure 1. Possible ancestors of the Mengwi dynasty

\section{New centres of power}

After 1650, Bali witnessed a shift in the power configurations. The old royal centre at Gelgel disappeared and new concentrations of power were on the rise. One of these was Klungkung, where, since 1687, the Gelgel dynasty continued unassumingly under the Dewa Agung who, while still the most prestigious among the Balinese lords, had little factual might, as evidenced by his letters to the VOC in 1693 and 1695 requesting weapons and other support to force his former vassals into submission (KITLV, Coll. De Graaf: $8 \mathrm{a})$. Meanwhile the Balinese coast was dotted with stronger centres such as Buleleng in the north, Karangasem on the east coast, and Badung to the south. In western Bali the Mengwi dynasty began to take shape (De Graaf 1941; 1949; ARA, VOC:1871). The coastal centres derived much of their power from the export of slaves, a trade which expanded greatly in the second half of the seventeenth century. The slave trade enabled coastal lords to amass riches and procure weaponry in order to build up an independent power base (Reid 1983:30-2; Schulte Nordholt 1980:32-54). Balinese slave trading will be discussed below, but first I will comment on the beginnings of the Mengwi dynasty.

Mengwi. Finally, according to yet another Balinese text, the Usana Jawa, Gajah Mada, the patih of Majapahit who conquered Bali in 1343, is said to be the ancestor of the Mengwi dynasty (Friederich 1850:28; Hinzler 1976). 


\section{Stylized expansion}

Just as the genealogical line from Majapahit and Gelgel to Mengwi is open to doubt, so also the manner in which the narrative describes the rise of negara Mengwi seems questionable. Rather than one king single-handedly establishing the negara at a single stroke, we should think of this achievement as attained by a succession of kings. In the narrative, the whole history is summarized in just one personage representing the 'epoch ruler', a figure frequently created in royal chronicles to symbolize the birth, growth, and flourishing of the realm (Henige 1974:34-7).

Comparable to this confluence of history in one person is the narrative's concentration of diverse, separate occurrences in one decisive event. This has to do with a second aspect. The available sources show that Mengwi hegemony expanded not in concentric circles but in irregular steps, some large, some small, retreating and advancing. The order imposed by the Mengwi narrative is due more to the structure of the tale than to the factual course of history, or, as Peter Worsley remarks relative to the comparable Babad Buleleng. 'While the babad is aware of time as duration, as an enduring sequence of events, as a succession of generations, it seems more concerned with the classification of periods of time which are characterized by certain properties.' In consequence of this, 'criteria other than chronological [ones] have determined the arrangements of what is ostensibly a chronological narrative' (Worsley 1972:81). Although valid for many Balinese genealogical narratives, this statement does not hold for all of them. Some do tell their story chronologically, which makes the text seem less polished, but the data more in keeping with the (very few) VOC communications regarding Bali. ${ }^{17}$ Nevertheless, neither the Balinese nor the VOC data allow us to pin down how the Mengwi dynasty began. We shall have to make do with a few bold strokes.

\section{The father}

The dynasty most likely started shortly before 1700 in desa Kapal, just south of desa Mengwi. ${ }^{18}$ During the ups and downs of bids for power a man called Agung Anom managed to rise from the entourage of a local lord to become lord of Kapal. But he, in turn, suffered defeat at the hands of another local noble. He fled to neighbouring Tabanan, where he was given protection (Babad Mengwi-Sedang:4). From here he allegedly moved to desa Blayu,

\footnotetext{
17 Examples of this are the babad of Mengwi-Sedang, Mengwi-Buleleng, and Arya Tabanan.

18 The various Balinese sources offer conflicting accounts: Babad Jero Tangeb Mengwi; Babad Arya Tabanan 1974; Bancangah Arya Kutawaringin; Babad Mengwi-Blahkiuh; Babad Mengwi-Sedang. I proceed from the version given by the last.
} 
north of desa Mengwi. It is after this that the great expansion must have begun. As far as can be ascertained however, this process was not a gradual one; it progressed by fits and starts.

Agung Anom had allied himself with the mighty ruler of northern Bali, Panji Sakti, the unchallenged king of Buleleng in the second half of the seventeenth century. By marrying his daughter, Agung Anom of Blayu obtained a powerful protector. ${ }^{19}$ According to the narrative, it was primarily on account of the support of the mighty king of Buleleng that Agung Anom was able to strengthen his home base (Babad Mengwi-Sedang:6).

Soon afterwards, in 1697, the Buleleng expedition was sent to Blambangan in East Java. ${ }^{20}$ This time Agung Anom was of service to his fatherin-law, as appears from Babad Surapati $(: 8,11)$, which mentions a Gusti Agung as a lesser relative (wargi) of Panji Sakti. In the list of Panji Sakti's vassals this Gusti Agung occupied a place of prominence. It seems quite likely that this Gusti Agung was none other than Agung Anom of Blayu, and that it was he who participated in the expedition to Blambangan in 1697.

In the first decade of the eighteenth century the relationship between Agung Anom of Blayu and his superior, the king of Buleleng, altered decisively, because of the instability attendant upon virtually every succession. King Panji Sakti of Buleleng died around 1704, leaving the realm to his

19 Concerning Panji Sakti see De Graaf 1949. For the genealogy of the Mengwi dynasty see Appendix. In all Mengwi babad it is said that the son of Agung Anom married the daughter of Panji Sakti. Also, this son allegedly established negara Mengwi. But this does not seem plausible. To be sure, Babad Mengwi-Sedang (:5-8) does mention Agung Anom's son as the first king and ancestor of all sub-lineages of the Mengwi dynasty, but, strangely, this 'first king' is remarkable inactive in the story. According to Babad Mengwi-Blahkiuh, this 'first king' (the son of Agung Anom) founded the negara, but in this text neither the father nor the son of the 'first king' do much. Given the VOC data this is evidently incorrect. These reveal that many deeds ascribed by Babad Mengwi-Blahkiuh to the 'first king' were in fact carried out by the second king. Moreover, Babad Mengwi-Sedang indicates that a number of actions which Babad Mengwi-Blahkiuh ascribes to the 'first king' were taken by 'his father', Agung Anom. Although in Babad Buleleng, too, there is mention of a (presumably fictional) 'first king' of Mengwi (Worsley 1972:163), a remark made in passing (Worsley 1972:175) shows that it was not the 'first king', but a certain Gusti Anom of Kapal who married the daughter of Panji Sakti of Buleleng. Now, if this Gusti Anom is the same man as Agung Anom of Mengwi, then it is he, rather than his fictional son as introduced in Babad Mengwi-Blahkiuh, who was the first king of Mengwi. This communication in Babad Buleleng further allows the deduction that Agung Anom still resided in Kapal when he married Panji Sakti's daughter, and that he had not yet moved to Blayu. In short, the 'first king' of Mengwi as mentioned in the babad probably never existed. The Mengwi babad conjured up a mixture of father and son. Most likely, the fictional 'first king' was introduced because the writer of the babad felt the need for one great ancestor. It may also be the case that Agung Anom changed his name, and that this second name was later mistakenly considered to refer to 'his son'.

20 KITLV, Coll. De Graaf:8a; Daghregister 31-5-1697; Kumar 1976:36; Generale Missiven V:597; De Jonge III:78-81. The babad of Mengwi and Buleleng tell us remarkably little of this campaign. The information in Babad Buleleng seems to have been taken from Babad Blahbatuh (Sugriwa 1975). The Balinese sources fail to mention that Macassarese mercenaries participated in the expedition (De Graaf 1949). 
sons, who quarrelled bitterly over it. At the same time, the lord of Blambangan, recently vanquished, rose in rebellion. ${ }^{21}$ Agung Anom must have seized the opportunity, for in 1710 he emerged as the great victor. He had come to an agreement with the lord of Blambangan and took advantage of the struggle between the brothers such that both became dependent on him. By way of battle and diplomacy, Agung Anom advanced from lesser to stronger kinsman.

In 1710 a VOC source contains the first mention of a certain 'Gusti Hagong van Magoehie', that is to say, Gusti Agung of Mengwi.22 Presumably, this is Agung Anom of Blayu, who by now had advanced to ruler over Mengwi and had gained great influence in Blambangan and Buleleng. It is not certain whether Agung Anom had left Blayu by then to move south, to desa Mengwi, which was to become the centre of the dynasty. ${ }^{23}$ As it was, he could not spend much time establishing a new centre, since the new strongman of western Bali was seldom at home. 'Strong government was literally on the move all the time,' writes Wolters (1982:21), and this applied to Agung Anom as well. ${ }^{24} \mathrm{He}$ simply could not control Buleleng and Blambangan from far-away Blayu. He had to be seen there, and assert his authority time and again to ensure the continued loyalty of the local nobles. This is why he was constantly on the move, to Blambangan, to Buleleng, a quick trip back to Mengwi, because even there his authority was frequently under pressure. In 1711 and 1712, for instance, and again in 1714 and 1718, he was in Blambangan to keep the area under control. At the same time he had to keep an eye on the lord of Buleleng, a son of Panji Sakti, formally a vassal but given to disobedience. In 1718-1719, for example, this lord of Buleleng initiated a large expedition to East Java and even to Madura, which Agung Anom was unable to prevent (KITLV, Coll. De Graaf:8b; Kamar 1926; Nagtegaal 1988:68-70).

Agung Anom's influence was felt not only in Blambangan (in the west) and Buleleng (in the north), but also east of Mengwi. Nevertheless, his authority was questioned in this area, too, as shown by the events following 1713. Agung Anom had a son by his wife, the daughter of Panji Sakti of Buleleng, named Agung Panji - a combination of his father's title and his mother's 'name'. To this son Agung Anom entrusted supervision of the Mengwi region while he himself was occupied in Blambangan. Before long

21 KITLV, Coll. De Graaf:8a; Daghregister 9-12-1704, which mentions the new king of Buleleng, Panji Danurdarastra; see also ARA, VOC:1871, report on Java's Northeast Coast 1716.

22 KITLV, Coll. De Graaf:8a, referring to the (unpublished) Daghregister 30-12-1710.

23 This probably happened some years later. See in this connection the data concerning the death of his son Agung Panji in 1713.

24 This corresponds with Charles Tilly's view that 'preparation for war has been the great state-building activity', and 'war made the state and the state made war' (Tilly 1975:74, 42). 
Agung Panji had to take action to suppress an insurrection by a local noble who enjoyed the support of Sukawati, the competing centre of power. The ensuing struggle was to last four years (1713-1717). Agung Panji did not survive the war. He died in a pitched battle (1713), as did two to three hundred of his followers (Generale Missiven VII:54-5). This casualty figure reveals that the quest for hegemony on Bali led to tough and, when necessary, merciless fighting.

Agung Panji is remembered as the dynasty's foremost hero, a man who preferred honourable death to cowardly retreat. For this reason a temple was erected at the site of his death. Moreover, in his father's puri in desa Blayu and in the Pura Sada, the old temple of Kapal, there were shrines dedicated to the memory of this hero. Smaller shrines were erected in the Pura Sada for the faithful followers who shared his fate. ${ }^{25}$ Temples and shrines thus mark crucial junctures in Balinese history.

The first decades of the eighteenth century were marked by unabated strife to establish and uphold authority on Bali. In this power struggle alliances tended to shift almost overnight, depending on the immediate advantages each of the parties thought they might gain. The ruler of Buleleng, for instance, allied himself with Dewa Anom of Sukawati, who had previously been involved in the war that claimed Agung Panji as a casualty. Both turned against Agung Anom of Mengwi. He, in turn, sought the support of Dewa Agung of Klungkung, who had a quarrel with his son, Dewa Anom of Sukuwati. Each of these alignments was unstable and subject to change at a moment's notice.

Adoption was one way to confer constancy on such friendships. Agung Anom of Mengwi, for example, adopted the son of the king of Karangasem (eastern Bali). ${ }^{26}$ After sending three of his own sons to Buleleng to pacify that area, he had the ruler of Buleleng, Panji Danurdarastra, adopt one of them. The others were assigned domains of their own. Things did not work out well, however, since one of the sons, to whom he had given a domain in Buleleng, was disloyal and was reassigned to desa Kapal, near Mengwi,

25 Amidst the sawah of Wahem, in east Mengwi close to the present desa Sedang, is the little temple of Padekdekan, dedicated to Agung Panji. In the saren kangin, the eastern quarter of puri Blayu, there is a palinggih (shrine) for Ratu (Lord) Panji. Another shrine dedicated to Agung Panji is located in Pura Sada in Kapal, which Grader (1960b:180, 183) mistakenly ascribed to Panji Sakti of Buleleng. In Pura Sada there are also a number of small seats for fallen followers. These are called satia, literally 'faithful'. Masatia in Balinese means 'following into death'. The location of these various places of worship - not one of them in desa Mengwi - suggests that by 1713 this desa was not yet the royal centre. An inscription on the inner gate of puri Blayu mentions the year Saka 1621 (= AD 1699), which may indicate that Agung Anom completed the building of this puri shortly after the raid on Blambangan.

26 Babad Mengwi-Sedang:9; Babad Mengwi-Buleleng:4a. 
while the son who was adopted by Panji Danurdarastra seemed to be more loyal to that lord than to his natural father. ${ }^{27}$

Surrounded by insecurity, Agung Anom of Mengwi assumed a royal title. In 1717 his name changed to 'Tjakoerda Gusty Agong Mangoej', or Cokorda Gusti Agung of Mengwi. ${ }^{28}$ The title did not, however, ward off the incessant attacks on the authority of the Cokorda of Mengwi, and such attacks continued to plague him for the rest of his life. Early in 1722 the regime of Cokorda Agung Anom ended when he died, 'struck down by illness' (KITLV, Coll. De Graaf:8b) The configurations of power would now depend on the strength of the new leader.

\section{The son}

Gusti Agung Made Alangkajeng was a son of the deceased Cokorda and he became the new king of Mengwi. It would take him eleven years to complete the work begun by his father. The details of the succession are not known, but it is noteworthy that a son from a marriage with a woman from the lower classes became the new ruler, while other sons whose mothers belonged to the nobility were passed by. ${ }^{29}$ Age, and especially personality, must have been decisive. The new ruler proved to be a fearsome leader. The political scene at the time was unfriendly to throne pretenders of high birth but tender age. Agung Alangkajeng's low birth was to a degree compensated for by the fact that he was adopted by Agung Anom's widow, a woman from Buleleng and of royal blood. In this way the birth of the new lord was artificially elevated..$^{30}$

Within four years Agung Alengkajeng fought his way to personal authority. Like his father, he was on the move most of the time. From 1722

27 Babad Surapati:24; KITLV, Coll. De Graaf:8b. Of the three sons only one occurs in the genealogy of the Mengwi dynasty. This is Agung Ketut Buleleng ('Bara Ketut'). Like Agung Panji, this was a son of Panji Sakti's daughter and assigned to the area from which his mother came. Once there he obviously opted for loyalty to his mother's family. He was recalled to Mengwi and was given a subordinate position in desa Kapal 'because he was stupid' (Babad Mengwi-Buleleng:4b). The other son of Agung Anom who was adopted by Panji Danurdarastra is not mentioned in the genealogy, nor is the third son, Gusti Jelantik (probably a son by a marriage with a woman from puri Blahbatuh), who was lord of central Buleleng.

28 KITLV, Coll. De Graaf:8b. Cokorda Agung Anom probably moved to desa Mengwi around that time.

29 Babad Mengwi-Buleleng (:2a) mentions that Agung Anom took to wife a Luh Alangkajeng, who was a commoner. In the other babad this Luh Alangkajeng is the wife of the 'first king' and is said to have given birth to Agung Alengkajeng.

30 Babad Mengwi-Blahkiuh a:29; Babad Mengwi-Sedang:9, 12; Babad Mengwi-Buleleng:4a. The Mengwi babad indicate that Agung Anom initially chose his son Agung Panji to succeed him. After this son died he adopted one of the sons of the king of Karangasem. But this Agung Nenghah Karangasem was in no position to assume the throne (or was sent away) once Agung Alangkajeng rose to power. 
to 1726 he was constantly busy regaining control over Blambangan and Buleleng. ${ }^{31}$ Not before many a battle had been fought, first in Blambangan and then in Buleleng, was Agung Alangkajeng able to secure his claim to kingship (KITLV, Coll. De Graaf:8b).

He tended to reside in Blambangan in East Java to a greater extent even than his father did, presumably for two reasons. First, both northern Bali and Blambangan were important stopovers for the well-plied shipping route between Batavia and the Moluccas. On the way to the Moluccas ships took on stores, and on the way back the main cargo was slaves who 'were sold like fowl' ${ }^{32}$ Second, ideologically East Java was of eminent importance; paradoxically, VOC sources provide far more information on this than do Balinese texts.

\section{The pilgrimage}

VOC sources indicate that both Agung Anom and his successor son Agung Alangkajeng made strenuous efforts to reach the site of the centre, four hundred years earlier, of the Javanese realm of Majapahit. The first such attempt was made in 1714, when Agung Anom decided to

'set out with a goodly number of armed men to Madja Pait, in order to subjugate [that] place to [...] Gusti Agong, as it had been before [...] ruled by his greatgrandfather [predecessors], intending to restore this now crumbled place to its former glory as a prestigious negara'. ${ }^{33}$

This 'sacred and holy site' was believed to be the cradle of the Balinese lords and the source of legitimacy for the Balinese hierarchy. In a sense it was the kawitan of the Balinese political system. The expedition was aborted on account of a war just then erupting between Mengwi and Sukawati (17131717); Agung Anom could not venture too far from Mengwi. A second attempt was not made until twelve years later, in 1726, during the reign of Agung Alangkajeng. That campaign was called off as well, evidently because Buleleng still posed too great a threat and the second king of Mengwi did not dare to set out on the long voyage (KITLV, Coll. De Graaf:8b).

In 1729-1730 the armed pilgrimage finally did take place. Agung Alangkajeng had once again left for Blambangan to ward off a threatening Buleleng attack and decided to push on to the ruins of Majapahit. These were located in the vicinity of desa Wirasaba, 'a fourteen-hour march' from Surabaya. ${ }^{34}$ On this occasion Agung Alangkajeng was accompanied by the

31 Babad Mengwi-Blahkiuh a:37; De Jonge IX:289-91. During his absence his younger brother (of the same low-born mother) and, later, his son or his nephew represented him in Mengwi.

32 Byvanck 1984:143; see also Beeckman 1718:168.

33 KITLV, Coll. De Graaf:8b, letter from Semarang 6-5-1714. I translate negorije as negara.

34 ARA, VOC:2169, letter W. Tersmitten, Semarang 6-3-1730. About a century earlier, Sul- 
ruler of Tabanan and by no less a personage than the Dewa Agung of Klungkung, the most prestigious ruler on Bali. The king of Mengwi had demanded his participation. ${ }^{35}$ A column of some 4,000 troops marched through East Java. Once again the expedition failed. During the rainy season, disease erupted among the followers. Furthermore, the realms of the campaigning kings were threatened by the lords of Buleleng and Sukawati, who were raiding Tabanan and Mengwi, forcing the kings to return prematurely. The physical distance between Bali and the ruins of Majapahit proved too great. Travel along the genealogical and ideological road back to this source, on the other hand, did meet with success, as is evidenced by the many Balinese babad written after 1730, each of them tracing the origins of noble lineages to Majapahit. ${ }^{36}$ The information contained in VOC documents confirms that the quest for roots in Majapahit was very real in the minds of Balinese leaders during the first decade of the eighteenth century.

The 1730 expedition to East Java was not, however, a complete failure, since prior to the journey to Majapahit something else had taken place. This was the pilgrimage to Mount Smeru in East Java, where in 1729 an important ceremony was enacted. According to legend, when Hinduism came to Java the holy mountain of Hinduism, the Mahameru, moved to Java and took on the name $\mathrm{S}(\mathrm{u})$ meru. After this, parts of Mount Smeru were moved by the god Pasupati to Bali (Gunung Agung) and Lombok (Gunung Rinjani). ${ }^{37}$ In 1729 there was still a Javanese Hindu shrine on or near Mount Smeru, whose priest was highly respected. That year, three events took place near that temple. First, the king of Mengwi, Agung Alangkajeng, married a daughter of the lord of Blambangan, to ensure the latter's loyalty. Of greater

tan Agung of Mataram had overrun Wirasaba as well, and his motive, too, was to legitimize his power (Ricklefs 1981:40).

35 De Jonge IX:155; KITLV, Coll. De Graaf:8b, from which the information given below is also taken. Babad Arya Tabanan (1974:56-7) and a version of Babad Dalem (I Wayan Warna 1986:114) refer briefly to this journey. The Dewa Agung is the second king of Klungkung, who came to power shortly after 1720 (Sidemen 1983; Babad Bali Radya; Wiener 1990:501-4). Both kings were enemies of Dewa Anom of Sukawati, who was son and brother to them respectively.

36 See for instance Babad Dalem; Pariagem Taman Bali; Babad Arya Tabanan 1974; Babad Mengwi-Blahkiuh; Babad Sukawati; Babad Jero Tangeb; Worsley 1972. On the dating of the post-Gelgel babad, see Hinzler 1976, 1986a, 1986b. At about the same time the gambuh theatre became very popular at Balinese courts, representing traditions concerning former East Javanese kings. This type of art offered the Balinese nobility the opportunity to identify with their supposed East Javanese background. The gambuh theatre performed Panji stories, about a young prince emerging from nowhere to prove himself in battle, conquer beautiful women, capture booty in war, and gather thousands of eager subjects. These stories explained the emerging Balinese kingdoms as a continuation of old Javanese polities (Vickers 1986a:275, 1989:53-64).

37 Stuart-Fox 1982:54. For important rituals in Besakih, the central temple of Bali on the slopes of the Gunung Agung, holy water from the Smeru is prescribed. 
significance, however, was that the great heathen priest Aria Sameroe [...] honoured Gusty Agong with the title of Pangeran Pourbanagara' (ARA, VOC:2169). The first king of Mengwi had fought his way to the status of the most mighty man in western Bali and was able to assume the title of Cokorda. His son had himself declared Pangeran Purbanegara (Javanese: master of the old land) on Mount Smeru's holy slopes and among witnesses such as the Dewa Agung of Klungkung, the ritual elevation of a successful warrior giving concrete form to the quest for the Javanese ancestry of Balinese royalty.

Remarkably, the Mengwi accounts report neither the expedition to Majapahit nor the ritual on Mount Smeru. One detail does receive mention: Agung Alengkajeng is said to have received from a Dukuh Smeru (a priest of the holy mountain) a kris that would make him invincible in battle. ${ }^{38}$

\section{The battle}

Political events on Bali drew the rulers of Mengwi and Klungkung closer together. Agung Alangkajeng of Mengwi was the stronger by far, but the Dewa Agung of Klungkung had more prestige. Each needed the power of the other to help strengthen his position. Their most important adversaries were a grandson of Panji Sakti of Buleleng and Dewa Anom of Sukawati, the brother of Klungkung's ruler.

In 1733 a great battle was fought in Banjarambengan (Buleleng), involving some 12,000 troops. The armies of Mengwi, Klungkung, Tabanan, Sibetan from Karangasem, and a thousand Blambangan warriors were pitted against the Buleleng army of the grandson of Panji Sakti, who was supported by Dewa Anom of Sukawati and the lord of Taman Bali (central Bali). ${ }^{39}$ At stake was desa Banjarambengan, governed by a brother of the king of Mengwi. But the real issue was a far broader one. Not only the hegemony of Agung Alangkajeng was at stake, but in view of the involvement of virtually every powerful ruler, the Balinese hierarchical order was at stake as well.

The battle must have been fierce; its echoes reverberate in the Mengwi babad, be it that the entire series of engagements between Mengwi and Buleleng was bundled into one single, decisive battle. In the end, victory went to Agung Alangkajeng. According to the narratives his success was due to the might of his 'flaming kris I Smeru', a 'gift of the god Pasuputi of Mount

38 Babad Mengwi-Sedang:10; Babad Mengwi-Buleleng:5a/b. I assume that the Aria Smeru mentioned in the VOC source and the Dukuh Smeru of the babad are identical.

39 In 1732 the son of Panji Sakti, Panji Danurdarastra, died, and from (another) conflict between brothers emerged Alit Panji. He was supported by the king of Mengwi, while the other brother, Alit Lanang, had allied himself with Dewa Anom of Sukawati. 
Mahameru [Smeru]'.40 Agung Alangkajeng had demonstrated his superiority as a warrior.

\section{Reflection}

Once the political landscape was stable, at least temporarily, Agung Alangkajeng returned to Mengwi. ${ }^{41}$ It was perhaps at this time, just after 1733, that he had his brahman priest narrate his ancestry for him. Most likely the priest recounted how the predecessors of Mengwi's monarch hailed from Majapahit, became patih of the Dalem of Gelgel, and finally founded the Mengwi dynasty. Thus it was that the authority achieved by Agung Alangkajeng was rooted and legitimized in Majapahit. After all, 'authority once achieved must have a secure and usable past' (Plumb 1971:41).

The image of a single, royal realm of Gelgel during the first half of the seventeenth century was transformed by 1730 into a configuration featuring a plurality of lords. They derived their legitimation from their origins in Majapahit, from which noble lineages fanned out over the island both genealogically and politically. The story of a single royal dynasty, immediate descendants of the gods, was replaced by accounts of various royal families, each of them tracing their origin back to Javanese nobles who had achieved prominence through battle. ${ }^{42}$ Such accounts were reflected in the actual relationships between the rulers of Mengwi and Klungkung as well. The Dewa Agung had great prestige, although the king of Mengwi was the stronger by far. To be sure, in terms of respect Agung Alangkajeng was but the patih of the Dewa Agung; nevertheless, he could afford to address the Dewa Agung in coarse and offensive language. It is said that this is why the lord of Klungkung called him Cokorda Banya (uncouth daredevil) (Babad Mengwi-Blahkiuh a:36). Kris and kawitan together forged the girders by which negara Mengwi was to be supported. The work begun by the father was brought to fruition by the son, Agung Alangkajeng, alias Cokorda Bima Sakti Blambangan. The patih at last became a king in his own right.

40 Babad Mengwi-Sedang:10-1; Babad Mengwi-Buleleng:5a/b. See also Worsley 1972:221, where, in connection with the kris of Panji Sakti, he refers to a passage in the Arjunawiwaha in which the god Siwa gives Arjuna a flame-throwing-arrow (Pasupati). This arrow made Arjuna powerful. Similarly, the kris of Panji Sakti was the vehicle of his power. It is likely that the author of Babad Mengwi-Sedang also associated the kris belonging to Agung Alangkajeng with Arjuna's arrow: in battle this kris was aflame as well.

41 Babad Bhoemi (:2) mentions that in 1733 Gusti Agung [Alangkajeng] returned to Tapesan, a village near the royal centre in desa Mengwi, where at that time a walled garden serving as temple was located.

42 Hinzler 1986a. In this respect one can speak of a process of 'sinking status' through which authority descended from the gods via Javanese priests and kings to Balinese 'patih-like' warriors, who eventually became kings in their own right (see also Guermonprez 1985). 


\title{
2. Entourage and circle
}

Mengwi's early history is fraught with violence and mobility. Both Agung Anom and his son Agung Alangkajeng had succeeded in surrounding themselves with large groups of followers, and this mobile force increased the battle-readiness of the kings. Hundreds, sometimes thousands, of troops were mobilized to follow the king to Blambangan, for instance, and to fight at his side, as in 1733 during the great battle in Buleleng.

On Bali a king's power was also expressed in terms of property (Balinese: druwé), manifesting itself in mobilized manpower. But the lord and 'vassal' relationship was not stable: a weak king might lose his possessions. The Balinese poem Bagus Diarsa expresses this very well:

\author{
subjects are like unto cattle, \\ their shepherd is the Anak Agung [lord]. \\ When he feeds them well they are fat, \\ their horns are pointed and sharp; \\ who dares molest them? \\ It is foolhardy to do so! \\ But when the herd is hungry, their flanks fallen [in], \\ they will travel in unwavering line \\ wherever grass is found in abundance. \\ If they wander they will be taken; \\ what price will be the ransom? \\ It is the herdsman who is the fool [then]; \\ he is his neighbours' laughing stock. \\ (Hooykaas-Van Leeuwen Boomkamp 1949:101-2.)
}

The metaphor reveals that the king had certain obligations towards his followers and was expected to reward their loyalty. He could not merely order them about, but had to motivate them first. This is demonstrated very clearly in a passage in Babad Buleleng (Worsley 1972:157-9). In 1697, when the lord of Buleleng planned a campaign to take Blambangan, he invited his major vassals to join him in a 'game of crows'. When they arrived, they were the 'crows' and were feasted lavishly: food, drink, clothing, weapons, and women. They could have anything they asked for. But then it was the king's turn to be 'crow'. He requested that his vassals follow him to Blambangan. 'In this manner he involved each of them personally, as it were, in the expedition, since their honour was at stake in the conquest of the Blambangan realm' (Swellengrebel 1941:521).

Babad Surapati (:10-4) recounts how a large scouting army was assembled and sailed for Blambangan in 1697. The leader, Panji Sakti's son, was surrounded by a select group of trusted officers, among whom were allied and related lords. Around them was a group of lesser nobles. All of these persons are mentioned separately. The list ends with rows of battle con- 
tingents, each with a name of its own. ${ }^{43}$ The image is that of a conglomerate of higher and lesser nobles, each commanding his own regiment. The army formed in this way was a temporary coalition, a pyramid structure of personal relationships of the greater and the lesser lords surrounding the king of Buleleng. At its core was a small coterie of warriors having direct ties with the king.

This sort of information is not available for Mengwi armies, but there is no reason to assume that their composition was greatly different. Data concerning the relationships between the king, his entourage, and the broader circle of his followers in the first half of the eighteenth century are lacking as well. In a few cases the relationship between a lord and his entourage can be traced. The following section will consider some of these cases with respect to Mengwi. Lords with a domain of their own, belonging to the clan or married into it, will be reviewed next.

\section{Followers}

Just a few traces remain of the first royal centre at desa Mengwi. The site is of a remarkably modest size. In the area which is now the northern part of the desa there was a minor crossroads. To the northwest of it the king had his dwelling, called puri Bekak or Kaleran (northward). ${ }^{44}$ Around this puri the king gathered his entourage, whose members were measured solely by loyalty and success in battle. Those who prevailed were likely to rise; a loser would fade into anonymity. The histories of several families will illustrate this.

Prior to the Mengwi dynasty's rise to power, the Gusti of the noble house (Jero) of Tangeb were a prestigious family in desa Kapal and desa Mengwi. ${ }^{45}$ But they could not compete with the new strongman: Agung Anom. The leader of jero Tangeb was forced to relinquish his kulkul (wooden slit gong) to Agung Anom, thus surrendering the 'voice' which mobilized his men and, hence, his say over them. Under the first king of Mengwi, jero Tangeb continued to be respected. Agurg Anom was married to a daughter of Gusti Tangeb and the latter's son was a noted warrior who, together with Agung Panji, the crown prince of Mengwi, fell in 1713 in the battle against

43 Such as Segara (sea), Gunung (mountain), Gagak (crow), Teruna (youth), and Batu (rock). This last name will return below in connection with the Mengwi army.

44 Bekak probably means 'old' (from pekak, grandfather). That Agung Alangkajeng, Mengwi's second king, lived in puri Kaleran is apparent from the name given him after his death: Batara di Kaleran, the divine one (who died) in (puri) Kaleran (Babad MengwiBlahkiuh a:38). This shows that at the time there was not yet a new, large royal puri in Mengwi. That must have been built later.

45 Babad Mengwi-Blahkiuh a:19; Babad Jero Tangeb Mengwi; Babad Mengwi-Sedang:7-9; data by G. Ngurah Ceger (Mengwi) and from other interviews in Mengwi. Jero means 'in', 'inside', and refers to the dwelling of a noble, of lesser importance than a puri. 
Mengwi's enemies in the east. But, one generation later, when the next Gusti Tangeb failed to achieve success, the house of Tangeb lost its prominence. He did not succeed in putting down a revolt against the king led by a lord west of Mengwi who proceeded to ally himself with the neighbouring king of Tabanan. Although this Gusti Tangeb died honourably in battle, jero Tangeb no longer played a role of significance in Mengwi. In fact, the family even lost its title; henceforth they were called Gusi (abbreviated to Si, which is the least title for a noble).

Another family that rose from the periphery of the nobility to great prominence lived in the small settlement of Umabian, between desa Blayu and desa Mengwi. ${ }^{46}$ Its members were very loyal to their king, and they were highly successful. This became evident when the lord of Abiansemal, just east of desa Mengwi, resisted the king by ignoring his summons. In the ensuing battle this lord of Abiansemal was beaten, and it was a man from the family in Umabian who became one of the new strongmen for the king of Mengwi. Four of his sons later participated in the second king of Mengwi's campaigns to Blambangan. They were part of the vanguard of Agung Alangkajeng, and proved their courage in many a skirmish. One of the brothers in particular, Ketut Badelod, was a redoubtable warrior. Upon his return to Mengwi the king rewarded him with important privileges. Ketut Badelod was given a new title and a new name: Sagung Bakungan. Sagung (Si Agung) was a title greater than Gusi and less than Gusti. Sagung Bakungan was granted a separate dwelling in Mengwi, the jeroan Bakungan in the southeast of the desa, just below a jero in rank. In addition, he was given the function of panampa or patih. ${ }^{47} \mathrm{He}$ had become the king's righthand man.

An even greater reward came his way. Panampa Sagung Bakungan was adopted by one of the concubines of the king, thereby becoming a 'son' of Agung Alangkajeng and sealing the bond of trust with a 'father-son' relationship.

As 'son' of the king, Sagung Bakungan became the leader of Agung Alangkajeng's raiders, who lived together just north of the puri. This group, too, was fitted into a framework of kinship. It is said that it consisted of some forty families from the wider Mengwi area whose men had conducted themselves honourably in campaigns such as the one to Blambangan. The king pronounced them his 'children' and brought them together in a new

46 Babad Bakungan-Blahkiuh:54b-8b; data from G. Ag. Gede Rai, puri Kaleran Mengwi; G. Ng. Ketut Bakungan, Umabian; G. Ketut Kaler, jeroan Bakungan, Blahkiuh; G. Ng. Putra, puri Grana.

47 Panampa, 'most important assistant', (from tampa, 'carrying something respectfully in one's hands'). The other brothers of Sagung Bakungan will be mentioned in the next section. 
clan, the soroh Batu Bata, 'the Clan of the Rock'.48 Their former family ties severed, the king's warriors entered into a new relationship with a status of its own.

The king made comparable arrangements for other loyal followers of low birth. He conferred on them the Gusi title of the lesser nobility, and together they constituted the prabali group. The prabali were the lesser fringes of the nobility, distinguished from the common people by reason of their special relationship with the king and the privileges appertaining to this.

I Kadua's family is a case in point. The story goes that I Kadua carried the king's kris into safekeeping when Agung Anom lost the battle of Kapal. Once Agung Anom regained his position in Blayu, I Kadua returned the weapon to his lord. Mengwi remembers him as an outstanding example of a loyal servant, and on account of his conduct he and his family were raised to the level of Gusi. They were even given the privilege of living in a jeroan on the southeast side of the same crossroads where the royal puri was situated. ${ }^{49}$

It seems that the families of other low-born followers were similarly rewarded. A royal decree dating back to the period lists the families belonging to the prabali class and hence carrying the title Gusi. ${ }^{50}$ The decree stipulated that for certain misdemeanours members of the soroh Batu Bata and the prabali families would receive punishments less severe than those meted out to ordinary folk.

These brief sketches indicate that there was a measure of mobility within the royal entourage. Entrance into this circle depended on the king, who rewarded loyalty. Such loyalty, however, needed to be proven over and over again, on pain of degradation. It is noteworthy that relations in the king's entourage tended to be expressed in terms of kinship. This was so in the cases of commander Sagung Bakungan and the soroh Batu Bata. It is true in another respect as well. To this day a number of these families trace their ancestry (as did the king) to Arya Kepakisan, the Javanese forefather of the Mengwi dynasty (be it by way of lesser branches). ${ }^{51}$ In this way there came to

48 Babad Bakungan-Blahkiuh:57a-7b. See also Babad Mengwi-Blahkiuh a:24 for an idealized version. At present there is still a ward in desa Mengwi called Banjar Batu. Soroh (literally, 'kind' or 'sort') is a commoner kin group.

49 Babad Mengwi-Blahkiuh a:18, and oral information in desa Mengwi. See also Map 4a.

50 KITLV, Coll. Korn:175, Paswara Mengwi:73. The decree proceeded from the king of puri Kaleran and must date from before 1750, since about that year puri Kaleran was razed (see below). This concerns the following families: Serangan (of I Kadua), Alangkajeng (from where the mother of Agung Alangkajeng probably came), Monang, Pangiasan, Lukluk, and Patilik (from whom Agung Alangkajeng married a woman). In his letters (KITLV:H281) Pierre Dubois describes the prabali as a group of followers living close to the royal puri.

51 Babad Jero Tangeb Mengwi; Babad Bakungan-Blahkiuh; oral information concerning the descendants of jeroan Serangan. An earlier family of followers of Agung Anom, the Gusti 
be a broad 'clan' headed by the royal dynasty, with families of followers forming successively lower branches.

\section{The priests}

Violence and lord-follower relationships constituted one side of royal authority. The other side was the dimension of ritual. For this, we need to consider the special relationship between a king and his brahman priest, the purohita. The bond between these two is an ancient and ubiquitous phenomenon wherever Indian influence took hold. It was the king who had to approve the consecration of a brahman priest (pedanda); conversely, only the pedanda could conduct the ritual prescribed for the inauguration (abhiseka) of a king (Korn 1932:140). Among the pedanda, or priests, the purohita was highest in rank, since he maintained the closest ties with the king. The purohita was not only a source of sacred knowledge; it was his task to confer legitimacy on the royal authority, as indicated by the preamble of the Mengwi babad, in which the king's purohita offered an account of the king's lineage. This priest knew the order of things and hence had insight into the hierarchy on earth and throughout the cosmos. Moreover, he celebrated the important royal ritual. I will return to this below. In a sense, the purohita was one source of royal power: a king without a purohita was unthinkable on Bali (Worsley 1972:32-3; Rubinstein 1991).

The purohita of Mengwi's kings belonged to the highest group of brahmans on Bali, the Kamenuh. These pedanda Kamenuh came from Banjarambengan in Buleleng; the entire family was brought south as spoils of war after the first king of Mengwi had taken control of Buleleng. ${ }^{52}$ The pedanda Kamenuh were carried off to Mengwi and ultimately given a house (gria, a brahman's house) in desa Den Kayu. It was there that the purohita of the Mengwi dynasty dwelled. Their prestige was great; formally they outranked the king, but in practice the purohita-king relationship counted most, since without a king there could be no purohita either. ${ }^{53}$

Celuk family from Kapal, traced their lineage to Arya Kepakisan (Bancangah Arya Kutawaringin-Arya Kapakisan).

52 Concerning the origins of the Kamenuh: Panita Peneliti n.d.; Babad Catur Brahmana:7582; information from Ida Pedanda Kamenuh, gria Gede Den Kayu. The pedanda of Kamenuh were purohita of Panji Sakti of Buleleng (Worsley 1972:153-7). The first purohita of the Mengwi dynasty is said to have been Pedanda Sakti Bukian, with his son Pedanda Sakti Wayan Kekeran succeeding him. Possibly this was the priest who recounted the king's ancestry (Babad Mengwi-Blahkiuh a:1). The other groups of brahmans are Manuaba, Keniten, and Mas, each of them with higher and lower subgroups.

53 The priest is sometimes looked upon as the king's 'older brother' (Guermonprez 1989; Worsley 1972:155). The Kamenuh of Den Kayu are at present the only brahmans from that group in the Mengwi region. Around 1700 desa Kapal housed other brahman gria, such as gria Gede and gria Tegeh of the Manuaba (genealogy of Brahmana Manuaba, gria Manuaba, Taman). It is not known why the kings did not enter into relationships with these gria. 
The purohita's position was expressed not only in the observance and celebration of ritual, but also in royal jurisprudence. Most of those who interpreted the Old Javanese codices and advised the king were brahman priests. In addition, these priests tutored the sons of the nobles, teaching them classical literature and the principles of government. Finally, the purohita's gria represented the top of a ritual hierarchy expressed in actions such as the pedanda dispensing holy water to his sisya (pupil, disciple, follower).

Sprinkling of holy water (high Balinese: toya or tirta) is an essential part of rites on Bali, one reason why the Balinese religion has been described as Agama Tirta, 'holy-water religion' (Hooykaas 1964, 1973). Holy water is important for many, and certainly for the nobility, in the relationship between the pedanda and the sisya, since virtually every pedanda has a circle of sisya families who request holy water from him for their rituals. In precolonial Bali these circles more or less paralleled the sphere of influence of the king or lord to whom the pedanda was linked. The royal dynasty of Mengwi had a bond with the king's purohita in gria Gede Den Kayu. Lesser personages in the entourage were sisya to minor gria, related to gria Gede Den Kayu. The families of the soroh Batu Bata, the royal raiders, for instance, were sisya of gria Bun and gria Seronggo in Mengwi. These gria were less prestigious branches of the gria in Den Kayu, home of the king's purohita. These ritual relationships, then, constituted part of the royal hierarchy, in which lesser followers were bound to their lord.

Jaba

At the beginning of the eighteenth century the entourage of Mengwi's king comprised an estimated several dozen persons with their families. The rest of the residents of desa Mengwi (possibly some 2,500 people) were neither nobles nor part of the entourage; accordingly, they were referred to as jaba, outsiders. But this did not in the least mean that the jaba were an undifferentiated mass. On the contrary, the various jaba kin groups differed greatly from each other. There were jaba families that were much respected locally and whose members held important positions in the villages. ${ }^{54}$ Although the non-nobles were primarily outsiders, many of them were linked to the king via his entourage, and so formed a more extended circle of followers.

Within the immediate royal entourage things turned on valour and reward. Not so in the wider circle of the jaba. Frequent violence rendered life on Bali dangerous; relative security was a scarce and dear commodity. To

54 The Bendesa and Pasek, for instance, who of old must have played a leading role in the desa (Korn 1932:179-238). They were also referred to as kaula wisuda (literally, pure or unblemished servants). On another commoner group with a special status, the Pande, see Guermonprez 1984. 
be assured of the protection offered by a powerful person was a matter of life and death for common folk. Two motives, that of gathering followers and that of seeking protection, combined to bring the high and the low together (see also Reid 1983:8). Yet, a peculiar paradox inhered in the situation as well: during the seventeenth and eighteenth centuries the kings on Bali were the major exporters of Balinese slaves. Along with the recruitment of followers they simultaneously let manpower go, in exchange for which the rulers were able to amass riches and weaponry.

\section{Slaves}

On the commercial map of the Archipelago, Bali occupied an advantageous position. The island was a stopover on the route from Batavia to the Moluccas and an entrepot for trade with the eastern part of the Archipelago.

Initially, slaves were not the major component of Balinese exports. Prior to 1650 items like cotton cloth, rice, pigs, cattle, and fowl were of greater importance (Meilink-Roelofsz 1962:102; Heeres 1894). After 1650, however, increasing numbers of slaves were exported, most of them shipped to Batavia. An estimated one thousand slaves were exported per year, so that between 1650 and 1830 some 150,000 slaves, male and female, were taken away from Bali. ${ }^{55}$ The magnitude of this trade must have had a serious impact on Balinese society. While the demographic consequences can only be guessed at, the political effects were obvious. I will comment on this later, but first turn to the background of the Balinese slaves (sapangan).

There were three broad categories of slaves: prisoners of war, debt slaves, and convicts. In the first group were those captured in the many battles and skirmishes all over the island (Korn 1932:173; Schulte Nordholt 1980:47). Wars generated slaves, but it seems likely that the demand for slaves also generated wars, as suggested by the patih of Karangasem in 1808:

'We wage upon the others when we, lords, lack money; at such times we swoop down on the weakest of our neighbours, and all prisoners and their entire families are sold as slaves so that we [...] have money to buy opium. ${ }^{56}$

During raids into someone else's domain, slaves were captured in large

55 See Van der Kraan (1983) and Schulte Nordholt (1980:32-54) for a brief outline of the Balinese slave trade. I disagree with Van der Kraan, because he uncritically links superseded nineteenth-century Marxist notions regarding the Asiatic Mode of Production and principles of adat law. In contrast with other centres of slave trading in the Archipelago, Macassar (Sutherland 1983a) and Jolo (J. Warren 1981), Bali exported its own inhabitants. Quantitative data on number of slaves exported are scattered and incomplete. The estimate is based on Daghregister 1650-1682; ARA, Coll. Ph.J. van Zuylen van Nijevelt:109, report Ph.J. van Zuylen van Nijevelt 1825; Coll. Van Alphen-Engelhard 1916:149/150, report C. Wikkerman 1805; ANRI, Bali:4.3, report Intje Boeang; see also Lekkerkerker 1918; Abeyasekere 1983. I am grateful to Luc Nagtegaal for some data concerning the early eighteenth century.

56 ANRI, Bali:5, report J. Moser 31-8-1808. On the import of opium see Chapter 3, section 2. 
numbers. But as a VOC report from 1722 indicates, they were taken individually in one's own territory as well:

'Sawang, from Abiansemal in Mengwi, is now called Sawang Abiansemal. He was a slave to Gusti Awang [?] of Mengwi, who had his servant Pan Mankan sell him for thirty rix-dollars. Sekar Badung, a woman, was the slave of Gusti Agung of Mengwi, sold by his servant in Badung for forty rix-dollars. Wayan Pincat from Mengwi was sold by Ince Pameregan, headman in Mengwi [presumably the leader of a group of foreigners], fetching twenty eight rix-dollars; from now on his name is Mengoei [Mengwi].'57

People like Sawang and Wayan Pincat probably belonged to one of the other two categories, debt slaves and convicts. As elsewhere in Southeast Asia, debt slavery was a widespread phenomenon (Korn 1932:173; Reid 1983:8-12). One would 'pawn' oneself for different reasons: ritual obligations, the need to buy livestock, or to offset a poor harvest. If one became a debt slave (tetunggon) of a rich and powerful man, one might be sold. This happened most frequently in families in which the man had died and no grown-up son was able to assume the tasks of the deceased. Such families would come under the 'protection' of the king or a lord, who was free to trade them. ${ }^{58}$

To procure slaves, Balinese kings and lords deliberately sought to increase indebtedness among their subjects. They would organize large cockfights, lasting for days, and their subjects would be obliged to attend and participate in them. 'If I do not enter [a cock] in the contest I will be sold and traded for gunpowder,' is the complaint of a commoner in the poem Bagus Diarsa. His fear was far from groundless, as we know from these words of a member of the king's entourage: 'If he does not want to he will be dragged away, bundled into a prahu and exchanged for opium' (Hooykaas-Van Leeuwen Boomkamp 1949:99, 113).

Kings and lords received a share of the gambling stakes during the cockfights. And invariably a number of participants would incur debts to the point that they became tetunggon and could be sold into slavery (Van Bloemen Waanders 1859:133).

The third category of slaves consisted of convicts. There is much evidence that royal jurisprudence towards the end of the eighteenth century tended to produce slaves because punishment was frequently meted out in terms of fines. Capital punishment, for instance, was equal to 40,000 kèpèng (copper coins), which amounted to about forty rix-dollars. This, in turn, was the price for which traders could buy a slave on Bali (KITLV, Coll. Korn:175,

57 ARA, VOC 1984:42-54. Balinese slaves were generally known by their place of origin.

58 This was called camput (to be without sons); see Korn 1932:532-4. Korn also mentions a case of forced camput. A lord had the head of a family killed and took possession of the members of the household. Increased demand for female Balinese slaves by Chinese immigrants on Java made the trade in women particularly lucrative (Lekkerkerker 1926). 
Paswara Mengwi:73). Moreover, the royal decrees of Mengwi show that the weight of the fines was inversely proportional to a person's position in the hierarchy. A prominent brahman might pay 2,000 kèpèng for a felony, whereas a lowly jaba would be fined 10,000 kèpèng for the same crime, thus far more readily incurring the risk of being sold into slavery (Paswara Mengwi:70).

Obviously, insofar as Balinese princes sold their own people, the trade had to be 'legal'. Pierre Dubois, who lived on Bali in the latter days of the slave trading era, made special note of this:

'The people, though living under coercive rule, nevertheless retain certain privileges which cannot be transgressed upon without courting insurrection [...]. Among these is that none can be deported from the island without cause' (ARA, MvK 3088, report Dubois 1837).

That is to say, a 'valid' motive had to be available. In the case of a king's servant this might mean that 'the least error, such as breaking a dish or glass, a task imperfectly executed, a lapse in the performance of a njembah [respectful greeting], led to deportation' (ARA, MvK 3088, report Dubois 1837).

And so it was that year after year ships from Batavia and other places were packed with Balinese slaves. All of them had in common that they had first been edged into an isolated position, through indebtedness, some misdemeanour, or as prisoner of war. On account of this they were removed from their local context, and the chances that their relatives would come to their aid was thereby reduced. ${ }^{59}$

The effect of the extensive Balinese slave trade on the political order can be summarized as follows. Both the violence of the times and the slave trade led the common people to seek the protection of a strong ruler, in spite of the fact that precisely these were the major slave traders. In this way, slave trading enhanced the hierarchy, the elite adding to their wealth and power, the lesser compounding their impotence. Lords and rulers amassed huge profits. Mengwi's dynasty, too, profited by the export of slaves, the more so since the dynasty controlled important harbours in northern Bali, at Blambangan, and south of Mengwi. If we assume that the average price for a slave was around thirty rix-dollars, the estimated 150,000 sold into slavery must have fetched four and a half million rix-dollars. This sum of money enabled the rulers to reward their followers and procure for

59 Presumably, there were also Balinese who, by way of slavery, sought to escape their island to advance themselves in the large city of Batavia. The famous slave-soldier-king Surapati seems to have been one such adventurer (Kumar 1976:155). De Haan (1922, I:477) suspected that many Balinese came to Batavia voluntarily. Some Balinese families, such as the Bebandem, pursued a career there and in the course of the eighteenth century acquired large tracts of land around Batavia (Lekkerkerker 1918). 
themselves opium and whatever luxuries took their fancy. In addition, their contacts with overseas traders allowed them to buy weaponry and import new military techniques, thereby rendering the exercise of their authority the more effective (De Graaf 1949; Valentijn 1726, II:256).

Slave trade furthered political violence on Bali and the fate of the unprotected became bleaker as time went by.

\section{Centre and satellites}

Mengwi's ruler was a mighty man; still, he had to share his power with others. The territory held by Agung Alangkajeng consisted of an unstable hierarchy of higher and lesser nobles, each controlling an area of his own while acknowledging, to a greater or lesser degree, the king's superiority. The royal centre at Mengwi and its major satellites were not established prior to the great conquests over Buleleng and Blambangan; these occurred simultaneously, expansion taking place on all fronts at once. The result was an unstable pyramid; the royal centre was surrounded by lesser satellites whose loyalty had to be repeatedly reaffirmed. I indicated above how changeable relations were between the Mengwi ruler and the more remote regions of Blambangan and Buleleng. The king had to travel there time after time to reassert his authority in person. Marriages, adoptions, violence, and even mass movements of groups of people - from Buleleng to Mengwi and vice versa, for instance, to draw potential adversaries into the central orbit and to place loyal subjects in far-away areas 60 - were inadequate means to eliminate instability.

Blambangan and Buleleng were the 'outer regions'. Around desa Mengwi lay the 'core region' controlled by the royal dynasty. Around it were the domains of subordinate nobles who did not belong to the royal clan. Lineages of the dynasty and lesser nobles shaped the satellites surrounding the royal centre. The relations between centre and satellites were marked by mutual rivalry, successions of alliances, and conflicts. In this tension-filled context royal authority was highly diffuse. These aspects will be discussed next.

\section{Expansion and tension}

By 1715, Agung Anom had acquired for himself a domain in and around desa Mengwi. In the course of the ensuing decades his realm was expanded to include much of central and southern Bali (see Map 3). From the royal centre dynastic lines branched out east and south. To the north was the

60 Nowadays many families in and around Mengwi trace their origins to Buleleng, while in and around desa Sukasada in Buleleng, some families claim to hail from Mengwi. These relationships become visible in the periodic ritual 'pilgrimages' from Buleleng to Mengwi and vice versa by people who come to worship at their place of origin. 
mountain range, largely inaccessible and sparsely populated. To the west the neighbouring dynasty of Tabanan held sway. The Mengwi dynasty spread over the fertile plain between two important rivers, the Sungi and the Ayung.

Expansion was effected in part through violence and in part by more peaceful means of annexation. A number of lesser lords near Blayu and Mengwi were overcome and rendered powerless; others forestalled disaster by surrendering themselves in time. This, at least, is the impression given by the Mengwi narratives (Babad Mengwi-Blahkiuh a:19-23; Babad MengwiSedang:6). According to these texts, the sons of the first king ensconced themselves around Mengwi and became the sires of the dynasty's branches. In this way the beginning of the eighteenth century saw the formation of the following dynastic subcentres: Munggu in the south; Kapal (twice) and Penarungan quite close to Mengwi; Sibang, Singasari, Kengetan, and Sayan to the east (see Appendix).

As far as can be determined, these subcentres in various degrees mirrored the royal centre. Just as the first king was the ancestor of the entire dynasty, so also the sons became the progenitors of the branches; just like the king, they lived in a puri located at the main intersection in their desa. Around this puri they, too, gathered a circle of loyal and privileged followers, and a local brahman priest would be part of their entourage. ${ }^{61}$ The leaders of the branches stood at the apex of the local pyramid, simultaneously being part of the larger hierarchy, at the head of which stood the king.

It is doubtful, however, that the ancestors of the various lineages were in truth all sons of one and the same king. ${ }^{62}$ Moreover, the genealogy wrongly suggests that the sub-branches made for entirely new noble centres in the areas where they became established. Closer investigation on this point reveals that in a number of cases local noble houses were incorporated into the dynasty.

One example of this sort of annexation is that of the Gusti Kamasan family, who controlled the areas around desa Penarungan and desa Sibang, just east of Mengwi. ${ }^{63}$ The first king of Mengwi married two daughters of

61 In the subcentres Sibang, Kengetan, and Sayan tradition places the puri, just as in the royal centre, northwest of the main crossroads, while the subsidiary lineages also maintained a ritual relationship with the royal purohita in Den Kayu and obtained their holy water for less crucial rituals from a local brahman priest. Information from G. Ag. Gede Rai, puri Kaleran Mengwi; G. Ag. Gejer, puri Kanginan Sibang; G. Ag. Putu Gedong, puri Gedong Sibang; G. Ag. Ketut Agung, puri Penarungan.

62 Certain royal princes appearing in VOC sources do not occur in the genealogy, namely, Alit Kaba-Kaba, Agung Jelantik, and the son who was adopted by Panji Danurdarastra of Buleleng (KITLV, Coll. De Graaf:8b). The standard genealogy is found in ARA, MvK, V:26-41940-9. However, some marriages of the second king of Mengwi (mentioned in VOC sources) are not listed, for instance the marriage with the daughter of the lord of Blambangan in 1729. 63 See Babad Mengwi-Blahkiuh a:29; Babad Mengwi-Sedang:7. Few traces are left of the 
this clan, daughters of the lords of Penarungan and of Sibang. From the marriage with the Penarungan woman issued two sons (see Figure 2). The king named the elder of the two in Penarungan as his 'heir', thus pushing aside the noble family of Penarungan, since the lord of Penarungan had to accept the son of the king rather than his own son as successor and heir. In a roundabout way the same effect was obtained in the case of the Gusti Kamasan family of Sibang. The woman from Sibang bore no son; hence, she adopted the second son of the Penarungan woman and he was eventually placed in Sibang as son and successor. The king thus 'broke into' the local noble clan of Gusti Kamasan, which receded to the background to make way for two new branches of the royal dynasty.

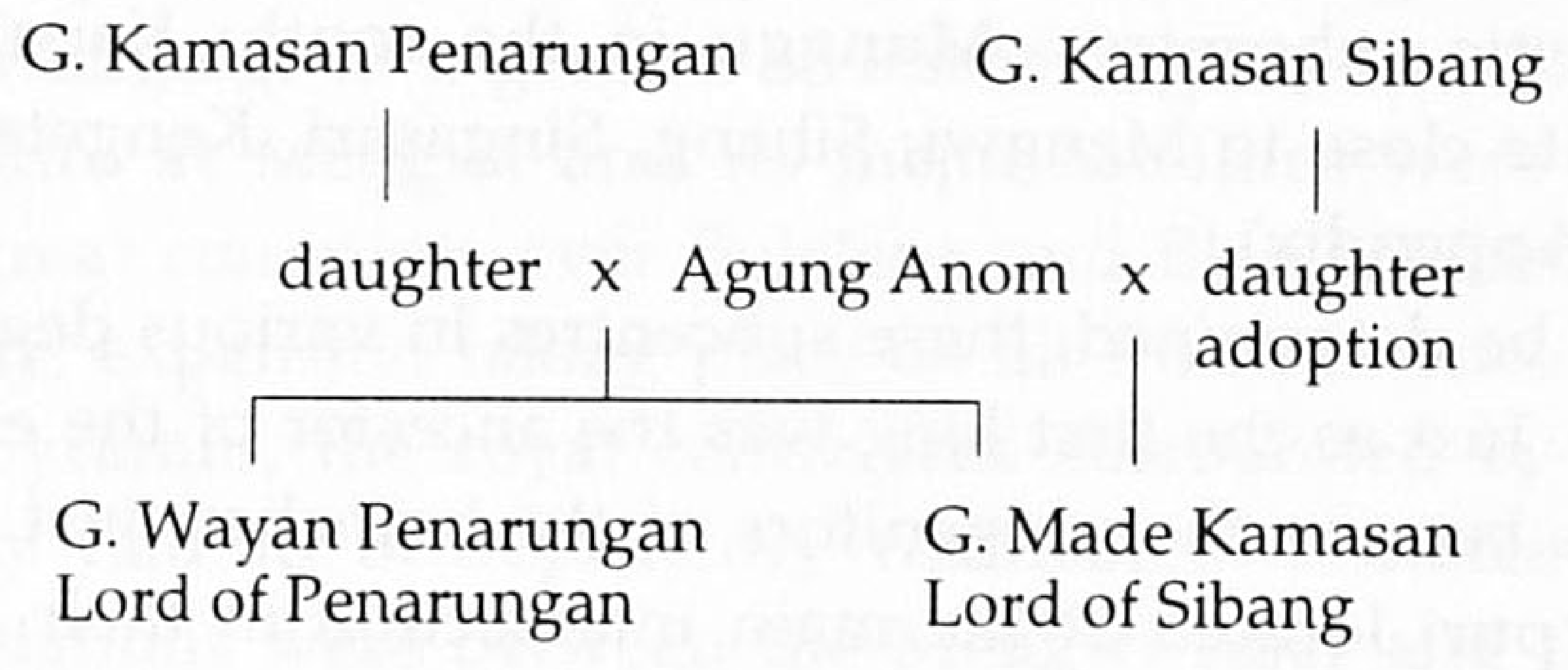

Figure 2. The annexation of puri Kamasan.

The king conferred on each of these branches the authority over a number of households. According to the genealogical narrative, the prince in Munggu received 550, Gusti Buleleng in Kapal Muncan got 500, Gusti Penarungan in Penarungan 450, and Gusti Made Kamasan in Sibang gained control over 400 (Babad Mengwi-Blahkiuh a:29). This meant that the king could not address these people directly; he had to depend on the leaders of the dynastic branches. These, in turn, now had a power base of their own.

Below I trace in some detail one of the branches, that of puri Sibang. ${ }^{64}$ This will serve to illustrate how fragmented manpower was and how it was controlled, locally and regionally.

Gusti Kamasan family. According to oral tradition in desa Sibang and desa Penarungan, they controlled large areas around the desa at the beginning of the eighteenth century.

64 Because the lineage of puri Sibang evinced great continuity, its history is better known than that of others. The brief history given here is based on interviews with G. Ag. Putu Gedong, puri Gedong Sibang; G. Ag. Gejer, puri Kanginan Sibang; G. Ag. Oka Pabean, Den Pasar; G. Ng. Oka, puri Kawan Sibangkaja; Pan Jagra, Banjar Busana Sibang; I Wayan Sutarka, mangku pura Dalem Sibang; Monografi desa 1983; genealogy puri Gede Sibang; and Ida Bagus Mayun 1979:143-54. 
The rise of puri Sibang

Gusti Made Kamasan, son of the first king of Mengwi, arrived in Sibang in $1716 .{ }^{65} \mathrm{He}$ moved into the puri of his father-in-law, pushed him aside, and became the new lord of Sibang. Around him Gusti Made Kamasan gathered an entourage of faithful followers who had come with him from Mengwi. ${ }^{66}$

Initially, Gusti Made Kamasan controlled only desa Sibang; the surrounding areas were still in the hands of other lords and notables. Gradually, however, puri Sibang penetrated further into local society and overran more remote areas. The first victim was the once mighty lord of Mambal, north of Sibang. A combination of factors caused him to lose his autonomy and he ended up as a subordinate of puri Sibang. Through this annexation puri Sibang also gained control over an important dam, which provided a large part of the Mengwi area with irrigation water. To seal the new relationship Gusti Made Kamasan married a daughter of the defeated lord of Mambal and took a brahman priest from his entourage with him to Sibang. ${ }^{67}$

A similar fate befell the local notables (bendesa) of desa Srijati, south of Sibang. Initially, Gusti Made Kamasan promoted the bendesa family of Srijati to the lesser nobility (prabali), and their house became a jeroan. But two decades later Srijati was incorporated in desa Sibang and the position of the bendesa family eroded rapidly. The reason for this was Gusti Made Kamasan's sudden rise in power after a crisis that affected not only Sibang and its surroundings but the very centre of the dynasty as well.

As mentioned, King Agung Alangkajeng often stayed in Blambangan for lengthy periods. He did so in 1739, when Madurese raids caused a great deal of unrest in East Java and the king had to move swiftly to put things in order (De Jonge IV:289-91). Gusti Made Kamasan was an able fighter. During the campaigns against Buleleng, for instance, he had accompanied his brother and demonstrated his bravery on the battlefield. ${ }^{68}$ But this time, while his brother was off on his expedition against the Madurese, Gusti

65 Genealogy of puri Gede Sibang. Sibang existed prior to the rise of the Mengwi dynasty. As early as 1680 the name of this village was given to the slave Seyban (= Sibang), Daghregister 1680:652-6, to identify him by place of origin.

66 These followers came from Mengwi, desa Banjar Sayan, and desa Baha, north of Mengwi. In Sibang they took up residence in the Mengwi and Busana wards.

67 The lord of Mambal, who belonged to the family of the once famous G. Ngurah Mambal Sakti, was ousted from desa Mambal and allowed to build a new puri in Sibangkaja (just north of Sibang). The location of the former puri Mambal remained an empty spot. It is still regarded as angker (fearsome). The brahman priest who moved from Mambal to the entourage of puri Sibang belonged to the Manuaba clan and came from gria Lelangon. See also Heyting 1925a.

68 A lance called Kawitan Buleleng, kept in one of Sibang's puri, is a reminder of this. There are still groups of people who trace their background to Sibang, as in banjar Sibang in desa Patemon. 
Made Kamasan seized the opportunity. Aided by allies from central Bali, he led a few thousand men against desa Mengwi and laid siege to the royal puri, which was defended by a royal son and a few hundred loyal subjects. ${ }^{69}$ Since the king himself was absent, the leaders of the other satellites did not lift a finger; they were content to await the outcome.

The story of how King Agung Alangkajeng restored order in Mengwi will not be taken entirely at face value by professional historians, but it does reflect an ideal image of tact and authority. ${ }^{70}$ The story recounts how Agung Alangkajeng was informed in Blambangan of his brother's coup and how he hastened back to Mengwi. But the manner of his return showed that he did not intend to attack Gusti Made Kamasan, Instead, he simply ignored the coup and, acting as if nothing were amiss, sent the customary messengers to announce his return; they even carried some presents for Gusti Made Kamasan. This demonstration of self-confidence confused the rebels in Mengwi and their allies. Why did the king not attack? Would there be a battle? Why did Gusti Made Kamasan take no action? The king's attitude prompted the allies of Gusti Made Kamasan to quit the scene. This isolated the rebellious leader of Sibang, whose followers, too, were becoming nervous. Finally, Gusti Made Kamasan decided to retreat, even before the king had arrived. Much ashamed, he went to Badung, whose lord granted him temporary refuge.

Gusti Made Kamasan's coup failed because the authority emanating from the king was too great. But the relationship between the two brothers was not yet healed. This time the king displayed great tact in his peacemaking strategy. He sent emissaries to his brother in Badung to tell him that he could return to Sibang unmolested. Gusti Made Kamasan refused, because his ignoble retreat still shamed him. Hence his reply to the king was that he would return to Sibang only as warrior and conqueror. Moreover, he demanded that his domain be extended. The king agreed, and Gusti Made Kamasan and his followers overran a number of desa.71

Gusti Made Kamasan returned to Sibang as a conqueror. The precarious balance between the two brothers was restored and the lineage of puri Sibang continued to be part of the Mengwi dynasty. It also meant that Gusti Made Kamasan had gained in strength and was to occupy a position which was virtually autonomous.

69 De Jonge IX:263, 289-91; Babad Mengwi-Blahkiuh a:37-8; Babad Mengwi-Sedang:13-4, where I Dewa Tampaksiring and I Dewa Pèjèng are mentioned as allies to G. Made Kamasan. According to Babad Bali Radya (1957:39), these were grandsons of the last Dalem of Gelgel, and controlled the area of Taman Bali.

70 Babad Mengwi-Sedang:13-4; Babad Mengwi-Blahkiuh a:37-8; oral tradition in Mengwi and Sibang.

71 Included were villages belonging to the branch of puri Kapal Muncan in desa Kapal. 
One of the desa attacked by Gusti Made Kamasan was Srijati. The local bendesa family resisted and was defeated. As a result, desa Srijati ceased to exist and became a ward of desa Sibang, while the bendesa family lost its privileged position.

In section 5 we will see how the third ruler of Mengwi created a new royal centre in desa Mengwi to demonstrate the authority of the dynasty. The same happened on a smaller scale in Sibang after 1740. Gusti Made Kamasan demolished the old puri of Sibang and created a new crossroads on the border of Sibang and the former desa Srijati. Southwest of the crossroads he had a new puri built. ${ }^{72}$ The greater power of the lineage of puri Sibang was illustrated by the size of the new puri, which was much larger than the old one. Moreover, the lineage multiplied and gained a firmer grip on the local population. North and northeast of the new crossroads, puri and jero of lesser sub-branches of puri Sibang were erected by sons and grandsons of Gusti Made Kamasan.

Formally, puri Gede (Great) Sibang continued to rule the whole domain, but the lesser puri and jero were given direct control over part of the population. More important puri were given a banjar (ward of the desa), while the smaller jero were assigned but a few families to serve them. If a puri had many subjects, certain persons were appointed to act as its agent. They were called mekel..$^{73}$ Usually such mekel were commoners who were given the task of overseeing some dozens of families. If a duty had to be performed - puri repairs, preparations for a ritual, accompanying the lord on a journey or in battle - the mekel had to mobilize their people. Conversely, if people sought a favour from the lord of their puri, they first turned to their mekel, and he would be expected to mediate for them. In short, the mekel were the puri's agents among the people; without them the puri would not be able to control the people.

The creation of a new ritual order was another important aspect of the way in which Gusti Made Kamasan increased his authority. Southeast of the crossroads the lord of Sibang erected a new village temple (pura desa/puseh) to signify the unification of the two former desa, Sibang and Srijati, into the larger unit of desa Sibang. ${ }^{74}$ Furthermore, the local priest of Sibang, who belonged to an old pre-brahman category of priests - the sengguhu - was

72 The location southwest of the crossroads corresponded to the place of the new royal puri in Mengwi (see section 5 below).

73 On mekel, pambekel, perbekel, or prabekel see also Korn 1932:291-2, 302-5; Geertz 1980: 54-68.

74 The death temple (pura dalem) of the former desa Srijati was made into the death temple of the enlarged village, while the desa temple of Srijati was degraded to a place of worship (pura pemaksan) for the inhabitants of the Srijati ward. Descendants of the bendesa family of Srijati became the priests (mangku) of this temple. 
pushed aside by two brahman priests closely related to puri Sibang. ${ }^{75}$ The first of these was the king's purohita, who resided in gria Gede Den Kayu, and this relationship sealed the position of puri Sibang within the Mengwi dynasty. The second priest was the pedanda from Mambal, who had been incorporated in the entourage of Gusti Made Kamasan. This priest would dispense holy water and conduct local rituals, while most of the followers of puri Sibang became his sisya. Ritual relationships thus corresponded to the bonds between a lord and his followers.

One more way of attesting that puri Gede Sibang was the apex of the local hierarchy was through the celebration every 210 days of the odalan (birthday) ritual of its house temple. ${ }^{76}$ All the puri and jero of the lineage of Sibang were linked to this house temple, or pamrajan gede, and at the odalan all members of the branch came together to pay homage to the ancestor of both the lineage and the dynasty. Yet the ritual was not a matter for the members of the lineage only; all the followers of the lineage of Sibang were expected to worship in the house temple as well. Obviously, they were not allowed to worship at the shrines of the dynasty. Instead, they prayed before the shrines dedicated to the gods of the mountains. ${ }^{77}$

On occasions such as the odalan of the pamrajan gede or a cremation of an important person from puri Gede Sibang, or in case of war, puri Gede Sibang had the right to summon all of Sibang's inhabitants. The leading position of the puri, however, did not go unchallenged. Behind a façade of unity, rivalry and fragmentation of authority were rampant. The major competitors controlled their own manpower and tried to gain more prestige for themselves. As the stories in Sibang show, competition for power and prestige were never absent, and sometimes even threatened the position of puri Gede itself. Occasionally internal conflicts would flare up, causing bloody scenes. More often, however, intrigues and feuds lingered on for decades, unnoticed by outsiders but always felt by those involved.

\section{Centre and satellites}

The lineage of puri Sibang was the strongest satellite of the dynasty. Other branches, such as puri Muncan, were smaller and weaker and hence more readily controlled by the king. Still others were more remote: puri Sayan, for instance. Surrounded by unfriendly lords, these were in need of the king's

\footnotetext{
75 Concerning the sengguhu see Korn 1932:155-8; Guermonprez 1991. Today, the name of banjar Senggu in desa Sibang is a reminder of the place where the sengguhu priest once lived. 76 Interestingly, the main house temple of the lineage of puri Sibang is still located at the spot of the old puri of Sibang in the northern part of the desa. Whereas the puri was demolished, the temple was not.

77 This is called maturan: appearing before, presenting offerings. This kind of maturan was and still is a general phenomenon on Bali.
} 
support. Nevertheless, any one of these satellites might turn against the centre openly or sever the bonds unilaterally and in secret.

In addition to branches of the dynasty, lords of unrelated noble families made up the second group of satellites around the king of Mengwi. Not counting the lower 'village nobility', there were nine or ten of these at the beginning of the eighteenth century. ${ }^{78}$ The links between the king and these lords were similar to, and as unstable as, those between the centre of the dynasty and its branches. The king was at war with some of them almost permanently. An example is the lord of Bun, who rebelled repeatedly. With others, the alliance was of the more durable kind, as in the case of two mutually related puri north of Mengwi: Blayu and Marga. ${ }^{79}$ As mentioned, Blayu was the king's original centre, and the lord of Marga had been his protector (Babad Mengwi-Blahkiuh a:16-7). The sturdy bond between the Blayu/Marga families and the kings of Mengwi dated from that time. This is not to say that the king had a great deal of say in the internal affairs of these puri and their domains; in exchange for their loyalty the lords of Blayu and Marga retained a large measure of autonomy, as a 'favour' bestowed by the king. A descendant of puri Blayu put it this way: 'We were permitted to kill without prior consent of the king, and we could always turn to him directly.' In other words, they did not need to approach the king via the entourage.

Most of the eight or nine others were in a similar position, be it that the size of their domain and its proximity to the royal centre determined the degree of subservience to the king. The strong lord of Blahbatuh (east of the river Ayung), for example, could permit himself a large degree of autonomy, since royal authority was less palpable here. Weaker lords living closer to the royal centre had less leeway and were under great dynastic pressure. I will return to this below.

The king was well advised to deal circumspectly with one noble lord in particular, who controlled a large domain. This was the lord of puri KabaKaba, situated southwest of Mengwi. ${ }^{80}$ The Mengwi rulers never did achieve control over the domain of puri Kaba-Kaba; they were able to chip away no more than small segments of it. Hence, the relationship between the king of Mengwi and the lord of Kaba-Kaba was more like that between equals than

78 Marga and Blayu to the north; Kaba-Kaba to the south; Payangan and Carangsari in the northeast; Bun, Mambal, and Abiansemal in the east; and Blahbatuh still further east. Kramas, southeast of Blahbatuh, should probably be considered a satellite of Mengwi as well (see Chapter 3, section 3). The domain of Mambal, as indicated above, was brought under the authority of the branch of puri Sibang.

79 On the families of puri Blayu and puri Marga, see Babad Patjung Getasan:1b-13b, and Babad Patjung Krambitan.

80 This noble family belonged to the clan of Arya Belog and, according to Babad Dalem $(: 3 b)$, was among the conquerors of Bali; see Babad Kaba-Kaba. 
between a king and his vassal. Formally, the lord recognized the king as superior to him and in wars he took his side, but that was about as far as it went. ${ }^{81}$ One single concession puri Kaba-Kaba had to make was that within its own domain it had to tolerate the physical presence of a dynastic satellite. This was the branch of puri Munggu, whose leader was Agung Nyoman Alangkajeng, a younger brother (with the same mother) of King Agung Alangkajeng. This dynastic penetration included two marriages of Agung Nyoman Alangkajeng, lord of Munggu, with women from puri Kaba-Kaba. Moreover, the padmi (principal wife) of King Agung Alangkajeng came from Kaba-Kaba. These marriages sealed the alliance between the families of Kaba-Kaba and Mengwi and created a visible bond (see Appendix).

In fact, marriages were the preferred means to manifest alliances or relationships of dependence. Two sorts of marriages served this purpose. The first was to make a woman the padmi, or principal wife of the king. He chose such women from strong noble families with whom he sought alliances. In the royal puri the position of a padmi was a privileged one and her sons were of greater importance than those born of penawing (concubines). ${ }^{82}$ These pewaning were a second, more numerous category, usually hailing from lesser, subordinate families belonging either to the king's entourage or to the local nobility. An example of this is the union of King Agung Alangkajeng and Gusti Luh Patilik, a prabali woman from Mengwi. This second type of marriage was not meant to uphold an alliance but to continue a relation of dependence. Noteworthy is that, in contrast with later times, most of the marriages of leading figures in the dynasty of the eighteenth century were not endogamous - within the clan - but rather with women from other noble families. Clearly, such marriages were preferred because the dynasty was still extending its control over the region.

Kinship - marriages, adoptions, the creation of classificatory kinship was a major means of expressing royal hierarchy. A characteristic feature in this was that women of lesser nobility always married upwards, in the direction of the royal centre, while royal daughters were never linked to lesser nobles. ${ }^{83}$

81 The relation is given in a somewhat obscure manner in Babad Mengwi-Blahkiuh (a:21-2), which says that the king and the lord of Kaba-Kaba were 'brothers' and that between them no struggle for power took place.

82 The next chapter will comment on the strong position of the padmi. A king might have a number of principal wives.

83 A possible exception is the Buleleng padmi of Agung Anom. The daughter of the powerful Panji Sakti married the lesser lord Anom of Kapal. She was probably a pewaning daughter of Panji Sakti, so that this sort of union was permissible. From the viewpoint of the Mengwi dynasty, however, she was looked upon as a high-born padmi. Daughters by the first king of Mengwi, in turn, did marry upwards: with the Dewa Agung of Klungkung and with a brahman priest in Sanur; see Appendix. 
In addition to these kinship relations, a person's relative position was also indicated by the system of noble titles. It was the king's prerogative to determine the hierarchy of titles and to grant or withhold them. The Sagung and Gusi belonged to the lesser entourage of the king. The titles of Gusti and Gusti Ngurah were used for local nobility not belonging to the dynasty. Dynasty members carried the title of Gusti or, if they were leaders, their title was Gusti Agung. The king alone could claim the title of Cokorda and the special ceremonial title Gusti Agung Ngurah Made Agung.

During the eighteenth century the nobles were in control of virtually all of the Mengwi region. With the exception of one or two desa where jaba notables retained their autonomy, all the villages in the areas were, as far as can be traced, ruled by puri and jero of the nobility. ${ }^{84}$ There is reason to believe, though, that the nobility was far less dominant in earlier times. Many oral village histories indicate that the jaba had to make concessions to the invading nobility and relinquish their power only upon the rise of the Mengwi dynasty. In a few cases, such as the bendesa family of Srijati, this process is more clearly remembered. ${ }^{85}$ In view of the lack of data, all that can be said about the shifts in the relation between the nobility and the locally prominent during the eighteenth century is that these probably were to the advantage of the nobility.

Although as a group the nobility had gained a position of strength, there was little internal unity. Rivalry characterized the relations between the noble families and between branches of these families. In addition, the degree of loyalty towards the king on the part of the satellites depended on the centre's power. In this connection a remark by Tambiah is worth noting. He suggests that, contrary to what one might expect, growth of the centre's strength was linked with growing power on the part of the satellites (Tambiah 1985:271-2). This is because the power of the centre enabled the satellites to reinforce their local power base. Such strengthened satellites could then become a threat to the centre. The history of puri Sibang underscores this remark. To this should be added that fragmentation of authority was furthered by the slave trade (Reid 1983:18). Since the king did not have a

84 An example of a local jaba elite that did manage to maintain its prominence is the family of the bendesa Tangkas of Gerih, a village east of Mengwi. From the lord of Mambal and, later, the lord of Sibang, this family received the privilege to control affairs internal to the desa, in exchange for loyalty (Prasasti Bendesa Tangkas Gerih). Outside of this, mountain villages were not controlled by nobles.

85 Another example, less precisely depicted, is given in Babad Mengwi-Blahkiuh (:19-21). It tells of a strong jaba, the Pasek of Buduk - a village south of Mengwi - who refused to recognize the supremacy of the king of Mengwi. In a duel to which the king challenged him the Pasek remained upright, an unprecedented feat. Nevertheless, in the end the Pasek capitulated because he realized that to fight would lead nowhere. He sought death voluntarily. The king, in turn, made sure that the Pasek was remembered with honour, by dedicating a shrine to him in the central temple of Mengwi. 


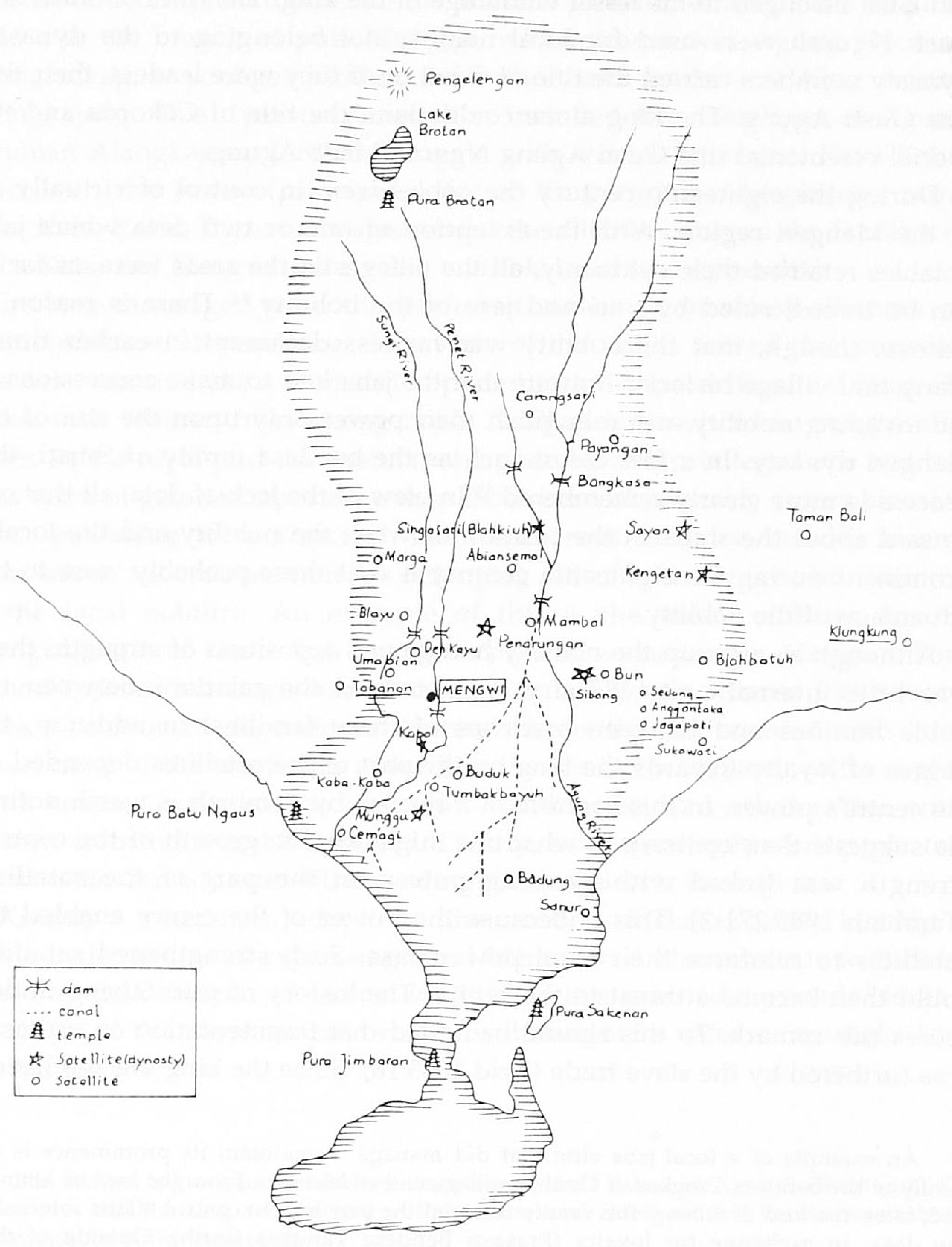

Map 3. Mengwi in the 18th century 
monopoly on the export of slaves, lesser lords could join in as well and thus were able to provide themselves with funds and weapons to add pomp and prestige to their local authority. This meant that they tended to grow into redoubtable spheres of power which the royal centre had to take seriously. The paradox of the rise of the Mengwi dynasty, then, is that as the royal centre gained in strength, rivalry with its satellites increased apace.

\section{Dynasty and irrigation}

One major objective of the nobility was to control manpower, and it was in this respect that rivalry was the greatest problem. More or less parallel to the vertical relations between lords and followers, the Mengwi region had unstable connecting lines from a number of large central dams to the rice fields. There was a certain correspondence between the fanning out of the dynasty and its increased control over the irrigation systems on the plain of Mengwi. Analogous to the formation of the royal hierarchy one could speak of the hierarchical order of Mengwi irrigation: the water coming from the mountains flowed via central dams, main conduits and lesser branches over the sawah (wet-rice fields), and finally down to the sea.

But these Mengwi irrigation systems did not at all imply a 'hydraulic bureaucracy' ruled by 'despotic monarchs'. ${ }^{86}$ As demonstrated above, the king of Mengwi was unable to exercise absolute control. On the other hand, the Mengwi dynasty was closely involved in the construction, upkeep, and mostly ritual - regulation of the regional systems of irrigation. The irrigation order, then, can be understood only in connection with the royal hierarchy. This connection will now be addressed. ${ }^{87}$

Water, village, and puri

Three rivers, the Sungi, the Penet, and the Ayung, descend the gently sloping Mengwi region which fans out from the mountains to the sea. For the most part the soil is such that rivers cut deep gorges, making it no easy task to lead the water to the sawah. ${ }^{88}$ Sometimes the water level of the river is dozens of feet below the sawah, so that in order to irrigate them a dam would have to have been constructed many miles upstream. The water collected there would need to be diverted via lengthy conduits to wherever

86 Wittfogel 1957. The case of Mengwi illustrates the point made by Michael Dove (1985: 17), that irrigation did not lead to the rise of states; instead, political povver 'creates the population concentration which both allows for and is maintained by agricultural intensification'.

87 In the next section the ritual dimension of this will be clarified, while Chapter 4 , section 2, will elaborate on agrarian relations in negara Mengwi during the nineteenth century.

88 The soil consists of an alluvial topsoil on a subsoil of weak volcanic rock. ARA, MvK, MvO.Controleur (district administrator) Badung, V.E. Korn 1921. 
it was needed (Sörensen 1921; Korn 1932, 1927). Construction of such central dams and conduits was often a prerequisite for large-scale irrigation. A second restriction was that the water could be distributed over extended, level terrain only. The landscape of southern Bali today - row upon row of adjacent sawah plains - is not how nature formed it, however, and is probably fairly recent. To be sure, descriptions of the eighteenth-century Balinese landscape are lacking, but it may be assumed that the Mengwi region in those days featured more forest than sawah. One indication of this is found in Valentijn, who describes Bali as 'a land of marvellous forests'. ${ }^{89}$ Local tradition, too, makes clear that at the beginning of the eighteenth century much of the Mengwi region was covered with trees. In many oral village histories dealing with this period one runs into the word alas (forest) whenever there is talk of establishing a village or of clearing the land around it. ${ }^{90}$ In such stories it is almost always mentioned that the local puri or the king ordered the clearing of the wooded area around the desa. The same puri would also be involved in the construction of the upstream dam. According to these village traditions the nobility, and in particular the Mengwi dynasty, was directly engaged in the building of the larger irrigation systems. ${ }^{91}$ One may deduce from this that the rise of the Mengwi dynasty went hand in hand with a sizeable expansion of irrigated sawah fields in the region.

The reason the nobility and especially the dynasty played a leading part in irrigation should be sought in the limited sphere of action open to most desa. According to a rough estimate the Mengwi region contained some seventy villages in the first half of the eighteenth century, their size varying from 100 to 2,500 inhabitants. ${ }^{92}$ There is, however, no accurate information on these eighteenth-century villages. During my fieldwork I researched the history of two villages, Blahkiuh and Abiansemal, and found that these desa had little political coherence at that time. The picture that emerged from

89 Valentijn 1726, III:245. He got his information from Balinese slaves on Ambon. Given the many Mengwi place names entered on his map of Bali, one may conclude that at least a number of them came from that region. Obviously, sawah irrigation on Bali was an established feature long before the eighteenth century; see also Sukarto 1986.

90 I heard comparable oral traditions in Blahkiuh, Penarungan, Sibang, Mengwi, Blayu, Baha, and Banjar Sayan.

91 See also Heyting (1925a), G. Ng. Ceger (1973), and G. Ag. Ketut Tantra (1980) for a written version of three of these stories. Smaller-scale irrigation, drawing upon a spring or a nearby river, often took place without intervention on the part of the nobility.

92 The number and size of the desa is uncertain. I base the number of 70 on a fieldwork survey in most of the Mengwi villages, in search of local history. For some villages it was ascertained that they were established after 1750. On the other hand, other villages disappeared in the course of time. On the basis of closer research into desa Abiansemal and desa Blahkiuh, I conclude that these contained no more than a few hundred inhabitants during the eighteenth century. 
this attempt at reconstruction is that of a thoroughly fragmented settlement. ${ }^{93}$ Inside the settlement as such, which was clearly distinct from the surrounding bush and arable land, there were scattered groups of dwellings in tree-shaded yards, the homes of mutually related people. Between the yards there were large areas devoid of dwellings, with palms, fruit trees, and bamboo. Presumably, a strong bond among these scattered groups did not exist. Tradition indicates that village temples constituted the only element of community. Autonomous, communal action by villagers in politics or agriculture, if it occurred at all, is not remembered.

For the most part, daily life ran its course inside the earthen-walled yards, the family being the economic unit. Tilling the wet and dry fields nearby, animal husbandry, gathering products in the forest, some trade and small home industry, these were the ways in which families supported themselves. It is likely that related and neighbouring yard-dwellers cooperated, but these linkages were too limited in scope to take on larger projects. Perhaps other villages displayed greater coherence; even so, they would not have been able to clear large tracts of woodlands or to construct irrigation works miles away from home. Furthermore, it is hardly likely that these settlements were capable of effectively guarding an irrigation system. The significance of most villages was purely local. In contrast, the Mengwi dynasty operated at the regional level and managed to create the conditions required to implement larger systems of irrigation.

The literature has been amiss in paying inadequate attention to the involvement of the nobility in southern Balinese sawah irrigation. It has one-sidedly emphasized the cooperative (and even autonomous) nature of local irrigation networks (subak), but has failed to note the crucial part played by the nobility in the construction and maintenance of the central dams and conduits. It is true that local cooperation is an obvious feature of Balinese sawah irrigation; it certainly is in the twentieth century. It should be equally obvious, however, that such cooperation could only materialize if there was indeed water to be shared. ${ }^{94}$ None but strong puri were able to mobilize the necessary manpower and to coordinate the extensive activities required. Moreover, the larger irrigation works needed strong puri to main-

93 Reconstruction was based on dozens of interviews with families spread over the two villages. Specific questions dealt with ancient stories, which were usually associated with special places (such as open spaces, old crossroads, and temples) in the village. I also traced the spread of a number of kinship groups in connection with ritual relationsh:ps between the house temples in each courtyard and the 'home courtyard'. Here I restrict myself to the political aspect and leave alternative conceptualizations of the desa (Guermonprez 1990) undiscussed at this point.

94 I will deal with this more extensively in Chapter 8, section 4. Hydraulic engineer P.L.E. Happé $(1915,1919)$ and V.E. Korn (1923) are the only ones who have noted the important role played by puri. 
tain them. Upkeep demanded as much manpower as did construction, since the large mud dams eroded in fast-flowing rivers and might be wiped out suddenly at the start of the rainy season by a flash flood (banjir). ${ }^{95}$ In addition, major and secondary conduits and tunnels required periodic inspection and repair, while the entire system had to be guarded to prevent sabotage. All of these factors put together required strong central control from the royal centre or the satellite.

\section{Puri and dam}

The location of the royal centre and of some of the satellites can partly be explained from the point of view of irrigation. It is said that the first king of Mengwi, together with the lord of Blayu, built a dam in the river Sungi, just west of Blayu, and proceeded to expand the sawah acreage around desa Mengwi (G. Ng. Ceger 1973). This placed the desa in the very middle of a wide, fertile sawah plain, some 200 metres above sea level, where rice was grown for the royal centre. ${ }^{96}$ The dam was guarded by the allied lord of Blayu. An important side-effect was that the newly constructed dam allowed the king to influence irrigation of the sawah belonging to downstream KabaKaba. If need be, he could even divert the river, virtually cutting off KabaKaba's water supply. ${ }^{97}$

But the king could not control all the irrigation in the region in this way. Some of the satellites maintained a system of their own outside the king's direct reach. To give an example, puri Penarungan and puri Kapal drew their water from another river, the Penet, in which they had built their own dams. Puri Sibang had its own dam as well, located in the river Ayung. In Balinese terms this dam, which provided water for the sawah surrounding Sibang, was quite remote: more than twenty miles northward and outside of the puri's domain, near desa Bongkasa. In view of the great distance, several Sibang families moved nearer the dam, to maintain it and guard it against sabotage. ${ }^{98}$ Only a puri as strong as that of Sibang was able to mobilize

95 See Van Naerssen (1918) for a detailed description, with photographs and drawings, of some dams. According to Sörensen (1921) one of the larger dams in the river Ayung was some 55 feet in height. Sörensen also explains the weakness of these dams. In the long run they became undermined because overflow water was diverted just below the dam.

96 KITLV, Coll. Korn:147, memorandum punggawa Mengwi 1921. Geertz (1980:21) has correctly noted the location of more than one royal centre at this level in southern Bali. Remarkably, however, he does not connect this with the nobility's involvement with irrigation (Geertz 1980:68-86).

97 Information provided by G. Ng. Gede, puri Kaba-Kaba. For its irrigation Kaba-Kaba depended largely on the river Sungi. For an example of diverting a river, see Chapter 3 , section 3.

98 Information from G. Ag. Putu Gedong, puri Gedong Sibang. The Sibang dam was located a little north of the present Kadewatan dam. Locals are still able to point out the place, aided by the existence of a small temple on the east bank that formerly belonged to the dam and is 
sufficient manpower from among its own ranks to build a dam in one of the most turbulent rivers on Bali, complete with a conduit that stretched for miles, and to continue to maintain both.

Puri Sibang not only looked after its own dam but was responsible for a second dam in the Ayung as well. This was the dam called Gumasih, located north of desa Mambal. ${ }^{99}$ It is very probable that construction was begun in the first half of the eighteenth century. It became by far the largest irrigation project in the region, with Gumasih providing water for thousands of acres of sawah south of Kapal. There are no data indicating that the king of Mengwi led the project, but this must have been the case. The entire system was spread over the domains of a number of satellites, those of puri Sibang, puri Kapal Muncan, and puri Munggu. In Munggu lived Agung Nyoman Alangkajeng, the king's younger brother. It was he who profited most by the new dam, since the greater part of the water flowed to his domain.

To coordinate upkeep of the great dam, of the tunnel that diverted the water and of the various weirs and conduits that branched out from them, royal supervision must have been exercised, if only to forestall possible conflict among the satellites over water supply issues. The system went far beyond the partial interests of the local lords; hence it was only by means of regional coordination that a project of this size could possibly work. Without the Mengwi dynasty the irrigation system of the Gumasih dam would have been unthinkable.

\section{Sawah and follower}

The king and the local lords had at their disposal a large group of functionaries for the management of their irrigation systems: the sedahan. Alongside the mekel these sedahan were a second group linking puri and people. The main task of the mekel was to mobilize manpower in service of the puri; the sedahan had a similar task relative to irrigation. Their duties were fourfold. First, they had to make sure that timely repairs to dams and conduits were made. Second, they coordinated the allocation of water to the sawah. Third, they managed those sawah whose crops were meant for the

still called pura Sibang. In connection with the dam at Kapal, a number of families also moved from Kapal to a small settlement called Panglan, between Kapal and Penarungan; information from G. Ag. Ng. Rai, puri Muncan Kapal, and mangku Pura Sada Kapal. A similar move took place when the Singasari dam was constructed, north of present Blahkiuh; information from I Ketut Ampreg, Banjar Pacung Grana, and I Wayan Pegeh, Banjar Pacung Selat-Sangeh. On Penarungan dam, see G. Ag. Ketut Tantra 1980.

99 Gumasih dam no longer exists, but was located north of the present Mambal dam in a shallow curve of the river Ayung. Here, too, the small temple of the old dam on the east bank remains. Information from G. Ng. Rai, puri Kanginan Sibankaja, and mangku pura Gumasih Mambal. 
puri. Finally, the sedahan collected a sawah tax which they turned over to the puri. Since the sedahan's authority was confined to the territory controlled by his lord, this meant that the king drew the total revenue of his own domain only. The tax was levied for fields allocated to followers of the puri. Accordingly, these followers were called pangayah (worker) and the sawah tilled by them was called pacatu. 100

In the Mengwi region there was a strong link between being a follower and working a pacatu. The pacatu was a reward for loyalty and for services rendered to the puri. On this point Geertz presents a contrasting view, writing that in pre-colonial southern Bali there was no 'systematic congruence $[\ldots]$ between the structure of political authority, the structure of land tenure, and the distribution of land tenancy' (1980:67). All the data I was able to gather during my fieldwork, however, indicate the opposite. A Sibang tradition is revealing on this point:

'When the dam at Sibang was built, many sawah around Sibang were opened up. The lord of Sibang reserved a large slice of these for his puri. Most of the remaining fields were divided among his relatives. Each of them received a larger or smaller [side] canal, and they could allocate the land on either side of it to their personal followers. Puri favourites received a larger piece of land, while ordinary followers were given about two acres.

The lord of Sibang caused the best fields to be selected for his own use. Puri slaves grew the crop for the puri. The other sawah were pacatu and as such were distributed among the many followers or pangayah. The pangayah were obliged to perform services for the lord, but they were allowed to retain their complete crop. Only a small portion had to be presented to the lord as tax. A pangayah whose loyalty and service towards the puri were found wanting would lose his pacatu. Such persons were ousted from the circle of followers. '101

This tradition shows that there was a strong coherence between political power, the distribution of land, and the relation between the 'owner' and the worker of the land. Moreover, there is no reason to suppose that the situation in Sibang was essentially different from that elsewhere in the region.

100 From catu, provision. On pangayah and pacatu see, for example, Korn 1932:227; Gunning and Van der Heyden 1926; De Kat Angelino 1921a; Happé 1919. In Chapter 4, section 2, I return to this.

101 As told by G. Ag. Putu Gedong, puri Gedong Sibang. His story seems quite plausible, since elsewhere in the region (Mengwi, Blayu, Kapal, Abiansemal, Blahkiuh, Bongkasa, KabaKaba, Munggu) both puri residents and jaba villagers provided similar information. There was a difference between land cleared by the puri and sawah already owned by villagers. To what extent powerful puri managed to incorporate these sawah, transforming them into pacatu land, is not known. 


\section{The kris}

In the course of the eighteenth century the sawah area probably expanded under the encouragement of the Mengwi dynasty. But this did not mean that the king centrally controlled the whole. If his control over manpower in the region was limited, his say in the matter of irrigation was no less so. The example of Sibang shows that the larger satellites each managed their own irrigation works and the concomitant taxes and servitude. The effect of this was that the position of the satellites in relation to the centre was quite strong. The satellites were micro kingdoms, mirroring themselves in the paradigm provided by the royal centre. Here, too, however, in order to bind followers, sub-branches were given the management of irrigation conduits and sawah of their own, in consequence of which the fragmentation of control over manpower permeated the satellites as well. In fact, distribution of irrigation water paralleled the fragmentation of control over manpower. In addition, the 'top' of the irrigation systems was just as vulnerable as was the top of the royal hierarchy. Either a weak king or a weak dam could cause the hierarchy to collapse. Conversely, the irrigation order and the royal hierarchy could be maintained only if the central authority was strong.

In my fieldwork the correlation between the two hierarchies found expression in a telling way. It so happened that until recently it was the custom in Kapal and in Sibang that, prior to starting work on the sawah, a procession would carry the kris from the puri to the dam, where, accompanied by ritual, the blade would be inserted and the powers believed to reside in the kris would be transferred to the dam. ${ }^{102} \mathrm{~A}$ similar ritual must have existed for the dam that stored water for the sawah of the royal centre, as may be deduced from the shrine dedicated to Dalem Smeru and placed in a little temple near the dam. Although none of my informants could tell me anything regarding the identity of the Dalem Smeru, it seems reasonable to suppose that it concerns the kris which King Agung Alangkajeng received from the priest of the Smeru in 1729 and which helped him win the great battle of Buleleng in 1733. The fact that this kris was given a shrine of its own at the Mengwi dam leads one to think that the relation between a strong ruler and a sturdy dam was an essential one, royal hierarchy and irrigation order supporting each other.

102 Data from G. Ag. Oka Pabean, Denpasar, and G. Ag. Ng. Rai, puri Muncan Kapal. The kris from Kapal, Batara di Galuh, is currently kept in the village temple (pura desa) of K apal. 


\section{Cokorda Munggu and the Taman Ayun temple, 1733-1770}

The Mengwi hierarchy soon met with danger. When King Agung Alangkajeng died, shortly after 1740, the dynasty at Mengwi found itself in great difficulties. ${ }^{103}$ For some time it was not clear who would be the new ruler. This caused the centre to weaken and the relations with satellites became tense. Violent conflict ensued.

On Bali, succession to a throne seldom went smoothly. Since there were usually a number of pretenders, an unbroken succession of a single royal house was illusory. As a rule, kingship shifted to another lineage every two or three generations. ${ }^{104}$ While in theory the eldest royal son, born of a padmi, should succeed his father, actual practice involved a choice among a number of options. An adult son whose mother was of low birth (penawing), or the king's widow might usurp the throne. ${ }^{105}$ Or else a brother of the deceased, or sons of a brother, might take over, which meant that a sideline of the dynasty usurped the throne; this is in fact what happened in Mengwi.

The centre was at its most vulnerable when a powerful ruler died and no strong successor was immediately available. Those satellites which had been forced to bow before the great authority of the former king would now grasp the opportunity to increase their power and expand their room to manoeuvre. Let the new king first prove himself! Royal authority could not be inherited, because each new king had to build up his power base and assert his authority all over again. I discuss below the conflicts arising from the succession issue in Mengwi. Special attention will be given to the lineage of puri Munggu, since it was from there that, after some turbulent years, the new leader would come. His broad power base and his violent actions will be sketched. We shall see how he completed building up negara Mengwi and created a new royal centre.

\section{Rebellion and succession}

Agung Alangkajeng must have known that the next king of Mengwi would not be his own son. According to the Mengwi narratives a conflict arose between the two, and the king exiled his son to desa Kapal. ${ }^{106}$ It seems that

103 VOC data on Mengwi covering the period from 1740 to 1770 are sparse. Hence the dates of some of the events described below are uncertain.

104 For Buleleng see Worsley 1972; for Tabanan see Babad Arya Tabanan 1974; and for Badung see Schulte Nordholt 1980. On such instability in Southeast Asia see Tambiah 1985b:324-5.

105 See for instance Agung Alangkajeng, whose mother was of low birth. Chapter 3, section 1 and Chapter 4, section 1 refer to royal widows who assume power.

106 Babad Mengwi-Blahkiuh a:37; Babad Mengwi-Sedang:15. The rejected son founded the branch of puri Kapal Kaleran, see Appendix. 
he appointed two of his nephews, Agung Putu Mayun and Agung Munggu, as his successors. They were sons of Agung Nyoman Alangkajeng, founder of the lineage of puri Munggu in the south and full brother to the king. ${ }^{107}$

So it was that after Agung Alangkajeng's death Mengwi experienced a double regime formed by the brothers from puri Munggu. The elder of the two took up residence in desa Mengwi and the younger succeeded his father as lord of Munggu. The effect of this succession was that the lineage of puri Munggu had taken over leadership of the Mengwi dynasty. But this did not mean that there was now one single centre of authority recognized by all satellites.

The elder brother was designated to become the new king, but he did not survive a rebellion in the eastern part of the Mengwi area. ${ }^{108}$ This rebellion led the dynasty to the brink of a most serious crisis, and central authority could be restored only by employing devastating violence.

If the concept of the 'contest state' (Adas 1981:218) applies anywhere, it would certainly apply in the case of Singasari and other areas of eastern Mengwi around the middle of the eighteenth century. On various levels greater and lesser lords sought to realize their objectives while conflicts and coalitions kept alternating. All these lords maintained contacts with groups of followers whose loyalty they sought to obtain and hold. It was this population which, willy-nilly, came to bear the brunt of the violent conflicts that were about to erupt.

From the outside, two major power centres sought to expand their influence in eastern Mengwi: Sukawati and the royal centre at Mengwi. Mengwi seemed to have the advantage because two branches of the dynasty controlled a large part of the area. The first was the lineage of puri Sibang, which had achieved a relatively stable and rather autonomous power base. The second was the branch of puri Singasari, in the northeastern part of Mengwi. This satellite was unable to stand alone. In the early eighteenth

107 The two brothers were of the same mother, the jaba wife of Alangkajeng. This explains, I think, why the bond between the king and puri Munggu was strong. It also highlights the importance of the female line in the dynasty. Regarding the succession, see Babad MengwiBlahkiuh a:38; Babad Mengwi-Sedang:15. A manuscript in the possession of G. Ketut Kaler of jeroan Bakungan Blahkiuh, formerly part of the collection of G. Putu Jelantik of Singaraja and copied in 1898, contains information to the effect that Agung Alangkajeng had designated both boys to succeed him. In the text, a legal code, there is an agreement dating from about 1731 between Mengwi's king and some lords from Buleleng. In it these lords are instructed to swear fealty to the 'children' of the king, I Barak (child) Pamayun and I Barak Made, names which probably refer to Mayun (Ag. Putu Pamayun) and Made (Ag. Made Munggu). The fact that the king speaks of his 'children' (anak isun) need not mean that they were his own sons. He may have adopted them, but the genealogical narratives of Mengwi make no mention of this. Putu refers to the elder child.

108 Agung Putu Mayun was never inaugurated as king of Mengwi, as indicated by his name, for he did not receive the ceremonial name Gusti Agung Ngurah Made Agung (Babad MengwiSedang:15). 
century the lord of Singasari had suddenly been attacked by his neighbour to the south, the lord of Abiansemal. According to local tradition many casualties were suffered during this attack and a serious dysentery epidemic took the lives of still more Singasari residents. Only with the help of the king of Mengwi could the lord of Abiansemal be defeated and the position of Singasari restored. 109

In spite of this assistance, however, puri Singasari would soon turn against the royal centre of Mengwi. This probably happened at the very moment that Agung Putu Mayun sought to claim central leadership of the dynasty. ${ }^{110}$ At the time that Singasari rose in revolt, another satellite contested the authority of Agung Putu Mayun as well. This was the local lord of desa Bun, who had challenged the Mengwi dynasty earlier, supported by the lord of Sukawati. The information given by one of the Mengwi babad is instructive, since it illustrates that unrestrained bravado on the battlefield was not enough to gain political control; it also indicates that there may well have been rivalry between the two brothers who now ruled the dynasty jointly.

Suddenly the lord of Bun renounced his loyalty to the king of Mengwi and subjected himself and all his people to the lord of Sukawati. When Agung Putu Mayun heard of this he became very angry and immediately marched his men to Bun. His younger brother, Agung Munggu, marched with him with men of his own. They pitched camp outside of Bun. But just before they were to engage in battle, Agung Munggu backed off. He went home pretending that he was needed there for ritual obligations. Agung Putu Mayun suspected that his brother was making common cause with the enemy. To prove that he could solve the issue alone he decided to move against the lord of Bun right away. This was a mistake, for in the ensuing battle the Mengwi leader met with death.111

Agung Putu Mayun's death caused a vacuum at the centre of the dynasty. It also demonstrated, informants say, that he was not smart enough and hence did not deserve the leadership of Mengwi. The time had come for

109 Puri Singasari was led by Agung Putu Pacung, who via his mother was related to the neighbouring house of Gusti Pacung of Payangan in central Bali (Babad Mengwi-Blahkiuh a:29). It is said that when his puri was attacked, Agung Pacung helped his 'in-laws' in Payangan who were threatened by enemies. The story of the epidemic that hit Singasari was told by the mangku of the death temple of Blahkiuh. The Sagung Bakungan family (see section 2 above) was involved in the subjugation of Abiansemal.

110 The precise factors leading to the Singasari revolt are unclear. According to two local informants, the immediate occasion was a marriage. The lord of Singasari refused to give his daughter to the king of Mengwi because he had promised her to a neighbouring ally.

111 Derived from Babad Mengwi-Sedang:16-7. Babad Mengwi-Blahkiuh (a:40-1) does not mention the dubious role played by Agung Munggu. Another indication for a secret alliance between Agung Munggu and the lord of Bun is that the latter raised the former's bastard son, later known as Gusti Meliling (see Chapter 3). 
Agung Munggu, the brother of the fallen leader, to take action.

Puri Munggu had developed into a strong satellite and Agung Munggu had at his disposal a great multitude of loyal followers and a tightly knit entourage. Among the more prominent of those around him were the brahmans of gria Pemaron. ${ }^{112}$ In addition to ritual matters, some of these brahmans distinguished themselves in battle as well, and they were to gain prominence as warriors in the entourage of the future king of Mengwi. In short, puri Munggu boasted a brahman centre of great renown.

This entourage and the broader circle of followers were strengthened even further by groups of fugitives from elsewhere, who were sheltered on condition that they show loyalty to the puri.113 One such group was that of Gusti Sukahet, who had fled Karangasem in eastern Bali. After much wandering they came to Mengwi, where the king assigned them to desa Munggu. They formed a ward or banjar in the village and were given the use of a number of sawah. They had to relinquish their title of Gusti, however; henceforth they were prabali of puri Munggu (Babad Sukahet:35-42).

As noted above, the construction of the great dam Gumasih at Mambal benefited the domain of puri Munggu most. The lion's share of the water flowed to the sawah of this satellite, so that around Munggu a broad arable acreage was created on which sufficient food could be produced to feed the expanding population of Munggu.

The authority of puri Munggu reached beyond its own domain. Jembrana, in western Bali, was made into a satellite of the Munggu branch of the Mengwi dynasty. In the eighteenth century Jembrana was a largely uncultivated area, but the Mengwi dynasty had a strategic interest in gaining a foothold there. Via settlements along the coast of Jembrana, contact between Mengwi and East Javanese Blambangan could be effected more easily than if one travelled entirely by land. In this sub-satellite Jembrana, Agung Munggu's father had appointed an anak astra to exercise authority in the name of the Mengwi dynasty. ${ }^{114}$ An anak astra was an illegitimate child

112 These were part of the brahman clan of Mas Timbul, concentrated mostly in southwestern Bali; genealogy brahmans Mas Timbul and additional information given by Ida Bagus Ketut Sindu, Mengwi, Ida Bagus Swarna, Blahkiuh, Ida Bagus Gede, Sempidi, and Ida Nyoman Raka, Abiansemal. Major Mas Timbul brahman centres were gria Kawisunya in Kaba-Kaba, gria Lod Peken and gria Taman in Sanur, and gria Gadung in Munggu. Another was gria Manara in Karangasem, which had moved to Munggu and was henceforth known as gria Pemaron.

113 Most of these came from neighbouring Badung, where in the beginning of the eighteenth century a serious internal battle had raged, after which many families fled. In addition there were fugitives from Karangasem, eastern Bali. Information given by I Dewa Putu Resik and I Putu Sedana, Munggu.

114 For the background of this pseudo-branch of the Mengwi dynasty, see Babad Arya Manguwi, which includes Babad Andul on Jembrana (31a-43b). I Wayan Reken in Negara, Jembrana, added much valuable information. 
sired by a nobleman, born of a jaba woman, and recognized by the father (Korn 1932:447). This young man's mission was to annex the local puri of Jembrana. He was sent as alleged heir of puri Jembrana and took on the authority of the local noble family, pushing them aside in the process. This is not to say that the anak astra of puri Jembrana was a fully fledged member of the dynasty. His position was not equal to that of members of the royal clan but was a couple of rungs lower. This was expressed, for instance, in his title, Gusti Ngurah, which was no different from that of nobles in the Mengwi region who did not belong to the dynasty.

In addition to the sub-satellite Jembrana, puri Munggu had two other important allies. One of these was nearby and powerful, the other was more remote but had great prestige. The nearer ally was the strong ruler of puri Kaba-Kaba, who ruled a virtually autonomous domain northwest of Munggu. The bond between puri Munggu and puri Kaba-Kaba was reaffirmed by each successive generation via marriages. Agung Nyoman Alangkajeng had married two Kaba-Kaba women; his son and successor Agung Munggu also married a daughter of puri Kaba-Kaba. ${ }^{115}$ This woman brought in a large area of sawah, together with the people who tilled the land, who in this way 'moved' from puri Kaba-Kaba to puri Munggu. ${ }^{116}$

The other ally lived at greater distance. This was none other than the Dewa Agung of Klungkung, the most respected king on all of Bali. Agung Nyoman Alangkajeng, founder of the Munggu lineage, had married a woman from the Klungkung court, and so puri Munggu shared in Klungkung's prestige (Babad Mengwi-Blahkiuh a:39).

Finally, it seems likely that puri Munggu profited more than any other satellite by the slave trade. Located in the coastal area, the domain of puri Munggu featured a number of small harbours from where slaves brought in from the hinterland could be exported. In sum, the lineage of puri Munggu was powerful when, after his brother's death, Agung Munggu decided to intervene. In doing so he did not hesitate to deal harshly with all who would oppose him.

To begin with, he dealt with the rebel lord of Bun. Unlike his brother who fell in battle, Agung Munggu did manage to mobilize the allies he needed before he marched on the enemy. The lord of Kaba-Kaba participated, of course, but so did the branches of Penarungan and Sibang

115 Babad Mengwi-Blahkiuh a:37. This woman was Ayu Oka; after her husband's death she would play a central role in the Mengwi dynasty.

116 Babad Arya Manguwi:29. At stake was the area around desa Cemagi, south of Munggu. Its population remained under direct control of Ayu Oka, however, her husband having no authority there. The alliance between puri Munggu and puri Kaba-Kaba was probably further strengthened by the kinship relations between the two gria in those places (gria Pemaron and gria Kawisunya), both connected with the local puri. 


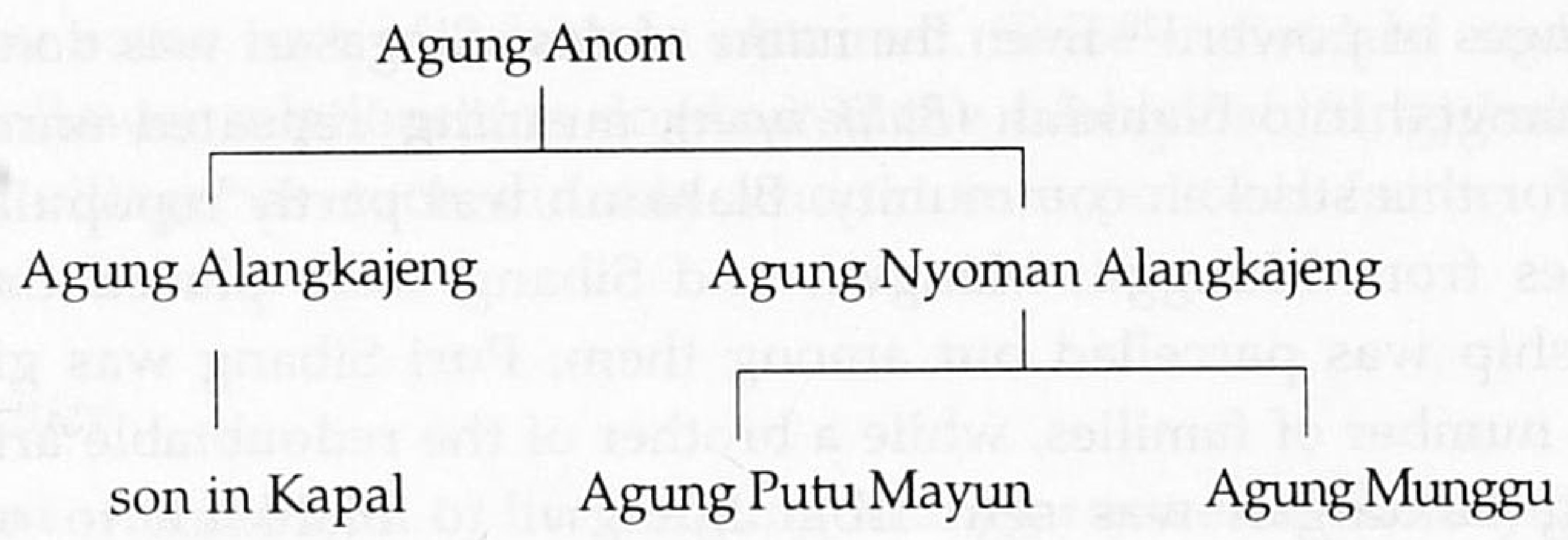

Figure 3. The descendants of Agung Anom

(Babad Mengwi-Blahkiuh a:41). Together they put an end to the autonomy of the lord of Bun. Not content with putting down this recalcitrant local lord, they robbed him of his puri and even his desa. Everything was razed to the ground. Those who managed to escape being sold into slavery fled south, to Badung; others were transported to Sibang as prisoners of war. They were assigned to new settlements on the south side of desa Sibang and added to the labour force of the local puri.117

Upon the destruction of Bun, Agung Munggu saw to it that the area was repopulated. He caused three new villages to be established: Sedang, Anggantaka, and Jagapati. This move led to mass migration: families were shifted to the new desa from Mengwi, Sibang, Abiansemal, and the northeastern part of the region. ${ }^{118}$ The new inhabitants of the three villages were placed under heterogeneous leadership, since various royal followers would rule the area from now on. These were appointed by Agung Munggu and included at least two prabali families from the royal entourage at Mengwi. They became the new ruler's agents in this unstable domain. Control over part of the population was assigned to puri Sibang. ${ }^{119}$

Agung Munggu dealt with the insubordinate lineage of Singasari in the same ruthless way. In spite of the fact that these belonged to the dynasty, their puri was utterly destroyed. Moreover, the lineage of Singasari was expelled from the dynasty and had to be content with a humble existence at

117 Babad Mengwi-Blahkiuh a:41. In the city of Denpasar (or rather, desa Badung) there is still a Bun ward whose residents claim descent from those who fled desa Bun. Prisoners of puri Sibang were made to live in banjar Den Bantas on the east side of Sibang. Moreover, the brahman priest of puri Bun was added to the entourage of puri Sibang (Babad MengwiLambing:47).

118 Babad Mengwi-Blahkiuh a:41; Babad Mengwi-Lambing:46-7. Information from G. Ag. Oka Pabean, Denpasar, G. Kompiang Tilik, Lambing, G. Ketut Jaya, Sedang, Pan Mujung, Karandalem, and the residents of jeroan Aseman, Abiansemal. Inhabitants of the new desa came from desa Kekeran and desa Tumbakbayuh, Mengwi, Abiansemal, Blahbatuh, Sibang, Lambing, and desa Sigaran, which migrated completely from the northeast of the region to the new villages.

119 Reference is made here to prabali Monang in desa Sedang and prabali Patilik, who moved from Tumbakbayuh to Lambing, north of Bun; see also the Bali Post 17-11-1983. 
the fringes of power. ${ }^{120}$ Even the name of desa Singasari was done away with and changed into Blahkiuh (Balik iyuh), meaning 'repeated unrest', a fitting name for this stricken community. Blahkiuh was partly repopulated as well. Families from Munggu, Mengwi, and Sibang were placed there and the leadership was parcelled out among them. Puri Sibang was given control over a number of families, while a brother of the redoubtable army chieftain Sagung Bakungan was sent from Mengwi to Blahkiuh to establish his jeroan Bakungan there. ${ }^{121}$

Agung Munggu had subjugated the eastern region with overwhelming violence. He was able to do so because Munggu provided him with a strong power base of his own and because he had mobilized enough support from allies. Puri Sibang played a prominent part, and managed to gain by it. As it was, the alliance with Agung Munggu provided puri Sibang with still greater authority in the east than it had had before. In other words, an ally would support the centre as long as it seemed profitable to do so. At the same time, however, tension between the centre and the allied satellite would mount, since both increased their power. On the other hand, Agung Munggu had managed to insert his own people into the contested area, which gave him a better grasp on the people of the area than his predecessors had ever had.

This violent intervention in the eastern region brings out very clearly that a warring nobility did not leave the people untouched. War was no knightly sport; it was a scourge that deeply scarred local life. In this respect the situation on Bali may be compared to that of Java. Ann Kumar concludes that the eighteenth-century Javanese desa was 'a loosely knit community in a considerable state of flux', with a

'high degree of partisan, factional involvement in dynastic warfare, with peasants following their locally based leaders in armed pursuit of their extra-local alliances, resulting in dramatic population fluctuations corresponding to periods of major turbulence, and weakness and lack of continuity in the institutional forms of society' (Kumar 1980:577). ${ }^{122}$

The data relating to the Mengwi region seem to indicate that in southern

120 This version is found in Babad Mengwi-Sedang (:28) and Babad Bakungan-Blahkiuh $(: 33)$. It is not clear where the descendants of puri Singasari settled afterwards. Indications are that they went to live in the northern desa Carangsari (Babad Bakungan-Blahkiuh:33; Babad Mengwi-Lambing:47), but the current inhabitants of puri Carangsari emphatically deny a genealogical link with the Mengwi dynasty.

121 Babad Bakungan-Blahkiuh:33; information G. Ketut Kaler, jeroan Bakungan Blahkiuh, G. Ag. Ketut Gedong, puri Gedong, Sibang, Pan Rai, Sibangkaja, I Made Suetama, Pekak Kocong, Pan Jiga, Blahkiuh. In addition to those in Abiansemal and Blahkiuh, another jeroan was established in this region, in desa Sangeh, directly north of Blahkiuh.

122 See also Carey (1986:67), who notes the 'essentially military character of the original Javanese polity'. 
Bali, too, the same sort of relations obtained. Since individual and extralocal lord-follower relationships dominated the (always shifting) balance of power, 'the village' as such did not amount to a political factor of much significance.

\section{The new centre}

Once the east was brought to heel, Agung Munggu annexed the royal centre of Mengwi. Prior to this, however, dynastic power was invested in him formally. He received the royal kris, up until then still in the possession of the descendants of the old core of the dynasty. His authority over Mengwi was now unchallenged. ${ }^{123}$

Agung Munggu did not leave the royal centre unchanged. He left his puri in Munggu and had it dismantled. The royal puri Kaleran in Mengwi was razed as well and in its stead he had a large new puri built in the southern part of the desa. The new king brought dozens of families of his entourage with him; these were housed throughout desa Mengwi. To the north of the old, demolished puri Kaleran a number of these new families settled in a new banjar (ward) Munggu; north of this, banjar Gambang was established to house families from a banjar of the same name in Munggu. On the east side of Mengwi arose a second banjar Munggu and other followers moved into a new banjar Alangkajeng in the southeastern part of the desa.

Some prominent brahmans also moved from Munggu to Mengwi. One of them was the priest Ida Padanda Made Alangkajeng, known especially for his courage in battle. He took up residence in gria Alangkajeng in the banjar of the same name. ${ }^{124}$ His younger brother, Ida Padanda Ketut Sidemen, was given a gria in Mengwi as well: gria Sidemen just east of Mengwi proper. Henceforth, gria Sidemen and the gria of the pedanda Kamenuh in Den Kayu would provide the royal purohita. Thus, the personal entourage of puri Munggu was added to that of the old royal puri in Mengwi. The effect went beyond mere enlargement, however, for the name and the location of the new gria Sidemen was not accidental: both were modelled on the gria of

123 Babad Mengwi-Blahkiuh a:42. This was the kris I Panglipur (the sources say no more about the kris I Dalem Smeru). Agung Munggu received it from the eldest daughter of the second king of Mengwi (see Appendix). Once again the role of women in the dynasty is emphasized; as oldest representative of the old royal core lineage it was she who transferred the kris and, hence, the authority to the lineage of puri Munggu.

124 Babad Arya Manguwi:29; information G. Ag. Gede Rai, puri Kaleran Mengwi, I Ketut Misma, Mengwi, and information from relevant banjar. Pedanda Made Alangkajeng is also called Ida Pedanda Made Pemaron. Comparison with the genealogy of the Mas Timbul brahmans shows that this is the same person. I am grateful to Ida Pedanda Sidemen and Ida Bagus Ketut Sindu of Mengwi, who explained some unclarities in the genealogy of their family. An earlier brahman from Munggu was also known for his bravery. This was Ida Mas of gria Gadung Siyuh, who had accompanied the second king to Blambangan and afterwards received from the king a gria of his own in Mengwi (Babad Bakungan-Blahkiuh:32). 


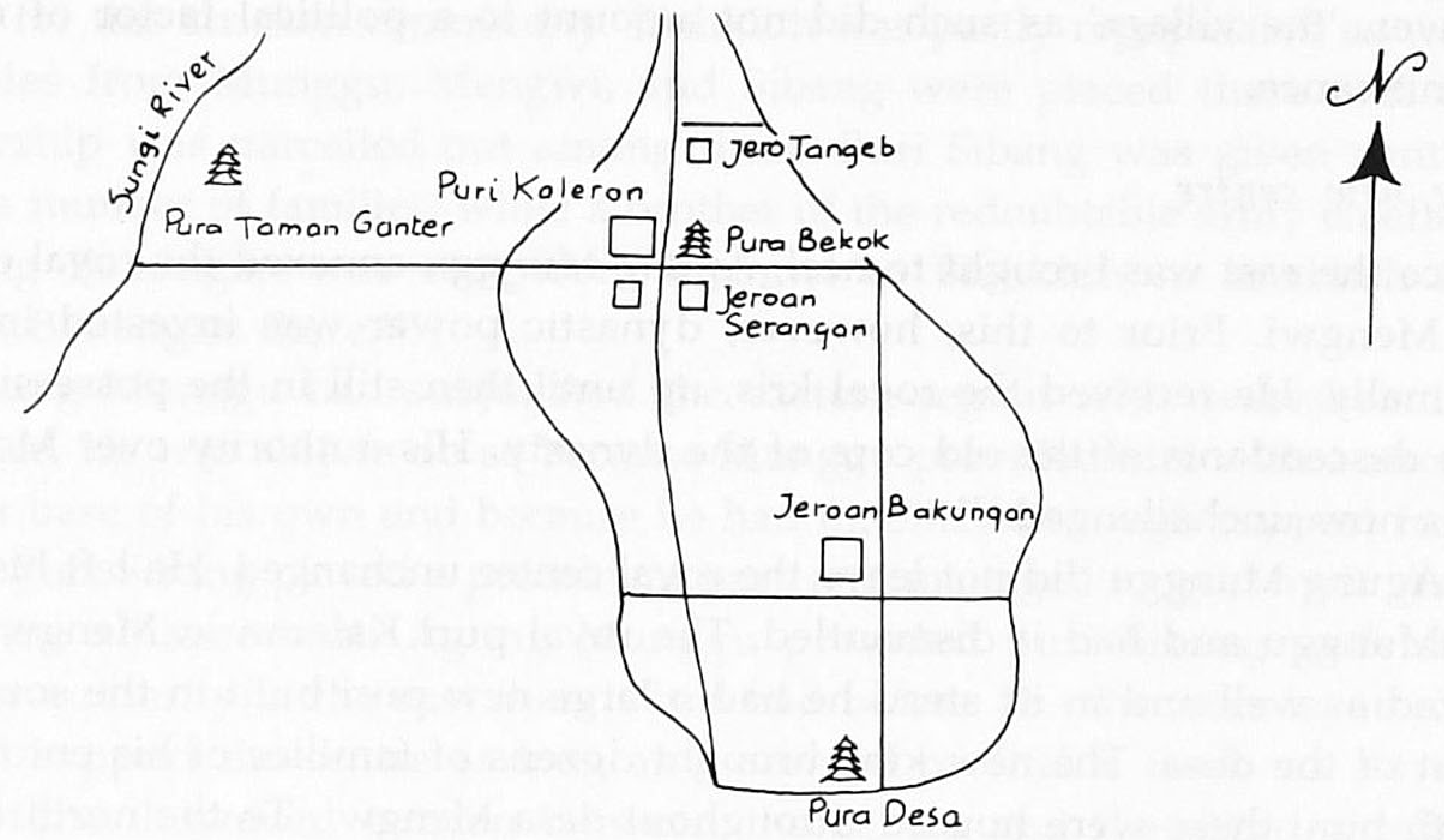

Map 4a. Desa Mengwi around 1730

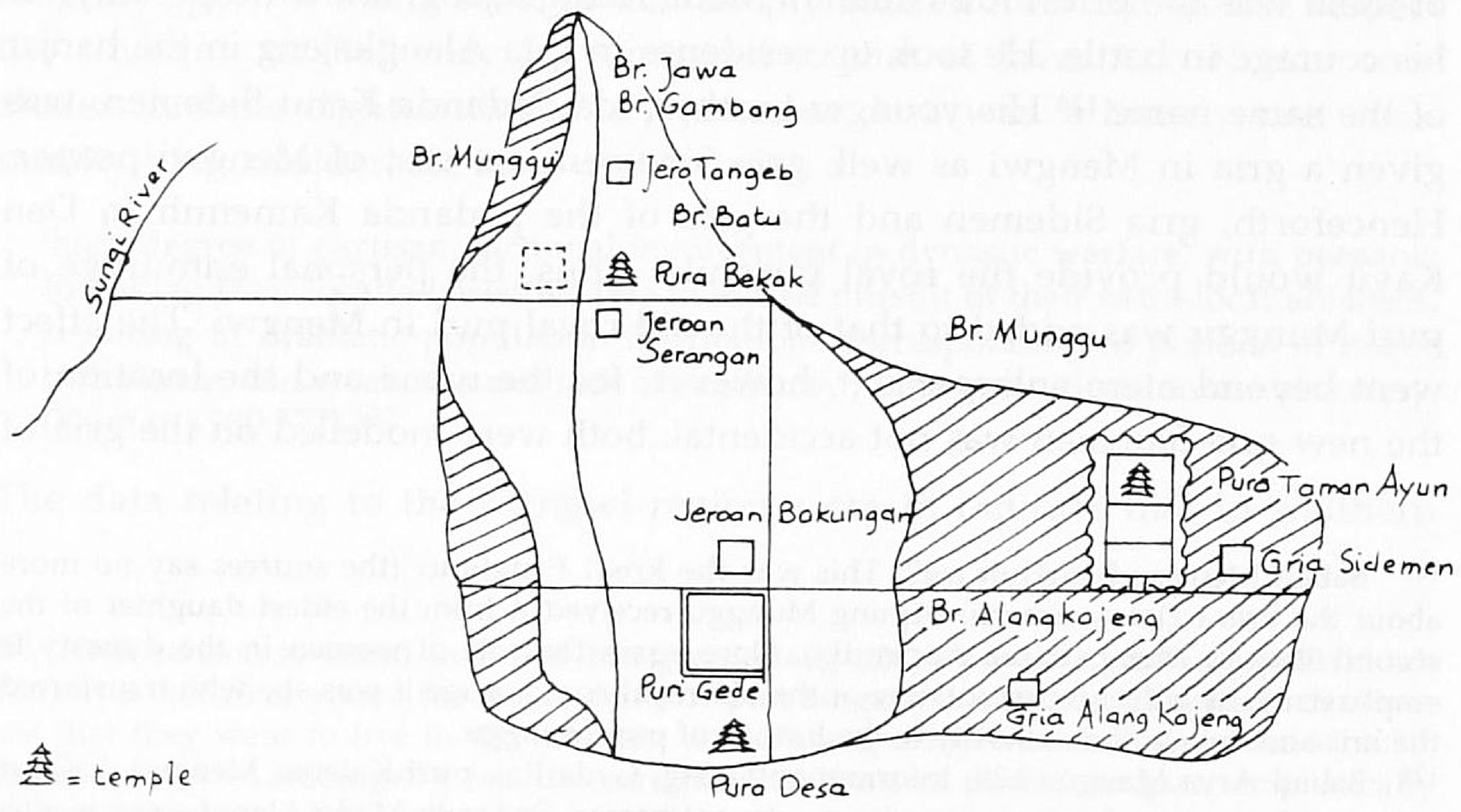

Map 4b. Desa Mengwi around 1770 
the purohita of Klungkung's Dewa Agung. The new purohita in Mengwi could certainly do with a bit more prestige, since he belonged to one of the lowest brahman clans on Bali. None of the other Balinese kings had a brahman of the kin group Mas as purohita. A brahman as 'lowly' as that could not really be a royal purohita unless his position was raised. This is what happened in Mengwi, because the Mengwi purohita now claimed membership of the clan of the priest of Klungkung. ${ }^{125}$

The arrival of these brahman priests from Munggu made it possible to expand the network of related gria throughout the Mengwi region. While the followers from Munggu made manifest the new king's manpower, the gria symbolized the ritual hegemony of the royal hierarchy.

At the top of the hierarchy, of course, stood Agung Munggu himself. He underscored his authority by erecting a new royal puri at a wide crossroads in the southern part of the desa. The new Mengwi puri was much larger than the former puri Kaleran and must have covered nearly ten acres. ${ }^{126}$ Just as in the case of the new royal purohita's gria, the puri, too, followed the example of Klungkung. Like the residence of the Dewa Agung, Agung Munggu's puri was situated southwest of the crossroads. ${ }^{127}$ The fact that the Mengwi puri was a replica of the Klungkung model underscored architecturally the idea that the king of Mengwi should be seen as the patih of the Dewa Agung. What it also expressed was that the Mengwi dynasty, via Klungkung, was connected with the Majapahit origins of Balinese royalty: allegedly, the puri at Klungkung in turn was a replica of the former court of Majapahit. ${ }^{128}$

Temple building was essential to Balinese kingship and hierarchy. In this respect the most important temple by far was pura Taman Ayun, which was

125 The purohita of Klungkung was a brahman of the Manuaba group. By going way back genealogically, the new purohita in Mengwi was able to link the two gria. At present many descendants of this lineage of Mas Timbul brahmans in Mengwi believe that they are Manuaba.

126 Memory of this has almost faded; in 1891 the new royal abode was completely destroyed. The current Cokorda of Mengwi still has a plan of part of this puri, based on the recollections of an old servant. But it depicts a small portion of the puri only, because this servant was not allowed to enter the quarters of the king and his wives. In the next chapter I describe the puri and its court life. On the destruction of the Mengwi puri, see Chapter 6, section 3.

127 Many informants in Mengwi mention the similarity with Klungkung. It is not clear whether the internal arrangement of the puri was also modelled on the one in Klungkung as well.

128 On the link between Klungkung and Majapahit, see Stutterheim 1948. According to Babad Mengwi-Sedang (:15-6) the architect of the Mengwi puri was Chinese; see Ida Bagus Mayun 1979:182-8. In many Balinese puri, Chinese influence is discernible, for instance in the green porcelain ornaments built into the walls. According to a tradition in banjar Jawa (Java) in desa Mengwi, the first residents of that ward came from Blambangan about the middle of the eighteenth century; they were brought to Mengwi to help build the puri. 


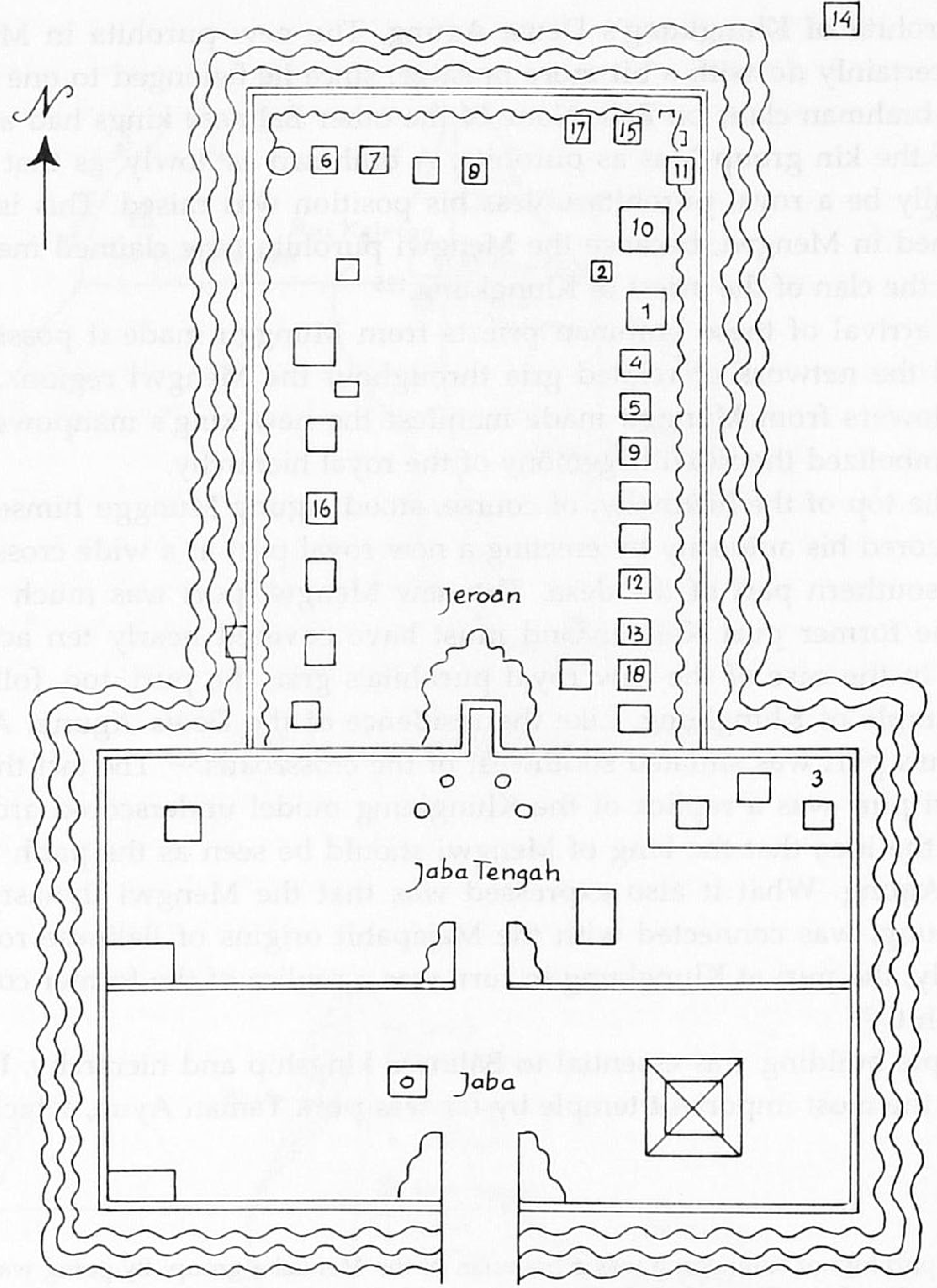

paibon

pasimpangan pura Sada Kapal

pasimpangan pura Bekak

meru pasimpangan Gunung Batur

meru pasimpangan Gunung Agung

pasimpangan (mountain/temple) Padang Dawa

pasimpangan (mountain/temple) Batu Karu

pasimpangan (mountain/temple) Bratan

meru pasimpangan mountain Pengélèngan

meru pasimpangan marine temple Sakenan

meru pasimpangan marine temple Jimbaran

meru pasimpangan marine temple Batu Ngaus

meru pasuruan, associated with the combatting of plagues

pura tengah segara

bedugul ulun carik

parvedan, pedanda's place

shrine for D.H. Nirarta

shrine for Pasek of Buduk, place of worship of soroh Batu Bata 
built northeast of the crossroads, opposite the puri. ${ }^{129}$ Taman Ayun was not an independent unit; rather, it constituted the umbrella, as it were, of the entire network of temples encompassing the Mengwi region. The temple connected three elements: the worship of the ancestors of the Mengwi dynasty; the crucial links between the gods in the mountains, the dynastic centre, and the sea; and the concern to assure fertility and the continuation of the agricultural cycle.

Taman Ayun was a large complex, surrounded by water. It consisted of three parts, hierarchically 'layered' towards the north (see Map 5). ${ }^{130}$ The jeroan, the inner court, was the highest, and at the northeast corner of it stood a closed edifice (paibon, no. 1 on the map), dedicated to the souls of the predecessors of the Mengwi dynasty. ${ }^{131}$

The mountains and the sea - dwelling places of the gods and of destructive (and purifying) powers - were represented by huge meru (literally: mountain), tower-like structures with layered roofs. Two of these (8 and 9) referred to the holy mountains in central Bali, which were of special significance because the gods of Mengwi dwelt on Mount Pengelengan, while it was believed that Lake Bratan was the source of the rivers Sungi and Penet, which provided half of Mengwi with irrigation water. ${ }^{132}$

Besides the shrines dedicated to the mountains, there were four shrines connected with agriculture. Two of these (10 and 11) represented the successive sea temples of the dynasty, while the other two (12 and 13) were specially meant to ward off misfortune from the sea that might threaten agriculture. ${ }^{133}$

129 According to Babad Mengwi-Blahkiuh (a:24) it was the first king of Mengwi who issued this order, but Taman Ayun was not built prior to the rule of the third king (Babad MengwiSedang:15-6). Taman Ayun was not the first central temple of the Mengwi dynasty. The earlier kings had added a number of shrines in the ancient Pura Sada in Kapal (Grader 1960b). Once the royal puri was established in Mengwi a small temple, pura Bekak, had been built northeast of the old crossroads, opposite puri Kaleran. The temple still exists; it has three shrines, dedicated to the mountains, the centre, and the sea. A larger temple, pura Taman Ganter, stood west of Mengwi, and was dismantled together with puri Kaleran.

130 Many provided me with valuable information on this temple. I mention only G. Ag. Gede Rai, puri Kaleran, Mengwi, G. Ag. Gede Rai, puri Selat, Selat-Sangeh, G. Ag. Gede Putra, puri Lambing, and mangku gede pura Taman Ayun. Use was also made of Grader 1960b; G. Ag. Gede Putra n.d., 'Pura Sada dan Pura Taman Ayun'; the chapter on Taman Ayun in Kumpulan n.d.: 129-36; Simpen 1958. Taman means 'garden'; Ayun means 'in front of' or 'swinging, rocking'; informants differed on the meaning of the name.

131 Characteristically, earlier ancestor shrines were not forgotten; they were absorbed into the new temple by way of pasimpangan, or representations (numbers 2 and 3 ).

132 Two meru (4 and 5) were related to the major mountains in eastern Bali, Batur and Agung.

Two others (6 and 7) represented mountains in western Bali.

133 Number 10 represented the ancient sea temple Sakenan, which in the old days, together with pura Batu Karu (7) in the Tabanan mountains, constituted the sea and mountain poles of Pura Sada (2). Number 12 represented a sea temple near Munggu meant to forestall crop failure. 


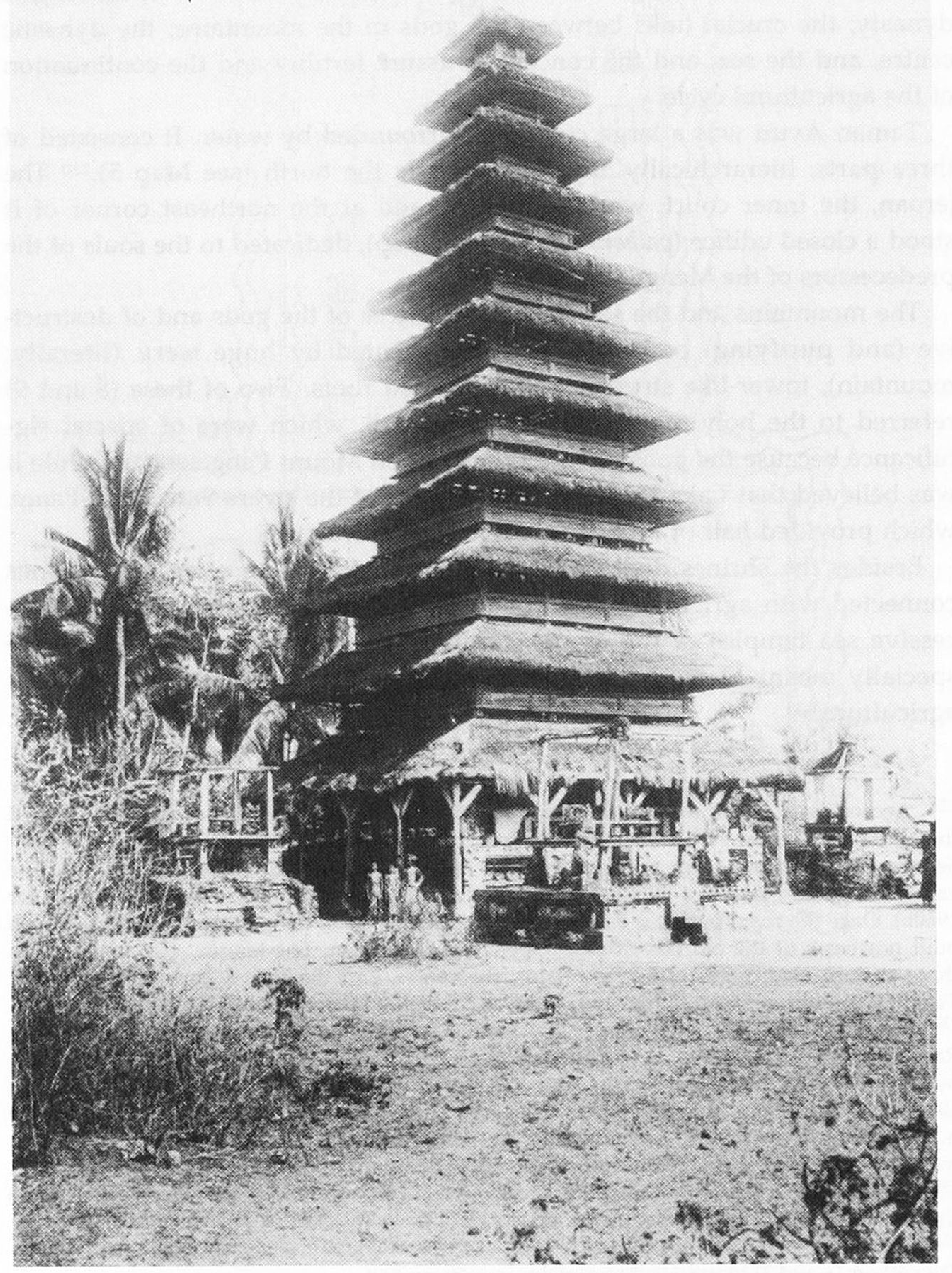

Meru in the sea temple at Jimbaran (KITLV 8335) 
Taman Ayun was not the only temple built by Agung Munggu. Some babad present explicit lists of temples built or repaired under his supervision. One such was the sea temple at Jimbaran. This was a pura ulun siwi (main temple of worship) directly connected with agriculture. The relationship between mountains, earth, and sea as marked by temples and again summarized in Taman Ayun was a crucial one. Without this temple axis, agriculture was not possible. For, as the Balinese represent it, water is a gift from the gods of the mountains, is distributed over the sawah, and flows into the sea, only to rise towards the mountains again. It is this life-giving cycle which was demarcated by temples and accompanied with royal rituals in these temples. ${ }^{134}$ Dynastic involvement with irrigation thus had its ritual complement in the main temples.

Pura Taman Ayun also represented the earth, or Mengwi, and was the centre of the imaginary axis connecting the mountains with the sea. Without this axis, life in Mengwi would not be in balance, which would render it impossible to maintain the hierarchical order. The hierarchy was meant to transcend factional conflict and was made manifest through the great public rituals held in Taman Ayun. Agung Munggu ordered the leaders of all the satellites to pay tribute to the new temple and to participate in its rituals, celebrated by the royal purohita. ${ }^{135}$ At every odalan, delegations from (ideally) all satellites would gather in Mengwi, present their offerings in the temple, and make the power of the dynasty visible. In this way Taman Ayun became Mengwi's most important symbol of hierarchy and unity.

\section{The hierarchy}

In the new royal centre of Mengwi, palace and temple constituted a dual though unequal unity of rank. The puri housed the king, who stood at the top of the human pyramid in the region. To the northeast of this puri hence higher in rank - was the pura, where the relations between gods, men, and demons were manifest. Pura Taman Ayun also symbolized the world (or Bali, or Mengwi) in that it rose up from the water (the sea) to a land of mountains (in the shape of meru) above, home of the deities. At the same time pura Taman Ayun was a replica of the Mengwi region, which the temple 'summarized' in a central way. In short, pura Taman Ayun was centre and symbol of negara Mengwi.

134 Two other shrines were also associated with warding off disease and crop failure. Number 14 was related to combating evil from the sea, the dysentery caused just prior to the rainy season (Lovric 1987a); number 15 was meant to secure fertility of the sawah around desa Mengwi.

135 During these occasions the purohita would sit on a raised platform (16), while a special shrine (17) was dedicated to his ancestor, Dang Hyang Nirarta. A separate shrine (18) was worshipped by the king's core army, the soroh Batu Bata. 
In this complementarity of puri and pura the royal hierarchy was given complete expression. While the pura could not exist without the puri, the latter was nevertheless subordinate to the former, which mirrored a higher, all-encompassing order of things. The shaping of negara Mengwi was not complete until pura Taman Ayun was built.

Although the kind of hierarchy that developed in Mengwi is less evident in other royal centres on Bali, one can question two views held by Clifford Geertz. The first view relates to his descriptive analysis of the royal puri of Klungkung as a temple (Clifford Geertz 1980:109-16). The example of Mengwi indicates that the royal puri and the negara temple, though linked, were two different edifices, the temple being held to rank above the puri. A second point has to do with Geertz's assertion that 'the driving aim of higher politics was to construct a state by constructing a king' (Clifford Geertz 1980:124). This is correct as far as it goes, but when Geertz also pictures this king as an immobile and even anonymous object of ritual (Clifford Geertz 1980:108), he distances himself too far from the historical context in which the Balinese kings lived and fought and ruled. The historical context presents us with the strong, active, and recognizable leader Agung Munggu. Once he had restored the dynastic order by violent means, had taken over the royal centre, and had completed the hierarchy by building a puri and a pura, Agung Munggu at last had his purohita inaugurate him as new king of negara Mengwi. ${ }^{136}$ Like his predecessors, his name was now Gusti Agung Ngurah Made Agung, Cokorda Munggu for short.

Whereas the first two kings strove primarily to establish their authority and to expand their might, Cokorda Munggu was particularly concerned with the internal buttressing of the royal hierarchy. He had proved himself a flexible leader who would not shun violence to avert threatening crises, and had at his disposal a strong power base and sufficient allies. In the course of subjugating the eastern region, he had established great personal authority. Furthermore, Cokorda Munggu displayed his talent as architect by creating a new centre that gave impressive form to the royal hierarchy.

Negara Mengwi was composed of a plurality of mutually interacting elements, as described above. A central position was held by the strong leaders, the warriors who triumphed in the struggle for power and at the same time went in search of their origins, so that the position they had attained might be rooted in a venerable past. Around them they gathered a loyal entourage which, in turn, bound a broader circle of followers to the

136 Babad Mengwi-Sedang:37. On the ritual of royal inauguration (abhiseka ratu), see Swellengrebel 1947 and Van der Mey 1986. Upkeep of pura Taman Ayun was entrusted to the lineage of puri Kapal Kaleran, the immediate descendants of the former king Agung Alangkajeng (Babad Mengwi-Blahkiuh a:43). 
centre. Side by side with linkages there was expulsion, for in the course of the eighteenth century thousands of slaves were exported, in exchange for which the authorities amassed riches and weapons.

Rivalry was endemic to the royal hierarchy, especially because the negara consisted of a number of more or less autonomous satellites surrounding the centre. These satellites not only repeated the 'form' of the centre, they each controlled their own manpower and, often, a system of irrigation. As aspiring centres, each of them strove for greater prestige and power, in consequence of which they repeatedly challenged the royal centre. Only a truly powerful and authoritative centre was able to contain these rivalries. The paradox, however, is that as the centre gained in power, so did a number of satellites.

Balinese politics was not confined to an elite far removed from the people and exclusively in pursuit of obsessions of its own. Because of the system of followers and the nobility's involvement in irrigation, and because of the repeated wars, the people of negara Mengwi, from high to low, were all involved in the affairs of the nobility. They were ritually involved, too, for the temple system and regional ritual conferred on the negara a higher, all-encompassing form and ideal unity. It was in this connection that the purohita exercised their proper function of celebrating the royal hierarchy. Of this royal hierarchy, in turn, the central temple Taman Ayun was the highest expression.

Nevertheless, the fate of the hierarchy depended on the quality of the central leadership. Just as the irrigation system would work only as long as the main dam held, so also nothing but a strong royal centre could uphold the complex hierarchy called the negara. It seemed as if a time of order and peace was about to come to Mengwi. Such hopes were idle, however: the very rise of the hierarchy contained the seeds of the kaliyuga, a time of chaos and destruction. 



\section{CHAPTER III \\ Crisis, 1770-1823}

In 1770 Cokorda Munggu was one of the most powerful kings on Bali. Except for Tabanan, every lord, from Blambangan in East Java to central Bali, acknowledged him. ${ }^{1}$ Viewed schematically, negara Mengwi comprised three kinds of areas. The first consisted of the remote satellites Jembrana and Blambangan to the west, Buleleng to the north, Blahbatuh and Kramas on the eastern side, and Badung in the south. Relations with these 'outer regions' were uneasy, the king was hardly able to wield direct and lasting influence in these places. This was also true, to a somewhat lesser extent, of the second type of area, the satellites within the Mengwi region. Although these were less remote, the king did not completely control these satellites either, since he could not appoint their leaders directly. He was free to appoint people only in the area that belonged to him personally, the royal domain including the immediate vicinity of Mengwi, a few localities in east Mengwi, and the southern coastal area around Munggu. The people and the sawah in this domain were for the most part controlled by mekel and sedahan having direct ties to the king.

Cokorda Munggu had put his anak astra in charge of part of the southern area. ${ }^{2}$ This 'illegitimate' son controlled a strategically and economically important region east of desa Munggu. Its strategic importance lay in its being a buffer against Badung, where a local noble clan was gaining in strength. The region's economic importance was due to its vast sawah plains which produced a sizeable agricultural surplus. The anak astra was given the right to call himself Gusti and to establish a jero in desa Padangluah.

Fifty years later this region would be at stake in a complex of conflicts which caused the Mengwi dynasty to lose much of its power. In the denouement of this crisis it was the leader of jero Padangluah who would play a decisive role. This happened during the extremely confused fighting in 1823 near Padangluah, in consequence of which the Mengwi hierarchy virtually

1 Cokorda Munggu was allied to the king of Tabanan through marriage. The fact that the Tabanan woman had married 'upwards' and no Mengwi woman married 'downwards' in return is indicative of his higher status. See Appendix.

2 The anak astra was Gusti Gede Meliling. According to Babad Mengwi-Sedang (:18-9) and Babad G. Gede Meliling (:1-2) he was conceived by a jaba wife of the lord of Bun on one of the occasions when Agung Munggu (the later Cokorda Munggu) lodged at Bun. 


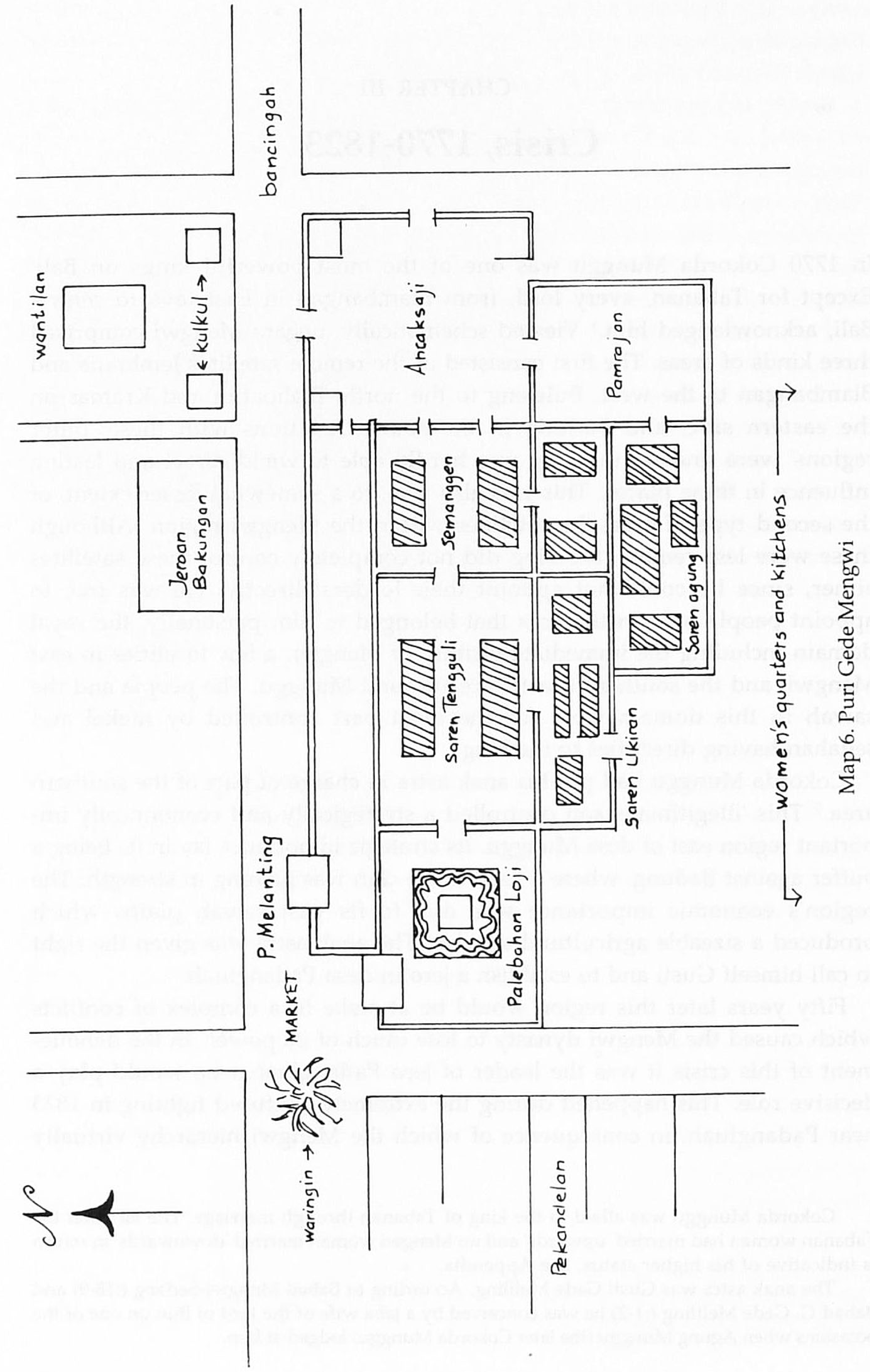


collapsed. These events will be recounted in section 3, with emphasis on the interaction between centre and satellites and on how the royal hierarchy was overrun in the end by conflicts.

The crisis confronting the Mengwi dynasty was closely tied to economic change. This is the theme of section 2, which also points out that the Balinese political system needs to be seen in the wider context of patterns of trade throughout the Archipelago.

But before I describe the complex of factors and the course of the crisis, I will, in section 1, discuss the ambivalent nature of negara Mengwi. After its violent founding and tempestuous expansion, the Mengwi dynasty proved unable to achieve stability. Rather, a chronic instability ensued, characteristic of the Balinese polity as a whole.

\section{The ambivalent centre}

Cokorda Munggu died in the 1770s. I turn now to a review of his legacy, which, in addition to a large number of satellites, included the centre. What did it look like? Who lived there? Who was in control? To what sort of tensions was it subjected?

The royal puri of Mengwi must have been one of the most beautiful on all of Bali. ${ }^{3}$ Situated to the southwest of the main crossroads and straddling a man-made mound, it was subdivided into walled quarters and yards placed in hierarchical order. Beyond the walls was the bencingah, the outer square which surrounded the crossroads. In the north corner stood two wooden slit gongs (kulkul) and the large, open hall, or wantilan, where at set times cockfights were held. In the shade of the trees were some food stalls, invariably frequented by passers-by and puri servants who would exchange the latest bits of news and gossip. Out of respect for the puri, equestrians were to dismount and cross the bencingah on foot.

West of the puri, near a lesser crossroads, was the market or peken where every day, in the shade of a great waringin tree, vendors and Chinese merchants sold eatables, textiles, pots and pans, and exotic items. Near that market and almost leaning against the high west wall of the puri were the small houses of the puri servants, pekandelan or roban, those who obtained their meals from one of the puri kitchens (De Kat Angelino 1921b). In a

3 P. Dubois, KITLV, H281, letter III; Jacobs 1883:200. The following description is based on scattered data from nineteenth-century travel accounts: Van Bloemen Waanders 1870; Van den Broek 1835; Graves 1967; Helms 1882; Van Hoëvell 1849-54; Jacobs 1883; Van Kol 1903; Medhurst 1858; Olivier 1827; Pleyte 1901; Sosrowidjojo 1875; Zollinger 1845, 1849; ARA, MvK V13-10-1893-Z12, report J.H. Liefrinck 25-5-1893. It is true that not all of these sources relate to Mengwi; nevertheless, they allow us to construct a picture that approximates the nineteenth-century court at Mengwi. I owe special thanks to Cokorda Gede Oka of puri Gede, G. $\mathrm{Ag}$. Gede Rai of puri Kaleran, and I Ketut Misma of Mengwi for their information. 


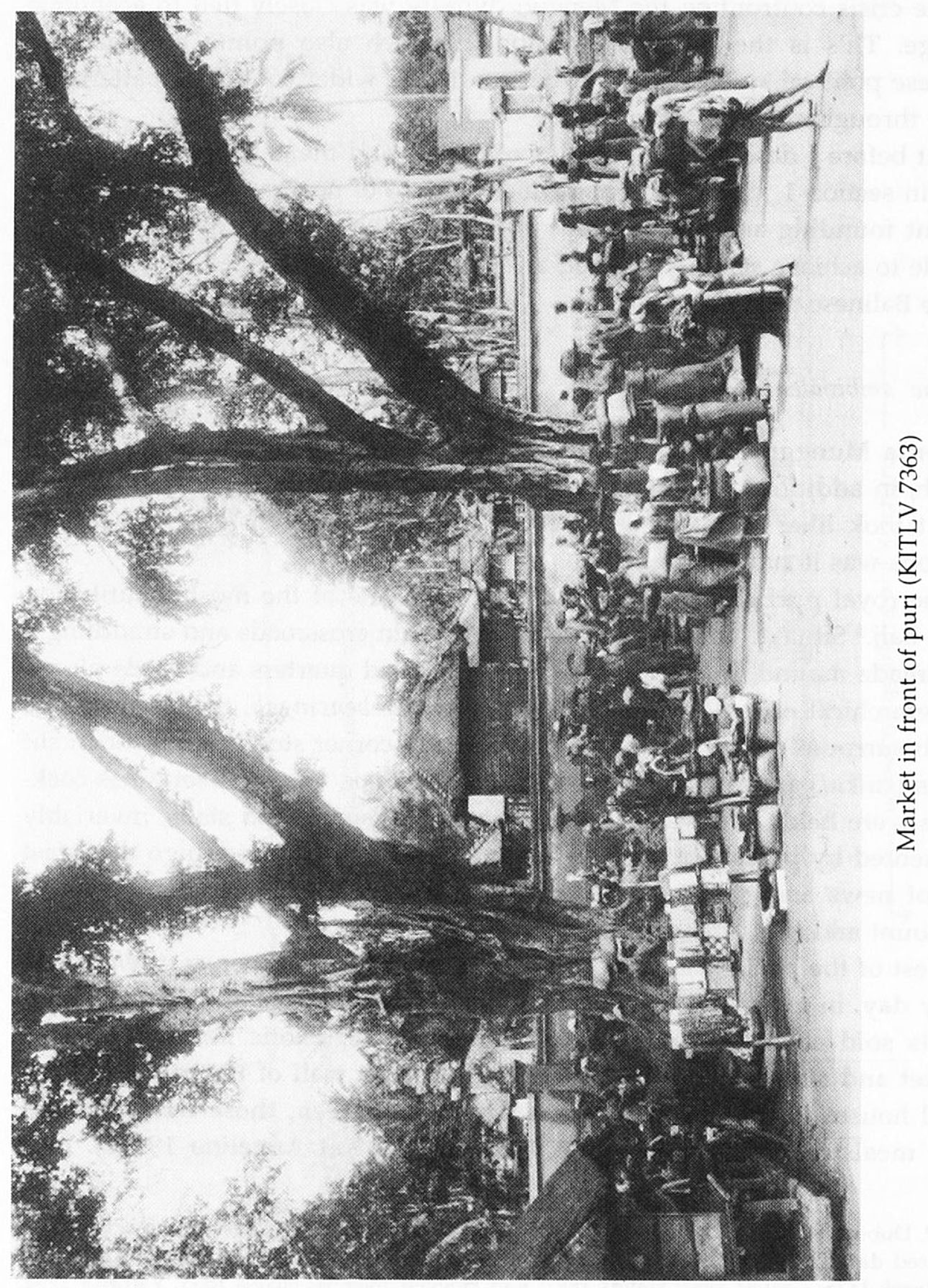


wider circle around the puri lived the prabali, the warriors, and other puri followers.

Upon entering the puri, those who did not belong to the royal entourage had to check in at the inner square, the ancak saji, with its two open gates in the northeast corner of the puri. This court marked the transitional zone between the outside world and the inner part of the puri. In this inner square stood some open pavilions (balé). Here, during performances, the king and his retainers would be seated and the orchestra would play. At the corners of the court were elevated pavilions (balé bengon) looking out over the outer square.

West of the inner court were three areas, each serving a specific purpose. One was the semanggen, where deceased members of the royal family would lie in state prior to cremation. Next was the patandakan, where the king conferred with his subordinates, although the inner square was used for this as well. Finally, the northwest corner housed the palebahan loji, a small pavilion surrounded by water, where the king could withdraw to meditate.

In the centre of the puri were the royal quarters or saren, rectangular, walled yards with open and shuttered pavilions. Around 1820 the king, his mother, and his grandmother each occupied one of these yards. East of this living area was the puri's house temple, or pamrajan, where members of the dynasty's core lineage worshipped.

Following an imaginary loop from the inner court to the house temple, the various parts of the puri were located in hierarchical order. The 'lower' half of the puri housed the many lesser royal wives and the kitchens. In separate yards in this section lived the puri's parekan, mostly sons of nearby lords staying temporarily at the royal centre to become acquainted with courtly culture. They were the king's retinue whenever he went out, and occasionally they would carry out confidential tasks for him.

The least part of the puri was located in the southwest corner. Here the pigs were kept and low-ranking women were sent here during menstruation.

From the outside the puri looked imposing: its lofty walls decorated with thousands of Chinese plates, green porcelain ornaments built into the walls, and skilfully sculptured gates and doorways. Once inside, however, one noted abandoned yards, dilapidated pavilions, broken-down gates, and entire sections of wall caved in. Moreover, depending on the season, the place was either hot and dusty or humid and muddy. Almost every nineteenthcentury European traveller voiced an identical complaint regarding the lack of hygiene in royal puri. They were amazed to see 'the small, dirty, stinking sties these Majesties use as their living and sleeping quarters [...]. In truth, 
the lodgings of the simplest Javanese villager are much to be preferred.' 4

The high-born were wont to begin their day late, some not until eleven, while others might not rise before dusk, sleeping late to catch up from the night before. But the servants would be at work from an early hour, making sacrificial rounds to ward off evil spirits, a pack of dogs following them, ready to pounce on a likely morsel from the offerings. When a special event was about to take place, a ritual, for instance, the place was like a beehive; puri servants and followers from elsewhere would rush to and fro to repair the walls, gates, and pavilions, to add decorations, or to roast the meat. Women would be busy preparing offerings. The kitchens, too, were crowded places at such times, since large quantities of food had to be prepared for the feast and for all those working in and around the puri.

One daily occurrence was the procession of young puri women who, accompanied by their servants and chaperoned by older women, left the puri to bathe at a place reserved for this purpose.

The high-born men, having risen towards the end of the morning and taken a bite to eat, wearing a kain (a longish cloth draped around the hips) only, would converge on one of the puri's outer courts. Here long rows of baskets contained the royal fighting cocks, often two hundred or more. But other men, especially the older ones, would go to the house temple first, to pray and meditate until the noon hour. If on a particular afternoon no cockfights were held in the wantilan opposite the puri or somewhere else in the neighbourhood, the men spent a large part of the day looking at the cocks, while the king and some of his confidants argued about the merits of the animals, or else sharing information on pretty girls they had recently spotted, or perhaps discussing current power configurations and intrigues.

When a cockfight was to be held, either on the occasion of a temple ritual or when the puri sought to replenish its cash by taxing the bets, the king and his retinue went among the crowd, looking at the fights and joining in the betting. Although the difference in rank between the king and the people remained evident, the physical distance was very little. The king was near and readily recognized. Betting was serious, the stakes enormous, and the king, too, might sometimes sustain heavy losses. If he took these with good grace he gained additional prestige. ${ }^{5}$

4 Jacobs 1883:196, 234. These observations are, of course, biased in favour of the Javanese aristocracy's colonial standards of living.

5 On the whole, the king won more than he lost. But if a jaba, who could not refuse to participate, lost, he might well be held as hostage or slave. In the latter days of the epoch of the kings, Henri van Kol attended a cockfight at which the Cokorda of Ubud 'measured his stake of rix-dollars by the bushel in order to save time counting them [...]. Sometimes he staked petrol cans full of rix-dollars, and often he would lose a fortune without twitching a muscle.' (Van Kol 1914:325, 346.) 
In the afternoon the king might go to one of the elevated pavilions in the inner court, which afforded a view of what went on outside the puri. The effect was twofold: the king would be entertained by the spectacle before him, but also, those outside could see him being visibly present to his subjects. From this place he would dispose of special cases and issues and ratify sentences pronounced by the brahman judges. On other occasions the king went outside the puri to sit on a stone specially reserved for him. Now the people could approach him, though they would usually not find it opportune to do so directly, and would ask their mekel, or one of the prabali in attendance, to speak for them. ${ }^{6}$

It was not until evening that the court really came alive. Around six dusk set in and the air cooled. Often, musicians performed until the small hours of the next morning, while the king and his group would sip a drink or smoke opium, gamble, tell jokes, or embark on intrigues. In the inner court there were frequent wayang and dancing performances for the king and his retinue. The king chose a seat in a separate pavilion. Everybody would be permitted to enter the inner court, so that on such occasions the king was near to his people again, and together they relived the classic stories from which the performers took their themes: dramatic renderings of the bond among gods, kings, and common folk. In the midst of daily chores and cares, expression was given to a hierarchical order capable of resolving conflict.

In addition to 'classics', the performances included markedly erotic dances. Often the dancers were the young boys (gandrung) who doubled as catamites for the puri lords. In addition, there were beautiful dancing girls and the girls recruited by puri agents for the royal harem. At times the king would have them accompany him as, far into the night, he retired at last. ${ }^{7}$

One remarkable difference as compared to the eighteenth century is that the nineteenth-century Balinese king tended to remain 'at home'. In the nineteenth century, the kings of Mengwi no longer undertook the long and

6 Unlike Thailand, for instance, where the distance between the king and his subjects was far greater (Akin 1969:41). In his analysis of the Balinese negara Geertz (1980) pays no attention to the physical proximity of king and people. Geertz derives much of his information from Tabanan, and could well have taken a nineteenth-century Tabanan king as example: Gusti Ngurah Agung, who ruled for an incredibly long time (1843-1903), was known for his daily habit of mixing with the people 'like an ordinary mortal' (Jacobs 1883:222, 227). The king was an active ruler, frequently holding court in the outer yard of his puri before noon, 'where all and sundry subjects might freely draw near to voice their complaints or requests' (Liefrinck 1921:11; see also Schwartz 1901a). Moreover, the king spoke Malay, spoke some Chinese, and knew a few English and Dutch words (ANRI, Bali:4.22, political report 1853). For a comparably imposing figure, Gusti Ngurah Kesiman, the strongman of Badung (18281860), see Schulte Nordholt 1980:71-104, 1981a. Stone seats are considered to be sources of power.

7 Royal personages frequently suffered from chronic indigestion because of inordinate use of opium, and were plagued by venereal disease because of their various sexual contacts. 
restless campaigns to the west and north of Bali and to East Java on which their forebears embarked. For the most part they stayed put in their puri, leaving the Mengwi region only in highly exceptional cases. If the king went forth it was to visit nearby lords, cockfights, or temples, or to engage an enemy.

When a king left the puri, his movements were attended by customary pomp and circumstance. At the same time things were quite relaxed, as a description from 1818 tells us:

'The presence of a contingent of the lesser wives befits the royal station; these accompany him publicly, to carry his betel box, writing materials, toilet utensils, mirrors, fans, and so on [...] while two or three hundred men who carry pikes, shields, and swords, most of them sons of nobles and important chiefs, make up the vanguard. The comport of this retinue of men-at-arms is uninhibited and easy except when His Highness addresses them, at which time they fall to their knees and respond to every word or command by raising their joined hands to their face, paying instant homage. On other occasions they laugh and loudly applaud every witty or well-turned phrase uttered by the king, meanwhile free to add a jest of their own (and unhesitatingly doing so), the king often sharing in their merriment.' (Van den Broek 1835:200-1.)

Another visitor added the observation that during these excursions the king was accompanied by payung (sunshade) bearers, and that the whole 'did not wear the aspect of stiff stateliness in walk and demeanour [one encounters] on Java'. On the contrary,

'the numerous following of the Balinese monarchs is a merry company, frolicking along the path. Frequently, the king himself joins in their discourse and will laugh as uproariously as they at their uncouth jests.' (Olivier 1827:469.)

These descriptions are exemplary for the ambivalent nature of the royal centre. The centre displayed the status and the pomp which is part and parcel of a hierarchy, but at the same time the entire royal system was deeply rooted in a popular context; respect and intimacy were two inseparable aspects of royal authority.

Even so, the king had to be constantly on guard. There was always the threat of a sudden attack on his position. This note of warning is sounded in the poem Bagus Diarsa:

Let your discourse be enlightening,

do not hide your meaning;

consult with your underlings,

and you will touch their hearts.

[...]

Permit no insolence among your subjects,

they would hold you in low esteem.

Be alert to equality and difference;

let their speech be seemly, 
their words sincere, courteous, clear, and friendly.

All this will prompt them to behave properly, instil obedience, and they will spring no surprises on you.

(Hooykaas-Van Leeuwen Boomkamp 1949:100-1.)

Certainly the hierarchy was an acknowledged model, but it was uncertain who stood at its pinnacle and how long that would last. Moreover, Bali housed several negara, each disputing the others' power and prestige, and internally these negara were a sum total of rival greater and lesser lords. In a political system as turbulent as this, royal authority, if it meant to survive, simply had to be highly visible and physically assertive. After all, a king was successful if and only if he manifested the hierarchical order and simultaneously was able to mobilize popular support.

\section{The widow}

'On Bali, intrigue is a transcendental art', Pierre Dubois wrote in one of his letters recounting his stay in southern Bali. ${ }^{8} \mathrm{He}$ is referring to the snarled intricacies in which royal Balinese centres were incessantly involved. Puri Gede Mengwi was no exception to this. Within its walls, too, intrigues flourished, most of them relating to Ayu Oka, the padmi of Cokorda Munggu. To be sure, when the Cokorda died there was a son, but he was a mere child living in the shadow of his mother, the regentess, a situation that was long perpetuated, as Ayu Oka retained the dynastic leadership inherited from her husband for more than thirty years. ${ }^{9}$

Ayu Oka's power base rested on three elements. First, she continued her husband's ways by making his entourage her own, honouring the tried and true followers from Mengwi and Munggu. Second, she herself came from puri Kaba-Kaba, a powerful satellite and ally of the dynasty. This in itself provided her with a secure 'home base', but the bond was strengthened even further when Ayu Oka arranged for the dauphin to marry a woman from puri Kaba-Kaba. ${ }^{10}$ Third, Gusti Ayu Oka had followers and land of her own in Mengwi, since, as a rule, padmi retained control over possessions brought in when they married, which ensured independence at court (Korn 1932:498-9).

The regentess was not wrong to rely on her entourage. About 1780 the lord of Badung aspired to distance himself from the Mengwi hierarchy and

8 KITLV, H281. From 1828 to 1831 Dubois lived in Kuta, in the south of Badung, to buy slaves meant to serve in the colonial army in the Java War (1825-1830). Dubois was an astute observer and the first European to engage in fieldwork avant la lettre on Bali.

9 The son's name was Gusti Agung Putu Agung; Samboengan Babad Mengwi:1.

10 See Appendix. This meant that in the fourth generation, too, a man of the dynasty's centre took a woman from Kaba-Kaba as padmi. 
swooped down on the sawah region of Padangluah. According to one of the Balinese sources, this is what happened:

'One day, the lord of jero Padangluah [the anak astra of the late Cokorda Munggu] took some of his people and left for Gumasih dam near Mambal, to repair it and to check the conduits which led the water to the sawah. When they were at work, word came to them that during their absence Padangluah had suddenly been overrun by people from Badung. The way home was cut off. The workers at the dam hastened to inform the royal puri of Mengwi of this calamity. Ayu Oka immediately moved into action. She caused the great kulkul to be sounded, and the warriors and mekel of Mengwi gathered at the puri. Ayu Oka came forth in person and earnestly beseeched her faithful warriors to help her, tearfully imploring them to do so. They responded by declaring their unwavering loyalty, even if it cost them their life.

That very afternoon the warriors marched on the Badung aggressors, Ayu Oka accompanying them. Beautifully dressed, seated in a sedan chair, and brandishing the royal kris she went, surrounded by her warriors, who were well armed with guns, blowpipes, and lances, to meet the enemy.

The first charge was a mighty one, but the men of Badung stood firm. Additional troops were called out from Mengwi and another attack was launched. Darkness was setting in. In the ensuing chaos those of Badung finally fled for their lives, which many of them lost anyway as they stumbled through the night and near the Badung border fell into traps lined with sharp bamboo stalks. ${ }^{11}$

Ayu Oka had successfully appealed to the warriors in her entourage; the action had been swift and efficient. This time, the crisis had been coped with. But this did not mean that the conflict with Badung was now resolved: this round of fighting was but the first in a long war that was to continue for more than a hundred years. The stakes were complex. The repeated clashes related not only to personal honour, but also to revenues from the Badung harbours and to control over the southern sawah and Gumasih dam.

The conflict with Badung points up the rise of new power centres on Bali which contested Mengwi's superiority. Ayu Oka was faced with the task of defending Mengwi and upholding the authority of the royal centre. Her efforts were only partially successful. According to Balinese sources, she committed two errors in quick succession, in consequence of which Mengwi came to be threatened not only from the south, but also from the west and the north.

All through the eighteenth century the alliance between Mengwi and Tabanan had been stable. The year 1793 marked the end of this stability. A violent internal power struggle broke out in Tabanan, and the cornered king

11 Taken from the Kidung Nderet c:41-9. I comment on its historical reliability in section 3 below. Regarding the noble house of Badung at the time, see Schulte Nordholt 1980:63-71. In 1768 Badung was still subordinate to the king of Mengwi, as evidenced in a joint communication on the part of the king and the lords of Badung sent to Batavia that year (Kats 1929). Soon thereafter, in 1771, the conflict between Mengwi and Badung erupted (De Jonge XI:142, $310)$. 
of Tabanan appealed to Mengwi. An elite of Mengwi warriors was dispatched to put down the insurrection and to reinstate the king. In this way the king of Tabanan became indebted to regentess Ayu Oka. But now she made the mistake of unilaterally determining the price for services rendered, and annexed a number of desa just across the Tabanan border.

In the ensuing conflict Mengwi prevailed. Mengwi troops penetrated deeply into Tabanan, which, its forces outnumbered, retreated. Although the 'peace' was sealed with a wedding, relations between the two former allies were permanently strained. On either side of the border fortresses were built, suspicious watchmen looking out across the gorge of the river Sungi. 12

A year later, in 1794, the crown prince of Mengwi died. Since he had sired no high-born sons, Ayu Oka took over entirely and would remain queen of Mengwi up to 1807, which demonstrates that in the Balinese political system women could be very powerful indeed. ${ }^{13}$ Before long, however, she erred a second time.

Towards the end of the eighteenth century, the house of Dewa Manggis had risen to power in the region around Gianyar, east of negara Mengwi. Its leader was Dewa Manggis DiMadia, a frequent guest in puri Gede Mengwi. ${ }^{14}$ In addition to being one of the rising rulers on Bali, he was an excellent gambuh dancer. No actor played the part of Panji more seductively than he, and as deep-voiced Prakarsa his appearance was imposing. In brief, Ayu Oka fell for him and he became her lover. This liaison was far from inconsequential, for Ayu Oka was so taken with her lover that affairs of state were forgotten; she became careless even about her position as queen of Mengwi. One source reports that she acted like a smitten village maiden and thus endangered the negara. For example, she gave Dewa Manggis two priceless heirlooms of the dynasty, one of which was the headdress worn by Panji during gambuh performances. The point is that this was not only a beautiful work of art, but also a pusaka, an object endowed with royal potency, which

\footnotetext{
12 Babad Mengwi-Sedang:18,37-9; Babad Arya Tabanan 1974:69-87. According to Babad Mengwi-Sedang, this conflict took place at the time of Cokorda Munggu, but Babad Arya Tabanan mentions the son, G. Ag. Putu Agung, and the year 1793. The date mentioned (Saka $1615=$ AD 1693) is a century too early; most likely the first two digits, 16, were erroneously added later. A comparison with the royal genealogies of both Tabanan and Mengwi indicate that this should be 1793. The 'peace wedding' was between a grandson of Ayu Oka and a high-born woman from Krambitan. See Appendix.

13 De Jonge XII:320. She derived this prerogative from being the widow of the last installed king of Mengwi. Ayu Oka was no exception: in Klungkung and in Badung during the first half of the nineteenth century women held great power (Vickers 1982; Wiener 1990; Schulte Nordholt 1981a:22).

14 For Gianyar during this period see Mahaudiana 1968:31-4; Schulte Nordholt 1980:57-61; for Dewa Manggis DiMadia (1793-1822) see De Jonge XII:305; Van der Kemp 1899:361, 364.
} 
meant that Ayu Oka, at the heart of the dynasty, was no longer in control of herself and was in danger of losing her power. ${ }^{15}$

The significance of this soon became evident when Dewa Manggis, bent on expanding his domain in Gianyar, attacked Blahbatuh and Kramas, the eastern satellites of Mengwi. The lord of Blahbatuh requested help from the Mengwi centre, but Ayu Oka did not respond. She left the lords of Blahbatuh and Kramas to their fate and relinquished the satellites (Sugriwa 1975:110-4).

The troubles besetting Padangluah, Blahbatuh, and Kramas show that in times of need these satellites were highly dependent on the centre as the only source of aid. Failure to meet the obligation of the higher to the lesser endangered the position of the dynastic centre. Ayu Oka brought down upon herself a crisis of confidence which in the end would cause the Mengwi hierarchy to totter.

\section{A difficult succession}

Since Cokorda Munggu's death there was still no new king in Mengwi. The matter was beginning to take on some urgency: Ayu Oka was ageing. The core lineage of the dynastic centre was in jeopardy, since high-born sons had died young. Ayu Oka resorted to the expedient of putting forward as pretender a low-born son of the deceased crown prince. ${ }^{16}$

The intervention was needed because in the royal puri a faction was being formed around Agung Putu Mayun, son and namesake of the man murdered at Bun. Formally he was the second person in the dynasty, the 'Younger King' (yuwa raja). By introducing her own grandson in time, the regentess was able to prevent Agung Putu Mayun from becoming the new king. In addition, she managed to bind this potential rival to her by having him marry a daughter of Cokorda Munggu. This union was the first instance in the Mengwi dynasty of preferential marriage among the nobility, whereby the man marries his father's brother's daughter to continue the lineage. ${ }^{17}$ This marriage remained without issue; consequently, Agung Putu

15 Babad Arya Manguwi:29-30. Panji and Prakarsa are two protagonists in the Malat stories enacted in gambuh performances. I wish to thank Adrian Vickers for pointing out to me the significance of the headdress. On the gambuh performances, the malat, and the figures of Panji and Pakarsa, see Vickers 1986a.

16 This was Gusti Alit Raka, born of a jaba woman. His prestige was shored up artificially when he was adopted by the padmi widow of the late Putu Agung of Kaba-Kaba. This adoption allowed the two women from Kaba-Kaba to strengthen their hold on the centre of the Mengwi dynasty. Babad Mengwi-Sedang:20-1; Babad Mengwi-Buleleng:8b-9a; Lekkerkerker 1926:327; Information from G. Ag. Gede Rai, puri Kaleran Mengwi, G. Ag. Ajeng, puri Labah, Kedampal. See Figure 4 and Appendix.

17 H. and C. Geertz 1975:133; Korn 1922b. G. Ag. Putu Mayun married Ni G. Ayu Nyoman Mayun. 


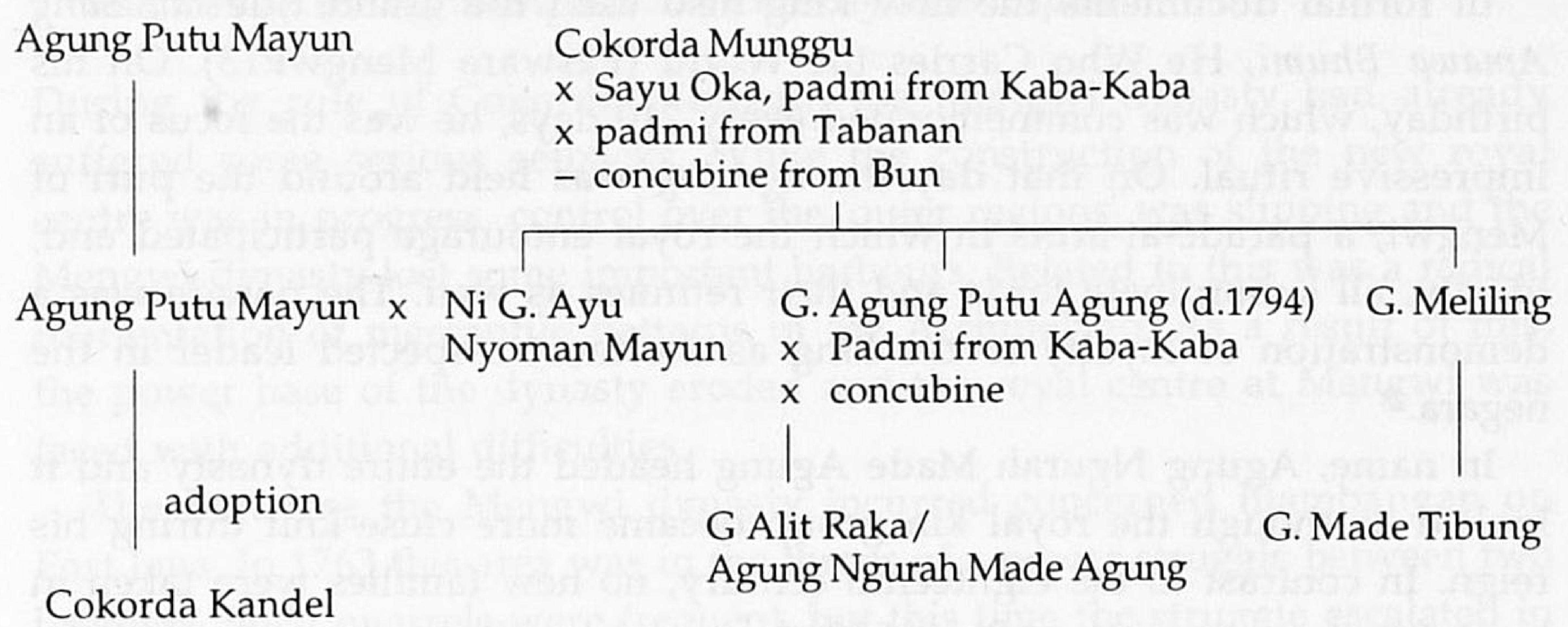

Figure 4. The succession of Cokora Munggu

Mayun adopted a scion of the high nobility of Sukawati. ${ }^{18}$ Although of higher blood, this boy could not aspire to the throne of Mengwi as he continued to be regarded as an outsider. His separate status at the Mengwi court was further illustrated by the fact that he lived outside the royal puri. To be sure, his quarters in no way amounted to a new puri; nevertheless, a separation was effected which would eventually give rise to the rival puri Mayun.

In spite of his low birth, Ayu Oka's grandson was preferred as new king of Mengwi. After all, in the male line he was a direct descendant of Cokorda Munggu. This preference for perpetuating patrilineal descent over the prestige of high birth was fairly general in those days. ${ }^{19}$ Even so, the provenance of the new crown prince was not altogether forgotten. In this connection Friederich observed: 'Among the elite it is often said that the land of Bali will perish, because the soedra [jaba] or the children of soedra mothers become kings' (Friederich 1850:33).

Notwithstanding his poor background, the new crown prince was installed as the new king of Mengwi, probably in $1807 .{ }^{20} \mathrm{He}$ assumed the official name Gusti Agung Ngurah Made Agung. It was only with great difficulty and improvisation that the centre of the Mengwi dynasty had managed to survive and to retain the throne.

18 Samboengan Babad Mengwi:4; Babad Sukawati a:32-6; Babad Sukawati b:15-23. The adopted son was Cokorda Kandel. This adoption was occasioned by an internal struggle in the noble family of Sukawati, after which part of the lineage had sought refuge in Mengwi and regained its territory from there. At that time an intimate bond was forged between the Mengwi dynasty and the lineage of puri Ubud of the Sukawati clan. The leader of puri Ubud was a half-brother of the Cokorda Kandel adopted in Mengwi.

19 In Badung, for instance, similar adoptions and successions occurred as well (Schulte Nordholt 1980:71-82).

20 Babad Mengwi-Sedang:25; KITLV, Coll. Korn:175, Paswara Mengwi:15-7, which mentions the year that power was transferred. 
In formal documents the new king also used the grand title Ida Sang Amawa Bhumi, He Who Carries the World (Paswara Mengwi:13). On his birthday, which was commemorated every 210 days, he was the focus of an impressive ritual. On that day the ngrebeg was held around the puri of Mengwi, a parade-at-arms in which the royal entourage participated and, ideally, all subordinate lords and their retinues as well. The parade was a demonstration of loyalty to the king as the most respected leader in the negara. ${ }^{21}$

In name, Agung Ngurah Made Agung headed the entire dynasty and it looked as though the royal kin group became more close-knit during his reign. In contrast to the eighteenth century, no new families were taken in by way of annexation. After 1800 the number of marriages within the dynasty increased. Rather than marrying daughters of unrelated allies, the members of the dynasty preferred marriages with women from related lineages. ${ }^{22}$ The dynasty seemed to be closing in on itself.

Moreover, the nobility began to manifest itself more as a closed group. If royal decrees dating from those days can be used as a guide, it appears that in 1801 and 1807 extensive prescriptions were formulated regarding the hierarchical order in Mengwi. ${ }^{23}$ The tragic death of Cokorda Munggu's daughter is a telling reminder of how seriously the royal centre took these prescriptions. She was married to her cousin but had a secret love affair with a jaba man. Such infidelity was unpardonable; she was burned alive on the burial grounds of desa Mengwi. ${ }^{24}$

It takes more than rules and ritual to uphold a hierarchy, however, nor could threatening conflict be averted by the royal pomp of puri Gede Mengwi. Certainly, Agung Ngurah Made Agung had been installed as king in strict adherence to proper ceremony; the question was whether he could exact the respect his title implied. 'He Who Carries the World' had to beware lest the negara slip through his fingers. As Dubois astutely remarked: 'The king's power solely rests on subjects who do his bidding' (ANRI, Bali:6.51).

21 Information from G. Ag. Gede Rai, puri Kaleran Mengwi; see also Korn 1932:302; Van der Tuuk 1897-1912, IV:689.

22 As indicated by the marriages of the two male representatives of the Mengwi centre. Four of the six noble wives of Cokorda Kandel and the new king came from within the dynasty. See Appendix. The royal kin group or sametonan (people of one origin) resembled a conical clan with agnatic descent. Members of the clan practice sidikara, which means that they obey specific rules with regard to the sharing of food, the use of language, the ritual obeisance to deceased clan members of senior rank, and the worship of clan ancestors (Gerdin 1981; Wiener 1990:139-43).

23 KITLV, Coll. Korn:175, Paswara Mengwi:1-17. The venerable provenance of these rules from old Majapahit was given explicit prominence (Paswara Mengwi:14).

24 Babad Arya Manguwi:55b. The victim was Ni G. Ayu Nyoman Mayun; see Figure 4 and note 17 above. 


\section{The loss of the harbours and the curse of Mas Sepuh}

During the rule of Cokorda Munggu, the Mengwi dynasty had already suffered some serious setbacks. While the construction of the new royal centre was in progress, control over the 'outer regions' was slipping and the Mengwi dynasty lost some important harbours. Related to this was a radical reorientation of mercantile patterns in the Archipelago. As a result of this, the power base of the dynasty eroded and the royal centre at Mengwi was faced with additional difficulties.

The first loss the Mengwi dynasty incurred concerned Blambangan on East Java. In 1763 this area was in the throes of a power struggle between two brothers. Such quarrels were frequent, but this time the struggle escalated in an unprecedented way because the VOC became involved. ${ }^{25}$ One of the quarrelling parties appealed to the VOC for help, in response to which Batavia decided to intervene. This action had nothing to do with Dutch interests in Balinese politics, but was inspired by the fear that British merchants might take over Java's eastern region. Various parties entered the ensuing war: Chinese, Buginese, and Mandarese merchants cum pirates, Madurese auxiliaries of the VOC, supporters of the different Blambangan factions, and, of course, the troops deployed from Mengwi.

The Mengwi units, their limited manpower coming from Jembrana and Kaba-Kaba, were unable to regain control of Blambangan. They were no match for the VOC troops, whose cannon spelled invincible superiority. 'These are great Dewa [gods], no mere mortals; we could not stand against their thunder and lightning', the Balinese footmen allegedly reported. This war, and all the phenomena of devastation in its wake, crop failure, and epidemics, decimated the Blambangan population. The last of the Hindu strongholds on Java was destroyed; Mengwi might was permanently ousted from East Java in $1771 .^{26}$

The Mengwi narratives are completely silent about the violent war in Blambangan. One aspect of the conflict, however, does get extensive coverage. This relates to an event in Mengwi concerning the murder of Mas Sepuh, one of the two quarrelling brothers from Blambangan. ${ }^{27} \mathrm{He}$ was suspected of being in secret communication with the VOC. The king ordered him to appear at Mengwi, which Mas Sepuh did in 1764. Upon arrival he and his retinue were taken into custody and, despite his repeated requests,

25 I will not expand on the conflict in Blambangan. See Lekkerkerker 1923a; Pigeaud 1932; Bassett 1964; Kumar 1979; Arifin 1980; ARA, Coll. Van Alphen-Engelhard 1916:149/150, report Wikkerman 1805.

26 ARA, Coll. Van Alphen-Engelhard 1916:149/150, report Wikkerman 1805.

27 Babad Mengwi-Lambing:51-2; Samboengan Babad Mengwi:1-2; information from Ida Ketut Sindu and I Ketut Misma, Mengwi, G. Ag. Oka Pabean, Denpasar. 
he was not admitted to the king, who was planning to get rid of him. At that time an epidemic broke out in Mengwi and the calamity was blamed on Mas Sepuh. Even though it seems likely that Mas Sepuh had not been overly loyal to the king, the babad emphasizes his innocence. It was the Mengwi dynasty, rather than Mas Sepuh, which was about to contract guilt. After some time had passed, the king ostensibly allowed Mas Sepuh to return to Blambangan as a free man. The lord of puri Sibang and a mekel from desa Munggu were his escorts. But as soon as the small party arrived on the beach of Seseh, the plot was revealed: Mas Sepuh was murdered. Just before he died, however, he cursed the puri of both Mengwi and Sibang, predicting the imminent demise of the Mengwi dynasty and its power. ${ }^{28}$ The message of the story is loud and clear: Mas Sepuh's curse resonated in Mengwi history until the end of the nineteenth century and marked the end of a period of expansion and the beginning of a period of decline and crisis.

From the east, too, Mengwi's might was challenged. In Karangasem a strong dynasty was on the rise, having conquered Lombok in the course of the eighteenth century. ${ }^{29}$ Expansion towards the west came next, and before the end of the century large parts of Buleleng had been taken over. ${ }^{30}$ As far as can be determined, not a single action was undertaken by Mengwi to put a stop to Karangasem penetration. Evidently the Mengwi dynasty was no longer able to retain its northern satellite; the action radius of the royal centre had shrunk.

Lack of response on the part of Mengwi invited further attacks. In the first decade of the nineteenth century the Mengwi dynasty suffered another setback: it lost control over the harbours of Jembrana. ${ }^{31}$ This time it was the

28 After the death of Mas Sepuh two commemorative buildings were erected for him in Seseh. The first was a kramat, a holy (Islamic) grave containing his body. Second, a temple was built nearby, the pura Mas, which held a meru with no less than eleven roofs, equal to a meru dedicated to the gods of the mountains, to ward off the curse of Mas Sepuh. Upkeep of the temple was, until recently, the task of puri Sibang (Heyting 1925b; Candrawati 1981). The combination of an Islamic grave and a Balinese temple suggests that by the middle of the eighteenth century Islamic influence had taken root in Blambangan. Interestingly, Mas Sepuh's body is not positioned in the direction of Mecca but, in typically Balinese fashion, facing north, towards the mountains. In Islamic contrast to this, as late as 1925 the Balinese charged with guarding the grave refrained from eating pork. On Islam on Bali see Vickers 1987.

29 On Karangasem see ANRI, Bali:4.3, report Intje Boeang 1805; Radermacher 1786; Van Hogendorp 1799:191-2; Van Hoëvell 1845; Byvanck 1894. Moreover, the Karangasem dynasty had gained great influence at the Klungkung court because the Dewa Agung had been forced to take a Karangasem woman as padmi. She turned out to be a redoubtable queen.

30 According to Robson (1971:53) Karangasem conquered a large part of Buleleng in 1765. Worsley (1972:59-68) suggests that towards the end of the eighteenth century Karangasem usurped more power still. Of the Mengwi sources, only Babad Arya Manguwi (53b-4a) mentions that the lords of Buleleng terminated their loyalty to the king of Mengwi.

31 On Jembrana at the time see ANRI, Bali:5 II, reports J. Moser 31-8-1808, B.D van der Wahl 3-2-1809; Van Lier 1866; Van Eck 1880:102-10; Lekkerkerker 1923a, 1926. I Wayan 
dynasty of the neighbour to the south, Badung, which overran these harbours in 1804 . They were assisted by Buginese who had an important trading centre in Badung. In times of war these Buginese were deployed as vanguard of the Badung army. They would be used again in this way later.

Once again, Mengwi did not respond to this annexation. The royal centre was probably too preoccupied with internal problems to deal with other matters.

The Mengwi dynasty sustained loss not only in the west and the north; before long it was threatened from the south as well. Agung Ngurah Made Agung had just begun his reign when, in 1809-1810, Badung troops attacked the domain of puri Sibang. In the days of Ayu Oka, when Padangluah was attacked, Badung had been beaten off, but now the Mengwi centre was unable to come to the aid of its satellite. Puri Sibang was left to itself and, led by a Dutch mercenary, the Badung troops prevailed in battle. ${ }^{32}$

This blow against the Mengwi dynasty hurt in more than one way. First, once again Badung showed that it did not consider itself subordinate to the king of Mengwi. This meant that the Mengwi dynasty permanently lost control over the 'outer regions' and that negara Mengwi was greatly reduced in size.

Second, the loss of the remote satellites meant that the Mengwi dynasty no longer controlled the various seaports. The only route to the sea still open to Mengwi was a small anchorage along the coast of Seseh. This shelter could not compare with the Badung harbours, where virtually all southern Balinese import and export converged. Mengwi thus lost direct access to inter-insular trade.

Third, Badung's attack underscored the importance of control over the central dams and canals of the large irrigation systems. In 1809-1810 puri Sibang was neither simply overrun nor shorn of all its power. The position of the lord of Sibang was too strong for that. But he did have to acquiesce in the digging of an additional tunnel, which diverted water drawn from the river Ayung to the Badung sawah region. ${ }^{33}$

Mengwi was faced with still another loss: the sea temple at Jimbaran. This

Reken, 'Sejarah Jembrana' (ms). After some years the Buginese occupiers of Jembrana were massacred by the lords of Buleleng, who transferred power to themselves.

32 This incident is documented in ARA, MvK V29-1-1842-43 geh., Dubois 29-2-1831; Coll. Ph.J. van Zuylen van Nijevelt:109, anon. report 1824; Friederich 1850:30; Van Eck 1880:203-8; information G. Ng. Rai, puri Lanang Sibangkaja, I Made Astra, Mambal. On the Dutch mercenary B.D. van der Wahl, see Babad Bhoemi:13 and Schulte Nordholt 1986a.

33 On the west side of the road between desa Mambal and desa Sibangkaja the entrance to the Badung tunnel can still be seen in the rock face of the gorge of the river Ayung. In addition, a large earthen bridge was built in the steep gorge that formed the boundary between Badung and the domain of Sibang. This bridge is still there, along with a newer one crossing the Ayung just south of Sibang. 
pura Ulun Siwi, important for agriculture, was situated on the Badung peninsula and constituted the southern pole of the 'ritual axis' of negara Mengwi. The Badung dynasty became lord and master in the area and denied the Mengwi dynasty access to the sea temple. This meant that the ritual cycle from the mountains to the centre and the sea and back again was broken.

\section{Economic challenge}

The loss of its harbours and access to the sea temple did not augur well for Mengwi. The links between agriculture and trade were to become more intimate in the first half of the nineteenth century. Within a few decades incisive change came to the area of export, with far-reaching consequences for the Mengwi dynasty. I will touch on the major factors in this economic upheaval. ${ }^{34}$

At the beginning of the nineteenth century Balinese export still consisted mostly of slaves. Each year some 2,000 Balinese were exchanged for kèpèng (copper coins), weapons, and enormous amounts of opium. Towards the end of the eighteenth century opium import expanded greatly; throughout the nineteenth century the drug was used by broad sections of the population. ${ }^{35}$ Puri were the location of the buying and selling of slaves and opium, with Chinese and Buginese traders as intermediaries between the Balinese and inter-insular markets.

Import of opium continued well into the nineteenth century. From 1815 onwards, however, four factors caused important changes on the export side. First, there was a sudden decline in the export of slaves, due to measures taken in the colonial areas. Demand diminished as European control over the Archipelago increased. Locally procured labour proved far cheaper than the relatively costly import of slaves (Reid 1983:33). Moreover, on Java, during the brief spell of British rule (T.S. Raffles, 1811-1815), a policy aimed at the abolition of slavery was initiated, which was continued by the Dutch. The formal prohibition of slave trade rapidly deprived Bali of its major export commodity, which meant a severe blow to the Balinese kings and lords whose income greatly depended on the slave trade (Tarling 1962:68-70).

34 See also Schulte Nordholt 1980:94-104, 1981a and the sources mentioned there.

35 KITLV, H281, letters Dubois; ARA, MvK:3087 idem; ARA Coll. Schneither:131, report Pangeran Said Hassan 1825; ANRI, Bali:4.3, report Intje Boeang 1805. From the second half of the eighteenth century onwards, increasing amounts of opium were exported from India to China (Wolf 1982:255-8). Later, Singapore became an important opium market. Bali imported most of its opium from Singapore via Buginese and Chinese merchants. Geertz's view that opium was the main driving force of Balinese trade (1980:89) is biased because it is based on conditions in northern Bali in the second half of the nineteenth century (Chapter 4, section 2). 
A second factor followed upon a natural disaster. In April 1815 the Tambora volcano on Sumbawa, an island east of Lombok, erupted with unprecedented violence. Large parts of the Archipelago were shrouded in darkness. When the light broke one or two days later, it became apparent that the immediate vicinity of the volcano had been destroyed beyond recognition, and for days on end a heavy shower of ash continued to fall. All of Bali was covered with a layer of ash, rendering the sawah unfit for cultivation. ${ }^{36}$ The short-term result was crop failure, compounded by a plague of mice, and in the wake of these calamities famine spread over southern Bali (Van den Broek 1835:176). Disruption of agriculture and the loss of puri income because of the drop in slave trading resulted in a most serious crisis.

Recovery was remarkably swift, however. Within twenty years southern Bali emerged as a major exporter of food crops, mainly rice. The Balinese rulers proved able to respond effectively to changing inter-insular marketing conditions, while the sawah, now covered with volcanic ash, became highly fertile within a few years. Together with Lombok, Bali became the Archipelago's prime producer of rice.

A third factor was that the stepped-up production of rice was matched by increased demand, on Java, in Singapore, and in China. In 1829 Dubois wrote that the Balinese 'harvest twice their need'. By 1846 Bali was called the 'chief granary for Singapore'. ${ }^{37}$ Halfway into the nineteenth century Balinese export had smoothly adapted to the increased demand. One merchant remarked: 'Bali is remarkable among the neighbouring countries for the production of articles suited for consumption in the Archipelago' (Earl 1850:541).

Related to this is a fourth factor: the advantageous location of Bali on the trade routes. These included, first, the long-distance routes between China, New South Wales (Australia), Singapore, and Mauritius; second, the monsoon trade inside the Archipelago; and third, the 'local' trade with islands east of Bali. The rise of Singapore, since 1819, played an important role in this network. In a manner of speaking, Bali was the eastern entrepôt of this new emporium (Wong Lin Ken 1960).

Balinese export had experienced a metamorphosis within little more than two decades; the noble puri continued to exercise control. 'Money is the nerve of power', wrote Dubois (KITLV, H281), indicating that kings and

36 On the Tambora eruption see the Java Government Gazette April-May 1815; Zollinger 1855, 1868; ANRI, Bali:6.51, letter Dubois 5-7-1829.

37 ANRI, Bali:6.51; Dubois 5-7-1829; Irwin 1955:115. In a memorandum dated 30-11-1836 J.C. Baud (ARA MvK V26-12-1837:308/t.geh.) listed some reasons to explain increased demand for Balinese rice: crop failures in China, Spanish prohibition of Philippine rice export, reduced rice production on Java because of the introduction of the Cultivation System. On rice exports from western Lombok see Zollinger 1847. 


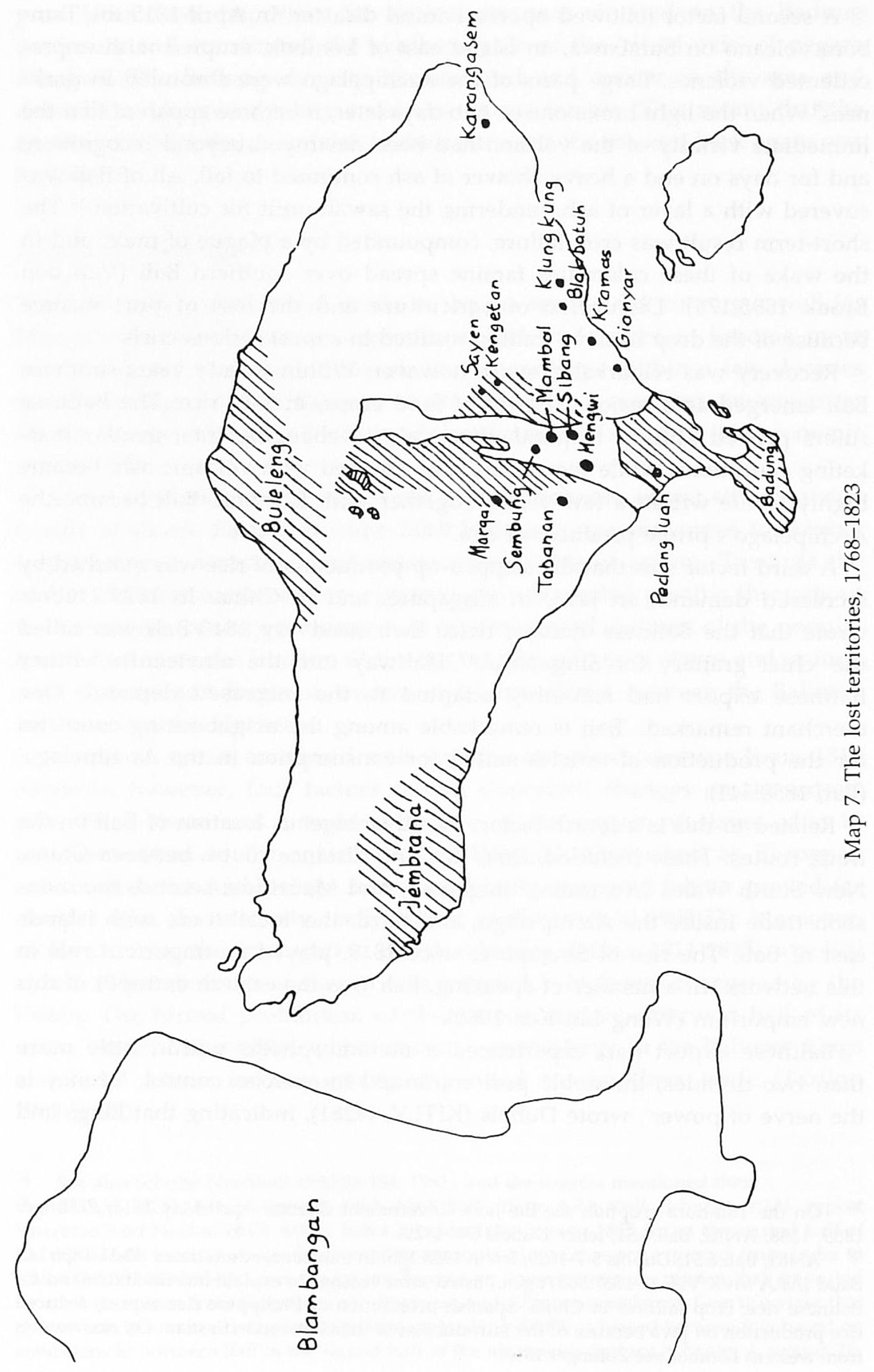


lords managed to derive the bulk of their income from the new export trade and related activities, such as toll levied on inland routes, at harbours and anchorages, and gifts received from merchants in exchange for protection. Some lords monopolized the hiring out of pack animals and so controlled transport to and from the harbours. In addition to this sort of revenue via 'skimming', a considerable number of southern Balinese puri were actively engaged in commerce themselves. They invested in ventures requiring vessels and the production of coffee, tobacco, and other second-harvest commercial crops. ${ }^{38}$ As regards the Badung dynasty, Dubois explicitly notes that, from 1820 onwards, the puri concentrated on the export of cash crops and the expansion of agriculture because of the steep drop in income from the slave trade. ${ }^{39}$

The change in southern Balinese exports greatly affected the population at large. Instead of being exported, its labour was now deployed to produce agricultural surplus for marketing. How this affected the bond between lord and followers is not known. It may be assumed that the cultivators of gardens, sawah, and the pengayah pacatu (see Chapter 2, section 4) were expected to boost production and that a larger share of the harvest was confiscated by way of taxation.

Really large plantations, expressly meant for raising export crops, were not established in southern Bali. To be sure, the Balinese nobles contributed substantially to the revised pattern of exports. But the question as to which of the competing kings and lords would take the largest slice of the new trade remained unresolved, as can be gathered from a scene on the Badung beaches in 1828, upon the arrival of a merchantman:

'they [the followers of the various puri] straightway ask the ship's master to subject himself to one of the kings [...] each recommending his own lord as the best [...]. If the stranger bows to one of the kings, he is beholden to continue in the service of that lord. It is not permissible to exchange one king for another. ${ }^{\prime 4}$

Rivalry among the southern Balinese nobility now extended, more than before, to control over irrigation systems. After all, the central dams and

38 Second crops are grown after the rice is harvested and the sawah is dry. See also ARA, MvK V29-1-1842-43 geh., memorandum Inspecteur Financiën, De Linge 30-9-1838, who mentions that the lord of Gianyar had tobacco gardens of his own. In the same period the queen of Badung had houses built for 'her' Chinese and Buginese merchants and, as shipowner, plied various routes. According to Dubois she was an excellent horsewoman and was not too proud to play at cards with the Chinese (ARA, MvK:3087; KITLV, H281).

39 ANRI, Bali:6.51, letter 5-7-1827; 4.11, letter 28-7-1829. In connection with the changing attitude of members of the Badung dynasty, Dubois also mentions the reduced use of opium among the new generation of leaders.

40 Javasche Courant 3-7-1828. Dubois observed that foreign merchants were often threatened by members of the lesser nobility who possessed only few followers and little sawah (KITLV, H281). 
main conduits took on even more crucial significance, since these constituted the very source of the exportable surplus, the new wellspring of profit for the powerful.

Mengwi, too, had to cope with disputes involving irrigation. The attack launched by Badung against Sibang in 1808-1809 was but a prelude to the battles to come. The problems that, after 1820, would cause the Mengwi hierarchy to totter were triggered by an irrigation issue. At the same time, the changing pattern of commerce cast its spell over the relationships within the negara.

The broader balance of power among all of the Balinese royal centres played a role as well. The Mengwi dynasty was now surrounded by strong competitors. Of these, Badung was the most fearsome, for its king had achieved a coalition with the kings of Tabanan and Gianyar and the lords of the Banjar district in central Buleleng. As a result, Mengwi was hemmed in by enemies on every side. Arrayed against these was another coalition, led by the eastern Balinese dynasty of Karangasem, of which Klungkung and Mengwi formed part. ${ }^{41}$

Although alliances such as these tended to be brittle and seldom posed a permanent threat, this time Mengwi was at a disadvantage. The members of the opposition did not get in each other's way. Mengwi was the common enemy, harassment of whom was likely to be profitable. Mengwi's allies, on the other hand, were too remote to be of immediate help. If they did come to the aid of the weakened Mengwi dynasty, the recompense would be extremely limited. Bereft of friends and led by an insecure royal centre, the Mengwi dynasty entered the most critical phase of the crisis.

\section{Loss of trust}

Informants say that ever since the rule of Ayu Oka, kaliyuga had overtaken Mengwi, a time of crisis, a time when people no longer knew their place in the hierarchy and when betrayal and destruction were daily occurrences. ${ }^{42}$ The crisis came to a head between 1820 and 1823. Forged in a complex of interacting relationships within the royal centre, between the centre and revolting satellites with internal struggles of their own, and between Mengwi and other royal centres, a veritable chain reaction of conflicts en-

41 Reports by Van den Broek in ANRI, Geh. Besl. 2-6, 5-6, 14-7 and 21-8-1818. Banjar in Buleleng was at that time still under the control of a brahman family from the Kamenuh clan.

42 See Schrieke 1957:77-8. Three periods precede the kaliyuga: the krtayuga, tretayuga, and dwaparayuga, marked by increasing prosperity and harmony. But then follows the kaliyuga, a time of greed and self-aggrandizement. The circle is closed with the pralaya, or destruction. Mengwi texts make little reference to this cycle, except that times of crisis are referred to as kaliyuga. 
sued, escalating to the point that the general picture was one of sheer chaos. I will describe the events from three vantage points: from the centre of the Mengwi dynasty, from a satellite, and from a rival royal centre. ${ }^{43}$

\section{The new sedahan}

During the reign of Agung Ngurah Made Agung, the composition of the royal entourage underwent drastic change. Old lineages of followers, such as the Sagung of jeroan Bakungan, were displaced by new favourites. Old mekel were edged out, inexperienced and untried warriors taking their place. It is hard to say why this change took place, except that Ayu Oka, old and mentally feeble, was losing control over the now fragmented royal entourage which dated back to the days of Cokorda Munggu. ${ }^{44}$ New personages gained the ear of the weak Agung Ngurah Made Agung, one of whom was Sagung Nderet. It was he who would play a dominant role.

Sagung Nderet came from Kramas, south of Gianyar. Early in the nineteenth century, when the Gianyar dynasty began to expand its influence, Kramas was one of the subjugated areas. Some members of puri Kramas fled to Mengwi, Sagung Nderet among them. He managed to gain entry into the Mengwi entourage. Soon his position at court was an influential one, that of sedahan gede, major-domus of the royal puri. ${ }^{45}$ In this function he super-

43 The most important sources are: Kidung Nderet c; Babad I G. Gede Meliling; Babad Mengwi-Sedang; Van den Broek 1835; ARA, Coll. Ph.J. van Zuylen van Nijevelt, anon. report 1824 and report Pangeran Said Hassan 1825; letters Dubois in ARA MvK:3087, KITLV, H281; ANRI, Bali:4.11, 6, 51. During fieldwork I collected local oral traditions from the following desa: Sibang, Gerih, Dalung, Gaji, Pererenan, Sempidi, Mengwi, Badung, Bongkasa, Kengetan, Sayan, Sembung, Marga, Blayu, and Kramas.

44 Kidung Nderet c:3-5, 22. It is from this source that many of the data for this section derive. According to G. Ng. Ketut Sangka of puri Gede Krambitan, the Kidung (a song) was composed in the second half of the nineteenth century by (or for) the king of Tabanan. One might argue that the Kidung Nderet is fiction and hence should not be used as a historical source, but I disagree. As far as other sources can be traced, the events recounted in the Kidung can be rather accurately located in time. In addition, a number of the events can be checked against other sources. Finally, the story as told in the Kidung Nderet impresses one as very realistic. Hence, I consider it legitimate to use this 'documentary song' as a source. Elsewhere (1992) I have discussed the nature of this text in more detail.

45 Information from G. Ag. Putu Meregeg and G. Ag. Megayasa, jero Tangeb, Tangeb, and G. Ag. Made Mantra, Denpasar. In the genealogy of puri Kramas, Sagung Nderet is not mentioned by name, but it is clear that at the beginning of the nineteenth century members of puri Kanginan Kramas did move to Mengwi. Descendants of this group still live in desa Mengwi, desa Buduk, and desa Tangeb, and consider puri Kanginan Kramas as their place of origin. According to the genealogy of jero Tangeb, one of the boys of the Kramas familty in Mengwi, G. Ag. Made Kajeng, was adopted by the leader of the emerging royal lineage of Mayun. If G. Ag. Made Kajeng was the same person as Sagung Nderet, then the adoption explains Sagung Nderet's privileged position in Mengwi. Since the Balinese often have more than one name or nickname, we need not be surprised that Sagung Nderet is not mentioned in the genealogies. Moreover, the Kiding Nderet was unknown at the time of my fieldwork. In Kramas Nderet's title was a higher one: Gusti Agung, which upon arrival in Mengwi was exchanged for the lesser title of Sagung, about equal in rank to the leaders of jeroan Bakungan. 
vised the sawah belonging to the puri and was in charge of tax collection in the royal domain.

Although his followers were few and the network of his relatives limited, Sagung Nderet was a man to reckon with. His smooth speech ingratiated him with the king, to whom he had direct access, and he was permitted to live in a jero of his own, adjacent to the puri.

As sedahan gede, Sagung Nderet bore down on the people heavily. He doubled sawah taxes, demanding payment in cash. He sought to take over the entire opium trade. In this connection he monopolized all contact with foreign traders. Nor did he stop here. To make his emporium more profitable still, he burdened taxable peasants with new levies. Cultivators living in and around Mengwi were made to produce second crops fit for export. Peasants at some distance from the centre were forced to deliver pigs, also meant for export. If obligations could not be met, no credit was given. Land was confiscated immediately (Kidung Nderet c:6-8, 38-9).

The Kidung does not speak well of Sagung Nderet. He is pictured as a selfish person exclusively out to line his own pockets. The story goes that he had puri agents carry off ugly daughters of the rich, to be ransomed at a steep price, the sedahan gede taking in the proceeds (Kidung Nderet c:8). Apart from this somewhat unsympathetic trait, Sagung Nderet was a man attuned to the shifting times. Presumably, he was aware that the royal centre should make an effort to increase control over the changing market, as indicated by his monopolizing of opium imports and the additional taxes introduced with an eye to centralization of organized exports. It is probable that his reputation as scoundrel rests primarily on the inadequate legitimation of his position as 'royal manager' in Mengwi. In people's minds he continued to be seen as the foreigner who fled from Kramas, the coward who shirked a battle, an undeserving favourite of the king. Moreover, old Mengwi lineages of followers with a long history of loyal service now stood at the sidelines, watching Sagung Nderet amass his fortune. The events surrounding the death of I Kemoning point up the conflict between the old royal entourage and the new, or between the battle-scarred warriors and the astute, calculating manager.

I Kemoning was a parekan (trusted servant) of puri Gede Mengwi, a famous former gambuh dancer, now old. ${ }^{46} \mathrm{He}$ decided that, since he had little left to live for, he would risk royal wrath and warn the king against Sagung Nderet. I Kemoning told the king how the people beyond the gates of the puri complained about the crippling taxes and the heavy-handed methods of exacting them. He said that people feared Sagung Nderet too 
greatly to voice objections openly. Furthermore, by replacing the old mekel with inexperienced newcomers the king was pursuing a foolhardy policy. The old parekan said that Mengwi was threatened within and without, and he implored the king to rid himself of this evil sadehan whose tongue was glib but whose power had no legitimation. Having spoken so, I Kemoning requested leave to withdraw and left the hesitant king to his indecision.

A third party witnessed the conversation: I Linggar, one of Sagung Nderet's henchmen. As soon as he could, this I Linggar went to the sedahan gede's house and reported on I Kemoning's advice to the king. While the two conspirators smoked a gold-encrusted opium pipe, Sagung Nderet decided to do away with the parekan. That very night he went to the puri and urged the king to have I Kemoning killed. The king allowed himself to be persuaded, though he stipulated that the old man should not be made to suffer. A puri servant was dispatched to I Kemoning's house. He was expected. I Kemoning had prepared for his execution, cleansed himself, and donned white apparel. The old man felt neither guilt nor regret. At the cemetery in desa Mengwi where he was about to be executed he danced a fragment of a gambuh story; a last demonstration of his loyalty to the old Mengwi order and its former king, Cokorda Munggu. When the dance was ended I Kemoning was struck down.

Sagung Nderet won this round handily, a clear signal that the old royal entourage was finished. It would not be long before a far more incisive conflict was to test the strength of the new entourage led by the ambitious sadehan gede. This time Sagung Nderet, reluctantly supported by a wavering king, pitted himself against Gusti Made Tibung, lord of the southern sawah region near Padangluah and scion of Cokorda Munggu's anak astra (see section 1 above; Kidung Nderet c:9-23).

\section{Sagung Nderet versus Made Tibung}

For many years the jero of Made Tibung had done well financially. Cokorda Munggu had decreed that the lord of Padangluah be exempt from most taxation, in consequence of which he now had at his disposal a relatively large agricultural surplus which he was free to sell to merchants from nearby Badung. Moreover, he had some eight hundred followers, an appreciable local power base. Sedahan gede Sagung Nderet wanted to change all this so that the royal centre would have greater control over the sawah region in the south. He proposed to the king that Made Tibung should pay a tax of 30,000 kèpèng per year as payment for irrigation water drawn from Gumasih dam. A small part of the rice crop, enough to live on, and the second crops for export would remain untaxed. If Made Tibung refused to pay, his water supply would simply be cut off, which was the only pressure the royal centre could apply. The king objected. After all, this was a privilege 
extended by Cokorda Munggu long ago. But Sagung Nderet convinced the king that it was within his province to review old rules, since he, the current lord, was the very incarnation of royal prerogative in Mengwi; was not the kris I Panglipur in his safekeeping and did not the authority over the temples rest with him? Surely, then, by status and by right the decision was his to take. Once again the king was swayed by Sagung Nderet's flattery. Henceforth, Made Tibung was to pay taxes for the irrigation of his sawah.

In the end Made Tibung opted for obedience. He did try to enlist support from the lord of puri Sibang, in whose domain Gumasih dam was situated (Kidung Nderet c:24-33). But the lord of Sibang was most reluctant to become involved. Sagung Nderet was too powerful and the lord of Sibang, though one of the important rulers in the negara, no longer had the ear of the king; he, too, had lost much of his influence. Aggrieved, but outwardly unmoved, the lord of Sibang bided his time.

It looked as if Sagung Nderet had come out on top in the struggle for control over the sawah. But in 1820 a minor mishap unleashed grave consequences. Just west of desa Mambal a flash flood washed away part of the tunnel that diverted water from Gumasih dam to the sawah near Padangluah, effectively halting sawah irrigation in that area. ${ }^{47}$ Five years of slipshod maintenance had left the main conduits in poor condition. The point was that the royal centre rather than the lord of Padangluah was now responsible for upkeep of the system. Ever since Made Tibung started paying taxes for irrigation, the utilities had been under the supervision of the king's sedahan gede, who was obviously guilty of neglect. ${ }^{48}$ Nor did he make any attempt to put things right, for Padangluah remained without water for several seasons. It is likely that in this way Sagung Nderet meant to undercut the position of his opponent. This, however, was a miscalculation.

Initially, Sagung Nderet's tactics seemed successful. The followers of Made Tibung complained that their lord did not look after their interests as he should. They had been made to pay taxes; why, then, was the sawah running dry? Why did Made Tibung do nothing about it? In point of fact, the lord of Padangluah had repeatedly approached the king with the request to give the supervision of the system back to him, but Sagung Nderet had prevailed every time. As noted, the lord of Sibang was of no help either.

47 Kidung Nderet c:72; Babad Bhoemi:13. Informants from desa Gerih, near Mambal, were still able to point out the place of collapse, because it is the former location of a temple of the lineage of the Bendesa Gerih. This temple fell when the tunnel caved in.

48 As long as the lord of Padangluah was not required to pay tax to the king, he had maintained the dam and the conduits himself (see section 1 above). An additional complication was that the damage was done to a tunnel rather than to an open canal. To repair tunnels it was usually necessary to contract outside specialists (Korn 1927). But Made Tibung, now paying taxes, could not afford to contract out the job. The events described next are derived from the Kidung Nderet c:72-91. 
Made Tibung stood alone, and if he wished to retain control over his followers he would have to move quickly. He called his people together and asked them whether they would join him to fight for the old privileges and had them swear allegiance to him. Thereupon he marched his followers to Mengwi to demand that the king depose Sagung Nderet and restore to him, Made Tibung, his former rights.

The next morning, when Made Tibung and his crowd of followers entered desa Mengwi, the outer court of the royal puri was deserted. Word of their coming had spread and the Mengwi chiefs kept themselves hidden. Made Tibung requested an audience with the king but was told that the king was indisposed, unable to receive visitors. Three days of waiting produced no king, and the men of Padangluah returned to their homes.

Back in his own jero, Made Tibung deliberated with some trusted followers. The king had avoided them; other satellites were reluctant to burn themselves; help would have to come from elsewhere. To be sure, Mengwi was hardly lacking for enemies; the negara was surrounded by foes on every side. One of these inimical royal centres was that of Badung, whose domain bordered on that of Padangluah. Accordingly, Badung was approached first (Kidung Nderet c:92-6).

The Kidung gives one the impression that the satellite Padangluah was a unified bloc. But this is entirely misleading, as Babad G. Gede Meliling (:4-8) demonstrates. The central theme of the text is the conflict within the clan of Made Tibung. Local interests proved stronger than the common bond which kept the group together and bound the domain to the dynastic centre. These local interests were those of lesser families who of old controlled the region and who were at best but partially integrated in the kin group of jero Padangluah. For this reason old conflicts lingered on. ${ }^{49}$ These local disputes now became complicated even further, as at the regional level they became intertwined with contrasts between Padangluah and Mengwi, and beyond that, between Mengwi and Badung. One permanent bone of contention in Balinese politics, the relationship between central authority and local interests, continued to play an important part in Padangluah. Interaction of the two levels served only to escalate hostilities. Local disagreements were carried to the larger and more violent regional arena, the regional conflicts adding fuel to local feuds.

49 Both the form and the content of these conflicts changed somewhat, since the disputing lineages, once annexed by jero Padangluah, turned into feuding sub-branches of this satellite of the Mengwi dynasty. The main opponents were now the sub-branch of jero Padangluah, deriving its authority from its direct descent from the king of Mengwi, and the sub-branch of jero Tibubeneng, which was matrilineally related to a local lineage of Bujangga Resi priests and hence guardians of the old sea temple at Canggu. The jero Padangluah faction would eventually turn to Badung, while the jero Tibubeneng faction remained loyal to the Mengwi dynasty (Babad G. Gede Meliling:4-8; regarding the Bujangga Resi, see Korn 1932:155-8). 
This escalating effect was very evident in 1823, when the crisis reached a climax. ${ }^{50}$ In 1821, the Mengwi royal centre had tried to prepare itself for a show-down by purchasing a large shipment of arms from Batavia (ANRI, Bali:6.51). More crucial than this, however, would be the measure of success the king would have in appealing to his followers and the satellites.

Meanwhile, Made Tibung had managed to enlist the support of the king of Badung. But when this lord put the matter to his relatives from the other Badung puri, one of them became suspicious. Was this perhaps a cunning Mengwi ruse? Was Made Tibung an agent provocateur? If so, the unsuspecting Badung troops deployed to assist Padangluah might be ambushed by a large Mengwi force. But the king of Badung would not withdraw his pledged support. One of the king's older relatives proposed a solution. In Badung lived a group of Buginese merchants, 'people without worth' (Kidung Nderet c:104-5). Let these be sent in first. Should they run into a Mengwi ambush, damage would be restricted to the loss of a number of foreign casualties. If no opposition was encountered, the Buginese would be the vanguard behind which the Badung Gusti and their troops could easily occupy Padangluah.

The Buginese of Badung were mobilized and told to prepare themselves for battle. Their chief dispensed a 'battle potion' among the men, the effect of which took hold without delay. In a kind of trance, the horde descended on Padangluah. ${ }^{51}$

In Padangluah, Made Tibung and his followers awaited the arrival of the Badung allies. Suddenly, towards the end of the day, an army of wild-eyed Buginese fell upon them, attacking without a moment's hesitation. In the ensuing mêlée the Padangluah leaders sought to defend themselves as best they might, while local residents fled in panic in all directions. Utter chaos prevailed when dusk set in and friend could no longer be distinguished from foe.

Misunderstanding and panic peaked during the night. The Buginese, returning home from the bloodshed they had inflicted, ran into the Badung Gusti and their troops. Surprised by this 'resistance' in the dark of night the undismayed Buginese rushed forward. The Badung army retaliated fiercely, convinced that they had marched into a Mengwi trap.

Dawn brought to light who had been slaying whom. The bodies were buried in a large pit. One of the Badung chiefs dared lament the death of so many of his Buginese: his income (from trade) was now much reduced.

From the Badung point of view the loss was compensated handsomely; Padangluah was now wide open for take-over; the royal centre at Mengwi 
was obviously unable to respond adequately. The Badung chieftains considered marching on, but decided to wait and see if their allies in Gianyar and Tabanan would take advantage of the situation. If they attacked Mengwi, Badung would meet with little resistance as its troops pushed on to occupy the entire southern sawah plain.

In the event, the two allies did attack, and within a few weeks almost the whole of negara Mengwi was overrun. From the northeast the lords of Taman Bali invaded the northern regions of Mengwi. From the east the king of Gianyar mounted an offensive against the two remaining Mengwi satellites on that side of the river Ayung. These were puri Sayan and puri Kengetan, branches of the Mengwi dynasty. ${ }^{52}$ As this battle on the east front raged, a cholera epidemic swept over the population, spreading like wildfire into Mengwi as fugitives headed in that direction. Organized resistance was entirely absent. The royal centre at Mengwi did nothing, leaving the threatened satellites to shift for themselves. The lord of puri Sayan was angered by this to the point that in a last bid to gain Mengwi assistance he trampled all over protocol. Upon arrival at the royal puri he did not cross the court on foot, as decorum demanded, but commanded his bearers to march straight into the puri. Such unprecedented insolence was a telling witness to royal loss of face. Left without aid, puri Sayan survived by withdrawing to desa Bongkasa, on the west bank of the Ayung. Here the lineage would remain the relatively autonomous, easternmost satellite of the negara. ${ }^{53}$

The other satellite, puri Kengetan, also moved. A period of wandering ended when the branch settled in desa Sembung, north of desa Mengwi. The reason for moving to Sembung was that the negara was threatened from the north as well. The lord of puri Marga, chief of the northern satellite, renounced his loyalty to the Mengwi dynasty and turned to the king of Tabanan. It may be presumed that the decision to sever the old bond with Mengwi was prompted by economic considerations. In the early years of the nineteenth century, the production of coffee had begun in the hills surrounding Marga. Chinese merchants transported it to the harbours of Buleleng. This new and lucrative export arrangement, providing puri

52 Kidung Nderet c:126-43; Uwug Kengetan, in Ida Bagus Mayun 1979:37-48; ARA, MvK:3087, letters Dubois. The Mengwi babad date this attack earlier, parallel to the attack on Blahbatuh during the reign of Ayu Oka (Babad Mengwi-Sedang:21-3; Babad Arya Manguwi:51b-2b). Comparison of the Kidung Nderet and Dubois's notes reveals that these were two separate wars. G. Nyoman Raka of Denpasar, Dewa Putu Kandel of Singakerta, and G. Ag. Gede Rai of Bongkasa provided valuable oral information.

53 Babad Mengwi-Sedang:23. From then on, the leader of puri Sayan was called Bima Sayan Upih (Bima of Sayan, The Insolent One). Names of banjar in present-day Bongkasa recall places east of the river Ayung, the former homes of the fugitives: Sayan, Kadewatan, Tanggayuda. 
Marga with a monopoly on the import of opium, was zealously kept beyond the reach of the royal centre at Mengwi. It seems plausible to suppose that Sagung Nderet sought to gain control over the northern coffee and opium trade. He only succeeded in turning the satellite Marga away from Mengwi altogether. ${ }^{54}$

Since the Mengwi dynasty was under threat from the east and from the north, the lords of Badung decided that the time had come to push on. They marched their army northward and took possession of almost all of the sawah around Padangluah. The days of Made Tibung and his jero were over. He himself was killed during the mad rush of the Buginese; the jero was razed to the ground. Padangluah was annexed by branches of the Badung dynasty, whose followers now settled in the area. Given the changed conditions, Made Tibung's descendants were shorn of their former importance; they lost their privileges and became utterly dependent on the new Badung lords. ${ }^{55}$

\section{The dismantled hierarchy}

Within a few weeks the royal centre of Mengwi had lost three-quarters of its territory. At the end of many years of hostilities the Badung dynasty emerged as final victor over the royal centre at Mengwi. Badung was now in possession of a large sawah region which formerly belonged to negara Mengwi. Moreover, the vanquished king had to acknowledge the Badung leader as his superior. ${ }^{56}$ Henceforth, he would amount to no more than a

54 I thank G. Gede Catra of puri Marga, who was most helpful in searching for and interpreting data on this issue. According to the genealogy of puri Marga, the conflict occurred when G. Ngurah Payuk was lord of Marga. The same name is mentioned in a report from 1824 (ARA, Coll. Ph.J. van Zuylen van Nijevelt, anon. report 1824). In connection with coffee production in Marga, see Graves 1967. Babad Arya-Manguwi (:64b-6a) does mention Marga's disloyalty, but ascribes it to a different motive. At stake was the kris of puri Marga, rather than the proceeds of coffee. This kris had been 'borrowed' by the king of Mengwi and a counterfeit was returned. The genuine kris proved to have lost its powers, which had entered the false one. When this was discovered, the lord of Marga withdrew his loyalty to the king of Mengwi. The babad in fact 'zeroes in' on the essence of the conflict: the king lost the power (the kris) over Marga on account of his own foul play.

55 During the war with Badung the dispute between the sub-branches of jero Padangluah and jero Tibubeneng was settled by force as well. Both lost their local authority to the invaders from Badung. The sub-branch of jero Tibubeneng moved to desa Pererenan, just inside the domain of Mengwi's king. Jero Padangluah was no more. There is a hill, west of where desa Dalung-Gaji is today, which has remains of a fortress going back to Made Tibung.

56 According to some sources, Agung Ngurah Made Agung, powerless and surrounded by enemies, was forced to swallow the last vestige of his pride. Prostrate before the king of Badung, he uttered a humble sembah (greeting), submissively asking for pardon and so relinquishing his royal authority. This is, however, denied by his descendants. Data concerning the surrender are derived from KITLV, H281, letters Dubois: ANRI, Bali:4.11, letter Dubois 15-1-1831, and Friederich 1850:37-8. The king of Badung was Gusti Ngurah Made Pamecutan (1817-1828). He was the leader of the lineage of puri Denpasar (Schulte Nordholt 1980:106), which probably was one of the largest puri on Bali. Van Geuns (1906:12) 
lesser vassal of Badung's king. Agung Ngurah Made Agung, 'lord' of Mengwi, subject to the king of Badung, now submitted part of the revenues of his much-reduced domain to Badung, delivered materials needed to complete puri Denpasar, and was expected to contribute to the royal cremations at Badung. This last, the forced contribution to Badung rituals, hurt the most, because it was a painful reminder of the inferior position now assigned to conquered Mengwi.

In retrospect, consolidation of newly attained authority proved far more difficult to achieve than the initial founding and expansion of the negara. One hundred years after its rapid rise in the eighteenth century, the Mengwi dynasty succumbed to the conflicts ravaging the hierarchy. The crisis announced itself at the very moment that the new royal centre was being completed and the dynasty seeming to settle in. Ironically, the rounding out of the dynasty was paralleled by diminishing control over the satellites. The first to fall away were the 'outer regions', since the royal centre was no longer able to assert its authority in these remote areas. Local leaders in these regions, commanding a power base of their own, capitalized on the erosion of the royal centre by acting the part of lords of equal status, or else they were incorporated into competing negara.

The centre's loss of strength also affected its relations with the regional satellites. Diminishing confidence in the centre caused the negara to fragment into a number of local centres, each in pursuit of its own ends and paying little respect to the king.

Change in the composition of the royal entourage was a major contributing factor to the crisis of confidence leading to the fall of the Mengwi hierarchy. The king's new entourage boasted no warriors of note, and included no men able to mobilize a large following. As a result, the centre's effectiveness was severely curtailed.

In the context of change in the royal entourage, I referred to the shifting pattern of southern Balinese export. The economic reorganization that overtook the Archipelago in the first decades of the nineteenth century put its stamp on Balinese politics. The royal centres insisted on increased production from their subjects. Although no exact information is available, data from the Kidung Nderet allow the formulation of a hypothesis. It is known that the nobility played an active part in the transition from export of slaves to export of agricultural products (especially rice). But there is no indication that a separate export sector (plantations) came into existence. The implication is that the royal centres sought to derive export surplus from their own domains by raising taxes. Furthermore, they made attempts

wrote: 'If ever an architect made rock to wear a grimmer countenance, it was he who gave the king of Badung his imposing puri'. 
to increase control over mercantile activities in the satellites. On the economic level this meant that the dynasty penetrated into local society to a far greater degree than before, and this, in turn, led to opposition. In this context the conflict between the royal 'manager' Sagung Nderet and Made Tibung of Padangluah illustrates central attempts to monopolize taxation and trade. The outcome, however, made clear that the centre's bid had failed utterly. This was not only because of the weak central leadership in the dynasty, but especially because the royal centre lacked the means to establish the required centralization effectively. For example, no patrimonial bureaucracy developed, by means of which the centre would have been able to control the negara. The attempts at control as undertaken by sedahan gede Sagung Nderet achieved the very opposite of what they intended. Rather than achieving enhanced control, the centre lost its control over events when the crisis climaxed just after 1820 .

It was the fragmented structure of the Balinese political system which prevented the negara from becoming a state with a permanent central power. Instead, the negara displayed a characteristic pendulum movement. One driving force was the ambition, inspired by Indian ideas, to found a realm with royal splendour, but this ideal kept colliding with an obstinate praxis in which the fragmented political structure continued to reduce the king to the level of 'chief'. ${ }^{57}$ It is from this oscillation between royal ambition and permanent fragmentation that Balinese politics derived its major dynamism.

In 1823, negara Mengwi fell apart and the hierarchy was dismantled; nevertheless, the royal dynasty was not destroyed. In the nineteenth century Balinese politics was no longer bent on wiping out competitors. What did happen from time to time was that the mutual order of ruling noble lineages was reshuffled. ${ }^{58}$ The Mengwi dynasty had dropped from the highest to one of the lowest rungs. It would have to wait for a new 'big man', one able to restore royal authority to its former glory.

57 Boon (1977:18) was early to note this: 'Thus [...] Bali appeared South Asian, kingly and stable [...]. Yet [...] outside its Hinduized rites and Sanskritic texts, Bali can appear as much Polynesian as Indic.' Concerning the Polynesian chief, see Sahlins 1963, 1973:20-7; Valeri 1972. I do not mean to say that Balinese kings were identical to these chiefs. Their position and the conical clan structure of Balinese nobility, however, are readily comparable to Polynesian chiefdoms.

58 In this respect the political structure on Bali was very similar to that of South Sulawesi; see Andaya 1978 and Sutherland 1983b. 


\section{CHAPTER IV \\ Restoration, 1823-1871}

The Mengwi hierarchy was revived in the course of the nineteenth century. The process of its restoration is traced in this chapter. The main protagonist in the story is the outstanding Mengwi leader Agung Mayun, the personification of the dynasty's new authority. Like his great predecessors a century earlier, Agung Mayun, too, was the linchpin of a set of interrelated phenomena that turned the wheels of the negara. Below, I describe these phenomena and their coherence. At every turn we shall meet with battles, temples, and rituals, since these were the means through which the Mengwi dynasty expressed its hierarchy and gave vital form to the negara. Sections two and three in particular will discuss these aspects.

First, however, the Mengwi dynasty had to overcome two impediments. To begin with, the royal centre was weak, radiating little or no authority. The second difficulty was that serious internal disagreements lay coiled at the dynasty's core and rendered the centre incapable of effective action. In Southeast Asia generally, such internal conflicts posed the greatest threat to the perpetuation of a dynasty. Bali was no exception. ${ }^{1}$ The frequent eruptions of such conflicts express the extreme precariousness of the power base of any given dynasty. Nor did the consequences of these quarrels remain restricted to the royal centres; invariably violence and fear soon spread throughout the realm. Mengwi's history shows that on Bali, as elsewhere, there was an immediate connection between relations internal to the political centre and the condition of the negara. This is the topic of section 1 , after an account of how the centre of the Mengwi dynasty managed to survive the kaliyuga, seeing that, in 1823 , its chances seemed slim indeed.

\section{Struggle for power, 1823-1842}

Balinese negara, since they did not constitute sovereign states, had no embassies or consulates, no formal relations between them. This is evident from a number of political agreements from the first half of the nineteenth

1 Tambiah 1985a:268-9; Adas 1981. On struggles of succession among the Balinese nobility, see Geertz and Geertz 1975:140-3. 
century. ${ }^{2}$ These documents do not stipulate agreements between one negara and another, or their kings; rather, kings and each and every lesser lord were mentioned by name. Hence, treaties reflected the balance of power of the moment, based on a gentlemen's agreement of all individuals concerned. This meant that whenever new lords rose to power, the relationships were reassessed.

All of this also applied to the kings of Badung and conquered Mengwi. Except for the Padangluah region, which had been factually annexed, the Badung centre was satisfied with nominal control over the remaining Mengwi domains. This implied that, along with the king of Mengwi, the leaders of the satellites had to promise loyalty to their new lord, the king of Badung.

Badung remained Mengwi's superior for a mere five years. In 1828 the king of Badung died of poisoning, the second in a quick succession of three dynastic murders. ${ }^{3}$ Badung was caught up in internal struggle. The king had tried to monopolize external trade, not hesitating to ingratiate himself with the Dutch colonial regime on Java. This brought him cash and weaponry, but evoked great resistance and distrust among the lesser lords. Not only was their own income from export jeopardized, they were also very much aware of the threat emanating from the new colonial power. The lord of puri Kaba-Kaba, a Badung satellite at the time, pronounced: 'Our lord Gusti Ngurah Made Pamecutan [the king of Badung] is an excellent king. Regretfully, he is blind and leads us to the Dutchmen's chains. ${ }^{\prime 4}$ Moreover, the power struggle was preceded by an event that had seriously eroded the authority of Badung's king. From March 1827 to November 1828 southern Bali was visited by the scourge of a smallpox epidemic; many succumbed and public life was lamed. No rituals were conducted, no war was waged, no music was heard. People did not go out; they remained inside, if at all possible, until the doom should be lifted. Disaster was added upon calamity when eastern Badung was hit by a great flash flood that washed the crops away. ${ }^{5}$ Epidemics and nature gone berserk were seen as the wrath of the gods, and this in turn created a climate in which removal of the king was at least thinkable, since the condition of the negara was held to be causally related to the person of the king. On this view, the king was responsible for the misfortune that visited his negara, and murder justified.

Korn 1922a; see Andaya 1978 for a comparable situation in South Sulawesi.

ANRI, Bali:4.11, Dubois 20-7 and 9-11-1828; Schulte Nordholt 1980:73-8.

ANRI, Bali:4.11, Dubois 20-7-1828. Those were the years (1825-30) of the Java War between the Dutch colonial regime and Prince Diponegoro. Dubois bought slaves to serve in the colonial army.

5 ANRI, Bali:4.11, Dubois 30-4, 20-7-1828 and 28-7-1829. The flash flood caused a break in the dam in the river Ayung. 
The new strongman in Badung was a brother of the deceased king. Although he had come out on top in the struggle for power over the Badung dynasty, control over Mengwi was lost, since its lords had not pledged allegiance to his person in 1823 . He would have to force them to do so now. A major obstacle, however, was the resistance put up by a son of the murdered king. He turned against his usurper-uncle and eluded him by fleeing to Mengwi, where, in 1828, as 'the true heir and successor' of his father, he discharged the lords of the obligation to pay homage to the Badung centre. Thus the Mengwi dynasty's subordination to Badung was 'formally' lifted, only to be exchanged for another. The fugitive Badung crown prince transferred authority over Mengwi to the Dewa Agung of Klungkung. ${ }^{6}$ This would soon prove to be anything but an empty gesture.

\section{Agung Putra, 1829-1836}

Although Badung's new strongman did try to muscle in, he had to admit failure in 1831, the year of a treaty with the new king of Mengwi which specified equality in rank. ${ }^{7}$ The new Mengwi king was Gusti Agung Ngurah Made Agung Putra - Agung Putra for short - the second son of Gusti Agung Ngurah Made Agung, who was vanquished in $1823 .{ }^{8}$

This new dynastic leader had trouble asserting his authority in Mengwi. The subjects in his own domain were difficult to keep in check, and his attempt, in the footsteps of his predecessor's 'manager', to gain a monopoly in the opium trade met with much resistance in the satellites. ${ }^{9}$

Agung Putra, bent on restoration of eroded dynastic authority and out to establish his own position as the new king, organized two great royal rituals. The first was the abhiseka ratu, his own inaugural ceremony. The second

6 ANRI, Bali:4.11, Dubois 4-4-1831; Friederich 1850:37-8; Van Bloemen Waanders 1868: 381-4. Presumably, the crown prince meant to place authority over Mengwi in the 'care' of the Dewa Agung until he recovered control of Badung. The new leader in Badung was G. Ng. Gede Kesiman who, until his death in 1863, would play an important role in southern Balinese politics (Schulte Nordholt 1981a).

7 ANRI, Bali:4.11, Dubois 4-4-1831. At the time, the new leader of Badung, G. Ng. Gede Kesiman, was still faced with resistance in Badung, so that he was unable to mobilize sufficient manpower against Mengwi. Moreover, he would have come into conflict with the Dewa Agung of Klungkung, who was now the new 'Overlord' of Mengwi.

8 In 1828, death drawing near, this Agung Ngurah Made Agung was old and melancholy, suffering not only because his royal authority had collapsed, but also because his oldest son and heir had died of smallpox that year. The old man lived in seclusion until his death (Dubois, see note 7).

9 ANRI, Bali:4.11, Dubois 30-9-1828, 24-4-1829; Samboengan Babad Mengwi:3; Babad Mengwi-Sedang:27; Babad Arya Manguwi:44b-5b; Babad Mengwi-Lambing:54-5. Agung Putra was of low birth, but was adopted by his father's padmi; see Appendix. According to Dubois (KITLV, H281) the new leader of Mengwi was 'timid' and from time to time needed Kesiman's help to gain control in his own domain. Sedahan gede Sagung Nderet was probably no longer part of the entourage, but his descendants continued to live in desa Mengwi, desa Buduk, and desa Tangeb. 
was related to this: the ngluer ritual for the soul of his father, Agung Ngurah Made Agung, who had died in 1829. The ngluer ritual was but rarely celebrated. It was the ultimate stage in the cycle of rituals for the dead. At the start of the cycle the corpse was burned, so that the soul of the dead king was freed of his corporeal remains. Next followed a series of rituals by which the soul was detached from earthly matters and prepared for entrance into the world of the gods. The burning of the body and the freeing of the soul were not only salutary for the deceased, but were of great significance for his successor as well. The heir could legitimate himself as rightful new king only if every vestige of a bond between the dead king and the earth was meticulously severed. ${ }^{10}$

It would soon be obvious that ritual alone doth not a ruler make. Even though the new king of Mengwi took a woman from one of the strongest satellites, puri Sibang, as padmi, the union did not bring him unconditional support. As in the case of Ayu Oka before her, this royal padmi, too, had her own power base and specific interests. ${ }^{11}$

The dynasty's centre was further divided by two more factions, one led by a younger brother and the other by a cousin of the new king. Both posed a threat to Agung Putra, who sought to rid himself of them.

The brother first. He was still a child, and in fact there were those who doubted whether the late king really sired him. Could the old man, his death not far away, still have performed? In the nick of time, just as Agung Putra was about to murder the boy, a faithful servant snatched him away into safety at Klungkung, where he was granted temporary shelter at the court of the Dewa Agung.

The cousin would come into contact with the Dewa Agung as well. He was accused of a secret liaison with Agung Putra's only daughter. But the girl was meant to marry the king of Karangasem. Thus discredited, the cousin was exiled to the island of Nusa Penida opposite the coast of Klung-

$10 \mathrm{KITLV}, \mathrm{H} 281$. Although the inauguration ritual is not mentioned explicitly, it may be assumed to have taken place, since as a rule it accompanied the death rites for the deceased king (see Swellengrebel 1947; Van der Meij 1986). In addition, Babad Arya Manguwi (:66a) uses the royal ritual name for Agung Putra. On Bali the rites for the dead form a distinct category and are called pitrayadnya. Twelve days after the cremation (palebon) is the ngorasin; 42 days later the mamukur takes place, and a year or so after that the maligya. For descriptions of the maligya see Mershon 1971, Brinkgreve 1981, Grader (no date). I am especially grateful to C.J. Grader, G. Ag. Gede Rai, puri Kajanan Mengwi, and G. Ng. Ketut Sanka, puri Gede Krambitan, who pointed out to me the legitimating aspect of rituals for dead royalty.

11 This padmi was Biang Agung. Her power was based on holdings and followers 'taken along' by her from Sibang when she married (Babad Arya Manguwi:45b). The data given below on dynastic incidents between 1830 and 1836 are derived from Babad Arya Manguwi:58b-69b; Babad Mengwi-Sedang:29-34; Babad Sukahet:35b-6a; Babad Bhoemi:13; Babad Mengwi-Lambing:58-65. This last source is the most detailed. 
kung. During his exile the cousin was under supervision of the Klungkung court.

Although two potential rivals were now out of the way, the king's position was not much stronger. He became embroiled with new difficulties caused by a group of gandrung, good-looking dancers with whom he was homosexually involved. Such relationships were not unusual, but in this case the gandrung managed to dominate the royal entourage and this did tend to raise eyebrows. The king even went so far as to adopt four of them and, having fathered merely one daughter, proclaimed one of his gandrung to be the crown prince, which outraged the whole dynasty. ${ }^{12}$ The newly adopted sons acted their part arrogantly, strutting about in finery, affronting old followers by refusing to let them enter the puri and carrying off their daughters. Consequently, the gandrung were less than popular and their behaviour did not bolster the authority of their royal 'father'.

Dissatisfaction mounted, especially in the satellites, who complained of lack of royal support, for instance when Marga and Tabanan joined in an attack on the Mengwi satellites Blayu and Sembung. Enemy pressure becoming too great and no help from the centre in the offing, the cornered lord of Blayu turned to the Dewa Agung directly. He appealed to the Klungkung king to release the two young men from the Mengwi dynasty who were under his protection, hoping that they might restore royal authority in Mengwi and redeem the dynasty's integrity.

Agung Putra's younger brother was called Agung Besakih. During his exile in Klungkung the fugitive had become a favourite of the Dewa Agung. It was here, too, that he received his name. According to tradition, this took place after he had furnished extraordinary proof that he was, indeed, a son of the late king of Mengwi. Sent off on a quest by the Dewa Agung, he had successfully reached the central mountain temple of Besakih via a tunnel which began at the Klungkung coastal temple of Goa Lawah. ${ }^{13}$ In accomplishing this miraculous feat he proved himself a favourite of the gods as

12 The person the sources name as potential crown prince is Gede Putra, who was of the subbranch jero Kadewatan of the branch of puri Sayan in Bongkasa. Another indication that Agung Putra was a homosexual is given by Dubois, who observed that the king had not a single concubine (KITLV, H281). It seems that in those years a conflict arose between the royal centre and the branch of puri Kapal Kanginan. Babad Mengwi-Sedang (:27-8) is the only source for this, but gives no clear reason for the conflict. The exile of the king's younger brother may have provided the occasion, since his mother came from puri Kapal Kanginan (see Appendix).

13 Samboengan Babad Mengwi:4. Whether this tunnel really exists is doubtful. The Goa Lawah temple on the coast is located in a bat cave, but it is uncertain where the cave ends. This is not easy to determine, since the bottom is covered with a mucky layer of excrement of the thousands of bats that inhabit the cave. Furthermore, I was told, a visitor would not survive the many poisonous snakes hiding in its farther reaches. 
well. The conclusion was that not his brother, but he alone, was the rightful heir to the throne of Mengwi.

The cousin's name was Agung Mayun. Tradition says of him, too, that he was the recipient of superhuman aid, not from the gods but from the powers of the nether world. The island of Nusa Penida chanced to be not only a place of banishment but also the abode of Ratu Gede Mecaling, the fearful demon known to spread cholera throughout Bali. Repeated and extended meditation equipped the exiled Agung Mayun with powers to ward off evil. ${ }^{14}$ Informants maintained that these years on Nusa Penida were decisive for the rest of his life.

\section{Agung Ngurah Made Agung}

Cokorda Kandel

Agung Putra Agung (d. 1828)

Agung Mayun

in Puri Mayun

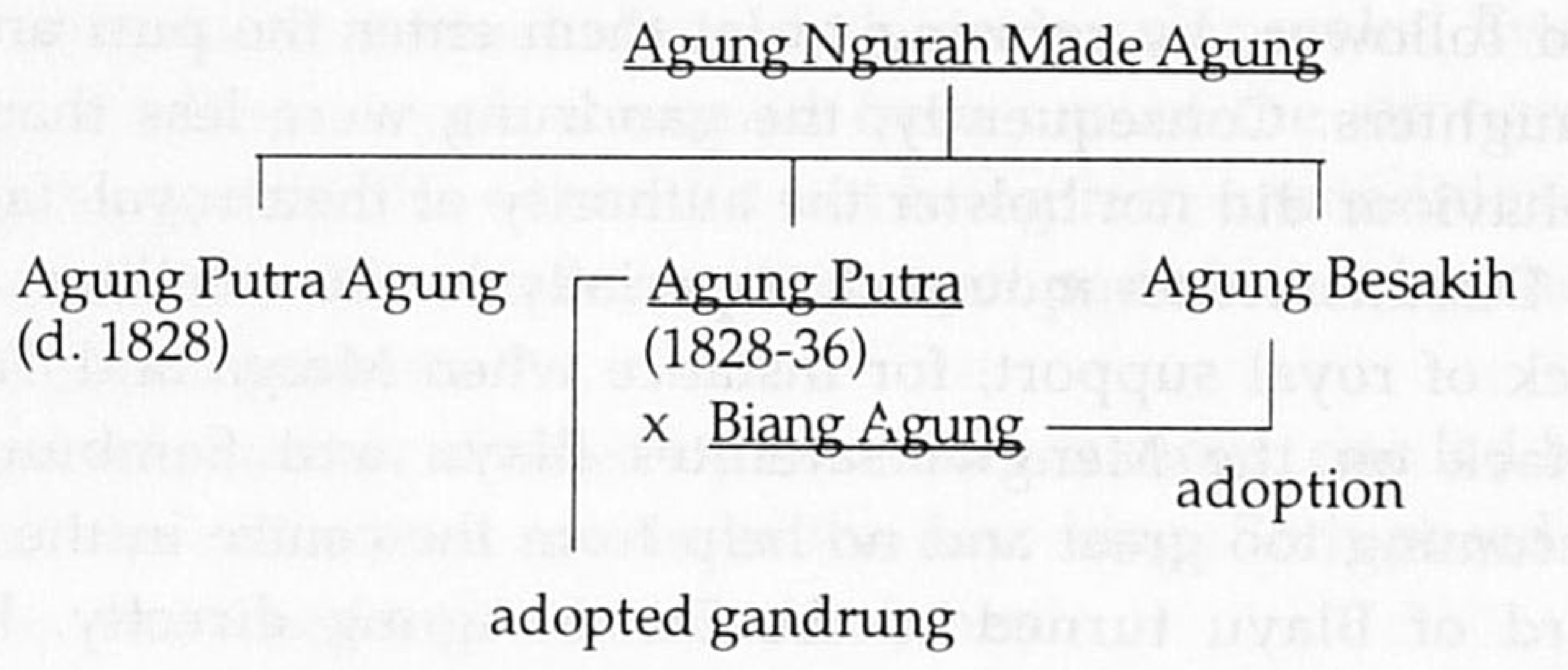

Figure 5. Royal factions in the 1830s

\section{The assault}

The Dewa Agung responded favourably to the lord of Blayu's request. About 1835 the two exiles returned to Mengwi. Formally, the king of Klungkung was still the highest authority in Mengwi, so named in 1828 by the Badung prince. He now saw an opportunity to increase his hold by way of his favourite, Agung Besakih. In the event, however, it was the cousin, Agung Mayun, who would play the major part.

Immediately upon his arrival, Agung Mayun mobilized warriors from Munggu and Mengwi. With these he brought relief to Sembung and Blayu and ousted the enemies that threatened the negara in the north. This effective intervention at once established Agung Mayun as the new strongman of the dynasty, although for the time being it only led to greater tension within the centre. Agung Putra was certainly not inclined to relinquish his position as king without a fight. Thus, at least three factions were pitted against each other in a power struggle. Each faction ensconced itself in a strategic location at the major crossroads of desa Mengwi.

14 Babad Mengwi-Lambing:60. On Ratu Gede Mecaling see Weck 1937:153-8; Lovric 1987a. In this period Agung Nyoman Mayun was still called Gusti Agung Nyoman Munggu. Near the end of his life he was called Cokorda Agung Gede Mayun. To avoid confusion I use the name Agung Mayun. 
Puri Gede, on the southwest corner, housed the first group, that of the king. His position weakened steadily as his power base eroded. The gandrung in his entourage hailed from small families of lesser nobility and afforded insufficient counterweight to the following mobilized by the dynastic opposition. ${ }^{15}$

The second group, led by Agung Mayun, lodged at the southeast corner in quarters built during his father's rule. Under his leadership this 'annex' of puri Gede advanced to the status of an independent puri of the Mayun lineage. As will be argued below, Agung Mayun did have recourse to a sturdy power base. For one thing, he commanded warriors from desa Munggu. For another, he could count on support from the eastern part of the negara whenever he needed it, since both he and his father had links there through various marriages.

The third party was that of Agung Besakih, who, as royal son, factually belonged in puri Gede but was unwelcome there. He took up quarters in the dwelling of an old family of followers just north of the royal puri. This was jeroan Bakungan, the former home of the chiefs of the Mengwi troops. Early on in the nineteenth century this family had been pushed to the sidelines. Agung Besakih, however, married a daughter from this jeroan and thus reinstated its prestige. ${ }^{16}$

In the very centre of the negara, within a stone's throw of each other, the disputing parties readied themselves for a decisive battle, which occurred in 1836. The king's prime opponents, however, kept out of sight as they had their followers do the dirty work. A rough summary of events follows:

'One of the mekel from the desa Munggu was I Gede Bandem. He belonged to a lineage which had a proud history of mekel to the king. One day I Gede Bandem, about to enter the royal puri, was stopped by the gandrung whom the king had elevated to crown prince. Addressing the mekel in the coarsest language, the gandrung ordered him to beg permission to enter the puri. I Gede Bandem was aghast at this affront; his privilege and the respect due to him as mekel were trampled upon. He turned away and presented himself to Agung Besakih. How different the welcome at jeroan Bakungan! Here he was treated with proper regard, invited to seat himself next to Agung Besakih, and encouraged to speak his mind. When the provoked mekel asked leave to kill the gandrung crown prince, Gusti Agung Besakih merely smiled in answer. ${ }^{17}$

15 The king could not count on support from the branch of puri Sibang, former home of his padmi, either, since it was involved in an intense internal struggle for local power just then. Genealogy of puri Gede Sibang and information from G. Ag. Oka Pabean, Denpasar, G. Ag. Putu Gedong, puri Gedong, and G. Ag. Gejer, puri Kanginan, Sibang.

16 This marriage restored the bond with the old army chiefs (see Chapter 2, section 2). Agung Besakih probably tried to re-establish ties with other old families of followers as well. These would look upon him as the man who could restore them to their old positions lost under Sagung Nderet.

17 Based on Babad Arya Manguwi:63-5. The Mengwi babad carefully cover up direct involvement on the part of Agung Mayun and Agung Besakih. However, the course of events 
Shortly thereafter, groups of followers left desa Munggu for Mengwi, to surround puri Gede. Just as in bygone days, when Made Tibung swept down on the royal puri to demand satisfaction, so the Munggu mekel marched on Mengwi. With one crucial difference: Made Tibung's had been the angry action of a relatively isolated group; now the Munggu leaders could count on significant support from within the dynasty.

Panic broke out as soon as word of the approaching Munggu force reached puri Gede. Both the king and his adopted crown prince decided to escape to Tabanan. It was when the men of Munggu were hard on their heels that the 'misunderstanding' occurred. Overtaking the fleeing party in darkness, the men believed they had caught up with the crown prince and did not hesitate to kill. The next moment they realized that the murdered one was the king rather than the hated gandrung.

Dutch sources contradict this account and assert quite openly that the murder of his brother was a planned move on the part of Agung Besakih (Friederich 1850:30-1; Van Bloemen Waanders 1868:379).

Removal of the king did not in itself end the power struggle at the heart of the Mengwi dynasty. Who would be king in his stead? A great meeting of all the important leaders of the negara convened in puri Mayun. Meeting here rather than in puri Gede reflected the expansion of Agung Mayun's influence within the dynasty. Still, even though his power soared, he would have to content himself with a secondary role for another twenty years. Someone else took pride of place all this time: Biang Agung, principal wife of the murdered king. Like Ayu Oka, this padmi widow managed to have her rights to the throne respected. She remained queen of Mengwi until her death in 1857.

To secure her position as leader of the dynasty, Biang Agung made sure that Agung Besakih would remain one rung below her on the dynastic ladder. The manner in which she contrived to do this reflects a talent for astute improvisation. The order of precedence was expressed in kinship terms: the padmi widow adopted her brother-in-law, so that, as 'son', Agung Besakih had to show his 'mother' due respect. Allowed to take up residence in puri Gede, he did not share in actual power as long as she ruled. ${ }^{18}$

From this time on, the centre of the Mengwi dynasty was made up of two puri. Royal authority resided with puri Gede, while much of the executive power was in the hands of puri Mayun.

makes it evident that Agung Mayun was the leader of the opposition.

18 Babad Mengwi-Lambing:62; Babad Mengwi-Sedang:34; information G. Ag. Gede Rai, puri Kaleran Mengwi. See also Appendix. In the third section I present another instance of improvisation regarding new relationships. 
Again, this new, dual leadership was expressed via a series of rituals. ${ }^{19}$ First, much ceremony accompanied the cremation of the murdered king. It was only after he had truly left the earth that his successors might truly assume power. Next, Agung Besakih's adoption by Queen Biang Agung was ritually sealed in the house temple of puri Gede. The two royal purohita, from gria Den Kayu and gria Sidemen, celebrated these rituals and thus brought divine approval to the new leadership.

Prestige of the rituals was much enhanced because the Dewa Agung of Klungkung attended them. The fact that the most highly esteemed king on Bali wished to witness the royal rituals personally meant that he, too, approved of the change of power in Mengwi. More than a century earlier the Dewa Agung was present on Mount Smeru at the inauguration ritual for a mighty Mengwi king (see Chapter 2, section 1). This time, though, circumstances were different. In 1729 the king of Mengwi was all-powerful, and having the Dewa Agung attend the ceremonies was meant to add lustre to the power attained by Agung Alangkajeng. Now, Klungkung's involvement with the Mengwi dynasty was more substantial; the Dewa Agung had been able to increase his influence in the Mengwi centre. The external contacts of the Mengwi dynasty were controlled by him. For instance, in 1843 and 1849 the Dewa Agung rather than Agung Besakih or his adoptive mother signed the contracts with the Netherlands Indies government 'on behalf of' Mengwi. ${ }^{20}$

One important effect of the rituals was that contact between the royal centre and the Mengwi people was re-established. The rituals served as a public announcement of a new leadership, confirmed by the Dewa Agung and the gods. Presumably thousands of people witnessed them, so that the restoration of the hierarchy was proclaimed to all of Bali. Still, Agung Putra had gone a similar route, yet met with violent death. Survival of the Mengwi dynasty would ultimately depend not on rituals or the Dewa Agung's concurrence, but on the strength of the central leadership. Such strength, however, did not emanate from the 'junior king' of puri Gede. Agung Besakih was 'soft', more interested in gambuh theatre than concerned with the welfare of the negara. A sign of his weakness was that he remained without the kris I Panglipur, the royal pusaka which the gandrung crown prince had taken with him in 1836 when he escaped to Tabanan. ${ }^{21}$

19 Information regarding these rituals is derived from Babad Mengwi-Lambing:65; Babad Mengwi-Sedang:34; Babad Arya Manguwi:68a-b.

20 Surat-surat perdjandjian 1964:11, 14-20; see also Weitzel 1859 and Schulte Nordholt 1981a. The relations between the Balinese kings and the Dutch Indies government are discussed in Chapter 6, section 1.

21 Samboengan Babad Mengwi:4 on the character of Agung Besakih. Regarding the kris, 
The weak king was eclipsed by his adoptive mother. Although usually not waking before one in the afternoon, she was known as an extremely energetic woman. Until her death in 1857 she continued to manifest herself as leader of the dynasty. ${ }^{22}$ Though she took pride of place, Agung Mayun's role grew in importance. In 1836 he had demonstrated his prowess in battle. In 1840 Badung and Mengwi stood poised to swoop down upon each other, but the Dewa Agung had managed to prevent war. Two years later battle did ensue, and Agung Mayun and his men emerged victorious. ${ }^{23}$ It was the first victory for the Mengwi dynasty in sixty years.

\section{The leadership of Agung Mayun}

Compared to what is known of the eighteenth century, in the nineteenth century the position of a king on Bali seems to have changed. The earlier kings were often far away from home. Their nineteenth-century successors seldom left the negara. Further, no eighteenth-century kings are known to have shared their power with a second man, or lineage, in the centre. In the nineteenth century this happened with increasing frequency. ${ }^{24}$ Central leadership came to be shared with other branches of the dynasty, branches less prestigious but more powerful. Hence, royal authority might lie with a weakened core lineage, while real power was in the hands of the leader of a strong branch. This division suggests that the position of dynasties as a ruling group had become less of an issue. No new dynasties emerged and the extant ones could afford a weak king as long as a strong sub-branch could guard the centre's power. At the same time, it made it easier to control rivalry at the heart of the dynasty, since an ambitious and possibly danger-

Babad Arya Manguwi (:74a-6b) does relate that the escaped gandrung returned it to Agung Besakih, but Dutch sources contradict this; these show that the gandrung did not return to Mengwi before 1857, after Agung Besakih's death. Further, Tabanan had experienced some upsetting events for which the presence of the kris was held responsible. In 1856 a crow desecrated some of the puri's trees with blood, flew into a kitchen, and changed a jug of water into blood. This event was associated with the Mengwi kris kept in Tabanan at the time. (ANRI, Bali:1.2; 1.4, political reports Bali and Lombok 1856, 1857; ARA, MvK V13-4-1883-14, report Resident Bali and Lombok 17-8-1882.)

22 ARA, MvK V9-7-1860-33/961 report P.L. van Bloemen Waanders 6-5-1856; ANRI, Bali: 4.22, political report Bali and Lombok 1855. A surviving letter of hers indicates that she held the first place in the hierarchy; see Van Naerssen et al. 1977:152.

23 In 1840 the Dewa Agung managed a postponement because of a great maligya (death rite) which was in preparation just then. War would obstruct its progress. It is noteworthy that, at least in terms of ritual, all of Bali was under the authority of the Klungkung court and that both Badung and Mengwi obeyed the Klungkung command. On the rituals at Klungkung see ARA, NHM:9419, report D.B. Schuurman 1840, and Vickers 1991; for the war of 1842 see ARA, MvK V29-1-1842-43 geh., report H.J. Huskus Koopman 13-12-1841.

24 These changes occurred not only at Mengwi, but also in Badung (Schulte Nordholt 1980: 73-89) and Tabanan (Liefrinck 1921:14). In Buleleng a patih gained much influence (Weitzel 1859). 
ous branch had a great deal of room to manoeuvre on condition that no disrespect was shown to the royal authority of the weak core lineage. In the short term the compromise prevented violent power struggles, but there was always the chance that in the long run the king's position would be undermined.

Sometimes a king managed to curb the rising power of rival branches by gathering about him ministeriales of lesser birth. In Badung and Gianyar such jaba or prabali held important posts during the second half of the nineteenth century. ${ }^{25}$ Their personal skills launched them on a career, and with their help the king could keep his own rivals in check. These talented servants of low birth constituted no threat to the throne; on the contrary, their position depended entirely on royal protection.

There were no ministeriales in the royal centre of Mengwi, where the branch of puri Mayun was gaining influence. Agung Mayun proved a versatile leader. As a warrior he was admired. As supervisor of irrigation projects he took personal interest in agriculture. As builder of temples he restored the ritual bond between gods and men. As ruler he shaped the hierarchical relationships in Mengwi. In combination, these abilities endowed him with great authority and eventually made him the undisputed leader of the Mengwi dynasty.

\section{The army}

The exact size of the Mengwi army is not known. One account mentions that towards the end of the nineteenth century the centre of the dynasty had a thousand guns. ${ }^{26}$ These firearms were meant for the elite troops, the core of a much greater assemblage including large groups of followers, in part armed with krisses and lances, others without weapons. These last were carriers, but their main function was to add to the fearsome aspect of the whole by vigorously beating a variety of percussion instruments. Just as in the case of major royal rituals, the leader's strength was demonstrated by sheer force of numbers.

Part of Agung Mayun's fighting force was recruited from desa Munggu, which belonged to the domain of puri Mayun. ${ }^{27}$ Furthermore, Agung

25 In Gianyar these were the brothers Made and Ketut Pasek, patih (army chief) and legislator of the king respectively (Liefrinck 1921:86; information A. A. Gede Agung and I Made Subaga, Gianyar; see Chapter 6, section 2). In Badung, two successive generations of members of the house of Saunggaling were patih, jaksa, and sedahan gede (KITLV, Coll. Korn:159, Nota vorstenbestuur Badung 1920; information Bapak Widyakusuma, Denpasar).

26 KITLV, Coll. Korn:149, report punggawa Mengwi 1920.

27 Between the follower families in Munggu and the centre of the dynasty a sturdy bond went back a long way. Agung Mayun was lord of Munggu, which is why in earlier years he was called Agung Munggu. KITLV, Coll. Korn:110, Nota G. Gede Raka 8-6-1938; information G. Ag. Gede Putra, puri Lambing. 
Mayun rejuvenated the royal corps in desa Mengwi, purposely reaching back to the days of the renowned second king of the dynasty, Agung Alangkajeng. The refurbished core unit reverted to the name Batu Bata and was commanded by a new clan of followers. These new commanders were of low birth and, unlike the old-style chiefs, were not raised to prabali level, nor did they become linked to the dynasty by adoption. They remained jaba and were not elevated to the level of Gusi or Sagung. Nevertheless, this clan's prestige rose markedly, as it was assigned living quarters northwest of the main crossroads in desa Mengwi, adjacent to the jeroan of the Sagung Bakungan, the former army chiefs. This housing, too, became a jeroan, its architecture more elaborate than that permissible for the dwellings of other jaba. In addition, the newly advanced members of the puri Mayun entourage had certain privileges, such as immediate access to the puri, reduced punishment for criminal offences, and the use of at least 25 acres of sawah, untaxed. ${ }^{28}$ Agung Mayun's relationship with this trusted group was manysided. They led the Batu Bata, they supervised the desa Mengwi, and their house became a centre for dancing, theatre, and music. Thus the new confidantes contributed to the rising authority of their puri Mayun in the military, in administration, and in courtly culture.

Memories of the Mengwi dynasty's heroic past were attached to the oldest son of Agung Mayun. His name was Agung Made Raka, but people identified him unambiguously with his eighteenth-century forefather and called him 'Agung Alangkajeng' or 'Bima Alangkajeng'. ${ }^{29}$ Agung Made Raka was put in command of his father's army. He became famed as a leader whose personal courage inspired his men to follow him. Dutch visitors described him as a square-built figure, impressing one as somewhat rough and uncultured but also as jovial, honest, and intelligent. ${ }^{30}$ His performance as a fighter was marked by his awe-inspiring physical appearance and immense strength, which was said to derive from the gods. Two tales will illustrate this.

Daring and strategic astuteness were the hallmark of the lightning attack

\footnotetext{
28 Babad Arya Manguwi:83b; Babad Mengwi-Sedang:42-3; information Ida Bagus Ketut Sindu, G. Ag. Gede Rai, puri Kajanan, I Ketut Misma, I Gede Sila Adjana, Mengwi, G. Gede Kaler, Umabian, G. Ketut Kaler, I Ketut Radi, Blahkiuh. On the earlier Batu Bata see Chapter 2, section 2. Remarkably, the clan of the Senggu (going back to old, non-brahman priests) is mentioned as providing outstanding warriors. Informants offered two reasons why, in contrast with former days, leadership of the renewed Batu Bata was not given to someone from jeroan Bakungan. First, the jeroan was too closely linked with Agung Besakih. Second, the clan had come into conflict with Agung Mayun. The Sagung Bakungan did gain more prestige because their dwelling was promoted from jeroan to the higher status of jero.

29 Samboengan Babad Mengwi:6; Babad Mengwi-Lambing:67-70; information G. Ag. Ajeng, puri Labah, Kedampal.

30 Jacobs 1883:200-1; ARA, MvK V24-12-1873-48, report Gekommitteerde voor Bali en Lombok, October 1871.
} 
Agung Made Raka launched against Marga in 1862. ${ }^{31}$ The northern lord had severed ties with the Mengwi dynasty around 1823 and his domain became part of negara Tabanan. In time, puri Marga was firmly allied with the Tabanan dynasty: no less than three daughters of puri Marga were married off to the Tabanan puri, and for important rituals the lord of Marga obtained his holy water from the purohita of the king of Tabanan. This intimate linkage was a thorn in Mengwi flesh. In two respects its ruler's honour was at stake. First, Marga's defection to Tabanan had gone unavenged, and second, the old mountain temple of the Mengwi dynasty was still held by puri Marga.

An opportunity to square the account arose when the puri of Blayu and Marga collided. Of old, the two houses were related, but since puri Blayu had remained loyal to the Mengwi dynasty, the bond between Blayu and Marga had turned sour. Matters escalated in 1855, when the lord of puri Blayu abducted a daughter of the lord of Marga, a girl meant to marry the king of Tabanan. The lord of Marga considered this abduction an especially serious insult and the event initiated a series of skirmishes between Blayu and Marga, which grew into a protracted border war. Moreover, the local conflict became a regional issue when the royal centres of Tabanan and Mengwi entered the dispute.

In 1862, after seven years of repeated border incidents, Agung Made Raka decided on a surprise move against the enemy. Suddenly he and his warriors breached the lines and marched straight on to desa Marga to occupy the puri. Taken aback, the lord of Marga fled to Tabanan. One single stroke had laid Marga wide open, but Agung Made Raka had not finished yet. Leaving desa Marga behind him, he did not hesitate to move on northwards, halting only when he reached the old mountain temple of the dynasty on the shores of Lake Bratan. At this place he organized an extensive ritual to pay proper homage to the gods and bring fertility to negara Mengwi. Presumably, Agung Made Raka never really intended to recapture Marga; three months after his flight the lord of puri Marga returned and Marga remained a Tabanan satellite. What Agung Made Raka did accomplish was that the honour of the Mengwi dynasty was vindicated, puri Marga badly humiliated, and his own prestige much enhanced, the more so since he had not forgotten the gods.

About the same time a similar conflict occurred in another border area. It was in this connection that the tale is told of the divine provenance of Agung Made Raka's might. ${ }^{32}$ This time the lord of another Mengwi satellite

31 ANRI, Bali:2.3, political report 1863; Van Bloemen Waanders 1870:424; Babad MengwiLambing:70-1; Babad Mengwi-Sedang:43-4; information G. Gede Catra, puri Marga.

32 Babad Mengwi-Lambing:67-9; corresponding data on this conflict are found in: ANRI, Bali:2.1, 2.2, political reports 1861, 1862; Geh. Besluit 14-11-1862-24, report Gekommitteerde 
had become embroiled in difficulties. Like the lord of Blayu, he, too, successfully appealed to the Mengwi army leader. This was the lord of puri Carangsari, whose domain lay in the northwestern part of the negara. Just east of Carangsari was the region of Payangan, between 1843 and 1862 the sporting toy of surrounding rulers, each in turn overrunning the area. In 1861, when the lord of Carangsari became involved in one such conflict. Agung Made Raka rushed to his aid. Pushing hard, he chased the enemy out of the Carangsari domain, penetrated deeply into Payangan, and so shifted the conflict outside of negara Mengwi. Once again, Agung Made Raka gained much respect by taking his troops far into enemy territory and returning unscathed.

People were now convinced that Agung Made Raka possessed superhuman powers, in token of which the gods had given him a special scarf. ${ }^{33}$ As before, Agung Made Raka concluded the expedition with a ritual. Prior to his return to Mengwi he paid a visit to the new mountain temple of the negara to honour the gods (who at this time rewarded him with the scarf). This done, he at last returned to Mengwi, where he was embraced as a hero.

The Payangan territory was not held for long. Shortly after Agung Made Raka's foray, a new conqueror occupied the area. Expansion no longer appeared to be the primary objective of the Mengwi dynasty; the negara's borders remained largely the same. On the other hand, Balinese politics left ample opportunity for disputes of rank. The personality of an army chief played a crucial role in this. Strong leaders such as Agung Mayun and Agung Made Raka awed those around them and wasted no opportunity to make clear that they, rather than their rivals, were worthy of respect. The point had to be made time after time; hence a strong dynasty was almost continually at war, or, as Agung Mayun said in connection with the expeditions to Marga and Payangan: 'War has always been waged on Bali. Mutual warfare may be called part of the Bali adat. ${ }^{\prime 34}$ This is one reason why the role of an awe-inspiring leader was so important: perhaps he would be able to avert the dangers of battle and its disastrous effects. The leader's physical appearance represented the violence of the dynasty. Equally import-

voor Bali en Lombok, 1-10-1862. See Mahaudiana (1968:68) for the effects of the border conflicts between Mengwi and Gianyar in 1868 and 1874 for the area involved.

33 Babad Mengwi-Lambing:68. The scarf was known as Si Naga Poleng, 'the checkered snake'. Interestingly, Bima, the hero of the wayang story, wears an identical scarf. The narrative places much emphasis on Agung Made Raka's appearance, the symbolism of the colours underscoring his strength. He is pictured astride a black horse, clothed in a white loincloth and a red jacket and wearing a yellow headdress. Black is the colour of Brahma, white the colour of Siwa, red the colour of Wisnu, and yellow the colour of the king. When Jacobs met him in 1881, however, he wore 'red silk' (1883:200-1).

34 ARA, MvK V4-10-1867-136 geh., report Gekommitteerde voor Bali en Lombok 20-9-1864. The official, rather than his informant, must have used the term 'adat'. 
ant, however, was that divine approval be manifested as well, for it held the promise that violence could be contained. Uncontrolled violence was destructive, but violence mastered by the leader lay at the root of the hierarchical system on Bali. ${ }^{35}$

\section{The northeastern frontier}

Agung Mayun's dealings with the people went far beyond those of a mere warrior. He concerned himself personally with the agrarian sector, especially in the northeast of negara Mengwi. This area, stretching from desa Blahkiuh to desa Plaga, was the last frontier in the Mengwi region. The land had been cleared for sawah since the middle of the nineteenth century. Agung Mayun played a many-faceted, key role in this. The combination of these various aspects underscored the success of his leadership. Violence, the establishment of a new puri, taking on lord-follower relationships, the construction of irrigation systems and sawah, announcement of regulations, the introduction of new export crops, and the building of temples - all of this was personified in Agung Mayun.

The young lineage of puri Mayun had gained access to the eastern part of the negara, mostly through marriages. Agung Mayun's father had married into three local noble houses; he himself was married to four women from the area. Notably, in his case most of them were low-born women whose families belonged to the village elite. In virtue of these relationships puri Mayun had potential local allies, fanned out across the east of the negara. ${ }^{36}$

One of the wives who came from this area belonged to the Bendesa Mas of desa Mambal. She was the mother of army commander Agung Made Raka. Her relatives were locally prominent jaba, serving puri Mayun well in controlling the dam at Mambal, which was important because of the need to secure irrigation supply to the area around Munggu, part of the domain of puri Mayun. In addition, this family was to play a role in the opening up of the northeastern part of the negara.

More than a hundred years earlier, the northeast region of the negara had belonged to the lineage of puri Singasari, until that satellite was destroyed (see Chapter 2, section 5). For a time the area sank into near oblivion. A number of lesser noble families and some groups of followers of the dynastic centre were its rulers. But towards the middle of the nineteenth century interest in the region quickened, prompted by economic change. Coffee had become a major export product on Bali, most of it routed

35 See also Hobart 1985:14: 'Power is represented in part at least as being represented by mastering violence, for how otherwise is one to know who has power'. Babad Mengwi-Lambing (:71) says of Agung Made Raka that he was sakti, endowed with supernatural power.

36 Babad Mengwi-Lambing:65-6. The wives of Agung Mayun came from desa Mambal, Sangeh, Punggul, and Grana; see Appendix. His mother was from Punggul. 
through the harbour at Buleleng. ${ }^{37}$ Cultivation of coffee was possible only in the highlands; consequently, the mountains of central Bali became a political bone of contention.

In 1842 a big slice of this area was controlled by the neighbouring dynasty of Bangli, which derived most of its income by far from the coffee (and opium) trade. ${ }^{38}$ The Mengwi dynasty had to wait another twenty years before it could establish firm control over the area. In 1862, at last, it was Agung Made Raka who, in connection with the Payangan campaign, achieved this by securing the region against enemy attacks. At that time, and certainly once the struggle over the area was ended, the expansion of puri Mayun translated into the creation of extensive coffee gardens north of desa Petang. In this way the Mengwi dynasty could still share in the profitable proceeds from this product. But this income had to be shared with the lord of puri Carangsari, in whose domain the new coffee gardens were located.

It was the lord of this peripheral satellite who was most directly involved in coffee cultivation. He mobilized groups of followers and ordered them to establish four new villages, which guaranteed that sufficient labour would be available in the newly developed area and that its defence could be organized from the settlements. ${ }^{39}$

Once this mountain area was opened up, immigrants came to the new villages. These were Hokien Chinese who moved north from the southern Bali coast and established a trade monopoly. They enjoyed protection from puri Mayun and puri Carangsari, from whom they leased the rights to coffee export. These merchants were financially advantageous to the puri in two further respects. First, they provided money if their noble protectors were in need of funds. Second, they imported large quantities of opium and, in order to secure a monopoly on sales, paid large sums of money to the puri. Along with the Chinese, then, the use of opium also penetrated more deeply into Balinese society. ${ }^{40}$

37 Between 1855 and 1875 especially, the cultivation of coffee expanded rapidly. In 1861, 5,456 pikol (1 pikol $=62.5$ kilogrammes), with a value of Dfl. 141,597, was exported from Buleleng. By 1873 the volume was more than four times greater: 23,690 pikol, Dfl. 1,298,047 (ANRI, Bali:2.1, 3.4, political reports 1861, 1875; Vink 1929). This was Arabica coffee, of which Vink (1929:4) notes that southern Balinese kings were actively involved in the cultivation of coffee gardens. See also Chapter 6, section 1.

38 Concerning coffee cultivation in Bangli, see Vink 1929 and Liefrinck 1877. Information regarding the occupation of eastern Mengwi by Bangli is taken from ANRI, Bali:8, diary H.J. Huskus Koopman, September 1842 to July 1843, 14-11-1842. See note 56 below, on evidence for Bangli presence in the area.

39 Data are from KITLV, Coll. Korn:147, memorandum punggawa Abiansemal 1920, in which these villages are said to have been founded by puri Carangsari. These villages were Kiadan, Nungnung, Bukian, and Plaga which, as will be clear below, also played a role in connection with the new mountain temple of the dynasty.

40 Information concerning the immigration of Chinese families is from interviews with Tan Susun and I Putu Balik, Carangsari; Lim Lin An, Petang, and I Ketut Segara, Blahkiuh. 
In view of the poor communications between the central dynasty and the satellite Carangsari, it is plausible that the lord of puri Carangsari was the one who profited the most from the new mercantile activities. And this, of course, enhanced his political power. Puri Mayun was much concerned to keep him in check. To make sure of this, Agung Mayun decided to have his youngest son move northeast, accompanied by a group of warriors. In desa Grana, just south of Carangsari, this son established a new puri, thus creating a sub-branch of the puri Mayun lineage (Babad Mengwi-Lambing:66).

Agung Mayun and the new puri in Grana were now in firmer control of the northeastern region and took its further development into their own hands. All around desa Grana coconut groves were planted, the products of which (oil and copra) were bought by Chinese exporters. ${ }^{41}$ More important than this was the cultivation of new sawah and the concomitant extension of the irrigation system in the area. Five complexes were made fit for cultivation. Water supply to existing sawah in the immediate vicinity of Grana was improved by means of a conduit no less than fourteen kilometres in length - an impressive achievement, since the first part of the work consisted of a tunnel cut through four kilometres of solid rock. ${ }^{42}$ Agung Mayun had now shown his ability to tackle nature as well as the enemy.

Farther south in the region, too, Agung Mayun increased his hold by enlarging his personal influence in desa Abiansemal and desa Blahkiuh. These places were governed by the jeroan of the Sagung Bakungan, a situation dating back to the eighteenth century. But this old house of followers did not belong to Agung Mayun's immediate entourage. To gain a measure of control over the two villages he backed his own henchmen. To this end he ordered some members of the Bendesa Mas family from Mambal to settle in Abiansemal and Blahkiuh, where he appointed them as mekel over part of the population. Through them these people, from then on, were bound to puri Mayun. ${ }^{43}$ Here too, control over people and extension of agriculture

Chinese families also settled in Plaga, from where coffee was exported to the harbour of Buleleng. On the connection between Chinese immigration and increased use of opium, see also Liefrinck 1877; on the role of Chinese merchants in Tabanan, see Geertz 1980:94-7. On the opium connections between Java and Bali, see Rush 1990. To protect the northern trade route a number of Buginese families were recruited from Badung. These settled in desa Angantiga. To this day the village is a small Islamic enclave with its own mosque; see also the contribution by A.A.B. Wirawan in Sejarah masuknya Islam 1979.

41 Export of copra began to flourish especially towards the end of the nineteenth century. See Koloniaal Verslag 1892:appendix C; ANRI, Bali:16, political report 1886.

42 Babad Mengwi-Lambing:63; information G. Ng. Putra and G. Ng. Rai Mirsha, puri Grana. The new sawah areas were Balangan, Bregiding, Babakan Bengkel, Buangga, and Karangdalem.

43 'Prasasti Bendesa Mas Abiansemal'; information I Wayan Gatra, Abiansemal, G. Ketut Kaler, jeroan Bakungan Blahkiuh, G. Ag. Gede Rai, puri Kajanan Mengwi. This is the same Bendesa Mas family from which Agung Mayun had taken a woman to wife. From then on Blahkiuh was controlled by three noble families: puri Sibang, jeroan Bakungan, and puri 
went hand in hand, Agung Mayun taking a personal interest in both. An abortive attempt at the cultivation of coffee northwest of desa Blahkiuh was followed by large-scale extension of sawah between that village and desa Sangeh. ${ }^{44}$

Much of the northeastern region, then, was added to the domain of puri Mayun because Agung Mayun employed the strategy of attracting confidantes who, in turn, controlled larger groups of followers. Some of these confidantes were related to him by marriage and had a power base of their own, the noble house of puri Punggul for instance; others were relatives of lesser birth and were moved to other villages, as in the case of the Bendesa Mas family. Finally, his own son, in desa Grana, represented the lineage of puri Mayun in the area. All of these relations were personal and essentially time-bound, since they converged in the figure of Agung Mayun. The expansion of agriculture, too, was closely tied up with the growing influence of puri Mayun. Agung Mayun was able to offer his followers both security and food, in exchange for which he could appeal to their loyalty.

As far as can be determined, extension of the sawah area in the northeast did not automatically result in the institution of new subak. In colonial literature the subak is usually pictured as an autonomous association catering to the irrigation needs of its members at the local level. This uniform organization is considered to be distinct from local relationships such as a ward or a village. ${ }^{45}$ In Chapter 2, however, I indicated that the autonomy of local irrigation should not be overemphasized. Supra-local intervention by the nobles was unavoidable because of the distance between the sawah and the major dams, the weakness of these dams, and general political instability. This was also true of the northeast. Moreover, the uniform way local irrigation is thought to have been organized is open to serious doubt. Oral traditions about pre-colonial times suggest something very different. Without exception, informants emphasized the leading part played by the puri in the building and maintaining of irrigation systems. They did not mention subak as separate organizations, referring rather to the village as the unit providing labour for larger projects. ${ }^{46}$ The term subak

\footnotetext{
Mayun. There are vague indications that part of the village was controlled from Bangli earlier, but this influence disappeared with the rise of puri Mayun.

44 KITLV, Coll. Korn:226, proces verbaal Raad Kerta 1926; information mangku pura Mumbul Sangeh, G. Ag. Gede Putra, puri Lambing.

45 See Liefrinck 1886-87; Korn 1932; Grader 1960a; Geertz 1980:68-86.

46 On various occasions I asked older informants in desa Grana, Sangeh, Punggul, and Blahkiuh about this. Informants from the more southern desa Lukluk and desa Kurabaya also thought that their village rather than a subak was the unit, led by local puri, for recruitment of labour for the conduits and weirs of the Mambal dam irrigation system. See Schulte Nordholt 1986b and Chapter 8, section 4, concerning the introduction of fixed standards for the local order under colonial rule.
} 
certainly existed, but referred to a person rather than to an autonomous irrigation association. A subak was the lowest link in the regional hierarchy of the Mengwi irrigation systems, appointed by the sedahan of the puri in charge of irrigation in a given area. ${ }^{47}$ Puri Mayun, for instance, had appointed a number of sedahan in the northeastern region, charged with the coordination of local irrigation. These had their subak supervise the sawah controlled by their lord and resolved local disputes concerning water supply.

Indications of the central role played by Agung Mayun at the regional level are also found in the decrees issued by the Mengwi dynasty. One of these paswara was composed by him and dealt specifically with agriculture. In it, he ordained no less than the death penalty for theft of paddy from the rice fields, even if the offenders belonged to the dynasty. ${ }^{48}$

Most likely, the precise organization of the various irrigation systems in negara Mengwi differed widely per locality. In every instance, however, lord-follower relationships determined the lines along which these systems were organized hierarchically. At the top were the puri of the noble rulers, each with their sedahan and lesser subak. At the lower end were the followers with access to the sawah. As noted in Chapter 2, these sawah were called pacatu. The follower/cultivator had rights of use to the entire crop, and in exchange he owed his lord loyalty, labour, and taxes. These pacatu sawah were common in southern Bali and constituted the material basis for followership. ${ }^{49}$ At issue was less the notion of land ownership than the question of who had access to the harvest of a sawah. A colonial estimate mentions that roughly 35 percent of the sawah in southern Bali was sawah pacatu. There is reason to think this percentage was much higher, possibly nearer 50 percent. ${ }^{50}$ Even so, much of the sawah was not categorized as

47 KITLV, Coll. Korn:193, report punggawa Abiansemal 1920, on the pre-colonial order in Mengwi. The informants mentioned in note 46 confirmed this. There were subak gede and subak cenik, leaders of larger areas of sawah and their helpers who each controlled a part.

48 KITLV, Coll. Korn 175:Paswara Mengwi:65-66. An exception was made for brahmans; they were to be exiled for life. This paswara further fixed penalties for cattle theft and damage caused to the fields by untended cattle. Sosrowidjojo (1875:28) also mentions in his travel account the heavy penalty Mengwi exacted for padi theft. He does not mention capital punishment, but he does refer to laming of the right hand and left foot of the offender. For extensive royal decrees on agriculture in negara Badung, see KITLV, Coll. Korn:159.

49 See Happé 1919; De Kat Angelino 1921a; Damsté 1925; Gunning and Van der Heyden 1926; Korn 1932:227, 267; KITLV, Coll. Korn:149, report Korn 1925. Geertz's view that the importance of the pacatu system is overemphasized in the literature (1980:177) seems to me in disagreement with available information. I do not discuss the supposed origins of the pacatu sawah, a point with which the colonial literature is much preoccupied.

50 ARA, MvK, Nota van Toelichting Gianyar, W.F. van der Kaaden 1938. Korn's statement (1932:227) that there were no pacatu in negara Tabanan is rejected, correctly I think, by Boon (1977:56). The estimate mentioned is probably too low; under colonial rule a rapid transition had been made from the pacatu system to private property. In consequence the number of pacatu sawah diminished visibly; see also Chapter 8, section 4, and Chapter 9, section 2. 
pacatu land. In part, these were sawah of which the produce was meant for the puri itself; others were plots of land held by individual peasants. This meant that part of the people were able to grow their own crops without becoming followers of a puri. It also meant that the puri did not control the whole of the surrounding land: labour and taxes were demanded of the cultivators of the pacatu sawah only. ${ }^{51}$

As to the amount and types of taxes levied in pre-colonial Mengwi, little can be ascertained. The most important levy was the pajeg, which usually went to the puri lord with authority over the pacatu sawah. According to one report this tax amounted to 500 kèpèng per tenah - a plot of varying size - which was cheap at the price. Many did not pay this tax, since there were a lot of exceptions and dispensations. Furthermore, part of the revenue paid the salaries of the sedahan of the puri. ${ }^{52}$ The available data suggest that sawah taxes were not the primary source of income for the puri in Mengwi. Other income was derived from the puri's own sawah, levies on coffee cultivation, the sale of opium, cockfights, and tolls charged to merchants. On the other hand, the pacatu system served to provide followers with secure access to sawah land and to bind them to one of the puri.

These data, though few, allow us to conclude that the Mengwi dynasty's grip on the negara was incomplete and unstable. The royal centre lacked a bureaucratic apparatus capable of properly controlling the available manpower and effectively insisting on its share of the agricultural surplus. The centre depended greatly on countless vertical relationships in which commoner loyalty was a fairly expensive commodity.

One tax was charged to all sawah cultivators. This was a levy on the use of irrigation water, called the suwinih. ${ }^{53}$ The tax was collected by the king but not meant for his own use. The dynastic centre used the suwinih to finance periodic rituals held in the regional agricultural temples. Just as control of physical violence required divine sanction, so also control of nature had a religious dimension. Participation in the rituals was not restricted to the circle of royal followers; ideally, everyone was expected to attend them. On these occasions the authority of Mengwi leadership was very much in evidence.

51 See Korn 1932:267; KITLV, Coll. Korn:193, report punggawa Abiansemal 1920. This does not mean that 50 percent of the total population was without some relation to the puri. Often, followers had, in addition to their pacatu sawah, a piece of land of their own. No data are available on the percentage of landless households in pre-colonial southern Bali.

52 KITLV, Coll. Korn:193, report punggawa Abiansemal 1920; ARA, MvK V17-11-1910-38, V28-6-1909-1; Schwartz 1901a:144; Korn 1932:300. For a review of the regional variations, see Korn 1932:293-301. A tenah was not a fixed measure. See Chapter 8, section 4.

53 Van der Heyden (1924) and Korn (1932:330) claim that this suwinih did not exist in Mengwi. This is incorrect; far into colonial times, informants say, this levy was paid as a matter of course. 
A clear illustration of this is the temple Agung Mayun had built in the northeast. This pura Arantaja lay just west of desa Petang on the dividing line between the coffee gardens in the mountains and the sawah south of them. ${ }^{54}$ The temple was just as natural a part of the opening up of the area as were the relationships between lord and followers, the establishment of puri Grana, and the development of coffee cultivation and sawah.

In this context pura Arantaja had three major functions. First, the temple had to foster fertility of the land. To this end a large meru with eleven tiers (representing Mount Smeru or Mount Agung) was built. Worship at this meru would court favour with the gods and move them to render the land fertile. In the outer court of the temple a smaller temple was situated with the specific purpose of safeguarding the harvest from plagues. Upkeep of the temple and seeing to the ritual was the responsibility of the various sedahan in the area. The whole was under the supervision of puri Mayun, whose responsibility went little further than granting permission to conduct a given ritual and personal attendance of the leaders at the more significant events. But if the sedahan or the temple priest shirked their duties, puri Mayun was obliged to intervene, so as to ensure that the ritual calendar and hence the agricultural cycle would not be disturbed. This, in fact, was a second function of the temple, since, ideally, the agricultural cycle began and ended with the rituals in this temple. ${ }^{55} \mathrm{~A}$ third function of pura Arantaja is indicated by the popular name by which the people refer to it: pura kerajaan (royal temple). By erecting his temple in the middle of the region opened up by him, Agung Mayun manifested his authority. ${ }^{56}$ Accordingly, his temple represented not only the link between gods and men, but was a permanent reminder of the new ruling order in the region.

54 Babad Mengwi-Lambing:63; information G. Ng. Oka, puri Carangsari, G. Ag. Gede Putra, puri Lambing. Expansion of the sawah at desa Sangeh, too, went together with the building of a small temple, also ascribed to Agung Mayun; information I Wayan Serogog, Blahkiuh, and others.

55 This is perhaps also the context of the odalan celebration of the temple. For this 'birthday' a much older solar calendar was used, rather than the customary wuku calendar. Hence, the odalan did not occur once every 210 days, but annually in October (at purnama kapat, the full moon in the fourth month), that is, after the harvest. I thank Hedi Hinzler for information regarding Balinese calendars.

56 By building this temple, Agung Mayun relegated another temple to the background. This was pura Dalem Alas Gegelang, more to the north at desa Sandakan. Most likely this temple was built by Bangli lords when they were still more or less in control of the region. Two shrines in this temple refer to craters of the Batur volcano in Bangli: puri kawan and puri kanginan (information mangku pura Dalem Alas Gegelang; Schwartz 1901b). In the southern desa Sempidi there is a shrine representing (pasimpangan) the temple. Information from 1842 indicates that Bangli had influence in both Sandakan and Sempidi at the time (ANRI, Bali:8, diary H.J. Huskus Koopman 14-11-1842). 


\section{Violence controlled}

Of all this Agung Mayun was the architect. And he was more than that. People were utterly convinced that he personally brought fertility to the land and that he possessed superhuman power. He himself was the link between the gods and the negara. Each one of his descendants agreed that 'where he walked the land became fruitful, the harvest rich, and plagues and illness departed'. In her work on nineteenth-century Klungkung, Margaret Wiener emphasizes the role of the Dewa Agung as sorcerer and healer, capable of transforming negative forces into positive power (Wiener 1990:191-8, 302-3). The same qualities were attributed to Agung Mayun of Mengwi.

The relevance of belief in the healing powers of a royal personage is underscored by listing successive plagues and epidemics which swept over southern Bali between 1850 and 1888.57

1850: Smallpox epidemic in Badung; 4,000 dead; spreads to Klungkung and Mengwi.

1856: Plague of mice destroys harvest in Mengwi, Tabanan, and Badung.

1861: Smallpox epidemic in Klungkung.

1862: $\quad$ Rice crop in southern Bali fails, largely because of mice. Famine.

1863: Cholera and smallpox in Mengwi.

1864: Smallpox unabated in Mengwi.

1868: In Tabanan and Mengwi rice crop fails because of plague of mice. Famine. Many brought to slavery through debts. Cholera and dysentery enter from Buleleng. At least 2,000 dead.

1871: Smallpox epidemic in southern Bali; 15,000 to 18,000 dead.

1872-73: Smallpox continues; in Mengwi 3,000 dead within a month; in desa Sempidi alone, 700 of 1,000 inhabitants die.

1874: Cholera in Badung and Mengwi: 'a terrible death-toll'.

1878: $\quad$ Mice destroy virtually the entire rice harvest in southern Bali.

1883: Smallpox epidemic beginning in Karangasem spreads, via Klungkung, to Mengwi.

1885: Smallpox throughout southern Bali, followed by a cholera epidemic.

1888: $\quad$ Earthquake and cholera in southern Bali.

To this list of calamities one must add a high degree of political instability.

57 Compiled on the basis of data by Van Eck 1880:86-90; T. 1874:452-4; Van Vlijmen 1875:912; ANRI, Bali:1.2, 2.1, 2.2, 2.3, political reports 1856, 1861-1863; 2.12, 5a, 6.25, 3.15, 3.18, resp. reports Buleleng/Jembrana 1872, October 1874, 1878, report Bali and Lombok 1885 and 1888; ANRI, Geh.Besl. 14-11-1868-24; ARA, MvK V4-10-1876-136 geh., report Gekommitteerde Bali and Lombok 20-9-1864; V24-12-1873-48; Mr.1872:495+; Mr. 1888:513+. See also Babad Mengwi-Lambing (:63) for mention of the healing powers possessed by Agung Mayun. 
This brought on violence that not only claimed the lives of the immediate victims, but also caused many crop failures and much illness. During wartime, epidemics would spread across the land like wildfire, and great groups of fugitives carried the disease, causing casualties elsewhere.

In sum, southern Bali was a highly dangerous place, where visible violence (human enemies) and invisible powers (disease and natural disasters) were a constant threat to daily life. But the fragmented political system was such that each of the separate, local rulers looked after himself first and took little thought for the welfare of his neighbours. This meant that the task of the royal centre was to defend the whole and, beyond that, to maintain the precarious balance between gods, humans, and demons. Agung Mayun had demonstrated that under his leadership violence was checked to some degree at least. This meant that the centre of the Mengwi dynasty could again be relied upon. Its trustworthiness renewed, the centre gained esteem; the hierarchical order in the region, and thus the negara, was manifest again.

\section{The crowning}

As in the case of his eighteenth-century forebear Cokorda Munggu, history pictures Agung Mayun as a builder of temples. The construction of pura Arantaja in the northeastern region was small in scale compared to the new temples built elsewhere. One of these was in the north, the other far to the south. Together they marked the 'ritual axis' that united the dynasty's central temple, pura Taman Ayun in Mengwi, with the mountains and the sea. During the lengthy crisis from 1770 to 1823 the Mengwi dynasty had lost control over the old mountain temple at Lake Bratan and the sea temple at Jimbaran. Agung Mayun did not recover these sanctuaries. Instead, he had new temples built, more or less within the puri Mayun domain: in the south in desa Seseh and at Tinggan in the northeastern mountains.

\section{The 'ritual axis'}

The small coastal village of Seseh grew into a new ritual centre of the Mengwi dynasty. It lay just south of desa Munggu, one of Agung Mayun's power bases. A complete regrouping of the temples and rituals related to the seaside of the negara took place here. ${ }^{58}$ First, a large temple arose as substitute (pasimpangan) for the old sea temple at Jimbaran. Central to the worship in this new sea temple was a tall meru with an eleven-tiered roof, a

58 Information concerning the sea temples in and near Seseh was gathered by way of interviews with the mangku of the temples and with members of noble families who, in earlier days, had supervised these: G. Ng. Gede, puri Kaba-Kaba, G. Ag. Gede Rai, puri Kajanan Mengwi, G. Ag. Gede Putra, puri Lambing, G. Ardana, jeroan Anggunan. 
place to beseech the gods to let the water rise up to the mountains so that it would flow down to the sawah again. The temple was supervised directly by the royal centre of Mengwi, and its maintenance was the task of the surrounding desa. ${ }^{59}$ In Seseh's vicinity were two more temples, also serving agricultural needs: their rituals were meant to stave off plagues and crop failure and to ensure lasting fertility. ${ }^{60}$

Seseh was not, however, a centre for agricultural rituals only. Oral tradition suggests that in the nineteenth century this coastal location was a centre for two other rituals as well. One was the malasti ritual, an annual event in March, just after the beginning of the new year in the Balinese calendar. Nyepi, the Balinese new year, is a time of cleansing, of taking away the stain or the evil that has settled upon the land in the preceding year. According to informants' recollection, on the day after Nyepi there were large processions heading for Seseh from all over the negara, followed by a ritual cleansing on the beach of the holy 'vessels' (in the shape of small statues, arca) brought along for this purpose from the temples. ${ }^{61}$ A second event was the mamukur ritual. Seseh was (and still is) the location of a follow-up ritual on the forty-second day after a cremation. The mamukur ritual involves offering to the sea the ashes of the deceased, so that the soul will rise to the divine forebears in the mountains and return to earth incorporated in new life. ${ }^{62}$

Thus, Seseh hosted a number of interrelated ritual functions, concentrated in one place under the leadership of Agung Mayun: to protect agriculture against the threat of evil, to cleanse society, to cause irrigation water to flow and so assure perpetuation of the agricultural cycle, and to assist the human soul in the journey to new life after death.

The other end of the ritual axis was located far inland, in desa Tinggan on the slopes of Mount Manggu. Here Agung Mayun built the large, new mountain temple of negara Mengwi as manifestation of the link between concern with agriculture and the position of the Mengwi dynasty in the

\footnotetext{
59 Adjacent to this sea temple is the pura Mas, in memory of the murder of the lord of Blambangan (see Chapter 3, section 2), supervised by puri Sibang.

60 One temple was pura Batu Ngaus, supervised by the puri of Kaba-Kaba, though worshippers came from all over the negara. The other was pura Batu Bolong, a pasimpangan of an older temple in desa Canggu, which had meanwhile fallen to Badung and functioned in the southern sawah region. Information G. Ng. Gede, puri Kaba-Kaba, and G. Ardana, jeroan Anggunan.

61 Malasti, from malali, 'to enjoy, to take delight in'. In popular terms, the gods of the various temples went to 'paddle around' on the beach. Nyepi is after the ninth month (kasanga) of the luni-solar Saka year, on the first day of the tenth month (kadasa).

62 These elaborate death rites were reserved for noble families. One may suppose that for most jaba such elaborate rituals were far too costly unless one 'followed' (joined in with) a large-scale noble ritual.
} 
region. ${ }^{63}$ At Tinggan the agricultural function came to expression in a pasimpangan for the old temple at Lake Bratan. From this lake, it was believed, two important rivers meandered their way through Mengwi. The temple's function was to have the water that rose up from the sea flow out anew over the Mengwi plain. ${ }^{64}$ In tandem with the sea temple at Seseh, then, this mountain temple served the whole of the negara. It also became the centre for rituals for agriculture in the immediate vicinity, while the surrounding mountain villages were given the task of maintaining the new sanctuary. ${ }^{65}$

Remarkably, even though built on the initiative of Agung Mayun, the temple retained a character of its own, more similar to that of the village temples in Tinggan than to other royal temples on the plain. Moreover, the royal purohita played but an insignificant part at best in the temple rituals. Not he but the temple priest, a jaba from Tinggan, looked after the holy water which, it was held, was provided by the gods themselves. ${ }^{66}$ The temple's features and the fact that brahman priests were not welcome there may well illustrate the intransigence of Balinese mountain culture, forever beyond complete control of the nobles of the southern sawah plain.

Nevertheless, supervision rested entirely with the centre of the Mengwi dynasty: above all, the temple at Tinggan was a Pura Panataran Agung, a negara temple. ${ }^{67}$ Just as in the case of pura Taman Ayun, lofty meru represented the gods whose abodes were spread across the Balinese mountains and who dominated the Mengwi region. One of these gods was of outstanding significance, for it was he who had granted special powers to the founder of the dynasty. This was the god of Mount Manggu, just north of desa Tinggan. ${ }^{68}$ One climbs a steep and narrow path through the region's

63 The information given here is derived from Babad Mengwi-Lambing:66; Kumpulan n.d.:25-37; Grader 1960b; interviews with mangku gede pura Panataran Agung Tinggan, G. Ag. Gede Putra, puri Lambing, G. Ag. Gede Rai, puri Kajanan Mengwi. There may already have been a temple in Tinggan related to a nearby mountain temple in the little village of Bon (Grader 1960b:157), which was taken over by the Mengwi dynasty.

64 The pasimpangan of the temple at Lake Bratan is a meru with nine tiers. It stands in the northeast corner of the jeroan, the innermost and highest part of the temple. The two rivers were the Sungi and the Penet. The big river Ayung, which begins in the northeastern mountainous area of Bangli, was not included. The position of the temples at the two ends of the 'ritual axis' is also expressed in their names: pura ulun danu (highest or head temple at the lake) and pura ulun siwi (highest or head temple of worship); I Wayan Warna 1978.

65 The ritual was the ngebekin, in which eight mountain villages participated. These villages were charged with maintenance as well (Kumpulan n.d.:25-37; Grader 1960b: 158).

66 On Bali distinctions are made between different kinds of holy water; see Stuart-Fox 1987:173-7. The most revered kind is dispensed by the gods themselves, as in Tinggan. Next in order are the holy water of the brahman priests and that of the temple priests.

67 See Grader 1960b:161, who mentions an alternative name: pura pengastulan jagat, 'place of worship for the entire realm'; see also Goris 1960.

68 Babad Mengwi-Blahkiuh:17. Another name for the mountain is Pucak Pengelengan (Grader 1960b:161). The god of Mount Manggu is associated with Brahma, the creator (in- 
last remnant of primeval forest to reach, after a three-hour journey, a little temple. Here, in the lonely mists of the mountain, the god of Mengwi dwells, and it is to him that the largest meru in the temple of Tinggan is dedicated. 69

The bond between the gods and the negara was restored. Because of the central authority exercised by Agung Mayun political stability in the region had increased, in recognition of which large annual processions from throughout the negara travelled to Tinggan to honour the gods when the fourth moon (October) had waxed full. A rarer occasion, held if possible every ten years, was the truly large-scale ritual of the malelungan, the 'itinerary' of the gods who, descending from the mountains, visited the negara. ${ }^{70}$ The procession, lasting a number of days, left from the mountain temple at Tinggan and moved on to important temples in the region to spend the night. There the local population met the journeying deities to worship them with offerings. Although the exact route might vary, four temples were never passed by. These were, on the first leg of the journey, a temple in the village of Sangeh, just north of Blahkiuh; next, the central temple of the negara, pura Taman Ayun in desa Mengwi; and then down to the sea temple in Seseh. At this point the procession turned, and on its way homeward visited pura Sada in Kapal, the temple that housed the kawitan, the central ancestral shrine, of the Mengwi dynasty. In this manner the gods visited 'their' realm and accepted the homage of the people.

The itinerary of the Mengwi gods is to be understood as a visualization of three vital aspects of the negara. There was, first, the hierarchical order embedded in the landscape in which human life unfolded. Second, the water, circulating from the sea to the mountains to the sea again, rendered the negara fertile, and hence capable of sustaining life. Finally, the cycle of the human soul traversed the same route. This cycle and its hierarchical order was intimately linked to the centre of the Mengwi dynasty. The dynasty ruled the region, but could do so only by guarding its life-sustaining hierarchical order. The restoration of the ritual axis across the Mengwi region meant that Agung Mayun had brought the negara to life again. ${ }^{71}$

formation mangku gede Tinggan). As noted earlier, army chieftain Agung Made Raka received his remarkable strength-cum-scarf in this temple.

69 This is a tower with eleven tiers, which is a stand-in for the small temple at the top.

70 Information from G. Ag. Gede Rai, puri Kajanan Mengwi, G. Ag. Gede Rai, puri Selat, A.

Ag. Gede Putra, puri Lambing, G. Ag. Ajeng, puri Labah, Kedampal, G. Ng. Oka, puri Carangsari, G. Ng. Putra, puri Grana, G. Ketut Kaler, jeroan Bakungan, Blahkiuh, mangku gede, Tinggan. Whether this malelungan was instituted by Agung Mayun or is of older date is not known.

71 I am quite aware of the speculative nature of this ritual structure. None of the informants told me this in so many words, but when I suggested this scheme to some, including the persons mentioned in note 70, none voiced objections (something they frequently did in other situations); in fact, they agreed without hesitation. It seems quite probable that, prior to the rise 


\section{Kingship}

Agung Mayun was the undisputed leader of the dynasty, his son Agung Made Raka a warrior of renown. Puri Mayun's domain was large and the northeastern region was brought under cultivation. The lineage controlled the new sea and mountain temples of the negara. Nevertheless, Agung Mayun remained a subordinate in the dynastic order. The highest authority still rested with puri Gede Mengwi, headed by the energetic Biang Agung. While Agung Mayun was gradually consolidating his power, she successfully kept the royal puri's prestige intact. To this end the queen had recourse to two powerful allies. The first was the branch of puri Sibang from where she herself came. Puri Sibang was still one of the stronger satellites where puri Mayun influence was negligible. A second ally, though remote, was probably at least equally important: the Klungkung court. In 1836 the Dewa Agung of Klungkung had intervened in the struggle for the throne of Mengwi. In 1850 the bond between the two dynasties was drawn closer when the new Dewa Agung married a daughter of Biang Agung. ${ }^{72}$ This alliance with the Klungkung court strengthened the position of the queen of Mengwi and upheld her status among the other Balinese rulers. It was she rather than Agung Mayun who, with the Dewa Agung of Klungkung, took care of the relationships with the other negara. ${ }^{73}$

But the position of puri Gede Mengwi was far from unassailable. As in the days of Ayu Oka, the continuity of the dynasty's main lineage was threatened by the lack of a male successor to the throne. This issue came to a head in the early 1850s with the death of Agung Besakih, the 'junior' king of Mengwi. He left but a single daughter. As widowed padmi, women could ascend the throne, but such rights to succession did not apply to daughters of a deceased king. ${ }^{74}$ For this reason the aged queen once again occupied the throne alone. In 1836 Biang Agung had been able to retain her position above Agung Mayun; this time she would be less fortunate.

Initially it seemed as if the queen would succeed in averting a battle for succession. Immediately upon the death of her adoptive son Agung Besakih, she adopted a young man from her own place of origin, puri

of the Mengwi dynasty, another, older 'ritual axis' existed, of which Pura Sada in Kapal was the centre, with the Tabanan mountain temple Batu Karu and the sea temple Sakenan on the east coast of Badung at the ends. Information mangku gede Pura Sada, Kapal.

72 KITLV, Coll. Mayor-Lange, letter Mads Lange 1-12-1850; see also Appendix. The new king of Klungkung was Dewa Agung Putra (1850-1903).

73 ANRI, Geh.Besl. 28-6-1847-XX; Geh.Besl. 7-3-1848-0, reports M. Lange to Resident Mayor, May-July 1847; ARA, MvK V9-7-1860-33/961, report P. van Bloemen Waanders 6-51856.

74 Van Bloemen Waanders 1870:426. See Appendix. 
Sibang. ${ }^{75}$ This new son was taken into the royal lineage, shored up by all the prescribed rituals conducted both in the house temple of puri Gede and in the central temple Taman Ayun. Next, rites were held on behalf of the deceased Agung Besakih. These were organized by Biang Agung and Agung Mayun jointly. The rites consisted of a palebon (cremation) and a maligya (symbolic second cremation) in the Taman Ayun temple to release the soul of the dead from the earth. Adoption and ritual seemed to have sufficiently smoothed the path to the throne for the queen's adopted son from Sibang. Suddenly, however, Biang Agung took ill and died before her new son could be inaugurated as king. She had been poisoned.

It remained unknown just who was responsible for the murder, but the consequences were very clear indeed. Without the protection of his adoptive mother, the young man from Sibang was powerless and soon left the royal centre. With him disappeared the opportunity for puri Sibang to head the dynasty. Puri Sibang remained a subordinate satellite, and relations with the centre had suffered.

Meanwhile, puri Gede Mengwi was virtually empty, the unmarried daughter of the late Agung Besakih its sole inhabitant. She was now the most desired bride in all of the negara, for whoever married her would become king of Mengwi. At this point Agung Mayun stepped forward by organizing the cremation of the murdered queen, in this way announcing that puri Mayun would be a contender in the battle for succession. ${ }^{76}$ Undeniably the mightiest man in the dynasty, he would, it seemed, encounter little opposition in his bid to take over Mengwi's unguarded royal puri. However, three major difficulties emerged, the one following hard upon the other.

The first crisis arose within the walls of puri Mayun. The main personage was a younger nephew of Agung Mayun, who formally represented the 'main lineage' of puri Mayun. ${ }^{77}$ It seems likely that Agung Mayun meant him to become the new king of Mengwi, though certainly in a humble position in the shadow of his uncle. Not only did he, like his uncle, hold the formal office of 'second king' - yuwa raja - of Mengwi, but he was 'engaged' to marry the daughter of the late Agung Besakih. This nephew, however,

75 Babad Arya Manguwi:80b; Babad Mengwi-Sedang:40, from which the information regarding the result is taken. The adopted son was G. Nyoman Karang (the later Ag. Gede Kamasan), born in the sub-branch of puri Sibang Kaleran, and adopted into the lineage of puri Gede Sibang. That is, he was adopted twice; information G. Ag. Oka Pabean, Denpasar, G. Ag. Gejer, puri Kanginan, Sibang.

76 Babad Mengwi-Sedang:41. Various noble informants affirmed that, generally, the person who organizes the cremation will also be (or claims to be) the successor.

77 This nephew was Agung Mayun Merta. He was the son of Agung Mayun's older brother. This nephew accompanied Agung Mayun during his exile on Nusa Penida. Samboengan Babad Mengwi:5; information G. Ag. Gede Rai, puri Kajanan Mengwi; see Figure 6 and Appendix. 


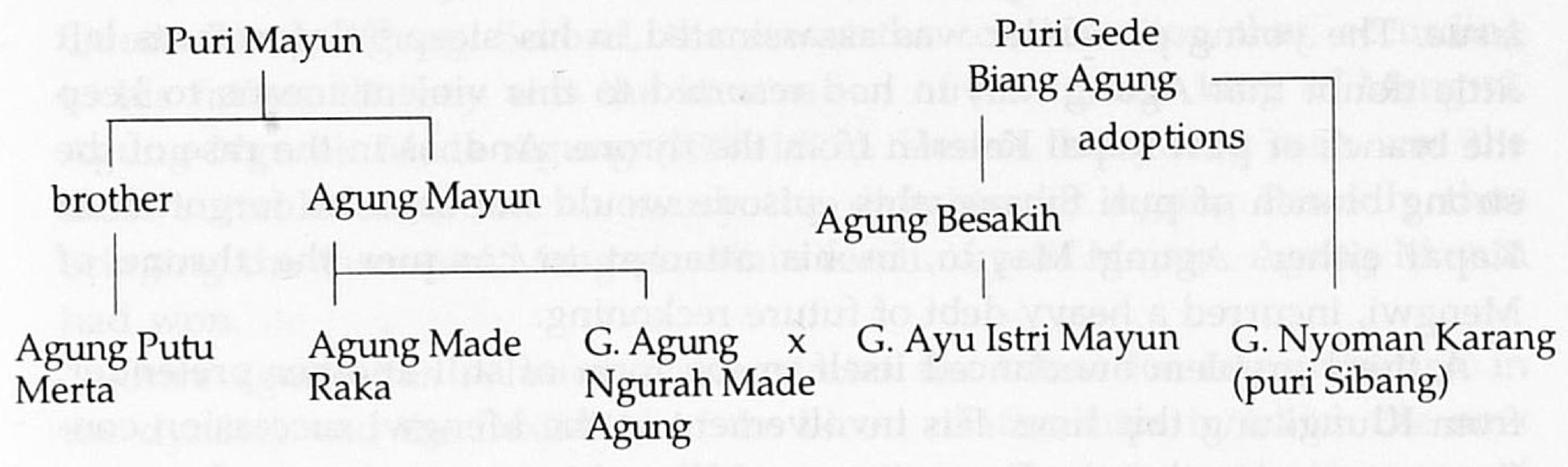

other pretenders: G. Alit Berata (Kapal)

Dewa Agung Rai (Klungkung)

Figure 6. The succession of 1857

came under the spell of one of his secondary wives, who practised black magic (ngleak). Agung Mayun was aware of the potential danger of this situation. When the nephew retreated once again for three days and nights to study magic, the lord of puri Mayun had the woman abducted and carried off to a far-away place. This intervention made matters worse: the nephew, upon hearing of the disappearance of his beloved wife, became despondent to the point that he turned against his own person. The unhappy nephew's attempted suicide left him badly wounded. Puri Mayun now found itself faced with a highly explosive situation. Suicide spells instability and ritual impurity; moreover, who could foresee what doom might blacken the puri? Agung Mayun reacted immediately. He had his wounded nephew placed on a hastily improvised bier and brought to the graveyard of the desa Mengwi, then struck him dead on the spot with his kris. Thus, suicidal death and the concomitant calamities were prevented. The corpse was immediately surrendered to the flames. Cleansing had been effected quickly, but might still prove inadequate. In retrospect, informants in fact believed that this incident sowed the seeds of the discord which, thirty years hence, would spread from puri Mayun to engulf all of the negara.

Agung Mayun was hard pressed to control the situation, as evidenced by 'disturbances' in Mengwi in 1857.78 Two pretenders sought to contest puri Mayun's claim to the throne of Mengwi. The first of these came from another powerful branch of the dynasty, puri Kapal Kaleran. This puri represented the old core lineage of the dynasty and descended from the famous King Agung Alangkajeng. For these reasons puri Kapal Kaleran claimed pre-eminence over puri Mayun and, hence, the right to the Mengwi 
throne. ${ }^{79}$ Whether these rights existed or not, it was a kris which decided the issue. The young pretender was assassinated in his sleep. ${ }^{80}$ Informants left little doubt that Agung Mayun had resorted to this violent means to keep the branch of puri Kapal Kaleran from the throne. And, as in the case of the strong branch of puri Sibang, this episode would not soon be forgotten in Kapal either. Agung Mayun, in his attempt to conquer the throne of Mengwi, incurred a heavy debt of future reckoning.

A third problem announced itself in the form of still another pretender, from Klungkung this time. His involvement in the Mengwi succession confirms once again that the Dewa Agung of Klungkung not only was the mostesteemed king on Bali in theory, but that he also meant to strengthen his position in practice. Immediately upon the death of the old queen, the king of Klungkung had sent his brother to Mengwi. Shortly afterwards, the Dewa Agung himself entered the dispute. He arrived in Mengwi and stayed there December 1857 to March $1858 .{ }^{81}$ Presumably, the Klungkung court tried to transform its nominal 'supervision' over Mengwi into something more tangible. If he were to marry the daughter of the late Agung Besakih, the Dewa Agung's brother would be sure to become the new king of Mengwi.

Agung Mayun now faced a critical situation, calling for a strategy of utmost circumspection. Violence against this Klungkung competitor was unthinkable and would unleash a highly inauspicious war on which neighbouring kings would immediately capitalize. The precise machinations of the solution are, unfortunately, no longer traceable; all we know is the denouement as Agung Mayun played his last card. In a meeting including the leaders of the four most powerful satellites, he successfully supported the candidacy of his second son. ${ }^{82}$ Two arguments must have tipped the

79 The higher position of the lineage of puri Kapal Kaleran was expressed, for instance, in the fact that the oldest daughter of Agung Mayun was married to the (higher) leader of Kapal ('Tjatatan Singkat', in the possession of G. Ag. Oka Pabean, Denpasar; genealogy puri Kapal Kaleran, in the possession of G. Ag. Gede Rai, puri Abianbasé). This pretender was Alit Berata, son of Agung Putu Kapal Guruh, leader of the lineage of puri Kapal Kaleran and lord of the strong satellite Kapal; see Appendix.

80 After his death the boy was named Batara di Kerisan, the one deified (passed away) by kris.

81 ANRI, Bali:1.2, 1.4, political reports Gecommitteerde Bali and Lombok 1857, 1858; Samboengan Babad Mengwi:6. This was Dewa Agung Rai, brother of the Klungkung king, and also his patih. It is very probable that the Mengwi wife of the Klungkung king (the daughter of Biang Agung) played a central part in this intervention by Klungkung.

82 The outcome is reconstructed on the basis of Babad Arya Manguwi:85b; Babad MengwiSedang:45; Van Bloemen Waanders 1870:426; ARA, MvK V9-7-1860-33/961, report Van Bloemen Waanders 6-5-1856; see also Figure 6 and Appendix. According to the babad, the old queen was still alive at the time of the meeting. But this seems improbable, and is possibly an ad hoc construction creating a picture of smooth, uncontested succession by Agung Mayun's son. The four powerful lords were the leaders of puri Kaba-Kaba, Blayu, Sibang, and Kapal Kaleran. 
balance. First, it is probable that this boy, too, was adopted by the former Queen Biang Agung. Second, there was the consideration that, according to his father, the boy was the incarnation of the former king of Mengwi, Agung Ngurah Made Agung (1807-1823). Hence, this young man was the most suitable candidate to marry the daughter of Agung Besakih, thus bringing the throne of Mengwi within reach of puri Mayun. Agung Mayun had won.

Once again, this solution demonstrates the talent for improvisation in the dynasty and the flexibility of the blood relationships in which the new situation was expressed. If one situates the new royal couple in terms of their biological bonds via the male line, they are relatives only in the fifth degree. But if one looks at the various adoptions, and the position of Queen Biang Agung as adoptive mother of both Agung Besakih and of Agung Mayun's son, the marriage turns out to be between an uncle and a younger niece (mother's son's daughter). To complicate matters even further, their union was proclaimed to be a nyeburin marriage. That is to say, the husband moves in with the wife and assumes her rights, while the wife assumes the higher position of first, male, heir. ${ }^{83}$ In other words, puri Gede Mengwi was now the residence of a 'higher' uncle married to a 'lesser' niece. Simultaneously, his position was the inferior one, because his 'higher' spouse retained full male rights of inheritance.

This intricate compromise meant that, formally, the heiress of puri Gede retained leadership of the main lineage of the dynasty. More important, however, was Agung Mayun's success. At long last, the position of strength carefully built up by his puri was crowned with the kingship of Mengwi. His eldest son, army commander Agung Made Raka, represented the physical strength of the puri; the inauguration of his second son presumably took place in 1859. No less than eight brahman priests conducted the ceremony. Pride of place among them was given this time to the purohita of the Klungkung court, proof that the new king had the blessing of the Dewa Agung as well. ${ }^{84}$ Like the ancestor whose reincarnation he was said to be, the new king assumed the ceremonial name of Gusti Agung Ngurah Made Agung. Sometime later his position was formally recognized by the lords of the four most important satellites, who declared their loyalty in a special

83 See Korn 1932:457-9. I am grateful to G. Ag. Gede Rai, puri Kajanan Mengwi, G. Ag. Ajeng, puri Labah, Abiansemal, and G. Ketut Kaler, jeroan Bakungan, Blahkiuh, for their information and help when I investigated this kinship puzzle.

84 Babad Mengwi-Sedang:45. The date mentioned there, Saka 1791 (= AD 1869), seems unlikely, since the struggle for succession was over in 1859. The purohita from Klungkung was pedanda Gede Nyoman Pidada. The Klungkung attempt to gain the throne of Mengwi probably failed because the Mengwi dynasty would not accept a stranger as leader. 
document. ${ }^{85}$ This precaution was needed, since the lords of puri Sibang and puri Kapal Kaleran had mixed feelings regarding the outcome of the struggle for the throne.

Although Agung Mayun did not himself become king, it was soon apparent that it was he, rather than his second son, who had usurped royal authority. Indeed, he too moved into the royal puri, and would reside there until his death. ${ }^{86}$ Hence, the new king was not only inferior to his wife, but also overshadowed by his father. In negara Mengwi there was no authority higher than Agung Mayun.

85 Babad Mengwi-Sedang:45. A Malay copy of this text survives (KITLV, Coll. Korn:166). The date mentioned in the document is Saka 1794 (= AD 1871-72). Presumably, it was composed shortly after the death of Agung Mayun (1871).

86 Babad Mengwi-Sedang:43. When he moved, his oldest son, patih Agung Made Raka, took over leadership of puri Mayun. ARA, MvK V4-10-1867-136 geh., reports Gecommitteerde Bali and Lombok 20-9-1864, 6-12-1866 and 27-12-1866; see also De Vroom 1872 and 1875. 


\section{CHAPTER V \\ Violence and order}

Before continuing the story of the Mengwi dynasty, we should take a closer look at the dynamic structure of the negara. In previous chapters the negara was pictured as ambivalent, hesitating between royal grandeur and chiefdom. There was no process of evolution or development from chiefdom towards statehood. This does not mean that the Balinese political system was static, nor does it mean that negara Mengwi kept changing from kingdom to chiefdom and back again. The point is that the negara had a character of its own which can best be described as 'fluid'. In this chapter I offer a conceptualization of this, beginning with the fragmented organization of the negara. After that I sketch how the hierarchy found expression and the central role played in this by the king. Throughout, the emphasis will be on the relation between the fragmented and violent scene and the ritual order overarching it.

\section{Fragmentation}

The exact number of inhabitants of negara Mengwi during the 1860s is not known. But the census of 1930 can help us to estimate, very tentatively, that the population must have been roughly $85,000 .{ }^{1}$ These people were spread over about a hundred desa, the size of which varied from a few dozen households in small, remote mountain villages up to 3,000 residents in the larger settlements of the southern sawah region. ${ }^{2}$ The desa were incor-

1 Detailed data per village in: KITLV, Coll. Korn:157, Census 1930. The domains of KabaKaba and Blayu are not included. I estimate the population in the nineteenth century at 10,000 and 5,000 people, respectively. The population in the rest of the former negara, the colonial districts Mengwi and Abiansemal, in 1930 was roughly 100,000. I estimate that in 1860 some 70,000 persons lived there. After the turn of the century especially, the population expanded rapidly. Estimates for the total population of Bali suggest an increase from 700,000 to 1.1 million between 1905 and 1940 (ARA, MvK MvO Residenten Bali and Lombok 1905-41; Assistent-Residenten South Bali 1929-40), which means a growth of more than 50 percent. Estimates of the population in the nineteenth century are widely divergent and quite unreliable. It seegns probable that no continuous growth occurred. In light of the many threats to life (insecurity, illness, crop failure), fluctuation around a fairly constant number is more likely; compare Reid 1988:18.

2 I have taken the later desa adat from the colonial period, a settlement with its own village temple (pura desa), as norm for the desa. For the number of desa I rely on the 1930 Census, KITLV, Coll. Korn:157. The largest desa were Mengwi, Kapal, and Sibang. 


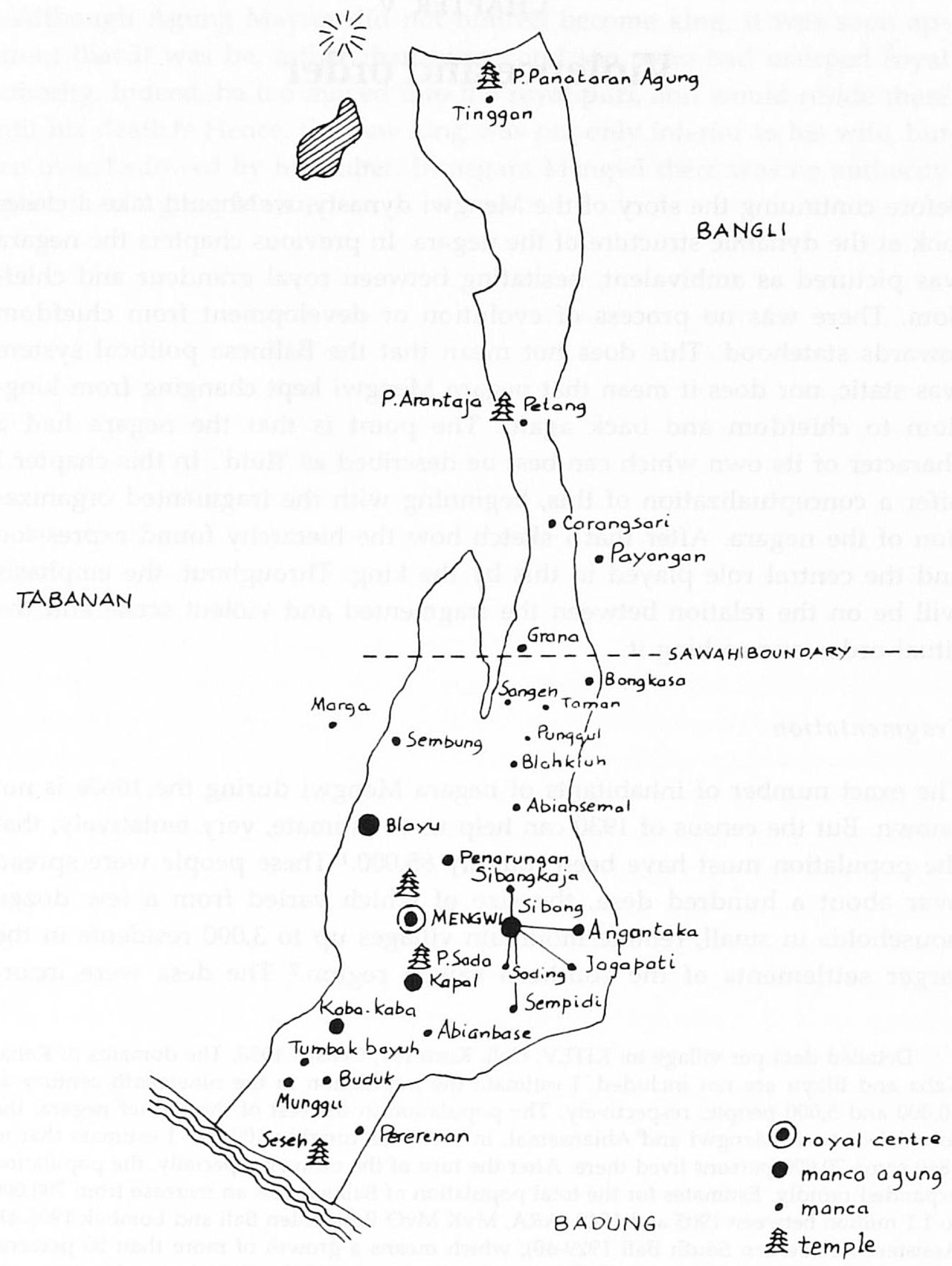

Map 8. Negara Mengwi around 1850 
porated in a network of twenty-seven satellites, large and small. This network was more or less maintained by the royal centre. ${ }^{3}$ In schematic terms, relations between the centre and the satellites can be seen to form three levels, or concentric circles, as happens elsewhere in Southeast Asia. ${ }^{4}$ First, there was the core area controlled by the royal centre. Around it were four large, semi-autonomous satellites, each of which had satellites of its own. Beyond that, finally, there was another circle of many smaller satellites under varying degrees of central control.

From 1850 onwards, the core domain of negara Mengwi was dominated completely by puri Mayun, and stretched between desa Sangeh in the northeast, the domain of puri Sibang in the east, that of puri Kapal Kaleran on the south side, the western river border with Tabanan, and, in the northwest, the domain of puri Blayu. ${ }^{5}$ Through its entourage the royal centre held virtually uncontested sway over all the inhabitants in this area and levied labour and agricultural surplus from them. Puri Mayun had two more satellites further away: in the northeast and in the south, the location of the negara's mountain temple and sea temple respectively.

Ruling the four large satellites around the royal core domain were four great lords, or manca agung. One might say that, organizationally and 'architecturally', their centres mirrored the royal centre, which outranked them in the hierarchy. Two of these four satellites were controlled by the powerful branches of puri Sibang and puri Kapal Kaleran. Though formally subordinate to the royal lineage, they were in practice largely autonomous within the limits of their own domain. The same was true of the other two satellites. These were ruled by noble families that were not part of the Mengwi dynasty: puri Kaba-Kaba in the south and puri Blayu in the north. Each of the large satellites had a system of mekel and sedahan of its own; these officials acted as intermediaries between the puri and its followers. The large satellites also had their own irrigation systems, and most of the taxes levied within their domain went to the manca agung. In addition to control over irrigation, these satellites had a number of sub-satellites. The same pattern characterizing the macro relation between the royal centre and its satellites was repeated at the micro level. Sibang, for example, had five sub-satellites, two of which constituted a sub-branch of the puri Sibang

\footnotetext{
3 The number, locations, and relation to the centre are from Korn 1922a:75-83; Babad Arya Manguwi:68a-b; KITLV, Coll. Korn:193, report punggawa Abiansemal 1920, supplemented by dozens of interviews with descendants of most of these local lords conducted from April to November 1983. These satellites are indicated on Map 8.

$4 \quad$ See Tambiah 1985a; for Java in particular see Rouffaer 1931 and Hugenholtz 1986.

5 Explicit reference to this is in KITLV, Coll. Korn:175, Paswara Mengwi:57. This was a symbolic arrangement, for the small domain of the lineage of puri Penarungan was in fact located in this central area.
} 
lineage while the others were ruled by lesser noble families. ${ }^{6}$

The royal centre had no direct impact on the satellites, since their leaders were not appointed by the king. Hence, the relationship between the centre and the large satellites was more like an alliance than one of subordination. This does not mean that the royal centre had no internal leverage. Within the domains of the manca agung, it had small enclaves of followers who, as direct extensions of the dynastic centre, were independent of the local puri. ${ }^{7}$ Within the domain of puri Sibang, for instance, such followers constituted a royal enclave at desa Sedang. These followers certainly were useful spies, able to inform their king of what went on in the satellite, but they did not amount to much of a power factor. The only way for the dynastic centre to exact a degree of loyalty from the large satellites was to arrange and engage in marriages. One of the principal wives of war leader Agung Made Raka, for example, was a daughter from puri Blayu; another of his wives was a woman from puri Kaba-Kaba. ${ }^{8}$ But such ties by no means guaranteed blind loyalty. Moreover, there were no marriages between the royal centre and the lineage of puri Sibang, which is evidence of the tense relations between these two.

The negara's political power depended largely on the relationship between the royal centre and the manca agung, with a strong and capable centre as prerequisite. Agung Mayun had achieved a centre of this kind, which enabled him to prevent the four great satellites from carrying their own policies too far and, if need be, to assist them in times of trouble. He did so when he sent his son to support (successfully) the manca agung of Blayu in the conflict with Marga.

The centre had to pay heavily for the loyalty of the large satellites, as was clear in the battle for succession from 1857 to 1859, when especially the lineages of puri Sibang and puri Kapal Kaleran revealed a tendency to move up dangerously close to the centre itself. In the end the new king could be invested only with the approval of the four satellites. On the other hand, as long as the precarious balance between royal centre and large satellites was not upset, the concentration of power was adequate to keep the negara's other satellites within the royal hierarchy's reach. This 'circle' consisted of a large number of smaller satellites, each headed by a manca. In 1860 there

6 Puri Sempidi and puri Sading were related sub-satellites; puri Sibangkaja, jeroan Anggantaka, and jeroan Jagapati were non-related sub-satellites.

7 This was the nyucuk arrangement (Van der Tuuk 1897-1912, I:580; KITLV, Coll. Korn:193, report punggawa Abiansemal 1920). If followers were dissatisfied with their local lord and if the centre was powerful enough, application for the status of nyucuk follower was a way of escaping from the local ruler's authority.

8 Moreover, Agung Made Raka had been engaged to a woman from Kaba-Kaba, but she died young (Babad Mengwi-Sedang:42). Another woman of his came from Sedang, Sibang's satellite. His sister was married to the lord of puri Kapal Kaleran. 
were fifteen of these. Five of them were part of the royal dynasty; the other ten belonged to lesser noble houses. ${ }^{9}$ Each of these local centres in turn possessed still smaller satellites, the leadership of which was made up of sub-branches, lesser nobility, or commoner followers. Emanating from the royal centre, then, was a complicated hierarchy of greater and lesser lords who through their entourages and followers controlled the local population. In every case the satellite was modelled on the centre above it.

Remarkably, the royal centre sought few or no marriage alliances with the smaller satellites. These were connected to the royal core in the loosest of ways, but their intrinsic weakness kept them from straying altogether. Every so often these local lords were in need of central assistance to withstand the threat of other local competitors. Traditions from the lineage comprising puri Taman, puri Punggul, and jero Selat show that the royal centre mediated internal conflicts on several occasions, and in doing so gained appreciable influence. Moreover, when threatened from outside, the smaller satellites needed the might of the central commander, as in the case of the attack from the east on Carangsari, when Agung Made Raka came to the aid of its lord.

But when the centre was weak and unable to take effective action, the royal hierarchy would be on its way to collapse. At such times the satellites looked after their own interests first. It was then that the negara was in danger of being ripped apart by two forces: strong satellites would advance to the centre and the smaller ones, drawn in by a neighbouring competing centre, would cease to orbit around the old. Conflicts in the centre and on the local level would begin to interact and so reinforce each other. Such conditions would soon cause the old hierarchy to fade into oblivion. The negara had gone through an experience like this between 1770 and 1823, and towards the end of the nineteenth century it was to undergo a similar process.

Seen from a Western 'state-making' perspective, more than anything, the royal hierarchy's endemic weakness was its inability to establish administrative control over the negara. Time and again the central power would disperse and dissolve in the characteristically diffused, fragmented control over the people. This fragmentation of power was implicit in the nature of the system of followers, aggravated by the dissipation of the agricultural surplus which supported the system.

Power in the Weberian sense, however, was not the only factor in the

\footnotetext{
9 See Map 8. The dynastic lineages were puri Kapal Muncan, puri Penarungan, puri Sayan Bongkasa, puri Sembung (related by marriage), and jeroan Pererenan (anak astra G. Gede Meliling's lineage; see Chapter 3). The other satellites were: the puri of Carangsari and Petang (both of the same clan), the puri of Taman and Punggul (a single clan as well), the jero of Selat and Camenggon (one clan) and the jeroan in Buduk, Tumbakbayuh, Tangeb, and Sedang. All of these were ruled by lesser nobles.
} 
Mengwi hierarchy. At least as basic was that satellites recognize royal authority, and this could not be achieved by mere force. At best, a strong royal centre managed to instil the idea that local power was a royal 'gift', a quality 'delegated' to the hierarchy's lower ranks. ${ }^{10}$ Such recognition would imply that each of these lesser lords really was a potentate in his own domain, but bound to inform the king of Mengwi of his decisions (Sosrowidjojo 1875:27).

The enormous local diversity characteristic of Bali - Korn (1932) takes 700 pages to illustrate this with respect to adat law - shows that the royal centres were not interested in establishing uniformity. Almost every satellite had its own rules and customs, sometimes differing in detail only, sometimes quite divergent from those in the domain of some other lord. This was true not only of domains ruled by certain puri; even the villages within these domains might differ markedly on points of local rules of justice, the composition of the desa ruling body, the organization of local irrigation, style of dancing, offerings and ritual, and the articulation of local hierarchical relationships. ${ }^{11}$ This exuberant diversity evolved to an important degree in the repeatedly changing interaction between representatives of the regional hierarchy and the local population. Naturally, the influence of the nobles was strongest in the immediate vicinity of the royal centre and the large satellites. Impact on the remote mountain villages was far less, in part because the nobility in far-away satellites such as Bongkasa and Petang did not display the pomp associated with the dynastic centre. Finally, there was a cyclical process in which phases of dynastic domination alternated with periods of minimal noble control. The history of the northeastern region around Blahkiuh is a good example of this: the lineage of puri Singasari had established itself there in the eighteenth century; after its collapse the area was left to shift for itself until the middle of the nineteenth century, when puri Mayun took over.

10 When referring to certain privileges which had given their ancestors a degree of local autonomy, noble and common informants often use the word anugerah, 'token of divine or royal favour'. Wiener summarized this phenomenon elegantly: 'Power has a centerpoint but is not centralized' (1990:127), because 'for the Balinese there is no contradiction between unity and multiplicity' (Wiener 1990:221).

11 See KITLV, Coll. Korn:147 for a survey of the differences on the level of local government in eastern Mengwi (compiled in 1920). It is noteworthy that Agung Mayun tried to achieve some uniformity in village government (Babad Mengwi-Lambing:63). To this end he gave the Mengwi desa certain regulations. These awig-awig later fell into disuse: a 1920 survey mentions that most Mengwi villages were without written bylaws. For some pre-colonial village regulations in the region see KITLV, Coll. Korn:159. Even in the royal centre there were local variations, as can be gathered from three banjar regulations from desa Mengwi. See Hinzler 1981:chapter 2 for differences in style across Bali relative to wayang. During my fieldwork I was struck by local differences in rituals and customary law, but I did not investigate this in depth. 
Control of manpower was greatly fragmented; many an intermediary stood between the king and the people, and lesser lords commanded a following of their own. It was no exception for a village to be divided into two or three factions, each beholden to a different lord. From a local point of view, however, villages did have significance. As a rule, a desa was led by a bendesa, a member of the jaba notables. It was he who was responsible for the upkeep of the village temples and the village rituals generally. He maintained local order and resolved differences according to local custom. Furthermore, most of the southern Balinese villages were subdivided into separate wards, or banjar, led by a klian. ${ }^{12}$ The precise relationship between the village leadership and the lord-follower configuration at the local level remains unclear.

A fluctuating hierarchy, then, rather than a permanent and uniform hegemony, was the typical relationship between dynasty and locality in the Mengwi region; the royal centre 'bestowed' its power in exchange for recognition of its authority. A first condition for such recognition, however, was that, when necessary, the centre had the potential to exact it with a show a strength. Royal authority was manifest above all in the person of a capable leader who had proven his ability in battle. His reputation secured a degree of safety for his followers and enhanced their prestige as well. But in the long run, violence bred counterviolence and would result in the destruction of royal authority. For this reason the ability to contain violence was far more important than unchecked display of it. This sort of control was the hallmark of an uncontested leader. Agung Mayun was such a leader. According to tradition he was sakti; able to draw on supernatural powers which encompassed far more than mere physical violence. Not only did he control physical violence, he had also demonstrated that even the forces of nature would bend to his will: he guided the waters to flood the thirsty land and coaxed the earth to fruitfulness. Royal control over both visible (sekala) and invisible (niskala) forces was a condition necessary to the survival of the negara.

\section{Fragmented and collective mobilization}

Negara Mengwi was neither exclusively a 'theatre state' nor only a 'contest state'. Its fragmented political relations were overarched by a ritual order, the purpose of which was to ward off threatening disorder so that life would be secure. From this point of view the negara resembled a segmentary state

12 ARA, MvK MvO Controleur Badung V.E. Korn 1921. The arrangement below is largely derived from KITLV, Coll. Korn:193, report punggawa Abiansemal 1920, concerning royal rule in nineteenth-century Mengwi. 
in which one can distinguish analytically between the centre's limited political power and its role as ritual umbrella. This distinction is relevant, because it was expressed in the two ways in which people were mobilized and the negara reaffirmed.

As long as nothing threatened the hierarchical order, there was no need to assert the negara. To all appearances the Mengwi region consisted of a confederation of higher and lesser lords, each ruling his own domain. It was only when a wave of disorder swept over the land that the negara had to be reaffirmed. Major causes of disorder were: war, natural disaster, and change at the top of the royal hierarchy.

Attacks launched against the Mengwi region from outside put the wellbeing of the entire negara at risk. War made for chaos and the outcome was always difficult to predict. Victory over one enemy might well shift the balance of power such that a new challenger would step forward. Competition in the arena of southern Bali was frequent and fierce. Ideally, it was the royal centre's task to mobilize all available manpower, including not only its own armed forces but the warriors of its satellites as well. Mobilization of the satellites could not, however, be done directly; the centre had to rely on the manca agung and the manca, who in turn mobilized their own following through their local agents (mekel).The same type of fragmented and indirect mobilization was used when the royal puri was in need of repair, which meant that, unlike the temple, the puri belonged to the sphere of fragmented power. Seen in this light, the role played by villages as corporate entities was negligible in the dynamics of vertical relationships.

A second kind of mobilization related to reaffirmation of the ritual order was used when the negara was threatened by natural disaster or invisible forces. Upon such occasions the whole population - not just the warriors was mobilized directly. In contrast with the first type of mobilization, the villages now played a crucial role: instead of issuing its summons down the fragmented hierarchy to the lesser lords, the royal centre sent a special group of messengers to the villages themselves to inform the local bendesa. ${ }^{13}$ Village heads throughout the negara, bypassed in times of war mobilization, were now called upon to gather their villagers.

An example of this was the collapse or breaching of a major dam, something that often happened at the beginning of the rainy season and was a serious threat to the agricultural cycle. To forestall crop failure and starvation, the bebanjaran mobilization would be put into operation; every household in every ward (banjar) was expected to contribute labour to repair the

13 These messengers were called pragae. They were a separate group in desa Mengwi; there is a ward known by that name. Pragae were also deployed in war to inform the manca agung and the manca. Furthermore, they were overseers of the pacalang, royal spies active throughout the negara. 
dam. Again, if society as a whole was threatened by a contagious disease or a poor harvest, it was the king's responsibility for the common good to restore order and to exorcise the evil powers. This would be done, for instance, by suspending all public life until the epidemic subsided, and by conducting extensive collective rituals. ${ }^{14}$

Another threat to the stability of the negara was a change at the top of the hierarchy, namely, the king himself, since it was he who represented the hierarchy. Instability threatened at four crucial junctures in the ruler's personal history. ${ }^{15}$ To begin with, there was the moment of entry into adulthood, marked by the ceremony in which the king or crown prince had his teeth filed. A second change occurred when he married a principal wife, and could be expected to produce legitimate royal offspring. Third, investiture of the king (abhiseka) meant that the top of the hierarchy was embodied by a new figure. Finally, there was the cremation of the king and other rituals for the dead that formally marked the end of his rule. The king's death was always a time of threat to the hierarchy. Inauguration of his successor would still be some way off and meanwhile, intrigues and violent battles for the throne might well ensue. One of the purposes of the rituals was to ward off threatening chaos. Accordingly, at each of the four crucial junctures marking the king's life, all of the negara's households were mobilized by the royal centre, via messengers who addressed the village heads directly. In other words, it was when the hierarchy was at stake that the negara would become highly visible. Whenever order was endangered, threatened to be overrun by disorder, the hierarchy had to be emphatically reasserted.

\section{The course of the waters}

While the royal dynasty did its utmost to create a hierarchy, this order was always jeopardized by conflict. In fact, negara Mengwi derived its major dynamism from this inherent tension between hierarchy and conflict. Following prominent scholars like Geertz and Tambiah, I should like to turn to metaphor to conceptualize this. Three kinds of 'water' flowed through the negara, giving form to the hierarchy: semen (kama putih), holy water (tirta), and the rivers (yeh). Their course and order were imposed by the king. On their downward route, however, the streams tended to disperse

14 See Van der Kaaden (1936) regarding the ritual cremation of mice during the colonial period, and Schulte Nordholt (1981a:46) on suspending public activities during an epidemic in 1850. In this connection Lovric (1987:117) says: 'It was the duty of the ruling raja to stage large-scale rituals considered crucial to the well-being of the subjects and the survival of the kingdom'.

15 These crucial events were repeatedly mentioned in interviews with G. Ag. Gede Rai, puri Kajanan, Ida Bagus Ketut Sindu and I Ketut Misma, Mengwi, G. Ag. Ajeng, puri Labah, Kedampal, G. Ng. Putra, puri Grana, G. Ketut Kaler, jeroan Bakungan Blahkiuh. 
into disorder. This is why powerful leaders were always needed to 'fight the current' to keep the hierarchy intact. ${ }^{16}$

In this metaphor, the top of the hierarchy is formed not so much by the person of the king as by his kris. Shelly Errington (1983) has shown that in South Sulawesi pusaka (sacred heirlooms) were looked upon as sources of divine power. At the hub of the political dynamism pusaka were immobile and ideally lasting centres of concentrated power. Although the context is not the same, the principle applies to Bali as well. The foremost pusaka on Bali was the royal kris. Various texts and stories contain the idea that the kris rather than the king was the divinely 'true' (wyakti) source of power. ${ }^{17}$ In the Mengwi dynasty, too, the royal krisses (I Dalem Smeru, I Panglipur) were looked upon as the 'true' or 'genuine' sources of power, and the king was the one who possessed this power. Moreover, the kris was linked with the idea of kawitan (origin or provenance); accordingly, the kris was called kris kawitan as well. ${ }^{18}$ Two kinds of origin, then, the deified ancestor and the divinely approved source of power, flowed together in the kris which conferred on the king his true authority. With his kris the king was the crucial connection between the divine order and the people. His kris symbolized the power which enabled him to give form to the hierarchical order on earth. Without royal power the hierarchy was unthinkable.

As I mentioned, the three 'streams' give shape to the hierarchy. The first stream was semen, thought of on Bali as a kind of water. ${ }^{19}$ Just as water cannot push its way uphill, so also semen can only flow downwards. That is to say, men were restricted to marrying women of equal or lesser birth, so that this flow ordered the social hierarchy in the negara. It was the king, first of all, who was to guard this order and to make certain that the rules of marriage were adhered to. ${ }^{20}$ In addition, none but he could elevate or lower the social status of clans and individuals.

It was fundamentally important for members of the hierarchy to observe these rules strictly: should they neglect the hierarchy, their superior position

16 This metaphor was not supplied by Balinese informants; it summarizes my view of the political system on Bali. But my informants considered the metaphor a fitting one.

17 Guermonprez 1985:45; Wiener 1990:121. Babad Blahbatuh (Berg 1932; Sugriwa 1975), for instance, is not primarily the narrative of a noble family, but rather the story of the krisses that belonged to the clan and rendered it powerful. The text was arranged around these pusaka such that every new event involving the weapons was placed in the context of a new generation. Goris came to a similar conclusion in a memorandum on 'state heirlooms': 'Symbolically, they are the realm; they express the continuity of the realm; whoever is in possession of them controls the power of state as well' (Coll. Goris, report 4-12-1934).

18 Korn 1932:445; information supplied by G. Ag. Oka Pabean, Denpasar, G. Ag. Ajeng, puri Labah, Kedampal, and others.

19 Here I borrow from Hobart 1978:21; see also Weck 1937:45.

20 See, for example, KITLV, Coll.Korn:175, Paswara Mengwi, for royal decrees regarding differences between various groups in Mengwi. 
would be lost as well. Two examples illustrate how zealously these rules were enforced, especially within the dynasty. The first is that of a daughter of Agung Mayun, remembered as Dewata Geni, 'the one deified through fire'. The name refers to the manner in which she was put to death in $1887 .{ }^{21}$ This woman was still unmarried and lived in the royal puri of Mengwi. She had an affair with one of the puri's mekel, a married jaba. Their secret trysting came to light when the woman was discovered to be with child. Punishment for this outrage against the hierarchy was swift. The pregnant woman was burned alive at the burial grounds of desa Mengwi, and the adulterous mekel and all his family were stabbed to death with the kris. The evil was thus routed out.

A second example is that of an entire branch of the dynasty. The events took place around 1880.22 The leader of puri Penarungan had become demented, and was no longer aware of his actions. One day, as he crossed the market opposite his puri, he picked up and ate remnants of food which had been left behind by various people, including lesser jaba. The rule was, and among the nobility still is today, that only equals are permitted to share food, after which servants and commoners may eat the remainder. The lord of puri Penarungan upset this order; he demeaned himself by this irresponsible action and his fall in the hierarchy was inevitable. Shortly afterwards he died. His closest relatives were now faced with a dilemma. The king of Mengwi would not allow the bereaved to honour the deceased in the usual way, for to do so would be to demean the family as well and would stigmatize the hierarchy with an intolerable blemish. But the dead man's sons, whose first loyalty was to their father, disobeyed the king, and the king responded by ousting the entire branch of puri Penarungan from the dynasty. Its representatives could dine and pray with him no longer. Puri Penarungan continued to rule its own domain, but the branch was isolated so that the dynasty would not be 'contaminated'.

As I have indicated in previous chapters, the boundary between nobility and commoners was observed more strictly during the nineteenth century, and ruling houses tended to close themselves off. New noble families did not arise, nor were commoners adopted into the ranks of the nobility, while among the ruling houses exogamous marriages were increasingly displaced by endogamous marriages. Gone were the times when in the heat of a battle

21 ARA, MvK Mr. 1887:576+, report Resident Bali and Lombok 4-10-1887. In 1885 a comparable execution took place in Karangasem. The victim was the son of the lord of Karangasem, because he maintained a forbidden relationship with a high-born brahman woman. Bound with ropes, they were thrown into the sea (ANRI, Bali:3.15, political report Bali and Lombok 1885).

22 I mention no names of informants, since the issue is still emotionally loaded. 
a leader would shout 'If you fight with me I will make you a Gusti'. ${ }^{23}$ The nobility that had risen to power since the late seventeenth century had grown in number and finally managed to rule Bali by itself.

Differences in rank were expressed in other ways as well. For instance, strict rules governed the arrangement of the yards of the homesteads. None but members of the lord's or king's entourage were allowed to adorn their gates or to have special pavilions. ${ }^{24}$ A note dating from 1890 indicates prescriptions regarding one's apparel, especially on days of feasting:

'Only the high-born and prominent [...] have the privilege of wearing rich clothing and silver ornaments. A commoner may possess them, but he will never appear in public with an expensive kris or kain. If he did, he would be "requested" to make a present of it to someone outranking him.'25

A person's prestige was expressed in marriage and dress, rules for which were prescribed by the king as supreme legislator and judge. In this he was assisted by his kerta, a brahman scribe, an expert on judicial texts. ${ }^{26}$ Most of the Mengwi royal court procedures are lost to memory. Still, the context allows us to deduce that the kerta's main task was to uphold the hierarchy. Sentences probably related mostly to granting permission for marriages, succession rights, and adoptions among the nobles. Court cases for commoners were decided by the local lords, whom the people approached through their mekel. Moreover, the aim of legislation was not to provide for equality among the jaba population; rather, it was aimed at safeguarding distinctions between high and low. One royal decree, for instance, stipulated punishments inversely proportional to the level of the offender's status. ${ }^{27}$

Brahman priests were the repository of knowledge concerning the hierarchical order and, hence, regarding the proper flow of semen. But they also

2.3 Babad Surapati, referring to the conquest of Blambangan by Buleleng.

24 Data provided through interviews in desa Sibang, desa Blayu, and desa Mengwi. As a rule, these pavilions were the balé bandung and the balé gede, at the north and the east sides of the yard, respectively.

25 ARA, MvK V24-11-1891-7, report J.H. Liefrinck 20-10-1890.

26 In the days of Agung Mayun this was Ida Pedanda Putu Bun, from gria Bun in Mengwi, a branch of gria Gede Den Kayu, home of the royal purohita (information from Ida Bagus Ketut Sindu, Mengwi). According to oral tradition and the 1920 report of the punggawa of Abiansemal (KITLV, Coll. Korn:193), each of the manca agung had a kerta of his own.

27 The higher one's station, the lower the fine: for the same offence, jaba were fined 10,000 kèpèng, a low-placed Gusti paid 8,000, a higher Gusti paid 4,000, a brahman 2,000, and the royal purohita no more than 250 kèpèng (KITLV, Coll. Korn:175, Paswara Mengwi:71-2). According to Dubois (KITLV:H281) Badung had the following hierarchy in jurisprudence around 1830: on the highest level the purohita and pedanda passed sentence on issues relating to brahmans only; the king, his council of nobles, and the purohita dealt jointly with legal matters touching the higher nobility, and the king and his council (without the purohita) passed judgement on members of the lesser nobility; finally, the king and the lords, assisted by a pedanda, each judged their own jaba subjects. In case of conflict between subjects of two lords, agreement would be reached by the pedanda representing the two lords. 
regulated a second stream, that of tirta, holy water, which they prepared meticulously. The objective of the Brahman ritual was to cause 'life-giving water' to descend from heaven to earth (Hooykaas 1964:139). On earth, too, this stream was allowed to flow downwards only, which meant that one could accept holy water only from one's equals or betters. Within the royal hierarchy the highest 'source' of this stream was the purohita. He was expected to confirm the royal hierarchy through knowledge drawn from the corpus of Javanese-Balinese texts. Besides this, he played an important role in rituals concerning the dynasty and the negara, pronouncing the holy texts and prayers, preparing and dispensing holy water. In the ideal case, holy water flowed down from the royal purohita throughout society, since not only the dynastic centre but the branches, too, received it from him. His lesser relatives, in turn, provided holy water to members of the entourages of the king and to satellites. Finally, followers of the various puri were 'pupils' (sisya) of the priest of the brahman gria attached to the local puri, from whom they received holy water for special rituals. ${ }^{28}$ The flow of holy water ideally paralleled the flow of semen and gave form to the hierarchy in the negara.

It was at the pamrajan (house temples) of the puri belonging to the dynasty that the two streams came together: at the place where the deified ancestors were worshipped and the brahman holy water was distributed. Not just the members of the dynasty were involved in this; many followers participated in the rites, which in this way simultaneously expressed the physical mobilization potential of these puri.

\section{The negara temples}

As elsewhere in Indianized Southeast Asia (Hall 1985:116-9, 166-7), the political geography of Bali was marked by a hierarchical network of temples. Locally, the hierarchy was manifest in the house temples of the various puri; in the central temple of the negara this was done on the macro level. In pura Taman Ayun in Mengwi all the ancestors of the entire dynasty were worshipped; on the days of great feasts all branches of the dynasty were expected to convene there. The royal purohita performed the rituals that concerned the negara as a whole. His holy water was used in celebration of the hierarchical order which constituted the negara. Upkeep of the temple,

28 In Chapter 2, sections 2 and 5, I referred to the correspondence in negara Mengwi between the spread of the royal dynasty over the region and the expansion of the two most important brahman families attached to the dynasty. In this light the prominent role played by the Klungkung purohita at certain royal rituals in Mengwi becomes clear. The higher authority of the Klungkung court was expressed in the more sacred holy water prepared during these rituals by the brahman priest from Klungkung. 
too, was not the responsibility of specific groups of followers; rather, all villages in the negara were meant to contribute to this.

Together with the royal puri, pura Taman Ayun was in many respects the centre of negara Mengwi. One important factor was that the temple was the centre of the 'ritual axis' between the mountains and the sea, both ends marked by a temple: the negara's mountain temple and sea temple, respectively. The third stream of water - the springs and rivers - followed this axis. Cascading from the mountains (or the gods), the river water spread over the sawah down to the sea, giving life to all the negara. In this the royal centre acted as guide, actively engaged in the construction and maintenance of the major dams and in the rituals accompanying irrigation. The relation between dynasty and irrigation was also expressed in a ritual involving the kris as source of power. Every year, just before the start of the new agricultural season, a procession carried the kris to the central dam, where it was thrust into the earth. The divinely approved power of the dynasty was thus called upon to control the violence of nature. Only then could life and order progress.

Unlike the two streams mentioned earlier, this third stream did not flow downward but circulated. Once the water spilled out into the sea it rose again to the mountains, only to descend again to the land and be redistributed at the major dams. The rituals in the mountain temple and the sea temple, led by the royal centre, assured continuation of this cycle. A.M. Hocart has correctly pointed out that dams and temples were of equal significance: 'Temples are just as utilitarian as dams and canals since they are necessary to prosperity; dams and canals are as ritual as temples since they are part of the same social system of seeking welfare' (Hocart 1970:271).

In close parallel to the circulation of irrigation water was the cycle of the human soul, which followed a course between the deified ancestors in the mountains, human life on the land, and the sea. ${ }^{29}$ The great temples of the negara marked important points in this cycle. The central temple, pura Taman Ayun, was connected with the ends of the 'ritual axis'; at the same time the temple was a replica of the negara.

This leads me to say that the ruler constructed his negara through the building of his temples. This conflicts with the statement by Clifford Geertz that 'the driving aim of higher politics was to construct a state by constructing a king' (Geertz 1980:124). I would add that Geertz's description of 'the palace as temple' (Geertz 1980:109-16) may be questioned. To begin with, temples (pura) and palaces (puri) were different places. Second, a temple was

29 It should be added, however, that the human soul traverses this cycle no more than a few times. After that, the soul is taken up among the deified ancestors. I am grateful to Annemarie Verkruisen for pointing this out to me. See also Schulte Nordholt 1988b; Howe 1991. 
of a higher (divine) order than was the dwelling of a (human) king. To be sure, the royal puri was the apex of the fragmented political hierarchy, but the central temples of the negara gave form to a far more comprehensive ritual order. In this context J.-F. Guermonprez has argued convincingly that the Balinese village temple was the apex of the ritual order at the local level. ${ }^{30}$ The negara temples encompassed these local orders at a higher, regional level as the summit of the negara's hierarchical order.

The negara temples were more than beacons in the land: they were the repository of the collective memory, expressed in the worship of deified dynastic ancestors in the central temple Taman Ayun and in the pura Sada in Kapal, where the dynasty's kawitan were kept. These places focused on a past from which the royal dynasty derived its identity. Moreover, the worship was not the concern of the dynasty alone: the court entourages and wider circles of followers were drawn in as well, so that the royal rituals in the negara temples were events that allowed followers to identify with their lords.

To be truly successful, the great royal rituals had to be executed exactly as prescribed, and needed to be given lustre by the attendance of a great multitude. ${ }^{31}$ The sheer massiveness of the ritual proved that the royal centre was in fact able to mobilize a large part of the population. At the same time the ritual was something of a battle. The crowdedness (Balinese: ramé) and the massiveness might well disrupt the course of the ritual and cause the event to end in chaos (Balinese: muug, destruction). Much depended on the central leadership, because the king's major task was to keep the world upright (enteg) (Wiener 1990:381-2). In this, too, the political system was reflected in its rituals. The temples as such were without impact; their significance resided in the rituals performed there. Just as in the case of power relationships, therefore, the ritual order had to be enacted time and again to make the negara visible.

If we want to understand what negara Mengwi was about, it would be misleading to emphasize distinctions between power and ritual, or between politics and religion (Geertz 1980). Just as the visible (sekala) and invisible (niskala) are two sides of a coin, so power and ritual cannot be separated (Wiener 1990:126-7). Public rituals were thoroughly political, and, at the same time, power was most dramatically visualized in rituals.

The royal dynasty created order, and order in turn implied hierarchy. As soon as order and hierarchy were introduced, however, there was also the danger that they would succumb to violence. Royal authority was not per-

30 Guermonprez 1990. In most cases these temples are a combination of the temple of origin (pura puseh) and the pura bale agung, a meeting place for the village deities.

31 Here I follow Vickers (1991), who demonstrates convincingly the ambivalent character of these rituals, making use of a Balinese description of a maligya ritual in Klungkung in 1842. 
manent, even a kris might not be: I Dalem Smeru, in the possession of King Agung Alangkajeng, was eventually lost. A kris might be duplicated, and frequently was. Nor did semen always follow the course set by the rules. The distribution of brahman holy water did not always take the prescribed route either. And, of course, the flow of irrigation water was often disturbed when dams collapsed, conduits and canals were blocked, or crops failed. In short, permanent conflict, incessant warfare, systematic political fragmentation, repeated epidemics, and frequent crop failures were the bane of the negara. Always faced with imminent death, the nineteenth-century Balinese negara embodied a never-ending quest for life. This meant that the emerging order was continually in jeopardy; new and strong leaders were always having to struggle upwards again to establish and assert their personal authority and to restore the waters to their proper course. Agung Mayun had been one such leader. He had restored negara Mengwi through his fame as war leader, by his intense involvement with agricultural improvement, and by constructing new temples. He finally succeeded in making puri Mayun the mightiest in all the region and was able to gain royal authority. His personal prestige allowed him to 'present' his hierarchical subordinates with power without giving up the negara's coherence. Another name by which Agung Mayun was known was Ratu Anak Agung Aji, the meaning of which is, roughly, Great Lord and Father. ${ }^{32}$ In a sense he was the 'father' of his subjects, because he defended them and was aware of their needs. His 'fatherhood' attracted the adherents needed to maintain the hierarchical order.

Agung Mayun died in 1871, during Galungan, the day on which the gods descended upon all the temples. ${ }^{33}$ The rule of an outstanding leader ended on an extraordinary day. His three sons, one of whom would become king and another the war leader of Mengwi, joined in performing the rituals for the dead. In this way they let it be known that they would take over their father's role as leader. This confirmation of puri Mayun's power, however, already contained the seeds of future conflict. Moreover, the Balinese political system would soon be contested by a new power: the Dutch colonial state.

32 Ratu means 'lord', as does Anak Agung (literally: big man). Aji, father, is an honorific; older nobles are so addressed. See Guermonprez (1989), who emphasizes the paternal aspect of Balinese kings.

33 Babad Mengwi-Sedang:46. Galungan coincides with the day called Buda-Klion of the five-day week Dunggulan. Although most dates in this babad are incorrect, this one seems to fit. If we rely on colonial reports, Agung Mayun was no longer alive after 1871 (Jacobs 1883; ARA, MvK V24-12-1873-48, report Gekommitteerde voor Bali and Lombok, October 1871). After his death a special shrine was erected in the house temple of puri Mayun in commemoration of Agung Mayun (now named Batari ring Galungan, he who was deified on Galungan). The holy water from this shrine was used to assure fertility in the sawah around Mengwi (information from G. Ag. Gede Putra, puri Lambing, G. Ag. Ajeng, puri Labah, Kedampal). 


\section{CHAPTER VI \\ Disaster and destruction, 1872-1891}

From 1872 to 1874 , soon after Agung Mayun's death, negara Mengwi was afflicted with epidemics and crop failures. The result was famine, distress, and a heavy death toll. These calamitous years foreshadowed the great crisis that erupted in 1883, when virtually all of the southern Balinese leaders became embroiled in a tangled web of conflicts. Southern Bali was transformed into one great battlefield. Negara Mengwi, too, was drawn into the maelstrom of shifting alliances, intrigues, treason, and chaotic battles. For Mengwi's royal centre the outcome was sheer disaster.

As in 1823, the crisis was played out on various levels; in the centre, in the relationships between centre and satellites, and between mutually hostile negara. Interaction between these levels was the prime reason why conflicts interlocked and escalated. But there was one big difference compared to the earlier crisis. This time a new factor presented itself in the shape of the Netherlands Indies government, a threat that added an unpredictable but decisive dimension to the crisis strangling southern Bali during the last two decades of the nineteenth century.

Before I turn to the course of events leading to the fall of the Mengwi dynasty in 1891, I sketch the hesitation and ambivalence characterizing the Netherlands Indies government's attitude towards Bali. Next I discuss the impact of the colonial threat on internal relations in southern Bali. The effects of this threat were such that the southern Balinese political system faced a burden it could not carry.

\section{Colonial ambiguity, $1836-1882$}

Throughout the nineteenth century the Dutch attitude towards Bali (and Lombok) was ambivalent. There was a strong tendency to concentrate Dutch colonial rule on exploitation of Java (and part of Sumatra) and to pursue a 'hands-off' policy towards the 'Outer Islands'. On the other hand, and indicative of the nineteenth-century colonial paradox, the Netherlands Indies government repeatedly dispatched sizeable military expeditions to those same outlying areas, not less than five of them directed against Bali. ${ }^{1}$

1 On this colonial paradox see Fasseur 1979. The campaigns against Bali took place in $1846,1848,1849,1858$, and 1868. 


\section{Diplomatic offensive}

Dutch intervention on Bali and Lombok began in 1836. It was rumoured that the British sought control over the lucrative rice trade on Lombok. ${ }^{2}$ Although the 1824 treaty had divided the Archipelago between a Dutch and a British sphere of influence, the status of Bali and Lombok remained unclear. These islands were not officially under the authority of the Netherlands Indies government, since there were no contracts to this effect with Balinese kings. Accordingly, the government in The Hague decided to take the initiative. Supported by the Nederlandsche Handel Maatschappij (Dutch Trading Company), which was expected to secure control over part of the export from Bali and Lombok, an emissary was sent to the two islands five times between 1840 and 1843 . He was to conclude a treaty whereby the kings would recognize Dutch sovereignty in their realms. Since shipping along the coast of Bali and Lombok had intensified, the new treaties were to include a clause forbidding the Balinese kings to continue their practice of plundering stranded ships. ${ }^{3}$

Gradually the Balinese political system was surrounded by expanding commercial and political interests of the Netherlands Indies colonial state. But on Bali Westerners continued to be looked upon as marginal foreigners, as W.H. Medhurst experienced firsthand when he visited the island in 1829. $\mathrm{He}$ considered the Balinese to be utterly devoid of manners:

'[They displayed] none of the respectful submissiveness generally encountered on Java. As we disembarked many of them approached us with singular lack of manners, stopping in front of us to look us over, upon which they departed without any politeness or courtesy, saying "they're Dutchmen".' (Medhurst 1858:199.)

These Dutchmen encountered a highly complex political system which long remained an enigma to them. 'Everything here is chimerical, nothing clearcut; every day the most blatant contradictions supplant each other', complained the despairing Dutch emissary after his first visit to Klungkung. ${ }^{4}$

It soon became clear that the Balinese kings were less than eager to

2 ARA, MvK.V18-11-1836-16, V26-12-1837-308/t.geh. For a more extensive review, see Ikhtisar keadaan 1973; Lekkerkerker 1923b; Schulte Nordholt 1981a. Earlier contact with Bali, in 1808-1811 and 1828-1831, had been restricted to the purchase of slaves (or recruits).

3 Tawaing karang, as it was called, was a frequent practice. The immediate reason for including the prohibition was the running aground and subsequent plundering of De Overijssel (Blom 1841; see also Utrecht 1962:173-4).

4 ANRI, Geh.Besl. 5-8-1840-LaK3, report H.J. Huskus Koopman 30-6-1840. The Dewa Agung had given him audience but had himself remained silent. The visit is mentioned in a Balinese source as well; evidently, two points in particular evoked comment: the impressive uniforms worn by the Dutch and the fact that their breath was foul (Pralambang Bhasa Wewatekan:19a/b, 24b/25a). For the Balinese the political objective of the mission was far less important than the Dutch gift to the Klungkung court: this gift was a rhinoceros, needed for a great maligya ritual soon to take place (Vickers 1991). 
conclude any kind of contract with the Dutch at all. They were sufficiently familiar with the colonial regime on Java to prefer the Dutch not to interfere with their internal affairs. The Dewa Agung of Klungkung wrote the governor general in Batavia that he did not feel a treaty was needed. The very manner in which the letter was worded is instructive. To begin with, he alluded to himself as susuhunan (High King) of all of Bali, residing in Klungkung, and addressed himself to the governor general of Java, residing in Batavia. In this way he made clear that Bali and Java were two different worlds, and that they should remain so. Second, he addressed the governor general as his 'son' and referred to himself as 'father', indicating that he placed himself above his colleague. ${ }^{5}$ The reference to the Dewa Agung as susuhunan over all of Bali (and occasionally over Lombok) introduced an issue which would nag at the Dutch for the remainder of the nineteenth century. How was one to define his position compared to that of the other Balinese kings? Initially the Dutch emissary supposed that the king of Klungkung was the 'spiritual leader of the Buddhist religion in Bali'. However, by 1849 , after three costly campaigns and a great deal of hard-earned experience, the Dutch had to admit that 'the influence of the Dewa Agung is far greater on Bali than hitherto supposed'. 6

In 1841 , then, prospects for concluding a treaty seemed rather dim, but the Dutch emissary suddenly returned to Batavia with positive results. The kings of Badung, Klungkung, Buleleng, and Karangasem unexpectedly recognized Netherlands Indies sovereignty over their realms. In the subsequent two years he managed to contract the kings of Tabanan and Lombok. ${ }^{7}$ No separate treaty was made with negara Mengwi, which wàs formally under the control of the Dewa Agung of Klungkung. In fact, the literal text of the treaty even referred to the Dewa Agung as 'Emperor of the Islands of Bali and Lombok'. ${ }^{8}$

Just how the emissary had managed these contracts remained a mystery for some time. But it would soon become clear that something was amiss with their content. Moreover, it quickly appeared that the Balinese thought differently about making agreements. And while the treaties excluded

5 ANRI, Geh.Besl. 5-8-1840-LaK3, report H.J. Huskus Koopman 30-6-1840. For a detailed description and interesting analysis of the diplomatic encounter between the Dutch and the Klungkung court, see Wiener 1990:chapter 8.

6 Ikhtisar keadaan 1973:434; ANRI, Geh.Besl. 25-8-1849-LaD2, report J. van Swieten 6-61849.

7 Schulte Nordholt 1981a:35-6. On these contracts see Surat-surat perdjandjian 1964. In addition, supplementary treaties prohibited the plunder of stranded ships. From the beginning of the eighteenth century Lombok was controlled by a branch of the Karangasem dynasty (De Graaf 1941).

8 Surat-surat perdjandjian 1964:3. On the status of Mengwi see ANRI, Bali:4.15, diary H.J. Huskus Koopman, March-May 1840. 
British intervention on Bali and Lombok, they also were the prelude to an escalating conflict between the Netherlands Indies government and some Balinese kings.

Although the agreements forbade it, the plundering of vessels run aground on the coast of Bali continued. And as the Balinese kings saw it, the contracts lost their relevance after the Dutch disappeared again in 1843. On Bali, written agreements lost their significance if they were not backed up with and accompanied by visible, personal ties. ${ }^{9}$

In 1844 the existence of disparate interpretations of the treaties came to light. In that year the assistant resident of Banyuwangi (East Java) was sent to northern Bali to exchange the ratified treaties. Apart from the fact that to the Balinese this sort of exchange was entirely novel, Buleleng denied that it had ever subjected itself to Batavia. ${ }^{10}$ Most likely the rulers of Buleleng were right. There is reason to believe that the Balinese kings were tricked. Contrary to instructions, the Dutch emissary H.J. Huskus Koopman had promised military aid to some of the kings. This induced the kings to sign, but the promised support never materialized. In addition, the emissary was said to have manipulated the content of the agreements. ${ }^{11}$ At first the Balinese kings refused to recognize contractual Netherlands Indies sovereignty over their negara. But emissary Huskus Koopman was under much pressure from Batavia to return quickly and successfully. It is probable that he proceeded as follows. In his talks with the Balinese kings he pictured the relationship between them and the Dutch as one between friends. And, as customary among good friends, there is no distinction between the property of the one and the possessions of the other:

'All goods must be considered as belonging to each reciprocally. The king of Buleleng, for instance, will admit that his realm belongs to the king of Karangasem also, and vice versa.'

Counting on the fact that this line of reasoning was generally accepted in Balinese circles, Huskus Koopman made it sound as if Java belonged to Bali, just as Bali also belonged to Java. Once this was agreed, Huskus Koopman composed the text of the treaty, but included only the second clause: that

9 On the plundering of ships see Ikhtisar keadaan 1973:455-6. The only Balinese ruler with whom personal ties were maintained was G. Ng. Kesiman of Badung. Through the Danish merchant Mads Lange he communicated regularly with colonial officials in East Java (Schulte Nordholt 1981a).

10 ANRI, Geh.Besl. 11-4-1845-LaD1, report Assistant Resident Banyuwangi 10-10-1844.

11 ANRI, Geh.Besl. 14-7-1845-LaB2, secret report Assistant Resident Banyuwangi 12-51845 , from which I also take the next quotation. This report was never forwarded to The Hague. It was kept in Batavia on orders of the governor general, with the notice 'for future reference'. The accusations uttered by the assistant resident against Huskus Koopman, who died in 1844, were not investigated by Batavia. See also Van Hoëvell 1849-54, III:46; K. 1849, and Jacobs 1883:59-61, who suspect that the agreements were tampered with. 
Bali also belonged to Java. ${ }^{12}$ It is easy to imagine the surprise felt at the Buleleng court in 1844 when the assistant resident tried to explain the terms of the treaty. The assistant resident, in turn, was indignant at the Buleleng king's point-blank refusal to agree to a treaty of this sort.

A year later the conflict flared up in earnest. J.F.T. Mayor, Resident of Besuki and Commissioner (Gecommitteerde) for Bali and Lombok, paid a visit to Buleleng. The very manner of his reception contained a clear message. He approached the king of Buleleng from the beach by sedan chair, but at the royal puri he was told to walk the rest of the way. ${ }^{13}$ To the Balinese it was self-evident that out of respect for the king one crossed the puri's bencingah (forecourt) on foot. But Mayor felt greatly offended. A ten-year term as Resident at the court of Solo in Central Java had accustomed him to extensive etiquette and politeness towards Europeans. The sudden transition to Balinese relationships must have been shocking to him. In the king's presence things did not improve. The king was seated higher. Mayor had to resign himself to a much lower seat. In addition, the Resident came face to face with Buleleng's strongman, patih Gusti Ketut Jelantik, who did not mince words:

'Visibly enraged, he beat his chest and said about the matter of Dutch sovereignty over Buleleng that, as long as he lived, such a thing would never come to pass; after his death the king might do as he preferred; that one could not become lord of the land on the strength of a mere piece of paper; that such lordship could be established by nothing other than the decisive might of the kris. ${ }^{14}$

The patih's way of manifesting himself in the midst of his followers was in stark contrast to the courtly culture of central Java:

'From time to time the Gusti [Ketut Jelantik] turned to one of his followers close to him in rank, a fat man whose face shone with oil and whose features expressed stupidity [...]. [The Gusti] would say something, the words impossible for us to catch, with a scornful twitch of the mouth and a contemptuous glance in our direction, whereupon the fat one would lead the others in a round of guffaws and loud, jeering laughter.'

Resident Mayor could not abide the scene; he left while the king remained seated.

Ultimately the conflict was played out in a key of 'derision and honour' which both parties could understand. Gusti Ketut Jelantik spit on the seapass held by a merchant sailing under the Netherlands Indies flag. The

12 The treaties were worded in Dutch and a very halting Malay, so that it is doubtful whether the kings really understood the text they signed. In the Malay text the word 'also' (djuga), which of course lost its relevance, was accidentally retained. It was deleted in the Dutch version (Surat-surat perdjandjian 1964:3).

13 ANRI, Geh.Besl. 14-7-1845-LaB2, report Resident J.F.T. Mayor 30-5-1845.

14 K. 1849:225, from which the next quotation is taken as well. 
action was meant to show that this paper was worthless. Governor General J.J. Rochussen reacted with a fine feeling for drama:

'Such scorn must be avenged. Otherwise our authority in the Indies will evaporate. Our statecraft can tolerate no longer that, within range of our cannon, there exists a core of resistance against our supremacy, where robbery at sea and on the coast is held to be a lawful and inalienable right.' 15

Aside from the matter of Dutch honour, two further factors played a role. First, it was feared in Batavia that the British would establish themselves on Bali and Lombok anyway. Second, the Dutch sought control over the expanding export of cheap rice from the two islands because Java was threatened with great food shortages. ${ }^{16}$

War, 1846-1849

In 1846 the first Dutch expedition to Bali took place. The idea was to 'discipline' Buleleng. To this end a large part of the royal residence in Singaraja was destroyed. The campaign closed with new contracts concluded with the kings of Buleleng and Karangasem. ${ }^{17}$ This time a Balinese text was added; nevertheless, these contracts, too, were of little value because after the campaign the Dutch withdrew again.

If the government in Batavia believed that the Balinese problem was taken care of, the Balinese themselves felt that the war was just begun. Not only did the conflict between the Dutch and Buleleng drag on, but longfestering tensions among the Balinese kings played a role as well. In consequence of this, various factions formed themselves, all of them waiting for Batavia's next moves. But the-Dutch hesitated. Resident Mayor recommended harsh measures. As he saw it, all of Bali should be conquered and the Dewa Agung of Klungkung should rule as 'High King' in the name of the government. But Mayor's superiors in Batavia and The Hague dismissed his recommendations: they did not feel inclined to actually incorporate regions outside of Java and Sumatra. ${ }^{18}$

In the meantime the Klungkung court was increasingly drawn into the conflict between the Dutch and Buleleng. The reason was that the position

15 ARA, MvK Semi-officiële correspondentie G.G. aan Min. v. Kol. 1-1-1846. The diplomatic offensive was an utter failure once some kings pointed out that the contracts had lost validity because they had been signed by government officials - Huskus Koopman and Governor General P. Merkus - who were now deceased (ANRI, Geh.Besl. 20-7-1845-Aa).

16 ARA, Semi-officiële correspondentie G.G. aan Min. v. Kol. 30-9-1846 and 25-4-1847. See also Elson. 1978. On rice export from Bali and Lombok, see Schulte Nordholt 1981a:29-30.

17 Surat-surat perdjandjian 1964:87, 102. The kings of Buleleng and Karangasem were close kin. One small military contingent remained in Buleleng. But it exercised no control. Instead, the unit's camp was besieged by patih Gusti Ketut Jelantik's troops (ANRI, Geh.Besl. 18-51947-LaDD).

18 ANRI, Geh.Besl. 18-5-1847-LaDD. 
of the Dewa Agung as 'High King' of Bali and Lombok was a pretext that both he and Batavia resorted to in attempts to gain control over events. At the samé time Buleleng tended to hide behind the Dewa Agung's authority to avoid the inconvenient Dutch demands. In practice, however, the Klungkung ruler had but limited influence, so that the Dutch soon began to look upon him as suspect and, with some reluctance, as an enemy.

Colonial involvement with Bali unleashed a chain of events which even Batavia could no longer ignore. Buleleng remained unmoved in its refusal to take the new contract seriously, and rivalry among the various Balinese negara escalated. ${ }^{19}$ The ruler of Badung, too, nurtured hopes of expanding his power in southern Bali, but he needed Dutch support for this. Accordingly, he strongly advocated an immediate second military expedition against Buleleng, the more so because other negara were becoming distrustful of him on account of his overt friendship with the Dutch. ${ }^{20}$ In the midst of the most explicit extremes, negara Tabanan, negara Gianyar, and negara Mengwi walked a tightrope of loyalty to Badung or Klungkung, 'neutrality, and careful overtures to the Dutch. ${ }^{21}$ In 1847 the queen of Mengwi tried to arbitrate between Karangasem and the Dutch. But just before talks were about to start, a Klungkung emissary let the queen know that she should keep out of things. Thereupon the Dutch representatives in Mengwi had to get out quickly, for fear of possible assault. ${ }^{22}$

The Dutch kept disagreeing among themselves as to just what should be done about Bali. Meanwhile Buleleng put up defences and bought large quantities of weapons and opium in Singapore. All was being readied for renewed confrontation. ${ }^{23}$ The Dutch could not disregard this, and in June 1848 the second military offensive was mounted. The attempt to capture the Buleleng stronghold of Jagaraga, however, ended dismally. Inadequate knowledge of the terrain, lack of drinking water, and an unexpectedly wellorganized defence caused the colonial troops to retreat and flee within the span of a couple of hours. The operation was an utter failure and the Dutch suffered a severe defeat. Only later did it become clear that the battle of Jagaraga had been won by Buleleng by little more than a hair's breadth.

19 The kings of Lombok staged a very large ritual in September 1846 (probably a death ritual, maligya, for an earlier Lombok king). According to Dutch calculations some Dfl. 150,000 was spent on the ritual, including the erection of a temporary 'city' on the coast. The Lombok kings were out to demonstrate that they matched the Dewa Agung and ranked no lower than he in the hierarchy (Friederich 1850:56; Zollinger 1847:350).

20 ANRI, Geh.Besl. 18-5-1847-LaDD.

21 It seems that the king of Gianyar paid for this with his life. Very soon after approaching - via the ruler of Badung - the Dutch in 1847, he died, presumably of poisoning (KITLV, Corr. Mayor-Lange, report Lange 1847; on the cremation of this king see Geertz 1980:116-20).

22 ANRI, Geh.Besl. 28-6-1847-LaXX; Geh.Besl. 7-3-1847-LaOO.

23 ANRI, Kab. 17-7-1848 no. 186 LaB1, report General Major Van der Wijck 4-7-1848. 
What happened was that as the Dutch attack subsided, the stronghold was almost empty. Lack of ammunition and opium had prompted most of the Balinese and Buginese warriors to run off. Surrounded by only a handful of followers, patih Gusti Ketut Jelantik remained, though he too despaired of victory. His opium was consumed and he 'cried like a child'. Suddenly, however, the colonial force withdrew en masse and, contrary to their own expectations, the Balinese in Jagaraga won the day. ${ }^{24}$

After this shocking experience Batavia could think of one thing only: retaliation. The Dutch now had to prove to the Balinese, to the British, and most of all to themselves that they were the dominant power in the Archipelago. Immediate preparations were made for the biggest military expedition ever undertaken by the Dutch. Major General A.V. Michiels, known from the Padri War in Sumatra, commanded an army of 12,000 men, which left in April 1849. Once again Buleleng was attacked and this time the Dutch, after heavy fighting, took the stronghold at Jagaraga. At last Buleleng was 'disciplined'. ${ }^{25}$

The operation continued; Klungkung, too, had to be taught that the Dutch claimed the highest authority on Bali. Accordingly, the expedition turned to southern Bali. As before, however, the war effort threatened to end in failure. Unfamiliar conditions, dysentery, and a surprise attack during the night - in which Major General Michiels was one of the casualties - took many lives and demoralized the expeditionary force. From then on, the Dutch were no longer in control of events. The outcome was decided by the coalition of southern Balinese kings led by Gusti Ngurah Kesiman of Badung. The Danish merchant Mads Lange sought to intervene, and it is largely because of this that, rather than engaging in a final and decisive battle for Klungkung, the Balinese and the Dutch made a timely peace (Schulte Nordholt 1981a:42-4).

The peace of Kuta, 1849

On 15 July 1849 the peace treaty was concluded. No less than 30,000 followers of southern Balinese kings attended the ceremony, which took place in

24 ARA, MvK V7-11-1848; ARA, Coll. A.H.W. de Kock no.1; Van Swieten 1849. The governor general dared not send reinforcements, fearing that the revolution which swept over Europe in 1848 might spread to the colony. He preferred to maintain the colonial army on Java at full strength. The Buginese played an important role on the side of Buleleng. Those who were active as merchants in Buleleng were forced to fight. Their families were held hostage. Other Buginese were deserters from the 1846 colonial expeditionary force; it was they who directed the construction of Jagaraga's defence works (ANRI, Geh.Kab. 26-10-1848-LaG6, report De Kock 13-9-1848; Van Eck 1878:408).

25 On this campaign see ARA, MvK V 16-4-1850/k geh.; Weitzel 1859; Schulte Nordholt 1981a:41-5. During the expedition the kings of Buleleng and Karangasem and the patih of Buleleng, Gusti Ketut Jelantik, were killed. 
Kuta, a coastal village in Badung. It was a spectacular event to which each of the participants ascribed his own meaning. At long last the Dutch had gained the contracts they had been after ever since 1836: a document in which the kings recognized the sovereignty of the Dutch government. Except for the kings of Buleleng and Karangasem, however, the Balinese kings were certainly not defeated. None of them was made to swear allegiance to the government, Batavia was given no voice in the appointment of new kings, and the kings were not compelled to send an annual mission of envoys to the governor general to pay their submissive respects. No official seat of the colonial government was established in southern Bali, and the Dutch even closed their eyes to the export of slaves, which was still going on, though in lesser numbers than before. ${ }^{26}$

The areas conquered by the Dutch - Buleleng, Jembrana, and Karangasem - were returned and divided among the kings of Bangli and Lombok. Most important for Batavia was that as 'victor' it could retreat with honour (and relieved alacrity) from the Balinese hornet's nest. But the southern Balinese kings looked upon themselves as victors as well: they had succeeded in keeping colonial influence at bay.

Finally, the peace of Kuta was significant for relations among the southern Balinese kings. The big loser was the Dewa Agung of Klungkung. His attempts during the conflict to assume a leading role in Bali had come to nothing. The winner was Gusti Ngurah Kesiman, ruler of Badung. This tactician successfully exploited his relations with the colonial government, so that he was the central figure in the Kuta peace talks. Furthermore, it was he who managed to turn the Dutch away from southern Bali at the crucial moment. ${ }^{27}$

The peace of Kuta ultimately meant that a decade of tension now came to a ritual close and that the temporary supremacy of Badung's ruler was witnessed by the thousands attending the ceremony. The ritual expressed that further escalation of violence in southern Bali had been forestalled.

26 See Surat-surat perdjandjian 1964; ARA, MvK V16-4-1850-118/k geh., report J. van Swieten; Weitzel 1859:215-9.

27 Gusti Ngurah Kesiman had gained much influence in southern Bali bacause he took advantage of the internal power struggle in Klungkung. With his backing, a young man had ascended the throne who subsequently married his daughter (ANRI, Kab. 20-5-1848-Ig; Geh.Besl. 1-3-1849-LaL; KITLV, Corr. Mayor-Lange, letters from Lange April-June 1850). As noted, Mengwi played a minor role in the Kuta negotiations. The kings agreed unanimously that Agung Besakih did not have the right to sign, and that the Dewa Agung of Klungkung represented Mengwi (Weitzel 1859:210). 
Colonial might in the margin, 1849-1882

Although the Dewa Agung had learned how to address Batavia - he now called himself the 'son' and the governor general 'father'28 - Klungkung had not relinquished the hope that he would be restored to his former position of 'High King of Bali'. Before this theme was taken up again, however, the Dutch, for their part, had yet to learn that after 1849 a strict hands-off policy towards Bali could not be maintained. Like it or not, the Dutch had become party to Balinese politics.

Little more than half a year after the peace of Kuta, it became evident that the move to place Buleleng under control of the king of Bangli had been illadvised. This person lacked authority there and the tensions between him and the lords of Buleleng did not take long to surface. In 1853 the more prominent lords of Buleleng requested that they be placed under direct jurisdiction of the colonial government. The king of Bangli, in turn, would rather be rid of this uncontrollable area. All of this forced Batavia to appoint its first official to northern Bali. ${ }^{29}$

Hesitantly, falteringly, and unenthusiastically, colonial rule in northern Bali took form from 1854 onwards. The lack of enthusiasm arose from the official policy, which continued thrifty non-involvement relative to the Outer Islands. The hesitation derived from the awareness that involvement could not be avoided altogether. Hence, the orders of the first controleur in Buleleng were highly ambiguous: he was to abstain from active intervention in the internal affairs of the region, but at the same time he was expected 'with force of argument' to supervise local government. Above all, he should prevent wars on Bali.

The first steps of the colonial regime were faltering ones, because the political relationships on Bali were but dimly understood or not fathomed at all. The Dutch controleur resided in Buleleng to maintain 'order', but as the Balinese lords saw it, he was a disruptive element who sought to wean them from their 'superstition' - that is, their religion - and stood in the way of their own struggles for power (Van Bloemen Waanders 1856, 1858).

Colonial involvement led to two more expeditions. This time the hostilities were aimed at two Buleleng lords who largely disregarded the Dutch controleur and refused to recognize the authority of the governmentappointed 'regent'. ${ }^{30}$ After the Javanese model, this regent was appointed to

28 ANRI, Bali:1.3, political report 1857. Moreover, the 1849 treaty referred to the Dewa Agung merely as susuhunan of Klungkung, rather than of all of Bali (Surat-surat perdjandjian 1964:14).

29 This was P.L. van Bloemen Waanders, who became controleur of Buleleng as of 1 January 1854. ARA, MvK V11-9-1857-434 geh., political report 1853; V28-11-1896-55, nota bestuursvoering in Buleleng.

30 The two expeditions were undertaken in 1858 against Nyoman Gempol, and in 1868 
Buleleng in 1861 to rule as government representative. ${ }^{31}$ But the Balinese took the regent to be establishing a new royal regime to replace the one defeated in 1849. Because of the protection this king/regent enjoyed from the government, he became very powerful very quickly, while the Dutch officials were unable to curb him.

Besides political change, the colonial presence in Buleleng also introduced economic change. This mostly had to do with the fact that non-indigenous merchants such as Chinese, Buginese, Arabs, and Armenians came under the immediate jurisdiction of the Dutch controleur. Furthermore, Buleleng was declared a free port, which meant that no import and export taxes were levied. ${ }^{32}$ As a result, Buleleng harbour developed into an eastern entrepôt in the trading network of Singapore. Particularly significant was the opium trade. Raw opium was imported in large quantities from Singapore, refined in Buleleng, and for the most part smuggled to Java. This lucrative smuggling, which was more or less government protected, in turn attracted many Chinese immigrants who soon completely controlled opium processing and trade. ${ }^{33}$

Part of the opium, together with increasing shipments of cheap textiles, found its way to the Balinese hinterland. This trade, too, was dominated by the Chinese. The most important Balinese export product was coffee, the cultivation of which, concentrated in the central Balinese mountains, expanded rapidly. ${ }^{34}$

One consequence of this fast economic growth in Buleleng was that in a few years the centre of Balinese trade moved from the southern harbours of Kuta to the north. A lively trade traffic began between northern Bali and the southern part of the island, and every year large groups of seasonal workers moved from the south to the northern coffee areas and the port of Buleleng. ${ }^{35}$ This in turn meant that the impact of the colonial presence on Bali was not limited to Buleleng in the north. For a second time in the nineteenth century, an economic shift occurred which would have far-reaching effects for virtually the whole of southern Bali.

against Ida Made Rai, Lord of Banjar. ANRI, Bali:1.3, 1.4, political reports 1857, 1858; ARA MvK V29-9-1869-2; Van Vlijmen 1875.

31 ARA, MvK V28-11-1896-2, nota bestuursvoering Buleleng. The regent was recruited from a branch of the old royal dynasty of Buleleng.

32 This happened in 1861. ANRI, Bali:2.1, political report 1861; ARA, MvK V29-5-1901A22, memorandum Directeur Financiën 19-4-1900.

33 ARA, MvK Mr. 1887:11+; Rush 1990:66-72, 160-70.

34 Between 1861 and 1875 opium imports rose from Dfl. 294,321 to Dfl. 4,485,716. Textiles rose from Dfl. 104,061 to Dfl. 484,006. The percentage of opium actually consumed in Bali and that which was illegally traded to Java is unknown. Most of the coffee was exported from the mountainous area of Bangli and Tabanan. In Buleleng and Mengwi, too, coffee was cultivated (see Liefrinck 1877; Geertz 1980:94-6; T. 1874:433-47; Chapter 4, section 2 above.

35 ARA, MvK Mr. 1887:11+, report Resident Bali en Lombok 30-12-1886. 
The southern Balinese leaders had to live with the fact that the trade controlled by them was now oriented towards Buleleng. Politically, however, it was difficult to assess the meaning of the colonial presence on their island, especially because Dutch policy seemed marked by indecision. In the years immediately after 1849 the southern Balinese kings were careful not to alienate the Dutch. If they planned war with a neighbouring negara, they first sounded out whether the colonial government was likely to approve. Once it became clear that Batavia planned no further annexation of Bali, southern Balinese politics soon resumed its own rhythm of shifting alliances and limited warfare. ${ }^{36}$ As long as the Balinese lords did not trouble the Dutch government directly, they had little to fear from them.

The colonial officials who intermittently came to visit southern Bali were always received with politeness. A sort of protocol even stipulated to the minutest detail the etiquette to be observed during such visits. J. Jacobs experienced the Badung version in 1881, when he accompanied the commissioner for Bali and Lombok on one of his journeys. Arm in arm, the commissioner and the king of Badung entered the puri and, following in order of eminence, the Badung lords linked arms with the other members of the colonial party. Inside the puri the guests were pleasantly surprised to find a 'square bottle' (Dutch gin) set out ready for them. ${ }^{37}$

However polite these receptions were, the Balinese kings refused to alter a single word in the treaties as agreed in 1849. These formulations were their guarantee against further Dutch intervention. ${ }^{38}$ It seemed as if the kings would be able to keep the Dutch at arm's length.

Suddenly, from 1866 to 1872, an ethical current rippled the colonial ranks. ${ }^{39}$ One consequence of this was that all of a sudden reports were being sent on to The Hague which spoke of 'atrocities' perpetrated on southern Bali. The alleged acts of cruelty related to the export of slaves, live burning of widows during royal death rituals, mutilation as punishment, and, more generally, royal 'oppression'. A humane government ought to put a stop to such customs. ${ }^{40}$

The most important target of this early ethical period was not located in

36 The events of 1853 were a test case. Gianyar overran the area of Tampaksiring, part of negara Bangli. After some hesitation Batavia contented itself with reprimanding the king of Gianyar. The Dutch did not wish to rush headlong into another complicated Balinese adventure, the outcome of which would be highly uncertain (ANRI, Geh.Besl. 16-8-1854LaJ1; ARA, MvK V11-9-1854-434 geh.).

37 ARA, MvK Mr. 1881:1079+, report Gecommitteerde 11-10-1881; Jacobs 1883:171-3. On the etiquette protocol see Jacobs 1883:appendix 1.

38 ARA, MvK V13-1-1854-50.

39 This brief 'ethical awakening' was a precursor of the later Ethical Policy, and coincided with the rule of Governor General P. Mijer (1866-1872). See Van Goor 1978. At the same time Multatuli's Max Havelaar was making an impact in Indonesia (Nieuwenhuys 1967:222-5).

$40 \quad$ ARA, MvK V4-10-1867-136 geh., reports covering 1864 to 1866. 
southern Bali. It was the regent of Buleleng who all at once found himself charged with nasty practices. He was exiled in $1872 .{ }^{41}$

Between 1866 and 1873, ethical and administrative considerations led to two proposals to expand government influence on Bali. Since 1849 the assistant resident of Banyuwangi (East Java) had also been the commissioner for the affairs of Bali and Lombok, a task added to his normal workload. To increase control over the two islands, the commissioner recommended that Bali and Lombok together should be made into a separate administrative district (Residentie). This seemed to him the only way to give proper expression to colonial authority. The governor general seconded this recommendation, but at the last moment the Minister of Colonies vetoed its implementation. The reason was that The Hague feared a propensity towards expansion among its colonial officials, as one advisory memorandum stated clearly:

'After the lessons of former days [the expeditions of 1846-1849] it is mandatory to refrain from taking steps the recommendations for which are born in evanescent impulses of philanthropy or the ambition of officials. ${ }^{\prime 42}$

Ethical motives, then, lost out against financial considerations. Bali did not become a Residency in its own right.

Nevertheless, colonial officials in the field continued to be concerned with 'the fate of the natives'. This was evident when the regent of Buleleng was exiled and a new arrangement had to be made for local rule in northern Bali. In 1873 a mission to this end was sent to Buleleng. Its findings were laid down in two hefty reports, which included a discussion of the relationship between the colonial government and the Balinese kings. ${ }^{43}$ In this connection two recommendations are worthy of note. First, the investigators were convinced that the people of Bali 'were crying for help'. That was why Dutch influence should be expanded by means of the establishment of a separate Residency. The second recommendation had to do with the position of the Dewa Agung of Klungkung. In the new administration this king should be appointed as colonial regent over all of Bali and Lombok. This would simultaneously mean his 'restoration' to the position of 'High King' of the two islands. Batavia rejected the proposals. They were too ambitious

41 ARA, MvK V24-12-1873-48; V31-12-1874-D34. For an impression of this affair see Schulte Nordholt 1987. In Jembrana, western Bali, which came under Dutch rule in 1855, two Balinese regents were exiled as well (Van Lier 1866; ARA, MvK V31-10-1866-F13; ANRI, Bali:1.5, 2.5, political reports 1856, 1866).

42 ARA, MvK V21-9-1867-16, memorandum Bureau C. In 1866 Banyuwangi was made into a separate Residency, so that the colonial officials in northern Bali no longer fell under the jurisdiction of an assistant resident, but under the Resident of Banyuwangi. For plans to establish a Residency for Bali and Lombok in those years see L. 1868.

43 ARA, MvK V31-12-1874-D34, report P. Zoetelief 8-4-1874. 
and the Dutch were already involved in a costly war with Aceh in northern Sumatra, which for the time being placed heavy demands on their energy.

Just what the Dutch had in mind with respect to Bali was an enigma to the kings. This made the colonial government an extremely unpredictable factor in Balinese politics. The Klungkung court, however, had not yet abandoned hopes that the Dewa Agung, if necessary with Dutch support, would at last be 'restored' to kingship over the island. ${ }^{44}$

\section{Confusion, 1882-1885}

After more than forty years of relative indecision, direct government was at last introduced in northern Bali in 1882. At the same time a new Residency was established, called, with some exaggeration, 'Bali and Lombok'. 45 The immediate cause was the administrative complexity in Buleleng. Henceforth colonial control was executed not by a regent but by a special Resident and Balinese district administrators, the number of whom was reduced from more than twenty to seven.

The new Resident also had to maintain relations with the southern Balinese kings. The kings were taken aback by this new development, and their suspicions aroused by the title of the new man in Buleleng: 'Resident of Bali and Lombok'. This led them to believe that the Dutch were announcing their intention to actually take over the south. When the kings were told, in writing, of the establishment of the new Residency they initially refrained from comment. They needed time to confer together. Eventually their reactions were largely the same, as the opening words of their letters indicated. The letters were addressed to the 'Resident of Buleleng', a none-too-subtle hint as to the area to which colonial government should restrict itself. Tabanan and Mengwi, for instance, had no doubts that further colonial penetration was likely to mean more military expeditions and deportations of kings. 46

The answer from the court at Klungkung was set in a somewhat different key. Its opening line was: 'From the Dewa Agung, Susuhunan of Bali and Lombok, ruler of Klungkung and Mengwi; to the Resident of Bali and Lombok, who governs Buleleng and Jembrana'. ${ }^{47}$ With these words the king of Klungkung portrayed himself as the equal of the new colonial official. At

44 As became clear later, this idea, toyed with by Resident Mayor back in 1846, had been mentioned anew by the official mission during its 1873 visit to Klungkung (ARA, MvK V12-121883-16, report Resident Bali en Lombok 2-5-1883).

45 ARA, MvK V13-10-1880-55; V29-10-1880-40; V17-2-1882-10; V25-2-1882-13; V3-4-188262, G.B. 4-5-1882-21.

46 ARA, MvK V12-12-1883-16; Mr.1883:603+.

47 ARA, MvK Mr. 1885:112+. Besides Buleleng, Jembrana too was brought under direct colonial administration. 
the same time he sought to enhance his own position by underscoring once again an ideal as old as the puri at Klungkung itself: the kingship on Bali (and Lombok), 'reinstatement' of which should be supported by the Dutch. As he saw it, cooperation with the Dutch was reasonable: did he not have the best claims and did not the colonial government have the greatest power? At Klungkung, necessity was the mother of invention. ${ }^{48}$ Ten years later this attitude still prevailed. In 1893, when a Dutch emissary visited Klungkung, the interpreter and advisor of the Dewa Agung once again formulated the king's view as follows:

'[The interpreter], to explain matters to me as clearly as he could, brought his hands together to form a pair of scissors. Pointing to one hand he said: "This represents the Resident of Bali and Lombok", and pointing to the other: "This is the Dewa Agung of Bali and Lombok. As long as the two halves mesh together the scissors cut well and the affairs of Bali and Lombok will run smoothly, as they should." '

The interpreter wound up his argument by stating the paradoxical, though correct, conclusion that 'there is only one Resident of Bali and Lombok, and just one Dewa Agung of Bali and Lombok; hence it is not clear what the course of future actions should be'. ${ }^{49} \mathrm{He}$ was not wrong. During the next two decades an avalanche of intrigues and warfare swept over southern Bali, while the colonial government in Buleleng looking on in amazed passivity.

The crisis about to erupt differed in two respects from the situation between 1846 and 1849. The colonial government, though present on Bali and looked upon as a potential aggressor by the southern Balinese kings, played but a marginal role. Rather than active penetration, colonial politics was one of strict non-involvement. Second, the southern Balinese kings this time were unable to achieve even a vestige of mutual accord, something they had managed, be it with difficulty, back in 1849. Perhaps it was the arrival of the colonial army in southern Bali which had then prompted a temporary and uncertain mutual truce. This time there was no actual army, only the possibility that the Dutch might attack, and a defence had to be anticipated against an enemy who would not abide by the rules of southern Balinese politics.

48 ARA, MvK Mr. 1884:337+; V19-1-1902-2, memorandum Controleur H.J.E.F. Schwartz 231-1900. A Balinese text, the Geguritan Rereg Gianyar, also mentions this Klungkung stance (Sidemen 1980:39). See Chapter 2, section 1, in which I mention that the first Dewa Agung of Klungkung called upon the VOC to help strengthen his position.

49 ARA, MvK 13-10-1893-Kab.Z12, report Controleur J.H. Liefrinck 25-5-1893. The principal Klungkung negotiators were Pedanda Ketut Pidada, his son (or nephew) Ida Bagus Rai, and the Banjarese interpreter Haji Usin (who was the spokesman). It seems that during the discussions the Dewa Agung asked to 'borrow' a controleur who would explain to him how the Dutch government had managed the drastic increase in tax revenue in Buleleng. The system seemed most desirable to the Klungkung king (Hoos 1894:211). 
The southern front

It seems probable that in Klungkung two political scenarios were considered, each purposing the 'restoration' of the Dewa Agung as king over all of Bali. On the one hand Klungkung sought to reach agreement with the colonial government and to share prestige and power. On the other hand there was an attempt to achieve one united southern Balinese 'front', under the leadership of the Dewa Agung, to arm itself against the Dutch threat. As early as 1883 the Klungkung court took the initiative in this. The kings who aligned themselves with this front, however, kept a careful eye on their own interests as well. The leaders of Badung, for instance, affirmed support for Klungkung, but if armed conflict broke out they would be able to blame Klungkung and hope to negotiate a favourable arrangement with the Dutch. ${ }^{50}$ Moreover, the Klungkung initiative ran up against the countless contrasts and conflicts that marked the various negara. Tabanan, for example, was willing to collaborate with Badung, but was most reluctant to enter into a coalition with Klungkung. Mengwi, on the other hand, was bound to Klungkung, but embroiled in a lingering border war with Tabanan. This made it difficult for Badung to bring Tabanan and Klungkung together, and an alliance between Mengwi and Tabanan seemed even more far-fetched.

The Klungkung court could not possibly resolve all of these conflicts. To be sure, the other kings recognized the greater prestige of the Dewa Agung, but this did not mean in the least that they were willing to obey him. Klungkung, of course, was aware of this. It was decided to build up a southern front in phases, by first eliminating the most important internal enemies. This failed. Instead of achieving a close-knit front, a violent war ensued, which was to drag on to 1900.51

The immediate occasion of the war was the fall of negara Gianyar in $1884 .{ }^{52}$ The king of Gianyar was old and was persuaded by a young mistress to oust two of his most important advisers, the famous brothers Made and

ARA, MvK V13-4-1883-14; V24-11-1891-7, rapport J.H. Liefrinck 20-10-1890. This plan was conceived by G. Ng. Ketut Kesiman, according to Jacobs (1883:196) an adopted son of G. $\mathrm{Ng}$. Kesiman (who died in 1863), the strong man in southern Bali during the expeditions of 1846 to 1849. G. Ng. Ketut Kesiman had been present as a youngster at the peace of Kuta and was adept at simultaneously befriending the Dutch and keeping them at bay.

51 For overviews of these turbulent years see Van Eerde 1921; De Kat Angelino 1921a; Liefrinck 1921; 1927:301-304; Mahaudiana 1968; Sidemen 1980; Bhuwana Winasa; KITLV, Coll. Korn:118; ARA, MvK Mr. 1885:349, MvO. Resident Hoos 1885; V13-10-1893-Z12, report J.H. Liefrinck 25-5-1893; ANRI, Bali:3.15, 3.16, political reports 1885, 1886. Wiener (1990:chs $6,8)$ presents a different interpretation with regard to the position of Klungkung during these years. According to her, the Dewa Agung did not follow the kinds of strategies described here. She seems to deny the existence of pragmatics in Klungkung politics. I find her arguments unconvincing.

52 I am grateful to Ida A.A. Gede Agung and I Made Subaga of Gianyar for their helpful oral information. 
Ketut Pasek who, although they were mere jaba, had gained much renown as war leader and administrator, respectively. After they were removed from the king's entourage, the royal centre's power disappeared as well. Soon a number of powerful lords shook off the authority of the king and crossed over to Klungkung. At the same time Klungkung initiated an offensive. The Dewa Agung had reason to do so, since in Gianyar he had been the butt of humiliating insults on the part of the Pasek brothers. ${ }^{53}$ Furthermore, he was out to strengthen the front by incorporating the weakened negara. The Dewa Agung informed the Dutch in writing that the king of Gianyar had submitted to him. In 1885, when attacks were launched from Bangli and Mengwi, too, the despairing king of Gianyar offered his collapsing negara to the Dutch, hoping to survive under colonial protection. The Dutch reaction, however, was most formal. After all, Gianyar was already part of Klungkung. Moreover, Batavia still clung to strict noninvolvement regarding southern Bali. In fact, officials were not allowed to travel in the region except with special permission from Batavia. ${ }^{54}$ Bereft of support, the king of Gianyar surrendered to the Dewa Agung, who seemed to have come out on top.

A mere twelve months hence, however, the precariousness of Klungkung authority and, thus, the weakness of the southern front became palpable. Neither Bangli nor Mengwi were prepared to hand over the conquered areas to the Dewa Agung. Furthermore, some lords in Gianyar refused to submit to anyone, and banded together to take up the battle against Klungkung.

Once it was clear that Batavia did not intend to interfere in southern Bali, the Klungkung plan to form a single united front under the leadership of the Dewa Agung fell to pieces. Like an oil slick, the war spread over southern Bali and Lombok. Negara Mengwi would soon be swept along in the course of events.

\section{Mengwi's fall, 1883-1891}

The Mengwi dynasty had played but a minor role in the conflicts between the Dutch and Bali. It had used the years from 1836 to 1870 to strengthen control over its own negara. Elsewhere on Bali royal centres of power had to contend with military expeditions and the introduction of colonial rule, but in the lee of all this puri Mayun was able to develop into the new royal centre of Mengwi. Still, colonial penetration had not left Mengwi entirely

53 At the entrance to the market they had placed an effigy of the Dewa Agung. All those who entered the market were required to hit the doll (Liefrinck 1921:88).

54 ARA, MvK Mr. 1885:112+. The Aceh War was once again the reason not to become involved. 
untouched. The fact that the northeastern mountain area was opened up to the cultivation of coffee illustrates that the royal centre responded adequately to the new opportunities offered by the new port at Buleleng. But these economic ties did not automatically lead to intensified political relations between Mengwi and the Dutch. In the years following 1849 the Dutch stuck to their policy of non-involvement, and official documents stated that Mengwi was under the 'supreme jurisdiction' of the Dewa Agung of Klungkung. Accordingly, political relations between the colonial officials and the royal centre in Mengwi were kept to a minimum.

From 1885, however, Mengwi was drawn into the war which had just begun. The Mengwi dynasty was faced with outside enemies and internal tensions between the centre and certain powerful satellites and between rival leaders within the centre.

Shortly after 1871 Mengwi seemed a strong and solid negara. No war of succession broke out upon the death of Agung Mayun and it appeared as if his three sons had divided the power suitably among themselves. From his puri in desa Grana the youngest son controlled the northeastern part of the negara. The second son resided in puri Gede Mengwi as king. Neither, however, represented the central leadership of the dynasty: the youngest was no more than one of the more powerful regional lords while the king was a spineless figure. He was ailing and greatly addicted to opium and eventually became lame in both legs. ${ }^{55}$

Whereas this immobile king was unable to exercise authority, his older brother, Agung Made Raka, certainly could. As war leader his renown had spread and now this patih was the central figure of the negara. After his father's death it was he who personified the dynasty's power. But, however strong Agung Made Raka might be, his authority did not go unquestioned. After some years he was confronted with courtly intrigues he was unable to cope with, and gradually he became isolated. The warrior was no politician. As a result, conflicts in the royal centre escalated and in their wake the relationships between the centre and the satellites and neighbouring negara came under great pressure.

The conflicts facing Agung Made Raka were primarily within the gates of his own puri. Although he acted as the leader of puri Mayun, he in fact belonged to a lesser branch. The oldest and therefore first-ranking lineage of puri Mayun was represented by Agung Pekel. ${ }^{56}$ This Agung Pekel was bent

55 Jacobs 1883:233; information from G. Ag. Gede Rai, puri Kajanan Mengwi. The youngest son was Agung Kaler; see Figure 7 and Appendix.

56 His name was Gusti Agung Putu Mayun. The nickname 'Pekel' means 'sharp', 'avaricious', and was prompted by the incident $\mathrm{I}$ am about to describe. The information is derived from Samboengan Babad Mengwi(:8) and interviews with G. Ag. Ajeng, puri Labah, Kedampal, and G. Ag. Gede Putra, puri Lambing. 
on enhancing his own position and found it advantageous to nibble away at Agung Made Raka's authority. The struggle between these antagonists in puri Mayun became public knowledge when Agung Pekel kidnapped Agung Made Raka's daughter. Although in itself this would not have caused a violent quarrel, in this case the girl was promised to someone else. Agung Made Raka had promised his daughter to the leader of puri Kapal Kaleran, hoping in this way to bind a prominent branch of the dynasty to him. Under the circumstances this plan came to nothing. Agung Pekel carried the girl off and took refuge in the royal puri Gede, on the opposite side of the central crossroads in Mengwi. This meant that the quarrel between the two men from puri Mayun expanded into a conflict between Agung Made Raka and the royal puri. According to informants, however, the situation was not so much that Agung Made Raka and the king were embroiled in a fraternal quarrel; the in-fighting was sustained by their respective principal wives. The king's padmi looked upon herself as the sole legitimate heiress of puri Gede Mengwi and she was willing to go to great lengths to push back the influence of puri Mayun.57 Discord within puri Mayun seemed highly opportune to her. Her major antagonist was the padmi of Agung Made Raka, a woman from the Badung dynasty who sought to usurp royal power at Mengwi for her husband. 58

The conflict led to a breach in the branch of puri Mayun. Supported by puri Gede, Agung Pekel and the kidnapped woman returned to puri Mayun to live in its north quarters. Agung Made Raka, who occupied the south part, responded by having a wall built to separate the two sections. In this way the south part became a new puri, called by that name once a house temple and a separate entrance were created: puri Anyar (new). Thus situated adjacent to each other, puri Mayun under Agung Pekel and puri Anyar headed by Agung Made Raka were divided by animosity.

Shortly after this a second conflict involved the person of Agung Made Raka, this time within the new puri. His oldest son tried to take advantage of the tense relations between his father and puri Gede. This son, whose name was Agung Kerug, turned against his father and was given protection in puri Gede. ${ }^{59}$

In consequence of these quarrels, patih Agung Made Raka became increasingly isolated. Puri Gede, puri Mayun, and his oldest son all turned against him, and they successfully incited followers in desa Munggu to oppose him as well. The weakness of the king was demonstrated by the fact

57 The marriage between the king and his padmi, too, came under pressure. At one point this wife fled to Klungkung, to solicit the support of the Dewa Agung's padmi, her kinswoman from Mengwi (Samboengan Babad Mengwi:9; Babad Mengwi-Sedang:47; see Appendix).

58 Samboengan Babad Mengwi:8; Jacobs (1881:233-4) also mentions this padmi.

59 His full name was Gusti Agung Ngurah Made. The nickname 'Kerug' means 'loudmouth'. 
that he was unable to contain the escalating conflict. Greatly disappointed, Agung Made Raka moved away to the puri of his in-laws in Badung in 1883, taking two pusaka krisses with him. ${ }^{60}$ His departure meant that both battlereadiness and central authority disappeared from Mengwi.

It is probable that Agung Made Raka only meant to withdraw temporarily, hoping that the people of Mengwi would soon realize that he was indispensable. This proved a miscalculation; no messengers were sent to Badung to beg the wronged patih to return. Nor did the manca agung, the leaders of the larger satellites, seem interested in having Agung Made Raka reinstated. His departure, they felt, allowed them greater freedom to act as they saw fit. ${ }^{61}$

The one to profit most by the new situation was Agung Kerug, the oldest son. He assumed leadership in puri Anyar and succeeded his father as patih of Mengwi. Together with Agung Pekel, the leader of puri Mayun, he took over control of the negara's centre. In this joint venture it was especially Agung Kerug whose policy was tough and who made many enemies. Mekel who failed to heed his instructions were murdered; he raised sawah taxes and monopolized leases in the coffee and opium trade. But these measures were not balanced by a leadership calculated to attract and bind followers. ${ }^{62}$

The two new leaders in Mengwi were straightway confronted with the crisis that erupted in Gianyar in 1884, the beginning of the great southern Balinese war. Initially they displayed loyalty to the Klungkung court. When Klungkung launched its attack on Gianyar in 1885, a Mengwi detachment joined the fray. Agung Kerug occupied the southwest part of Gianyar and conducted the conquered king to Klungkung, where the captive would die in exile. ${ }^{63}$

But the friendship between Mengwi and Klungkung soon cooled, since Agung Kerug was loath to relinquish to Klungkung the part of Gianyar it had conquered. In 1886, when Agung Kerug also extended asylum to three

60 Samboengan Babad Mengwi:8, Bhuwana Winasa III:36; ANRI, Bali:3.13, political report 1883. This last source mentions that 'a plot against the king was discovered, whereupon the patih of Mengwi [Agung Made Raka] departed to Badung'.

61 En route to Badung, Agung Made Raka allegedly had a talk with the leaders of puri Sibang and puri Kapal Kaleran, in which it was decided that they would make an effort to have him return to Mengwi (Samboengan Babad Mengwi:8-9). They did not do so, presumably because they were still offended because of the way representatives of their branches had been side-tracked in the struggle of succession from 1855 to 1859 (see Chapter 4, section 3).

62 Samboengan Babad Mengwi:9. Informants in Mengwi largely agreed in their negative evaluation of Agung Kerug. Among written sources, Babad Mengwi-Sedang alone presents a highly positive picture of this patih, but its author was none other than Agung Kerug himself.

63 Sidemen 1980:20-1, 47-9. In 1883 an attempt was made to reconcile Klungkung and Gianyar. For this purpose most of the southern Balinese kings, with hundreds of followers, had gathered in Klungkung (Babad Mengwi-Sedang:47; Bhuwana Winasa I:14). 
lords from Gianyar who were resisting the Dewa Agung, his relations with the Klungkung court deteriorated rapidly. ${ }^{64}$ For the time being, however, the Dewa Agung could not afford open conflict with Mengwi, since he was still seeking to consolidate his southern Balinese front.

Meanwhile Agung Kerug had run afoul of two other negara, Badung and Tabanan. The tense relations with these neighbours needed but the slightest spark to flare up again. This time the occasion was the death of Agung Made Raka. When the former war leader of Mengwi died in 1885, Agung Kerug requested that the king of Badung give him his father's body. In spite of the quarrel between father and son, Agung Kerug wished to stage a great ritual to burn the remains of the famous Agung Made Raka. This would enhance his claim to succeed his father and he would regain possession of the two mightiest pusaka which his father had spirited away to Badung. But the king of Badung refused and held the cremation in Badung. ${ }^{65}$ This meant that Agung Kerug's honour was now at stake. His revenge was not long in coming. ${ }^{66} \mathrm{He}$ shut off the supply of irrigation water to Badung at the border, desa Sempidi. Intermittently water was let in, but it was contaminated with leaves that caused itch and stupor, so that the inhabitants of Badung could neither drink nor bathe.

This irrigation blockade proved an effective weapon; the following year crops failed in a large part of Badung. Alarmed by the threat of a food shortage, which might induce groups at the border to defect to Mengwi, the king of Badung appealed to the Resident in Buleleng for arbitration. But the principle of non-involvement in southern Bali stood in the way of Dutch colonial intervention.

Moreover, the Badung king could not count on help from the Dewa

64 These lords were those of Blahbatuh, Abianbase, and Sukawati. Typical of the uncertain control of Agung Kerug over his own satellites was that these Gianyar lords were first held in custody by the lords of Sibang and Kapal. Agung Kerug experienced great difficulty in having them released, after which he immediately sent them on to Karangasem, in eastern Bali. ARA, MvK Mr. 1886:59+; ANRI, Bali:3.16, political report 1886; Babad Mengwi-Sedang:47; Sidemen 1980:65-7.

65 ANRI, Bali:3.15, political report 1885. The ritual was organized by the Badung puri Dangin, where the deceased's padmi came from (information from A.A. Alit Konta, puri Dangin, Denpasar). After his death Agung Made Raka was named Batara ring Laut, the one deified at the seashore (Badung). According to Babad Mengwi-Lambing (:74), the temple priest of pura Panataran Agung, the mountain temple of negara Mengwi at Tinggan, had a vision in which he was charged to erect a shrine for the deceased. The shrine was placed in the forecourt of the temple and was called Palinggih Batara Kawitan. Kawitan refers to the ancestral powers Agung Made Raka was said to have received in this temple (information from G. Ag. Gede Putra, puri Lambing, mangku gede Tinggan).

66 The data are taken from ANRI, Bali:3.15, political report 1885; ARA, MvK Mr.1886:349, MvO Resident Hoos 1885; Mr. 1886:271+, report Resident 28-3-1886; Mr. 1887:244+, report Resident 18-4-1887; Private Archive Gianyar, report Resident 25-1-1886; information from Ida Bagus Gede, gria Gede Sempidi. 
Agung either, since Klungkung was still much preoccupied with keeping Gianyar under control. Tabanan alone came to Badung's aid by attacking from Marga a number of times and by closing the northern trade route between Mengwi and Buleleng. This blockade was especially damaging to the lords of Mengwi; now Buleleng could only be reached by a long detour by sea.

Negara Mengwi was now faced with a front which stretched all the way from the north, along the western border with Tabanan, right up to the southern border with Badung. Such conflicts were not new, but as the pressure from outside mounted, patih Agung Kerug faced the necessity to assert himself as leader of the Mengwi dynasty.

Within his own negara, however, the Mengwi patih became controversial as well. Almost simultaneously he came into serious conflict with two of the most prominent manca agung, the lords of the powerful satellites Sibang and Kaba-Kaba. The loyalty of yet a third leader, the lord of puri Kapal Kaleran, was not wholly assured either. The internal crisis now erupting would make puri Anyar and puri Mayun - as joint heirs of the former leader Agung Mayun - pay for the way the throne of Mengwi was gained in 1859 at the expense of other contenders.

Ever since the eighteenth century puri Sibang had been largely autonomous within the negara; in fact, it had attempted to secure the Mengwi throne twice, in 1739 and in 1858. Accordingly, the royal centre was careful in its dealings with this satellite so as not to upset the precarious balance. But little circumspection was in evidence during an event occurring around 1880: the lord of Sibang was accused of incest involving his daughter. ${ }^{67}$ When it became known that the royal centre at Mengwi intended to seriously investigate the allegation, the lord of Sibang fled to Klungkung. He could count on the support of the Dewa Agung's padmi, whose mother belonged to the lineage of Sibang. ${ }^{68}$ This personal relationship guaranteed that the Klungkung court, already unhappy with Mengwi policy regarding Gianyar, would back the lord of Sibang. This meant that in the event of a clash between the Mengwi centre and Sibang, hostilities would immediately escalate.

67 Information derived from ANRI, Bali:3.20, political report 1890; ARA, MvK V24-111891-7, report J.H. Liefrinck 20-10-1890; Samboengan Babad Mengwi:9; information G. Ag. Putu Gedong, puri Gedong Sibang, G. Ag. Oka Pabean, Denpasar. According to Babad MengwiSedang (:53) the accusation was made by the lord of Sibankaja, who, although he was subordinate to Sibang, was nevertheless hostile. If incest had in fact occurred, the entire domain of satellite Sibang would have become 'hot', and ritually contaminated. Such allegations were frequent preludes to war and were intended to confuse the ranks of the enemy.

68 This padmi, Ayu Istri Muter, was the daughter of a former queen of Mengwi, Biang Agung from Sibang; see Appendix. 
For the moment, however, that calamity was avoided because Klungkung managed a more advantageous solution. The Klungkung priest/ diplomat pedanda Gede Ketut Pidada was able to restore peace between Sibang and the Mengwi centre. At the same time he made certain that the alliance between Klungkung and Sibang was upheld, in witness whereof the Dewa Agung presented Sibang with a temple, the pura Dalem Dasar. The temple was visible proof that Klungkung and Sibang were firmly committed to their alliance and, furthermore, that Klungkung had obtained a sure foothold in negara Mengwi. Formally, Sibang continued to be part of negara Mengwi, but without real loyalty to the royal centre.

A similar process occurred in another strong satellite, Kaba-Kaba. Its manca agung, too, had maintained a large measure of autonomy for their domain. These lords, from the inception of negara Mengwi, were allies of the kings of Mengwi rather than subordinates. This special relationship between the royal centre and Kaba-Kaba was expressed by the fact that most Mengwi kings made sure to acquire a padmi from Kaba-Kaba. This strategy was continued by the current king of Mengwi. However, unlike some of her predecessors, Ayu Oka for example, this particular padmi was unable to exert any influence in the centre of the dynasty. Puri Kaba-Kaba was about to suffer because of this.

The conflict between Kaba-Kaba and the leaders at Mengwi originated in what seemed to be a trivial local quarrel. ${ }^{69}$ In 1889, some men from neighbouring Munggu had cut alang-alang (tall grass) on Kaba-Kaba land, whereupon part of the water supply from Kaba-Kaba to Munggu was cut off. Munggu complained to the king of Mengwi, who tried to negotiate a settlement. He sentenced Munggu to payment of two hundred pikol (1 pikol = $62.5 \mathrm{~kg}$ ) of alang-alang to Kaba-Kaba; Kaba-Kaba was to repair the damaged conduits. Remarkably, the people of Munggu, the obvious offenders, refused to agree. The most likely reason soon became clear, when the conflict suddenly intensified. A small band of warriors led by Agung Kerug and Agung Pekel, the two leaders of Mengwi no less, attacked desa Kaba-Kaba and captured the lord of its puri. Evidently, then, it was not a patch of alangalang that was at issue, but the power at the centre of the dynasty. Rumour had it that the lord of Kaba-Kaba would soon replace Agung Kerug as patih of Mengwi. This change would have enhanced puri Gede Mengwi greatly, and it is probable that the plan was hatched by the king's padmi from KabaKaba. It was thwarted in time by Agung Kerug because he and his followers in Munggu (the traditional domain of the patih of Mengwi) provoked the

69 Information from ARA, MvK Mr.1889:547+, report Resident 16-8-1889; Mr.1889:612+, report Resident 23-8-1889; Babad Kaba-Kaba; G. Ng. Gede, puri Kaba-Kaba, I Dewa Putu Resik, Munggu. 
incident with Kaba-Kaba and used it as a pretext. The captured lord of KabaKaba was murdered and the inhabitants of the area were forced to swear a new oath of allegiance to the Mengwi centre. Many members of the branch of puri Kaba-Kaba had fled to Tabanan, biding their time, in the hopes of regaining their domain.

In the span of one decade the position of negara Mengwi had deteriorated from a relatively solid hierarchy into a precarious collection of localities under eroding control. In the centre it was dog-eat-dog; the negara was practically at war with Badung and Tabanan; and on top of all this, serious conflicts had erupted between the royal centre and its two most powerful satellites. Although Agung Kerug was at the core of each of these conflicts, he, too, was but a prisoner of the restrictive Balinese political system. In a way his problems were similar to those confronting the Dewa Agung of Klungkung in the broader arena of southern Bali. Both were hampered by having insufficient authority to claim their subordinates' loyalty at critical moments. And, pressed by dangers from without, both resorted to violence to force the issue. The upshot was that conflicts continued to intensify.

This interaction of conflicts at the local level within the Mengwi region and, on a larger scale, in all of southern Bali, eventually accelerated into a full-blown crisis with disastrous results for the Mengwi hierarchy. In 1889 Agung Kerug once again came into conflict with Gianyar and gained an additional enemy. This time the Klungkung court turned against him in open hostility. The Mengwi centre had manoeuvred itself into fatal isolation.

For the southern Balinese leaders the role played in this by the colonial government - or rather, the role it avoided playing - was a problem in its own right, alongside all the intrigues and shifting alliances. Since 1883 Dutch officials had not put in an appearance on Bali; they were under strict orders not to interfere. It was not until 1890, when the convergence of conflicts had become hopelessly complex, that a notable exception was made for Controleur J.H. Liefrinck to travel through southern Bali on a reconnaissance mission. ${ }^{70}$ One place he visited was Mengwi, where Agung Kerug entertained him with dancing and horse racing and filled him in on recent political developments. 'I Twan Liefring', however, was expected to offer explanations as well. ${ }^{71}$ The behaviour of the white Tuan in Buleleng was an enigma to the leaders in Mengwi. At a time when virtually every Balinese faction had become involved in the greatest conflict of the century, one of the strongest parties kept itself far removed from things. Yet, in former days the Dutch government had intervened on some occasions, even to the

70 ARA, MvK V24-11-1891-7, report J.H. Liefrinck 20-10-1890.

71 The Balinese used the word 'Twan', tuan, lord, to address foreigners; Babad MengwiSedang:54, 58 . 
point of using violence. Where were they now? Surely, by adroitly capitalizing on current conflicts, the Dutch would be in a position to advance their own interests considerably. The primary reason this did not happen was that the Aceh War had to be finished first. As long as that struggle continued, colonial officials in Buleleng had to tread water. Southern Balinese leaders found this behaviour inexplicable. As they saw it, the colonial government in Buleleng was a strange power behaving most strangely indeed.

Meanwhile, in Gianyar political power relations shifted significantly in 1889 and 1890. The Dewa Agung lost much terrain. The new strongman in the region was Cokorda Sukawati of Ubud. In his father's time Ubud had grown from a fairly insignificant desa into a place to be reckoned with. This was largely due to the successes gained in battle by the lords of puri Ubud. The Cokorda followed in his father's footsteps and, together with kinsmen from neighbouring places, he managed to gain control of almost the entire northwestern part of Gianyar. This confronted Mengwi with a new power bloc on the eastern border which they would rather not tangle with. In view of deteriorating relations with Klungkung - which was hostile to Ubud as well - Agung Kerug had a change of heart. He allied himself with Cokorda Sukawati of Ubud and openly turned against the Dewa Agung. ${ }^{72}$

The new coalition decided to launch a joint attack on the Dewa Agung's henchmen who still controlled southern Gianyar. In July 1890 and January 1891 the enemy was engaged near the Gianyar desa of Negara. But the Klungkung alliance stood firm. In May 1891 a new attack on Negara was carried out, and this time the Ubud and Mengwi troops won. The puri of Negara was burned down and Klungkung resistance seemed broken. A sudden counterattack was mounted, however, and in the ensuing chaos and panic many Mengwi warriors took to their heels, while a large number of others were killed.

In the end, Mengwi intervention in Gianyar had not brought much gain. Mengwi troops had suffered a severe setback through the unexpected outcome of the capture of Negara. The Cokorda of Ubud had little to offer, since he himself needed all his energy to keep his domain secure. This was the moment for Klungkung to embark upon a frontal assault on the Mengwi centre.

72 The events of 1889-1891 were very complex. I restrict myself to some major points, taken from a variety of sources. Sidemen 1980:52-3, 74-96; Mahaudiana 1968; chapter 9; Babad Sukawati A:52-62; Babad Mengwi-Sedang:54; Bhuwana Winasa IV:14-6; ARA, MvK V4-41892-W4, report Resident 23-1-1891; Mr.1891:458+, report Resident 25-5-1891. The most important kinsmen of the Cokorda of Ubud were the leaders of puri Tegallalang and puri Pliatan. The fact that the Mengwi puri Mayun and the puri of Ubud were remote kin may have played a role in the alliance (puri Ubud was established by the brother of Cokorda Kandel, alias Ag. Putu Mayun, adopted from Gianyar, see Appendix). 


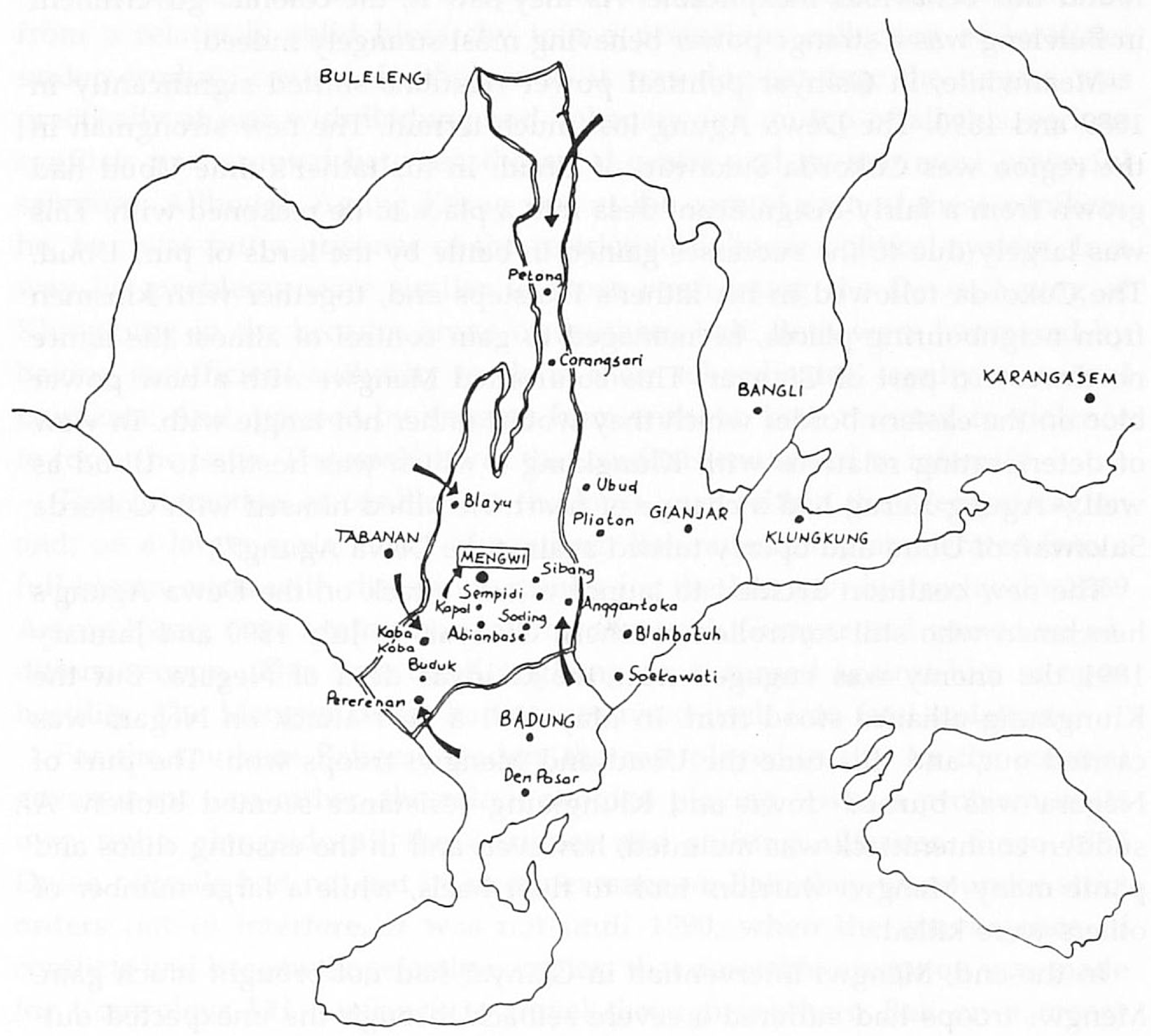

Map 9. The fall of Mengwi in June 1891 
This offensive took shape in the first months of 1891 . The lord of puri Sibang cut his ties with Mengwi and placed himself under the authority of the Dewa Agung. This moved the focus of the southern Bali war from Gianyar to negara Mengwi, and the wave of conflicts came still nearer the centre of the Mengwi dynasty. In and around Sibang the conflicts on various levels converged and then erupted all at once: the royal centres of Mengwi and Klungkung, the centre of Mengwi and satellite Sibang, puri Sibang and the subordinate lord of Sibangkaja, supported by Agung Kerug, all of these fell upon each other. Local friction was fruitful soil for regional quarrels, and these in turn intensified the local conflicts. In other words, a process was set in motion that no one could control and no one could keep out of. ${ }^{73}$

The Dewa Agung sent an important emissary, his brother Dewa Agung Rai, to Sibang to underscore that he had accepted control over this satellite. In fact, this Dewa Agung Rai himself had a bone to pick with puri Mayun: he had been one of those who was passed over in 1859 on the occasion of the succession to Mengwi's throne. Ostensibly he mediated between Sibang and the centre at Mengwi, but his first concern was to make sure of Sibang's loyalty to Klungkung.

\section{The ending}

The peace arranged by Dewa Agung Rai between Sibang and Mengwi was merely a fleeting calm before the onset of the last attack on Mengwi. The call was sounded by the Klungkung court. The king of Mengwi was ordered in writing to deliver up his controversial patih to Klungkung. Agung Kerug was certainly not about to obey the summons. The mildest punishment he could expect was exile to the island of Nusa Penida, but cold-blooded murder seemed more likely. ${ }^{74}$

During his visit to Mengwi, Controleur Liefrinck had spoken with Agung Kerug and Agung Pekel, not with the king. Weak and ill, the king played no significant political role. The other two, from puri Mayun and puri Anyar respectively, were the ones who held on to the eroding power of the damaged hierarchy. They too, however, were unable to stave off catastrophe; the problems were too many and too great. There was the conflict with Sibang and Klungkung, and the threat of war on the borders with Badung and Tabanan; Bangli was lying in wait to take possession of the northeastern coffee region. Sibang and Kaba-Kaba had turned their back on the royal centre. The loyalty of other satellites was doubtful. Theirs was a wait-and-see attitude, each of them hoping for the best. And as the various conflicts

73 Sidemen 1980:71-2, 91-100; ARA, MvK V4-4-1982-W4, report Resident 24-4-1891, reports J.H. Liefrinck 29-6 and 16-7-1891; V24-11-1891-7, report J.H. Liefrinck 20-10-1891; informants in Sibang and Mengwi.

74 Babad Mengwi-Lambing:75; information G. Ag. Gede Putra, puri Lambing. 
approached a climax, the central authority of the Mengwi dynasty shrivelled and shrank. Even before the fall of the royal centre was a fact, the royal hierarchy of Mengwi had collapsed.

Succour could only come from the outside. Mengwi's last remaining strong ally was the Cokorda of Ubud, but this man of prowess was too busy with the repeated flare-ups of war in Gianyar to become involved with a hornet's nest like Mengwi. Since it was quite clear that the Dutch could be counted on to do nothing, the Mengwi centre, in a desperate last attempt to find help, appealed to the lord of Karangasem. There was a slight bond of kinship between the dynasties of Mengwi and of Karangasem and they shared a dislike for Klungkung. The lord of Karangasem, Gusti Gede Jelantik, made a hazardous journey to Mengwi and tried to mediate between Klungkung and Mengwi. He failed. The conflicts had risen too high, and he was in no position to force the issue by the threat of violence. ${ }^{75}$ Moreover, Klungkung was not interested in peace. The Dewa Agung was clearly losing terrain in Gianyar and, if he was to achieve his ideal of bringing at least part of southern Bali under his control, he had no choice but to carry out his attack on Mengwi. Capture of Mengwi would compensate for his losses in Gianyar and would weaken the bond between Mengwi and Ubud, which in turn would strengthen his hold on Gianyar. ${ }^{76}$

Early in June 1891 the Klungkung court initiated the final assault on Mengwi. Throughout the negara, lontar letters were distributed among the manca and mekel, in which they were told that the Dewa Agung had deposed the king of Mengwi and that his negara was temporarily under Badung and Tabanan control. ${ }^{77}$ Undoubtedly, this sample of psychological warfare accelerated the disintegration of the Mengwi ranks.

Badung and Tabanan heeded the words of the Dewa Agung. In quick succession they marched on Mengwi. Badung had sufficient reason to want to square accounts with Mengwi, because ever since 1885 a large part of the irrigation system was blocked so that during six long years the sawah of Badung's west had produced little or no harvest. The consequent food shortages had caused unrest among the people. In addition, the inhabitants

75 ARA, MvK V4-4-1892-W4, report J.H. Liefrinck 16-7-1891, report Resident 20-7-1891; Sidemen 1980:108-11. Gusti Gede Jelantik was lord of Karangasem, which since the colonial expedition of 1849 had come under the authority of the Balinese king of Lombok. The remote kinship was through Agung Nengah Karangasem, supposedly adopted by the first king of Mengwi, but who later returned to Karangasem (see Appendix).

76 The logic of this argument would prove fallacious, since the fall of Mengwi presented Klungkung with nothing but new problems, such as war with Karangasem in 1892; see Chapter 7, section 1).

77 Samboengan Babad Mengwi:10; ARA, MvK V4-4-1892-W4, report Resident 20-7-1891. These letters were the more authoritative because the padmi of the Dewa Agung hailed from the Mengwi dynasty. 
of the border desa had expended much effort over the past years. They had erected fortifications all along the border with Mengwi and manned them continuously with shifts of watchers. The Badung leadership was not entirely certain they could mobilize sufficient troops for a large-scale attack on Mengwi. According to tradition, the patih of Badung hit on a simple but effective plan, which was as follows: Have all the warriors converge on one point, opposite the Mengwi desa Anggantaka, where the rice is ripe in the fields. If we say 'There is your food, go get it', our people will forget their hunger and they will fight. ${ }^{78}$

Thus it was that Badung began the attack, while at the same moment the men of Sibang hit the Mengwi defences from the rear. The Mengwi line crumbled and the Badung force continued to the point where the irrigation system had been blocked. For a moment it seemed as if Agung Kerug and Agung Pekel might halt the Badung advance, but they were given no support by the other lords of Mengwi. In addition, there was a sudden alarm: Tabanan was attacking at a point dangerously close to desa Mengwi. This danger, too, was fended off, but Mengwi was faced with vastly superior numbers. ${ }^{79}$

Badung now attacked on a second front and penetrated deeply into the southern part of negara Mengwi. Without encountering much opposition, a whole string of desa were taken: Sempidi, Sading, Buduk, Pererenan, Abianbase, and Kapal. Almost the entire rice plain south of Mengwi fell to the enemy, including the valuable dam at Mambal. After a hundred years of warfare, Badung at last controlled the inlets of its own irrigation system.

Mengwi's ability to resist was almost wiped out. Most of the manca and mekel realized that it was useless to continue the fight, and they turned in great numbers to the conquerors to swear allegiance to their new masters.

When the leaders in Tabanan and Bangli heard that Mengwi was beaten, they swarmed to the kill. Tabanan marched to Blayu, where the lord of puri Blayu took his own life. His domain was immediately incorporated in Tabanan. In Kaba-Kaba the members of puri Kaba-Kaba who had fled to Tabanan some years before returned and their domains, too, henceforth

78 Information Bapak Widyakusuma, Denpasar, and Cokorda Gede Ngurah, puri Satria, Denpasar. The patih was Ketut Saunggaling Gogotan, brother and successor of Gede Saunggaling Sebeng. Both were jaba who, as royal ministeriales in Badung, had gained much prestige.

report events of June 1891 as sketched here are derived from ARA, MvK V4-4-1892-W4, report J.H. Liefrinck 16-7-1891, report Resident 4-8-1891, letter from king of Badung to Resident 21-12-1891; Mr. 1892:872, report Resident 8-9-1892; Mr.1892:990, letter from king of Bangli to Resident; V7-7-1892-A10, report J.H. Liefrinck 25-5-1893; KITLV, Coll. Korn:110, request G. Gede Raka 6-8-1938; Sidemen 1980:101-6; Samboengan Babad Mengwi:10; Babad Mengwi-Sedang:58-60; Bhuwana Winasa IV:18-33; information of (among others) Anak Agung puri Gaji, Badung, Cokorda Gede Ngurah, puri Satria, Denpasar, G. Ng. Putu, puri Pererenan, G. Ng. Gede, puri Kaba-Kaba, G. Gede Catra, puri Marga, G. Sutarja, Blayu. 
belonged to negara Tabanan. Bangli fell upon the domains of the puri of Carangsari and Petang. No fighting was necessary. The lords of both puri recognized the king of Bangli as their new superior and began to pay him tribute in the form of part of their trade profits from coffee and opium.

By 20 June 1890 negara Mengwi was reduced to a small area around desa Mengwi. ${ }^{80}$ Badung did not really want to carry on the fighting; all objectives had been attained. Irrigation was taken over, as was the southern sawah region, and the Mengwi dynasty was in severe disarray. The intention was not to destroy the Mengwi dynasty altogether. Accordingly, the king of Badung sent an emissary to Mengwi to ask the king to surrender, as had happened in 1823.

The king of Mengwi did not surrender. He did nothing. While the army of Badung kept closing in on Mengwi, the remaining leaders there called a hasty meeting in puri Gede. The king hesitated, not knowing what to do. Agung Kerug and Agung Pekel let it be known that they intended to fight to the end. Meanwhile Badung troops, Buginese snipers among them, were reported to have reached a desa just south of Mengwi. In great haste the wooden slit gongs of puri Gede were sounded and the remaining warriors gathered in the forecourt of the royal puri for one last desperate attempt to force the enemy back.

Ida Pedanda Made Bang, the king's friend and counsellor, personally led part of the decimated Mengwi army. It even looked as if he might turn the tide, but a bullet shattered his head and the enemy advanced. Other leaders, Agung Kerug and his younger brother Gusti Munggu among them, were wounded and could fight no longer. Both, however, managed their escape, as did Agung Pekel. Once the leaders were either dead, wounded, or had taken flight, the fighting stopped and their followers tried to make a getaway.

The king was now alone. When he heard that the battle was over he had himself placed on his sedan chair to meet the enemy. He had made up his mind at last, preferring an honourable death above a humiliating surrender of a negara of which nothing was left. It was a way of demonstrating his loyalty to the Dewa Agung as well. After all, he had never wronged the king of Klungkung. The lame king ordered his carriers to set out from the puri forthwith, for it was a disgrace for a Satria to have to die within the walls of his puri. And so the king was carried to his death by a small band of faithful

80 Information on the final stage of the war is derived from ARA, MvK V4-4-1892-W4, report J.H. Liefrinck 29-6-1891, letter king of Badung 23-6-1891; Sidemen 1980:101-6; Samboengan Babad Mengwi:10; Babad Mengwi-Lambing:75; Babad Mengwi-Sedang:60-3; Bhuwana Winasa IV:27-33; interviews with Cokorda Gede Oka, puri Gede Mengwi, G. Ag. Gede Rai, puri Kajanan Mengwi, Ida Bagus Suela, gria Tohpati Sukasada, Buleleng, I Putu Sedana, Munggu, and I Putu Jawa, Abiansemal. 
followers. Just south of Mengwi the men of Badung were met. The carriers were shot, whereupon a jaba from Badung struck down the last king of Mengwi with a fatal thrust of his lance. Negara Mengwi was no more. 



\section{CHAPTER VII \\ Colonial penetration, 1892-1908}

In 1891 the end of the southern Bali war was nowhere in sight; in fact, the fall of Mengwi marked the beginning of renewed fighting on new fronts. The violence of war spread to eastern Bali and to Lombok, and the Netherlands Indies government was about to exchange its 'hands-off' policy for systematic annexation of the 'Outer Islands'. It is in this context that the final conquest of southern Bali took place between 1906 and 1908 under Governor General J.B. van Heutsz. Thereafter, Dutch colonial rule changed southern Balinese society drastically.

The colonial period (1906-1942) will be viewed mainly from the perspective of Mengwi. But I do place this regional history in a broader context, entailing four important aspects. The first concerns colonial policy towards the southern Balinese dynasties. In the course of time this policy underwent remarkable changes which greatly influenced the regional power relationships. The attitude of the Dutch held a certain ambivalence towards the Balinese dynasties, originating in contradictions within the colonial administration itself. Colonial policy regarding the Balinese dynasties was neither constant nor entirely coherent. Moreover, it would be a misunderstanding to think that official colonial policy and administrative practice were completely congruent. There were significant discrepancies. For the most part, I ran into this during fieldwork. Data from colonial sources often proved highly unreliable, while fieldwork provided me with information on matters passed by in silence in colonial documents.

The combination of colonial sources and fieldwork is even more crucial in relation to a second point. Government presence touched more than only the southern Balinese nobility. The impression that the colonial regime left the rest of the people to their own traditions and in the familiar context of their own villages is a myth. To be sure, colonial ideology claimed that Western rule watched over native cultures and even 'restored' them if necessary; but from the viewpoint of the region, fundamental change was at work. The colonial period left a great deal more than mere 'scratches in the rocks', since the entire complex of power relations in the Mengwi region was changed in essential ways. In the process, those involved assumed or were forced into new positions. In southern Bali a new hierarchical order was emerging, intimately intertwined with the colonial regime. 
Third, the changes occurring in southern Bali cannot be reduced to a 'one-way' traffic in which the colonial administration consciously guided a passive native society. Rather, there was interaction, such that the Balinese did not just react to, but sometimes successfully anticipated, colonial measures. Noble families in particular were able to profit from the manoeuvring room left for them under colonial rule and the position they were able to create for themselves. As I shall show, some even built a stronger position of power than would have been conceivable under the old royal system.

Finally, I will devote attention to conflicts. Much of the change in the power relations on the regional and local levels escaped the eye of outsiders. Official documents seldom mention them. Instead, the mushrooming popular descriptions of Bali underscored the harmonious and peaceful character of its society. 'Happy and peaceful Bali' was proclaimed as the 'last paradise on earth'. ${ }^{1}$ This 'dream of a long summer afternoon', as Kraemer (1933:39) expressed it, masked a great misunderstanding. It was the Pax Neerlandica rather than the Balinese character which made it appear as if conflict no longer existed. Overt eruptions of violent conflicts, quite normal in the days of the kings, now suddenly belonged to a remote past. But this in no way meant that conflicts had disappeared from the Balinese political system. They were less obvious and were fought out in other ways.

Chapters 8 and 9 will deal with the colonial period and its 'unnatural' peace. Below I recount how southern Bali crossed the threshold to the twentieth century and left the old order behind forever. It is the story of a chain of events unforeseen, with an involuted outcome.

\section{Regrouping, 1891-1900}

After the king of Mengwi fell in battle in June of 1891, fighting ceased and Badung troops began to dismantle the vanquished royal centre. Puri Gede, the massive manifestation of the Mengwi dynasty, was ransacked and gutted by fire. Eleven years later, when Henri van Kol travelled through desa Mengwi, he found nothing but mounds of debris at the spot where the puri had stood, and between the rubble banana trees were already growing. ${ }^{2}$ Along with valuable artefacts, the royal regalia, too, were taken from puri Gede Mengwi and moved to Badung to be added to those of the conqueror. In addition, the king of Badung gathered about him some survivors from the former Mengwi centre, among others the purohita and some close kin of the late king, including his two sons and successors to the throne. The

1 Covarrubias 1973:405; Powell 1930. On colonial imaging of Bali, see Schulte Nordholt 1986b.

2 Van Kol 1903:486. The temple Taman Ayun was not destroyed, for fear of awakening the anger of the gods. 
king's corpse was cremated during an impressive ritual in Badung. This served to express the notion that legitimate authority over Mengwi henceforth rested with the Badung court. ${ }^{3}$

But not every member of the Mengwi dynasty was now under Badung control. The two foremost Mengwi leaders, Agung Kerug and Agung Pekel, had narrowly escaped in 1891. 'Much the worse for wear, with the white band of battle still around their heads', they arrived in Karangasem a few days after the fall of Mengwi. Bitterly they accused the lord of Karangasem of having abandoned them, whereupon he felt ashamed. ${ }^{4}$ To avenge the fall of Mengwi, the lord of Karangasem took up battle with Klungkung and the war spread to eastern Bali.

The Klungkung court was forced to take the defensive because in Gianyar the lord of Ubud kept gaining territory. The fame of Cokorda Gede Sukawati, lord of Ubud, had spread far and wide. From colonial sources he emerges as a typical 'man of prowess':

'All praise him greatly because when a battle is anticipated he invariably accompanies his subordinates [...]. He spoke in terse sentences and a deep voice, and wore a golden "helmet" set with precious stones [...]. Robust, faithful to his duties towards the gods, often remaining in the temple through the night, he soon gained a reputation for holiness and invincibility. It was believed that the gods had given him his krisses. ${ }^{5}$

Ubud became the refuge for the vanquished Mengwi leaders and the place from which they would launch various attempts to regain the negara. The first to arrive in Ubud were Agung Kerug and Agung Pekel. In 1892 they were joined by other important members of the Mengwi dynasty who had managed to escape from Badung. One of them was the crown prince of Mengwi, Agung Gede Agung. ${ }^{6}$ At the same time a new alliance was formed in southern Bali among the lords of Karangasem and Ubud and the fugitives from Mengwi. Together they turned against Klungkung. They

3 ARA, MvK Mr.1892:872; Sidemen 1980:134-6; Samboengan Babad Mengwi:10. The purohita was Ida Pedanda Gede Putu Kekeran from Den Kayu. Among the detainees were the king's padmi from puri Gede, all his children, and his brother Agung Kaler of puri Grana; see Appendix. According to the Bhuwana Winasa (V:15-16) a daughter of the king married a member of the Badung dynasty. Usurping the Mengwi regalia, the king of Badung also made clear that he, rather than the Dewa Agung of Klungkung, had taken over control of Mengwi.

4 ARA, MvK V4-4-1892-W2, report J.H. Liefrinck 29-6-1891. Liefrinck was present at this meeting.

5 In succession: ARA, MvK V13-10-1893-Z12, report J.H. Liefrinck 25-5-1893; Private archive Gianyar, report Resident December 1896; report Controleur J.C. van Eerde 1-6-1897.

$6 \quad$ ARA, MvK Mr. 1982:872; Sidemen 1980:137; Samboengan Babad Mengwi:10; Babad Mengwi-Lambing:75-6. The detainees had been housed in various Badung puri and probably had sufficient freedom of movement. Among the escapees were the two sons of the late king, his brother Agung Kaler, and the purohita of Mengwi. A notorious bandit, I Ngandeng, is said to have helped them leave Badung without attracting notice. 


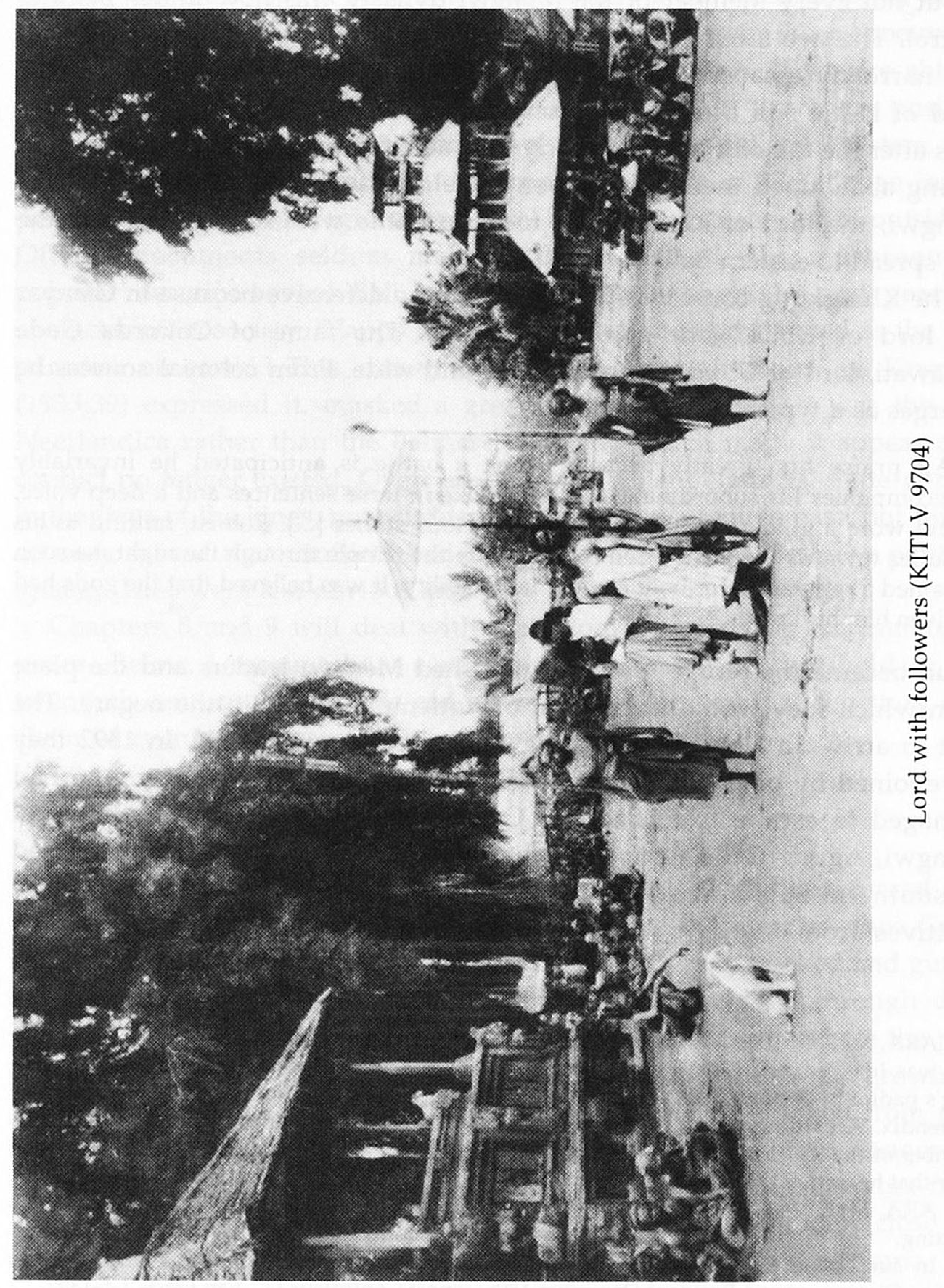


fought on three fronts. In the east the lord of Karangasem became involved in a border war with Klungkung; the lord of Ubud gradually ousted the Klungkung adherents from Gianyar. A third front was opened up in August of 1892 from Ubud by the Mengwi exiles. Aided by followers of the lord of Ubud, they tried to recapture Mengwi. With surprising speed they penetrated all the way into desa Mengwi and within a few days were in control of much of the area around it. Although the Mengwi manca and mekel reportedly received them enthusiastically, the conquerors were unable to maintain their position. This became clear when troops from Badung and Tabanan arrived to straighten things out.

In 1891 Badung and Tabanan had been satisfied with an oath of allegiance sworn by the local leaders in Mengwi. This time a crushing campaign was launched, calculated to break resistance once and for all. Hardest hit were desa Sempidi and desa Kapal. Badung troops plundered these places and burnt down countless houses. Desa Munggu, traditionally loyal to the Mengwi dynasty, was dealt with harshly. Desa Mengwi was to suffer as well. Troops from Badung and Tabanan left a wide track of destruction there. Finally, Den Kayu, the residence of the royal purohita, was burnt down. ${ }^{7}$ If necessary, extreme violence was not shunned.

The longer-term consequences of Badung and Tabanan retaliation were, if possible, even more disastrous. In 1893 a cholera epidemic began near Kapal, taking the lives of an estimated two-thirds of the population. In the ensuing panic, fugitives from the smitten area spread the disease far into Gianyar, where it claimed many additional victims. Shortly afterwards, when J.H. Liefrinck journeyed through southern Mengwi, he reported:

'If these desa formerly could be counted among the most prosperous of the landscape, with much bustle in the pasar [market], now they are as if abandoned [...]. In Sempidi all the houses of the well-to-do natives are destroyed and I estimate that no more than a third of the population remains [...]. In Kapal, with its c. 3,000 inhabitants, once one of the most populous desa, not a soul is to be found.' 8

The core area of the Mengwi dynasty looked desolate. Badung refused to take further risks. The punishing campaign and the epidemic were followed up with occupation by members of the Badung dynasty. They and their followers took over areas around desa Kapal, desa Munggu, desa Mengwi, and the small locality of Gerih, near Mambal dam.

In Kapal the Mengwi puri Kaleran and Muncan were razed to the

7 ARA, MvK Mr.1892:872, report Resident 8-9-1892; Schwartz 1901a:125; information from I Putu Sedana and Dewa Putu Resik, Munggu, I Ketut Misma and G. Ng. Ngwi, Mengwi. On the attack by the Mengwi exiles in 1892, see ARA, MvK Mr. 1892:791, report Resident 8-8-1892; Sidemen 1980:138; Bhuwana Winasa V:5-7.

8 ARA, MvK V13-10-1893-Z12, report J.H. Liefrinck 25-5-1893. 
ground. The new lord of Kapal, the Badung war leader Gusti Alit Raka Debot, established himself in banjar Muncan, and a relative of his took up residence in Abianbase, south of Kapal. Another Badung jero, Titih, was erected in the centre of Kapal, and relatives of the Badung jero Kuta moved into Panglan, north of desa Kapal. Badung control over Kapal was complete, as is indicated by the fact that the new rulers annexed virtually all the sawah around Kapal and had their own followers cultivate them. The few previous occupants still remaining were rendered landless in $1893 .{ }^{9}$

Many fled Kapal and Mengwi because of all this violence and looked for refuge in Ubud, eventually forming a large Mengwi colony of some thousands of people. ${ }^{10}$ This colony not only added to the manpower of the lord of Ubud, but also increased his prestige, because he incorporated the remnants of the Mengwi dynasty in his own entourage. ${ }^{11}$ For their part, the Mengwi exiles now had a following of their own, so that they could make another attempt to recapture their negara. The domain of puri Sayan in Bongkasa, just west of Ubud and left unmolested in 1891, could be used as launching point. Before this was about to transpire, the lords of Carangsari and Petang suddenly sought to join Ubud in 1893. Their reason for doing so was not difficult to discern. Ubud was closer than Bangli, to which they had been subjected since 1891, and Ubud strength was growing rapidly. It seemed the better part of wisdom to live in peace with Ubud rather than under its threat. After the fall of Mengwi, the lord of Carangsari had expanded his

Up to the land reforms of 1963-1964 most of the sawah around Kapal remained in the possession of Badung immigrants. In Munggu much the same thing happened. There, too, at least half of the sawah came into Badung hands and the people were forced to serve the Badung lords. Desa Mengwi and vicinity met the same fate. Its people and its sawah were divided among various Badung puri. West of Mengwi, in desa Gerih, Badung immigrants were stationed to guard Mambal dam. Just north of desa Mengwi, a line of defence was created by means of a number of new Badung settlements. In a small place called Ulunuma, for instance, Badung people from desa Dalung and desa Gaji came to live, and a group of Buginese, armed with modern rifles, was stationed there as well. Only those Mengwi manca who had remained completely uninvolved in the recapture campaign of 1892, such as the lords of Pererenan and Sembung, were left alone and retained their possessions. KITLV, Coll. Korn:147, 159, 163, respectively: memorandum punggawa Mengwi 1920, paswara and pangeling-eling King of Badung concerning Mengwi; information from Ida Bagus Ketut Sindu, G. Ag. Gede Rai, puri Kajanan, I Ketut Misma, G. Ng. Ngwi, Mengwi, I Putu Cetog, Gulingan, G. Ag. Gede Rai, Abianbasé, G. Ag. Ng. Rai, Kapal, A.A. Medan Angkasa, puri Jerokuta, Bapak Widyakusmuma, Denpasar.

10 Private archive Gianyar, report Controleur J.C. van Eerde 13-12-1896, which mentions a figure of 6,000 refugees.

11 Moreover, two marriages confirmed the bond between puri Ubud and the Mengwi exiles. Unlike the previous time, these women from the Mengwi dynasty were in a lesser position (see Appendix). According to Babad Mengwi-Lambing(:76) Cokorda Gede Sukawati had a new puri (Kelodan) built in Ubud for the exiled Mengwi dynasty members, who gathered a Mengwi entourage about them, one of whom was the priest of the Mengwi gria Alangkajeng, once a source of power in the royal centre. This priest established a new gria (Pemaron) in Ubud. 
own domain farther south; hence, the entire northeastern part of negara Mengwi came under control of Ubud all at once. ${ }^{12}$

The Lombok expedition and annexation through diplomacy, 1891-1900

The war in southern Bali consisted of a chain of surprising events. As mentioned, after Mengwi's fall in 1891, war broke out between Karangasem and Klungkung. At that moment the king of Lombok (to whom the lord of Karangasem was subordinate) became involved in the fighting as well, and various conflicts escalated very quickly. What happened was that Sasak troops were sent from Lombok to Karangasem. This forced participation in the war occasioned a Sasak revolt against the king of Lombok, who was now unexpectedly faced with enemies on two fronts. ${ }^{13}$ The shipments of troops from Lombok to Bali were terminated immediately, and troops were now suddenly sent from Karangasem to Lombok to squash the Sasak revolt. ${ }^{14}$

Apart from the hostilities in Karangasem and on Lombok, the king of Lombok had also become formally involved in the conflicts involving Gianyar. To oppose the Dewa Agung of Klungkung, a number of Gianyar lords and the Mengwi exiles had placed themselves under the authority of the king of Lombok. Since royal centres at Mengwi and Gianyar had been done away with, the exiles made this temporary and tactical move to make clear that they did not intend to accept the authority of the Dewa Agung. ${ }^{15}$ The declaration did not at all mean that the king of Lombok had any voice in Gianyar. This would soon lead to a critical misunderstanding, as became

12 After the fall of Mengwi the lord of Carangsari had annexed the domain of puri Grana and the possessions of puri Mayun in Sangeh and Blahkiuh. This meant a sizeable expansion of the area under his control. But the addition to his domain of the northeastern part of negara Mengwi also meant extra material support for the lord of Ubud. Carangsari and Petang were centres of coffee and opium trade, and part of the profits now went to Cokorda Gede Sukawati by way of tribute. ARA, MvK V13-10-1893-Z12, report J.H. Liefrinck 25-5-1893; Sidemen 1980:170-1; Babad Mengwi-Sedang:64.

13 The Sasak made up the Islam majority in Lombok. They had been ruled by the dynasty of Karangasem ever since the eighteenth century. After internal dynastic quarrels in 1838-1839 and the colonial expedition of 1849 , one (Lombok) branch of the Karangasem dynasty dominated both Lombok and Karangasem. See De Graaf 1941; Lekkerkerker 1923b. On the Sasak revolt of 1891 see Cool 1896; Van der Kraan 1980:16-29; Van Goor 1982; ARA MvK V4-4-1892W4, V13-10-1893-Z12.

14 ARA, MvK V4-4-1892-W4, report J.H. Liefrinck 24-6 and 16-7-1891. Pressure on the Karangasem inhabitants increased greatly, because the regular rice imports from Lombok ceased as well. This led to food shortages in Karangasem. 'It often happens that those who march in battle must pawn the little they own, to provide themselves with sustenance', wrote J.H. Liefrinck. Even so, G. Gede Jelantik, Lord of Karangasem, managed to meet his obligations to his followers at least to some degree. If one of them fell in battle he gave the next of kin 5,000 kèpèng and a white cotton cloth to take care of the cremation.

15 ARA, MvK V13-10-1893-Z12, report J.H. Liefrinck 7-6-1893. On a comparable situation in the Netherlands during the Eighty Years' War (1568-1648), see Locher 1985:98. 
apparent when Batavia took a new look at the complex developments on Bali and Lombok.

Once war and violence had spread to Lombok, the colonial government felt compelled to take action. Controleur J.H. Liefrinck was sent to investigate. In two ways his reports contributed to a change in the Dutch attitude. First, he showed that the power of the Dewa Agung of Klungkung was in fact rather slight. Although the king of Klungkung counted all of Gianyar and Mengwi as part of his domain, a chronic lack of manpower prevented him from exercising much influence there. ${ }^{16}$ This led the Dutch to no longer take seriously his claim to be recognized as 'High King' of Bali and Lombok. The Klungkung court lost its last chance of colonial cooperation.

Second, Liefrinck's reports caused a change of opinion about the conflict that was being played out on Lombok. At first Batavia wanted to have nothing to do with the Sasak revolt. The rebels were Islam adherents and hence no favourites of colonials. But Liefrinck was able to convince Batavia that the Sasak population on Lombok was subjected to royal arbitrariness and unbearable exploitation: the colonial government ought to intervene. ${ }^{17}$ In 1893, when Governor General C.H.A. van der Wijck took office, the advocates of active expansionist policy gained influence in Batavia. These 'hawks' introduced a remarkable argument for violent military intervention on Lombok. They pictured the king of Lombok as extremely powerful, as a man who not only controlled all of Lombok and eastern Bali, but who had also usurped Gianyar and Mengwi. He might well soon take over Bali as a whole and become a threat to the Dutch. ${ }^{18}$ Batavia might have known better, but it was necessary to create a fictional enemy to justify military intervention.

The large-scale policy of expansion now set into motion was clothed with 'ethical' motives. The colonial government, representing the 'civilized state', could not tolerate royal exploitation and arbitrariness on Bali and

16 ARA, MvK V4-4-1892-W4, report J.H. Liefrinck 9-11-1891, V13-10-1893-Z12, report J.H. Liefrinck 7-6-1893.

17 ARA, MvK V4-4-1892-W4, report J.H. Liefrinck 16-10-1891; later reports in V13-10-1893Z12. Initially Batavia feared that a 'Muhammedan state' would be established on Lombok, and there was even a tendency to support the 'Hindu' king of Lombok (V4-4-1892-W4, memorandum Gouvernements Secretaris 7-10-1891). A little earlier (1888) this anti-Islam stance was strengthened by the disturbances in Banten (Sartono Kartodirdjo 1966). Liefrinck's reports transformed the Sasak from Muslims into victims of royal capriciousness. Remarkably, Van der Kraan (1980) pays no attention to this at all.

18 ARA, MvK 4-4-1892-W4, Advices Raad van Indië 4-12-1891 and 29-1-1892. Gianyar and Mengwi were reckoned as belonging to the 'kingdom of Lombok' on the basis of the tactical recognition of the king of Lombok on the part of the lords of Gianyar and the Mengwi exiles. Until then, the colonial government had not felt threatened by the Balinese kings, since they were largely quarrelling among themselves. Concerning the imperialism of Governor General Van der Wijck see Van Goor 1978. 
Lombok, the less so because on the strength of treaties these areas were subject to Dutch sovereignty (De Bruyn Kops 1915:464).

In 1894 a military expedition at last ended the Balinese dynasty on Lombok. The island was placed under direct colonial rule. ${ }^{19}$ Not the Klungkung court, which since 1882 had sought to gain power throughout Bali, but the Lombok dynasty (accidentally involved in the struggle) became the first victim of Dutch imperialism; such is the irony of history.

Although proposals were submitted to follow up the take-over of Lombok with military subjection of southern Bali, this did not happen. ${ }^{20}$ But the military conquest of Lombok did have immediate consequences for Bali. Karangasem belonged to the Lombok dynasty and had fallen to the Dutch in 1894. But Batavia shrank from introducing direct rule there for fear of becoming involved in the southern Balinese war. A solution was found in 1895. Karangasem was proclaimed to be a Gouvernementslandschap (Protectorate), and the lord of Karangasem was appointed as Stedehouder (Stadtholder) representing the government. ${ }^{21}$ This construction was a novelty in colonial law, but did not mean that the Dutch now had complete control over Karangasem. The position of Gusti Gede Jelantik was both consolidated and greatly enhanced. As Stadtholder he enjoyed the support of a colonial state whose proven might was still vivid in Lombok memory. One important result of this diplomatic annexation was that Karangasem was removed, as it were, from the southern Balinese political arena because henceforth the area was part and parcel of the Netherlands Indies. A neighbouring king about to take on Karangasem would have to contend not only with Gusti Gede Jelantik but with the colonial state as well.

Resident F.A. Liefrinck (1895-1901) ${ }^{22}$ was probably the major architect of the Protectorate construction, which made it possible to add new areas to the Netherlands Indies through peaceful negotiation. It proved to be a successful model. Soon, other southern Balinese lords also safeguarded their autonomy by seeking timely protection from the colonial government.

In 1900 negara Gianyar became the second Protectorate. The man appointed as Stadtholder was a son of the former king of Gianyar. ${ }^{23}$ In contrast

19 On this expedition see Cool 1896 and Van der Kraan 1980:30-99.

20 'In the interest of the population', Resident C. Dannenbargh advocated subjecting southern Bali as well. ARA MvK V7-7-1892-A10, report 25-4-1892.

21 ARA, MvK V27-1-1897-3, G.B. 31-8-1895-1; see also V28-11-1896-V19. During the Lombok expedition G. Gede Jelantik, lord of Karangasem, had avoided confrontation with the Dutch. For this reason he was able to gain the confidence of the colonial government. The term Stadtholder stems from the days of the Dutch Republic.

22 F.A. Liefrinck was the older brother of Controleur J.H. Liefrinck.

23 For a review of the events in Gianyar between 1893 and 1900, see ARA, MvK V21-1-18973, V19-1-1901-2; KITLV, Coll. Korn:118; Sidemen 1980. The Stadtholder of Gianyar was Dewa Made Raka (Mahaudiana 1968:110). 
to the lord of Karangasem, this royal son found little to consolidate, since the dynasty had lost almost all of its power. The royal centre of Gianyar had fallen in 1884, and when the sons of the deceased king managed to escape from their Klungkung imprisonment in 1893, they found no royal basis of power left in Gianyar.

One man had attained great power and wealth: Cokorda Gede Sukawati, lord of Ubud. He had succeeded in expanding his domain from about 40 to 130 villages, and together with his allies he was able to mobilize 18,000 followers. ${ }^{24}$ To consolidate all this, the lord of Ubud decided to follow the example of Karangasem. If Gianyar became a Protectorate, it would mean the end of the incessant fighting with neighbouring enemies, which had caused one-quarter of all the sawah in Gianyar to be without irrigation for years. Moreover, he found it advantageous that the appointed Stadtholder was the returning royal son, whose power was so slight that Ubud's strong man had little to fear. Officially, therefore, he supported him heartily, while in practice he went his own way. ${ }^{25}$

The paradox manifesting itself on Bali towards the end of the nineteenth century was that those lords who had placed themselves under the protection of the colonial government at the right time would hang on to their power and royal allure longest. In this respect Gusti Gede Jelantik of Karangasem and Cokorda Gede Sukawati of Ubud were the great winners. They understood that by accommodating the Dutch now, they would be able to consolidate their position and even strengthen it later.

The provisional negara Abiansemal, 1898-1900

The changes brought about after 1895 in the Balinese political system had far-reaching consequences for the exiles from Mengwi. They lost their temporary superior, the king of Lombok, when he fell in 1894. But the returned royal son at Gianyar was a useful alternative. However, when he became Stadtholder for the Dutch, the exiles were afraid that they, too, would become subject to the colonial government. This unsought annexation would bring them not one step nearer to regaining their own negara. The Dutch prohibited armed conflict between governmentcontrolled areas and the independent parts of southern Bali. Since Ubud was now part of the Gianyar Protectorate, this refuge could no longer serve as a springboard for action by the exiles.

24 Private archive Gianyar, reports Controleur J.C. van Eerde 13-12-1896 and 1-6-1897; Van Kol 1903:459-61, 472.

25 In 1903 the Stadtholder was inaugurated as king of Gianyar (Swellengrebel 1947; Van der Meij 1986). This ritual simultaneously marked the beginning of a stubborn rivalry between the royal puri of Gianyar and the puri of Ubud, a rivalry that was to continue throughout the colonial period. 
By 1900, however, the Mengwi exiles were no longer completely dependent on their mighty protector in Ubud. Two years earlier, in 1898, they had mounted a big offensive to retake Mengwi. ${ }^{26}$ Returning from a pilgrimage to their mountain temple in desa Tinggan, they suddenly swooped down on the Badung-occupied part of Mengwi. Not by accident, the major objective was the temple Taman Ayun. Pura Taman Ayun was not only a symbol of the negara, but constituted its very core. Whoever controlled this temple controlled symbolically the entire negara again.

Reoccupation was short-lived. Once again the exiles were ousted from desa Mengwi by Badung troops. But just east of desa Penarungan they made a stand. From June 1898 until the beginning of the rainy season in OctoberNovember a veritable trench war was conducted in the small border area between Abiansemal and Penarungan. ${ }^{27}$

While Badung occupied the area west of the trenches, Mengwi followers regrouped on the eastern side. Members of the Mengwi dynasty moved in, together with their followers. Mengwi's crown prince, Agung Gede Agung, appointed himself the new lord of the area and settled in desa Abiansemal. ${ }^{28}$

Formerly, Abiansemal consisted of a set of separate settlements, each with a leader from the lesser nobility or a mekel from one of the puri of Mengwi. But after 1898 the Mengwi crown prince effected unification under his central authority. In the middle of the desa he had a puri built. Though it could not compare with the destroyed royal puri Gede in Mengwi, to the local people this puri seemed very impressive indeed.

Agung Gede Agung did not arrive in Abiansemal unaccompanied. Some 300 followers came with him, not counting women and children. They hailed from various parts of negara Mengwi and had fled to Ubud between 1891 and 1893. Now they were housed around the new puri, their new dwellings placed in a wide circle. Most of them were allotted fallow plots in the midst of the resident population. In this way Abiansemal changed from

\footnotetext{
26 ARA, MvK V19-1-1901-2, report Controleur H.J.E.F. Schwartz 23-1-1900; KITLV, Coll. Korn:118; Babad Mengwi-Lambing:76-81; information from G. Ag. Gede Rai, puri Selat Dauh, and G. Ag. Ajeng, puri Labah, Kedampal.

27 A reminder of this war is the deep ditch, or pangkung, which still marks the border between the two desa. Agung Kaler, former lord of puri Grana and younger brother to the late king of Mengwi, was killed in battle. Puri Penarungan remained neutral. Ever since this branch had been ousted from the Mengwi dynasty (see Chapter 5), it had given no active support whatsoever to the royal centre. In various yards in Blahkiuh and Abiansemal I found lesung, large hollow stones for grinding rice, which are said to be 'spoils from Penarungan', souvenirs of the trench war.

28 Data from Pamancangah Dalem Mengwi:37; Babad Mengwi-Lambing:78-9; KITLV Coll. Korn:147, report punggawa Abiansemal 1920; Silsilah Brahmana Mas Timbul; information from G. Ag. Ajeng, puri Labah, Kedampal; Ida Bagus Putra, Ida Bagus Gadung, Ida Bagus Mangku, I Made Regeg, I Made Widya, G. Tantra, G. Gede Oka, Pan Warti, and I Wayan Gatra, Abiansemal. Formerly, most of the area belonged to puri Mayun. After the fall of Mengwi it was controlled by puri Carangsari up to 1898.
} 
a conglomerate of groups of yards, interspersed with bamboo groves and gardens, into a continuous, built-up area. The former leaders of Abiansemal were replaced by followers of the puri. They took over in the desa, and the difference in prestige between the new lords and the rest of the people was strongly accentuated.

Agung Gede Agung also gained access to the sawah around Abiansemal. To this end he arranged a thoroughgoing reallocation of land, himself claiming most of it and distributing other sawah among his followers. To be sure, the former leaders of Abiansemal did meet with some leniency, but many of the original inhabitants lost access to their land or had to accept a subordinate position as share-cropper for the new lords.

The arrival of the puri entailed organizational and ritual change as well. Groups of immigrants were placed in separate wards, or banjar. In the centre of Abiansemal, for instance, was banjar Sempidi, housing puri followers who had fled desa Sempidi. Furthermore, some smaller desa in the Abiansemal vicinity were added and thus reduced to banjar. ${ }^{29}$

In 1904 the centralization of the new desa was crowned with the building of a large village temple at the southeastern side of the same crossroads where the puri was located. This provided the reorganized desa with a fitting centre. In the new village temple the bond between dynasty and desa was underscored by means of four shrines, two of which were dedicated to the late king of Mengwi and his brother, the renowned Agung Made Raka. Moreover, the odalan, or 'birthday', of the temple coincided with that of the last king. ${ }^{30}$ Agung Gede Agung had taken possession of Abiansemal.

Continuation of the dynastic tradition was further expressed in another temple. This was a substitute for pura Sada in Kapal and was located northeast of Abiansemal. Pura Sada contained the central ancestral shrine of the dynasty, but was now out of reach because of the Badung conquest. The bond with the ancestors was restored by means of this pasimpangan. Finally, the royal purohita were brought back as well. They established themselves in two localities north of Abiansemal. ${ }^{31}$

Abiansemal became the centre of a 'provisional negara'. Within a short

29 These were desa Kedampal and desa Juet, north and south of Abiansemal respectively. In 1900, an estimated 1,500 people lived in Abiansemal.

30 The third shrine was for Agung Panji, son of the first king of Mengwi, who died heroically in 1713 (see Chapter 2). The fourth was dedicated to Pedanda Made Bang, killed in battle when Mengwi fell (Chapter 6). The shrines are in the northern, highest part of the temple. The day of odalan is called macekan agung and lies between the important days of Galungan and Kuningan.

31 The priest from Den Kayu took up residence just north of desa Ayunan and named his settlement after the place from which the Kamenuh brahmans came in Buleleng: Banjarambengan. The priest from gria Sidemen settled in desa Taman. 
time an entirely new network of satellites formed around the desa. ${ }^{32}$ North of Abiansemal the branch of puri Mayun came to live in desa Blahkiuh. The area was familiar to them: since the middle of the nineteenth century Blahkiuh and its surroundings had belonged to puri Mayun. Compared to the position of Agung Gede Agung in Abiansemal, the presence of puri Mayun in Blahkiuh was rather insignificant. They had returned from exile almost destitute, accompanied by only a handful of followers. At first they could not even afford to have housing built for themselves and had to be satisfied with temporary residence in a local gria. ${ }^{33}$ Who could foresee that puri Mayun in Blahkiuh would soon turn into one of Bali's most powerful noble centres?

Compared to puri Mayun, a stronger impression by far was stamped on the provisional negara by the branch of puri Anyar. The sons of the former war leader of Mengwi, Agung Made Raka, were posted to various strategic positions to act as representatives of the puri of Abiansemal. ${ }^{34}$ One of them was Agung Kerug, the Mengwi leader under whose rule the negara had gone to ruin. His part was played out, however, for he was held responsible for the fall of Mengwi. Ignored by his kinfolk, he lived in isolation in desa Sedang, his mother's place of birth. His position as patih was taken over by his younger brother, Gusti Munggu. Through this appointment, Agung Gede Agung restored the bond between his own royal lineage and the important lineage of puri Anyar. ${ }^{35}$

More than before, the members of the Mengwi dynasty had to depend on each other. Except for a few of them, they found themselves in a new environment which still lacked a reliable power base. At the same time they had to make preparations for a new confrontation with Badung. The dynasty tried to strengthen the mutual bond by means of marriages, which were suddenly occurring between branches that previously hardly talked to one another. ${ }^{36}$ Agung Gede Agung, too, entered into several marriages in

32 Data from KITLV, Coll. Korn:128, processtukken Raad Kerta Badung 1924-1926; Babad Mengwi-Lambing:78-81; Interviews with Ida Pedanda Sidemen, Mengwi, Ida Bagus Mayun, Taman, and offspring of all the leaders of the satellites involved. See also Appendix.

33 These were Gusti Made Ringkus and his younger brother Gusti Putu Mayun, sons of the late leader of puri Mayun, Agung Pekel.

34 Sons of Agung Made Raka settled in desa Getasan, Abiansemal, Bongkasa, Lambing, and Sedang. The lineage of puri Anyar spread out into six sub-lineages; see Appendix.

35 The new patih was posted in desa Bongkasa, the centre of the lineage of puri Sayan. Members of the lineages of puri Muncan and puri Kapal Kaleran had sought refuge in Bongkasa as well. The patih was given the task of binding his kinsmen gathered in this eastern spot to the new centre in Abiansemal.

36 From 1895 onwards, after a period of relative isolation, marriages were suddenly arranged by the branch of puri Sayan with puri Kapal Kaleran, puri Muncan, and, later, with puri Mayun ('Tjatatan singkat'). Furthermore, the lords of the dynasty recruited a great number of jaba women in the vicinity, which provided them with new local families of followers. 


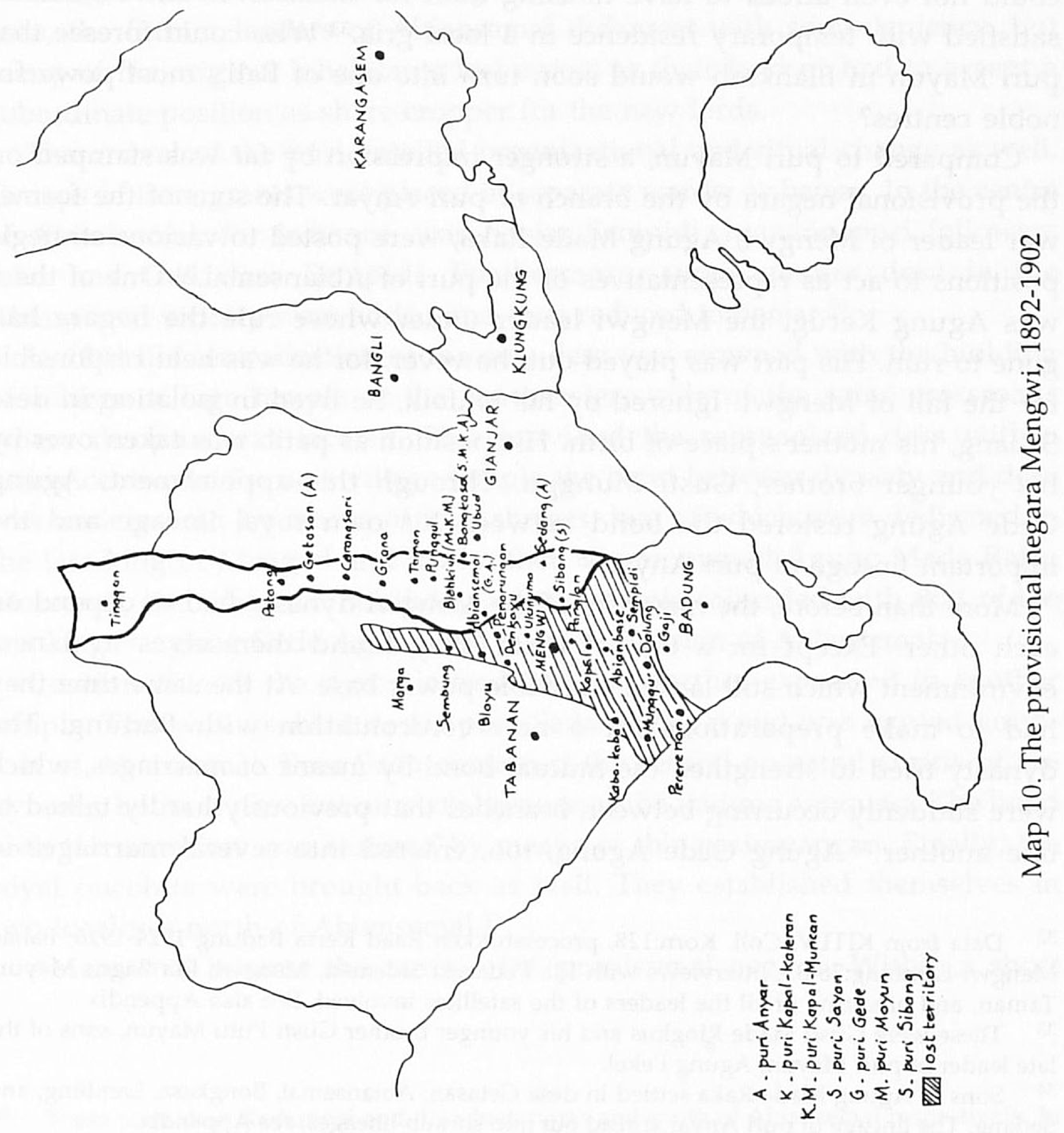


order to bind some of the more important satellites to himself. Upon his arrival in Abiansemal, he used this means to strengthen the ties with the branches of puri Anyar and puri Mayun. ${ }^{37}$

Agung Gede Agung also married a daughter from puri Sibang. The core lineage of the Mengwi dynasty and the branch of puri Sibang had been overt enemies for a decade, and it had been in part because of the revolt of puri Sibang that the royal centre in Mengwi had fallen in 1891. But the marriage sealed a renewed rapprochement between the two parties.

At the same time, the union mirrored the growing influence of the Klungkung court in this region. Even prior to the fall of Mengwi, puri Sibang had placed itself under the authority of the Dewa Agung of Klungkung. In 1900 Agung Gede Agung did likewise. This was the year in which Gianyar had become a Protectorate. Agung Gede Agung was loath to be incorporated into the Netherlands Indies; consequently, he severed his ties with the king of Gianyar and placed himself under Klungkung authority. Soon after this, the lords of Carangsari and Petang joined Abiansemal. The provisional negara of Agung Gede Agung, including the domain of puri Sibang, now embraced 54 desa with a total population of about $20,000.38$ The Mengwi dynasty had now regrouped.

\section{Mengwi's recapture}

After a diaspora of nine years it seemed that the Mengwi dynasty had regrouped successfully around the new centre at Abiansemal. But permanent settlement in this region was out of the question, since the prime objective continued to be to recapture the old royal centre of Mengwi. Moreover, the position of the new leader in Abiansemal looked sturdier than it really was, because under the surface old internal conflicts continued to smoulder. These erupted in 1902, when some began to understand that after Lombok, Karangasem, and Gianyar, the rest of southern Bali, too, would be incorp-

37 He took a woman from puri Anyar as padmi, and his sister married a man from that branch. He gave his daughter in marriage to puri Mayun in Blahkiuh. Before the fall of Mengwi he had already married a woman from the branch of puri Kapal Kaleran. See

38 Babad Mengwi-Lambing:78; ARA, MvK V19-1-1901-2, report Controleur H.J.E.F. Schwartz 31-9-1900. The lords of Carangsari and Petang availed themselves of the situation of Gianyar becoming a Protectorate to undo their ties with the strong lord of Ubud and to ally themselves with the weaker Abiansemal, which was less of a threat to them. Because Agung Gede Agung had not yet been formally installed as king, he needed the temporary protection of the Dewa Agung (information from G. Ag. Gede Rai, puri Kajanan Mengwi). To symbolize the bond between Klungkung and Abiansemal, the Klungkung court gave the puri of Abiansemal a photograph of the Dewa Agung's son. Tradition says that the Dewa Agung himself dare not appear on a photograph, because he feared losing his power (personal communication M. Wiener). 
orated by the colonial government. At this point the leader of the puri Mayun branch took action. In 1900 Gusti Made Ringkus had come to live north of Abiansemal in desa Blahkiuh. ${ }^{39}$ Using the strategy by which the lords of Karangasem and Ubud had consolidated their position, he displayed timely anticipation of the inevitable approach of the colonial state.

In February 1902 Gusti Made Ringkus presented a letter to the Resident in Singaraja. ${ }^{40} \mathrm{He}$ offered the area controlled by the Mengwi dynasty to the government. He did so for a number of reasons. First, the provisional negara was threatened by Badung and Tabanan raids. The powerful lord of Ubud could no longer be appealed to, so help had to come from elsewhere. Gusti Made Ringkus hoped that the colonial government would offer protection. Second, it is quite probable that he, more than other lords around him, understood that complete annexation of southern Bali by the colonial government was merely a question of time. ${ }^{41}$ In that case Klungkung assistance would be an illusion and it seemed the better part of wisdom to trade loyalty to the Dewa Agung for recognition of the Resident as the new superior. Finally, Gusti Made Ringkus hoped that an adequate response to developments would significantly strengthen his own position in the Mengwi dynasty.

His initiative seemed in danger once the contents of the letter became known in Abiansemal and Klungkung. Almost immediately the Dewa Agung's brother arrived in person to make sure that Agung Gede Agung remained loyal to the Dewa Agung. ${ }^{42}$

Agung Gede Agung ordered his satellites to remain loyal to the Dewa Agung as legitimate leader of free Bali. Gusti Made Ringkus alone ignored the summons; henceforth his allegiance would be with the Dutch. The result was that the Mengwi dynasty was ripped apart into a 'Dutch' camp and a 'Klungkung' camp.

39 Gusti Made Ringkus (to grab) was so named because of his bold behaviour in 1902-1904. In this he emulated his father, who was called Pekel (avaricious).

40 ARA, MvK V10-6-1904-40, report Resident 11-4-1902; Samboengan Babad Mengwi:10-1. The letter was carried by Ida Made Oka, a brahman who grew up in Singaraja, but was later adopted by relatives in Blahkiuh. This brahman was a vital link between puri Mayun and the Dutch. Not only did he have the confidence of Gusti Made Ringkus, who temporarily lived in his gria in Blahkiuh, but he was also known in Buleleng. Gria Cempaka in Buleleng, his place of birth, had been established on Mengwi initiative in the first half of the eighteenth century. Contact with kin in the area of origin had not been lost. Information from Ida Bagus Made Manggis and Ida Bagus Ketut Swarna, Blahkiuh.

41 There is no evidence for this in the archives, but informants (see note 40) emphasized that, through his confidant, Gusti Made Ringkus was aware of the Dutch plans concerning southern Bali.

42 ARA, MvK V28-4-1903-2, report July 1902; Babad Mengwi-Sedang:71. This brother of the Dewa Agung was Cokorda Gede Raka. In Sibang, also, a Klungkung 'agent' was posted, the jaba I Wayan Rana, who 'advised' the lord of Sibang; information from G. Ag. Putu Gedong, puri Gedong, Sibang. 
Since most of the satellites remained loyal to Abiansemal, Gusti Made Ringkus in Blahkiuh was completely encircled by the 'Klungkung' camp. ${ }^{43}$ Skirmishes ensued. From both sides followers were threatened, families ran over from one side to the other, crops were destroyed on both sides, and pedlars from the one camp were waylaid by warriors of the other. ${ }^{44}$

Gusti Made Ringkus had taken a risk, for he did not know whether the Dutch would respond favourably to his offer. This happened a month later, in March 1902. The Resident made it known that he was prepared to protect eastern Mengwi. At the same time the rift within the Mengwi dynasty came out into the open. Supported by the Klungkung court, Agung Gede Agung, Lord of Abiansemal, proclaimed that he was opposed to Dutch intervention and had never requested it. The Dutch, however, could not alter their course and were more or less forced to protect only Gusti Made Ringkus and his small domain around Blahkiuh. To seal the covenant with the Dutch, the Gusti sent his younger brother to Singaraja, where for some years he received a Dutch education. He alone of all the Mengwi dynasty had an early opportunity to get to know the Dutch intimately, which provided the branch of puri Mayun with an important head start on competitors. ${ }^{45}$

Dutch meddling led to a new and incisive realignment in eastern Mengwi. Because of the many lesser incidents, the government wanted to introduce a strict geographical delimitation of the 'Dutch' and the 'Klungkung' camps. Unlike the Mengwi lords, the Dutch used a map to mark which areas belonged to them and which did not. This was the first time southern Bali had experienced the primacy of territorial division over control of largely dispersed groups of followers. Between 1902 and 1904 the consequences of this were keenly felt by a large part of the population. From 24 to 26 March 1902 a Dutch controleur drew a boundary around Blahkiuh, which would from now on demarcate the domain of Gusti Made Ringkus. As a result some hundreds of families, including two complete desa and a number of

43 ARA, MvK V10-6-1904-40, report Resident 11-4-1902. G. Made Ringkus controlled some 3,700 men, women, and children in and around Blahkiuh. The neighbouring domains, those of the lords of Abiansemal and Sibang, had about 9,000 inhabitants, and the area east of Blahkiuh, including desa Taman, Punggul, and Bongkasa, had a population of about 1,200. The northerly domains of the puri of Carangsari and Petang, both of whom once again adopted a wait-and-see attitude, had about 5,000 inhabitants.

44 ARA, MvK V28-4-1903-2, monthly reports 1902.

45 Blahkiuh was formally incorporated in the Protectorate of Gianyar, as were the domains of Carangsari and Petang (which shifted loyalty once again), but in practice this made for an autonomous position for G. Made Ringkus. ARA, MvK V10-6-1904-40, report Resident 11-4-1902. An attempt by Agung Kerug of Sedang to have his son enrol in the Singaraja school failed. He had become too insignificant; Van Kol 1903:477-8. 


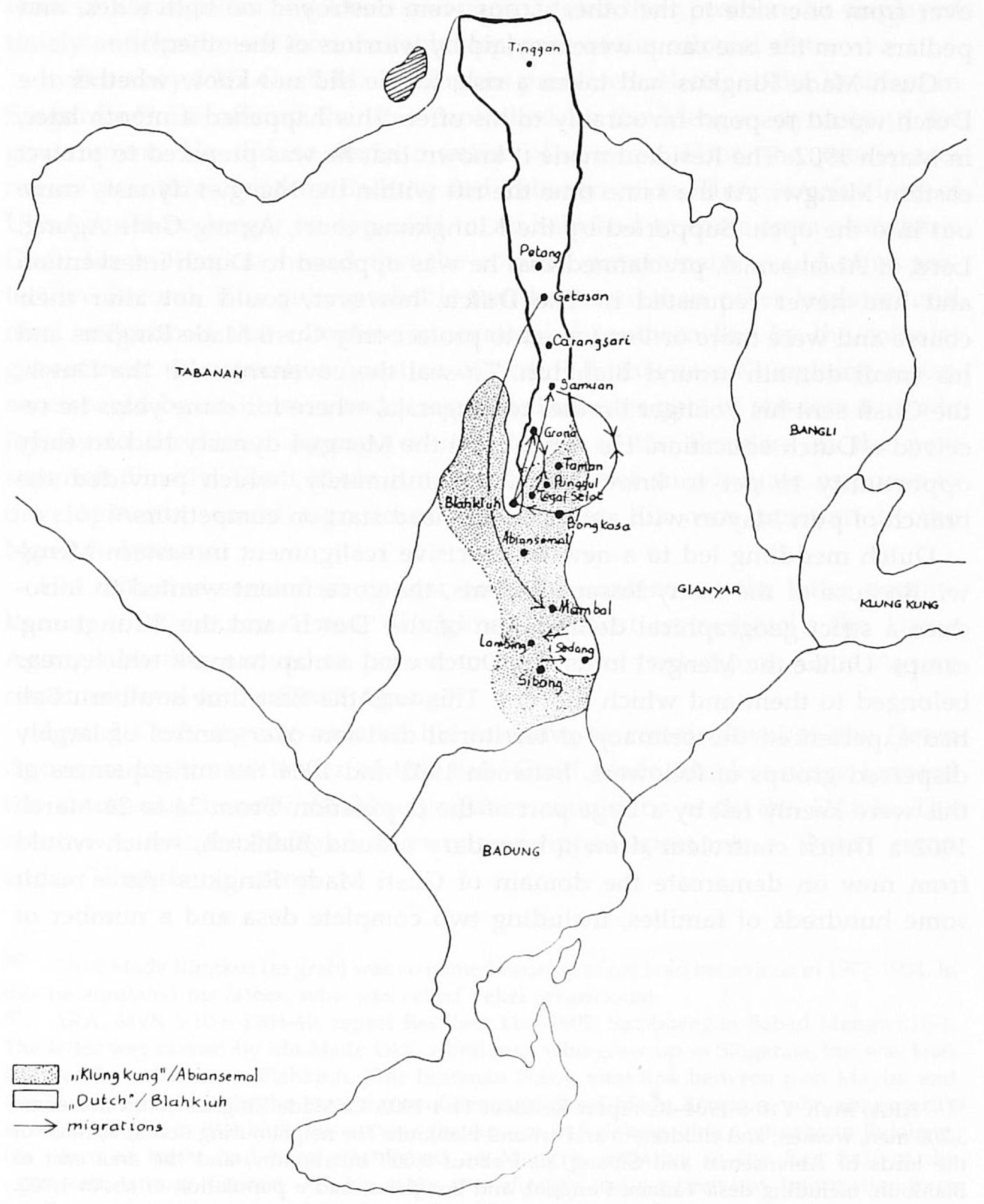

Map 11. Regrouping, 1902-1904 
wards (banjar), had to move to the other side of the new border. ${ }^{46}$ Every last inhabitant of desa Grana and desa Tegal Selat moved to each other's area because the residents of Grana were followers of the puri Abiansemal while the desa lay inside of the new boundaries of the domain of Gusti Made Ringkus. Conversely, those who lived in desa Tegal Selat were loyal to Gusti Made Ringkus, but their area now lay in the domain of puri Abiansemal. Some aged informants remember how, as children, they trekked to their new village in a long caravan taking along furniture, livestock, temple shrines, and dismantled pavilions. A similar exchange of banjar or families also took place between desa Bongkasa, Taman, Punggul, and Samuan and, more to the south, between the domains of puri Sibang and puri Sedang. ${ }^{47}$

Gusti Made Ringkus strengthened his hold on the northern part of his new territory by having a complete ward move from Blahkiuh to Grana, and a number of families to desa Samuan. In addition, some eight marriages underscored the bond with those members of the dynasty who had chosen his side and held local positions of power within the territory. ${ }^{48}$

Rivals in the region exchanged not only followers but also their sawah. Due to the existing complexity in the relations of possession, pawning, and share-cropping, complications were bound to arise, the more so since the soil was not equally fertile everywhere. But Gusti Made Ringkus could count on the colonial government to support him and it, in turn, gave him the benefit of the doubt. The outcome was that Gusti Made Ringkus saw to it that the new inhabitants of desa Grana received more and better sawah than they had formerly had in Tegal Selat, while those forced to migrate to Tegal Selat had to be satisfied with land of lesser quality. ${ }^{49}$

46 Map 11 indicates the major migrations. Data derived from ARA, MvK V10-6-1904-40; KITLV Coll. Korn:110, 128, 147, 163, memorandum G. Gede Raka 8-6-1938, processtukken Raad Kerta Badung 1924-26, report punggawa Abiansemal 1920, overeenkomsten tussen Blahkiuh en Abiansemal en tussen Sibang en Sedang 1904; Babad Mengwi-Lambing:81-2; interviews with offspring of all migrant groups.

47 Puri Sayan in Bongkasa and the puri of Taman and Punggul remained loyal to puri Abiansemal. Because of internal conflicts, however, small groups from these places moved to the domain of G. Made Ringkus. In the south, Agung Kerug of puri Sedang joined the Dutch side, while puri Sibang retained its loyalty to Klungkung.

48 Gusti Made Ringkus married daughters from the branches of puri Kapal Muncan (which had moved nearer to Blahkiuh) and puri Sedang, while six of his own daughters were married off to representatives of puri Sedang, puri Lambing, puri Sayan-Samuan, and puri Kapal Muncan. See Appendix. It is interesting that the banjar that moved from Blahkiuh to Grana to this day belongs ritually to the desa temples of Blahkiuh. In spite of some violent confrontations the immigrants from Blahkiuh refuse to contribute to the temples of Grana.

49 Data from interviews with informants in Grana and Tegal Selat. According to G. Ng. Putra (puri Grana, formerly puri Tegal Selat), Gusti Made Ringkus had intervened successfully when the new settlers from Tegal Selat sought to regain their old sawah around Grana. He threatened that he would summon the 'Kumpeni' army if they did not take to their heels immediately. Actually, not all migrants acquiesced to their fate. Families that had moved from Bongkasa to Samuan had second thoughts and returned. But in Bongkasa their sawah 
Surprisingly, his opponents succeeded in taking the eastern part of desa Blahkiuh away from Gusti Made Ringkus. He was forced to retreat to the western part. ${ }^{50}$ Nevertheless, compared to a few years earlier, his position was strengthened greatly. He now ruled a continuous area, controlled through followers and kinsmen, and protected by the colonial government against outside attacks. Moreover, his contacts with the Dutch provided him with useful information regarding the next phase of colonial penetration in southern Bali. Gusti Made Ringkus's small but protected enclave was a reliable base from which to carry out his projected plans. He had sworn that he would take control of pura Taman Ayun in Mengwi. ${ }^{51}$

\section{Colonial expansion and the massacre at Badung, 1901-1906}

When 'Ethical Policy' became the official guideline of colonial government politics in 1901, it meant that every autonomous negara in southern Bali would soon have to bow before Dutch imperialism. ${ }^{52}$ The general colonial consensus now was that ethical-imperial expansion was needed even with respect to regions which, like Bali, appeared to hold little promise of economic advantage. After all, the government was also charged with a civilizing task which implied that 'royal arbitrariness', slavery, and opium smuggling should be done away with. Governor General W. Rooseboom (1898-1904) formulated this vision as follows:

'We [...] shall, wherever there is injustice [...] not be able to remain inactive in the protection of the weak and the oppressed. This is in complete accord with the ethical direction in colonial politics.'

Inactivity would mean: 'shared guilt in wrongs that can only be condemned.' 53 The Dutch, however, were not of one mind as to the speed and the manner in which annexation of southern Bali was to take place. In The Hague, the Minister of Colonies was somewhat worried about the rapidity and scope of colonial expansion in the Archipelago. In the margin of the

had been given to others, so that they were reduced to a beggarly existence as landless folk (ARA MvK V27-8-1902-2, reports December 1902, January 1903, interviews in Bongkasa and Samuan).

50 This penetration split the desa in two. According to some informants, a small path that ran through the middle of Blahkiuh to desa Sangeh was the boundary. East of it Blahkiuh was dominated by a member of the branch of puri Kapal-Kaleran who was loyal to Agung Gede Agung in Abiansemal. G. Made Ringkus moved into a modest puri among his followers in banjar Pikah. The division in the village was so strict that those who lived on the western side, for instance, had no access to the pura dalem (temple of the dead) in the eastern part. For this reason a new temple of the dead was erected in the western part.

51 To signify this promise of his, he had erected a tugu, a small sacrificial shrine, opposite the small market in Blahkiuh.

52 On the coherence of ethics and expansion in Dutch government policy, see LocherScholten 1981:194-200.

53 ARA, MvK V28-3-1903-H5, memorandum 15-3-1903. On Bali, see Craandijk 1906. 
passage cited above he scribbled: 'To be sure, but to take this ethical direction as a guiding principle is to come into conflict everywhere; hence selfrestraint is needed.' Along with southern Bali, the Dutch were also involved in Aceh, Jambi, Southeast Kalimantan, Flores, and South Sulawesi. A list of priorities in conquests had to be drawn up. The result of this was that upon conclusion of the military expedition to South Sulawesi it would be Bali's 'turn'.

Again, regarding the manner of government incorporation of southern Bali a difference of opinion arose in Batavia between champions of a tough approach and advocates of a soft or more lenient approach. Governor General Rooseboom and his successor J.B. van Heutsz (1904-1909) were hawks: they urged abolishment of royal rule, if need be through the use of violence, and introduction of direct colonial rule. Southern Bali was to be inducted into 'modernity' by military means.

Counter to this was the soft approach. The spokesman for this group was F.A. Liefrinck, former controleur on Bali and Resident of Bali and Lombok from 1895 to 1901, now a member of the Raad van Indië (Council of the Indies). ${ }^{54}$ In this position he tried to continue the policy he had pursued as Resident, and advocated diplomatic annexation of the remaining southern Balinese negara. Not military might but treaties should gradually bring the kings within the sphere of influence of the colonial state. This stance led him to collide with Van Heutsz, who reproached him for being far too lenient. 'To be sure, as colonial administrator Liefrinck was well thought of; still, he was not a man of initiative and insight. He was not progressive', wrote the governor general, who managed to decide the case in his favour. ${ }^{55}$

In 1905 a new Resident of Bali and Lombok was appointed, who was expected to support Van Heutsz's hard line. Prior to his departure to Bali, the Resident was summoned to an audience with the governor general, who 'responding to my request for some instructions, showed me a map of Bali and, waving his hand over the negara of southern Bali, said, "All of this has to change" ' (De Bruyn Kops 1915:466). And so it would. The time of pussyfooting was over; annexation through direct confrontation was about to begin.

The first clash between the government and one of the Balinese negara occurred in 1903, when it became known that during a royal cremation in Tabanan some of the king's widows were to be burned alive. In spite of

54 This Council of the Indies was the highest advisory body to the governor general, and Liefrinck had a seat on it from 1904 to 1908.

55 ARA, Coll. Van Heutsz:79,2, correspondence with Minister van Koloniën 20-4-1908. In 1908 , as a result of the controversy between Van Heutsz and Liefrinck, the latter did not become vice-chairman of the Council (Minister van Koloniën 30-7-1908); for Van Heutsz's policy see Lamster 1946. 
military threats by the Dutch, the ritual took place anyway. Afterwards, escalation of the conflict was nipped in the bud because widow-burning was abolished by treaties. ${ }^{56}$

No more than a year later came the next conflict. In 1904 a Chinese prahu, sailing under the Dutch flag, was plundered just off the Badung coast. In contrast to earlier cases of plundering, this incident was taken very seriously in Batavia. ${ }^{57}$ Although the Minister of Colonies believed that 'this Chinese junk really was not worth an expedition', Van Heutsz capitalized on the event to justify harsh military intervention.

'The raja [king] of Badung has to learn that we are the true masters whose decision is to be obeyed [...] and, ultimately, I fear, all of Bali shall, by means of military action as introduction to necessary economic progress, need to be brought under our control. 58

Just at that very time, several experienced southern Balinese leaders died in rapid succession. Through long years of contact with Dutch officials these leaders had been able to keep the Dutch away by meeting colonial demands in time. ${ }^{59}$ Their successors lacked this experience and in addition were faced with a new generation of Dutchmen who displayed less patience and asserted themselves more harshly.

The king of Badung, too, was no longer prepared to compromise. $\mathrm{He}$ must have come to understand rather quickly that there was no way to avoid the demise of his negara; hence he decided to honour none of the governmental demands. 60

A blockade of the Badung ports preceded the moment at which the military expedition would be launched, and F.A. Liefrinck made a last

56 This was the so-called masatia. It was probably the last of these to take place on Bali. Governor General Rooseboom was so indignant at not being permitted to forestall the masatia by force that he tendered his resignation. The Minister of Colonies refused. On this incident see ARA, MvK V28-4-1903-2, V9-12-1903-K19, V11-12-1903-M19, V21-12-1903-D20, V28-121903-M20, V4-1-1904-L1, V19-1-1904-01, V31-12-1904-Y28, V25-4-1905-1; on the treaties see Surat-Surat perdjandjian 1964:42, 184, 213, 297.

57 ARA, MvK V1-5-1906-59, monthly reports May-June 1904. The facts of the event never did become entirely clear. When Van Kol (1914:389) subsequently visited Bali and wished to investigate the incident he was boycotted by Dutch administrators.

58 ARA, Coll. Van Heutsz:79,2, correspondence with Minister van Koloniën October 1905.

59 These were the Dewa Agung of Klungkung (1850-1903) and his brother, the king of Tabanan (1843-1903), and G. Ng. Ketut Kesiman, who maintained contact with the Dutch as representative of the king of Badung. ARA, MvK V27-8-1904-2, V16-8-1905-F19, V1-5-1906-59.

60 The most important demand was payment of damages in the amount of Dfl. 7,500 for the plundered vessel. According to Cokorda Ng. Agung and Bapak Widyakusuma in Denpasar, the king was convinced that even if he were to pay, new colonial demands were sure to follow soon. A poem ascribed to the king of Badung, Kidung Purwa Sanghara, probably written in 1905, also reflects the premonition of approaching ruin. The poem describes the heroic death of various figures in classical Old Javanese literature. My thanks to Ida Bagus Gede Agastia for this information. 
attempt at mediation. ${ }^{61} \mathrm{His}$ mission failed. But the blockade did not have the desired effect. Trade was rerouted and now crossed the hinterland of Mengwi from Badung to the harbour at Buleleng. The local lords in the Mengwi region profited the most from this sudden increase in trade activities in their domains. ${ }^{62}$

Meanwhile, in the Mengwi region, the lords, and Gusti Made Ringkus in Blahkiuh in particular, were tensely waiting to see if, on the political level, too, they would be able to reap a profit. The moment for this came in September 1906, when a large colonial force landed at Sanur beach to march on Badung. In contrast to the expeditions of the mid-nineteenth century, this time the colonial army had unstoppable firing power. For days on end, the royal centre of Badung was shelled. Against this superior might, Balinese resistance did not have a chance. On the morning of 20 September the bombardment was followed up with the final colonial assault.

The previous night some hundreds of faithful followers of the Badung king had readied themselves for this last battle. Although in Batavia a possible massacre had been foreseen, the actual denouement turned into an unprecedented drama. When the expeditionary army approached Badung the king, seated in his sedan chair and surrounded by kin and followers, left the puri and went to his temple. Having offered prayers, the doomed procession, decked in white, went out into the street to face the colonial force. Puputan, the ending, came swiftly:

'About eleven, a mass of people, armed and clothed in white, passed the crossroads [...] the artillery opened fire, with horrible consequences for the packed crowd. Women, a lance or kris in their hands and children on their arms, stepped forward fearlessly to face the troops and meet their death. If we tried to disarm them we merely risked more casualties on our side. Repeatedly, the survivors were ordered to lay down their weapons and to surrender. In vain. Whenever we stopped firing, those who were still unhurt would use the moment to kris the wounded, whereupon they resumed their rush on the troops, brandishing their naked weapons. Those who turned to flee as the firing began, faced about again and, ashamed as it were of their lack of steadfastness, sought death. Soon the drama came to an end, but not before the king, his relatives and wives, and a number of children had died. ${ }^{63}$

61 ARA, MvK V13-5-1905-L12, V16-8-1905-F19.

62 ARA, MvK V1-5-1906-59, V28-4-1906-R5 and R9. One route ran via Sedang, Sibang, Abiansemal, Blahkiuh, and Carangsari to the Buleleng mountains, the other via KabaKaba, Blayu, and Marga. Besides levying toll, the puri in this region also invested in transactions with Arab, Armenian, and Chinese merchant houses in Buleleng.

63 ARA, MvK V1-5-1908-S2, report Chef Staf Bali expeditie. The puputan was predicted a year earlier; see V16-8-1905-F19, memorandum Resident 13-3-1905. Other sources regarding the puputan are: Van Rietschoten 1910; Van Geuns 1906; Fischer 1907; Van Weede 1908, II:403-518; Nieuwenkamp 1906-1910; ARA, MvK V3-7-1906-20, V8-9-1906-Z18, V22-91906-F20, V22-10-1906-A22; Coll. Grader, memorandum Algemene Secretarie 1932; Balinese reports are Djelantik 1980 and the Bhuwana Winasa, of which A.A.A. Konta (1977) published a very free version. The novel by Vicky Baum (1949) relates to this event. KITLV is 
It is probable that more than a thousand Balinese lost their lives. ${ }^{64}$

The violence unleashed in Badung was a turning point in the final penetration of colonial rule in southern Bali. After Badung, negara Tabanan also fell to the Dutch, and the dynasty there was dismantled. ${ }^{65}$ If Governor General Van Heutsz had had his way, the remainder of southern Bali would have been brought under direct rule as well, and in the Protectorate of Karangasem and Gianyar the royal regime would have disappeared also. ${ }^{66}$ Once again, however, he was opposed by F.A. Liefrinck, who accompanied the expedition to make arrangements for new political regulations in southern Bali. This time Liefrinck's political approach prevailed. He not only left intact the existing Protectorates but added two more: negara Bangli and negara Klungkung. ${ }^{67}$ This meant that the Klungkung dynasty continued, although it had to relinquish authority over the region around Abiansemal.

After the fall of Badung and the new treaty between the colonial government and Klungkung, the entire Mengwi region was formally a part of the Netherlands Indies. Certain Mengwi lords, however, had swung into action as well.

\section{Mengwi's resurrection and the fall of Bali, 1906-1908}

While farmers in the fields around Blahkiuh and Abiansemal suspended harvesting because they were frightened by the thunder of the bombardment of Badung, the lords in this area had secured their domains. Shortly after the colonial army landed in Sanur, the lords of Abiansemal and Sibang - two enclaves still under the authority of Klungkung - had surrendered to the Dutch. Immediately after the fall of Badung other lords in the region followed suit. ${ }^{6}$

In the course of the expedition, Gusti Made Ringkus proved a decisive

in possession of photographic reports of the expedition.

64 The officially announced number of casualties was four hundred dead (ARA, MvK V1-51908-S2, telegram 21-9-1906), but Van Kol (1914:402) suspected that this figure was kept intentionally low. Djelantik (1980) mentions a figure of 1,100 casualties.

65 The king of Tabanan and his son committed suicide after surrendering themselves to the Dutch. ARA, MvK MvO Controleur A.M. Zandveld 1907; Nieuwenkamp 1906-1910:182; information from G. Ng. Ketut Sangka, puri Gede Krambitan.

66 In March 1906 he wrote to the Minister of Colonies: 'a violent intervention by us in the small independent states would first of all be a blessing for the commoners there, who are exposed to the greatest possible arbitrariness of kings and local rulers' (ARA MvK V3-7-190620, letter 9-3-1906).

67 ARA, MvK V12-10-1906-B2, V15-10-1906-F22. See also Surat-Surat perdjandjian 1964:46, 300.

68 ARA, MvK V1-5-1908-S2, report Chef Staf; Babad Mengwi-Sedang:75-6. These were the lords of Kaba-Kaba, Blayu, and Marga. To let it be known that he did not consider himself linked to negara Tabanan, the lord of Marga organized cockfights on the day that the expeditionary army marched on Tabanan (Nieuwenkamp 1906-1910:182). 
leader. He was able to convince the leaders of Abiansemal and Sibang that if they wished to save their necks they should arrange timely surrender to the new rulers. Apparently, he also made sure that the Mengwi region would not send support for the king of Badung. He did even more. Soon after Badung fell, the leader of puri Mayun had taken possession of the old core area of negara Mengwi, and his first act was to occupy the central temple Taman Ayun. Recapture of the old royal centre had come to pass at last. ${ }^{69}$

F.A. Liefrinck was the ideal discussion partner for Gusti Made Ringkus in achieving his objective. From the start, Liefrinck had been of the opinion that the Mengwi region could best be annexed by supporting the leaders of the old dynasty. ${ }^{70}$ Gusti Made Ringkus was the right man to implement this plan. Moreover, because of his relations with Dutch officials he had sufficient advance knowledge to be able to anticipate the colonial penetration effectively. As a result, the leader of the lineage of puri Mayun outdistanced his competitors. At a single stroke, he had managed to enlarge his small domain around Blahkiuh by annexing the core area of the old negara. To signify this, he took up temporary residence in the forecourt of the central temple Taman Ayun, leaving his younger brother to control the domain around Blahkiuh.

While in Badung and Tabanan the royal puri were razed to the ground to eradicate all reminders of the days of the kings, and houses and offices of Dutch officials were erected in their place, the old leaders stayed in power in the Mengwi region. On 31 August 1907 the birthday of Queen Wilhelmina was celebrated in the new colonial seat at Badung for the first time. On this occasion the most important local lords in the Mengwi region were appointed colonial district officers. ${ }^{71}$ Both Van Heutsz and Liefrinck saw part of their wish fulfilled.

It took one more military expedition to finally bring all of southern Bali into the Pax Neerlandica. The action was aimed at the Klungkung court and the occasion was resistance to the introduction of the colonial opium directive in April 1908. In Klungkung tension mounted. This was in part because the puri were about to lose an appreciable part of their income from the opium trade, and even more because the establishment of numerous small colonial opium depots made the colonial presence in the Protectorates very visible indeed. The situation culminated in an assault on one of the

\footnotetext{
69 ARA, MvK V1-5-1908-S2, report November 1906; information from G. Ag. Gede Rai, puri Kajanan, and I Ketut Misma, Mengwi; G. Ag. Ajeng, puri Labah Kedampal. This time the recovery involved no more than a few violent incidents.

70 ARA, MvK V28-4-1903-2, V26-7-1907-9, report 18-10-1906.

71 Staatsblad N.I. 1907:449; ARA, MvK V18-9-1908-3, report Assistant Resident H.J.E.F. Schwartz 4-12-1907. See Chapter 8.
} 
new depots, taking the lives of several officials. ${ }^{72}$ This incident sparked off general resistance against the Dutch, led by the Klungkung court. On 28 April a brief military action was carried out, once again ending in puputan. Surrounded by a few hundred followers, the Dewa Agung left his puri and the group rushed headlong into a hail of colonial bullets. Klungkung had placed its trust in the pusaka krisses which they had brought with them, but their hopes literally went up in smoke; when the krisses were thrust into the soil the colonial army did not retreat. ${ }^{73}$ It was not merely the Klungkung dynasty that had fallen: 'Bali' was now definitively in Dutch hands. Bali's most prestigious king, the living link between the Balinese hierarchy and its East Javanese origins, was no longer alive. In Klungkung the Dutch were seen as 'white demons', whose violent actions had brought misery and 'pollution' over Bali (Wiener 1990:350-3).

As the puri of Klungkung was being torn down, elsewhere on Bali Gusti Made Ringkus was raising a small temple in the forecourt of pura Taman Ayun to commemorate his recapture of Mengwi. He had made good the promise he once made in Blahkiuh. ${ }^{74}$ At the same time the little temple symbolized the ambition of the lineage of puri Mayun to regain power in the old negara, be it under the Dutch colonial regime.

The period between 1894 and 1908 embraces more than the story of colonial expansion and Balinese defeats. In the end, the tactics by which the Dutch had gained control over parts of Bali varied greatly. These differences reflected to a high degree the difference in the stances of Van Heutsz and F.A. Liefrinck, but also had to do with the way some Balinese leaders had anticipated the arrival of the Dutch. Those who resisted lost; and in Badung, Tabanan, and Klungkung direct colonial rule was introduced. Others had met colonial demands in time; hence, the royal regimes in Karangasem, Bangli, and Gianyar were continued. The Mengwi region was in an inbetween position. On the one hand, the area was included in the directly ruled part of Bali; on the other hand, part of the dynasty continued in power.

After 1891 new Mengwi leaders had come forward. Under their guidance, internal power relations shifted drastically. For the time being, Gusti Made Ringkus of Blahkiuh was the winner. Like Gusti Gede Jelantik of Karangasem and Cokorda Gede Sukawati of Ubud, he too had been successful in strengthening his position with the assistance of the colonial government. In this way he laid the basis for the future strength of puri Mayun.

\footnotetext{
72 ARA, MvK V28-6-1909-1, MvO Resident G.F. de Bruyn Kops 1909. See also Sidemen 1983. 73 Van Kol 1914:285; interview I Made Kanta, Klungkung.

74 Information from G. Ag. Gede Rai, puri Kajanan Mengwi; G. Ag. Ajeng, puri Labah Kedampal; G. Ag. Gede Putra, puri Lambing.
} 


\section{CHAPTER VIII \\ Colonial reorganization, 1906-1920}

Peace and quiet, law and order, this is what the colonial government wanted most of all. Peace of a sort was exacted by means of expeditions and enforced via centralized government. Up to 1942 the colonial presence on Bali would not be seriously challenged. But order was something else again, it would have to be forged out of what the Dutch in 1902 saw as downright chaos. To introduce and establish colonial government meant to have one political system clash with another. The Balinese system consisted of a great variety of continually shifting, personal hierarchical relations, whereas the colonial government was bureaucratic and uniform. To gain control over South Bali, the Dutch needed to create uniformity and impose order.

In this chapter I trace how the desired uniformity in South Balinese society was achieved. This operation, performed 'with incredible alacrity'1, effected a linkage between the new colonial framework and the old hierarchical relations. This led to drastic change in the South Balinese political system. I highlight the most important aspects of all this with special attention to the Mengwi region. I will show how under pressure of the colonial state, the fluid character of the political system gradually changed into a hierarchy imposed and fixed from above. In the process, Western notions regarding the 'true' nature of Balinese society played a major role. Under colonial government Bali was transformed into a well-defined, 'traditional' society with clear-cut geographical boundaries and hierarchical categories. Districts, 'castes', villages and subak (irrigation collectives) were formed, which I shall discuss below. Existing power relations were drastically altered because of this colonial reorganization; between 1906 and 1920 many puri lost their former power and status. On the other hand, a number of noble families managed to expand their authority appreciably. One such winner was puri Mayun in Blahkiuh.

Colonial reorganization produced grave tensions. For one thing, the ritual dimension of the old system came under disruptive pressure. By the end of this chapter it will be clear that precisely on this point the attempts to

1 Korn 1932:310. The reorganization was mainly led by the first assistant resident of South Bali, H.J.E.F. Schwartz (1906-1909), whose previous task had been to maintain politial relations with the southern Balinese kings. 


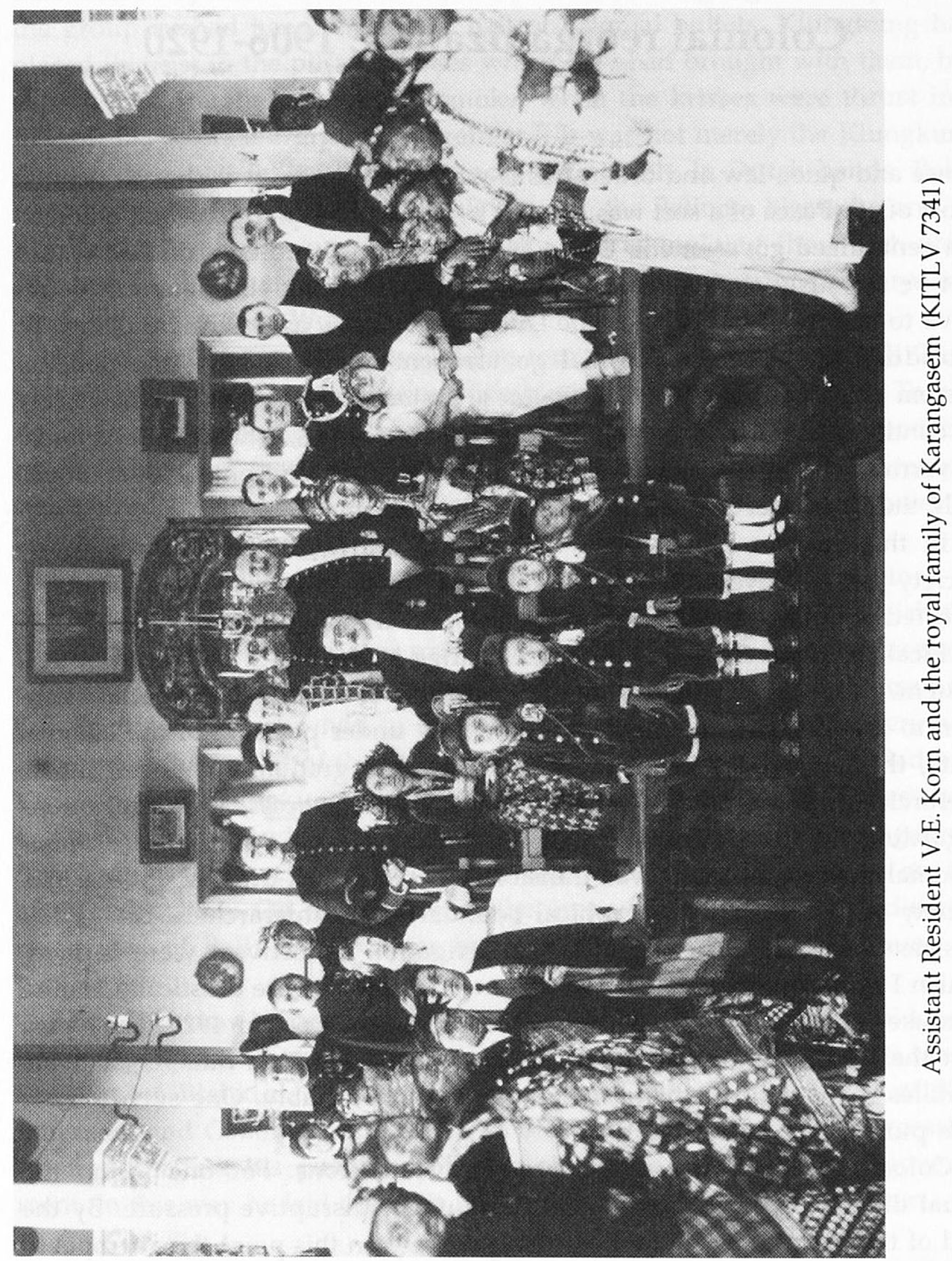


introduce serenity and transparent order harvested only insecurity and chaos.

\section{Districts and modern officials}

Colonial government was introduced in South Bali at high speed. In each of the former negara a controleur was stationed, and the region as a whole was placed under the authority of an assistant resident. ${ }^{2}$ Denpasar (the new name of desa Badung) became the new administrative centre for South Bali. The assistant resident's house, surrounded by offices and dwellings of officials, was built on the spot of the former royal puri. Denpasar was where the controleur of the Badung subdivision, comprising the old negara of Badung plus most of the former negara of Mengwi, was stationed as well. ${ }^{3}$

In order to achieve 'regularity, order, and uniformity' the Interior Administration (Binnenlandsch Bestuur, or BB) formed clearly delineated districts within the new subdivisions. These districts were placed under authority of a Balinese official or punggawa.4 Badung subdivision had fifteen such districts, five of which covered the Mengwi region. ${ }^{5}$ These were Mengwi, Kapal, Blahkiuh, Abiansemal, and Sibang. Two subdistricts were created: Carangsari and Sedang/Anggantaka. In this way the BB commenced the creation of territorial 'order'.

In each one of the districts, the puri leader with the greatest influence was appointed punggawa or, in the case of subdistricts, manca. The lords of the largest domains in the Mengwi region survived this first administrative reorganization. The BB considered their inclusion as punggawa in the colonial framework the best guarantee for 'maintaining the peace'. Four puri from the Mengwi dynasty retained their domains when their leaders were appointed punggawa. The lineage of puri Mayun netted the greatest profit, since Gusti Made Ringkus became punggawa of Mengwi district, while his younger brother Gusti Putu Mayun was made head of Blahkiuh district. But Agung Gede Agung, dynastic crown prince and lord of Abiansemal, was

2 ARA, MvK MvO Resident G.F. de Bruyn Kops 1909; Staatsblad N.-I. 1913:594. South Bali became an administrative division under an assistant resident, and consisted of six subdivisions (Karangasem, Bangli, Gianyar, Klungkung, Badung, and Tabanan) each with a controleur. South Bali was under the authority of the Resident of Bali and Lombok, whose domicile remained Singaraja.

3 Babad Badung-Krambitan (:20) gives an accurate description of the government buildings that replaced the old royal centre. The new Tabanan subdivision included former negara Mengwi domains of puri Blayu, puri Kaba-Kaba, and puri Marga.

4 ARA, MvK V18-9-1908-3, report Assistant Resident H.J.E.F. Schwartz 4-12-1907, G.B. 211-1907-13, 7-11-1908-11, 6-7-1908-37; MvO Resident G.F. de Bruyn Kops 1909. The term punggawa was in use to designate Balinese district heads in Buleleng, but was not applied generally in South Bali until after 1907.

5 ARA, MvK V18-9-1908-3. 
forced to step down: the only position available for him was no more than a position as punggawa of the small Abiansemal district, and his 'degradation' to ordinary punggawa eroded his royal aspirations further still. The puri Sibang lineage, on the other hand, simply continued its two centuries of control over its surroundings; not a thing seemed to threaten the power of Sibang's leader when he, too, was appointed punggawa. ${ }^{6}$

The administrative reorganization claimed its casualties as well. For the leaders of the lineages of puri Kapal-Muncan and puri Anyar, no position on the district level was available. The fall of Mengwi had left them without their former domains, and during the ensuing regrouping they had been unable to create new realms. Puri Kapal Kaleran was restored in its old domain: the BB preferred to entrust Kapal district to a punggawa of the Mengwi dynasty rather than to a representative of the Badung conquerors. ${ }^{7}$

The lesser local lords lost part or all of their power, since their domains were incorporated into the newly formed districts. The domain of puri Penarungan, for example, became part of Mengwi district, and the domains of puri Bongkasa, puri Taman, and puri Punggul were officially included in Blahkiuh district. ${ }^{8}$

Although the most prominent lords in the Mengwi region had weathered the administrative onslaught of the BB, the conditions under which they were able to continue their power were irrevocably changed. From now on, the colonial government was the decisive power factor. The position of a noble leader was no longer determined by the loyalty of his followers and by alliances with neighbouring lords. Ultimately, what counted was whom the controleur would put forward to be appointed punggawa by the Resident. In these years of transition, the punggawa were caught in between the old political system and the new colonial order. They were largely unfamiliar with the nature of colonial rule and were poorly equipped to carry out their new administrative tasks. Nevertheless, they were supposed to meet the directives of their white superiors punctually and, above all, they were expected to maintain law and order in their district. These demands could be met only by punggawa who knew their district well and had an informal network of followers. ${ }^{9}$ If they pursued their own interests too overtly, their

6 Appointed in 1907 as manca of the subdistricts of Carangsari and Sedang/Anggantaka were the lord of puri Carangsari and Agung Kerug of Sedang, respectively.

7 The Badung lords, however, retained their power and land in and around Kapal, which they had taken in 1891-1893. Kapal's new punggawa was a relative of the branch of puri Kapal Kaleran: Dewa Gede Raka Togog, who came from Klungkung.

8 This meant that the lineage of puri Mayun controlled two districts, and, in addition, gained the ascendancy over two related branches, those of puri Penarungan and puri Sayan in Bongkasa.

9 Initially a punggawa's salary lay between Dfl. 75 and Dfl. 150 per month. They were forbidden to levy taxes of their own. Some punggawa, those of Sibang and Abiansemal, were 
position was in immediate danger. The first to experience this was none other than Agung Kerug, the one-time patih of Mengwi.

In 1907 Agung Kerug had been appointed to head Sedang subdistrict, but he did not hold the job for long. A complaint was made against him because he allegedly demanded from the inhabitants materials and labour for repairs to his puri. The Dutch felt that this was improper conduct for a Balinese official and Agung Kerug was summarily dismissed. ${ }^{10}$

In 1910 the punggawa of Kapal, too, lost his position. In 1893 most of the original inhabitants of Kapal had fled, and some three hundred Badung families had taken up residence there. After the fall of Badung, however, many of the fugitives returned to Kapal. They resettled in their former yards, but their sawah had been taken over by the Badung invaders. The assistant resident forbade them to reclaim access to their land; he was afraid that redistribution would cause serious disruption of the peace. The issue continued to smoulder for three years or so when suddenly, in January of 1910, just before the planting season, hundreds of landless returnees occupied their old sawah. Surprised BB officials reported 'rather serious disturbances'. The anatomy of disorder was soon laid bare. Secretly, the punggawa of Kapal had promised the landless that their sawah would be restored to them. The promise was even sealed with an oath in the old Pura Sada of Kapal. In addition, the punggawa had arranged that, by way of compensation, he would receive no less than 15,000 rix-dollars in all, and 60 rixdollars in advance. Through the person of the punggawa, puri KapalKaleran had made a commitment it could not make good. Nothing happened, so that the landless finally decided to take matters into their own hands. Their action failed because the BB stuck to the state of affairs as encountered in 1906 and was unwilling to re-allocate the land, thus leaving the majority of the Kapal inhabitants without land. It was simultaneously the end of the brief career of Kapal's punggawa. Charged with corruption, he was exiled from Bali for ten years. The branch of puri Kapal-Kaleran had definitively lost its credit with the BB. ${ }^{11}$

The incidents at Sedang and Kapal demonstrate the vulnerability of the punggawa. If they were unable to control internal conflicts, the BB considered them failures and irrevocable dismissal followed.

compensated financially for the loss of income from the opium trade, which was now controlled by the government. Punggawa were assisted only by a small number of clerks. ARA, MvK V18-9-1908-3, V28-6-1909-1.

10 ARA, MvK MvO Controleur Badung, G. de Haze Winkelman 1912. The complaint was probably supported by his opponents in the Mengwi dynasty, who were eager to obstruct him. He was succeeded by the lord of puri Anggantaka, a rival from the same subdistrict.

11 KITLV, Coll. Korn:147, report punggawa Mengwi 1920; ARA, MvK V25-7-1910-39, report January 1910; V10-8-1911-18, report February 1911; MvO Assistant Resident A.J.L. Couvreur 1920. 


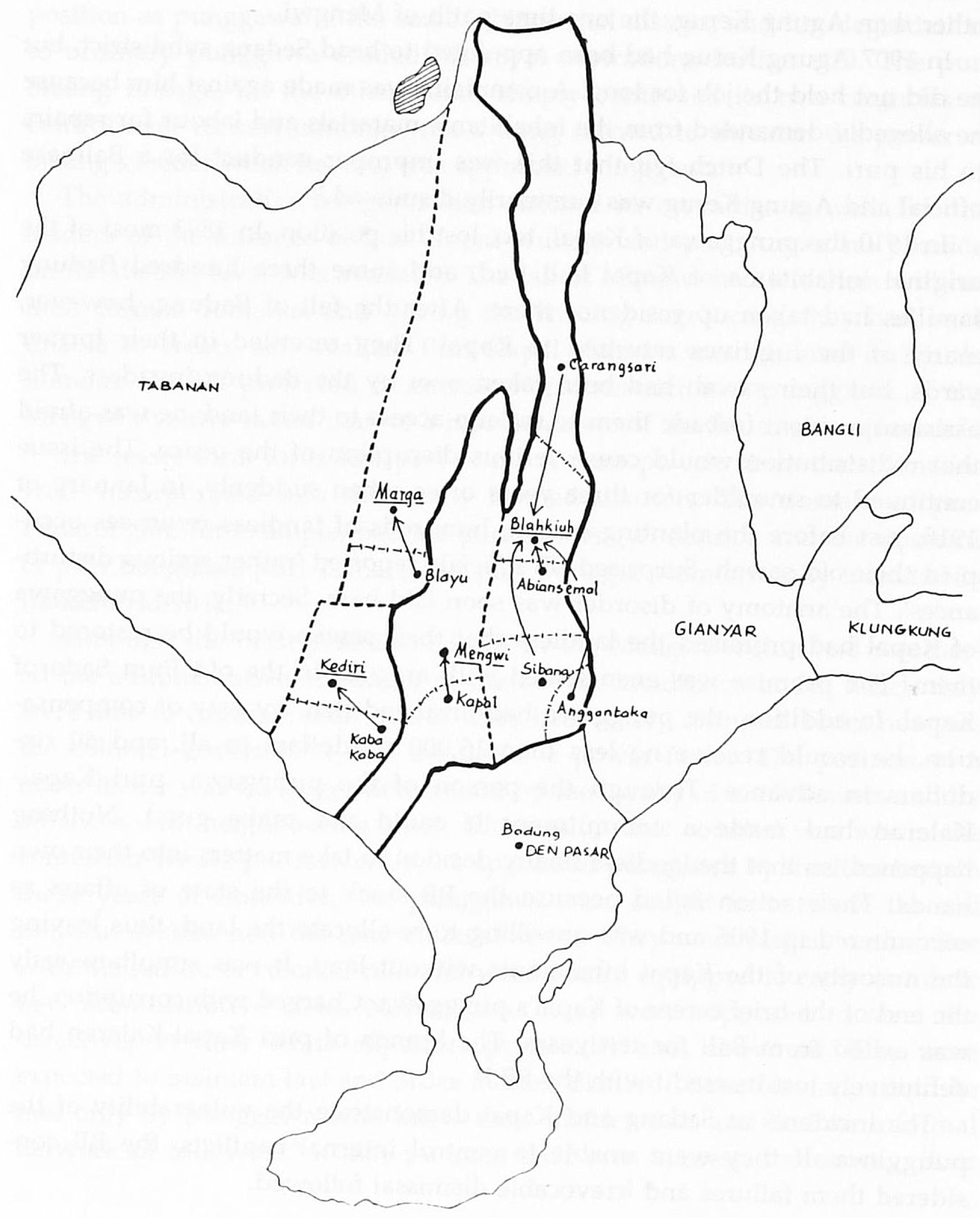

Map 12. Administrative reorganization, 1907-1915 
Even the position of punggawa who had gained sufficient control over their district was still far from secure. In a few years new dangers arose, in the face of which they were almost powerless. Rather than resolving the issue of land possession in Kapal, the government used the incident to call into being a new administrative reorganization. Kapal District was joined to Mengwi district, which made Gusti Made Ringkus punggawa of Kapal as well.

Now that a measure of 'peace' had been secured through the appointment of the most important noble leaders as punggawa, the BB moved on to 'simplify' district administration by mergers. This phase, too, was carried out at great speed: between 1910 and 1915 the number of districts in Badung subdivision was reduced from fifteen (including two subdistricts) to five. ${ }^{12}$ Rapid realization of this objective seemed more important than the question of improving the quality of the administration. The various amalgamations were effected with a dose of arbitrariness:

'here one punggawa proved unsuitable, another was inadequate somewhere else, a neighbour would be given an additional area and eventually would turn out to be unfit to rule so large a domain. In the end, though [...] the reduction stood at five.' (Korn 1932:323.)

The mergers were like a lottery; the punggawa just had to wait and see who would be fated to disappear and who was elected to survive. Added to this was the fact that in those very years there was a rapid succession of controleurs. As a result, these officials had little opportunity to familiarize themselves with the people they were expected to deal with. ${ }^{13}$ The reorganization caused most noble families to lose their administrative posts on the district level. In the former negara Badung, only two families retained a leading position, and in Mengwi the only branch to remain in power was that of puri Mayun. ${ }^{14}$

Two brothers belonging to this lineage controlled most of the old negara. Gusti Made Ringkus was punggawa of the merged districts of Mengwi and Kapal; his younger brother was punggawa of an area covering all of eastern Mengwi. This district was formed in the course of a reorganization between 1911 and 1915, when three smaller districts and two subdistricts were made into one. In 1911 the BB decided to do away with Sibang and Blahkiuh

12 ARA, MvK V3-1-1914-20; MvO Controleurs Badung, G. de Haze Winkelman 1912, C.C. Krom 1914, H.C. Prins 1915, J.W. Dankmeyer 1915; see Map 12.

13 ARA, MvK V29-3-1919-6, report J.H. Liefrinck 4-6-1918. In the space of ten years there were twelve successive controleurs in Badung, none of them in office for more than two years.

14 In former negara Badung, the nine districts were reduced to three. In the Mengwi part of the subdivision, only two districts remained. In the rest of South Bali, similar amalgamations were put into effect. In Tabanan, Kaba-Kaba district was added to Kediri, and Blayu merged with Marga district. 
districts and to add them to Abiansemal district. The leader of puri Sibang thus lost his position as punggawa. His territory was hence formally limited to desa Sibang and he was demoted to village head. The domain of puri Sibang had now shrunk appreciably and this once strong lineage lost much of its regional power.

In 1911 Agung Gede Agung, the crown prince at Abiansemal, also lost his position as punggawa. The BB no longer wished to retain him, as he looked upon himself too much as heir to the Mengwi throne and refused to conform to the new colonial framework. Inability and unwillingness led to his appointment being withdrawn. As one informant put it: 'After all, how can the son of a king be a mere official?' Until his death in 1920 Agung Gede Agung lived in Abiansemal as 'unemployed' crown prince, sadly watching the steady erosion of his puri's lustre. Opium alone provided him with illusions of the grandeur of former royalty. Although in formal terms he remained the most respected member of the dynasty, he was gradually outpaced by his son-in-law Gusti Putu Mayun of Blahkiuh.

The $\mathrm{BB}$ gave the post of punggawa over the enlarged Abiansemal district to Gusti Putu Mayun. ${ }^{15}$ It is probable that three reasons led to this appointment. First, he was the brother of Gusti Made Ringkus, who had caused the Dutch to be beholden to him during the colonial penetration and whose recommendations were taken seriously. Second, from 1902 to 1906 Gusti Putu Mayun had attended a colonial school in Buleleng. At that time the boy had come to know the Dutch intimately, while the BB prepared this scion of the Mengwi dynasty for an administrative career. Finally, Gusti Putu Mayun's age was in his favour. In 1911 he was about twenty years old and, compared to the older punggawa who had been in action in the days of the kings, he seemed to be someone who could be made into a model official, skilled to meet the requirements of 'modern' government.

Given the possibilities open to Gusti Made Ringkus, by 1915 he had reached the maximum attainable: his lineage controlled most of the former negara including the old royal centre. The paradox, however, was that the dynastic aspirations of Gusti Made Ringkus could be realized only in close cooperation with the colonial government. The lineage of puri Mayun had reconciled itself to embracing the colonial regime.

Even now, the dangers stalking the thinned-out ranks of the punggawa were not allayed. Along with the 'simplification' of the districts, the colonial government began to place new demands on the punggawa. A punggawa no longer needed to be a member of the local nobility; the candidate's admin-

15 Although Gusti Putu Mayun became punggawa and continued at Blahkiuh, the newly amalgamated district was named Abiansemal. In 1914 Sedang/Anggantaka subdistrict was terminated and added to district Abiansemal. In 1915 the subdistrict Carangsari (which up to 1933 had a separate manca who came from Carangsari) was merged with Abiansemal as well. 
istrative skills were what counted. The new criteria reflected both the growing self-confidence of the $\mathrm{BB}$ and the increasing bureaucratization of the colonial apparatus. South Bali was becoming more 'peaceful' and 'orderly'; the time of alliances with the local nobles was considered by the $\mathrm{BB}$ to be over. Balinese administration should be run according to strict administrative and bureaucratic norms. Batavia felt that in South Bali 'too many superfluous remnants of the days of the kings [...] ill equipped to adapt to evolution' were still extant. They should be cut away. ${ }^{16}$ What was needed in their place was a new type of official, deployable in various places; to this end the BB recruited mostly young, Western-educated Balinese. ${ }^{17}$ Officials of this kind were difficult to find among the nobility of southern Bali, but they could be recruited from Buleleng, where jaba were increasingly getting colonial schooling. As a result, many lesser posts in the south were filled by non-noble Buleleng officials, while members of the southern nobility had to relinquish their position.

In 1918 the Mengwi region suddenly got a taste of this changed outlook on the part of the colonial regime. In that year Punggawa Gusti Made Ringkus died. Contrary to expectation, he was succeeded by a Buleleng jaba nobody knew. ${ }^{18}$ The appointment of an unknown official in the centre of the former negara caused great consternation for people in Mengwi. As the lineage of puri Mayun saw it, the BB had terminated the alliance unilaterally and without apparent motive. The fact that this new punggawa was not of noble birth was a most serious affront.

The man's name was Ketut Sandi. He owed his position entirely to the BB. In 1906, during the expedition to Badung, he had acted as interpreter; after that he gained administrative experience as clerk and mantri in various South Balinese subdistricts. To him, a new-style punggawa, now fell the

16 ARA, MvK V3-1-1914-20, memorandum Bureau Buitenbezittingen 8-3-1913. This Batavia-based agency put increasing pressure on the BB outside of Java (see also Locher-Scholten 1981:76).

17 In addition, Javanese officials were placed in lesser administrative functions. The new attitude was criticized as well. According to former controleur J.H. Liefrinck - by then member of the Council of the Indies - the mostly young BB officials 'placed a higher premium on a little theoretical training and some office experience' because, Korn added later, 'not those at home in their own art and literature, but those possessing a modicum of Dutch writing ability were popular with the new lords of the land' (ARA, MvK V29-3-1919-6, report J.H. Liefrinck 4-6-1918; Korn 1932:647).

18 G. Made Ringkus was about 60 years old when he died, but his sons were young and had no administrative experience. G. Made Ringkus had requested burial rather than a pyre, which was highly unusual. He felt that through meditation he had achieved the loftiest kind of purity (nisreasa, Sanskrit: nisreyasa), so that purification by fire was superfluous. Accordingly, he was interred in a kramat (Islamic holy grave) south of the temple Taman Ayun. KITLV, Coll. Korn:110, 147, memorandum G. Gede Raka 8-6-1938, report punggawa Mengwi 1920; interviews with Cokorda Gede Oka, puri Gede, G. Ag. Gede Rai, puri Kajanan, Ida Bagus Ketut Sindu, Mengwi, G. Ketut Kaler, Blahkiuh. 
heavy task of establishing colonial authority in Mengwi. Formal integrity and loyalty to his Dutch superior would not be enough, and Ketut Sandi was very much aware of his limitations. He was an unknown and isolated jaba. He could rely on neither a network of followers nor sufficient means to gain control over the district. ${ }^{19}$ As an administrator, he knew that he was surrounded by a dynasty that bore him ill will and refused to recognize him. His most prominent opponent was the youngest son of the last king of Mengwi, Gusti Ketut Agung, who claimed to be the legitimate leader of the Mengwi dynasty after his older brother died in 1920. Gusti Ketut Agung, 28 years old, had no formal education and, colonial reports say, spent most of his time on cockfights, drinking, and women. But the Balinese did not look upon gambling and womanizing by members of the royalty as negative; on the contrary, these were seen as positive signs of kingship (Wiener 1990:16970). Just as his older brother had done in Abiansemal, he too refused to comply with colonial demands. Without consulting the punggawa, he convened meetings in the puri of Abiansemal, attended by members of the various branches of the dynasty, together with many former mekel and new village heads of Mengwi district. Major topics in these meetings were ensuring the continuity of the hierarchical order in the Mengwi region by conferring noble titles and resolving conflicts. ${ }^{20}$

Jaba official Ketut Sandi and Prince Gusti Ketut Agung personified the clash between the new administration and the old hierarchical order. Their battle remained undecided. Ketut Sandi could count on the protection of the $\mathrm{BB}$ and sought to rule the district along formal lines through his subordinate officials. In contrast, Gusti Ketut Agung based his power on the 'invisible' network of old followers, and was supported in secret by the only dynastic punggawa left, Gusti Putu Mayun in Blahkiuh.

\section{Gusti Putu Mayun's power base}

Gusti Putu Mayun was the only member of the Mengwi dynasty to survive the quick succession of administrative reorganizations between 1907 and 1918. Moreover, compared to his colleagues, his position in South Bali was a special one, since he remained in office longer than anyone else - from 1907 to 1938 - and throughout those years continued as punggawa of the same district, namely Abiansemal. It is not known why he was never transferred;

19 In those years punggawa salaries were increased from Dfl. 250 to Dfl. 400 per month, depending on training and number of years of service (ARA, MvK MvO Resident L.U. van Stenis 1919).

20 KITLV, Coll. Korn:147, report punggawa Ketut Sandi 1920. In a remarkably frank appendix to this report, he unburdened himself regarding the secret workings of the dynasty against him. Interviews with G. Ng. Ceger, Ida Bagus Ketut Sindu, I Ketut Misma, Mengwi, confirm the marginal position of the punggawa. 
the effects of his long tenure, however, can be quite easily traced. In 1983 a number of buildings in Blahkiuh, his residence, were still reminiscent of the punggawa's golden age, and he continues to live on in many stories. A measure of the great power he managed to achieve is that most of my informants, when speaking of the early twentieth century, did not refer to 'colonial times' or zaman Belanda but to 'the days of puri Mayun'.

Gusti Putu Mayun drew his strength from various sources, the combination of which eventually made him one of the most powerful punggawa on all of Bali. To begin with, he proved an able administrator of his district. He had the ability to introduce colonial measures promptly and apparently without inciting protests. To his superiors he seemed an industrious man. ${ }^{21}$ In short, he knew the rules and made sure that his performance was a shiny one.

Second, he made efficient use of several follower families. They made up his local administrative corps. All but one of these families had been part of the entourage of puri Mayun for some generations, and they had accompanied the exiled leaders of this lineage after the fall of Mengwi. From among them, Gusti Putu Mayun recruited a large number of functionaries for his district, and they became vital links between the new administration and the old hierarchical order. ${ }^{22}$ The two most important posts - the village head (perbekel) of Blahkiuh and the regional irrigation supervisor and tax collector (sedahan) - were held by members of three families in succession. Lesser posts were divided among five families. This provided Gusti Putu Mayun with direct and continuous control over desa Blahkiuh and over the organization of irrigation and taxation in most of his district. Other sectors were placed under the supervision of loyal followers as well: the market in Blahkiuh, the government-controlled opium trade, and the recruitment of corvée labour. Utilizing the old hierarchical relations, now subsumed under the new administrative umbrella, the punggawa was able to satisfy his Dutch superiors that peace and order were guaranteed. Taxes were paid on time, road construction progressed, registration was kept up to date, and no uprisings or irregularities occurred.

As the punggawa gained the confidence of the BB, his power grew apace. At the same time, the influence of his lesser functionaries expanded. After all, they could count on the might of the colonial administrative apparatus. In addition, it was not by accident that four of the five follower families belonged to the nobility. Together, they soon constituted an elite with great local influence. The authority of the most prominent family, the brahman

$21 \quad$ ARA, MvK MvO Controleur Badung, H.C. Prins 1915.

22 These functionaries and their families are listed at the end of this chapter. I return to them below. The brahman family lived in Blahkiuh earlier, but G. Made Ringkus had maintained a relationship with them based on trust (see Chapter 7, section 2). 
Manuaba family, derived from high birth combined with the relationship of trust with puri Mayun and their administrative positions. This also applied to the two families of lesser nobility. Their loyalty to the punggawa, official positions in the administration, and increasing wealth allowed them, with the puri's approval, to upgrade their title of Gusi to that of Gusti. In these ways Gusti Putu Mayun strengthened his own position while at the same time his followers gained power and status.

In addition to a strong local power base, the punggawa maintained important contacts within Badung subdivision. Each of his six brothers had received official appointments as well. ${ }^{23}$

His strong home base, the contacts with his kinsmen, and the support of the BB made it possible for Gusti Putu Mayun to gain influence in the domains of the other puri in his district. This, in turn, caused the power of these nobles to become restricted to their local environment so that gradually they had to give up their regional influence. ${ }^{24}$

Gusti Putu Mayun used his old relationships of followers and his new administrative power to shape his dynastic aspirations. The dynastic authority of puri Mayun and the punggawa's royal ambitions were manifested in a new centre in desa Blahkiuh, created by Gusti Putu Mayun from 1910 on. This centre was more than merely a reflection of the punggawa's power. It was a separate source of power for Gusti Putu Mayun. ${ }^{25}$

The nucleus of this centre was a newly constructed crossroads. To this end, two existing parallel paths in the western and eastern parts of the desa, which ran north and south, were blocked and replaced with one broad new road through the desa. Practically all traffic was routed this way. ${ }^{26}$

Northeast of the crossing, the punggawa built his puri. ${ }^{27}$ Like the one in

23. See Appendix. His youngest brother was strategically placed: as clerk at the Badung subdivision court, he was able to influence proceedings in legal cases embarrassing to the punggawa.

24 In Chapter 9, section 3, I will discuss the relationships between the punggawa and some of these lords in more detail.

25 Elsewhere (Schulte Nordholt 1991b) I describe the history of this centre separately. In Chapter 9, section 3, I discuss two elements of this centre, namely the puri and the temple. A map of the centre is reproduced there as well. Almost all my information on the sources of Punggawa Gusti Putu Mayun's power was gathered by way of lengthy interviews with many informants in and near Blahkiuh.

26 Part of the old eastern road was turned into sawah. In 1983, a row of small sawah stretching from north to south still allowed one to recognize the old road. The construction of the crossroads and the detours took place around 1916, when the colonial administration was engaged in a sustained effort to build roads in South Bali. The punggawa availed himself of the opportunity to construct the new crossroads without attracting notice. The work was carried out by corvée labourers who were not paid. The village head of Blahkiuh and brother of the punggawa, G. Ketut Rai, supervised construction.

27 This was in 1910. Up until then he lived in Pikah, in the southwestern part of Blahkiuh (see Chapter 7, section 2). To site the puri on the northeastern side was a novelty; in general, members of the Mengwi dynasty used to live on the southwestern side. The 'move' to the 
Abiansemal, this puri was modest in size and consisted of three parts: the house temple on the north side, just one yard with living quarters in the middle part, and an open court on the south side. The importance of this small puri was expressed in the house temple. It was the main temple of the entire branch of puri Mayun, so that ritually, the puri in Blahkiuh was one of the three major puri of the Mengwi dynasty. ${ }^{28}$

Diagonally across the puri, a piece of land was allocated to a prominent follower family in Gusti Putu Mayun's entourage. This was the brahman Manuaba family, who proceeded to build a gria southwest of the crossing. Although its inhabitants were brahman and hence of higher birth than their lord, their dwelling was located 'below' the puri. But the Manuaba did not officiate during rituals; rather, they held lesser administrative posts; this meant that they should literally live 'under' the punggawa. ${ }^{29}$

Between the puri and the gria, the people of Blahkiuh would gather on two sites that together constituted an essential part of the new centre: the market and the open hall, or wantilan. Both were located just south of the puri, adjacent to the crossing. ${ }^{30}$ Blahkiuh did hold a small market every three days, but Gusti Putu Mayun turned it into a daily affair. He also made certain that the Blahkiuh market took on regional significance by forbidding nearby villages to hold markets. As a result, women far from Blahkiuh came to sell their wares, and the market at the crossroads became the point where one dealt with the merchants from Denpasar. Blahkiuh market developed into the most important trading centre of the district. The wantilan adjacent to it housed large meetings of minor officials. From time to time cockfights were held there as well.

In the shade and shelter of the puri, the market and wantilan made for a

'higher' location was probably inspired by the situation in Gianyar. Most of the puri there were on the northeast side of the crossing, and members of the puri Mayun branch had lived there during their exile. At the rear of the puri lived some follower families and the punggawa's servants. Families who lived in this part of the desa were evicted from their yards and were given new living quarters elsewhere in Blahkiuh.

28 After 1891, the house temples of the three most important branches of the dynasty came to be located outside of desa Mengwi. The main house temple of the royal lineage was in puri Gede Abiansemal. The main house temple of the branch of puri Anyar was in puri Sedang. Information from G. Ag. Ajeng, puri Labah, Kedampal, G. Ag. Gede Rai, puri Kajanan, Mengwi, G. Ag. Gede Putra, puri Lambing. In the next chapter I discuss the rituals conducted in the house temple (or pamrajan gede) of puri Mayun and around the centre of Blahkiuh.

29 For important rituals, puri Mayun sought assistance from the old purohita family of the brahmans Mas/Manuaba, who had found refuge in desa Taman after 1891, and from a brahman priest from Negari (Gianyar), with whom contact was established during exile.

30 The market was within the walls of the former jero Kapal, which had controlled the Klungkung part of the village from 1902 to 1906, when Blahkiuh had been divided into a 'Dutch' and a 'Klungkung' part (see Chapter 7, section 2). This is why puri Mayun could not be erected right next to the crossroads: ill would befall those who settled on the spot of a former gria or puri. 
lively atmosphere around the new centre. An empty and forsaken centre would be of no significance.

For the time being, the creation of this centre was completed when a small waringin tree was planted as part of a ritual in which various brahman priests participated. ${ }^{31}$ Soon the waringin grew into an enormous tree, visible for miles around and literally crowning the centre of Blahkiuh. The tree itself was a source of strength, and came to play an important role in the death ritual mamukur, which was customarily held 42 days after a cremation. On the pyre the soul of the deceased was liberated from the body and dwelt for a while among the leaves and branches of the waringin tree. During the mamukur ritual, the soul was brought down from the tree and dispatched to the sea, from where it would, in purified form, rise to join the deified ancestors on the mountains. To the inhabitants of Blahkiuh, then, the waringin became a crucial element in the life cycle of the human soul.

Road crossing, puri, gria, market, wantilan, and waringin were the elements of the centre which made manifest the authority of Gusti Putu Mayun. The one element which could be said to be lacking was a temple, ${ }^{32}$ though this certainly did not mean that the punggawa, as a modern administrator, was not interested in temples. On the contrary, he took upon himself the care of the dynasty's mountain temple near desa Tinggan, located in his district. ${ }^{33}$ While colonial reorganizations were forging ahead, Gusti Putu Mayun laid the basis for his power. In addition, the new centre and the old mountain temple legitimated the punggawa's administrative position and made visible the dynastic dimension of puri Mayun.

\section{Nobility and commoners}

The influence of colonial policy went far beyond the level of district administration. South Balinese society as a whole underwent fundamental change. Along with the introduction, simplification, and modernization of district rule, the BB sought to 'restore' southern Bali to its 'original' way of life. The simultaneous implementation of two conflicting objectives - moderniz-

31 This consecration probably took place in 1916. Informants recall that the tree was no more than ten feet tall.

32 Immediately opposite the market was a small sacrificial shrine made of stone (a tugu), erected there in 1900 by Gusti Made Ringkus. G. Putu Mayun had the brahmans Mas take care of this tugu. This sort of transfer of responsibility for places for offerings or for temples was fairly common in southern Bali. Only rarely were places of worship dismantled; under a new regime they were more likely to be given a new function.

33 The punggawa's mother was G. Ag. Istri Ratu, popularly called Ratu Biang. She retired just north of Blahkiuh in a little shack on the sawah, devoted herself to meditation, and prepared her own holy water. She was the architect of the temple repairs. She also restored the mountain temple pura Pucak Tedung near desa Petang. 
ation and restoration - created a number of contradictions typical of the colonial period. ${ }^{34}$ One of these had to do with the relationship between the nobility and the commoners.

The Dutch attitude towards the Balinese nobility was ambivalent, especially in relation to the royal dynasties. On the one hand, the colonial government wanted to get rid of the old rulers. 'The rule of the Balinese kings is not popular anywhere; the people look upon it as a necessary evil', according to a brief brochure handed out to soldiers readying themselves for the 1906 expedition (Gegevens 1906:9). The reorganization of district administration, too, indicated that the colonial government was not inclined to be overly sensitive in its dealings with old dynasties. ${ }^{35}$ In fact, the BB intended to take the place of the old rulers. In justifying this take-over of power, it was argued that the Balinese nobility actually did not originally belong on the island at all. This view rested on the thesis proposed by T.S. Raffles (1817, II, appendix K:ccxxvi), that on Bali one found old Java still living on. The notion was adopted by influential authors such as J. Crawfurd (1820), W.R. van Hoëvell (1845, 1846a, 1846b), and R.H.Th. Friederich (1849-1850). Van Hoëvell was convinced that 'in a way, the Balinese are in a situation identical to that of the Javanese at the beginning of the fifteenth century' (1846a:32). A few years after him, Friederich concluded that the Balinese nobility had come from Java; at the nadir of the Majapahit empire they had swooped down upon the island and conquered it. In saying this, Friederich had rounded out the first colonial model of Bali: there was a non-indigenous culture of nobility whose origin was Hindu-Javanese; through the ages it continued to exist unperturbed. This point of view took deep root in colonial thought and became politically relevant as well. ${ }^{36}$

On the other hand, the colonial government could not easily rid itself of this 'foreign' nobility. According to the model, Bali embodied everything which, since the arrival of Islam in the fifteenth century, had disappeared from Java, namely, the old, superior Hindu civilization of lost Majapahit. Westerners were predominantly anti-Islam; consequently, the supposed need to restore Hindu Bali took on an extra dimension. According to Van Hoëvell, it was due to Islam that Java had 'regressed and been corrupted both morally and spiritually, in the course of four centuries, whereas Bali

34 In Chapter 9, section 2, I discuss this at greater length. See also Schulte Nordholt 1986:34-49.

35 This was also true for the dynasties that had survived colonial annexation. In 1908 the Council of the Indies recommended that 'in due time' royal rule in Bangli, Gianyar, and Karangasem should be ended. ARA, MvK V28-6-1909-1, Advice Raad van Indië 11-12-1908 and letter G.G. to Resident Bali and Lombok 28-12-1908.

36 See for instance Hanna (1976:3), Swellengrebel (1960b:21), and Zoetmulder (1974:20) for repetition of the story of the Balinese nobility's conquest and migration. Boon (1977:72-3) and Geertz (1980:14) cast doubt on the historical accuracy of this. See also Chapter 2, section 1. 
remained untouched' (1846a:17). Seventy-five years later the same opinion still prevailed, as we glean from a statement by the then assistant resident of South Bali: 'Throughout, the history of the Indies has demonstrated that conversion to Islam brings regression, morally, physically, financially.' 37

The colonial government was faced with a dilemma. If the highly valued Hindu culture on Bali was to be conserved, the island should not only be shielded against 'damaging' influences from outside; the 'foreign' nobility, as major representative of culture, should be protected as well. However, the greatest threat to the nobility emanated from the colonial administration itself. After all, a succession of administrative reorganizations had pushed most of the regional lords aside. How long could the weakened nobility still continue to function as bearers of traditional culture?

The Western view of Bali became more complicated when, forty years after Friederich, the young controleur F.A. Liefrinck discovered 'original' Bali in Buleleng. Central to his conception of Bali were autonomous, egalitarian communities constituting the 'original' elements of society. Liefrinck called these communities 'village republics'. ${ }^{38} \mathrm{He}$ took them to be far older than the 'foreign' royal regimes, which overran Bali much later and, he believed, never managed to penetrate the local communities.

Liefrinck's views were hardly unique. They were congruent with the nineteenth-century Western concept of the Asian state in which despotic kings ruled over autonomous local communities. ${ }^{39}$ Moreover, his findings corresponded with the needs of the colonial state. 'Foreign' royal rule could, of course, be replaced by a colonial government prepared to respect and, if necessary, restore Balinese village communities. It further implied that the government need not exert complex control over individuals; control over

37 KITLV, Coll. Korn:284, letter Assistant Resident Berkhout to Korn 5-8-1921. A the end of the nineteenth century the local Muslim leaders in Java and Sumatra were the greatest threat to the colonial state, as was Sarekat Islam at the beginning of the twentieth century. On the anti-Islam climate in Europe, see Said 1979; on the interaction between Bali and Islam during the pre-colonial period, see Vickers 1987.

38 Liefrinck 1927:281. The term 'village republic' would long echo in colonial literature; see Korn (1933). Between the time of Friederich and the time of Liefrinck, others had written on Bali, for instance colonial official Van Bloemen Waanders $(1859,1868,1870)$. But his descriptions made for a highly complex picture, soon forgotten when Liefrinck presented his much simplified and convenient model of Bali.

39 See Dumont 1970b; Cohn 1987; P. Anderson 1974:462-95; Breman 1980. It is likely that Liefrinck was influenced by studies on India, as indicated by his 1890 reference to G. le Bon, Les civilisations de l'Inde, Paris 1887. Liefrinck's discovery of 'original' Bali made him one of the founding fathers of the adat law school, the Western formulation of local institutions and customs (see Van Vollenhoven 1928). The study of adat law was predicated on a belief in gradual evolution from communal villages to greater individual freedom. Often, essential changes were pictured in terms of deterioration and destruction due to royal penetrations. In addition, the adat law school applied a strictly legal approach focused on formal rules and institutions, rather than on dynamic socio-political relations. 
villages would suffice. Accordingly, villages were made into the basic administrative units, control of which the Dutch found not only more convenient but also a good deal cheaper.

At first sight, this egalitarian 'village' model of Bali seems difficult to reconcile with Friederich's model of a hierarchy of nobles. But one did not need to choose between them since the models were not mutually exclusive. They could be applied alongside each other, because noble Bali and village Bali were seen as separate worlds, essentially without interaction.

As Liefrinck's prestige rose within the colonial bureaucracy, so did the popularity of his model. After 1906 the first administrators in South Bali used it as a matter of course. The prevalent notion was that national feeling, a bond among desa holding together a small realm - that sort of thing does not exist; every desa is a small republic' and 'the institutions of the people - desa and subak - make no caste distinctions'. ${ }^{40}$ The Dutch were convinced that in South Bali, too, they would find the 'original' Bali, covered with an 'aristocratic dome' which was 'essentially alien' to the people. ${ }^{41}$

The result of this separation of the nobility and the people was that the BB left no room for the dynamics of vertical relationships between lords and followers. Instead, a compartmentalized, static concept of Bali arose, in which nobility and common folk lived their separate lives each in a world of their own. Moreover, it conferred on the colonial government a guiding and corrective role. The $\mathrm{BB}$ took it upon itself to make reparations for the damage to 'original Bali' caused by royal rule. With full conviction, the Resident wrote in 1909: 'Many excesses have come to cling to the adat like parasites, due to utter arbitrariness on the part of the powerful, and this, of course $[\ldots]$ can be done away with.'

He had to admit, however, that at times it might be difficult to distinguish 'genuine' adat and royal 'parasites':

'The colonial official will find it far from easy to determine whether he is dealing with an exaggerated display based on some old institution, or with an unjustified distortion of adat. He will find it almost impossible if the native judges and headmen prove to be incompetent or unreliable informants.' (ARA, MvK MvO Resident G.F. de Bruyn Kops 1909.)

40 Gegevens 1906:9; Van Roon 1916:262. The first assistant resident of South Bali, H.J.E.F. Schwartz, applied Liefrinck's model very strictly. Liefrinck himself probably would not have done so, in view of his efforts to retain some power for the southern Balinese dynasties (see Chapter 7). His model did prove applicable to Buleleng, because in northern Bali the relationship between court and commoners had been very different. Moreover, since 1872 royal rule had ceased to function there.

41 Damsté 1922:7-8. A typical trait in the colonial perception was that the Western conqueror saw himself as farther advanced in time than the conquered peoples, who were considered to live in an ea:lier evolutionary age (see Fabian 1983). 
Eventually these problems were solved through the use of Friederich's and Liefrinck's models. Accordingly, South Bali did not become a new area to be researched; rather, it was a region badly in need of a 'restoration' effort along lines set out in authoritative treatises, the more so since the Balinese themselves were obviously at a loss as to how their society was actually meant to be. In this situation, power was not the offspring of knowledge; colonial dominance produced the desired social 'insight'. This knowledge and the prescriptions that followed from it did not belong to the realm of ideas alone. Pragmatic considerations lurked behind the desire to restore Bali to its 'original state'.

\section{'Caste' hierarchy}

During the 'new order' that followed upon the chaos created by colonial conquest, the Dutch were most unwilling to upset the Balinese nobility. This cautious approach led to the appointment of many local lords as punggawa, but its consequences reached still further. Although many individual noble punggawa lost their positions during the administrative reorganizations after 1910, other measures aimed at protecting the nobility as a category remained in force throughout the entire colonial period. These measures eventually resulted in the creation of a rigid caste system. This happened in 1910, when it was decided to 'uphold the caste system, as it is the foundation of Balinese society'. ${ }^{42}$ In addition to an awareness that the nobility represented a unique Hindu culture, it was especially the colonial need for law and order that gave rise to this decision. Law and order would be assured as long as the nobility was not made to lose too much face. ${ }^{43}$ Furthermore, to render the relationships clear and controllable, it was most expedient to introduce order into the complexity of the Balinese hierarchy.

In pre-colonial Bali, the hierarchical order had been flexible and typically displayed a good many regional variants. There was a certain degree of openness and vertical mobility. The colonial bureaucracy could not accommodate this dynamic sort of framework, which is why the BB felt it 'best to conform as much as possible to the theoretical four-caste system'.44 And so the old hierarchical order was formally transformed into a uniform

42 KITLV, Coll. Korn:166, Notulen bestuursconferentie september 1910. The meeting was attended by all members of the BB on Bali and Lombok; some Balinese nobles acted as advisors.

43 See, for instance, the article by Controleur J.J. Fraser (1910:872-3, 900-1). He acknowledges the primacy of egalitarian popular law as formulated by Liefrinck. Still, keeping in mind the lesson of the Mutiny of 1857 in India, he felt that it was politically more opportune that the BB not go too far in alienating the nobility.

44 Korn 1932:174-5. To be sure, the four-caste model had long been known on Bali, but not until Dutch rule was it subjected to a uniform and stringent classification. See Boon (1977:40): 'Caste is largely taken as a fact rather than ideology.' 
system of three closed castes. These were the Brahmana, Satria, and Wesya jointly known as the triwangsa - to which some six to eight percent of the population belonged. Below the triwangsa were the 'rest' of the Balinese, collectively given the name of Sudra. Often, informants employed by the BB to indicate who did and who did not belong to the nobility were themselves Balinese nobles. Having their own interests at heart, they 'proved only too eager to give the widest possible interpretation to the Sudra concept'.45

The new caste system took no account of the special position of the many intermediate groups that played an essential role in the earlier lordfollower relationships. Consequently, a number of privileges of most prabali families and eminent jaba were lost, largely because the Dutch indiscriminately counted these people as Sudra. The distinction between nobles and commoners, then, was too heavily emphasized.

The creation of uniform, closed categories also caused shifts within the nobility. The leading nobility of Mengwi suddenly found themselves belonging to the lower Wesya 'caste', while their counterparts in Bangli, Gianyar, and Klungkung were counted as members of the higher Satria 'caste'. The differences in prestige, which had not been great in former days, were translated into the absolutes of caste boundaries. Members of the Mengwi dynasty could only see this as degradation, since they had always looked upon themselves as Satria rather than Wesya. ${ }^{46}$

To legitimize the new caste system, the BB fell back on certain 'authoritative' sources. The assistant resident caused two old codes of law to be given the status of standard works (Adi-agama and Agama 1909). These consisted of a compilation of Old Javanese texts, augmented and mixed with royal decrees written in Balinese. It is probable that the codes had functioned as a normative source of law, though likely with room for interpretation and, in many cases, subject to the ruler's fiat. Though rife with inconsistencies and far from exhaustive, these books henceforth constituted an absolute standard. ${ }^{47}$

The Dutch created new indigenous courts. These Raden Kerta, established in each subdivision, were instructed to adhere to the above books as their

45 Korn 1932:174-5. I do not think that the term Sudra can be used as synonym for jaba in this context. The term jaba refers to a person's position outside of the nobility. Sudra - a word primarily used by the Dutch - points to a status within a closed group below the nobility.

46 ARA, MvK MvO Resident G.F. de Bruyn Kops 1909, H.W. Veenhuyzen 1914. Information from G. Ag. Gede Rai, puri Kajanan, Mengwi; G. Ag. Ajeng, puri Labah, Kedampal.

47 The Dutch administrators could and should have known better. Concerning the time of royal rule, the controleur of Tabanan (ARA, MvK MvO A.M Zandveld 1907) noted that 'little attention was paid to legal codes [...] highest authority lay with the will of the leaders'. For a trenchant criticism of the use of these codes, see Korn 1932:57. It was only after Korn's Adatrecht van Bali (1924, second revised edition 1932) that the codes receded somewhat to the background, while 'Korn became the new Bible' (personal communication former controleur F.W.T. Hunger). 





guideline. Moreover, the majority of the courts' members were brahmans. ${ }^{48}$ The judges were recruited from the nobility and promoted the continuity of the colonial caste system. Accordingly, during almost the entire colonial period, disproportionate emphasis was placed on legal rules of HinduJavanese derivation. In spite of Liefrinck's authoritative model of 'original' Bali, political pragmatism and bureaucratic routine led to continuous reproduction of the noble model:

'Every administrator who does a stint on Bali knows that he is being posted to the island of Hinduism. He goes in search of that Hinduism and he finds it: on his desk, in the court, in the titles and the temples [...]. All of which makes for the same administrative errors over and over, without end. ${ }^{49}$

The absolute differentiation between noble and non-noble was manifested in another area, too. This happened when colonial administration literally penetrated South Bali by constructing an extensive road system. Corvée labour was required of the inhabitants, though not everyone was subjected to it. Those who belonged to the nobility were exempted from heavy physical labour. They performed light duties such as courier services only. From jaba households, one 'able-bodied' man was put to work on the roads without pay for 36 days a year. ${ }^{50}$ Corvée was tangible proof of the rift between nobles and commoners. If a person did not do physical work, he was a noble, and being conscripted showed that a person belonged to the Sudra.

Obviously, the intermediate groups mentioned above felt especially threatened, and sought to avoid conscription. The point was not so much

48 Kerta (karta,kreta), Balinese: custom, regulation (from Sanskrit/Old Javanese Krta); priest-judge (from Sanskrit/Old Javanese kartr), Van der Tuuk 1897-1912, II:180. Comparable councils were in existence during the royal regime as well, but under colonial rule the political context in which they functioned was changed in fundamental ways. In 1932 there were 23 judges on Bali, 17 of whom were brahman, 5 were Gusti, and just one was Sudra (Korn 1932:416). The courts were chaired by the controleur.

49 Korn 1932:57. At iast, under Resident H.T. Damsté (1919-1923), a beginning was made of closer study of local adat law (see Korn 1955). To be sure, the stipulations in the royal penal codes were not all adopted without qualification. Cruel punishments, for instance, were mitigated; nevertheless, transgression of caste boundaries was punished severely. If a brahman woman and a jaba man were caught in each other's company they would not be killed, as they would have been formerly; their punishment would be exile from Bali for life. The severity of the penalty was reduced if the perpetrators were of nobler birth (KITLV, Coll. Korn:166, Notulen bestuursconferentie sept. 1910). In addition to illicit male-female relationships, transgressions of rules of courtesy were punished heavily as well. In 1906, for instance, a jaba from Singaraja was banished for life because he had insulted a brahman judge (Fraser 1910:883).

50 Officially stipulated by Staatsblad van Nederlandsch Indië 4-12-1913. From 1915 onwards, corvée was remunerated (initially 20 cents per day, later 55 cents), and the number of working days was reduced to 22 per year. In 1920 South Bali had 105,263 corvée labourers registered; 10,195 members of the nobility performed lighter tasks (ARA, MvK MvO Assistant Resident A.J.L. Couvreur 1920). 
that they objected to the heaviness of the work; what bothered them was that their 'being fully obligated to perform corvée led to the conclusion that they were Sudra' (Korn 1932:176). For this reason members of both the lesser nobility and the more prominent jaba made every effort to retain their traditional status. Families of the lesser nobility sought formal recognition of their titles from the indigenous courts, which led to a veritable 'struggle for caste'. In 1910 the Raad Kerta of Badung had to process no fewer than 150 title claims in a single month. Seventy of these requests were honoured. These happy few were now assured of government-supported noble status just prior to the finalization of the caste system. The losers were Sudra, unalterably so. ${ }^{51}$ Most unfortunate were the jaba families who sought to save face by refusing to engage in corvée labour. Repeated military intervention in 1910 and 1911 and heavy sentences were meant to teach the obstinate that henceforth they were just common Sudra. In these matters, Dutch officials followed the norms of the nobles, a telling illustration of this being that they would seek and heed the advice of the brahman priests. ${ }^{52}$

To the people, corvée was a new phenomenon, very different from what they were used to. The oldest informants in Blahkiuh remembered vividly that in the days of the old noble regime a lord could customarily appeal to his own followers only, that is, to those who worked a pacatu sawah. In exchange for land, followers owed their lord loyalty and servitude. The new ruling put an end to this trade-off type of situation. Corvée was mandatory for every single jaba household, regardless of their relation to the punggawa responsible for its implementation. Furthermore, conscripts were made to work not just from six to eleven in the morning, but to the end of the day. The type of work to be performed was new as well. They were used to labour tangibly linked to their lord - repairs to the puri and the like - or of benefit to the workers themselves, as in the case of preparations for large rituals. But now roads had to be built, far from home, and for no apparent purpose. One result of all this was that corvée tended to be left to the women. The

ARA, MvK MvO Controleur Badung C.C. Krom 1913; V10-8-1911-18, report March 1910.

52 In the area of Batur (part of Bangli) the nobility had little authority, and resistance was rather general. In Karangasem groups of village notables (the pasek and the bendesa) did not come to work. In both areas corvée could only be enforced by military coercion (ARA, MvK V10-8-1911-18, report February 1910; V6-6-1912-15, report November 1911; MvO Controleur Karangasem W. Doornik 1913). In Gianyar the Pandé Wesi, members of the clan of blacksmiths, refused corvée. After their leaders were arrested and convicted, their resistance, too, was broken (V6-6-1912-15; concerning the Pandé Wesi see Guermonprez 1987, especially $141-9 ; 238-46$ ). The brahman advisers of the BB did not fail to strengthen their own position if they could. For example, they managed to force groups of Pandé Wesi to obtain holy water from them, rather than from their own priests or Empu. In Gianyar another category of priests, the sengguhu, lost the right to distribute holy water as well (ARA, MvK V3-6-191345, report March 1912; V6-6-1912-15, report January 1912; on the sengguhu see Korn 1932:15166. 
men experienced conscription as unjust, and were most reluctant to perform useless labour. ${ }^{53}$

The corvée stipulation took on an added dimension in districts where the old nobility, through administrative positions, had managed to retain its power. The punggawa was responsible for mobilization of the conscripts and for the construction of roads in his district; consequently, the new rules provided him with an additional source of power. Officially, records had to be kept in each district, so that the BB could keep an eye on things. In practice, Dutch officials had little or no control over regional mobilization and labour distribution. An inquiry showed that registration was shoddy almost everywhere. Some punggawa used this situation to their own advantage by using corvée labourers for their own private purposes. ${ }^{54}$ Moreover, if their subjects refused to comply, they were subject to colonial sanction: incarceration in the boei (prison) in Denpasar. Conscripted nobles conducted them there.

Because of his administrative position in Blahkiuh, Gusti Putu Mayun had recourse to an extraordinarily large reservoir of labour. In addition, as lord of puri Mayun, he was able to bestow personal favours such as exemption from labour or reduction of the workload. As the people saw it, corvée was a new duty towards the lord of puri Mayun rather than service to the Dutch; this link between conscripted labour and the puri was readily made because the intermediaries were members of Gusti Putu Mayun's entourage. ${ }^{55}$ Hence, the fact that Gusti Putu Mayun had his new centre in Blahkiuh built by conscripts caused no surprise. This sort of work made more sense to people than building roads for the government.

The forced-labour laws drastically changed power relations in the Abiansemal district. Gusti Putu Mayun could avail himself of more labour than ever, while the demands upon him were few. Moreover, as punggawa he controlled manpower in the domains of nobles in his district, so that their positions were still further undermined. ${ }^{56}$

53 ARA, MvK MvO Assistant Resident A.J.L. Couvreur 1920.

54 ARA, MvK V29-3-1919-6, report J.H. Liefrinck 4-6-1918; KITLV, Coll. Korn:97, memorandum Resident H.T. Damsté (n.d.), in which is said: 'There is no supervision whatsoever of the deployment of corvée in the districts and villages.'

55 These intermediaries were the village head of Blahkiuh, responsible for mobilization, and the mandor jalan, labour overseer. See the appendix at the end of this chapter.

56 This did not mean, however, that the conscripts had no further duties towards their own lords. In many cases their workload doubled. 


\section{3. 'Restoration of the village'}

Colonial annexation had put an end to the old royal rule. On the other hand, the Dutch administration strengthened the status of the nobility as a whole and the power of some. Legitimized by law and effectuated by corvée, the uniform caste system even triggered a new phase of Hinduization in South Bali after 1906.

Paradoxically, Liefrinck's model of 'original' Bali was a seamless fit for this. The Dutch thought in terms of three noble castes and just one undifferentiated 'miscellaneous group' below these: the Sudra. ${ }^{57}$ But the vast majority of the people carried a double identity. Levelled by the caste system and spread over countless South Balinese villages, this majority also represented 'original' Bali, so that it was easy to identify the Sudra as representatives of 'egalitarian' and 'village' Bali and fit them into Liefrinck's model.

Liefrinck's notion of the village contained three components useful to the $\mathrm{BB}$ in controlling the South Balinese people. First, every desa was 'a micro-republic'; second, relations within a village were 'entirely democratic'; third, village society was largely religious in character. ${ }^{58}$ The BB used the myth of the democratic village republic as a pretext to strengthen the caste system. Misuse of power on the part of the nobles was inconceivable, since the closed, egalitarian village community was assumed to be strong enough to keep the nobility at bay. In the second place, the Dutch saw the 'republican' character of the desa as the means for colonial rule to permeate to the village level. To effectuate this, though, a thorough reorganization was needed, because the situation as encountered by Dutch officials bore little similarity to the model as sketched by Liefrinck. Once again, as in the case of the introduction of the caste system, a theoretical blueprint was turned into an absolute standard. In consequence, in-depth research into the nature of local relationships in South Bali was considered superfluous.

The major impediment to the reorganization of the South Balinese village system was the existence of countless vertical relationships typical of the earlier royal rule. Lords and followers had been connected via a chain of intermediaries, the lowest link of which were the mekel. Groups of followers of a single lord often lived spread out over various villages, so that one village might have several mekel. This meant that the village as such was not part of the royal pyramid. There was a village council led by a bendesa, and most villages were subdivided into wards headed by a klian (see Chapter 5). The Dutch found this complex system of royal mekel, local bendesa, and ward heads too confusing. The solution was to 'simplify desa

57 In this connection Resident H.W. Veenhuyzen linked the terms sama (equal) and kaula (servant) (ARA, MvK MvO 1914).

58 Liefrinck 1927:281, 285; see also Schulte Nordholt 1991a:11-5. 
administration and to restore it to the original situation', for 'it proved necessary to purify desa government of royal appendages'. ${ }^{59}$

This plan of desa renewal complied with the wishes of the BB in every respect. The 'restored' villages turned out to be uniformly organized, territorially defined segments, eminently suited to function as the lowest administrative units. Next, the BB introduced a single village head, the perbekel. Formally elected by the people, he became the lowest link in the colonial administrative hierarchy. He replaced the many mekel and gradually edged out the bendesa.

Just how completely administrative pragmatism took precedence over the confessed ideology of village restoration can be deduced from the largescale reassignment of villages between 1907 and 1910. Although the criterion for determining a 'genuine' village was entirely clear, in practice this rule was often deliberately not applied. What happened was that

'desa were joined arbitrarily so that [groups of] two hundred corvée labourers resulted. To this end, desa were sometimes demoted to banjar [wards], or unconnected banjar belonging to different villages were amalgamated. ${ }^{60}$

The newly formed village of Mambal, for example, was a hodge-podge of no less than seven small desa; in Blayu nine associated wards (banjar) were made into three different villages. Hence, the result of colonial village restoration was that confusion arose on the local level as to who belonged to what village.

Dutch officials denied, however, that they had created an entirely new village system. Their argument was that the religious character of the desa had been meticulously observed and that the desa had remained 'essentially untouched'. ${ }^{61}$ They appealed to Liefrinck's thesis that the Balinese desa was first and foremost a religious community. But the Dutch officials who came after him did not interpret this in a broad sense; rather, they isolated religion and made it a separate sphere of life. In this way 'religion' was severed

59 ARA, MvK MvO Assistant Resident H.J.E.F. Schwartz 1909, cited in MvO A.J.L. Couvreur 1920 (italics mine).

60 Korn 1932:129. The criterion was that wards which were ritually bound to the same village temple (more accurately, with the balé agung of the pura puseh/desa), together constituted one desa (ARA, MvK MvO Controleur Badung G. de Haze Winkelman 1912). West of desa Mengwi the situation become more complex still. There were three banjar - Bajra, Tapesan, and Umabian - that belonged to desa Mengwi, but had fallen to Tabanan in 1891. During the reorganization the BB assigned banjar Bajra to the new desa Bringkit (district Marga, Tabanan subdivision); banjar Tapesan was joined to desa Abiantuwung (Kediri district, Tabanan subdivision); banjar Umabian went to the new desa Peken (Marga district, Tabanan subdivision) (KITLV, Coll Korn:147, Overzicht dessa's in de Onderafdeling Badung 1920; information G. Sutarja, Blayu). In the early 1930s a number of these amalgamations were nullified; see Hunger 1932.

61 ARA, MvK V28-6-1909-1, report January 1909; MvO Resident H.W. Veenhuyzen 1914; KITLV, Coll. Korn:118, Nota's dessawezen 1907-1920. 
from the 'worldly' arena of politics and administration. As long as the sphere of 'religion' was respected, the colonial government could claim the world of politics for itself. But this meant that Bali was being introduced to a completely new distinction between religious and worldly authority. The upshot of all this was that leadership in the desa was divided between the new-style perbekel as 'worldly' village head and the old bendesa as religious leader or adat head. The BB had managed to leave the desa 'untouched' and to gain control nevertheless.

Whereas the BB claimed to have reinstated the desa in their traditional closed character, the old vertical relationships from the days of royal rule were in fact replaced by a new colonial chain of command through which corvée conscripts were mobilized. The key figure in this new order was the perbekel. He controlled a territorially well-defined area, and he was the sole link with the higher echelons of the colonial administration. For the common people, this meant that the old alternative of falling back on a mekel of another lord when things got rough was no longer available. It was nearly impossible to oppose the new perbekel, since he was backed by the colonial apparatus.

To be sure, in theory the colonial perbekel shared the leadership of the desa with the old bendesa. But in many cases the bendesa was pushed to the sidelines of local power relations. Kicked upstairs as 'spiritual leader', he was rendered virtually powerless by the new colonial chain of command.62

When we take a closer look at the background of the perbekel, we are again struck by the degree of pragmatism that guided colonial politics. The vast majority of the newly appointed perbekel were nobles. When royal rule in South Bali was done away with, many of the lesser links in the old hierarchical networks lost their function. This group of low-level nobles was a potential threat and hence had to be kept under colonial control. The simplest way to achieve this was to recruit the new perbekel from among them, and the BB did so on a large scale.

'A veritable army of former manca and perbekel, taken over from the days of royalty, now had to be taken up into the desa administrations; most of the manca became perbekel, whereas the [former] perbekel became klian banjar [ward head], which meant that a klian banjar had lost his position. ${ }^{63}$

This is how one controleur described the process in Gianyar subdivision. In the Mengwi region the same recipe was applied. During the reorganization,

62 ARA, MvK MvO Controleur Badung V.E. Korn 1921. Interviews with descendants of village leaders in the Mengwi region confirmed that this process took place.

6. De Kat Angelino 1921a:238-9. He described this shift in Gianyar subdivision where, according to a report from 1916, no less than 85 of the 140 perbekel were of noble descent (ARA, MvK V4-9-1917-32, report Controleur A.M. Ballot). 
the 87 existing desa were reshuffled into 47 new villages, only nine of which had a non-noble perbekel in 1920. The other villages were henceforth controlled by a perbekel who, as far as traceable, was recruited from the regional nobility. ${ }^{64}$

Most noble families, then, lost their power on the regional level, but on the village level the nobility gained a greater hold over the people than they could ever have achieved in the old days. The separation between nobility and the common people existed only in the colonial image of Bali. It was on this image that the myth of the 'democratic village republic' was based. This myth, in turn, was the pretext that facilitated efficient colonial control.

\section{Puri Mayun and desa Blahkiuh}

The official view was that a perbekel was elected by the people, whereupon the district punggawa would propose the candidate to the controleur, who after ascertaining literacy in Malay, appointed the village head. In this way those whose mastery of the colonial language was inadequate were excluded; moreover, the 'advice' of the punggawa was decisive. A controleur was usually not familiar enough with local relationships to be able to judge independently. Furthermore, he would feel strongly that the punggawa should have loyal village heads.

In Abiansemal district Gusti Putu Mayun was successful in having a good many perbekel appointed with whom he had personal ties. He was able to forestall undesirable candidates by advising the controleur negatively. Should a perbekel, once appointed, prove lacking in loyalty, he could turn to the controleur again and recommend dismissal. ${ }^{65}$ Informants do not remember there having been free elections in Blahkiuh. The 'wishes' of the punggawa tended to be respected, as a result of which confidants of the punggawa became village heads in Blahkiuh throughout the colonial period. One of these, a younger cousin of the punggawa, very readily admitted: 'Of course the people of Blahkiuh were afraid of us; after all, we lived in the puri.' Korn's words, that the noble perbekel 'ruled the entire desa like a little king' (1932:312), applied to the perbekel of Blahkiuh and many other places.

Compared to the opportunities offered by the pre-colonial system, the new arrangement allowed Gusti Put Mayun to control his immediate en-

64 KITLV, Coll. Korn:147, 157, resp. Hoofdenregister Onderafdeling Badung 1920, Staat dessa dan bandjar Onderafdeling Badung 1931; interviews conducted in 1983 with people spread over the region. These interviews indicated that prior to the reorganization a far greater proportion of village heads were jaba. After 1916 the number of villages was reduced further, to 38 . Of the nine jaba perbekel, five headed small mountain villages where no nobles resided.

65 For instance, G. Putu Mayun expanded his influence in desa Abiansemal by blocking the candidature of a puri Abiansemal intimate and by having his own candidate appointed. 


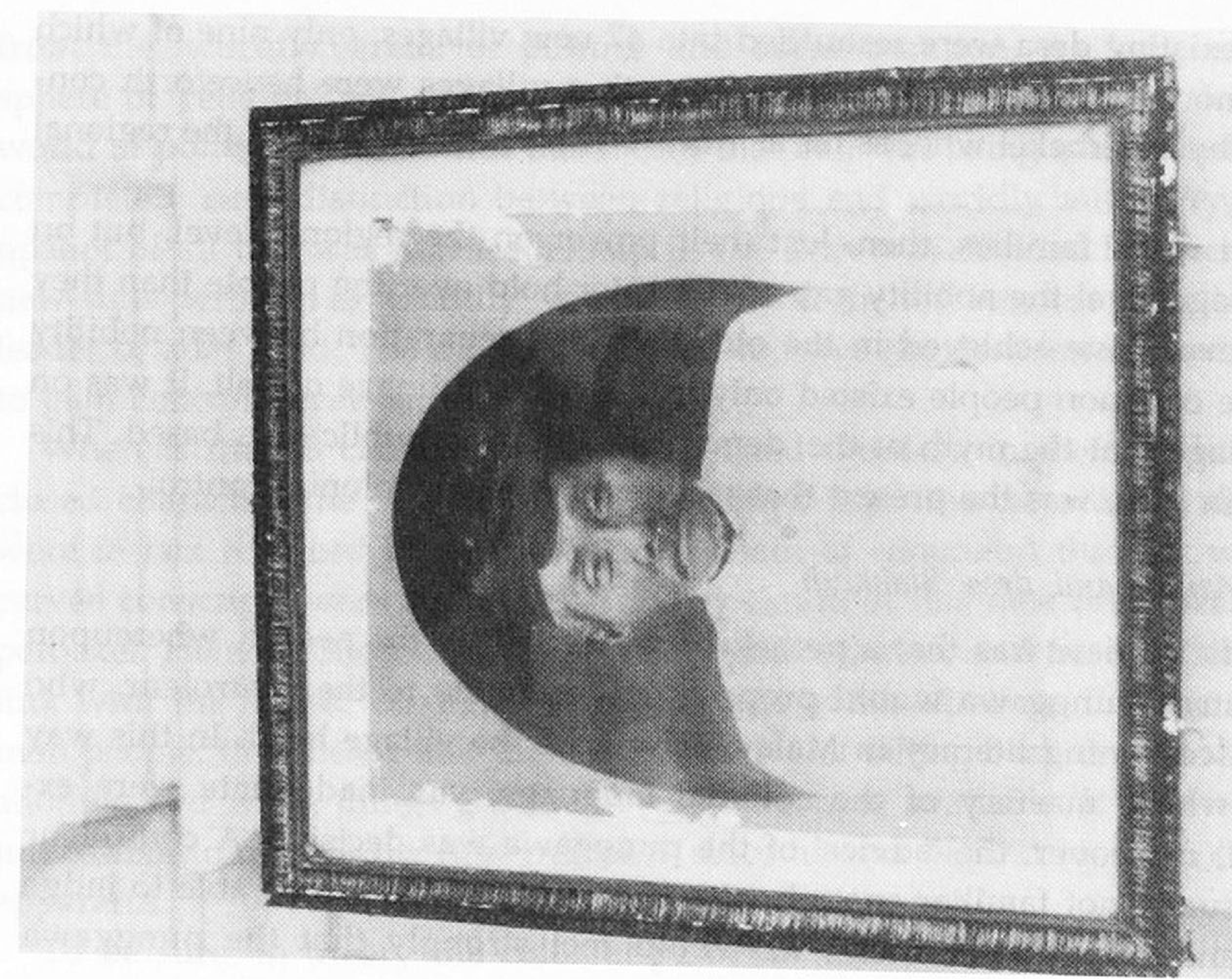

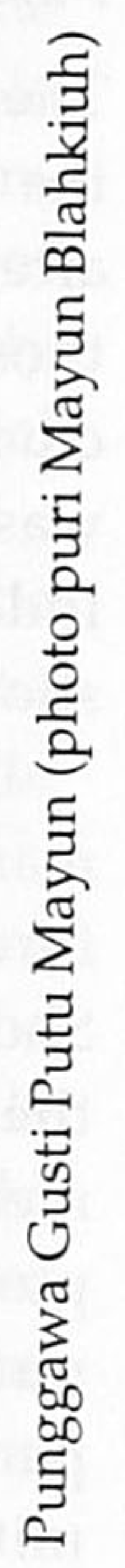


vironment more efficiently and with less manpower. Capitalizing on the colonial monopoly of power, the punggawa could make do with one perbekel and three klian banjar and yet control all of Blahkiuh. These four loyal subordinate officials replaced the plurality of intermediaries of the old system. These four were the exclusive entry to the puri, and they alone communicated the puri's commands.

The dominance of puri Mayun over local relationships was felt not only in administrative matters but permeated much farther. In the area of adat, too, Gusti Putu Mayun's were passed down by his perbekel. For example, the puri prescribed that the jaba in Blahkiuh should all have the same type of gate to their yard. A more embellished gate was reserved for those who belonged to the entourage of the punggawa. Other regulations had to do with more meticulous observance of ritual duties, which implied substantial expenditure for the people. ${ }^{66}$ Most informants said that under Gusti Putu Mayun the gap between the nobility and the common people greatly widened, in consequence of which the jaba in Blahkiuh were levelled to a uniform layer of Sudra.

Although little of puri Mayun's power remained in 1983, informants in Blahkiuh still spoke in hushed, respectful tones of the old punggawa. Their tales were ambivalent, mingling awe and pride. People were afraid of Gusti Putu Mayun, who, unlike the anonymous, far-away officials of the BB, very tangibly personified the new, mighty regime. ${ }^{67}$ If one came face to face with him it was always in the presence of one of his henchmen, who did the talking. The villager would fear to speak because he might err, or simply because he had not mastered high Balinese. Far better to keep your distance, call no attention to yourself, unless, of course, you were part of the entourage of the puri. Still, recalling the days that puri Mayun ruled Blahkiuh, people would evince pride, too. As the power of the puri increased, so did the prestige and status of Blahkiuh. The village was brought out of relative obscurity and grew into the major locality in the region. In spite of fear of the puri, people were proud to live in Blahkiuh because its lustre shone on them as well.

Half-hidden behind the myth of the 'original village republic' and firmly ensconced in the new administrative framework, Gusti Putu Mayun was able to provide his dynastic authority with a solid foundation.

66 When jaba twins of unequal gender were born, for instance, purification (caru) was a very costly ritual in the desa. But if the higher nobility was blessed with such twins, it was considered most fortunate (see Belo 1970b).

67 Repeatedly, this fear was expressed in terms like ngetor, trembling (of the knees), and jejeh, rigid (with fear). 


\section{Subak 'restoration'}

A second colonial myth went along with that of the village republic. It was forged in the early twentieth century and was related to the local irrigation associations in southern Bali, the subak. The myth was that, separate from the village and independent of higher bodies, the subak was an autonomous and harmonious cooperative, efficiently distributing water over the plots of its members, whether wealthy or poor, meek or mighty. ${ }^{68}$ These subak, together with the desa, were the pillars on which 'original' Bali was seen to rest.

As in the case of the desa model, BB officials had not gained their insights into southern Balinese irrigation systems through research of their own. They relied on the colonial expert, F.A. Liefrinck. His description of northern Balinese subak was applied as an absolute standard when the BB began to restore the south to its 'original' state. ${ }^{69}$ But there were significant ecological differences between northern and southern Bali. Buleleng featured small-scale irrigation systems, while southern Bali had large, dam-controlled regions. Furthermore, organization of irrigation in southern Bali varied by locality, and the boundaries between village and subak were often fluid. Finally, an important aspect in southern Bali was the interaction between the regional nobility and the local irrigation networks. ${ }^{70}$ Liefrinck, however, had presented a uniform model in which no consideration was given to local variants nor to the role of the regional nobles. As he saw it, royal rule originally was in essence unrelated to the subak; it had insinuated itself in the local irrigation networks, appropriating taxes as self-appointed arbiter.

Using Liefrinck's model, the first colonial administrators observed that in southern Bali little was left of the 'original' subak. Assistant Resident H.J.E.F. Schwartz accordingly concluded that irrigation in Badung subdivision was 'sorely neglected'. ${ }^{71} \mathrm{He}$ immediately embarked upon an ambitious programme of restoration, the first successes of which were announced within eight months: at that time he reported that the subak in Badung had been 'restored' in conformity with the Buleleng model. ${ }^{72}$ Two

\footnotetext{
68 For a description of this 'traditional' subak, see Grader 1960a and Geertz 1980:68-86. It is remarkable that so little attention has been paid to the many rules in the available subak documents concerning theft of water, refusal to work, and other conflict situations. These certainly indicate a great deal of tension on the local level. See KITLV, Coll. Korn:193, irrigatiereglement negara Badung eind 19e eeuw.

69 Liefrinck 1886-1887, reprinted in Liefrinck 1927. English translation of part of this text in Swellengrebel 1969:1-73.

70 See above, Chapter 2, section 4 and Chapter 4, section 2.

71 KITLV, Coll.. Korn:97, report January 1907.

72 KITLV, Coll. Korn:97, report August 1907.
} 
years later, the retiring Resident noted with satisfaction that 'in Badung the subak system, the division into irrigation societies, and everything connected with these, is now regulated on all of the more important matters'. ${ }^{73}$

Just what had been 'corrected' the Dutch officials would come to realize eventually. For the time being there was no time for this. The 'restoration' of the subak to its 'original' state, like the village, fitted the needs of the government. Here too, smaller units were joined together to form fewer irrigation networks, all of them organized along the same lines. In this way the basis was laid for a new colonial system of taxation, the 'land rent'. Just as the village was the recruitment unit for corvée, the subak became the lowest level for taxation. The next chapter will expand on this.

The idea of restoration was no more than a flimsy veil covering administrative pragmatism. A memorandum concerning Klungkung subdivision is a telling instance of this:

'The irrigation system, too, ought to be overhauled drastically. In the days of the kings [...] all the nobles and prominent people had their own tax collector who made sure that his own land was watered aplenty. Urgently needed is a separation between irrigation workers and administrative personnel; a division of irrigation areas, headed by a penglurah [or sedahan] must be designed; the subak have to be assigned in groups to avoid too large a number of pekaseh [subak heads] which would impede administrative control. ${ }^{74}$

Within the span of a few years the BB replaced the plurality of relationships from the royal days with a far smaller bureaucracy as a colonial umbrella. In each subdivision a sedahan agung was appointed to head a number of sedahan on the district level. These sedahan, in turn, were in contact with the various subak within their district. ${ }^{75}$ These Balinese officials had a twofold task. They were expected to coordinate irrigation and to collect the land rent tax. The BB looked upon this reorganization as providing a welldefined and controllable entity which, moreover, was integrated into the colonial governmental apparatus. The Balinese thought differently. For them, the colonial reform programme bred disintegration and confusion.

The terms and titles henceforth used in the Mengwi region were novel. To be sure, the name subak was known, but formerly the word referred to a lesser irrigation functionary (Chapter 4, section 2). In its place the Gianyar term pekaseh was introduced, while subak came to stand for a local irrigation network. The terminological shift was not insurmountable, but great confusion ensued when the $\mathrm{BB}$ commenced to reorganize existing irrigation networks. These were joined together at high speed into overarching irrigation districts, supervised by a sedahan. The need for strictly circumscribed 
areas was so strong that in a number of cases the boundaries of the new irrigation districts proved to coincide exactly with those of the administrative districts. This meant that such irrigation districts were not coherent ecological wholes, so that a proper flow of water was seriously hampered (Happé 1919:192; Sörensen 1921). In Badung subdivision, moreover, a tendency became apparent which had occurred in the administrative reorganization as well. The twelve irrigation districts formed in 1907 were reduced to six within ten years. ${ }^{76}$ These amalgamations led to areas of a size that made proper coordination of the irrigation nearly impossible. All the work which formerly was done by the many pre-colonial sedahan, usually intimately familiar with local conditions, now fell to a single Balinese official. The same was in fact true of the subak. It is unknown how many local irrigation networks existed in the nineteenth century; interviews suggest that there must have been many more of them then, and much smaller in scale. As far as we can rely on the estimates by informants, these networks usually had a few dozen members. Colonial reorganization largely ended this by regrouping these countless little networks into new subak. ${ }^{77}$

Many of the new subak lacked cohesion; sheer size stood in the way of mutual cooperation. Subak comprising three to four hundred members were not exceptional. In such cases people remained strangers to each other. Members no longer had shared interests, and the distance between them and the subak chief widened greatly. ${ }^{78}$

The distance between the irrigation leaders and the peasants increased even further because of the bureaucratization of the regional irrigation personnel. In the selection of these officials the Dutch preferred candidates with bureaucratic skills, and often this led to loss of expertise in matters pertaining to irrigation. In addition, the $\mathrm{BB}$ tended to recruit the new irrigation personnel from among the nobility. There were two reasons for this: the Dutch felt that nobles were more literate, and there was the consideration that the government should be careful not to alienate the nobility. These newly appointed noble officials did not lose sight of their group interests and took full advantage of the opportunities temporarily left them by the BB.

76 Adatrechtbundel 1934:472 and KITLV, Coll. Korn:155, Staat soebak 1919. Four of these six irrigation districts were located in the Mengwi region: Mengwi, Kapal, Yeh Lauh, and Blahkiuh, comprising 52, 50, 27, and 26 subak respectively.

77 The result was that Badung subdivision had 229 subak in 1919, of which 155 were located in the Mengwi region.

78 ARA, MvK MvO Assistant Resident A.J.L. Couvreur 1920; Happé 1919:195-7; Korn 1932:316. Fieldwork data concerning the subak in the vicinity of Blahkiuh and Abiansemal confirm this. But the interviews suggest that the old irrigation networks continued to function as cooperatives in the form of munduk (parts of a subak). Nevertheless, water supply depended on the new subak and especially on the new subak head. 
The sedahan agung in particular quickly rose to a key position. He was the only Balinese official on the subdivision level who answered immediately to the controleur, and his position gained him great influence. The controleur, largely unfamiliar with the subdivision, soon turned to him for counsel in many matters. The controleur of Badung wrote in 1912:

'If the controleur can gain his goodwill, which is not difficult to achieve by occasionally asking for his opinion (he is very sensitive to this), you automatically have the district heads, too. ${ }^{79}$

This Dutch official did not realize that the sedahan agung in fact capitalized on the controleur's gullibility. In the course of the seven years that this official, of noble Badung birth, held the post he managed to have several relatives appointed to important administrative positions. Next, this group successfully added large tracts of land to its possessions by means of judicial manipulation. But he went too far when he sought to expand his influence to include the Mengwi irrigation district of Yeh Lauh. The district was still held by an old sedahan from the royal days. This Pan Gelgel, a jaba, would have to make way for a relative of the noble Badung sedahan agung. Pan Gelgel won the day because the subak heads of Yeh Lauh unanimously declared their unwillingness to work with the new leader. Soon thereafter, the self-enriching practices of the clan of the sedahan agung were exposed at last and a number of dismissals followed. Still, the BB had little control over the situation. The new sedahan agung, who proved to be a protégé of the Resident, was able to build a small family empire, right under the colonial administration's nose. Once again the position of Pan Gelgel was threatened, and this time the old sedahan lost out to a noble successor. This meant that about 1914 the last jaba had disappeared from the select roster of irrigation officials in Badung. ${ }^{80}$

Although, according to the $\mathrm{BB}$, district administration and irrigation were entirely separate, in practice relations and interests were often closely intertwined. ${ }^{81}$ Before the sedahan agung appointed his subordinate sedahan, the punggawa of the districts were consulted. The sedahan in turn consulted with the punggawa in connection with naming their subak chiefs. In the Mengwi region both punggawa of puri Mayun thus gained control over irrigation and taxation. Two of the four sedahan in the Mengwi region came

79 ARA, MvK MvO Controleur Badung G. de Haze Winkelman 1912.

80 On the first sedahan agung of Badung, see ARA, MvK VI-5-1908-52, report January 1907; MvO Controleur Badung C.C. Krom 1914; Korn 1932:326. Concerning his successor, see ARA, Coll. Heyting:1; MvK MvO Controleur Badung H.C. Prins 1915; KITLV, Coll. Korn:122; Korn 1932:148. On fraud in Badung, see Happé 1919:197.

81 Happé 1915, 1919. Formally, subak members elected their leader; just as in selecting the perbekel, however, 'advice' from above (the punggawa) usually determined the outcome. 
from the Mengwi dynasty. ${ }^{22}$ Gusti Made Ringkus used his connections with irrigation personnel to rebuild, speedily and 'without rocking the boat', the landed possessions of puri Mayun, largely lost when Mengwi fell. He was not alone in this; colonial intervention in agrarian relations led to farreaching realignments of power and property in many places.

\section{Puri Mayun and irrigation control}

To oversee irrigation in Blahkiuh district, punggawa Gusti Putu Mayun arranged for the appointment of a loyal follower. Although this follower was quite illiterate and lacked special knowledge of irrigation, he held this post for no less than a decade. His successor was a brother, who functioned as sedahan up to $1934 .^{83}$ In addition, from 1908 to 1927 this sedahan family also controlled the large subak Sengeh, north of desa Blahkiuh. The subak south of Blahkiuh was entrusted to another follower family, and the family retained this post up to 1920 .

In former days puri Mayun had been in possession of much land around Blahkiuh, large parts of which were lost to others after the fall of Mengwi. But once Gusti Putu Mayun became punggawa, all this changed. Using the minor officials who belonged to his entourage, he expanded his sawah land at a rapid pace. Through the village headmen, the ward chiefs, and the superintendent of the corvée conscripts, the men of Blahkiuh and Sangeh were mobilized to reclaim two large tracts of land east of subak Sangeh. One of the conscripts summarized the operation as follows:

'By command of the puri we were drafted to turn the land of Tengguli into sawah.

We received neither wages nor food. Once the work was done, the sawah we had made suddenly became the property of the puri. ${ }^{.84}$

In this way Gusti Putu Mayun gained possession of dozens of hectares of sawah land. He divided these among share-croppers, retaining two-thirds of

82 The sedahan of the irrigation districts Yeh Sungi and Yeh Bolo, both inside the boundaries of the Mengwi administrative district, were a brother and a brother-in-law, respectively, of Punggawa G. Made Ringkus. KITLV, Coll. Korn:97; see Appendix. In nearby Marga/Blayu district, puri Marga controlled most administrative posts up to 1912. In addition to the punggawa, two successive sedahan, a subak head, three perbekel, and the overseers of the livestock market and the ordinary market came from puri Marga (KITLV, Coll. Korn:164, genealogy puri Marga 1918).

83 For their names see the appendix at the end of this chapter. Informants invariably referred to these two brothers using the old term sedahan puri. The fact that the sedahan were colonial officials was meaningless in terms of the local point of view. In Chapter 9, section 3, I will discuss the role played by this second sedahan and his wife in more detail.

84 The tract of land was called Tengguli and was later named munduk Tengguli. Asked whether the reclaimers had not protested, an informant replied: 'Sir, whatever the punggawa wished would come to pass. If you dared to object, you would eventually surely be penalized. And you had to face the music alone, others saw no profit in antagonizing the punggawa.' 
the harvest for himself and letting the cultivators have the remaining onethird. Some years later the sawah area around Blahkiuh was expanded further. Under the leadership of puri Mayun, three tracts were added to subak Sangeh and the dam of subak Blahkiuh was thoroughly repaired. This time the reclaimers did receive a fair recompense, since the sedahan divided the new land among them. ${ }^{85}$ The puri had taken care of itself first; this time the punggawa made sure that a large group of inhabitants of Blahkiuh became beholden to him because they had been given new sawah land.

Meanwhile the sedahan, too, had looked after his own interests. 'When we first came here,' his grandson recalled, 'we had nothing at all. But when my grandfather became sedahan, well, it turned out that we had sawah everywhere. Ten hectares at first. A lot more later. How that happened? I told you, didn't I, he was sedahan puri.' 86

Not everyone in Blahkiuh, however, acquiesced to the new power relations, as became clear in 1920, when the leader of jeroan Bakungan of Blahkiuh started legal proceedings against puri Mayun. At issue was a piece of dry land on which puri Mayun had tried to plant coffee in the nineteenth century, but since then had come into the hands of the jeroan. Once the lineage of puri Mayun came to live in Blahkiuh, Gusti Putu Mayun took possession of the land, arguing that it had originally been puri Mayun domain. The jeroan responded with a complaint against the punggawa. But it was utterly useless to press charges. By right of office, the punggawa conducted the preliminary hearing and in his report he, of course, denied the claims of the jeroan. The claim was dismissed and the jeroan lost the case. ${ }^{87}$ This jeroan had taken the daring initiative of turning to the court, but many ordinary folk were afraid to do this. Moreover, they lacked the knowledge and the means needed. Given this situation, Gusti Putu Mayun could quietly carry on with the expansion of his landed possessions.

\section{Taxation and landownership}

The freedom the BB left to its subordinate Balinese irrigation officials rested largely on the BB's unfamiliarity with regional relationships. In conse-

85 Sawah land around Blahkiuh thus grew to more than 350 hectares. Subak Sangeh, where puri Mayun and the inhabitants of Blahkiuh owned most of the land, consisted of 226 hectares. The puri had less interest in subak Blahkiuh, which can be explained by the fact that most of the land there was cultivated by people who lived in desa Abiansemal.

86 It is highly probable that debt relationships played an important role in the family's expanding possessions. In addition, the sedahan could also officially transfer tracts of land to others, including himself (see also Chapter 9, section 3).

87 KITLV, Coll. Korn:122, 226, Raad Kerta Badung 6-4-1920 and Verklaring G. Putu Mayun 6-4-1920; information G. Ketut Kaler, Blahkiuh. A telling argument advanced by the controleur during the session was this: 'It is inexplicable how a non-official [the leader of jeroan Bakungan held no administrative post] could ever possess a tegal [tract of dry land] of that size.' 
quence of this and pending definitive legislation, it was decided for the time being to leave the 'traditional' levying of taxes 'untouched'. 88 But this was not how it was in practice. Between 1910 and 1914 total sawah tax receipts in Badung subdivision increased from Dfl. 71,393 to Dfl. 172,291. ${ }^{89}$ The official primarily responsible for tax collection was the sedahan agung. Distribution of the burden of taxation locally, however, fell to the noble sedahan and the subak heads. Different tax classifications were assigned to the plots depending on rough assessments of their yield, whereby the better sawah were taxed more heavily. Distribution of the taxes over individual fields was subsequently decided upon within the subak, hence by the subak head. This made the subak the smallest taxation unit. ${ }^{90}$

Pious wishes not to touch the agrarian order notwithstanding, drastic changes took place in the nature of landownership between 1910 and 1920 . First, the flexible Balinese measuring unit for the area of land was deleted. Instead, the amount of tax was now fixed on the basis of a uniform measure, the tenah of 4,500 $\mathrm{m}^{2} .{ }^{91}$ This new standard was the basis for a second change, fundamentally influencing the old regional power relations. In very short order, the old pacatu system disappeared. That system was characterized by bartering between a lord and his followers. In exchange for labour and loyalty, the lord allocated his follower a piece of land to cultivate. The follower would not become the owner, but he could do as he wanted with the harvest. In other words, access to harvest was more important than ownership of land. The BB put an end to this through the introduction of individual landownership. The concept of druwé (ownership), which under the earlier political system stood for the scope of power the lord had over his followers, was now given the narrower meaning of landownership.

The outcome of this redefinition was that pacatu sawah was counted as

88 ARA, MvK V5-9-1912-6, G.B. 16-4-1910-13 and G.B. 2-7-1912-11. A definitive tax was not introduced prior to the 1920s; see Chapter 9, section 2. Provisionally, tax collection was left to Balinese irrigation officials.

89 ARA, MvK MvO Controleurs Badung C.C. Krom 1914 and H.J. Prins 1915. Tax receipts for the intervening years were: Dfl.96,450 (1911); Dfl. 125,722 (1912); and Dfl. 155,022 (1913). Taxes were mostly paid in kèpèng, after which the BB exchanged these coins for Dutch Indies currency.

90 ARA, MvK V17-11-1909-38. Liefrinck's descriptions of northern Bali were again taken as guidelines (for example, Liefrinck 1927:164-93 and his report of 10-12-1874 in ARA, MvK V291-1880-4). The sawah were divided into five categories, taxed in amounts varying from Dfl. 7 (class 1) to Dfl. 3 (class 5) per $4,500 \mathrm{~m}^{2}$. In the next chapter I will discuss the colonial land taxes in greater detail.

91 This changed the meaning of the tenah fundamentally. The old tenah expressed a certain amount of harvested padi (a bundle of sheaves weighing about 25 kilograms). This fixed harvest measure allowed for variation in the amount of land and water needed to obtain the yield. The old tenah might vary from 2,700 to $7,500 \mathrm{~m}^{2}$. By order of the $B B$, and rather arbitrarily applied by the Balinese irrigation personnel, the colonial tenah came to mean a standard measure of area (Happé 1915, 1919; Korn 1932:617). 
either the property of the cultivator or of the lord. Noble families who, owing to administrative reorganizations, had lost much of their power, now lost their control over their old pacatu sawah as well. The ledgers listed the sawah as the individual property of those who cultivated them. This, in turn, implied that a follower could suspend his service to the lord without running the risk of losing his land. Conversely, powerful puri were able to turn their pacatu sawah into large-scale property, which meant that the cultivators could no longer claim the full harvest. They were reduced to share-croppers, usually allowed to retain no more than one-third of the harvest. This transition was for the most part implemented beyond colonial purview. ${ }^{92}$ The strongest puri profited most by the lack of precise rules and the absence of direct colonial control. In the Mengwi region the puri of Blayu, Marga, Kaba-Kaba, Sibang, and Blahkiuh were able to establish themselves as large landowners, while official registration rested with 'friendly' sedahan.

These irrigation officials also enjoyed a great deal of freedom in the implementation of taxation. For example, they were authorized to give exemptions, mostly benefiting powerful noble families and their immediate followers. ${ }^{93}$ Moreover, large landowners were able to pass on the tax assessments to their share-croppers, and it is likely that this happened very often indeed. ${ }^{94}$

When pacatu sawah were turned into landed property, the new sharecroppers continued to be obliged to work for the puri. They were now in fact burdened threefold: as share-croppers they retained only one-third of the harvest, they were made to pay the land tax of their masters and, third, they were assessed for a new income tax. This last was the 1914 Tax on Business and Other Revenues, from which landowners were exempted, while landless share-croppers were assessed. To make matters even worse, the new tax was levied by punggawa and perbekel who did as they saw fit without bothering with preliminary inquiries. ${ }^{95}$ In the colonial model of the

92 One exception was Korn 1917, while more recently Geertz (1980:255) has pointed this out as well. There was some discussion on the Dutch side as to what precisely was a pacatu, without awareness of the extent of the changes then going on (see Happé 1919; De Kat Angelino 1921a; Damsté 1925; Gunning and Van der Heyden 1926; Korn 1932:227). On a comparable transition in Gianyar, see De Kat Angelino 1921b:604-5 and KITLV, Coll. Korn:97, 118, reports Controleurs Gianyar 10-10-1921 and 28-1-1927.

93 In 1914, for instance, the Resident frankly admitted that he was 'groping in the dark' as to the practical implementation of the taxes and the exact areas to be taxed (ARA, MvK V48-1915-39, report 19-1-1914). At the same time, the Balinese rulers successfully appropriated most irrigation water via officials (Happé 1919:188-9; KITLV, Coll. Korn:99).

94 See Korn 1917; Happé 1919; ARA, MvK V29-3-1919-6, report J.H. Liefrinck 4-6-1918. According to informants, this was the rule in the Mengwi region also.

95 See Korn 1917 and ARA, MvK MvO Controleur Badung V.E. Korn 1921. The tax was introduced under pressure from the Batavia Bureau Buitenbezittingen, to 'prod the natives to 
'original' Balinese subak, there was no slot for the nobility. The myth of the egalitarian and autonomous subak glossed over the process by which powerful puri greatly strengthened their control over the people.

\section{Irrigation dams without temples}

The disappearance of the old negara had virtually ended royal concern with central dams and irrigation conduits. The role of regional nobles in these matters seemed pretty well played out, too. Owing to administrative reorganizations their numbers were drastically reduced, while the remaining punggawa had no official dealings with irrigation. To be sure, the Dutch had appointed new irrigation officials, but these functioned primarily as tax collectors. From the beginning, coordination of irrigation was not on centre stage. ${ }^{96}$ This meant that problems with the central inflow of irrigation water had to be solved by the Dutch, as became clear between 1909 and 1914, when some of the larger dams collapsed and hundreds of hectares of sawah fell dry. But attempts by the BB to direct repair work were utter failures. ${ }^{97}$ Since the credibility of the colonial government was at stake, the BB in 1914 called upon the Public Utilities Service (Burgerlijke Openbare Werken, BOW), which from now on would maintain the central dams and conduits. ${ }^{98}$ This shifting of the major irrigation tasks to a separate colonial service made great inroads on the old vertical links between central and local irrigation. Ironically, it was precisely this intervention from above which was instrumental in achieving the colonial image of the 'traditional' Balinese subak as a purely local and autonomous affair.

Another essential aspect of the old irrigation systems receded to the background at this time. This had to do with the ritual bonds between central and local irrigation and between the mountains, the sawah, and the sea. Once the overarching royal hierarchy disappeared, the great rituals to promote the well-being of the negara disappeared as well. In this way the progress of agriculture was in jeopardy, and even life itself was endangered.

While the Dutch believed that the introduction of 'law and order' in South Bali was completed, a process of 'ritual erosion' was set in motion and was soon to come out into the open in a dramatic way.

\footnotetext{
industriousness'.

96 See Happé 1919:192; KITLV, Coll. Korn:164, report Controleur Tabanan V.E. Korn 1917.

97 Van Kol 1914:306-8; ARA, MvK MvO Resident H.W. Veenhuyzen 1914, MvO Assistant Resident A.J.L. Couvreur 1920, MvO Controleur Badung V.E. Korn 1921; V6-3-1913-19, V29-31919-6.

98 The effect of Public Utilities Service (BOW) supervision became noticeable in the course of the 1920s, when a number of old dams were replaced with durable concrete structures. See Groothof 1918, 1922; Sörensen 1921; Van der Veer 1918; Hengeveld 1920.
} 


\section{Unrest and chaos}

During the first decade of colonial rule the BB put great effort into restructuring South Bali. To establish order new, rigidly defined frameworks were applied. Districts were staked out, villages were reorganized into administrative units, irrigation was made uniform, and the hierarchical structure was slotted into a fixed system of castes. At the same time, colonial policy contained certain contradictions. The BB sought to introduce a 'modern' apparatus to serve as an efficient extension of the colonial bureaucracy. 'Modernization', however, was strangled by the desire to restore the local order to its 'original' state. And although the BB claimed that it meant to safeguard the common people against noble influence, it turned out that the nobility ended up with the positions of power on the local level.

The Dutch attitude towards the nobility was ambivalent. On the one hand, the noble status as a category was carefully retained via the colonial caste system; on the other hand, the nobility was supposed to manifest itself on the local level only. The old rulers were not expected to play a role of importance regionally. The negara of Tabanan, Badung, and Klungkung had been dismantled completely, and the dynasties that had survived colonial penetration were in danger as well. It was not long before the royal dynasties of Gianyar, Bangli, and Karangasem realized this. In 1913 the old kings of Gianyar and Bangli were succeeded by their sons, but rather than receiving a royal name they had to be satisfied with the colonial title of 'regent'. The principle of hereditary succession was abrogated, which meant that the future of these dynasties would now depend on the Dutch. On top of this, negara Bangli and negara Gianyar lost their status as Protectorates in 1917 and were formally incorporated into the Dutch Indies. At the same time the pacatu system in both negara was done away with, so that the dynasties lost their hold on a large part of the people. ${ }^{99}$

This governmental intervention hit the royal puri of Gianyar and Bangli very hard. The old king of Gianyar was 'shocked out of his mind' when he realized what the implications of his resignation would be. But the BB thought his son 'bright' enough to be shaped into a reasonably 'civilized' and 'useful' regent. By way of encouragement, he received a sizeable government subsidy to defray the costs of the large-scale cremation ritual for his father. ${ }^{100}$ But the new regent of Bangli refused to accept the situation. He personally returned a bagful of rix-dollars the government had awarded him as provisional compensation for the loss of the royal corvée labourers. Moreover, he refused to act the part of government official.

99 ARA, MvK V3-6-1913-45, V9-7-1914-46, MvO Resident H.U. van Stenis 1919, MvO Assistant Resident A.J.L. Couvreur 1920.

100 ARA, MvK V9-7-1914-46, V12-7-1916-48. 
'This Regent loathes modernity. The old man does not really administer, but he knows what is going on. Every morning he ensconces himself in front of his puri under a pala tree on a flat rock - which he has had recast into a horrible, cemented monstrosity - and listens to what passers-by can tell him of the day's affairs. Meanwhile he carves little wooden statues.' ${ }^{101}$

In Karangasem, on the other hand, the position of the royal dynasty remained virtually untouched. This was mostly due to the young stadtholder, Gusti Bagus Jelantik. The Dutch saw him as 'malleable, tractable, and industrious'. The BB considered him an exponent of the new generation of Balinese officials through whom law and order might be maintained in an efficient manner. ${ }^{102}$

In spite of the fact that the status of the nobility as a category was strengthened, two groups of nobles lost a good deal of their former power. The first was that of the royal dynasties. A second, much larger group was that of the regional lords who were side-tracked in the course of the successive administrative reorganizations. They were increasingly reduced to their immediate environment and even there they could at best retain authority as perbekel only.

Other families, however, were able to expand their power greatly. One of these was the lineage of puri Mayun in the Mengwi region. Administrative resources, follower relationships, and landownership combined to nourish the power of Gusti Putu Mayun. Capitalizing on his position as punggawa, he also managed to strengthen the dynastic authority of his puri. This linkage of the old order and the new colonial framework provided him with a strong basis. To be sure, the domain of Gusti Putu Mayun remained bound by the limits of his district. But within this context puri Mayun consolidated its power, for instance, in the pattern of its marriages. Gusti Putu Mayun's wives all came from the district. The other branches of the Mengwi dynasty increasingly tended to look for wives within the lineage. ${ }^{103}$ This meant that marriages of alliance between different lineages or families receded. Puri Mayun had little interest in a marriage into a strong family outside of its own district. Politically speaking, it was far more expedient to work on the 'alliance' with the $\mathrm{BB}$, and this required not marriage but access

101 ARA, MvK MvO Assistant Resident A.J.L. Couvreur 1920.

102 ARA, MvK MvO Controleur Karangasem, W. Doornik 1913; MvO Assistant Resident A.J.L. Couvreur 1920. A man of the world, Stadtholder Jelantik named the various pavilions in his puri after European cities, such as Amsterdam, Paris, and Berlin. He was not seen as entirely civilized, however, since he lacked education and hence could 'not yet be invited to a dinner' (Bijl de Vroe 1980:158-9).

103 The padmi of the punggawa came from puri Abiansemal, and his two penawing came from Sedang and Blahkiuh (see Appendix). Study of the genealogies of the other lineages of the Mengwi dynasty indicate that, more than before, marriages took place between persons of the same lineage. 
to education and spotless performance. The other branches, thrown back upon their direct surroundings, were primarily concerned with bolstering their internal cohesion. In this way, each of the distinct lineages sought to survive as best they might.

Under the new conditions the old negara had lost much of their coherence, as was especially evident on the ritual level. While the eastern Balinese dynasties found it increasingly difficult to fulfil negara-related ritual tasks, in Mengwi these had disappeared altogether. Except for the mountain temple at Tinggan, the great negara temples were in a state of neglect. The central temple Taman Ayun was in serious disrepair and important rituals relevant for the negara as a whole were no longer conducted. ${ }^{104}$ The Mengwi region was not only disfigured by new district boundaries, but the 'ritual axis' which had held mountains, sea, and centre together had ceased to function. A heavily damaged dynastic centre was in no position to restore the old negara to coherence. Gusti Ketut Agung as royal heir lacked both the power and the means to do this. After the conquest of 1891 the old royal centre had never recuperated, and the royal heir held no administrative post from which to derive new opportunities. Some unknown jaba official had been appointed district head of Mengwi. The struggle between this 'modern' punggawa and the scion of the old dynasty remained undecided, but there could be no doubt that the latter suffered setbacks. Almost all of the former royal sources of income were gone. The government controlled the opium monopoly, commercial trade no longer depended on the protection afforded by strong puri. The pacatu system was gone and the royal centre had lost its control over labour and taxes. Mobilization of labour and collection of taxes were taken care of by the colonial apparatus. The BB did not use the proceeds for rituals but for 'worldly' matters such as road building. Gusti Putu Mayun alone had been able as punggawa to use colonial means to strengthen his dynastic authority. But these same colonial structures made it impossible that he could ever bring to life again the old negara, whose demise, like that of the others, seemed complete.

The great shock

On the morning of 21 January 1917, southern Bali was hit by a powerful earthquake. Less than fifty seconds were enough to inflict enormous

104 A report from 1920 even makes mention of a general 'deterioration' of adat in Mengwi. Art forms such as the gambuh theatre (formerly sponsored by the royal puri) disappeared as well (KITLV, Coll. Korn:147, report punggawa Mengwi 1920). Korn (1932:34) refers to the disappearance of a great many rituals supported by the nobility. Gusti Putu Mayun did keep up the dynasty's old mountain temple at Tinggan, but it no longer represented the whole of the former negara. 
damage. Countless houses, temples, and puri were destroyed and in the north of Abiansemal district a number of villages were wiped out. Many roads, dams, and conduits collapsed because of destructive flash floods which swept great streams of mud along on their downward path and crippled agriculture. That day more than 1,350 persons died. ${ }^{105}$ For days on end, new shocks continued to be felt, and whenever the earth rumbled the frightened people fled to open spaces. ${ }^{106}$

In Badung subdivision the earthquake reduced available arable land by ten per cent, and between 1917 and 1919 the price of rice rose by more than 400 per cent. ${ }^{107}$ At the same time the people were faced with a greatly increased workload, since they had to help repair the roads, dams, and conduits in addition to rebuilding their own homes. ${ }^{108}$ In 1917 there was nothing left to harvest.

Disaster was not limited to earthquakes and failed harvests, but took a truly dramatic turn when, in the course of 1918, a world-wide influenza epidemic swept over Bali. An estimated 22,300 people succumbed to this 'Spanish flu'. ${ }^{109}$ Old informants recall that every few days the death toll rose. The atmosphere was one of fear and helplessness; death stalked the yards and refused to go away. On top of this southern Bali was visited by a plague of mice in 1919 and the harvest was a failure again.

As all these calamities transpired, life in southern Bali lost every vestige of orderliness. Many were convinced that the anger of the gods had descended on the land. Who else could make the earth heave in destruction, whose invisible hand could take so many lives and let a plague of mice swarm across the land? In a joint communiqué, the stadtholder of Karangasem and the regents of Gianyar and Bangli let it be known that Mount Batur in central Bali had caused these events because the people had neglected their ritual duties towards the gods. ${ }^{110}$ In other words, ever since the years of chaotic warfare at the end of the nineteenth century, southern Bali had

105 See Kemmerling 1918, and ARA, MvK V28-8-1917-62, V8-10-1918-44, V24-10-1919-52, MvO Resident H.U. van Stenis 1919.

106 Information from Kak Bakti, Blahkiuh.

107 ARA, MvK MvO Controleur Badung V.E. Korn 1921. Prices increased from Dfl. 6 to Dfl. 25 per pikol. An additional phenomenon was that the earthquake had sped up a process of erosion so that many conduits silted up and many sawah were covered with sand.

108 A heavy burden was the great harbour project at Benoa. Every day hundreds of corvée labourers were sent there. Moreover, the burden of irrigation repair was not divided equally, since only the sawah cultivators affected were mobilized. A general mobilization, as would have been the usual approach under royal rule, was not used. ARA, MvK MvO Controleur Badung V.E. Korn 1921, V29-3-1919-6.

109 ARA, MvK MvO Resident H.U. van Stenis 1919. On Lombok more than 36,000 persons died. See also Brown 1987.

110 ARA, MvK V8-10-1918-44. They stressed worship in the central temple complex of Besakih. This temple had fallen into disrepair by the end of the nineteenth century, and the earthquake all but destroyed it. See Stuart-Fox 1987:345. 
become ritually 'unclean' and was now being punished. ${ }^{111}$

In immediate response to this, a number of efforts were begun designed to contain and exorcise the evil. Together with the regents of Gianyar and Bangli, the stadtholder of Karangasem sought to resume the role of ritual leader by organizing annual pilgrimages to Besakih. ${ }^{112}$ But in the Mengwi region there was no royal centre able to initiate a large-scale ritual of that order. The punggawa of Blahkiuh undertook no action, probably because he could not claim royal authority. Instead, local initiatives arose among the people. During the influenza epidemic, representatives of desa Blahkiuh asked the punggawa permission to worship in the small temple opposite the puri. It still contained the small pillar erected by Gusti Made Ringkus in 1900. Towards the end of his life, Gusti Made Ringkus had attained an aura of holiness and had become renowned as a healer. For this reason the people hoped that in making use of 'his' temple in Blahkiuh the deathly illness could be driven out. ${ }^{113}$

Alongside of this, another phenomenon seemed to be happening to which I want to draw attention in a tentative way. During and shortly after the influenza epidemic, new barong were manufactured on a large scale in the Mengwi region. Barong are dragon-like figures moved along by two men. Great powers are ascribed to them. Most barong are kept in temples and addressed by the same title as one would address a lord: Ratu. In a number of cases informants explicitly linked the epidemic and the barong, which were to drive out the invisible evil. ${ }^{114}$ It seems probable that the barong constituted a local alternative for the lost royal centre, which would have been responsible for cleansing the negara.

The new Dutch rulers certainly did not see this as their responsibility. The BB conceived of itself as in charge of 'worldly' order and left 'religion' to itself. But in so doing, the government had saddled the Balinese with an enormous problem. Arrival of colonial rule had created a ritual vacuum that the Dutch did not aspire to fill, while the old Balinese dynasties were no

111 The text Bhuwana Winasa (the destruction of the world), written by the Blayu Pedanda Ngurah in 1918, seems to suggest this. The text recounts the warring among kindred people and the destruction of the southern Balinese negara, and ends with the earthquake of 1917. It seems to me certain that this was not only the understanding of the Balinese elite but a belief shared by many common people. See also KITLV, Coll. Korn:218, report Controleur Tabanan 1910 , in which a connection is made between decreasing rice production and the neglect of negara temples.

112 ARA, MvK V18-6-1918-39; MvO Resident H.U. van Stenis 1919.

113 Information G. Ag. Rai Jaya, Jakarta, Ida Bagus Ketut Swarna, Pan Patri and Nang Kembang, Blahkiuh.

114 Most barong currently extant in Abiansemal district were manufactured shortly after 1918 in two gria in Abiansemal and Blahkiuh. Naturally, there were barong before, but they were fewer in number. The barong moved through the desa while the yards were cleansed with holy water. 
longer able to organize the great purification rituals. Up to 1917 the BB had proved to be a powerful ruler. During the years of the calamities, however, the Dutch could not ward off evil and in fact did not feel called upon to do so. This meant that the Dutch had opened up a box of snakes and seriously undercut their own law-and-order policy. Great unrest was arising related to the fearful disorder brought about by a decade of Dutch rule. 


\section{APPENDIX}

\section{Entourage of puri Mayun/lesser officials of Punggawa Gusti Putu Mayun, 1907-1938}

Relatives of G. Putu Mayun

G. Ketut Rai: perbekel Blahkiuh 1916-1920

G. Gede Rai : perbekel Blahkiuh 1934-1927

G. Made Rai Kerebeg: kanca (clerk) Raad Kerta Badung c.1920

Brahman family of Ma.

Ida Made K.: mantri opium Abiansemal; sedahan tegal Abiansemal district 1931-1934; sedahan Abiansemal district 1934-

Ida Bagus S.: supervisor Blahkiuh market c. 1915

Ida Nyoman O.: klian banjar in Blahkiuh c. 1920

Ida Bagus M.: perbekel Blahkiuh 1927-

Ida Bagus R.: assistant sedahan Abiansemal district 1931-

Brahman family of Ms.

Ida Made O.: perbekel Blahkiuh 1907-1916, 1920-1924

Ida Bagus Made R.: pekaseh subak Sangeh 1927-

Gusti C. family

Gusti Putu A.: sedahan Abiansemal district 1908-1918

Gusti Kompiang R.: pekaseh subak Sangeh 1908-1918; sedahan Abiansemal district 1918-1934

Gusti Made S.: pekaseh subak Sangeh 1918-1927

Gusti Nyoman K.: klian banjar in Blahkiuh c. 1930

Gusti A. family

Gusti Made K.: klian banjar in Blahkiuh c. 1920

Gusti Putu B.: mandor jalan 1920s; klian adat desa Blahkiuh 1920s-1930s; klian banjar in Blahkiuh 1930s

Jaba family

Pan R.: pekaseh subak Blahkiuh 1908-1920

Pan M.: klian banjar in Blahkiuh 1933-

Pan L.: pekaseh subak Blahkiuh 1930s 



\section{CHAPTER IX \\ Turning tide and crisis, 1920-1940}

After the earthquake of 1917 the Balinese lived in fear. The royal hierarchy had broken down, the cycle of life seemed to falter, and people felt that the gods had turned their backs on Bali. For a time it appeared as if a new god was manifesting himself. The governor general of the Netherlands Indies visited the stricken island in 1918. In the midst of abject misery, his coming was surrounded with pomp and circumstance achieved at extravagant cost and effort. ${ }^{1}$ One major event was an impressive ceremony staged in the open field in front of the house of South Bali's assistant resident. On this occasion a pedanda welcomed the colonial dignitary as follows:

'This memorable event causes each of us to feel as if Batara Maha Dewa [the supreme deity] has descended from the Gunung Agung and has come into the world, revealing himself to mankind, dispensing great joy and gladness among us; as if we are the recipients of holy water; yea, as if, by thy restoring breath, thou grantest us renewal of life.' (Schmidt auf Altenstadt 1920:169.)

Flowery speech and flattering words, however, could not hide the fact that this was mere colonial theatrics, carefully orchestrated and directed by the $\mathrm{BB}$ and resting on many long extra hours of Balinese labour input.

The governor general was unable to give new life, but his visit did mark a watershed in colonial policy on Bali. The Dutch were warming to the idea that colonial control would be the most secure if the old royal dynasties were reinstated. In sections 1 and $4 \mathrm{I}$ will discuss this process. The Mengwi dynasty made efforts to have their former negara reinstated as well. I will trace in detail the role played in this by the leaders of puri Mayun.

Along with a reinstatement of the old dynasties, colonial policy evinced a growing tendency towards the preservation of 'traditional' Bali by closing it off from the outside world. The resulting contradictions will be considered in section 2. The economic changes that occurred in South Bali after 1920 will be looked at as well. The literature has tended to gloss over this. Analysis of political constellations, however, demands that attention be paid to the effects of economic change on regional power relations, as I shall do in section 3, with special reference to the Mengwi region and, more specifically, to Blahkiuh. 
During the 1930s the power struggle in the Mengwi dynasty came to a climax. Facing each other were the leader of puri Mayun in Blahkiuh, who derived his power from his position as a colonial official, and Gusti Ketut Agung of Mengwi, who represented the old dynastic centre. At stake was the 'restoration' of the negara and the Mengwi throne. Their struggle took a surprising turn which was to reshuffle their relations radically.

\section{Popular chiefs}

The very year that the governor general honoured Bali with a visit, a degree of uneasiness arose in government circles regarding the way colonial rule had taken shape in Bali. Gradually it became evident that the controleurs hardly knew what was happening in their subdivisions. Ensconced in their offices, swamped by growing mountains of paperwork, they were far removed from the people. They found their subordinate Balinese district heads less reliable than they had been. Many of the punggawa were young, Western-educated officials who were repeatedly transferred to new posts and other districts; in addition to this, they often operated in isolation and had little control over their own areas. The government feared that colonial rule would lose its control over the people. ${ }^{2}$ Java had demonstrated what this sort of thing might lead to: large-scale political mobilization by emerging political parties, and protest movements among the masses. ${ }^{3}$

In response to what was seen as a dangerous undermining of the colonial system, the government created the so-called popular chief. This was a leader to whom 'traditional' authority was ascribed and who was expected to act as native official within his familiar context. At the same time, this popular chief would be part of the colonial bureaucracy, though in practice he would have little say (see Sutherland 1979:ch.10). There could be no misunderstanding about the role to be played by these chiefs on Bali:

'An intellectually well-developed chieftain is useful for administrative purposes. But to rule the country, hence to keep in touch with the people, it is better to fall back on less talented persons, as long as they are natives and possess some prestige.' (ARA, MvK MvO Assistant Resident A.J.L. Couvreur 1920.)

But this choice in favour of a noble popular chief was not without its problems. The question was whether this sort of support for the nobility

2 ARA, MvK V29-3-1919-6, report J.H. Liefrinck 4-6-1918; MvO Assistant Resident A.J.L. Couvreur 1920.

3 See Onghokham 1978 on the gap between administration and people on Java in the early twentieth century; Sartono Kartodirdjo 1973:142-85 on the unrest caused at the local level by Sarekat Islam between 1912 and 1914; Takashi Shiraishi 1990 on the early days of popular movements in Central Java. 
would not detract from 'original' and 'egalitarian' Bali. ${ }^{4}$ Resident H.T. Damsté (1919-1923) was particularly aware of this dilemma (Damsté 1922, 1923). He was very much opposed to the idea and did not want to see Bali dominated by the 'non-indigenous' nobility, 'essentially foreign' to the island. This sort of 'aristocratic umbrella' would, he feared, seriously impair the 'ancient democratic girders' of its society. But Damsté shied away from the implications of his own views. If the more prominent noble centres were to be dismantled still further, the unique structures of the Hindu religion would certainly collapse, which would spell the end of Balinese culture. This, of course, should be prevented, whatever the cost. So far, Bali had 'not yet taken on the Islamic greyness and sameness'. ${ }^{5}$ Like it or not, then, Damsté had to choose in favour of the nobility. Strengthening of noble authority served colonial interests. In this connection Resident P. Moolenburgh, Damsté's successor, lamented: 'Can we not widen and deepen the Bali Straits? At any rate, let us not build a bridge across those troubled waters to still more troubled regions [Java].' (ARA, MvK MvO Resident P. Moolenburgh 1926.) Noble 'popular chiefs' were to fend off 'evil' influences from outside.

The revaluation of the nobility served internal political relations on Bali as well. In 1925 Controleur V.E. Korn anticipated great difficulties unless the BB provided timely support for the old noble centres: 'Should the recognition of traditional authority disappear and we wish to keep in check a people as courageous as the Balinese, we shall need to take vastly different measures.'6

Popular chiefs would provide colonial rule with a familiar Balinese façade. Tradition and 'natural authority' were the key notions in the colonial conception of the popular chief. Who other than the old royal dynasties embodied these qualities? Accordingly, in July of 1929 eight representatives of the old dynasties were appointed as 'negara administrators' on Bali. These appointments were an intermediate step towards a more comprehensive 'reinstatement' of the former negara and the old dynasties which finally took place in $1938 .^{7}$

4 ARA, MvK Mr.1919:515x, concerning the question whether, just as on Java, regency councils should be introduced. The regencies would give the old negara a new lease on life and the regents could be recruited from the old dynasties. Batavia was not enthusiastic: 'After all, history shows that the common people of Bali did not feel they belonged to these little kingdoms; rather, they simply had to subject themselves to the despotic coercion of the rulers [...]. There is reason to doubt whether that domain [the negara or regency] is a living reality, a true society in the legal consciousness of the people, which in Bali can be said of the village exclusively.' (Director Department of Interior Administration (Directeur BB) to G.G. 21-51919).

5 Damsté 1923:141. It is clear that Damsté's thinking is shaped by the prevailing nineteenth-century views regarding Bali; see Chapter 8, sections 2, 3.

6 KITLV, Coll. Korn:147, memorandum Controleur Adat V.E. Korn 22-12-1925.

7 Staatsblad N.-I. 1929:226, G.B. 8-7-1928-23. See also ARA, MvK Mr.1929:2380. In 
Meant as 'pillars of Dutch authority and a bulwark against nationalism', negara administrators were considered especially important as guardians of the colonial order. ${ }^{8}$ But the reinstatement of the old dynasties had an apolitical character. The Dutch treated the negara administrators as relatively powerless puppets without much room, really, to manoeuvre on the administrative level. They were thought to have a purely religious task: 'The king was, first of all, the religious leader; his administrative task was a means rather than a goal; he maintained peace and order so that people could serve the gods in peace. ${ }^{\prime}$

Negara administrators were eager to exploit the space granted them in the realm of 'religion'. They used their ritual tasks to refurbish their royal image and took the initiative in the staging of large-scale cleansing rituals. Under their leadership, the important negara temples were cared for again and the old court culture was given a new lease on life. In all this they carefully avoided the slightest hint that their activities might have something political about them. ${ }^{10}$

\section{The return of puri Mayun in Mengwi}

The turn-about in colonial policy also affected relationships in the Mengwi region, though this took some years to take shape. When in 1921 the punggawa, the jaba Ketut Sandi, was transferred, the way seemed cleared to

Buleleng, Jembrana, Tabanan, Badung, and Klungkung, descendants of the former dynasties were appointed negara administrator, while the royal regents of Gianyar and Bangli and the stadtholder of Karangasem were given this post as well. The position of the negara administrators was ambivalent. On the one hand they were senior officials and, as such, subordinate to the Resident and the assistant resident. On the other hand, they were allowed to carry royal titles, which meant that the government implicitly recognized the principle of dynastic hereditary succession. See Visman 1928 concerning the policy on restoration of 'selfrule'.

8 ARA, MvK Mr. 1934:1095x, political report Bali 1934.

9 ARA, MvK, H.J. Hoekstra, Nota van toelichting Tabanan 1938; W.F. van der Kaaden, Nota van toelichting Klungkung 1938. Typical terminology in those days was used in a speech by the Karangasem negara administrator, who emphasized the 'religious' task with which he and his colleagues were charged: 'Surely the Dutch Indies government is an equitable government, but it looks to our material interests alone. The [former] Balinese kings were less concerned with these matters, but they taught the people to respect the deities and they provided the means of customary rituals so that the people could send the souls of the dead on their appointed way' (Korn 1932:341).

10 In Gianyar a nangluk merana, a ritual burning of field mice, was organized (Van der Kaaden 1936). In Badung the gambuh theatre was revived (personal communication C.J. Grader). In addition, the negara administrators concerned themselves intensively with the maintenance of the temple complex at Besakih and the rituals held there (Stuart-Fox 1987:352-5).

The old dynasties did not recover to the same degree everywhere. In Karangasem, Gianyar, and Bangli, where royal rule had been more or less continued in the guise of a stadtholder and regents, the royal centres soon became more powerful than in the rest of Bali, where they had disappeared and after 1929 had to manifest themselves anew. 
have a representative of the Mengwi dynasty rule the region once again. Puri Gede Mengwi, however, was unable to put forward a suitable candidate, so that once more a jaba was appointed as punggawa of Mengwi. This was I Ketut Widjanegara, from Buleleng, and former sedahan in Ubud. ${ }^{11}$ Like his predecessor, I Ketut Widjanegara proved unable to deal with the Mengwi situation. Two factors in particular made it a nearly foregone conclusion that he would fail as punggawa. First, Dutch support was waning fast, because the BB was appointing strings of noble popular chiefs all over Bali, which put I Ketut Widjanegara in powerless isolation. Second, he was confronted with strong opposition within the district of Mengwi. Resistance was led by Gusti Ketut Agung, crown prince of the Mengwi dynasty. In the early 1920s the prince had moved from puri Abiansemal to Mengwi, where he behaved as the legitimate heir to the Mengwi throne. After the death of his older brother, he had come into landownership; also he possessed certain royal pusaka with which he bolstered his claim to leadership in Mengwi; from puri Abiansemal he had brought a number of valuable krisses and the kulkul, through which the 'voice' of the king could be heard again in Mengwi. ${ }^{12} \mathrm{He}$ began repairs to the old royal puri; thirty years of neglect had reduced it to little more than a ruin. Furthermore, Gusti Ketut Agung was a talented dancer and he gathered about him a group of dancers and musicians reminiscent of the old courtly arts. ${ }^{13}$

Owing to Gusti Ketut Agung's opposition, punggawa I Ketut Widjanegara could not get a hold on his district. After five laborious years he was demoted in 1927, because of 'clear lack of ability', to become a clerk at the court in Jembrana. ${ }^{14}$ Such was the lacklustre end of this 'modern' jaba official's career.

Once I Ketut Widjanegara was out of the way, Gusti Ketut Agung fully expected to become the new punggawa of Mengwi. After all, throughout Bali the old dynasties were coming back to power. Nevertheless, the crown prince of Mengwi was passed over. Although in the eyes of the people he

11 KITLV, Coll. Korn:110, 284, report G. Gede Raka 8-6-1938 and anonymous letter to Korn 63-1922, respectively. Information G. Ng. Ceger and Ida Bagus Ketut Sindhu, Mengwi.

12 His move to Mengwi simultaneously marked a break with puri Abiansemal, because the heirs of his brother (Agung Gede Agung) claimed leadership of the dynasty as well. They disputed their cousin's right to take away the regalia and even accused him of theft. I was unable to ascertain which krisses were at issue. Gusti Ketut Agung gained the support of his cousin G. Made Agung, who went with him to Mengwi. The dispute was resolved eventually, in token of which two mutual marriages took place (see Appendix). One generation later, another marriage united the puri of Abiansemal and Mengwi. Liaisons within a single branch as close as this were legitimate, but informants considered them 'too hot'. As one informant expressed it: 'Those marriages are beautiful, but you get crazy kids.'

13 Information from Pan Soko, Mengwi, a member of the dancing group.

14 ARA, MvK Mr. 1928:331x, political report Bali 1927. 
personified the royal tradition, his reputation among the Dutch was poor indeed. In spite of all its restoration plans, the BB was disinclined to appoint this 'known misfit and cockfighter' to a high position. ${ }^{15}$ Accordingly, rule over Mengwi was given to another scion of the Mengwi dynasty rather than to the leader of puri Gede. This was Gusti Rai Kepakisan who, in contrast with Gusti Ketut Agung, did have administrative experience.16 Moreover, he was a younger brother of Gusti Putu Mayun, which meant that the lineage of puri Mayun, after a break of nine years, controlled most of the former negara again.

In the immediate past, the power struggle had been between the dynasty and jaba outsiders acting as officials; now the conflict pitted the branch of puri Gede against the branch of puri Mayun. Gusti Rai Kepakisan wasted no time in making clear that from now on he was the highest authority in Mengwi. He settled northwest of the central crossroads in desa Mengwi, thus placing himself 'above' the puri occupied by Gusti Ketut Agung and situated southwest of the crossroads. ${ }^{17}$ Even so, puri Mayun had not ruled Mengwi for nine years and had to prove itself, while Gusti Ketut Agung had settled in Mengwi again; hence Punggawa Gusti Rai Kepakisan did not succeed in getting complete control over the old royal centre. He did manage to have some close relatives appointed to important administrative posts, but still he was not able to control affairs entirely.18

It is true, then, that towards the end of the 1920s Mengwi was ruled by a member of the dynasty again, but this was very far from meaning that the leaders in Mengwi were sufficiently united to restore the former negara. In the event, the initiative for this did not come from them but from the most powerful man in the Mengwi dynasty, Gusti Putu Mayun, the punggawa of Blahkiuh.

\section{The architecture of power}

By now Gusti Putu Mayun had been punggawa of the same district for some twenty years and had seen a long succession of controleurs and assistant residents come and go. Through the years he had had ample opportunity to

15 KITLV, Coll. Korn:128, letter Assistant Resident V.E. Korn to Resident 28-8-1930.

16 He began his career as second clerk at the Raad kerta of Badung. In 1922 he was appointed punggawa of the Badung district of Kesiman, and transferred to Mengwi in 1927 (ARA, MvK V26-4-1940-9).

17 The dominance of the lineage of puri Mayun was underscored further because two more representatives lived at the crossroads. G. Made Rai lived in puri Mayun Mengwi on the southeast side and G. Gede Sayan, a son of G. Made Ringkus, lived on the northeast side in puri Kajanan (see Appendix).

18 He could not prevent, for example, that a cousin of his, sedahan of the irrigation district of Mengwi, came into great difficulties when accused of fraudulent practices. The man panicked and committed suicide. 
strengthen his personal power base in the district. When the BB made the move to give precedence to popular chiefs, the position of this member of the Mengwi dynasty became almost unassailable.

The artificiality of the Dutch view that 'politics' and 'religion' were two separate realms is exposed as soon as we take a closer look at Gusti Putu Mayun's situation. In the previous chapter I recounted how he manifested his authority in the creation of a new centre in Blahkiuh. The project was completed during the late 1920 s and early 1930 s. ${ }^{19}$

The earthquake of 1917 had destroyed most of Gusti Putu Mayun's puri. Turning necessity into virtue, he restored the puri to 'modern' standards: northwest of the central crossroads in Blahkiuh a genuine Dutch villa was erected. ${ }^{20}$ The villa was set back from the road with a flower-bordered lawn in the midst of which stood a flagpole. One entered this Western 'court' via an arched gate adorned with the Dutch crown and a tree-lined drive just wide enough for the punggawa's motorcar. On formal occasions Dutch visitors would halt their vehicle before the villa's French doors and be welcomed by Gusti Putu Mayun. This structure conferred on the punggawa the image of a modern administrator, one who did not cling to former traditions but kept abreast of the times and was aware of what went on in the world. ${ }^{21}$ Still, the villa was no more than a façade behind which the dynastic tradition of Mengwi lived on.

Although he had an office just across the road where his subordinate clerks sat at their desks, the district administrator was seldom seen there. In no way did he differentiate between his public function and his personal interests. He spent most of his time on the back porch of his villa, overlooking the part of the puri that had been restored in the old style. Precisely at the boundary between the old and the new, but with his eyes turned towards the old, he was busy shaping his royal ambitions.

These ambitions were expressed in two temples. The first was the house temple in the northern part of puri Mayun. On its birthday (or odalan) the members of the lineage of puri Mayun gathered here, together with many lesser officials, followers, and families dependent on Gusti Putu Mayun. In addition, people showed up from near and far to demonstrate their loyalty to the puri. Whoever paid his respects to the punggawa might later call on him if he got into difficulties, and at any rate one might prevent needless ill

19 For a detailed description see Schulte Nordholt $1991 \mathrm{~b}$.

20 The villa was built by a Balinese contractor from nearby Bongkasa (who also built the house of Margaret Mead and Gregory Bateson in Bayung-Gede), who modelled the structure meticulously on Dutch homes in Denpasar. To counter the danger of collapse during future earthquakes, he mixed mortar and cow dung to build flexible walls.

21 All this did not meet with unqualified approval from the Dutch, as is clear from the criticism by artist Rudolf Bonnet (Philokalos 1936). 

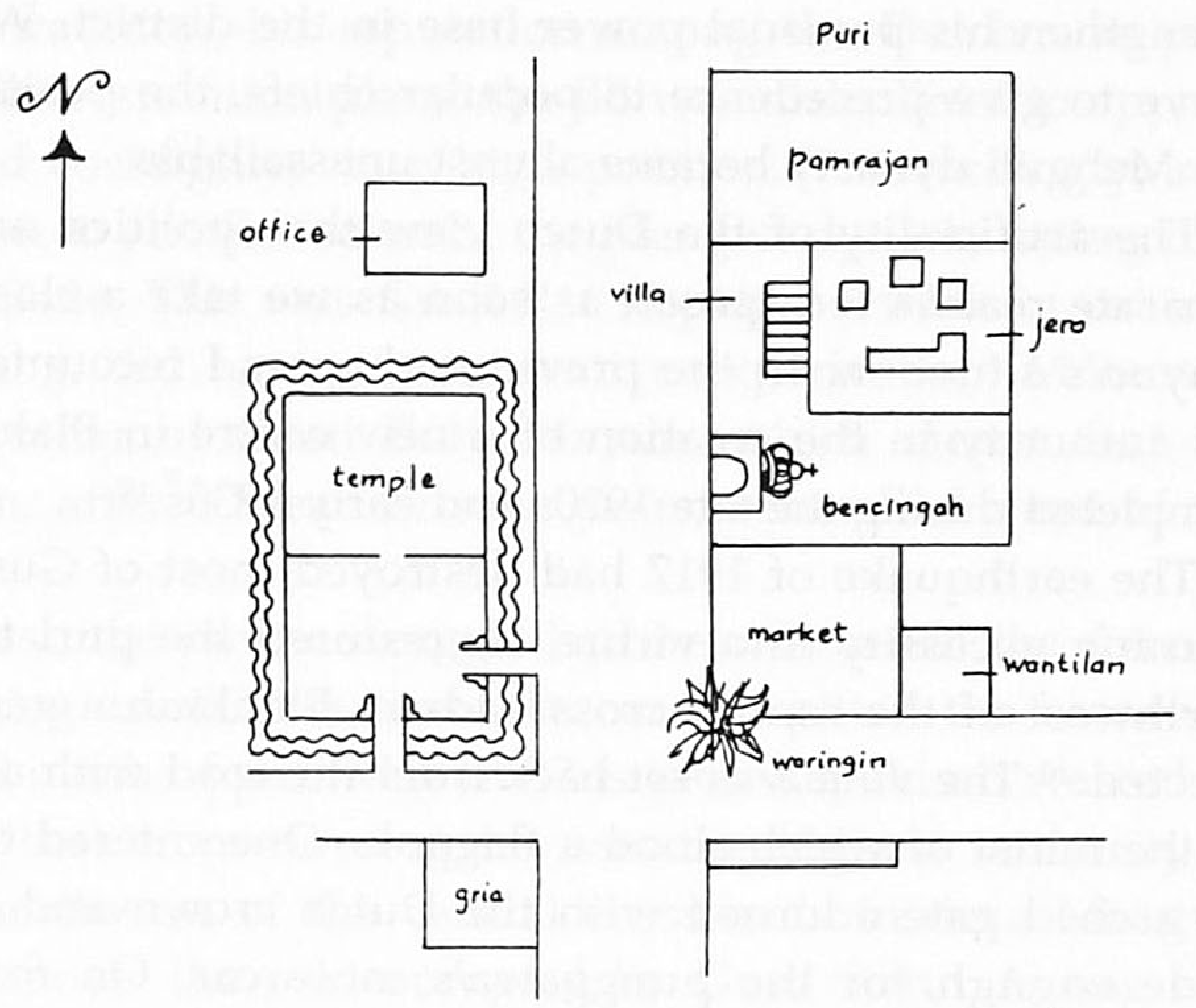

Jaba pura

15. kulkul

16. bale agung

17. moat

18. gelebeg, rice barn

\section{Jeroan}

peliangan

shrine of Ratu Ng. Sakti

shrine of Ratu Gede Sakti

melanting, shrine for the marketplace

bale pelik pengraruman

pamujian Dewa Laut, pasimpangan pura Batu Ngaus

surya

shrine for D.H. Nirarta

gedong sari

pamujian Manik Galih, Batara Sri

bale paselang

pawedan

bale gong

4. bale piasan, ${ }^{*}=$ pedanda's place

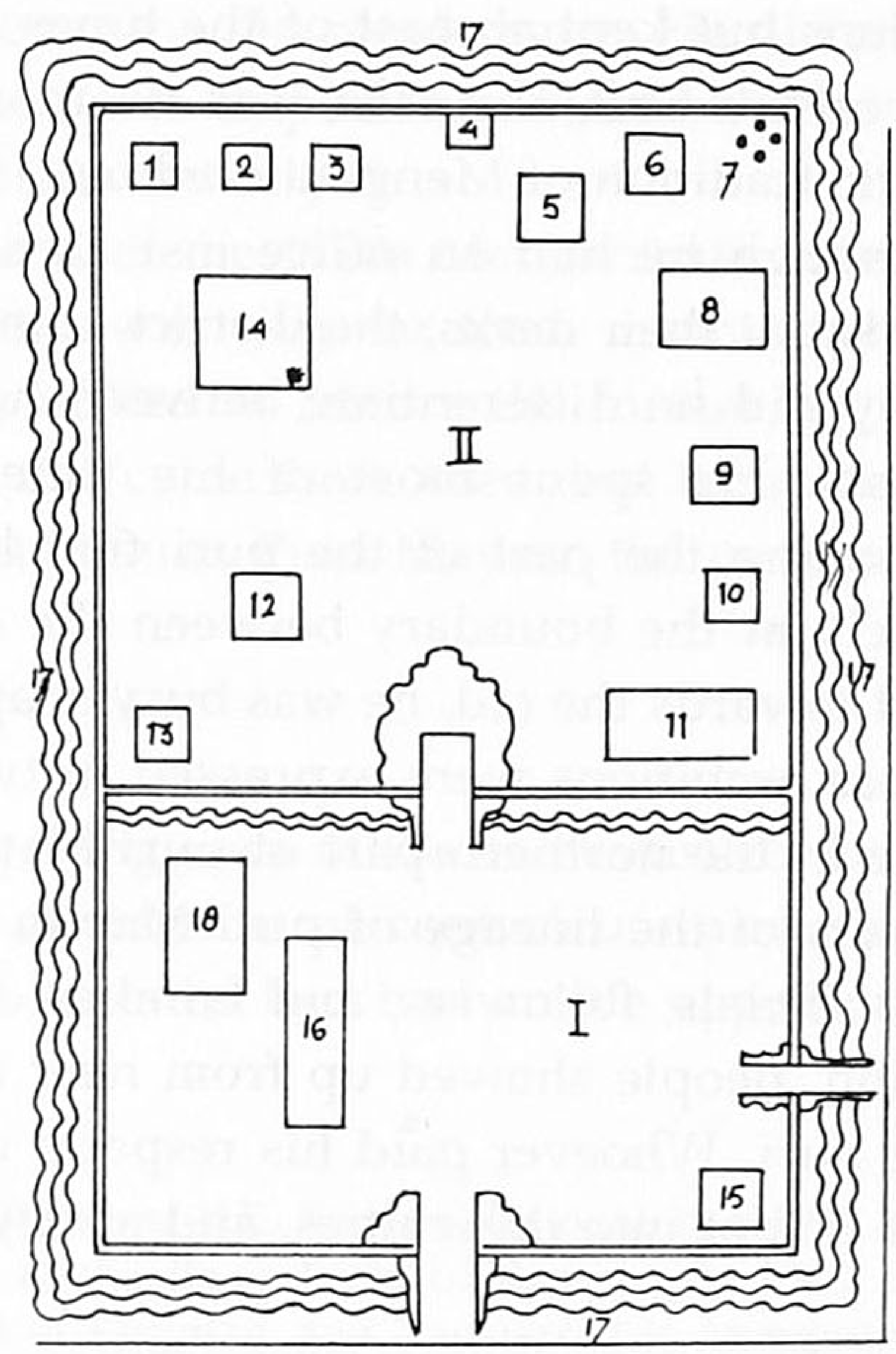

Map 13. The centre of Blahkiuh and pura Giri Kusuma 
will on the part of the punggawa. The punggawa's relatives gathered in front of the ancestral shrine; the others brought their offerings to separate shrines dedicated to the gods of the mountains. This 'religious' happening, occurring every 210 days, was a continuation of an older tradition in which both the bond between lord and subject and their ranking were made visible. ${ }^{22}$

The contrast between the punggawa's modern villa and the tradition of the old dynasty was further emphasized by a second temple, pura Giri Kusuma or 'flower hill'. Gusti Putu Mayun had this temple built in 1928, opposite the puri, northwest of the central crossing. ${ }^{23}$ The 'political' function of this 'religious' spot found expression in various ways. First, the temple symbolized the world and, hence, the punggawa's domain. The temple, surrounded by a wide moat, consisted of two parts: a forecourt and, north of this, on an artificial mound, an inner court. The water symbolized the sea, the forecourt the plains, and the raised inner court the mountains. There is no doubt that Gusti Putu Mayun meant to construct a royal temple, using pura Taman Ayun in Mengwi as his model. ${ }^{24}$ Through this royal temple the punggawa expressed his authority within the boundaries of his district in a way more readily understandable by the people than the multiple regulations issued by the colonial government. On the other hand, had these regulations not existed, Gusti Putu Mayun would not have been able to build the temple. As he had done before, he recruited corvée conscripts in large numbers to provide himself with the necessary labour. The conscripts did the coarse work, while craftsmen in the area embellished the temple walls and shrines with painted reliefs. The temple radiated perfection, thus underscoring once more the prestige of Gusti Putu Mayun as Lord Protector.

Furthermore, pura Giri Kusuma became the centre where people and goods were mobilized in connection with periodic rituals. While the temple was under construction, the punggawa gave desa Blahkiuh a large, im-

22 For an identical situation in the pre-colonial period see Chapter 2, section 3. Although Gusti Putu Mayun could no longer officially mobilize labour for his puri, he had 'volunteers' build a sturdy wall around the house temple, promising a non-noble clan in Blahkiuh, which was desirous of carrying the Gusti title, that he would honour their wish if they built the wall. When the job was done the punggawa never even mentioned his promise, and those who had been deceived had no way of exacting it.

23 The temple replaced a small stone shrine that G. Made Ringkus had erected there in 1900. See also Map 13.

24 Gusti Putu Mayun was unable to take possession of Taman Ayun, since it was located in another district and was therefore outside of his territory. One of the names of the temple in Blahkiuh underscored its royal character: pura Luhur, a name used especially for royal mountain temples. My thanks to J.-F. Guermonprez, who pointed this out to me. Much information was given by G. Ag. Gede Mayun, G. Ketut Kaler, Ida Bagus Taman, Ida Bagus Swarna, Pan Karya, Nang Kembang, and I Ketut Radi, Blahkiuh. 


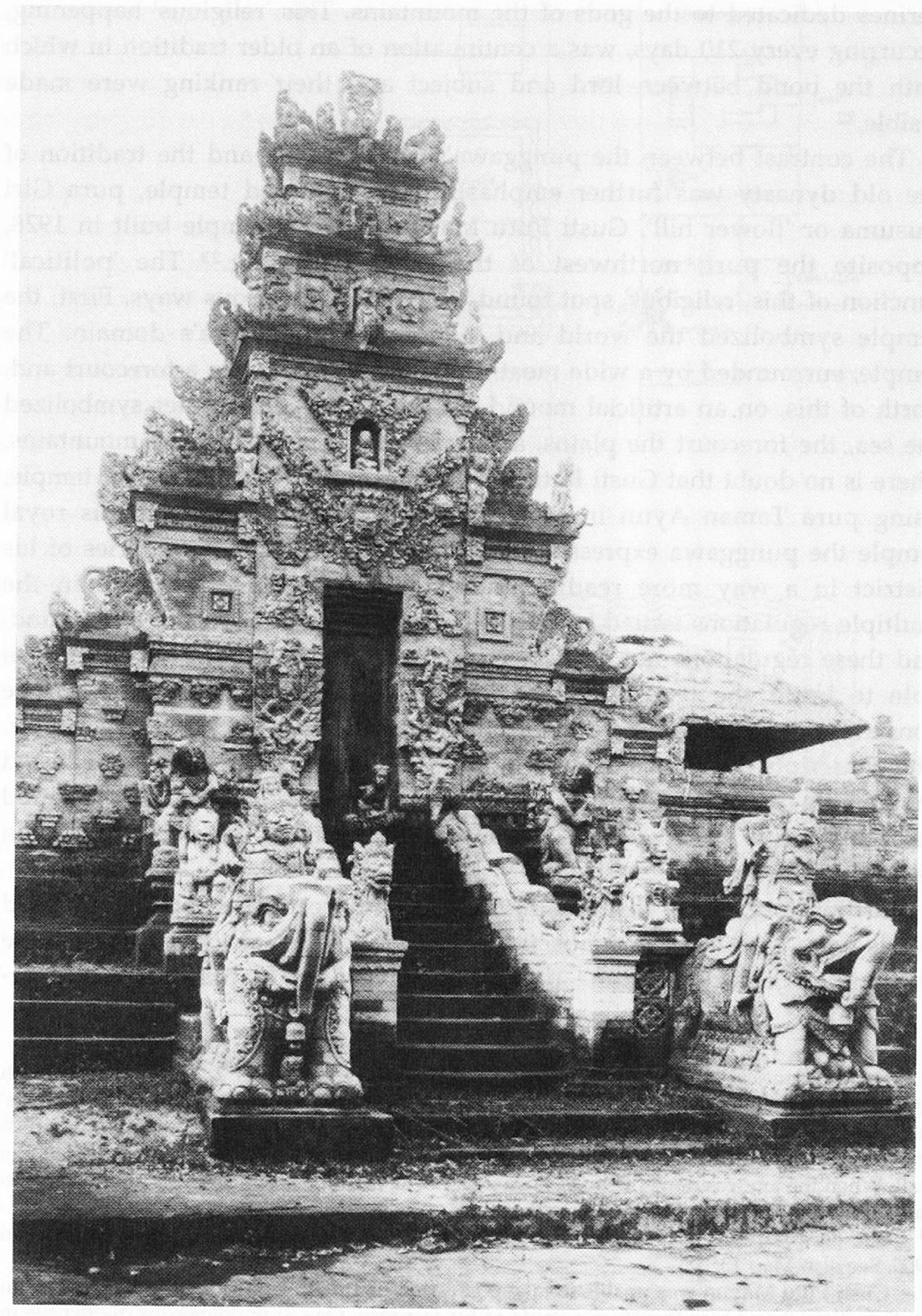

Pura Giri Kusuma Blahkiuh (KITLV 8235) 
posing balé agung (pavilion), which raised the status of the village considerably. ${ }^{25}$ This bale agung was intended for meetings of the village council, or krama desa, and really should have been in the village temple in eastern Blahkiuh. But the punggawa stipulated that the structure should be placed in the forecourt of his new temple. At the same time, he donated a new kulkul. The slit gong, too, was installed in the forecourt of pura Giri Kusuma. Gusti Putu Mayun had shifted the 'village centre' to his temple. The kulkul of pura Giri Kusuma outdid the kulkul of the village temple, and it drew the members of the krama desa together in the new balé agung, now part of the new centre of the punggawa.

The fact that the centre of Blahkiuh and the centre of the puri henceforth coincided was made unambiguously clear during the great annual purification ritual held the day before the Balinese new year. ${ }^{26}$ By drawing this ritual to his centre, the punggawa indicated to the villagers that their future welfare was intimately linked with his puri.

Not only the village but the surrounding areas, too, gravitated to pura Giri Kusuma. Involved in this were two kinds of water, holy water and irrigation. As the BB proceeded to take control of the main dams in southern Bali, the strong puri lost their grip on the organization of regional irrigation. But the Dutch made no provisions for the ritual dimension of the agricultural cycle. After all, 'religion' was not the business of the Public Utilities Service in charge of the dams. Gusti Putu Mayun was quick to turn this to his own advantage and monopolized the ritual dimension of irrigation in his district.

Ever since the fall of Mengwi, the ritual links between the mountain temples and the holy places near the sea had been neglected. But the 1917 earthquake and the crop failures in its wake demonstrated the folly of such neglect. Accordingly, Gusti Putu Mayun had a special shrine built in his new temple, worship of which was meant to prevent crop failures. The shrine was a pasimpangan representing pura Batu Ngaus, a coastal temple whose function had always been to ward off crop failure and the plagues which, arising at sea, swept over the land. ${ }^{27}$ Gusti Putu Mayun next used his power as punggawa to deny neighbouring puri the right to maintain a similar shrine. This meant that the punggawa obtained exclusive rights to guard over the fertility of the sawah in the district, which increased his prestige

25 The balé agung was modelled on the type often found in Balinese mountain villages. It had no less than 32 pillars. Informants also stressed that the new balé agung would bring prosperity to the village. The fact that the new bale agung required relocation of the village centre is not unique. A similar shift had occurred before, in neighbouring Mambal and Ayunan, in order to fuse two villages together.

26 This is the pacaruan kasanga, the cleansing in the ninth month held all over Bali at central temples and crossroads.

27 Map 13, no. 6; see Chapter 4, section 2. 
greatly. His authority was made visible annually, when representatives of more than twenty subak gathered about the shrine to present their offerings. The punggawa arranged to have irrigation officials who belonged to his own entourage. These same officials were also responsible for collecting an unofficial temple tax from the subak in the district. ${ }^{28}$ Payment was made in kind, and stored in a large rice shed in the forecourt of the temple. In this way, part of the agricultural surplus was skimmed off the surrounding areas to maintain the temple and to defray the costs of the great rituals. Moreover, a large, well-stocked rice shed reflected the wealth achieved through intervention by the puri.

In addition to the temple, Gusti Putu Mayun 'donated' to desa Blahkiuh a public bathing place adjacent to a large pond. ${ }^{29}$ In the centre of the pond there was a small island with a padmasana or open seat for the gods, corresponding to the most important shrine in the temple. This shrine was dedicated to Dang Hyang Nirarta, the legendary ancestor of the Balinese brahmans. ${ }^{30}$ Worship of Nirarta in pura Giri Kusuma had an extraordinary aspect. It was said that the deified ancestor of the brahmans himself prepared the holy water in this temple. This took place on the pawedan, where a brahman priest normally officiates. ${ }^{31}$ Therefore, the brahman priests were not permitted to seat themselves there. Instead, the jaba temple priest placed the ritual instruments on the bale pawedan for the 'invisible Nirarta' to prepare the holy water. The temple priest received this and distributed it among the worshippers, while a pedanda who might happen to be present would have to be satisfied with a much lesser place. ${ }^{32}$

Puri Mayun had no brahman priests in Blahkiuh. There was a gria southwest of the crossing, but only lesser officials lived there. But the lack of brahman legitimacy was overcome because the temple functioned as a kind of 'super gria'. After all, it was the ancestor of all brahmans himself, rather

28 This 'ritual' tax was called suwinih by informants. The BB had terminated this tax in 1906 (Korn 1932:327), but probably remained unaware that the punggawa of Blahkiuh had reintroduced it again. According to informants, the proceeds amounted to some twenty to thirty tonnes of brown rice annually.

29 That is, he had conscripts construct these. An inscription mentions 1928 as the year in which the bathing place was built.

30 Gusti Putu Mayun was probably inspired by his mother, who worshipped D.H. Nirarta in a special way. Nirarta was reputed to have been a great temple builder. The upper part of the shrine was a closed space, like a cupboard, which rested on a base consisting of a turtle surrounded by two snakes. The roof was shaped like a candi with a number of tiers. The padmasana - a seat (asana) on a lotus (padma) - symbolized the world; a turtle (the sea) carried a kind of pedestal (the earth) on which was a raised seat (the mountain); two snakes encircled the pedestal. This arrangement also symbolized how the elixir of life is produced: the snakes function as churning ropes and the mountain as dasher. See Zoetmulder 1974:68-71.

My thanks to G. Ketut Kaler and Hedi Hinzler for their explanation of these symbols.

31 See Map 13, number 12. Number 8 is the shrine for D.H. Nirarta.

32 The pedanda would sit in the bale piasan, where the offerings were placed. 
than an 'ordinary' pedanda, who prepared the holy water. The temple came to share in Nirarta's holiness.

Together, puri Mayun and pura Giri Kusuma represented the top of the regional hierarchy, and proclaimed the royal character of the centre in Blahkiuh. This was also expressed in one of the names used by the people to refer to the temple: pura kerajaan, the royal temple. Furthermore, the bond between the puri, the pura, and the old negara was made very tangible indeed during a special ritual dating back to the days of the old royal regime. This was the ngrebeg, or parade of the faithful, through the centre of the negara on the king's birthday. Gusti Putu Mayun reinstated this occasion, though in Blahkiuh rather than in Mengwi. ${ }^{33}$ As informants recollect, the ngrebeg soon outshone the gatherings in the house temple of the puri. Lesser officials, followers, share-croppers, and countless individuals who wished to pay their respects to the punggawa participated in the parade, which developed into the largest event in Blahkiuh. On those occasions the centre of Blahkiuh was teeming with life, physical evidence of Gusti Putu Mayun's power. It is likely that the Dutch looked upon the Blahkiuh ngrebeg as just another 'religious' happening; the participants themselves thought differently. They identified with their leader and recalled the days of the old negara.

The bond between the old negara and the temple was made more explicit still in the tale of the temple's origins, a story constructed about the same time that the building was in progress. The tale once again featured Dang Hyang Nirarta, and harked back to the days of the first king of Mengwi.

'A man from Blahkiuh (still called Singasari then) on a journey stopped for the night in a nearby village. Dang Hyang Nirarta appeared to him as he slept and gave him a message for the king of Mengwi. When the man awoke he found a lontar leaf placed behind one of the ceiling timbers. The lontar was addressed to the king, so the man took it with him to Mengwi. ${ }^{34}$ The king was exhorted to build a temple in honour of Nirarta, next to the market place. Moreover, all those passing the temple should respectfully alight from their horses, wagons, or sedan chairs and cover the distance on foot. Since Mengwi already had a temple, the story continues, the king decided to build the new temple in Singasari and gave it to a branch of the dynasty that ruled there. Later, when this branch was destroyed, the place was called Blahkiuh. And so it is that next to the market in Blahkiuh stands a temple whose priest is a descendant of the man who found the lontar. ${ }^{35}$

33 The parade was held on Manis Kuningnan, the birthday of the last king of Mengwi.

34 Its opening line was 'Cening Made Agung' which is the equivalent of 'Dear Made Agung', though literally it means 'Little Made Agung', a form of address which is both condescending and familiar, which was allowed because the position of the ancestor of the brahmans was far higher.

35 In the temple a lontar leaf was long kept, surrounded with mystique and riddle. It was said that no pedanda was able to decipher it because the lines would disappear or run together. The text was literally beyond the reader's power. Recently the lontar turned to dust. 
For almost all informants this was the 'true' story. To be sure, some of them remembered very well that the temple was built in 1928. But this did not contradict the story. To understand the glaring discrepancy we must look at how the past was used to 'explain' or legitimize the present. As Bateson (1970:135) has pointed out: 'The past provides not so much the cause of the present but the pattern on which the present should be modelled.' To the Balinese, history was no res gestae long past; it is always close to us and alterable. History was the language in which one could speak of the present. In this connection two terms were used: éling, commemorating, and uning, knowing. The people in Blahkiuh knew that the temple was built in 1928, but commemorating extended to the bond between puri Mayun and the roots of the Mengwi dynasty.

\section{The babad}

At the time the temple at Blahkiuh was being built, the first phase of the restoration of the old dynasties in Bali was forging ahead. But it was by no means certain that the Mengwi dynasty, too, would be eligible. Since Mengwi was part of Badung subdivision, it might well be taken up into the reinstated negara Badung, which was hardly what the Mengwi leadership wanted. Gusti Putu Mayun and his younger brother Gusti Rai Kepakisan together ruled the greater part of the old negara Mengwi. Towards the end of the 1920s they came forward as spokesmen of the dynasty, without losing sight of the interests of their own branch.

The Mayun brothers were faced with two problems. First, they had to prove to the BB that negara Mengwi had a right to exist. Second, they had to solve the problem of finding a suitable candidate to rule the newly restored kingdom of Mengwi. The first difficulty was not insurmountable. Together with a few relatives, Gusti Putu Mayun composed a new genealogical narrative of the Mengwi dynasty. As in the case of the temple in Blahkiuh, this babad served as legitimization rooted in a far past. ${ }^{36}$ The new babad was a beautiful narrative, containing many references to classic texts such as the Ramayana and the Mahabharata. From this it derived much of its

36 Babad Mengwi-Blahkiuh. Information from G. Ag. Gede Mayun, Blahkiuh, G. Ag. Gede Rai, puri Selat-Dauh; see also Schulte Nordholt 1992. There was an evident correspondence between the construction of temples and of texts representing the past, because both formed equivalent paths to communing with the Divine (personal communication Raechelle Rubinstein). The text was also a response to another babad, written by the aged Agung Kerug around 1923, babad Mengwi-Sedang. The enemies of Agung Kerug considered this babad totally inadequate and unreliable. Meanwhile, Agung Kerug himself had become a resi, a priest, which was more common among non-brahman nobles (see Korn 1932:144-5), and had changed his name to Sang Gede Resi Putu Mayun. 
persuasive power. ${ }^{37}$ As punggawa, Gusti Putu Mayun was in an excellent position to declare his version the only 'genuine' one. The text became the authoritative source for legitimizing the link between the dynasty's illustrious past and the royal ambitions of puri Mayun's leader.

For the Balinese, the babad provided ample proof of negara Mengwi's right to exist. But the BB needed convincing as well. Gusti Putu Mayun and Gusti Rai Kepakisan ${ }^{38}$ turned to the Dutch with a proposal intended to satisfy their criteria.

The BB put great store in appointing a ruler that was a direct descendant of the last king of the old negara to be restored. In Mengwi this would be Gusti Ketut Agung, but he was not popular with the Dutch. Hence, the two punggawa proposed that a council be formed in Mengwi to rule the negara. ${ }^{39}$ In this way the 'incompetent' Gusti Ketut Agung could be bypassed and the two punggawa would be the most influential persons in the council.

Efforts to restore negara Mengwi ran into a blank wall. Mengwi had fallen in 1891 and the BB would recognize nothing but the situation as encountered in 1906. Whatever did not exist in 1906 would not be restored. The leaders of puri Mayun lost; not the babad but the Staatsblad announcements determined who would become king and who would be passed over.

\section{Preservation versus change}

When old dynasties were 'restored' in Bali in 1929, Resident L.J.J. Caron used an interesting metaphor. He presented Balinese society as a house that had now been given 'a protective roofing'. ${ }^{40} \mathrm{He}$ omitted mention of the fact that this 'purely' Balinese 'house' was designed by Dutch architects and supported by the colonial regime. As the Dutch saw it, Balinese society was a completely integrated whole worthy of assiduous preservation. 'Bali is unique [...] more finely grained than any other part of the Indies', wrote Controleur V.E. Korn. He, too, felt that Bali should be closed off from the outside world to keep harmful influences at bay (Korn 1925).

Dangerous threats were seen in Islam and rising nationalism, and also in

37 According to informants, the language of the babad was 'sekadi parwa', as (beautiful as) a parwa (the parts that make up the epic Mahabharata). To underscore the 'genuineness' of the new babad it was said that the new text was based on an 'old manuscript' that had disappeared after the fall of Mengwi but had been suddenly rediscovered in Badung.

38 This name, too, is a link with the past, a reference to the ancestor of the dynasty, Arya Kepakisan.

39 ARA, MvK MvO Controleur Badung J.H. Boerstra 1928. This type of council was initially provided for in the governmental reorganization plans and was not unlike the regency councils instituted on Java. In the event, the government did not institute these councils on Bali.

40 ARA, MvK MvO Resident L.J.J. Caron 1929. On this theme see also Schulte Nordholt 1986b:34-49. 
Western missionary work. In 1932 the alarm was sounded when it appeared that evangelists were active on Bali. Established 'Bali experts' all opposed this 'Christian action'. Dr R. Goris, language official and adviser to the BB on Bali, warned that 'unrest of state-endangering proportions' would result if Christianity were to infiltrate Bali, because unemployed brahman priests would pose a political threat, and 'Calvinism' would be an agent of 'cultural destruction'. ${ }^{41}$ In the $\mathrm{BB}$, too, the majority opposed missionary work. The arguments advanced by Goris decided the issue: the governor general forbade missionaries to enter Bali. ${ }^{42}$ The Balinese themselves were not a party to the clamour around the missionary issue. They were not consulted, because concern with the 'fragile' Balinese culture was exclusively a white men's affair. ${ }^{43}$

In the area of education the same sort of thing applied. Initially, there was much demand for Western-educated young people to fill the lower ranks of the Balinese colonial bureaucracy. In view of this, a Dutch Native School (Hollandsch-Inlandsche School, HIS) was established in Denpasar. But around 1920 the tide turned when 'popular chiets' were gaining ground. 'What are we to do with all those Dutch-speaking Balinese?' Controleur Korn asked. ${ }^{44}$ Later he added that the HIS groomed 'half-baked intellectuals [...] making for a fateful element in a still rather primitive society'. ${ }^{45}$ As a result, Balinese access to higher education was intentionally blocked. Instead, more attention was given to three-year elementary education in desa schools. ${ }^{46}$ To prevent young people from being exposed to undesirable influences, schooling was adapted to 'the indigenous atmosphere', effectuating a process called 'Balinization'. ${ }^{47}$

41 Coll. Hooykaas, letter Goris to Resident 4-8-1932. For a review of the arguments against mission work see Bosch 1932, Lekkerkerker 1933, and Covarrubias 1973:396-405. Those supporting mission work on Bali included H. Kraemer (1933) and M.J. IJzerman (1932). They noted the dark and gloomy heathendom lurking behind the brilliance of Balinese culture. In this context the journalist Zentgraaff (1933) introduced the term 'the Bali Reserve'.

42 Coll. Goris, memorandum Goris to Adviseur Inlandsche Zaken 20-8-1934; Adviseur Inlandsche Zaken to G.G. 31-7-1934, G.B. 2-2-1935-23 geh. In the event, officials looked the other way as long as no active conversion activities were undertaken. Towards the end of the colonial period Bali had some 1,600 Christians, most of them in Badung and Mengwi (ARA, Coll. Boon, MvO Resident H.J.E. Moll 1941).

43 The negara administrators did request from the governor general in 1932 that mission work be prohibited, but it is likely that this happened at the instigation of Goris. On the other hand, the Balinese found it hard to understand why the Dutch had not introduced their religion much earlier. After all, when Bali was conquered by Majapahit, the Javanese rulers had introduced their religion (personal communication C.J. Grader).

44 ARA, MvK MvO Controleur Badung V.E. Korn 1921.

45 KITLV, Coll. Korn:147, memorandum 22-12-1925.

46 The number of desa schools on Bali increased from 68 in 1923 to 195 in 1941, compared to just two Dutch Native Schools (ARA, MvK MvO Resident H.T. Damsté 1923; Coll. Boon, MvO Resident H.J.E. Moll 1941).

47 KITLV, Coll. Korn:147, report Resident H.T. Damsté; Te Flierhaar 1941. The showpiece 
Neither restricted access to secondary education nor the Balinization of the course materials could prevent Balinese youth being exposed to new ideas, particularly in the informal schools established on Bali by Javanese representatives of the nationalist movement. ${ }^{48}$ These schools attracted many students who were denied entry to government schools. In this way the Dutch in fact encouraged the very thing they sought to prevent, since these 'maverick schools' spread the seed of nationalism over Bali.

In conjunction with this educational policy, the caste system, too, was meticulously maintained. Primacy of the caste hierarchy was underscored by the restoration of the old dynasties and was zealously guarded by the native courts of justice. Even so, there was some commotion during the 1920 s when a jaba association was established that opposed the idea of caste barriers, and advocated assessment by achievement rather than by birth. ${ }^{49}$ Their interest in this matter had to do with the introduction of popular chiefs. Jaba officials were being passed over for these appointments; they could become officials but the caste hierarchy took precedence.

In addition to concern with religion, education, and the caste system, the colonial government tried to preserve the indigenous character of Balinese art. This was most evident shortly after the earthquake in 1917. Dutch architect P.A.J. Moojen took it upon himself to supervise the restoration of many damaged temples and puri. Moojen immediately sounded the alarm, speaking of an emergency situation because the 'repairs' being made were inappropriate. Rather than rebuilding the structures in the old style, the Balinese were introducing all kinds of novelties copied from the Europeans, which was something that, of course, could not be condoned.50 Colonial control over art was short-lived, however, because the bureaucratic BB was not the proper body to pursue a coherent policy in this field.

Balinese art did remain under Western supervision, though. Towards the end of the 1920s a small but influential group of Western artists settled in Bali and took it upon themselves to protect indigenous art against 'decad-

of this kind of education was Siladarma, the elite private school in Klungkung, opened in 1928. Formally, the regents of Gianyar and Bangli and the stadtholder of Karangasem had taken the initiative in this, but the Balinese character of the school was watched over by Dutch personnel (ARA, MvK MvO Controleur Klungkung J.C.C. Haar).

48 Towards the end of the 1930s there were 15 such schools, established by the Parindra. ARA, Coll. Boon, MvO Resident H.J.E. Moll 1941; on the Parindra see Pluvier 1953.

49 See Korn 1932:124-5, Bagus 1970, Putra Agung 1974, and Vickers 1989:150-5. One of the founders of this association - Surya Kanta - was the former punggawa of Mengwi, Ketut Sandi. This meant the end of his career as an administrative official. The Resident held that he was politically unreliable and could be retained no longer (ARA, MvK MvO Resident P. Moolenburgh 1926).

50 On the activities of Moojen, see Moojen 1920; ARA, MvK V18-6-1918-39, V24-10-1919-52, V13-1-1922-65, MvO Resident H.T. Damsté 1923; KITLV, Coll. Moojen. See also Schulte Nordholt 1986a. 
ence' and 'degeneration'.51 Ironically, this group introduced far-reaching innovations in the visual arts on Bali.

In the course of the 1930s Bali developed into an important area for anthropological research. Western scholars such as Jane Belo, Gregory Bateson, and Margaret Mead characterized Bali as 'static' and 'in equilibrium'. Like many of their contemporaries, they were unaware that the 'traditional' situation, which they took to be authentic, had been deeply influenced by the presence of colonial rule. 52

Bali came to be known as an idyllic place, where time stood still and traditional life, untouched, moved in harmony with nature. Popular accounts such as those of Miguel Covarrubias (1973) and Hickman Powell (1930) reinforced this image. This quasi-arrested Bali turned into a kind of open-air museum where the international and well-to-do bohemia found temporary refuge from the Great Depression. The image ascribed to Bali became the more convincing through repetition, and travellers found what they wished to find.

In colonial policy 'traditionalization' of society became a major theme. In this connection the study of adat law was a fitting means to exercise stable colonial control. Adat, the totality of written and unwritten rules for daily conduct and affairs, had always been a flexible system. But as soon as Dutch researchers, most of them lawyers, laid these rules down in law books, flexibility disappeared and the character of adat was transmuted into an unchangeable tradition carrying the seal of approval of the colonial government. ${ }^{53}$ The study of adat law was expected to provide the key to understanding indigenous society, so as to impose order on it and to control it. ${ }^{54}$ Preservation of the 'traditional' order was thus inseparably linked with

51 Prominent in this group were Walter Spies and Rudolf Bonnet (see Rhodius n.d.). A typical instance of the paternalism of the Western artists is this statement by Walter Spies: 'Upon us, a race that would contribute to culture, and in possession of a certain degree of historical knowledge of the development and demise of other, widely diverse races and their native art, devolves the task to point out the harm which neglect of indigenous, original elements can do in terms of dulling and decay of native art, to warn of the dire consequences when modern affectations are short-sightedly adopted, to counteract in particular the blind, superficial aping of foreign expression of art copied from strange races and with complete lack of understanding' (KITLV, Coll. Korn:117, MvO Controleur Gianyar H.K. Jacobs 1934).

52 For a collection of articles from the 1930s, see Belo 1970. For a critical analysis of Mead's views on Bali, see Pollmann 1990, and Asad 1973 on anthropological images during the colonial period.

53 See also Benda 1958:67-8, and Ranger 1983 who describes a similar development in colonial Africa.

54 See Korn 1932:676 and Schulte Nordholt 1986b:48-9. To shield local adat from administrative inroads, colonial influence extended still further into the local level to reach the wards (banjar) during the 1930s. Just like the village, the banjar was split up into an administrative sphere, called banjar dinas (from the Dutch word dienst, service/task), and a banjar adat. As a result, the Balinese were now confronted with two kinds of leadership in their banjar: a dinas head was appointed as the agent of the perbekel, while the adat head 
the colonial presence on Bali. The contradiction characterizing the latecolonial period was that the Dutch thought they could close Bali off from the rest of the world and preserve it in a quasi-traditional situation, while exactly because of the colonial presence the island was experiencing accelerated and irreversible change.

\section{Trade}

The arrival of colonial rule brought unprecedented expansion of commerce and trade in South Bali. The Pax Neerlandica offered an entirely new standard of safety to traders formerly threatened by pirates, robbers, and feuding lords. Other barriers, dating from the days of royal rule, were removed as well. The monopolies usually leased by powerful puri to Chinese families and the countless toll-gates along the trade routes were abolished. ${ }^{55}$

Moreover, an infrastructure was created which greatly promoted trade between the Balinese hinterland and the world market. The administrative centre of Denpasar became the hub of an extensive network of roads built in the space of a single decade by corvée labourers and covering most of South Bali. ${ }^{56}$ Along these roads moved an increasing stream of trade goods. In the nineteenth century small 'pikol horses' were the most frequent means of transport. In the first two decades of the twentieth century they were edged out by carts and lorries, which penetrated far into the hinterland via the new roads and bridges. ${ }^{57}$ This network of roads connected many South Balinese local markets with Denpasar, which functioned as the main import and export market. A road ran from Denpasar to the harbour of Benoa on the southern peninsula. This harbour was made suitable for sea steamers and featured a long, dredged, embanked channel.58 Ships shuttled to

was placed in charge of a ward's internal 'religious affairs'. (Hunger 1932; ARA, MvK MvO Resident G. de Haze Winkelman 1937).

55 ARA, MvK MvO Resident G.F. de Bruyn Kops 1909; V28-6-1910-9.

56 ARA, MvK MvO Resident H.U. van Stenis 1919. The most important east-west route ran from Karangasem, via Klungkung, Gianyar, Denpasar, Kapal, and Mengwi to Tabanan. A number of roads went to Buleleng: from Tabanan (via Pupuan), Mengwi (via Baturiti), and Gianyar (via Bangli and Kintamani). Initially it was intended that the major north-south route would traverse the middle of the island, passing by Blahkiuh. This would have increased the importance of the market at Blahkiuh and, hence, of punggawa Gusti Putu Mayun's residence. In the event the plans were not executed, however. Most roads were grass paths on firm ground. From the 1920s onwards a start was made to pave the larger longdistance roads.

57 In 1920 eight lorries were registered in Badung. Transport by pikol horse was replaced by pulling carts (cikar) and one-horse chaises (dogkar). ARA, MvK MvO Controleur Badung V.E. Korn 1921.

58 The road to the harbour of Benoa was constructed by corvée labourers as well. It was heavy work, far away from home, in an area rife with malaria. ARA, MvK MvO Assistant Resident A.J.L. Couvreur 1920, MvO Controleur Badung V.E. Korn 1921. 
Surabaya, Batavia, and Singapore, thus connecting Bali with the world market. Balinese exports consisted mainly of pigs, copra, coconut oil, and rice; textiles and petroleum were the major imports.

The trade pattern in South Bali was characterized by monopolies on the one hand and small merchants on the other. By 1915, when Benoa was taken up into the sailing routes, transport overseas was controlled almost completely by the Koninklijke Paketvaart Maatschappij (KPM), the Royal Packet Line. The main market at Denpasar was dominated by a few large trading houses. The most prominent of these was a subsidiary of the Nederlandsche Handel Maatschappij, which controlled most of the imports and exports. ${ }^{59}$ In the South Balinese hinterland, small trade was predominant, however, and engaged in by Chinese families and Balinese women. They were the link between Denpasar and the dozens of local markets which, in turn, were connected with Balinese households.

Production of Balinese export goods was not monopolized because there were no large livestock farms or extensive coconut plantations. Nor did the nobility have a monopoly on production and trade. Some noble families did engage in commerce, but in this sector they were unable to establish a new power base. They gravitated to careers in the official world of the colonial administration.

Production took place within the individual Balinese households. The woman played a crucial role in this, since it was she who from time to time sold some pigs from her yard or coconuts from her garden or part of the rice crop to intermediate traders. As I said, most of these intermediaries were women. After the royal monopolies were abolished, they had gained a more advantageous position, alongside of the Chinese networks, and possessed a large degree of independence. ${ }^{60}$

One such (jaba) merchant woman lived in Blahkiuh. She had begun as an agent for a Chinese trade network, but soon started trading on her own. She bought coconuts in the neighbourhood and had them processed in her own yard by daily labourers. The copra was transported on her own carts to Denpasar to be sold to one of the largest exporters. In addition, this woman dealt in pigs, which she bought in large numbers and also sold to exporters in Denpasar. Ultimately her large turnover enabled her to deal in finance. Her yard turned into a kind of local bank, where Balinese kèpèng could be

59 This was the Afscheep- en Commissie Zaak Zuid-Bali (Shipment and Commission Office South Bali) (ARA, NHM:9238). There were also a few Armenian, Arab, and Chinese firms. Because Denpasar became the centre of trade of South Bali, the harbour at Buleleng gradually moved down to second place.

60 Some did not marry, but maintained informal relationships. 'She lives with [him] with no strings attached and if he becomes too demanding she gets rid of him' (ARA, MvK MvO Resident H.W. Veenhuyzen 1914). 
exchanged for Dutch Indies currency and where loans could be obtained. ${ }^{61}$

Although Chinese merchants had had to give up their former monopolies, they continued to control a substantial part of the local markets. Especially because of their extensive networks of relatives and colleagues, they could respond quickly to price fluctuations. In addition, they made much profit by taking advantage of varying exchange rates between the Dutch and Balinese currencies (De Kat Angelino 1921c). In contrast with Balinese merchant women, whose networks were much smaller, a number of Chinese families managed to set up, though not always successfully, a rice-husking plant, an oil factory, or workshops to process copra. One such network extended to Blahkiuh, where in the second half of the nineteenth century a family had settled which had connections in Mengwi, Carangsari, Kapal, and Denpasar. Via advance payments (porsekot, from Dutch voorschot), rice and coconuts were bought from individual farmers and either processed locally or sent to small factories of relatives. The husked rice, the oil, and the copra were also sold to one of the merchant houses in Denpasar, after which KPM vessels transported these goods to Surabaya, Batavia, or Singapore. ${ }^{62}$

Between 1908 and 1928 South Balinese exports grew spectacularly, from Dfl. 1.1 million in 1908 to more than Dfl. 8 million in $1928 .{ }^{63}$ In consequence of this, a large amount of Dutch Indies money flowed to the South Balinese hinterland and countless households came into contact with the colonial monetary economy. In other words, colonial monetization took place and was linked up with the existing circulation of the Balinese kèpèng.

Money earned from export was spent partly on imported goods available from the merchant houses in Denpasar and on the local market. Cooking utensils, petroleum for lighting, and textiles were the most-bought commodities. Aside from this, money earned was used to pay colonial taxes. The relationship between trade and taxes was of crucial importance.

\section{The colonial land rent tax}

The 1920s were characterized by a paradoxical development. The distance between the BB and the people increased, even as the colonial system penetrated society to ever greater depths. By now, Dutch officials felt that they were sufficiently familiar with Bali, so that they saw no need to engage in new research. Furthermore, officials had to spend most of their time in

61 In 1983 all that was left displaying former riches was the large house temple containing a shrine to the goddess of trade. Her son and grandson turned out to be incorrigible gamblers who lost no time in squandering her fortune.

62 Information from I Ketut Segara, Kak Darti, and Pan Muka, Blahkiuh.

63 For a specification see Tables 1 and 2. This upward line faltered twice, around 1919 after the earthquake and crop failures and around 1923 in consequence of the economic recession. 
their office, simply to keep abreast of the mounting volume of bureaucratic paperwork. The monthly journey through the subdivision, too, underwent change. Now that roads were built and the controleurs had motor cars, contact with the people became more sketchy. A stop-over in a village became a rare occasion. On horseback the journey used to last a number of days; now the trip amounted to a routine visit taking just a single day. Moreover, the small European community gradually isolated itself in a social enclave in which the Club and fenced-in tennis court were the most important meeting spots. ${ }^{64}$

Although to all appearances the BB was withdrawing from society, the people were faced with increasing penetration of the colonial system in the shape of a new taxation structure. Up to the beginning of the 1920s a preliminary tax was levied, which between 1922 and 1927 was replaced by a new system of 'land rent'. In contrast with the old system, all taxable land was measured, and test measurements allowed far more accurate estimates of the expected yield. ${ }^{65}$ The consequences of the new approach were farreaching. Much more land was taxable, and taxes levied on sawah increased by large increments, even more than for dry land. In Badung subdivision the sawah tax was raised 50 per cent (see Table 2). ${ }^{66}$ On top of this added burden, people were confronted with a new way of paying the tax. Land tax could no longer be paid in kind or in kèpèng. Payment had to be in Dutch Indies currency. ${ }^{67}$ This meant that Balinese taxpayers had to 'buy' Dutch Indies currency before they could pay their taxes. The easiest way to obtain Dutch Indies money was by way of commerce. As a result, export of Balinese products came to be intimately interwoven with the new land tax.

The new taxation system was not controlled by the BB. A separate Landrente Dienst (Land Rent Bureau) was created, which drew much criticism. Korn, for example, criticized the purely fiscal nature of the new land rent system. For one thing, no consideration was given to other obligations on the part of taxpayers, such as ritual burdens or the labour required of them by the subak. ${ }^{68}$ In addition, the Land Rent Bureau gained

64 The European tennis court in Denpasar was situated on a field facing the office and dwelling of the Resident. The fence symbolized the irrevocable boundary between the white caste and the Balinese (information Ibu Jasmin Oka, Denpasar).

65 ARA, Mvk V9-3-1922-60, V26-9-1922-72, V23-8-1923-21. In Badung and Mengwi the new system was introduced in 1924.

66 In Gianyar taxable sawah increased by 40 per cent and dry-land taxes by 197 per cent. Sawah tax rose by 60 per cent (Korn 1932:338).

67 Lekkerkerker 1923c:183. The Dutch administration wanted to do away with the enormous quantity of kèpèng, which always required exchanging (at a loss) via local (mostly Chinese) money changers.

68 KITLV, Coll. Korn:164, report Controleur Badung V.E. Korn 20-3-1921. Up to 1929 the Land Rent Bureau acted autonomously, and the BB had no voice in the reorganizations carried out by this agency (ARA, MvK MvO Resident L.J.J. Caron 1929). 
considerable influence over appointments of irrigation personnel. Since preference was given to administrative skills, appointments as sedahan and sedahan agung largely went to former teachers and clerks. The primary role of Balinese irrigation personnel was now that of colonial tax collector.

The Land Rent Bureau influenced not only personnel appointments, but also the subak as such. Together with the introduction of the new tax, there was a large-scale reorganization on the local level, whereby countless subak were amalgamated into greater units. In Badung subdivision alone, the number of subak was reduced from 266 to $146 .{ }^{69}$

After the administrative reorganization around 1910 and the fiscal revamp of the 1920s, there was little in the southern Balinese subak to remind one of the local bonds of pre-colonial days. Centralization of the administration and emphasis on tax collection had caused an increase in scale which made its inroads upon local irrigation associations. Even so, this process did not automatically spell disintegration. On the central level the colonial rulers guaranteed a steady water supply, a new phenomenon altogether. Owing to the enforced peace on the island, water supply was no longer threatened by recurrent outbursts of hostilities. Moreover, the Dutch ultimately conquered nature as well, by replacing a number of the more vulnerable dams with new concrete structures that could not be swept away in the violence of the annual flash floods. In the river Ayung, for example, in the period between 1914 and 1931, four concrete dams were built which together irrigated 12,763 hectares of sawah. ${ }^{70}$

Colonial control and the construction of the new dams greatly increased the continuity of South Balinese agriculture, as the increase in rice production and rice exports showed. Taxpayers were able to pay the land rent by selling part of their surplus. In addition, the market price for rice was far better than the fixed amount on which the tax assessment was based. ${ }^{71}$ The increased taxation could therefore be met through profits gained in exports. Improved roads and rising prices allowed Balinese taxpayers to 'buy' the Dutch currency with which they could discharge their tax obligations.

The new land rent system undoubtedly provided better insight into the

69 Korn 1932:316-7, 327-8. In Tabanan the number of subak went from 447 to 180.

70 These were the following dams: Oongan (1914-1929, 3,248 hectares), Praupan (1920-1924,

365 hectares), Mambal (1926-1927, 6,000 hectares), and Kadewaten (1927-1931, 3,150 hectares). The colonial government invested Dfl. 633,000 in these projects. Maintenance of the dams was the responsibility of the Public Utilities Service (BOW)). ARA, MvK Nota van Toelichting Badung H.J. Hoekstra 1938.

71 Based on a series of rice prices over the years 1914 to 1922, the Land Rent Bureau had fixed the new land tax at Dfl. 1.90 per pikol (62.5 kilogrammes) of rice. The market value during the 1920s, however, was many times higher. ARA, MvK V9-3-1922-60; Nota van Toelichting Badung H.J. Hoekstra 1938. 
total taxable land area, but it remained unclear who actually paid the tax. It is true that the separate plots were registered by name, but when the taxes were collected, no check was made to see whether payment was made by the owner or by someone else. In other words, the tax was collected by plot rather than by owner. ${ }^{72}$ Upon the introduction of the new land rent, the numerous privileges and exemptions dating from royal times were abolished. Noble large landowners were now taxed as well. But they managed to have their share-croppers do most of the paying. This meant that a share-cropper generally had to take care of the entire land rent tax, as well as deliver the regular share of the crop (one-half to two-thirds) to the landowner and provide periodic labour. ${ }^{73}$ A 1929 study of taxation in the Outer Islands showed that in the Netherlands Indies the most heavily taxed area by far was Bali. ${ }^{74}$ This heavy burden, however, could be met with income from retail trade. As far as can be determined, collection of the new land rent did not give rise to problems. Some share-croppers even had sufficient funds to buy off their corvée labour obligations, an opportunity many availed themselves of between 1927 and 1929. ${ }^{75}$ During the 1920s, the new system of taxation was possible only because the export climate was favourable. People were able to meet the new obligations as long as they could buy enough Dutch Indies currency by exporting pigs, copra, and rice.

\section{Crisis}

'Suffering' was not a concept frequently associated with Bali in the 1930s. Most publications painted a rosy picture of the island, its people living out a timeless tradition, without a care for the morrow. According to Bateson, the Balinese were 'not hungry or poverty stricken. They are wasteful of food. 76 A second look, however, shows that the 1930s were not free of problems, but Bali's reputation worked against the island, and the consequences of this

72 Payment was made on the basis of a pipil, a strip of dried palm leaf marked with data concerning the plot of land. Information from G. Ketut Kaler, Blahkiuh, and G. Ag. Ajeng, Kedampal, who still possessed some of these pipil. When the tax was paid, a stamp was placed on the pipil.

73 See for instance Hunger 1933. This statement also rests on interviews with a large number of people in the Mengwi region whose families were share-croppers under noble large landowners in the late 1920s and 1930s.

$74 \quad$ Verslag Belastingdruk 1929. In 1927 Bali yielded close to Dfl. 2 million, which amounted to two-thirds of the total land rent collected from the Outer Islands. Per hectare of sawah, the average taxation on Bali was Dfl. 10.87 (Dfl. 17.71 in Badung). On Java average taxation was far less per hectare of sawah (Madiun, Dfl. 4.20; Semarang, Dfl. 4.42). I thank Geoff Robinson for sharing his research material on this matter.

75 The amount needed for this was Dfl. 5 per year, which was paid by $90 \%$ of the conscripts. Work on the roads from then on was done by 'free labourers', daily workers (ARA, MvK MvO Assistant Resident C.C. Ouwerling 1929).

76 Bateson 1970:391; see also Hanna 1976:107: 'The ordinary people had on the whole plenty of rice and relatively few complaints.' 
were felt when, from 1930 onwards, the effects of the world-wide economic depression took hold.

The crisis manifested itself almost immediately in two areas: in exports and in land rent taxes. As of 1930, the bottom dropped out from under export prices, in consequence of which far less Dutch Indies currency flowed in. (Table 1; for the seven tables belonging to this chapter, see pp. 324-6). After the peak year of 1928, when more than Dfl. 8 million was exported, income fell sharply, to Dfl. 1.9 million in 1935. In 1934 a pig fetched no more than a quarter of the former price, and a pikol of copra decreased from Dfl. 10 in 1929 to Dfl. 2.60 in 1934 . At first, people sought to compensate for the recession by continuing exports and importing less. Imports, which in 1929 reached Dfl. 6.4 million, fell to Dfl. 1.6 million at the height of the crisis. In addition, expenditure was reduced in that corvée labour was no longer bought off. Within two years an army of labourers went back to work (Table 4). But these savings were insufficient; gold and silver were leaving the island rapidly (Table 3). ${ }^{77}$ By about 1934 South Bali had no reserves left, and the end of the crisis was not yet in sight. To add to the calamity, the rice crop failed twice in succession (1935-1936) in large parts of South Bali owing to plagues of mice and walang sangit, small insects that ate rice kernels. ${ }^{78}$

The $\mathrm{BB}$ responded to these dramatic developments with qualified optimism. In 1932 Resident H. Beeuwkes reported that on Bali there was no poverty, merely 'austerity'. ${ }^{79}$ To his mind the problem was rather simple, because he assumed that on Bali people could fall back on barter trade and that enough cheap food was being produced. Instead of imported petroleum, for instance, the familiar coconut shells were again being used, and the costly imported sarongs made way for cheap Japanese trousers. 'In this way, then, equilibrium is reached,' he concluded reassuringly. ${ }^{80}$

'Equilibrium', however, there was not, nor was 'austerity' a fitting description. V.E. Korn was one of the few to call attention to the spread of poverty:

'Those who get to know more intimately the living conditions of the common people on Bali discover just how grey and poverty-stricken is the mass populating this

77 It was also becoming difficult to find work as a migrant labourer. Coffee production in the Balinese mountains had stopped because of the crisis (KITLV, Coll. Korn:195, report Controleur Gianyar H.K. Jacobs 11-2-1933).

78 In section 5 these crop failures will be discussed further.

79 Although his predecessor Caron had already remarked in 1929 that 'the Balinese have to live very soberly indeed to make ends meet' (ARA, MvK MvO Resident L.J.J. Caron, 1929; MvO Resident H. Beeuwkes 1932).

80 ARA, MvK MvO Resident L.J.J. Caron, 1929; MvO Resident H. Beeuwkes 1932. The seriousness of the crisis was glossed over, because at the same time there was a revival of the arts. 
beautiful island [...]. In Gianyar, Badung, and Karangasem the majority of the people live in abject poverty [... with] conditions deteriorating steadily. ${ }^{\prime} 1$

Older informants, too, remember the 1930 s as years of poverty. Many compared the recession years - malèsèt - with the period from 1963 to 1966, a time when the economy was seriously derailed and food in great shortage.

Soon after the collapse of exports, payment of land rent taxes became an insurmountable problem. Land rent rates had been fixed when the economy was going strong, and they were projected over ten years. As soon as exports ceased, the capability to buy Dutch Indies money was lost, but land rent rates remained unchanged up to halfway through the crisis. ${ }^{82}$ By 1933 the situation proved hopeless. In South Bali arrears in land rent payments were roughly 50 per cent, while in Badung subdivision arrears had reached 61 per cent, in spite of incidental exemptions granted that year (Table 5). When numerous enforcement orders and confiscations failed to yield the required cash, the BB decided to decree a general crisis exemption varying from 25 to 40 per cent. ${ }^{83}$

The tax was, furthermore, reduced at the next ten-year revision. This made it look as if the greatest troubles were over, except that the belated concessions yielded a distorted picture, because the tax reduction was partly undone by another factor. Land rent still had to be paid in Dutch Indies currency, which continued to be in short supply. In fact, colonial money had become much more expensive compared to the Balinese kèpèng. In 1931 one paid between 1,375 and 1,875 kèpèng for a rix-dollar, but by 1934 the price had gone up to 2,025 kèpèng or even 2,300.84 Consequently, the Balinese looked upon the tax reduction as far less sizeable because of the unfavourable exchange rates.

In the first half of the 1930s many households lost control over their sawah land because they were behind in paying their taxes. Accurate figures cannot be given. In part this is owing to European lack of knowledge of how formal rules were implemented in practice and for another part it is because debts were frequently contracted informally. Formally, a tax-indebted person

81 Korn 1932:336-7. In addition, the controleur of Klungkung-Bangli reported that the majority of the inhabitants of his subdivision were 'very poor' (ARA, Mvk MvO Controleur Th.B. van Aalst 1931).

82 In 1931, when Balinese pleaded for a reduction of the land rent taxes, the assistant resident declared that this was not to be considered. The Balinese should follow the example set by Britain and the Netherlands, where the people were asked to sacrifice for their country (ARA, MvK MvO Resident H. Beeuwkes 1932).

83 KITLV, Coll. Korn:117, MvO Controleur Gianyar H.K. Jacobs 1934; ARA, MvK Nota's van Toelichting Tabanan en Badung H.J. Hoekstra 1938.

84 ARA, Coll. Boon, MvO Controleur Karangasem M. Boon 1934. In 1937 the rate dropped to about 1,750 kèpèng per rix-dollar. Eventually in this year it was proposed to have the Balinese pay their land rent in kèpèng. It is not clear whether this in fact happened (ARA, MvK MvO Resident G. de Haze Winkelman 1937). 
received an enforcement order (or dwangsrip, from Dutch dwangschrift). If this had no effect, the crop was confiscated (lélang galur), and finally one's land could be confiscated (lélang). If official records can be trusted, very few land confiscations occurred in Badung subdivision, but informants tell a different story. ${ }^{85}$ According to them, there was large-scale confiscation. Interviews indicated that in Abiansemal district dozens of hectares changed hands, and the impression is that elsewhere in the Mengwi region matters were similar (Krapels 1939:271).

$\mathrm{BB}$ officials were almost never involved in the actions leading to confiscation. This was the responsibility of Balinese tax personnel, the regional sedahan in particular. It is highly probable that these officials operated very autonomously in this matter, and that countless informal arrangements were made that were never entered in the ledgers. ${ }^{86}$ I come back to this below. Moreover, the Dutch lacked adequate insight into the appreciable differentiation in landed possessions and into the reshuffle of them during the crisis years. Large landownership and landlessness were mentioned in passing, but never investigated. ${ }^{87}$ The Dutch could not tell what percentage of the population had no immediate access to sawah land since the administration did not list the landless as a separate category. The general assumption was that on 'egalitarian' Bali, landed possession was evenly distributed as a matter of principle. On average each South Balinese household was thought to hold 0.48 hectare of sawah. ${ }^{88}$ Large landownership was not easy to trace either, since a separate certificate of ownership (pipil) was written out for every single plot. This meant that large landowners might well possess dozens or even hundreds of such certificates, the Dutch believing that they were held by so many different persons, each with a little

85 ARA, MvK Nota van Toelichting Badung H.J. Hoekstra 1938. In 1934 letters of enforcement totalled Dfl. 10,344, while supposedly a mere Dfl. 181 worth of land was confiscated.

86 Information from G. Ketut Kaler, Blahkiuh, Ida Bagus Made Rai, Bongkasa, who were assistant sedahan during the 1930s, and others. Assistant Resident B. Cox, too, suspected that the BB was not officially apprised of all goings-on. In this connection he mentioned autonomous activities undertaken by sedahan in Badung and Gianyar, who arranged confiscations themselves without informing the controleur (ARA, MvK MvO Assistant Resident B. Cox 1940). When the question was put to former controleur F.W.T. Hunger, he replied that he, too, knew that sedahan paid the land rent for others, thus gaining possession of the land (personal communication).

87 See Hunger (1933) and Peddemors (1933) for references to large landowners. In 1934 Controleur H.K. Jacobs noted widespread landlessness in Gianyar (KITLV, Coll. Korn:117, MvO 1934).

88 Bakker 1937c. In Badung this average was supposed to be 0.45 hectare. In a series of articles Bakker (1936, 1937a-d) sought to demonstrate that the Depression had no really serious effects. He calculated the household budgets of selected families in terms of hypothetical guilders and a fictitious balancing of the books, and concluded that taxation was not a heavy burden. 
plot of their own. ${ }^{89}$ The extent and possible growth of large landownership, then, was largely hidden from the Dutch administrative purview.

This was also true for the landless as a group. One exception to this was the southern part of the Mengwi region, where since the end of the nineteenth century most of the land belonged to Badung immigrants. The majority of the landless in this region were migrant workers; however, once the crisis put an end to the export of coffee, this seasonal source of income was suspended as well. ${ }^{90}$ When Controleur Grader toured the region in 1932, it was clear that people were going hungry. He was told with some hesitation that 'many consider themselves lucky if they can get a reasonable meal just once a day'. ${ }^{91}$

It is no coincidence that precisely in this impoverished part of Mengwi mission work met with success. There were large groups who considered themselves abandoned by their former Mengwi lords and who noted that the large landowners from Badung were prepared to offer them little. The resulting erosion of the hierarchical order, with which public ritual (or 'religion') was intimately connected, made possible a fairly widespread transition to Christianity. ${ }^{92}$

Alongside of this visible concentration of landless people, all of South Bali probably experienced increasing 'hidden' landlessness. Two factors contributed to this. The first was the growing shortage of land, and the second was the unequal power relations between the strong noble families and weaker groups of people.

Between 1905 and 1930 the population on Bali grew from about 700,000 to over a million (Table 6). With some reservations it may be said that the Pax Neerlandica and the decrease in vast epidemics constituted the major factors for growth. ${ }^{93}$ These growing numbers of people had to be absorbed in the agrarian economy. To keep Bali 'traditional', the BB had strongly opposed the introduction of plantations and industry in the 1920s, while during the

\footnotetext{
89 See Bakker 1937c, who equated the number of registered certificates with the number of individual owners.

90 According to Krapels (1939) this involved some 20,000 labourers. Vink (1929) calculated that in the 1927-1928 season, migrant workers from the south (from around Kapal and Sempidi) earned about one million guilders' worth of kèpèng picking coffee in the Balinese mountains.

91 Personal communication C.J. Grader.

92 In some localities 40 per cent of the population belonged to Christian congregations. Private Coll. Swellengrebel, zendingsverslagen Bali 1933, 1937. Interviews with Dr J.L. Swellengrebel, I Putu Cetog, Gulingan, and others revealed that economic motives played a role in this transition as well. The expectation was that Christianity would require less in the way of ritual obligations and would provide a degree of financial support.

93 Medical care was modest, so that the death rate for children remained high (Lekkerkerker 1923c:178-9; ARA, MvK MvO Controleur Badung J.P. Verheul 1923). According to Hunger (1937:618) the death rate for children in the 1930s still stood at 40 per cent.
} 
crisis years the income via commerce had virtually ceased. ${ }^{94}$ Bali just had to try and feed itself. Initially this seemed feasible in view of improved irrigation on the central level. However, the population grew and the expansion of arable land stopped. ${ }^{95}$ At the same time, erosion in the eastern mountain area took on serious proportions because the woods on the slopes were being cut down and the land used for agriculture. From this area flowed a major river, the Ayung, which served a large segment of the Mengwi region. One effect of the ongoing erosion was that less water and more sand reached the rice fields in the south. Hence the problems spread from the eastern Balinese mountains to include the southern Mengwi region, where branches of the Ayung provided water for the sawah. ${ }^{96}$

To cope with the population growth, people had no other choice than to intensify cultivation of available land, a move restricted by the dwindling water supply. ${ }^{97}$ Colonial aid programmes were not initiated until the late 1930s; they were too narrow in scope and too brief in time to effectuate real improvement in agricultural production. ${ }^{98}$ Population growth made arable land, and sawah in particular, a scarce and increasingly costly commodity. The economic crisis rendered it increasingly difficult for the weaker groups to have access to land. But if one had administrative power and a well-filled purse, one could enlarge one's might and riches in the 1930s by shifting the heaviest burdens to the weakest groups.

During the 1930s regional power relations were reshuffled in the southern Balinese sawah plain. Access to land was the stake in a battle that yielded many losers and a handful of big winners. For many puri whose leaders could no longer exert regional power, these were difficult times. They could not pay the land rent taxes and hence lost many of their old possessions. Countless owners of small plots lost access to them because, faced with

94 ARA, MvK MvO Resident H.T. Damsté 1923; KITLV, Coll. Korn: 147, memorandum V.E. Korn 22-12-1925, arguing for a 'genuine and purely agrarian Bali'.

95 In 1932 there was 89,700 hectares of sawah and 253,100 hectares of high ground (arable) on Bali (ARA, MvK MvO Resident Beeuwkes 1932). In Badung subdivision there was some loss of arable land: 1923, 19,340 hectares sawah, 26,865 hectares high ground; 1937, 19,157 hectares sawah, 20,586 hectares high ground, (ARA, MvK MvO Controleur Badung H.D. von Meyenfeldt 1926; Bakker 1937c). The large reduction in arable high ground had to do with the collapse of coffee cultivation.

96 ARA, MvK Nota van Toelichting Badung H.J. Hoekstra 1938; Coll. Boon, MvO Resident H.J.E. Moll 1941.

97 In 1934 sawah land was used for 128 per cent (padi) and 134 per cent (padi and a second dry crop) in Badung, and for all of South Bali these percentages were 103 and 123, respectively (Bakker 1937c). For a statistical overview of the agrarian situation on Bali see Raka 1955.

98 These programmes related mostly to retention of forestry reserves and the construction of ways to protect slopes in order to combat further erosion, agricultural information, and migration from densely populated areas to the empty western part of Bali (ARA, MvK MvO Assistant Resident B. Cox 1940; Coll. Boon, MvO Resident H.J.E. Moll 1941). 
rising debts, they had had to pawn their sawah. The conditions under which share-croppers were allowed to cultivate the land deteriorated further still; their share in the harvest was reduced, while additional burdens were placed on them.

To be sure, there were exceptions to the rule. Some large landowners did manage to retain their possessions, while certain groups of share-croppers were able to improve their position by arranging collective contracts. This happened, for example, in Kaba-Kaba (Hunger 1933). Although the lord of Kaba-Kaba had not been a colonial district ruler for the past twenty years, he continued to be a rich and powerful man. None of the punggawa to whom he was officially subject had been able to control his domain to any great extent, and he held hundreds of hectares of sawah worked by more than a thousand share-croppers. They had to surrender half the crop to their lord, pay the entire land rent, and carry out various tasks for the puri. 'After all, whenever a grand seigneur needs money, he turns to his share-croppers. ${ }^{\prime 9}$

During the 1920s the share-croppers in Kaba-Kaba were still able to meet their obligations by selling part of their share of the crop at favourable market prices. But once prices dropped owing to the crisis, the sharecroppers had to sell almost all of their harvest just to pay the land rent. They were left with little or nothing to live on. In response, they all terminated their share-cropper contracts and returned the land to the lord of Kaba-Kaba, who now ran into problems himself. He could not possibly pay the total tax assessment and was already in debt because of his high living standard and the great expense of his children's education. His sawah monopoly in his domain now turned against him, for he was unable to have other sharecroppers work the fields instead. The share-croppers capitalized on the situation by bargaining with him. As a result, a new agreement was reached such that both lord and share-croppers gained by it. To begin with, it was agreed that from now on the land rent would be taken care of by the lord and the share-cropper in equal amounts. Next, the share-croppers 'lent' a small sum of money to the lord, so that he could repay most of his debts. At the same time these 'loans' bound him. The arrangement was that the lord could not oust his share-croppers as long as he had not repaid the loans. He would not be able to do so for some time, which meant that the sharecroppers were certain of food for at least as long as the crisis lasted. ${ }^{100}$

This kind of guarantee for share-croppers was not attainable in all of South Bali. Unnoticed by the BB, some strong puri which combined noble prestige with administrative power were able to add greatly to their riches.

99 Hunger 1933:177. Along with Peddemors, Hunger is one of the few Dutch officials who pointed out the effects of large landownership in South Bali.

100 This kind of agreement via a binding loan is known as palais (Korn 1932:583). 
Especially in densely populated areas where land was scarce, mighty lords continued to add to their share-croppers' burdens. In large parts of Badung subdivision, share-croppers were burdened with the entire land rent. In Gianyar the situation was even worse. Here share-croppers had to be satisfied with a quarter of the yield and the large landowners did not hesitate to dismiss them if they failed to pay the whole land rent on time (Peddemors 1933). Naive Western visitors might think of Bali in the 1930s as an exotic paradise, but for most of the inhabitants these were dark and dismal years.

\section{The power of puri Mayun}

The 1930s witnessed drastic alterations in agrarian power relations in Blahkiuh. Towards the end of the colonial period 38.5 per cent of the roughly 440 households were without sawah, while 45.5 per cent were smallholders (having .01 to .50 hectare; see Table 7). ${ }^{101}$ On the other hand, more than 220 hectares were held by a small elite that had share-croppers work their land. Most share-croppers were local landless folk or owners of very small sawah plots. As a rule, two-thirds of the rice yield and one-third of the 'dry' second crops went to the owner. In addition, the share-cropper had to perform extra services for the landowner and pay the entire land rent.

At the beginning of the 1930s puri Mayun already possessed much sawah that had been accumulated over the years. There had been 'donations' by the desa when the family established itself in Blahkiuh. Certain tracts were added by way of new clearings. Fault-finders whisper that the puri usurped a lot of land when the new land rent was introduced in the 1920s. New certificates of ownership (pipil) were issued, and on a number of these the punggawa was named rather than the old owner. ${ }^{102}$ It was useless to protest. The old pipil had been surrendered and it made little sense to incur the wrath of the puri.

Land possessions of puri Mayun increased during the years of the crisis by an estimated 30 hectares, and ultimately reached a total of approximately 100 hectares. More than 200 share-croppers and their families depended directly on the punggawa and were on call for a variety of chores in and around the puri. 103

101 Many of the data presented here come from confidential talks with a large number of informants. Since the issues discussed here continue to be sensitive, I decided to withhold their names.

102 This sort of manipulation with certificates of ownership occurred elsewhere, too, for instance in Gianyar (ARA, MvK MvO Assistant Resident B. Cox 1940; KITLV, Coll. Korn:118). 103 It proved extremely difficult to ascertain the exact size of the possessions, the more so since about half of them were spread over the remainder of the district. Moreover, since the 1950s, landownership of the puri has gone almost entirely to others. The descendants of Gusti 
Formally, there were few dispossessions. Registered transfer of ownership to the punggawa did not happen on a large scale either. Instead, Gusti Putu Mayun 'helped' many share-croppers and owners of small plots who were unable to pay the tax. Some of them had turned to the punggawa via intermediaries in the puri; others were summoned to come to an 'agreement' regarding arrears. The result of these interventions was that the tax debt was paid with a kwitansi puri. In return for this 'assistance' the punggawa took the debtor's certificate of ownership, retaining it as long as the debt was not paid up. In practice this meant that one became a share-cropper on one's own land, for Gusti Putu Mayun demanded part of the crop as interest on the 'assistance rendered' and further required contributions of labour and materials for his puri and the rituals. 'Aid' and dependence came to the same thing; while to the BB it appeared that in Blahkiuh, notwithstanding the crisis, taxes were collected smoothly, the punggawa increased his hold on the surrounding land.

Officially, the punggawa had nothing to do with land rent collection, because district administration and sawah control were strictly separated. From the Balinese point of view, however, these distinctions were not made. The punggawa was seen as the head of the regional hierarchy, while the lesser officials were viewed as belonging to his entourage and also profited from the informal shifts in landownership. Descendants of at least one assistant sedahan and two clerks of the punggawa admitted without reservation that the lion's share of their present sawah consisted of plots that had been dispossessed in the 1930s and given to them by the puri. ${ }^{104}$

\section{The sedahan of Blahkiuh}

In these years the sedahan of Blahkiuh became a powerful man, for he now stood at the hub of all dealings in debts and land. As senior official immediately below the punggawa, he was responsible for registration of landownership and collection of land rent. At the same time, the sedahan played a major role in the entourage of puri Mayun. Ever since the introduction of colonial rule, two brothers had held the position of sedahan. They were part of the Gusti C. family, who among them shared a number of lesser functions. ${ }^{105}$ During the depression years, the younger of the two managed

Putu Mayun have moved to the city. The figures given here are based on estimates by former irrigation officials, tax collectors, share-croppers linked with the puri, and persons unconnected with the puri.

104 Repeatedly, when a question was put regarding the provenance of the landed possessions of these families, the self-evident answer was: 'Well, grandfather worked for the punggawa.'

105 The eldest brother (G. Putu A.) was sedahan from 1908 to 1918; he was succeeded by his younger brother (G. Kompiang R., 1918-1934), who previously was pekaseh of subak Sangeh (see the appendix to Chapter 8). 
to enlarge his personal power and wealth greatly. This he owed less to himself than to his wife. She was an illegitimate child from a neighbouring village, not recognized by her father, who was a noble. All she could expect was a life bereft of privileges. As a young maiden she was contracted to puri Mayun, where she became a servant girl and met the young pekaseh of subak Sangeh who assisted his older brother, the sedahan. It is said that 'the puri' - that is, the women close to the punggawa - decided to marry the girl off to the young pekaseh. The marriage was formalized in the puri and underscored the special ties between the newlyweds and the punggawa.

The man and his wife acquired a yard of their own in northern Blahkiuh. In 1918 he succeeded his brother as sedahan and became closely involved in the introduction of the new land rent. This is when the married couple made their first advantageous 'deal'. The former sedahan had died, leaving some ten hectares of sawah, spread over a large area. It was decided that the new sedahan (the younger brother) would sell these unconnected parcels of land and buy some larger fields closer to home. These would go to the sole (adopted) son and heir of the late sedahan. What actually transpired, however, was something else altogether. Once the various transactions had taken place, it turned out that the new fields were now all owned by the younger brother and his wife. In a single stroke, the new sedahan and his wife had appropriated the inheritance while the legal heir was left emptyhanded.

This sort of manipulation was common enough, and quarrels involving inheritance are found in the history of virtually every Balinese family. This conflict, then, was no exception. It shows, though, that the advantages that certain follower families derived from their position were not distributed equally. Within the families belonging to puri Mayun's entourage, a power struggle was continually waged, the stake being a monopoly on the favours and privileges granted by the punggawa. The new sedahan had won this battle; most informants ascribe this especially to the decisive action undertaken by his wife. ${ }^{106}$

The couple would gain greater riches still. The woman started a business

106 Not only informants from the family but also many outsiders viewed the wife as the brain behind this and other dubious transactions. In spite of them, the family of the sedahan did not break up. The house temple of the - now impoverished - home yard continued to be the ritual centre where all the relatives would periodically meet in seeming harmony. The only odd thing during these occasions was that certain people exchanged not a word with certain other people. In fact, they did not talk to each other for many years. The 'family ties' were strengthened in another way: the new sedahan's wife arranged a number of adoptions and marriages. She was in a position to do so, since almost all of the impoverished relatives were share-croppers working for her. If they left the family circle they would be worse off still. The other two brothers of the sedahan possessed little land. When they left the home yard they had been 'given' just a few sawah fields. One of them lost even these, owing to gambling debts. 
in copra and her yard became one of the centres where coconuts from far and wide were bought and processed and the product sold to merchants from Denpasar, who paid her in Dutch Indies currency. She made even larger profits dealing in money. In this her husband played a crucial role. It was he who, as sedahan, was responsible for collection of the land rent in his irrigation district. He kept the money and his ledgers in a small office in the yard, just beside the kitchen where his wife ran her coconut and banking business.

Transactions in finance proceeded on two closely related levels. The first was local. If taxpayers had too little Dutch Indies money, they could obtain it by paying kèpèng to the woman, who would add a hefty charge. Next the client would go to the office next door to pay off his newly acquired cash to the sedahan. The second circuit consisted in far larger financial transactions between the woman and financiers in Buleleng and Denpasar. The rate of exchange of kèpèng varied greatly with the season, so that smart financiers could profitably hold on to large sums, to be dumped on the market when the opportunity arose. On this level the woman managed to obtain cheap rix-dollars which she would sell dearly to local taxpayers. Thus it was that a lot of money, both Dutch Indies and Balinese currency, flowed to the sedahan's yard. As an intermediary controlling the exchange, the woman did very well indeed.

Especially during the Great Depression the wealth of the couple multiplied. The woman was one of very few in the region still in possession of Dutch Indies currency. Ever more kèpèng were needed to buy rix-dollars. Eventually the taxpayers were cleaned out and became indebted to the woman. She proceeded to lend them Dutch Indies cash, charging a high interest rate and simultaneously taking their sawah as security. The profits allowed her to buy a great deal of sawah, so that soon the couple owned some forty hectares of land. Just how she amassed all this property remains unclear. The transactions were kept confidential; after all, the woman's kitchen and the sedahan's office were but a few metres apart. Consequently, many who lost their land to the woman owing to insufficient financial means now fell into her clutches altogether. Often they would become share-croppers on their former land and made to perform labour in the sedahan's yard and to contribute to his rituals. In this way the couple bound to themselves a group of about eighty share-croppers, underscoring the growing power of the sedahan. Second only to the punggawa, the sedahan was now the richest and most powerful man in all of Blahkiuh.

In 1934, at the nadir of the crisis, the sedahan was suddenly dismissed. 'Greed undid her', was the terse comment of some informants. What they meant was that the couple had gone too far, both with respect to the punggawa and to the people. By erecting a power base of their own, the 
woman in particular was able to achieve increasing independence from the punggawa. In this way her position as a loyal, subordinate puri follower changed into one of a potential local competitor. Moreover, her harsh treatment of taxpayers undermined the punggawa's authority. As the people saw it, the sedahan and his wife were part and parcel of the entourage and hence operated with the punggawa's blessing.

It seems likely, however, that Gusti Putu Mayun had a second reason for ridding himself of the sedahan and his wife. The family to which the sedahan belonged had been useful while the punggawa was in the early phases of establishing his own position of power. Once this process had more or less come to fruition, Gusti Putu Mayun needed another type of follower to represent punggawa authority on the local level. To this end he recruited two brahmans from another family in his entourage. He appointed one as perbekel of Blahkiuh, and the other became the new sedahan. ${ }^{107}$

The two brahmans acquitted themselves in the manner intended by Gusti Putu Mayun: informants compared them very favourably with their predecessors. Both the perbekel and the new sedahan are locally remembered as honest officials. They did not gain much wealth, for instance, and did not use their position to expand their possessions. On the contrary, it is said that the new sedahan truly aided certain deeply indebted families by lending them money without taking their land.

The fall of Si Putu B.

In addition to the Gusti C. family, the punggawa ousted another local follower family, the Gusti A. family. Their leader was Si Putu B., and he had acquired a poor reputation. ${ }^{108}$ As overseer of the district's corvée labourers he was known for his harshness. The punggawa frequently availed himself of his services in less savoury situations. In addition he was klian banjar (head of the ward) of western Blahkiuh and, on the punggawa's recommendation, was 'elected' adat head of Blahkiuh. ${ }^{109}$ In each of these positions Si Putu B.'s arrogance caused much irritation among the people. He looked upon himself as patih of the puri and made sure that all were aware of the privileges he considered befitting his position. He would issue commands

107 That is to say, he recommended and secured their appointment to the $\mathrm{BB}$. These two persons appear in the appendix to Chapter 8. They were Ida Bagus M., perbekel as of 1927, and Ida Made K., who became sedahan in 1934. The latter maintained close ties with the punggawa because they were 'suckling brethren' (as a baby Gusti Putu Mayun was nursed by the mother of Ida Made K.).

108 See the appendix to Chapter 8. Although he had gained the title of Gusti, informants insisted on calling him Si.

109 As klian desa adat he was responsible for the internal 'religious' affairs of the village. This function had been created by the BB towards the end of the 1920s. 
left and right in high-pitched, nasal tones, not bothering to consult with anyone, and saw to it that his high status was emphasized. In contrast with the ordinary man, he wore expensive clothes and leather sandals. He demanded that he be spoken to with the proper respect. Many could not stomach his attitude. Before long he was known as the High King (Dalem) of Pikah (the ward he lived in) or the Jester (Delem) of Pikah. ${ }^{110}$ But people turned against him with other weapons than words, too. In the end he was the focus of one of Blahkiuh's most talked-about conflicts of the 1930s.

In addition to proper respect, Si Putu B. demanded money and labour, much of which he reserved for himself. For repairs and maintenance of the village temples he had every yard pay two rix-dollars. This was an exorbitant amount, the more so since it was well known that temple expenditure required far less. He also pressed a number of villagers to build a high wall around his yard, and did not pay them for their work.

Si Putu B. evoked particularly strong opposition among fellow-residents of his ward. They belonged to the same marginal nobility and were most affronted by his haughtiness. As they saw it, he was their equal and did not have the right to act high-handedly towards them. Moreover, they resented Si Putu B.'s receiving so many privileges while they themselves were overlooked. True followers, having served the puri in many ways in former days, they evidently did not merit reward or recompense. ${ }^{111}$

The action taken by the residents of Pikah ward was an extraordinary one. En masse they shed themselves of the authority of the controversial head by declaring their own ward to be an autonomous desa. To this end they built a small temple in Pikah which was to serve as village temple, 'navel' temple, and temple of the dead. Next, they refused further payment of the high contributions to desa Blahkiuh and paid no attention to the commands issued by Si Putu B. From the moment they declared independence from Blahkiuh they no longer considered him their adat head. The strategy was that the conflict was not a 'political' one, but a 'religious' one involving a temple. 'Political' conflicts were forbidden in the colonial context, but 'religious' differences of opinion were tolerated at least to a degree. Provided they could be expressed in terms of 'adat law', religious differences could be brought to court. This is what happened. The Raad Kerta of Badung was to deal with the case of 'Pikah versus Blahkiuh'. It was no secret, though, that the real conflict involved the person of Si Putu B., and it was widely known

110 Delem is one of the clowning servants of the 'bad guys' in the parwa stories of the Balinese wayang. Like this servant, Si Putu B. was fat and he waddled.

111 The inhabitants of Pikah had settled in Blahkiuh in 1900, together with the members of puri Mayun. The leader of the puri had lived there a while, from 1902 to 1906 (see Chapter 7, section 2). At the core of resistance in Pikah was Si Putu B.'s father-in-law, so that the conflict was a family feud as well. 
that what was behind this conflict was widespread disenchantment with puri Mayun.

The punggawa could not prevent the Pikah affair from causing turbulence. After the Raad Kerta had made two attempts to deal with the case and still proved unable, or unwilling, to pass sentence, the BB realized it would have to take over. The Resident of Bali and Lombok himself came to Blahkiuh. In the forecourt of the Giri Kusuma temple a special meeting was convened, attended by all parties. Gusti Putu Mayun was there, too, seemingly neutral and keeping himself out of the limelight. Once again the people of Pikah could state their grievances. This time their plea was heard and they won their case: Pikah was recognized as a desa in its own right. ${ }^{112}$

The rejoicing that now followed told its own story. A tumultuous march of Pikah residents, accompanied by many dozens of people from Blahkiuh, moved towards Si Putu B.'s house. They saw him as the personification of the injustices perpetrated against Pikah in the past. Now that justice had been done at last, the displeasure held back so long was released around his home. The former adat head was jeered at and ridiculed in public. While in Pikah people sang and danced and roasted pigs, Si Putu B. wisely stayed indoors. Before long, however, he was ousted from the new village. ${ }^{113}$

The festivities had an undertone of resistance against the puri as well. To be sure, nobody would stand up to the punggawa openly, but now that a major follower of the puri had been disgraced, the authority of Gusti Putu Mayun was dealt a severe blow as well. In addition, Pikah residents had achieved recognition of their identity over against the powerful puri, which meant a moral victory over the lord who had neglected them.

Gusti Putu Mayun had no choice but to get rid of Si Putu B. at the earliest opportunity. Animosity against Si Putu B. mounted after an incident when another ward head in Blahkiuh addressed him in 'low' language, using the familiar Bapa instead of the polite Gusti or Tu Aji. ${ }^{114}$ Si Putu B. was not about to accept this and haughtily demanded satisfaction for this affront. The man, however, continued to speak thus, and Si Putu B. went to lodge a complaint with the punggawa. Rather than agreeing with him, Gusti Putu Mayun removed him from his post as adat head of Blahkiuh and, in his place, appointed the leader of jeroan Bakungan. This person did not belong

112 Since Pikah had a village temple, the ward was recognized as an independent desa. In terms of administration Pikah continued to be the responsibility of the perbekel of Blahkiuh. 113 He continued to live in Pikah, but his yard was not part of the desa. Si Putu B. remained a member of desa Blahkiuh. This exile continued up to 1981, at which time his descendants were at last allowed to become part of desa Pikah, though not before they had sworn by a serious oath that their conduct would never again display such arrogance.

114 The person who addressed him as a mere equal was jaba Pan M., whose family was among the lesser followers of the puri (see the appendix to Chapter 8). 
to the entourage of the puri but was respected by the inhabitants. ${ }^{115}$

Just as the greedy sedahan was replaced with a trustworthy brahman, so Si Putu B. had to make way for the noncontroversial leader of jeroan Bakungan. In both cases the punggawa got rid of close followers at the very moment they felt their loyal service entitled them to reap generous rewards. The punggawa put an end to their aspirations as soon as his own position was threatened. The new functionaries would cause the mistakes of their predecessors to be forgotten, and were meant to restore the punggawa's authority. They were but partially successful, since the real problem rested with Gusti Putu Mayun himself. The complaint against some of his followers was that they took too much, but of him it was said that he gave too little. Especially in the depression years, the punggawa proved a man who stayed aloof of his people and showed little generosity. While most of the people became impoverished at an alarming rate, he continued to add to his riches. In spite of apparent 'traditional authority', the position of Gusti Putu Mayun no longer rested on the loyalty he once commanded among the people. Rather, it was now based on the dominance derived from his position as a colonial official. Whenever the punggawa went out, either walking or by motor car, the people would make polite obeisance. When summoned by the punggawa, or upon obtaining a hard-to-get audience with him, one wore one's best clothes. Barefoot and with a flower tucked behind one ear - 'as if we went to the temple', as one informant said - one would squat and shuffle towards the punggawa. For an audience, one was invariably accompanied by someone from the puri entourage. This person alone could approach Gusti Putu Mayun directly and in many cases did the talking. The supplicant was afraid to speak and tended to be unfamiliar with the polite speech required on such occasions.

In addition, Gusti Putu Mayun had the means to force the people to contribute to pura Giri Kusuma and to the rituals that supported his centre. Formally speaking, there was supposed to be reciprocity, since the punggawa himself contributed to rituals staged by his dependants. This reciprocity was most unequal, however; the puri received far more than it donated. The puri organized rituals that were larger and more frequent than those of the common share-croppers; consequently, the latter had to contribute repeatedly, while the puri could get away with a minimum donation when a sharecropper celebrated a wedding or arranged a cremation ritual. ${ }^{116}$ In view of

115 At the same time this appointment ended a lingering conflict between the puri and the jeroan (see Chapter 8, section 4).

116 In this connection see Hunger (1937:632): '[The nobility] paid a fixed minimum contribution to poorer families, but staged comparatively more frequent adat celebrations, including cremations, than poorer people, although the latter did have to pay the patus [contribution to the cremation costs] or an amount equal to this on a regular basis.' 
this, it is not surprising that a powerful puri was able to stage large and very expensive cremation rituals without running into debt. In fact, when the books were closed the figures might well show a profit.

At the very time that people needed his support, Gusti Putu Mayun neglected one of the roles associated with a good lord. Rather than being a 'father' to the people, he distanced himself from his subjects.

\section{The punggawa and his district}

In the broader context of the district, too, Gusti Putu Mayun enjoyed little popularity, but, as in Blahkiuh, he had little need to worry. Compared to the situation of royal rule in the nineteenth century, the political opportunities of the people were much restricted. In the nineteenth century desertion would be inevitable if the lord failed to care for the needs of his subjects or failed to bind his many followers adequately. During the 1930s the relationship was much reversed. Once the colonial state was the primary base of power, many lords in administrative positions stopped paying attention to the interests of their subjects. The voice of the people was heard no more, and the dynamics of the old follower system ceased to be operative.

Rather than having to deal with a multiplicity of vertical relationships, the modern district administrator could rely on a small number of subordinate officials to retain control over a large area. Towards the end of the 1930s a mere sixteen perbekel sufficed to control the 54 desa in the district and its 45,000 inhabitants. Each of these perbekel belonged to families that had ruled the region back in the nineteenth century. But compared to their position in the days of royal rule, there had been important changes. Successive colonial reorganizations had thinned out the ranks of local rulers, and the remaining perbekel had concomitantly risen in power. But their freedom with respect to the regional ruler had shrunk appreciably, because power was now centralized. Under royal rule, consultation between regional lords and local leaders had been the usual approach; under the new order a colonial administrator was able to appoint his own village heads. Moreover, the colonial bureaucracy provided the punggawa with far more means to reinforce his control over his perbekel. Those who did not toe the line could be summarily dismissed; the punggawa would not be confronted with mass desertion and loss of labour power, as he would have been a century earlier. The dynamic balance of power between the higher and the lower was largely replaced by a fixed framework of colonial bureaucracy. These changes were reflected in the way relationships of loyalty found expression. Whereas alliances and relationships with subordinates used to be sealed through marriages, they now resulted in appointments to administrative posts. Gusti Putu Mayun no longer married women from his own region; he now rewarded loyal subordinates by giving them an 
administrative job and by assisting their family members to become clerks. The punggawa was also able to help children of these families to enrol in secondary education, so that they would be more likely to enter colonial officialdom.

The hold Gusti Putu Mayun had over his district rested on a combination of administrative means and dynastic authority. This duality was repeated in the sixteen perbekel: on the one hand they were the lowest link in the chain of colonial rule, on the other hand they represented the punggawa's authority. Eight of them had been recruited from noble families with whom ties had been maintained for some time, and six were members of the Mengwi dynasty. ${ }^{117}$

One perbekel who belonged to an old follower family of the dynasty was the brahman Ida Bagus Ketut Kajeng. He became village head of Mambal in 1925. His family had been part of the royal entourage of Mengwi and had settled near Mambal after Mengwi's fall. At that time the area was controlled by puri Abiansemal, but gradually Gusti Putu Mayun increased his influence there by appointing trusted men to local administrative posts and by edging out followers of puri Abiansemal. On the punggawa's recommendation, Ida Bagus Ketut Kajeng attended the Dutch Native School (HIS) in Denpasar for two years, upon which he received his appointment as perbekel. Simultaneously, his brother became the head of a large sawah complex around Mambal. Through these two brahmans, the punggawa was now able to control the region. ${ }^{118}$

Local appointments of this sort facilitated the spread of Gusti Putu Mayun's influence throughout the district. Conflicts would sometimes arise, however, and when they did, the punggawa did not shun harsh measures. One opponent who ran into financial problems because of the depression was the lord of Taman, who had never bowed to puri Mayun dominance. In fact, he had asserted his desire for independence by erecting in his village a pasimpangan of the sea temple Batu Ngaus, thus openly negating pura Giri Kusuma in Blahkiuh which Gusti Putu Mayun had decreed to be the centre of worship related to agriculture for the entire district. When the lord of puri Taman was unable to pay his land tax, the punggawa pounced on him immediately. Without granting extension of payment, he had the sedahan place a lien on a few dozen hectares of land which were subsequently expropriated. This caused the lord of Taman to

117 ARA, MvK Nota van toelichting Badung H.J. Hoekstra 1938. Only two perbekel were jaba, and these administered five mountain desa containing no nobility.

118 Interviews with Ida Bagus Ketut Kajeng, Lambing. In one of our talks he offered a terse characterization of the Dutch system: 'Well, the Dutch made sure that the nobles floated on top and retained leadership, but administration took a lot of paper and I had to buy that myself.' 
lose face, while at the same time he lost control over the share-croppers who worked the expropriated land. He took another loss when the punggawa appointed a new perbekel for Taman. As in the case of Blahkiuh, the new village head was a brahman whose family had long been closely associated with the Mengwi dynasty. Thus punished, the lord of Taman could not compete with the punggawa's regional power and was forced to acknowledge the authority of puri Mayun. From this time on, the Taman peasants brought their offerings and contributions to the temple of Blahkiuh.

Gusti Putu Mayun could not deal this harshly with all the lords in his district. The lords of Carangsari and Sibang in particular needed to be handled with caution. In the past they had been rather autonomous, and even now they had enough local influence to keep the punggawa at arm's length. Unlike the situation in the nineteenth century, however, they were not strong enough to expand their influence since the colonial government had delimited their domains quite strictly. To gain some control in these domains, Gusti Putu Mayun resorted to a tried and proven method: he used informal straw bosses, persons who unofficially acted as the eyes and ears of the district administrator. They enjoyed personal protection and could, if necessary, operate as agitators by stirring up trouble behind the backs of the local lords. ${ }^{119}$ On top of this, puri Carangsari lost much face when the BB did away with the subdistrict in 1932. The lord of Carangsari, who had been a manca, now joined the ranks of the other village heads and became a mere perbekel. ${ }^{120}$

\section{Puri Mayun and the dynasty}

The domain over which Gusti Putu Mayun had the least influence was the domain of the lord of Sibang, who ruled as perbekel over no fewer than 6,200 persons. As long as the Mengwi dynasty had existed, the lineage of puri Sibang had possessed a large degree of autonomy, retained into the colonial period. ${ }^{121}$

With respect to other related lineages in his district, Gusti Putu Mayun netted greater progress. He did so by making appointments, granting privileges, and acting as 'family banker'. 122 He took advantage of his adminis-

119 One of the agents Gusti Putu Mayun placed in the domain of puri Carangsari was an enterprising jaba from Blahkiuh who aspired to a noble title. In Blahkiuh he could not carry one, but the punggawa permitted him to be addressed as Gusti provided he move to a hamlet near Carangsari. This made him a Gusti unless he visited Blahkiuh, where he had to revert to the behaviour befitting a mere jaba.

120 The 'shame' that came upon puri Carangsari was exacerbated because the last manca had committed suicide in 1932. Personal communication C.J. Grader; ARA, MvK MvO Resident G. de Haze Winkelman 1937.

121 This was true also, though to a lesser degree, for the lineage of puri Sayan in Bongkasa.

122 The term 'family banker' was used by various informants. 
trative authority, for instance, to edge puri Abiansemal towards marginal power. In 1911 the crown prince of puri Abiansemal had to relinquish his position as punggawa, and his sons even lost control over their immediate surroundings. The death of the oldest royal son in the 1920s occasioned a bitter battle over the inheritance. As district administrator Gusti Putu Mayun had intervened, and largely because of this the puri's possessions had become fragmented.123 Furthermore, the punggawa prevented the younger generation of puri Abiansemal to continue secondary schooling. This privilege was reserved for sons from his own lineage, who thus became eligible for administrative posts. Finally, in the early 1930s, Gusti Putu Mayun publicly bypassed the heirs of puri Abiansemal when he appointed a new perbekel to Abiansemal from neighbouring Penarungan, a scion of the disgraced lineage of puri Penarungan. It would be difficult to conceive a greater affront to puri Abiansemal; the action was calculated to point up the powerlessness of the damaged royal lineage. ${ }^{124}$

As family banker, Gusti Putu Mayun caused many impoverished relatives to become indebted to him by lending them money. This allowed them to conduct the proper cremation rituals and generally to retain a vestige of their tarnished prestige. The drawback to this aid was that these relatives frequently had to relinquish their last valuables to Gusti Putu Mayun as 'pawn' or 'gift'. Informants say that in this way the punggawa added an impressive number of krisses and other heirlooms to his own collection. ${ }^{125}$

Two other related puri were virtually completely taken over by Gusti Putu Mayun in the 1920s. In these cases he combined his administrative authority with the traditional dynastic strategy of adoption. The first puri so gained belonged to the aged Sang Gede Resi Mayun, better known as Agung Kerug, the last patih of Mengwi and still hated by the other branches of the Mengwi dynasty.

Sang Gede Resi Mayun lived in Sedang, where he devoted the remaining years of his life to dance, literature, and meditation. ${ }^{126}$ Just north of Sedang a younger brother of his lived in desa Lambing. He, too, was an old man and had no heir. He asked Sang Gede Resi Mayun's permission to adopt one of his sons. Sang Gede Resi Mayun agreed, since the adoption would

123 KITLV, Coll. Korn:128, and oral information. Gusti Putu Mayun supported the youngest royal son, Gusti Ketut Agung, who moved to Mengwi. The remaining heirs of puri Abiansemal lost two-thirds of the landed possessions.

124 The appointment of this perbekel simultaneously signified exoneration for puri Penarungan (see Chapter 5). The fact that Gusti Putu Mayun took it upon himself to grant this reinstatement caused great anger among the members of puri Abiansemal, since as heirs in the royal lineage they considered none but themselves competent to decide in these matters.

125 This was especially true of most relatives from the lineage of puri Anyar, who had been unable to regain landed possessions after the fall of Mengwi.

126 His puri was the major centre of the lineage of puri Anyar. 
strengthen the bond between puri Sedang and puri Lambing and would allow them to hold their own in the face of hostile relatives in Sibang, Abiansemal, and Blahkiuh. In a gesture of goodwill and as a sign of trust, Sang Gede Resi Mayun gave his younger brother in Lambing control over a large part of his sawah, designated as 'provision' for the adoptive son. This greatly expanded the sawah land of puri Lambing, but the son never got them. At the very last moment, punggawa Gusti Putu Mayun forced puri Lambing to adopt someone else as heir: a cousin and favourite of the punggawa himself. Just how the punggawa managed this intervention remains unclear. As a result, however, the bond between Sedang and Lambing was broken altogether, an adoptive son from the lineage of puri Mayun usurped puri Lambing, and the landed possessions of puri Sedang shrunk considerably. ${ }^{127}$

Although Sang Gede Resi Mayun certainly was acquainted with colonial jurisprudence, he was unable to do anything about Gusti Putu Mayun's penetration. The punggawa controlled official notices concerning his district, and it was he who composed the reports to the Kerta council on matters pertaining to his district.

Sang Gede Resi Mayun's end was humiliating. In the early 1930s he had to relinquish still more of his property, owing to rising tax debts. Once again Gusti Putu Mayun had a hand in this. Soon afterwards, when Sang Gede Resi Mayun died, his own puri did not have the means to cremate him in proper style; puri Sedang had fallen prey to poverty and disorder. Gusti Putu Mayun refused to offer any help and, for lack of anything better, the body was taken to Abiansemal, where a younger brother of the deceased arranged a sober cremation. The part played by Sang Gede Resi Mayun in the fall of Mengwi was neither forgotten nor forgiven by his enemies within the dynasty. ${ }^{128}$

The second annexation victim was the lineage of puri Selat, just north of Blahkiuh. ${ }^{129}$ This branch was led by four brothers (see Figure 8). Although initially they avoided contact with Gusti Putu Mayun, the punggawa was able to put two of the brothers into his debt (puri Sangeh and puri Dauh), by appointing them as perbekel of Sangeh and Selat, respectively. In their turn,

127 This new heir was G. Gede Raka, son of the punggawa's elder brother G. Made Ringkus (see Appendix). Various informants, including the current leader of puri Lambing, confirmed that this was intentional annexation and explained that the cousin was 'parachuted' ( $\mathrm{di}_{\text {- }}$ drop) by Gusti Putu Mayun on Lambing.

128 In subsequent years puri Sedang continued to be plagued by problems and quarrels. In 1988 the descendants of Sang Gede Resi Mayun at last decided upon a great purification ritual to rid puri Sedang of the sins of their controversial ancestor.

129 This branch derived from a younger brother of the last king of Mengwi, who had settled in desa Grana (see Appendix). In 1902 puri Grana had joined the Klungkung side and had moved to Selat (see Chapter 7, section 2). 
these brothers needed the punggawa's support to resolve a lingering conflict with the other two (from puri Dangin), who occupied almost all of puri Selat's sawah and refused to divide it equally. It was, however, insecure property since neither of the two brothers from puri Dangin had sons.

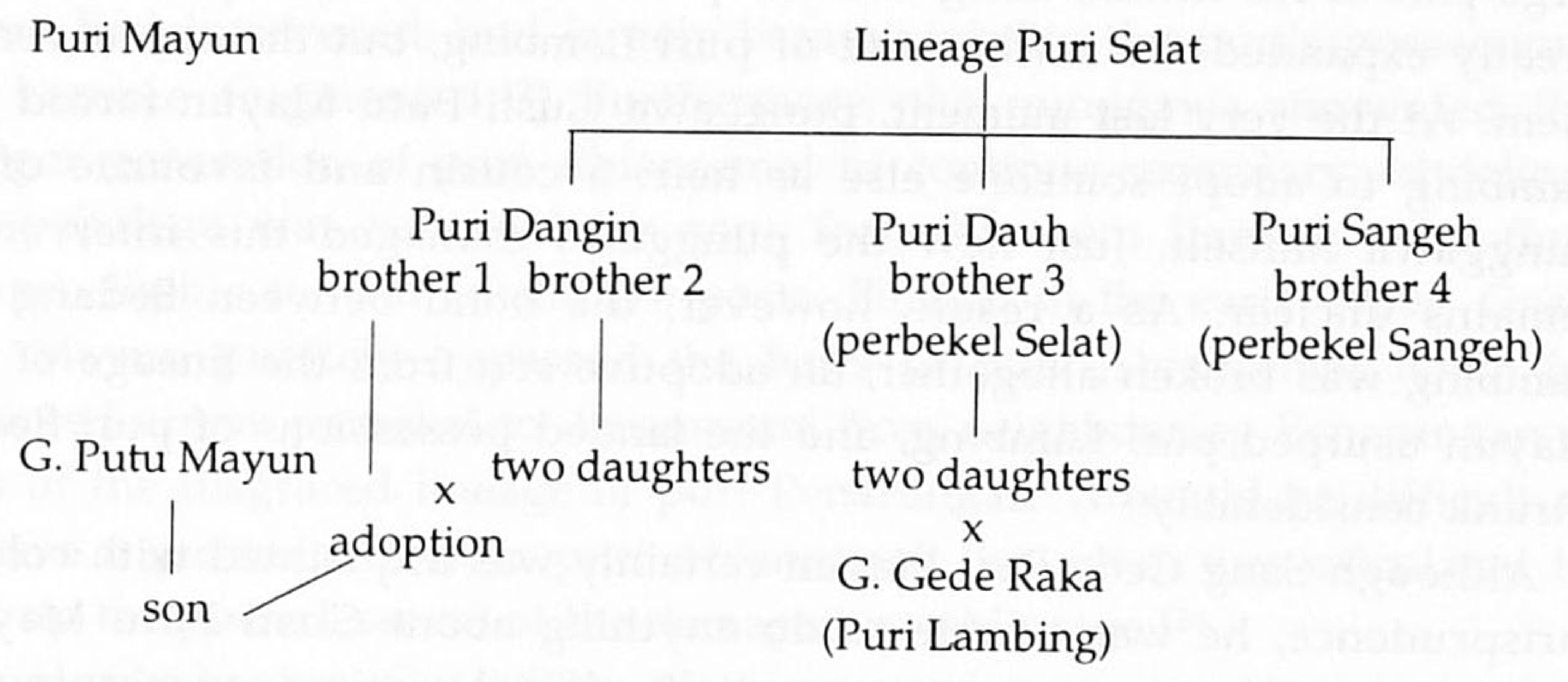

Figure 8 . The annexation of puri Selat

Gusti Putu Mayun acted. People do not remember just how he went about it, but within a few years he had taken over the entire sawah possessions of the lineage of puri Selat and had reduced this lineage to a branch of his own puri. Utilizing his prominence in the dynasty, he made sure that his second son was adopted by one of the brothers of puri Dangin. To make doubly sure, this son shortly afterwards married the two daughters of the other brother of puri Dangin.

Formally, an adopted son was expected to relinquish all ties with the puri of his origin. But this did not happen. All informants viewed the adoption and the subsequent marriages as an unequivocal power take-over on the part of the punggawa. When asked in what category of adat law one should place this particular instance of adoption and marriage, an informant shrugged and said:

'It all comes down to the same thing, whether you speak of pakidih [interim control of an inheritance by a husband from outside] or nyeburin [the woman marries but takes over the role of the male heir]. The point is that the punggawa made up the rules and used them as he saw fit. After all, he pulled the strings.' ${ }^{130}$

130 As it was, the annexation caused a great deal of confusion among the members of the puri Selat branch: 'We were confused; everything was mixed up; how were we supposed to place him [the adoptive son]?' If the adopted son were considered a 'true' son of his adoptive father, the marriage with no less than two father's-brother's-sisters would have to be seen as too close and too 'hot'. If the boy were seen as son of the punggawa, he had married two women from a higher generation. To marry an 'aunt' ran counter to the rule that the male seed should flow 'down'. To make matters more complex still, the punggawa managed to create a 
The punggawa's strength soon became evident, when the duped brothers of puri Selat took legal action to have their share of sawah returned. In 1926 they lost their case before the court of Badung. ${ }^{131}$ Two further measures enabled Gusti Putu Mayun to further erode the position of puri Selat. First, in 1938 he capitalized on a new reorganization of local administrative units by joining the villages of Selat and Sangeh to the neighbouring villages of Punggul and Taman, and handing control over them to the brahman perbekel of Taman. ${ }^{132}$ The punggawa also restored a small temple in Sangeh in 1935. ${ }^{133}$ When the restoration was completed, he charged the four villages with maintenance and observance of ritual. In this way he added a ritual dimension to the administrative amalgamation of the four villages. Annexation of puri Selat, then, was finalized by the creation of a central place of worship where the people of the four villages gathered under the auspices of the punggawa, and where his authority was further affirmed.

Just as in the case of the temples at Blahkiuh and Sangeh, Gusti Putu Mayun sought to give shape to his royal ambitions through the old mountain temple of the dynasty. This temple was pura Panataran Agung in the mountain village of Tinggan in the north of the district. But he did not control this temple entirely, since it belonged to the core lineage of the Mengwi dynasty. In consequence of this a conflict arose concerning the question of jurisdiction, which pitted the royal son, Gusti Ketut Agung, over against the punggawa, Gusti Putu Mayun. The conflict did not remain limited to the temple dispute, but would end in a bitter battle for dynastic supremacy.

\section{4. 'Restored' royal rulers}

Characteristic of the late colonial state was its conservatism and its faith in the 'traditions' it had itself created. Both came to expression in the emphasis placed on 'the authority of traditional popular chiefs', who were expected to guarantee the continuity of the colonial system. For this reason, 'restoration' of 'royal rule' in areas outside of Java was taken up again in 1936, as soon as the economic crisis began to ease. Meanwhile, some of the policies

link between the two puri annexed by him: he had his nephew, the new heir of puri Lambing, marry two daughters from puri Dauh.

131 Controleur Korn was aware that in this affair Gusti Putu Mayun played a dubious role. He appended a note to the formal papers to the effect that 'the preliminary investigation should, of course, not have been conducted by the punggawa. It contains inaccuracies.' (KITLV, Coll. Korn:128, memorandum 8-2-1926.)

132 The brahman perbekel was the person mentioned above in connection with the conflict with puri Taman. Through his mother he was related to puri Mayun (see Appendix).

133 This was pura Bukit Sari, located in the 'Monkey Forest' near Sangeh. 
followed by the colonial government had changed. The importance ascribed to local and regional councils during the 1920s now receded into the background. In the place of these 'Western councils', a 'policy of reinforcing existing traditional-indigenous organizations and the authority of chiefs rooted therein' was now emphasized. ${ }^{134}$ The position of these headmen was anchored in a kind of 'adat state law' meant to strengthen the link between the traditional-indigenous system and the colonial state. ${ }^{135}$

Along with the 'restoration' of royal rule, an extensive administrative reform took place. In the regions outside of Java three large administrative umbrellas - or territories - were created where 'restored' royal rule was to be encouraged. Bali was assigned to the new territory called 'De Groote Oost' (The Great East), established 1 July 1938, its administrative centre located in Makasar. ${ }^{136}$ At the same time, eight Balinese zelfbestuurders or 'self-rulers' were installed. Their appointment completed a process begun in the 1920s, which had led to the appointment in 1929 of negara administrators. Eight of these were now given royal status. ${ }^{137}$

Viewed from the centre of the colonial state, the introduction of self-rule was just one part of a far larger political scheme, but in the eyes of the Balinese it was a unique event. In 1932 and again in 1935, the negara administrators had requested the governor general to reinstate them as kings. In contrast to the 1920s, they not only stressed the 'religious' task of kings but now also openly mentioned possible advantages in the political arena: 'Fortunately, Bali has not been infected as yet with evil as other regions are; but the danger exists that evil may infiltrate from without; introduction of self-rule may counteract this. ${ }^{138}$

The 'evil' referred to was nationalism; the prospective kings, then, presented themselves as guardians of the colonial order. In 1937 their request was granted, when Governor General A.W. Tjarda van Starkenborgh Stachouwer announced the restoration of self-rule during a formal feast in the puri of Karangasem (Van der Kaaden 1938:286).

In addition to accepting this political argument, the Dutch were convinced that the unique character of Balinese culture could best be preserved

134 KITLV, Coll. Korn:110, Memorie van Toelichting Volksraad 1937-1938. In addition, the complex decentralization measures of 1903 - in which the councils were a prominent feature was replaced by the Korte Verklaring (Abridged Declaration) as constitutional basis (ARA, Coll. Boon, M. Boon, De staatsrechtelijke positie van Karangasem, 1940).

135 Haga (1924) was considered definitive on adat state law (personal communication J. van Baal). See also Van Helsdingen 1941:460-70 and Logemann 1955:25-7.

136 The other newly created territories were Sumatra and Borneo (Van Helsdingen 1941:471-

82).

137 Besluit GG 7-6-1938-21, Staatsblad N.I. 1938:165, 281; ARA, MvK V15-7-1938-14.

138 ARA, MvK V15-7-1938-14, quoted in memorandum Directeur BB 3-5-1935. Interestingly, the request was formulated by only three of the negara administrators: those of Karangasem, Gianyar, and Bangli. The Resident added the names of the others. 
if 'traditional' royal rule were 'reinstated' to its former glory. By strengthening the position of these 'natural' leaders, it would be possible to guarantee the self-containedness of the island. There was still another, important argument: in the end, restoration of self-rule would prove to be the cheaper form of colonial control. ${ }^{139}$

In spite of the consensus, some uneasiness was still felt on the Dutch side. Could one in fact be sure that the people were best served by 'restored' royal rule? Had the situation of Balinese of the younger generation, those with Western schooling, been sufficiently taken into account? The director of the Department of Interior Administration anticipated no problems on this score. During a brief visit to Bali he had heard no complaints. He concluded that the desire for reinstatement of royal rule was shared by the people at large. Moreover, there was no reason to think that the rulers would make improper use of their position. And now we see that the myth of egalitarian village republics was very much alive in this man's thinking, for he concluded that if one takes into account the democratic character of Balinese society, it is not likely that restoration of self-rule on Bali would result in autocratic self-rule. ${ }^{140}$

The younger generation of Western-educated Balinese was marginalized from the outset. The fear expressed by this group, that royal rule would encourage conservatism, was not taken seriously. On the contrary, according to the director of the BB, 'Young Bali demonstrated enormous overestimation of Western forms of democracy, alongside of utter underestimation and denial of Oriental institutions and usage.' And he added:

'Happily, the time is past that Western democracy finds general acclaim and is held up as an example. The recognition has dawned that administration is better served if the state structure adapts to Oriental relationships, and structures appropriate to the East are increasingly meeting with approval. ${ }^{141}$

So, it was not the rulers but the younger generation who were not in tune with the times. The interaction between colonial power and theorizing had at last created a situation in which Balinese society was interpreted, ordered, and controlled such that the Balinese had no voice whatever. The only action remaining for the rulers was to play along, hoping that in this way they might create some room to manoeuvre.

Installation of the royal rulers took place on 29 June 1938, during a carefully orchestrated ritual. ${ }^{142}$ Its timing coincided with Galungan, the day

139 ARA, MvK V15-7-1938-14, reports Regeringscommissaris bestuurshervorming buitengewesten 27-2-1932 and Resident 20-7-1936.

140 KITLV, Coll. Korn:110, Handelingen Volksraad 1937-38 (zittingen 16-2 en 29-3-1938).

141 ARA MvK V15-7-1938-14, memorandum Directeur BB 31-10-1936.

142 Van der Kaaden 1938; Nieuwe Rotterdamsche Courant 10-7-1938 in KITLV, Coll. Korn: 267; ARA, MvK V15-7-1938-14. 
of the descent of the gods and ancestors on Bali. In this way the ancestors could witness the inauguration, so that the position of the rulers received additional legitimation and the dynastic character of self-rule was underscored. The location of the formalities, too, was picked with propaganda in mind. Once the rulers had signed the Korte Verklaring in their own locality, the actual inauguration took place in the temple complex of Besakih, which under colonial rule had expanded into the ritual centre for all of Bali. ${ }^{143}$ The predominantly colonial ceremony was thus embellished with a 'traditional' Balinese decor. The ceremony itself also contained Balinese elements: offerings were presented, the oath was Balinese, and it was read by a brahman priest. The Western elements were the uniforms, the formal photographs, the champagne, and the speeches. The Resident's address was especially important, because it explained the meaning of the ceremony. $\mathrm{He}$ emphasized that the newly appointed rulers and the BB - Bali and the Netherlands - were all part and parcel of the Great Dutch Realm.

Thus, the ritual not only made visible the bond between the Dutch and the Balinese, but also affirmed the subordination of both parties to the Dutch queen. This lent additional weight to the ceremony, which served as a political model on the basis of which colonial authority was to be continued. ${ }^{144}$ Nevertheless, the significance of the ceremony was open to diverse interpretations.

The Dutch certainly did not intend that the newly appointed rulers would actually rule their negara. These rulers were considered entirely unfit for this. Rather, the BB would keep the bureaucracy firmly under its own control and the rulers were to be given some menial administrative tasks. The important thing was that the rulers would maintain law and order, in exchange for which they could give the outward appearance of being autonomous, and the BB would be backstage, to 'direct and correct if needed'. ${ }^{145}$

The rulers did indeed maintain 'law and order' in their domains and they made good their promise to fend off 'evil' influences. Resident H.J.E. Moll, for one, was quite satisfied with the vigour with which the rulers had

143 See Stuart-Fox 1987:chapter 11. Besakih had never hosted a royal inauguration ritual before, however.

144 The previous year another ritual had taken place in Karangasem, also in connection with the planned installation. A great maligya was held in honour of the area's newly appointed self-ruler's father, who had died in 1916. An audience of fifty thousand people, including the king of Siam as guest of honour, witnessed the spectacle, which purposed to sever all bonds the deceased might still have had with the earth, so that succession by the new king could begin (Mershon 1971; personal communication C.J. Grader).

145 ARA, MvK MvO Assistant Resident B. Cox 1940. Many doubted the sincerity of the ritual, as indicated by the witticism circulating among Western-schooled Balinese to the effect that self-rulers were but 'share-croppers' in their own 'landscape' (Lan = land; sakap = share cropper) (personal communication C.J. Grader). 
countered the activities of the nationalist Parindra. ${ }^{146}$

Maintenance of law and order also meant that the caste system and the royal hierarchy were zealously guarded. The rulers used the barriers of caste to prevent Western-educated young people of lesser background from attaining important administrative posts and to favour their own relatives. In this context I would like to mention a remarkable protest against the official hierarchy on Bali: a small booklet published in 1939 by a teacher, Gusti Nyoman Wiryasutha. He cast doubt on the legitimacy of the caste system - the catur wangsa, or four hierarchically ordered groups - by pointing out that it originated in the political strategy of thinkers (brahmans) and warriors (satria) who were bent on keeping conquered people in an inferior position. The author saw this same principle repeated in Europe, where the Germans placed themselves as Aryans above the Jews. On Bali it meant that the Dutch were the true nobility - triwangsa - while the Balinese in fact amounted to no more than powerless and subjugated sudra. His conclusion therefore was that the Balinese should not look upon themselves as divided into separate groups (wangsa), but ought to unite as one nation (bangsa). The booklet was outlawed immediately. 147 Soon afterward, the assistant resident was pleased to note that 'Young Bali is developing itself well, but fortunately Old Bali still rules the roost'. ${ }^{148}$

Young Bali was given no voice but neither were the other subjects of the royal rulers allowed to vent their views. To be sure, a council assisted each ruler, but the members were largely appointed by the ruler. Moreover, these councils were allowed to offer advice only 'if, according to the ruler, contributing to greater insight'. ${ }^{149}$ Actually, the Dutch considered these councils utterly devoid of importance:

'The people generally have no need of a council [since] they have a voice in their own adat communities, the desa and the subak. In these, true democracy prevails.

146 ARA, Coll. Boon, MvO Resident H.J.E. Moll 1941. Towards the end of 1939 the Parindra had some 200 members on Bali, most of whom lived in Tabanan, Badung, and Buleleng (ARA, MvK Mr. 1940:433+). Repressing nationalist influences took on paranoid proportions as in the case, in 1939, of a student of the Taman Siswa school - there were eight such schools operating outside of official government education - who was apprehended because in an essay on 'My future' he had vented 'undesirable political statements' (ARA, MvK Mr. 1939:500+).

147 Wiryasutha 1939; ARA, MvK MvO Assistant Resident B. Cox 1940. On the rising consciousness of national identity see B. Anderson 1983.

148 KITLV, Coll. Korn:138, letter B. Cox to V.E. Korn 24-4-1940.

149 ARA, Coll. Boon, M. Boon, De staatsrechtelijke positie van Karangasem ,1940. These were the negara councils. Typical of the situation was that the BB had R. Goris, government linguist and archaeologist, first investigate whether such councils could be considered 'traditionally' Balinese. His appraisal was affirmative: even prior to the Gelgel era (before AD 1400) kings gathered councils about themselves. But the office of patih was not considered sufficiently traditional to be eligible for reinstatement since this was a recent (!) phenomenon, dating from Gelgel days or later (later than AD 1400); Coll. Goris, nota Rijksraden January 1938; ARA, MvK V15-7-1938-14, memorandum Directeur BB 30-6-1938. 


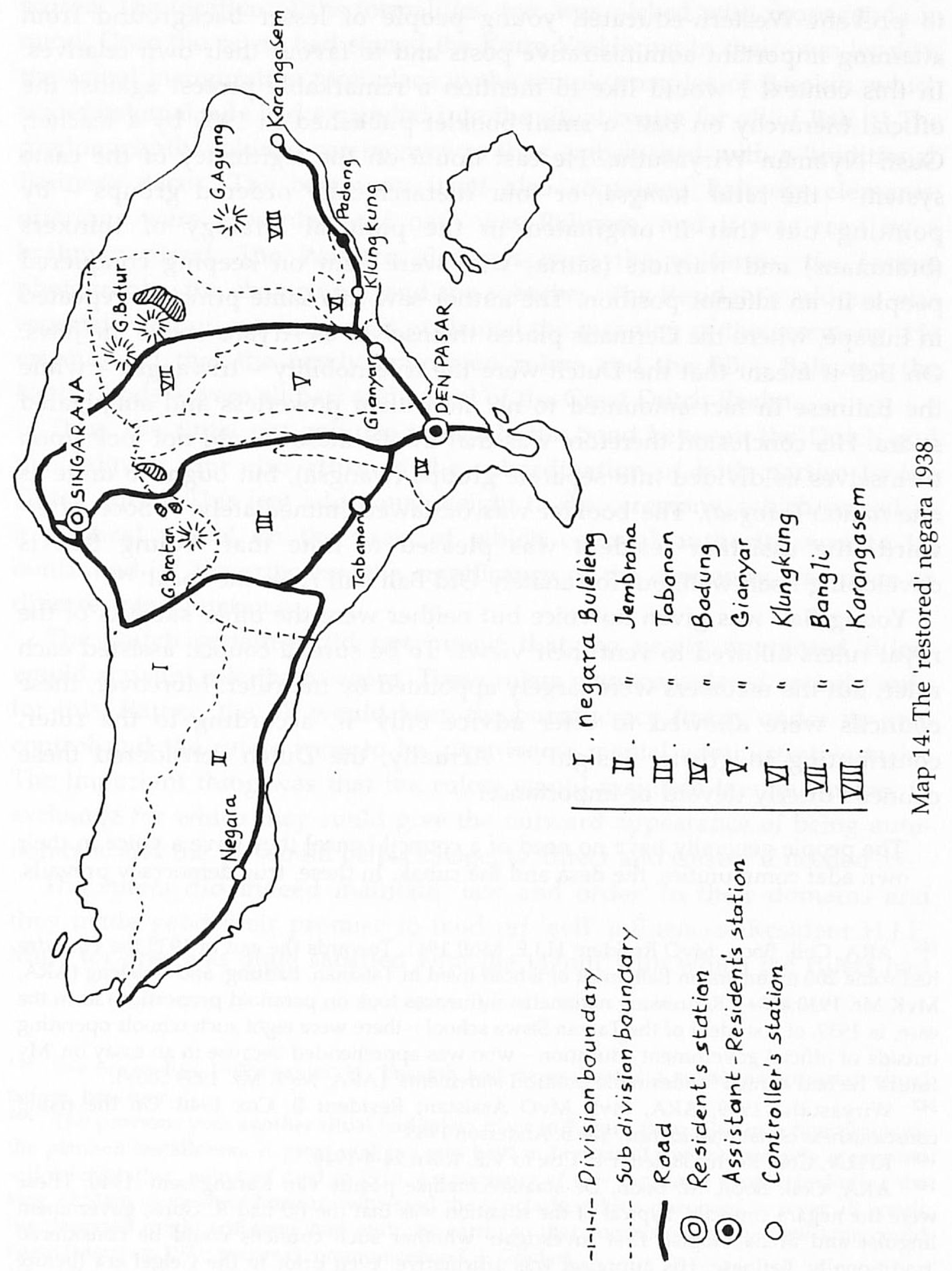


The masses are happy to leave representation of interests on a higher level to more elevated chiefs.' 150

The royal rulers in turn were members of another council. Under chairmanship of the Resident, this council discussed matters of public interest, whereby the rulers could take little or no initiative. At best, the council could rehash decisions long since taken by the $B B$ and now in need of a touch of local colour.

If the position of the royal rulers relative to the Dutch was one of powerlessness, within the 'restored' negara their personal power reached a peak. They lost no time capitalizing on their renewed royal status to look after their own interests first. The Dutch were well aware that such practices could not be tolerated officially, but on the other hand, the fiction of selfrule should not be tarnished. Reminiscing, a former controleur formulated the quandary as follows: 'Look, we had just put those kings back in. Surely we couldn't drag them into court the next day and bring them before a judge because they had stepped out of line, could we?' To which another person added: 'We were aware of goings-on around Anak Agung [...] that weren't cricket, things like palace murders and such, but we were not supposed to know that sort of thing.' 151

In addition to the personal freedom they were given, the royal rulers also profited from the fact that the number of district administrators and village heads was reduced. In consequence of new amalgamations, South Bali as a whole had only twenty-two punggawa in 1940, while some forty years earlier that many could be found in a single negara. ${ }^{152}$ When the BB was about to appoint a punggawa, the advice given by the royal rulers was taken very seriously, which meant that the rulers were able to keep out troublesome competitors and have the posts go to loyal kin. Moreover, the post of district administrator became hereditary, so that those who survived the latest amalgamation were now ensconced comfortably. ${ }^{153}$ To this we

150 ARA, MvK V15-7-1938-14, report Resident 20-7-1936. Once again the myth of the democratic village republic was used as an argument in favour of royal rule.

151 Interviews with J. van Baal and F.W.T. Hunger 1982. Not all self-rulers, however, were able to add greatly to their power. The self-rulers of Badung, Tabanan, Jembrana, and Buleleng were much weaker than their colleagues in Gianyar, Karangasem, Bangli, and Klungkung because the former had to rebuild their positions from the ground up.

152 ARA, MvK MvO Assistant Resident B. Cox 1940. Tabanan, Badung, Gianyar, Bangli, and Karangasem each had four punggawa; Klungkung had two. See Chapter 5 for a comparison with nineteenth-century Mengwi.

153 ARA, Coll. Boon, MvO Assistant Resident H.J. Jansen 1937. On the one hand the punggawa were selected on the basis of birth, on the other hand they were called to administer increasingly expanding regions while the measures to be taken multiplied annually. In 19401941 the BB only just had time to note this contradiction, but was no longer able to do anything about it (ARA, Coll. Boon, MvO Resident H.J.E. Moll: 'It would seem advisable to do away with the fiction of the punggawa as "popular chief" all along the line'). 
must add that the perbekel, too, were counted as 'popular chiefs' and were preferably recruited from noble families. ${ }^{154}$ These measures made it possible for the restored dynasties to anchor their power securely in the colonial bureaucracy.

The colonial interventions at the end of the 1930s completed a process in which the largely fluid character of the southern Balinese political system virtually disappeared. In its stead there was created a fixed, hierarchical system defined by the Dutch and leaving room for only a very limited number of Balinese rulers. In spite of the fact that in the colonial state they played the part of subordinates, in their own negara they were more powerful than ever before and resistance had very little chance of success.

\section{Discord in Mengwi}

On the occasion of the inauguration ceremonies in Besakih in June 1938, the Mengwi dynasty was conspicuously absent. Mengwi was granted no selfrule. As the Dutch saw it, there was nothing to restore, because the government had had no hand in the fall of negara Mengwi. This argument dated from 1928 and remained in force. But the leaders of puri Mayun were not to be put off and stubbornly continued efforts to change the mind of the BB, the Volksraad (People's Council), and the Dutch parliament, and finally even appealed to Queen Wilhelmina.

Hope of recognition soared when Badung controleur $\mathrm{H}$. Hirschman noted in 1931 that the negara administrator of Badung had little control over the Mengwi region, since the Mengwi dynasty continued to be highly influential. ${ }^{155} \mathrm{He}$ was referring especially to Gusti Putu Mayun and Gusti Rai Kepakisan, the brothers from the lineage of puri Mayun who ruled the greater part of the Mengwi region as punggawa of the Abiansemal and Mengwi districts, respectively. They also joined forces in various activities designed to demonstrate negara Mengwi's right to be recognized.

Above, mention was made of the babad which was written about 1928, recounting the dynasty's glorious past, and tying past and present together genealogically. In addition, in the early 1930s the restoration of pura Taman Ayun was begun under the leadership of the punggawa of Mengwi. Ever since the fall of Mengwi, this central temple had been neglected and had

154 ARA, MvK MvO Resident G. de Haze Winkelman 1937. This was a continuation of the reorganization of village administration introduced around 1910. Once again a contradiction surfaced. On the one hand administrative control by the noble perbekel over the people was legitimized, while on the other hand the desa adat was formally made independent in the course of the 1930s and a banjar adat was created as well. This seemed to separate adat and colonial rule, but the power of the adat chiefs could not begin to compete with that of the perbekel.

155 KITLV, Coll. Korn:110, MvO H. Hirschman (political section). 
become little more than a ruin. Since this temple had been the embodiment of the negara, rapid restoration was required, for the restored temple would once again grow into the ritual centre of the entire region and mobilize its people. It would be possible again, via pura Taman Ayun, to identify with the dynasty and the negara. The masses attending the rituals would furnish incontestable proof of negara Mengwi's continued existence and would show that for this reason the dynasty's claim to self-rule was valid. ${ }^{156}$

These restoration efforts took place at the height of the Great Depression and it took a great deal of persuasion to mobilize enough people. Precisely on this score, punggawa Gusti Rai Kepakisan was weak. Like Gusti Putu Mayun in Blahkiuh he, too, was known as a man out for his own profit, failing to consider the needs of the people. He was an authoritarian ruler but, unlike Gusti Putu Mayun, his position was not unassailable. Gusti Ketut Agung, the 'unemployed' royal son, lived in Mengwi as well. The leaders of puri Mayun left him out of their counsels almost completely, and he feared that he would be passed over altogether if and when negara Mengwi were ever 'restored'. It was around this prince that resistance against puri Mayun concentrated and proved successful. Before long, punggawa Gusti Rai Kepakisan was in trouble because of being charged with fraud. It was said that he had pocketed monies meant for the restoration of pura Taman Ayun. More important than the content of the accusation was the fact that it was passed on to the assistant resident, who decided to take action. ${ }^{157}$ Gusti Rai Kepakisan was relocated to the island of Nusa Penida, the very island known in the history of Mengwi as the place where members of the nobility were exiled. This relocation, then, meant not only that puri Mayun had lost control over the Mengwi district, but also that the lineage suffered a severe setback in the struggle for dynastic leadership. ${ }^{158}$ Moral victory apparently went to Gusti Ketut Agung.

Meanwhile, respect for this royal scion in Mengwi had risen to unprecedented heights because he had demonstrated unequivocally that he possessed supernatural powers. After the worst of the economic crisis in

156 Pura Giri Kusuma in Blahkiuh could not fulfil this function, since its role remained restricted to the administrative district of G. Putu Mayun.

157 ARA, MvK V15-7-1938-14, report Resident 20-7-1936; Mr. 1936:926+. It seems probable that behind the scenes prince Gusti Ketut Agung played an important role in pressing the charge.

158 After the relocation of G. Rai Kepakisan, Mengwi was temporarily ruled by a Gusti from Buleleng. In September 1937 Gusti Ketut Katon was appointed new punggawa. He, too, hailed from Buleleng and, in contrast to his predecessors, quickly became popular. He prided himself on the fact that his family roots lay in Mengwi, from which place an ancestor in the eighteenth century had been stationed in Sukasada (in the Buleleng district). Moreover, he took an active interest in the restoration of pura Taman Ayun. Informants remember him as one of the best punggawa of Mengwi. ARA, MvK Mr. 1939:265+; KITLV, Coll. Korn:110, report G. Gede Raka 8-6-1938; interviews with G. Ng. Ceger, I Ketut Misma, Mengwi, and others. 


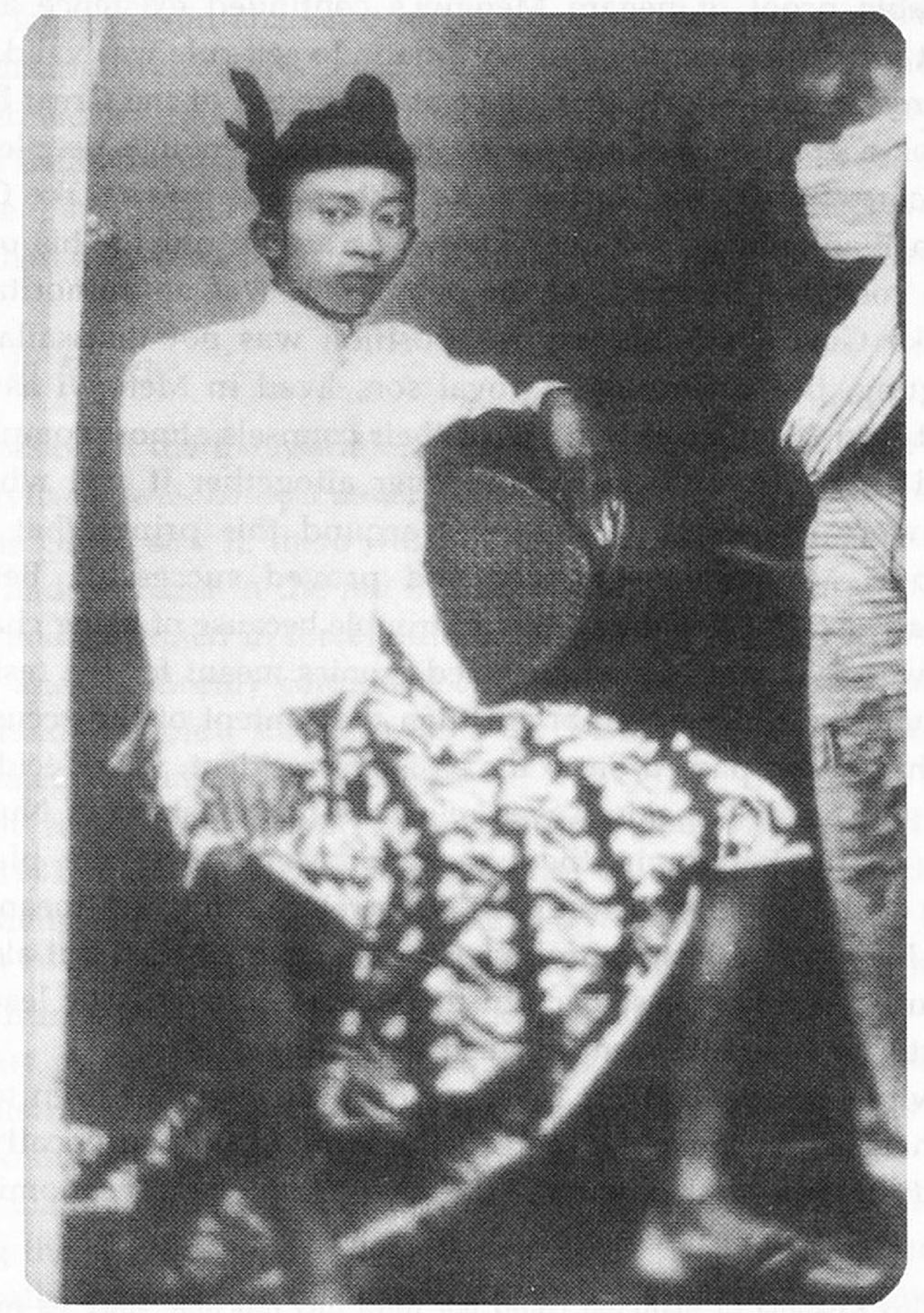

Gusti Ketut Agung of Mengwi (photo puri Gede Mengwi) 
1934, the years 1935 and 1936 presented the Mengwi region with successive crop failures. To the burden of great indebtedness was now added scarcity of food. Neither the Dutch nor the Balinese administrators were able to avert the plagues, so that help was finally sought from the heir to the Mengwi dynasty. Led by a number of subak chiefs, groups of peasants from the vicinity of Mengwi went to puri Gede and requested that Gusti Ketut Agung accompany them to drive out the evil that had come over the land. With a show of hesitance and reluctance he agreed at last. Seated in a sedan chair and with a crowd following him, he was brought to a number of stricken villages, where he sprinkled some holy water from the puri Gede house temple over the rice fields, and then returned to his house. ${ }^{159}$ This performance was repeated more than once, for people came to Mengwi from all around to request Gusti Ketut Agung's assistance. He visited dozens of areas in the region, including some desa in the neighbouring district where Gusti Putu Mayun was the punggawa. This powerful leader of puri Mayun stood by helplessly as more and more peasants in his district placed their trust in puri Gede Mengwi.

Sometimes Gusti Ketut Agung did not even need to visit the sawah; he would restrict himself to a visit to the village temple of that desa. ${ }^{160}$ If he was disinclined to come, he would dispense some holy water, though in many cases the holy water was not the most important thing, since the Gusti's bathwater would do as well.

If Gusti Ketut Agung did deign to come, his attitude was one of studied nonchalance. His son recounts:

'Father did not want to come, but he was asked time and again. Sometimes I was allowed to accompany him on the bicycle, while he was being carried in a sedan chair. Countless beautiful maidens stood at the side of the road, so my father would notice them. But father saw only cocks. If he spied a likely cock he would have the bearers lower the chair and he would move among the people to discuss the qualities of the animal with its owner. Then he would move on. Usually he did not go to the sawah, all he needed to do was to pay a brief visit to the desa. That was enough. But he found it tiresome. ${ }^{161}$

This account implies not modesty but great self-assurance which, combined with ostensible disinterest, evoked great respect.

Results were not long in coming. In 1937 the rice crop was unusually

159 The holy water came from the shrine in honour of Ayu Istri Mayun, the padmi of the last king of Mengwi who, according to tradition, had possessed supernatural powers. Similar powers were ascribed to Agung Mayun, the great nineteenth-century leader of Mengwi (see Chapter 4, section 2, and Chapter 5). Information regarding the crop failures and the part played by G. Ketut Agung was gathered by many interviews all over the region.

160 This indicates that the pura desa was important to the ritual cleansing of agricultural land as well.

161 Interview with Cokorda Gede Oka, puri Gede Mengwi. 
bountiful, while the depression, too, began to lift. The general conviction was that this had been the work of Gusti Ketut Agung. None other than this royal son had rendered Mengwi fertile again. Expressions of gratitude abounded; people from all around came in long lines to puri Gede Mengwi to proffer the first bundles of the newly harvested rice as a sign of respect. Even from Blahkiuh people came to honour Gusti Ketut Agung. 'I dared not stay at home', one informant told me, 'for everybody went.' In the face of this demonstration of supernatural strength, Gusti Putu Mayun was left powerless. To be sure, he was a strong punggawa, but when the chips were down, the specially dedicated shrine in his own temple in Blahkiuh failed to drive off the evil. In contrast, Gusti Ketut Agung had revealed himself as sakti.

This development sharply reduced the likelihood that Gusti Putu Mayun would be able to crown his power by becoming ruler of Mengwi. Not only was time running out, but Gusti Ketut Agung had become a serious contender. Tensions between puri Gede Mengwi and puri Mayun mounted and could hardly be kept hidden from the outside world. It is true that in October 1936 Gusti Putu Mayun and Gusti Ketut Agung jointly signed a plea for Mengwi self-rule, but when the director of the BB visited Bali shortly thereafter, there appeared to be little concord. ${ }^{162}$ In private talks Gusti Putu Mayun sought to persuade the director to grant self-rule - not to Mengwi but to his own district, whereby he, Gusti Putu Mayun, would be appointed as ruler. This attempt backfired. Since Mengwi evidently harboured conflict, the director became more convinced than ever that for the Mengwi region no restoration whatever could be contemplated. ${ }^{163}$

Meanwhile, Gusti Ketut Agung had come to realize that in the eyes of the Dutch he could not be considered a candidate. He lacked Western education and pursued a life-style to which the BB objected; consequently, he would never be appointed ruler. Although he had gained great respect among the people, this was irrelevant to Dutch decision-making. Available documents even indicate that the Dutch were largely unaware of his miraculous achievements. The only course of action left to Gusti Ketut Agung was to prevent his rival in Blahkiuh from taking over leadership of the dynasty. At this time he told the Resident that 'personally, he was not in favour of restoration, and would in fact oppose it if Gusti Putu Mayun were to become

162 This request is mentioned in a letter from G. Gede Raka to the self-rulers of Karangasem and Jembrana, 31-7-1938, Archives puri Kanginan, Amlapura.

163 ARA, MvK V15-7-1938-14, memorandum Directeur BB 31-10-1936. G. Putu Mayun made this (desperate) suggestion when he understood that the BB did not intend to restore the former negara Mengwi in its entirety, while in addition the future self-ruler of Badung would have to relinquish more than half of his domain, which of course was unacceptable to him. 
ruler'. ${ }^{164}$ If the Dutch had already closed the door to restoration of the negara, Gusti Ketut Agung had thrown away the key.

This is not the end of the story, for the conflict between punggawa Gusti Putu Mayun and Gusti Ketut Agung continued to fester. The battle was between the colonial power of puri Mayun and the revitalized royal authority of puri Gede Mengwi, with supremacy in the Mengwi hierarchy at stake. Though he knew better, Gusti Putu Mayun continued to scheme for rulership. One of his younger nephews acted as primary spokesman. This was Gusti Gede Raka, whom his uncle had made heir to puri Lambing in the 1920s and who had been given control over a large part of puri Sedang possessions. Gusti Gede Raka was favoured by Gusti Putu Mayun over his own sons. When he had completed the Dutch Native School in Denpasar, the punggawa sent him to Java to attend secondary school. Next, the young man began his official career. He became Algemeen Ontvanger (General Collector of Taxes) in the residency office in Singaraja. In this position Gusti Gede Raka had access to plans for administrative reform and was able to keep his uncle abreast of developments. At the same time, Gusti Gede Raka was a prominent member of a group of Western-educated Balinese called 'Young Bali'. 165 'Young Bali' was a heterogeneous company; some opposed the rigid barriers between castes, others went so far as to question the Dutch presence on Bali; Gusti Gede Raka, however, looked after the dynastic interests of his relatives.

To bolster his argument, Gusti Gede Rake used 'modern' means. In the Javanese daily Darmokondo of 13 December 1937 he published an impassioned plea for Mengwi's restoration. This publication was effective. Questions were asked in the Volksraad, and the director of the Department of Interior Administration was called upon to clarify why Mengwi had not been granted self-rule. ${ }^{166}$ Just before this, another ploy had been tried. In a meeting of all members of the Mengwi dynasty in puri Gede Mengwi, Gusti Gede Raka had proposed that the Dutch be presented with a petition demonstrating that the people of Mengwi desired restoration of self-rule. To this end he had had hundreds of lists printed, to be distributed among the

164 ARA, MvK V26-4-1940-9, report Resident 10-7-1939. Tradition has white-washed this episode somewhat. In 1983 G. Ketut Agung's son said: 'Restoration of Mengwi was possible, but father declined.'

165 Data derived from ARA, MvK V26-4-1940-9, report Resident 10-7-1939; interviews with G. Ag. Gede Mayun, Blahkiuh; Ida Pedanda Kamenuh, Singaraja; C.J. Grader. The General Collector was the accountant who registered taxes for the Residency of Bali and Lombok. G. Gede Raka was chairman of the debating club Bali Dharma Laksana, which published the periodical Djatajoe.

166 KITLV, Coll. Korn:110. The article was signed with the pseudonym Kawyapura Tjaraka, the messenger from Mengwi. 
perbekel, who would fill in as many names as possible. In this way the voice of the people would carry the day.

While the newspaper article at least drew some attention in Batavia, the petition led to nothing at all. At the meeting in Mengwi, representatives of puri Gede had kept silent and afterwards they secretly boycotted the plan. When Gusti Gede Rake distributed the lists all over the Mengwi district, the entire pile was forthwith handed in to the assistant resident. ${ }^{167}$ Even though official restoration of negara Mengwi was definitively banished from the political mind, the conflict between puri Mayun and puri Gede Mengwi took on ever more acrimonious forms.

Unexpectedly, on 7 April 1938, Gusti Ketut Agung died.168 Puri Mayun capitalized on the situation immediately by undertaking a last and decisive action. Once again, a meeting was convened of all members of the dynasty; the venue this time was the house temple of puri Mayun in Blahkiuh. Gusti Gede Raka was again the great instigator. He composed a petition which was presented in June 1938 to the governor general, the Volksraad, the Dutch parliament, and Queen Wilhelmina. ${ }^{169}$

The text included a number of appendices, each of which contained a separate argument. The core consisted of an extensively documented memorandum, based on BB reports from the residency archives. The whole demonstrated that Mengwi could legitimately claim existence as an independent negara, couched in terminology and argumentation borrowed from the BB. ${ }^{170}$ A Malay translation of Babad Mengwi, augmented with a brief genealogical link with the present, contained the argument that the Mengwi dynasty had continuously exercised authority over the region. ${ }^{171}$

167 Interview with G. Ag. Gede Rai, puri Kajanan Mengwi; archives puri Kanginan Amlapura, letter G. Gede Raka to self-rulers of Karangasem and Jembrana, 31-7-1938. The meeting took place 18 September 1937. The action was thwarted by the new punggawa of Mengwi, who took the side of Gusti Ketut Agung, whose position, as he saw it, was the wiser strategy. In this way he could avoid difficulties with puri Gede and at the same time serve the BB with timely intelligence concerning possible 'unrest'.

168 G. Ketut Agung died of tuberculosis; Samboengan Babad Mengwi:14.

169 For the text of the petition see ARA, MvK V26-4-1940-9 and KITLV, Coll. Korn:110. The meeting was held on 16 May 1938 and, as in the case of the earlier meeting, the representatives of puri Gede Mengwi did not speak (archives puri Kanginan Amlapura, letter G. Gede Raka 31-7-1938).

170 G. Gede Raka, because of his work at the Residency office, had access to the local BB archives. The main documents he used were the reports by F.A. Liefrinck and H.J.E.F. Schwartz, dating back to the beginning of the century. These authors recommended that Mengwi should continue to be ruled by the old dynasty. At the same time G. Gede Raka sought to show that negara Mengwi certainly still did exist at the time the Dutch took over (1906). After all, members of the dynasty had stayed on in eastern Mengwi, had they not? On this basis, then, the Dutch certainly should agree to restoration. A map was added, which was copied from the Adatrechtbundel 23 (1924:185) and showed the old negara.

171 This was babad Mengwi-Blahkiuh and Samboengan Babad Mengwi. To obscure the fact that members of puri Gede Mengwi did not support the petition at all, Gusti Gede Raka 
The petition as such was signed by just forty-four persons, thirty-seven of whom came from the administrative district of Gusti Putu Mayun. ${ }^{172}$

Although the Balinese rulers had already all been installed, the petition went through the official channels anyway. The Dutch officials praised the document as an excellent piece of work and left matters there. Just before the German occupation, Queen Wilhelmina decided on 3 May 1940 not to grant the Mengwi request for self-rule. ${ }^{173}$ The only result of this last action was a new ruling that the filing cabinet containing the residency archives would henceforth remain locked. Curious Balinese officials should be kept out. ${ }^{174}$

When the official response to the petition became known at last, the die had already been cast on Bali. By 1939 puri Gede was the final victor in the dynastic tug-of-war, while puri Mayun had suffered a decisive setback.

Because puri Gede Mengwi had declined to support the petition in any way, the conflict led to a public break with puri Mayun. ${ }^{175}$ In great anger, Gusti Gede Raka declared that his lineage would no longer recognize puri Gede as leader because it had betrayed the dynasty. He no longer considered puri Gede as a puri but as no different from the house of a lowly jaba. ${ }^{176}$ If one did not act as a satria, one did not deserve recognition as a leader. The behaviour of puri Gede had seriously damaged the dynasty's prestige. To himself, however, Gusti Gede Raka ascribed the role of Bima. This hero in the wayang story Bima Swarga had faced grave dangers as he descended into the nether world to save his parents. ${ }^{177}$ The parents, Gusti Gede Raka explained, referred to the kawitan: the origins and the identity of the

introduced the term 'puri Mengwi'. According to him this covered the main lineage of puri Gede as well as those of puri Anyar and puri Mayun, since each of these branches derived from Agung Mayun. Hence, an eligible self-ruler would not have to come from puri Gede; Gusti Putu Mayun would be equally eligible.

172 Of these 44 persons 32 belonged to the Mengwi dynasty. The other 12 were perbekel from punggawa G. Putu Mayun's district. All of the 37 signers from the punggawa's district maintained a special link with puri Mayun. In this list, too, the term 'puri Mengwi' was used to hide the fact that not a single member of puri Gede had signed the petition. A closer look reveals that of the 21 names to which was added 'puri Mengwi', 12 belonged to puri Mayun and 5 belonged to the annexed puri Selat. The strong branch of puri Sibang - in G. Putu Mayun's own district - was represented by only one name. Of the 7 persons outside of the punggawa's district 4 belonged to the marginal sub-branch of puri Sembung.

173 ARA, MvK V19-8-1940-7, machtiging Koningin 3-5-1940. The Dutch argument remained largely the same: in 1906 Mengwi no longer existed and could therefore not be restored. Furthermore, the dynasty was internally divided.

174 ARA, MvK V26-4-1940-9, report Resident 10-7-1939.

175 Upon the death of G. Ketut Agung, a cousin became the leader of puri Gede. This was Gusti Made Agung, born in puri Abiansemal and later residing in Mengwi (see Appendix).

176 Archives puri Kanginan Amlapura, letter G. Gede Raka to self-rulers Karangasem and Jembrana 29-7-1938. He used the low-Balinese word umah (house) to refer to puri Gede.

177 For the Bima Swarga story see Hinzler 1981 and Chapter 2, section 1. 
dynasty. Whoever betrayed the kawitan, as puri Gede had done, violated his relatives and lost the right to respect. ${ }^{178}$

The virulence of Gusti Gede Raka's criticism of puri Gede and his emphatic insistence that he was right could not, however, hide the fact that puri Mayun had gradually become isolated. By virtue of his administrative post in the colonial system, Gusti Putu Mayun was one of the most powerful punggawa on Bali. But his might was limited to his district; outside of it he proved to wield little influence. This became painfully clear when his candidacy for self-rule found no support whatever in the broader region. Within his own district, Gusti Putu Mayun could force his authority upon people, and his wealth allowed him to cause many to become dependent on him. The great majority of those who signed the petition were heavily dependent on the punggawa and would have been in dire straits should they have refused to cooperate. All this had created distance between him and his subjects. Perhaps he still saw himself as a 'fatherly' leader, but he had long ceased to listen to his followers.

He must have been sorely disappointed when the Dutch refused to grant him self-rule. Instead, the Dutch treated him as an official, and like any civil servant he retired in 1939 after more than 30 years of faithful service. The occasion was marked by a ceremony in Blahkiuh, for which the punggawa had mobilized the required labour and contributions from the people. Two guests of honour pointed up the ambivalent character of this event. The first was the Resident of Bali and Lombok. He represented the colonial state, the source of Gusti Putu Mayun's power. In the name of the state the punggawa received a gold star, the reward for a lengthy official career. It must have rubbed Gusti Putu Mayun the wrong way that it was not the Resident but the new ruler of Badung who pinned the decoration to his chest. 179 The second guest of honour was none other than the ruler of Klungkung, the Dewa Agung. He represented that which had been Gusti Putu Mayun's quest in all these years: restored kingship. That night the Dewa Agung performed for the guests a warrior's dance (baris). ${ }^{180}$ This dance exemplified kingship under the colonial regime. It was theatre, portraying an illusion, and even this had remained unattainable for Gusti Putu Mayun.

Gusti Putu Mayun's prestige - or what was left of it - literally went up in

178 Hinzler 1981 and Chapter 2, section 1. In this connection he used the words kawah tai, a barrel of excrement, with reference to puri Gede.

179 ARA, MvK V26-4-1940-9, G.B. 28-12-1938-21.

180 Some informants from Blahkiuh still recall this dance. 'It was not beautiful', one of them said (as a child the Dewa Agung had damaged his knee during the puputan of Klungkung, and limped), 'but the fact that the Dewa Agung did come to dance was quite an honour.' 
smoke in August 1939, when Gusti Ketut Agung was cremated. ${ }^{181}$ In almost every respect this ritual contrasted with the unbending and rigid ceremony in Blahkiuh. Gusti Ketut Agung's son likes to recount how puri Gede's coffers held a mere Dfl. 75; nevertheless the cremation ritual was one of the most magnificent ever. This means that voluntary contributions and labour by the inhabitants of the Mengwi region had made this great event possible. Outsiders, too, like Gusti Ngurah Ketut Sangka of puri Gede Krambitan, vividly remembered the ritual. A young boy then, he had gone to watch and was struck by the enormous numbers of people present in Mengwi on the day of the cremation. He was also impressed by the great respect displayed towards the deceased. This was expressed in two ways. Most of the men from desa Mengwi had shaved their heads. This gesture, called masatia rambut, expressed a subject's loyalty. ${ }^{182}$ Popular veneration was further evidenced in the fact that thousands of people had come to puri Gede to honour the deceased with a sembah. ${ }^{183}$ Like the masatia rambut, this homage was rare, a deference shown only to rulers with very great prestige indeed.

The bier on which Gusti Ketut Agung was borne to the cremation site had been constructed by the residents of Mengwi. It was a layered tower with eleven tiers, the number reserved for satria. In addition to contributions from the Mengwi people, other puri, too, had presented gifts. Puri Ubud provided the lembu, a sarcophagus in the shape of a bull, in which the corpse would be burned; puri Sibang gave a nagabanda, the figure of a snake used only when a high-placed satria was cremated. Both puri Ubud and puri Sibang thus demonstrated that they had not forgotten Mengwi as royal centre.

On the day of the cremation ceremony it seemed as if negara Mengwi had never disappeared. A great crowd milled around the bier tower as it was conveyed from the puri to the cremation site. ${ }^{184}$ Soon after the fire below the lembu was kindled, a heavy thunderstorm erupted over Mengwi, which was taken to signify a divine cleansing. This event added a new name to Gusti Ketut Agung: Batara ring Tirta, the 'deified one in the water'. This

181 The cremation (palebon) took place shortly after the birth of princess Irene (5-8-1939) in Holland. On that day some members of old follower families of puri Gede could not attend the cremation. As government officials they had to gather on the square in front of the assistant resident's house in Denpasar to sing an aubade to the Dutch royal house.

182 According to Korn (1932:306) the masatia rambut was a sacrifice of the hair, meant to overcome the lack of balance in the land resulting from the death of the king. It seems to me that one can also think in terms of loyal followers symbolically accompanying the dead king. 183 An obeisance whereby the person kneels and raises his joined hands above his bowed head.

184 The impression of the cremation is based on many interviews with older residents of Mengwi and surrounding localities. 



Cremation of Gusti Ketut Agung (1939) (Collection puri Gede Mengwi) 
name referred not only to the rainstorm during the cremation but to the supernatural powers ascribed to the royal son. After all, when the economic crisis in Mengwi was exacerbated by crop failures, he had rendered the land fertile again. It was this action, as various informants stressed, by which 'he returned royal authority to puri Gede Mengwi'.

Puri Gede Mengwi had remained entirely aloof of the colonial regime, even though the fate of puri Mayun was closely bound up. with it. The massive attendance of people from far and near to witness the cremation of Gusti Ketut Agung therefore also symbolized more than veneration for the deceased. Behind the magnificence of this royal ritual lay an unspoken protest against the chilling might of puri Mayun. To be sure, Gusti Putu Mayun had achieved 'law and order', but he had shown no concern for his people. Moreover, when decisive action was needed he proved powerless, while the man who had no official post at all, the prince from puri Gede, turned out to be the stronger. Gusti Putu Mayun had lost; the people left no doubt about it.

\section{The spell}

Upon his retirement, Gusti Putu Mayun - or the punggawa pensiun, as he was now usually called - withdrew to a small bungalow he had had built in western Blahkiuh. ${ }^{185}$ His youngest son, Gusti Agung Ngurah Putra, succeeded him as punggawa. This young man had attended the Dutch Native School and the OSVIA in Probolinggo in East Java, after which he had gained a great deal of administrative experience. ${ }^{186}$ In contrast with his father, the son proved to be very much a capable administrator. From the outset he distinguished sharply between his task as public servant and the private interests of his relatives. Administrative tasks he carried out in his office, always arriving on time. The proceeds of the fruit trees along the road, formerly immediately confiscated by the punggawa, were left to desa Blahkiuh. He closed the house temple to those who did not belong to the lineage or to the restricted entourage of the puri. Because of this, the days were past when hundreds of people would pay homage to the punggawa on the odalan of the house temple.

Although, compared to the father, the son was better liked, he too distanced himself from the people. His strictly official attitude weakened the

185 It is noteworthy that in interviews the punggawa was virtually never referred to by his deified name, while G. Ketut Agung always was.

186 ARA, Coll. Boon, MvO Controleur Badung M. Boon 1938; interview G. Ag. Gede Mayun, Denpasar. OSVIA was the Opleidingsschool voor Inlandsche Ambtenaren (Training School for Native Administrators). He had gained experience as mantri polisi in his father's district and as voluntary clerk for the punggawa of Ubud. The oldest son of G. Putu Mayun had not completed the Dutch Native School and the second son had been 'adopted' by puri Selat. 
hold puri Mayun had long had on the surrounding area, and his behaviour as administrator prevented him from wielding personal authority. Puri and government were no longer identical; this meant that within a few years he put an end to his father's dynastic manner of government.

Towards the end of the colonial period the Mengwi dynasty was torn by conflict between puri Mayun and puri Gede. Puri Mayun's power shrank; puri Gede was still without a new leader. In the wake of repeated colonial reorganizations, the other lineages were too much restricted to their immediate areas to be able to play a major role. In 1940 the remnants of the Mengwi dynasty amounted to no more than a loose collection of relatives, each distrustful of the others. According to many, the effects of the spell cast over Mengwi by Mas Sepuh - lord of Blambangan - just before he was treasonably slain on the beach of Seseh (Chapter 3, section 2), continued undiminished. Paradoxically, only the death of Gusti Ketut Agung had brought negara Mengwi briefly to life one last time. 


\section{APPENDIX \\ Tables}

Table 1. Exports and imports, South Bali (in Dfl.)

\begin{tabular}{lcc}
\hline & Exports from South Bali & Imports to South Bali \\
\hline 1908 & $1,151,653$ & 992,828 \\
1916 & $2,579,299$ & $2,501,009$ \\
1919 & 666,827 & $5,464,559$ \\
1924 & $3,820,278$ & $1,815,438$ \\
1928 & $8,067,276$ & $6,305,665$ \\
1930 & $4,324,633$ & $6,120,252$ \\
1933 & $2,904,004$ & $1,855,956$ \\
1935 & $1,898,944$ & $1,786,188$ \\
1937 & $3,176,011$ & $2,815,027$ \\
\hline
\end{tabular}

Sources: ARA, MvK MvO Resident G.F. de Bruyn Kops 1909, P. Moolenburgh 1926, H. Beeuwkes 1932; MvO Assistant Resident A.J.L. Couvreur 1920, C.C. Ouwerling 1929, B. Cox 1940; MvO Controleur Badung J.H. Boerstra 1928, O.H. Hirschmann 1931; Nota van Toelichting Badung H.J. Hoekstrå 1938; NHM: 9238, reports N.V. Afscheepen Commissie Zaak Zuid-Bali 1915-1934. The figures report South Balinese trade via Benoa harbour.

Table 2. Land rent tax receipts (in Dfl.)

\begin{tabular}{llcrl}
\hline & Land rent assessment: & Old land rent & \multicolumn{2}{c}{ New land rent } \\
\hline Badung & sawah & 217,310 & 326,791 & \\
& high ground & $\frac{38,448}{255,758}$ & $\frac{91,445}{418,236}$ & $(1924)$ \\
total & sawah & 126,200 & 202,000 & \\
Gianyar & high ground & $\underline{33,700}$ & $\underline{50,900}$ & \\
& total & 159,900 & 252,900 & $(1925)$ \\
Tabanan & sawah & 216,822 & 284,176 & \\
& high ground & $\underline{28,355}$ & $\underline{106,093}$ & \\
& total & 245,177 & 390,269 & $(1923)$ \\
\hline
\end{tabular}

Source: Korn 1932:338. 
Table 3. Exports of gold and silver (South Bali) (in Dfl.)

\begin{tabular}{lrr}
\hline & Export & Import \\
\hline 1930 & $2,073,000$ & - \\
1931 & $2,749,000$ & - \\
1932 & $1,081,000$ & - \\
1933 & 740,000 & - \\
1934 & 547,000 & - \\
1935 & 301,000 & - \\
1936 & - & 410,000 \\
1937 & - & - \\
\hline
\end{tabular}

Source: ARA, Coll. Boon MvO Assistant Resident H. Jansen 1937.

Table 4. Redemption of corvée, Badung subdivision*

\begin{tabular}{lcc}
\hline & Number of redemptions & Number of days worked \\
\hline 1931 & 25,791 & 62,884 \\
1932 & 6,607 & 493,150 \\
1934 & 945 & 670,886 \\
\hline
\end{tabular}

Source: ARA, MvK Nota van Toelichting Badung H.J. Hoekstra 1938.

* Total number of conscripts approximately 30,000.

Redemption payment up to 1931: Dfl. 5; 1932: Dfl. 3.

Table 5. Land rent in Badung (in Dfl.)

\begin{tabular}{lcrrr}
\hline & Assessment & Exemption & Crisis exemption & Arrears (\%) \\
\hline 1928 & $408,917 *$ & - & - & - \\
1929 & 404,002 & - & - & - \\
1930 & 412,107 & 4,447 & - & 27 \\
1931 & 418,936 & 9,010 & - & 50 \\
1932 & 418,628 & 24,959 & - & 54 \\
1933 & 418,413 & 3,796 & 83,068 & 61 \\
1934 & $289,337 * *$ & 2,774 & 321 & 26 \\
1935 & 289,111 & 29,250 & 321 & 24 \\
1936 & 287,653 & 28,398 & 321 & 16 \\
1937 & 287,497 & - & - & 6 \\
\hline
\end{tabular}

* Dfl. 312,614 (sawah); Dfl. 91,344 (high ground). It remains unclear why the total assessment was higher.

* Ten-yearly review.

Source: ARA, MvK Nota van toelichting Badung, H.J. Hoekstra 1938. Exemptions were granted in connection with crop failures. 
Table 6. Population growth

\begin{tabular}{rrrc}
\hline & \multicolumn{1}{c}{ Bali } & South Bali & Badung and Mengwi \\
\hline 1909 & 750,000 & 143,400 & \\
1920 & 947,000 & 766,800 & 173,300 \\
1930 & $1,092,037$ & 889,527 & 192,400 \\
\hline
\end{tabular}

Sources: ARA, MvK MvO Resident G.F. de Bruyn Kops 1909; Lekkerkerker 1923c:1667; Korn 1932:310. Except for the 1930 data, the figures are approximations.

Table 7. Sawah possessions in Blahkiuh, about 1940*

\begin{tabular}{llll}
\hline $\begin{array}{l}\text { Large landownership } \\
\text { (more than 0.5 ha) }\end{array}$ & c.70 households & $(16 \%)^{* *}$ & c.220 ha \\
$\begin{array}{l}\text { Smallholders } \\
\text { (from 0.1 to 0.5 ha) }\end{array}$ & c.200 households & $(45.5 \%)$ & c. 80 ha \\
Landless & c.170 households & $(38.5 \%)$ & none \\
\hline
\end{tabular}

* During the fieldwork these data were gathered by way of a survey interview with all households in Blahkiuh. As far as feasible, the results were compared with other sources: Bakker 1937d; KITLV, Coll. Korn: 157, population survey 1931; ARA, MvK Nota van Toelichting Badung H.J. Hoekstra 1938. Compared to these sources the survey showed only minor deviations. Nevertheless, the figures presented here are emphatically meant to give an indication only; they do not pretend to reflect reality accurately.

* Within this category a restricted elite $(1.5 \%)$ possessed dozens of hectares (much of which was located elsewhere in the region), while the others possessed 1 to 2.5 hectares 



\section{CHAPTER $X$ \\ From fluidity to fixation}

The pre-colonial negara was characterized by a high degree of segmentation. Fragmentation of power and recurrent conflict proved to be normal, while periods of peace and centralization were the exception.

Even so, one might still wonder why pre-colonial southern Bali did not witness the rise of a strong state. At first sight, conditions for this would seem to have been favourable. The idea of kingship was known, as were a jurisprudence and a hierarchy which would make central kingship possible. Ecological and economic conditions, too, were advantageous. The southern Balinese plain was highly fertile, relatively densely populated, and not unwieldy in size, so that a central authority would have been able to control large groups of people. Moreover, the great irrigation systems provided a ready opportunity for a strong man to control an appreciable part of the food production. Finally, slave trade and, later, agricultural exports, concentrated in a few harbours, made for an important source of income which might well have been monopolized without too much trouble. Both ideologically and materially, conditions favoured the rise of a centralized southern Balinese state. What actually occurred, however, was the opposite. Not only did Mengwi fail to achieve enduring dominance over the other negara, but even within its own boundaries all attempts to strengthen central authority drowned in violence. A history of two centuries did not provide the Mengwi dynasty with a state, because the fragmented nature of the political system was too stubborn to adapt to permanent centralized control.

It would be very wrong to picture the Balinese negara as a 'failing state'. Rather, Bali should be viewed in both the broader context of Southeast Asia and the immediate environment of eastern Indonesia. Recent research on the political landscape of Southeast Asia makes it increasingly clear that smallness of scale, instability, and above all fluidity were normal features. Accordingly, negara Mengwi belonged to a set of small-scale polities, each with their own rhythm of rising, expanding, and receding. In Southeast Asia such polities constituted the large majority. ${ }^{1}$ Viewed in this way, the rise of imperial kingdoms such as Angkor, Ayutthya, and Majapahit is far less selfSouth Sulawesi see Sutherland 1983b, and for Southeast Asia as a whole see Reid 1988. 
evident than has long been assumed. Moreover, the scale of these Indianized 'empires' should be relativized a great deal, since these kingdoms apparently never were centralized polities. They were confederations of various small centres which shared a unitary ideology derived from Indian notions of hierarchy expressed in the image of the World Ruler.

Although the negara adorned itself with notions of the cosmos and kingship derived from India, in terms of scope the Balinese political system fits well into the eastern Indonesian context. Future research is likely to shed more light on eastern Indonesian patterns in Balinese culture. Perhaps this will bring out more clearly the position of Bali on the 'anthropological Wallace line' between the Indianized parts of western Indonesia and the islands to the east. ${ }^{2}$

The issue of the nature of the negara leads to the question as to what kind of kingship Bali had. The history of Bali after 1650 mentions no divine kings. Kings were mortal but kingship was not (Guermonprez 1985; StuartFox 1991). Kingship was one of the central political institutions in which strong leaders sought to realize their power. ${ }^{3}$ In this context the issue of the relation between order and violence is of interest. It is not correct to view this relation as an unmitigated contrast where order is legitimate and violence illegitimate. The concept of legal kingship was never developed on Bali. ${ }^{4}$ Rather, both order and violence emanated from a single divine source; both were made manifest through the actions of the king. Actually, the divine 'legitimacy' of successful kingship was manifested through violence, and violence was instrumental in establishing order. Eventually, however, the success of royal leadership depended on the extent to which a king demonstrated his ability to control violence, hence to reinforce order. In other words, kingship was a necessary condition for the continuation of life, and I suppose that for the majority of Balinese the 'flow of life' was unthinkable without kingship.

Although the Balinese polity experienced no evolution from chiefdom to state, the negara was anything but static. Against a background of enduring structural order - marked by a ritual axis stretching from the mountains, via

2 In this connection see the important studies by Guermonprez (1985, 1989 and 1991). Regarding the position of king and priest he states: 'When the Indic spectacles are removed [...] [it] becomes theoretically possible to envision the "Hindu kings" and the "Brahmins" of Bali as transformations of the "war chiefs" and "ritual chiefs" who form remarkable pairs in the ethnography of the ceremonial domains of eastern Indonesia' (1991). See also Fox 1980 and 1988; H.G. Schulte Nordholt 1971. Apart from this, research should be done on early Chinese influences on Bali. Few traces of this are found in Balinese texts; but Chinese influence is very noticeable in material culture, such as in the Barong and in the architecture of the housing of nobles.

3 Following Sahlins (1985:32-54) one might characterize the negara as a heroic polity in which the king was the pivot of significant events.

4 I would like to thank J.-F. Guermonprez for discussing this subject with me. 
the royal centre, to the sea - important changes took place between 1650 and 1900. The rise of new kingdoms after the fall of Gelgel was closely associated with a sharp increase in slave trading in the Archipelago. Until far into the eighteenth century power relations on Bali were in the throes of violent reorganization, and the founding of new dynasties; royal power in Mengwi was almost constantly in motion. It is probable that during this period the new dynasties penetrated more deeply into local society. But expansion was easier than consolidation; growing power of a royal centre went hand in hand with increasing tension with various satellites, which led to violent confrontations threatening the continuity of the negara.

Around 1800 new changes occurred. Once again power was redistributed. This time the Mengwi dynasty was forced into a defensive position. Mengwi lost its grip on the more remote satellites, which assumed independence or were incorporated by rival powers. At the same time the export of slaves was replaced by agricultural exports, as a result of which control over central irrigation systems became an extra stake in armed conflicts.

Paradoxically, the losses suffered by the Mengwi dynasty accompanied a stabilization of hierarchical relationships on Bali. In Mengwi the 'familial' character of the royal regime was displaced by an order primarily based on a sharper differentiation between nobility and commoners. The nobility as a whole closed itself off from outside groups and seemed to emphasize its internal differentiation more zealously than ever. The dynasty, too, turned in upon itself. Faithful followers were no longer adopted by the king or promoted to the lesser nobility, and noble families in the area were no longer annexed. Henceforth principal wives were drawn from the husband's own kin group. Unlike his eighteenth-century predecessors, the king in later times preferred to remain at home. On Bali a pattern developed of 'hostile coexistence' in which annihilation of neighbouring rivals was no longer the prime objective. Instead, the powerful continued to probe each other's weaknesses time after time in order to adjust mutual ranking.

Pushed back into its own region the Mengwi dynasty, due to restored central leadership, proved able to maintain itself until the end of the nineteenth century. But at that time Bali was confronted with an external threat to which the island would succumb: the colonial state. The attempt of the Klungkung court to establish a closed southern Balinese front against Dutch expansion soon led to violent outbursts of internal conflicts spelling the end of Mengwi. The 'ideological' order in which the ruler of Klungkung outranked all other Balinese kings and lords failed when put to the test of political practice. The struggle to retain the Balinese order ended under colonial pressure in self-destruction, dramatically expressed in the puputan of 1906 and 1908. 


\section{Colonial fixation}

Western expansion since the nineteenth century has had an indelible influence on Southeast Asia in two ways: it initiated an unprecedented process of state formation and it incorporated the region irrevocably into the world market. From the early twentieth century Bali has become part of these larger constellations, and the developments on the island in the course of the twentieth century cannot be seen apart from this broader context.

Entirely without precedent was the monopoly of power held by the colonial state, rendering it capable of forcibly prescribing a state of peace. Besides serenity, peace, and law, the Dutch also introduced 'order'. Shortly after the establishment of colonial rule the political system was revamped from top to bottom. The fluid character of the old kingdoms was replaced with fixed frameworks, such as districts, villages, and subak, defined and controlled by an external bureaucracy. The Dutch further introduced a uniform and rigid caste system which pushed aside the old, more flexible hierarchies and their regional variations.

The colonial period was characterized by a number of contradictions, the consequences of which left deep furrows in Balinese society. By effecting an artificial separation between the nobility and the village, the colonial government on the one hand sought to maintain the myth of egalitarian village republics, eminently amenable to efficient introduction of a territorial system of rule, and on the other hand retained most of the noble hierarchy, rendering it subservient to maintaining colonial authority. The Dutch did manage to create a modern apparatus of government, but from 1920 onwards the preference was to let traditional popular rulers control society. The ultimate result of this was that 'restored' old dynasties put a Balinese face on colonial rule. If the term 'theatre state' is to be applied to Bali, then the. 'restored kings' of the 1930s fit the bill.

Another Dutch effort was to close off Bali from the outside world and to preserve it in a condition supposedly 'traditional'. At the same time, the very presence of the colonial state brought irreversible change and Bali was irrevocably caught up in the world market.

This merging of the old political system and the external colonial state made for fundamental change in power relations in South Bali. An end was made, at least officially, to the complex networks of lords and followers and the shifting alliances between various warlords as decisive factors of power. Moreover, the number of Balinese powerholders was greatly reduced. Most of them were relegated to their own immediate surroundings and had to be content with a position as village head. A mere handful survived colonial interventions through timely anticipation of Dutch intentions. Among them were the leaders of the lineage of puri Mayun in Mengwi. Gusti Putu 
Mayun eventually became one of the most powerful punggawa on Bali.

In this study I have analysed the changes that took place during the colonial period in the interface between state and society. Puri Mayun and its entourage in Blahkiuh constituted this interface. I have tried to shed light on the colonial experience of ordinary village people on Bali by describing in detail the history of punggawa Gusti Putu Mayun and those around him, including his sedahan.

The power of people like Gusti Putu Mayun no longer rested on their ability to mobilize masses of followers; it now depended on the degree to which 'law and order' were maintained in a given district. Utilizing means of power derived from the colonial state, Gusti Putu Mayun successfully surrounded his power with attributes such as a temple and rituals referring to the old royal order of Mengwi. In spite of these familiar symbols, however, the distance between the punggawa and his people widened. This separation was accentuated as the old pacatu system disappeared. From then on, followers no longer gained access to sawah land in exchange for labour and loyalty; many lost their land and were reduced to the position of sharecroppers dependent on noble large landowners. Among the burdens with which these share-croppers were saddled was the new colonial land rent tax which, compared to earlier tribute, was far heavier to bear. As long as the export climate was favourable the people were able to cope with the tax burdens, but once the world-wide economic crisis reached Bali countless households were faced with great difficulties and many were reduced to poverty. Among the noble lords there were but few who took on the role of 'father' which would have made them respected leaders in the nineteenth century; instead, many a lord used his position to expand his own property.

At first sight it seemed as if the various kinds of water (see Chapter 5) continued their downward flow without interruption during the colonial period. But this was mere appearance. To be sure, the direction of the flows did not change, but the political landscape traversed by it was now completely different. The colonial government had taken over management of the central dams and had replaced the more important ones with concrete constructions. Hence, the Dutch had appropriated the distribution of irrigation water. The flows of semen and holy water, too, were led through a new colonial channel, since the hierarchical relationships in Balinese society had been fixed in colonial frameworks.

The most important difference between the old and the new, however, was that, in spite of all Dutch attempts to preserve 'traditional conditions', the ritual care of the crucial cycle of life no longer rested with the royal centre, and was not looked after by the colonial state either. To the Dutch the establishment of colonial authority meant serenity and order; but many Balinese experienced the colonial presence as a time of unrest and disorder. 
In 1906 the foreign conquerors had underscored their monopoly on violence in an overwhelming way when they shelled Badung. From then on the majority of the people were fearful of Dutch officials. The frightening apprehension that the old order had passed away forever became a certainty in 1917, when Bali was hit by a heavy earthquake in the wake of which the island was plagued by an influenza epidemic and crop failures. For most Balinese, life was far from paradise; it was rife with uncertainties, for instance because the white authorities were not about to discharge their ritual duties regarding the flow of life. The consequences of such negligence on the part of the foreign rulers were underscored in the 1930s when Bali was caught in the world-wide economic crisis. The colonial regime merely added to people's fears of all sorts of serious threats to the continuity of life. ${ }^{5}$

In spite of the fact that the Pax Neerlandica ended the semi-permanent state of war under the old order, hidden from Dutch eyes countless conflicts were going on. Western image makers pictured Bali as one of the most peaceful areas on the face of the earth, but the battle between puri Gede and puri Mayun shows that the nobility was engaged in covert warfare. Also, there was resistance against a number of Balinese rulers, as evidenced by the ousting of Si Putu B. in Blahkiuh and mass participation in the impressive cremation of Gusti Ketut Agung in Mengwi (August 1939). During this last ritual the colonial regime was rejected in language derived from the old order.

\section{The kawitan}

When the Dutch colonial regime was wiped out in 1942, the young punggawa of puri Mayun in Blahkiuh, like many other Balinese officials, entered into the service of the Japanese occupiers. But after the Japanese were forced to leave in 1945, puri Mayun soon lost the last of its power.

In a brief span of time the old Gusti Putu Mayun lost three sons. The eldest died of tetanus during the Japanese occupation. The other two were murdered by guerrillas at the beginning of the revolution. Once more Gusti Putu Mayun moved into the puri as interim punggawa under the protection of the Dutch military. At his suggestion, a nephew (brother's son) was appointed shortly thereafter as punggawa of Abiansemal district. The

5 See Vickers 1989:132-4, 145-6. In a recent study Unni Wikan emphasizes the degree to which danger and fear are the undertone of life on Bali: 'There is a host of [...] specific dangers and threats that always appear to be prominent in Balinese awareness. Balinese seem, in a sense, to live perpetually on the verge of disaster, a fact to which their reflections on life, actions, and somatic imagery and ailments all attest. To live with danger and the attendant fear [...] provides the ubiquitous context which colors most social action in Bali' (1990:32). 
nephew held this position until 1950, at which time the Dutch moved out and left puri Mayun surrounded with enemies.

Straightaway the new punggawa became the victim of one of the many acts of vengeance which rendered Bali unsafe in those years. The old Gusti Putu Mayun died in 1950. In broad daylight, during the mamukur death ritual in Blahkiuh, the punggawa was shot from a passing jeep. Some had known that an assassination attempt was planned, but the punggawa was not informed. He had lost his grip on his domain. Seriously wounded, the punggawa was taken to the hospital in Denpasar, where a second assault took place. He fled Bali and settled in Jakarta. This was the end of half a century of puri Mayun rule in eastern Mengwi. ${ }^{6}$

In Abiansemal the Indonesian government appointed a district head from neighbouring Carangsari. This man was a noble as well, but his kin had turned against the Dutch during the revolution. ${ }^{7}$ Meanwhile, puri Mayun was unoccupied, since the young heirs had moved to Denpasar, where they eventually became members of the bureaucracy. The landed property of puri Mayun was largely sold off over the years; some plots were 'lost' because of the absence of the owner and poor administration. The puri itself deteriorated gradually, as did pura Giri Kusuma. The annual purification ritual no longer took place at the central crossroads near the temple and the kulkul of pura Giri Kusuma remained silent because the voice of puri Mayun was mute.

The people of Blahkiuh looked upon the departure of the Mayun family with mixed feelings. On the one hand there was relief that the strict regime of puri Mayun was no more. On the other hand, the disorder of puri and temple was lamented. 'The puri has forgotten us', was the general complaint. When in more recent times the family returns to the puri during feast days, little notice is taken. A special ritual in the puri draws only a few villagers. Those who do offer their services tend to take a generous reward for their labours. 'Nothing for nothing', was the laconic comment of someone who, in 1983, appropriated half a pig during the preparations for a marriage ceremony.

Other Mengwi dynasty puri, such as those in Sibang and Bongkasa, managed to retain their influence at the village level because their landed property remained largely untouched and their leaders functioned as village heads. Representatives of still other puri pursued careers in the Indonesian

6 On the revolution on Bali see Pendit 1979; Robinson 1988. From 1946 onwards the Dutch tried to restore the old dynasties and use them as allies against nationalist revolutionaries. This policy proved unsuccessful.

7 The revolutionary hero I Gusti Ngurah Rai, who lost his life in.1946 at Margarana, came from puri Carangsari as well. 
bureaucracy, some attaining high positions. ${ }^{8}$ Relatively few members of the dynasty reverted to sources of income in occupations other than officialdom. A few individuals became rich through the building trade, thanks to connections with relatives in government circles. $^{9}$

Puri Gede Mengwi, too, weathered the times. The son of Gusti Ketut Agung, Cokorda Gede Oka, became the post-war leader of the dynasty. In the final days of the colonial period the Dutch gave him a crash course in 'government practice', in order to appoint him punggawa of the Mengwi district. But the Japanese occupation got in the way. In 1945 he was at last installed in this position and was told to keep revolutionary guerrillas out of his district. He was hardly successful in this. Puri Mengwi was more like a beleaguered citadel; those working for the Dutch sneaked in under cover of darkness, afraid that the guerrillas would take them from their beds. In 1950, as soon as the Dutch were gone, Cokorda Gede Oka quit his job as punggawa. After a couple of small business adventures he remained without an occupation, as his father had before him. But he continued to enjoy prestige, because memories of the old dynasty are still vivid in Mengwi. The camat (district head) of Mengwi, for instance, whose office was adjacent to the puri, admitted in 1983 that he achieved but little if the Cokorda refused to cooperate.

The authority of Cokorda Gede Oka is closely linked to the central temple Taman Ayun, which has been restored to its former glory and constitutes one of the few tourist attractions in the Mengwi region. The Cokorda started restoration of the temple even while the revolution was going on. Progress was halted a number of times, but the work was done by 1972 . The completion of this undertaking, he said, meant that he had fulfilled his duty as dynastic leader. During the odalan of the temple, it is not only families from the immediate surroundings who come to pay their respects, but countless people from farther away. On these days lengthy processions - mostly women - carrying luxurious gifts on their heads and lorries filled with pilgrims trek to pura Taman Ayun and keep alive memories of the past.

The two post-war decades were a very turbulent period in Bali's history. The central state had lost its power monopoly, so that relatively autonomous power concentrations were able to arise at the regional and local levels. At the same time nation-wide political parties entered the regional arenas and national party conflicts mixed with local feuds. The village was no

8 One example is Gusti Agung Gede Putra from puri Lambing, who in 1985 became a director general in the Ministry of Religion. Earlier, during the late 1950s, Gusti Gede Raka - the man who had argued for self-rule by Gusti Putu Mayun - was Minister of Agriculture.

9 Tourism, too, brought little profit to members of the Mengwi dynasty, in contrast to the dynasties of Badung and Gianyar, because the most important tourist centres are outside of the Mengwi region. 
longer an administrative unit in the state, but became an arena for competing factions at the local and regional levels. ${ }^{10} \mathrm{~A}$ variety of conflicts finally culminated in horrible bloodshed, lasting from the end of 1965 to the beginning of 1966; death toll among the Balinese ran to tens of thousands. In nearly every village in the Mengwi region people were murdered or disappeared, and houses were set ablaze and razed to the ground. In this period the members of the Mengwi dynasty played no prominent role in Balinese politics. Because the majority had sided with the PNI, the massacre of 196566 claimed few victims among the old royal clan. Puri Abiansemal was one exception. Its leader was an active adherent of the PKI, and during the murder raids he disappeared and his puri was burnt to ashes.

Since 1966 Bali has again been experiencing a period of peace and order. Party politics has been abolished and the island is once more part of a strongly organized, authoritarian state. ${ }^{11}$ Back in the 1950 s a great many people were actively engaged in a genealogical search for their ancestors and the temple where those ancestors should be worshipped. After 1966 this reorientation to the kawitan took on more earnest proportions. According to many informants, people had become disoriented in the years preceding 1966, and the search for ancestral roots provided a way to determine one's identity. In contrast to the colonial period, almost every Balinese family can now currently name his ancestor quite readily and indicate the temple where this person is worshipped (Schulte Nordholt 1988b)

Among the successors of the Mengwi dynasty, too, there were those who went in search of their ancestral shrine. After the great conflict between puri Mayun and puri Gede in the 1930s, the dynasty divided into factions and no longer met as a whole. It was feared that, if this condition were to continue, the dynasty would lose its identity altogether. Finally, in 1983, a great reunion took place. During the consecration of the newly restored Pura Sada in Kapal, representatives of all branches gathered about the shrine of the first king of Mengwi. Shortly prior to this, one of the dynasty's members had gone into a trance at the shrine in Pura Sada, and the ancestor had spoken through him the liberating words 'It is I'. Around this kawitan they found confirmation of their identity. Orienting themselves to the past once more, they were able to face the future.

10 On political developments during this period see Robinson 1992; Bagus 1991; Lane 1972; Vickers 1989:161-73.

11 For developments during the New Order on Bali see Vickers 1989:175-213. Carol Warren (1990) brilliantly describes political developments at village level. See Schulte Nordholt 1991a for an analysis of government policy regarding village rule, adat, and great public purification rituals. 

Genealogy of the Mengwi dynasty 

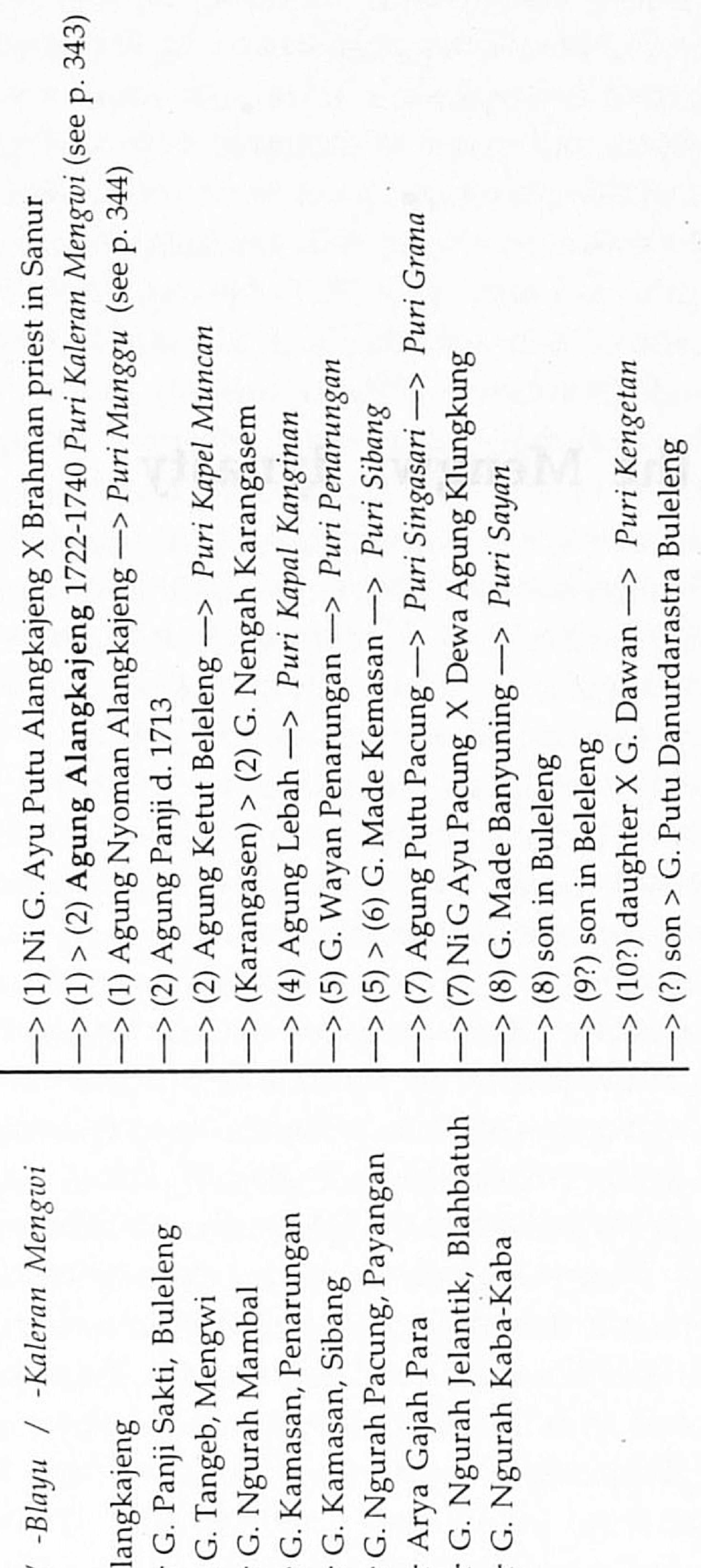

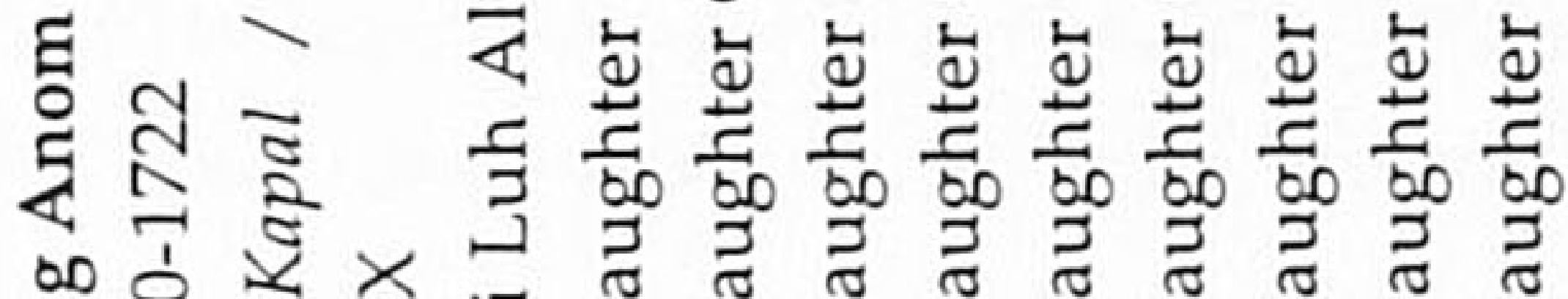

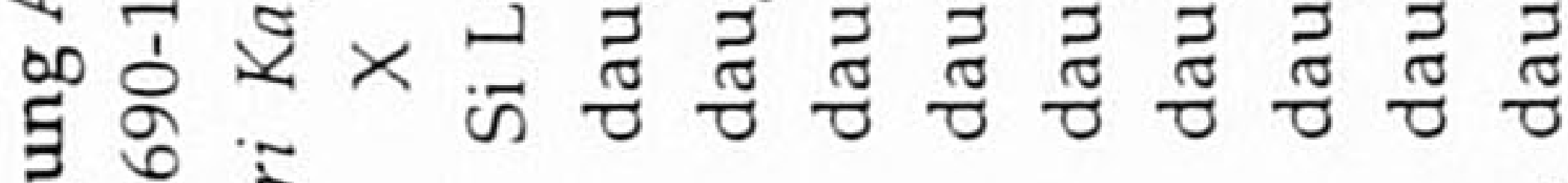

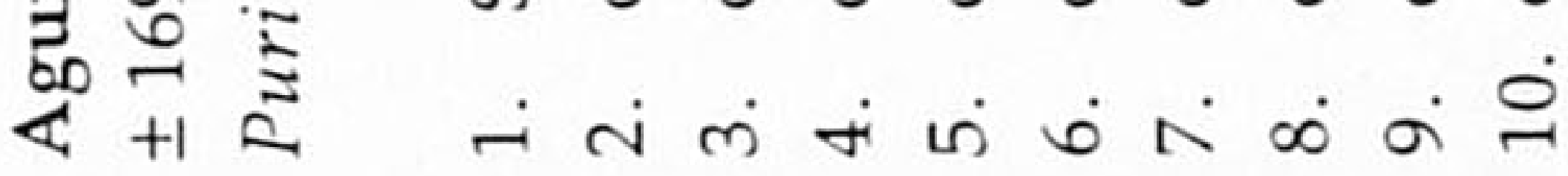




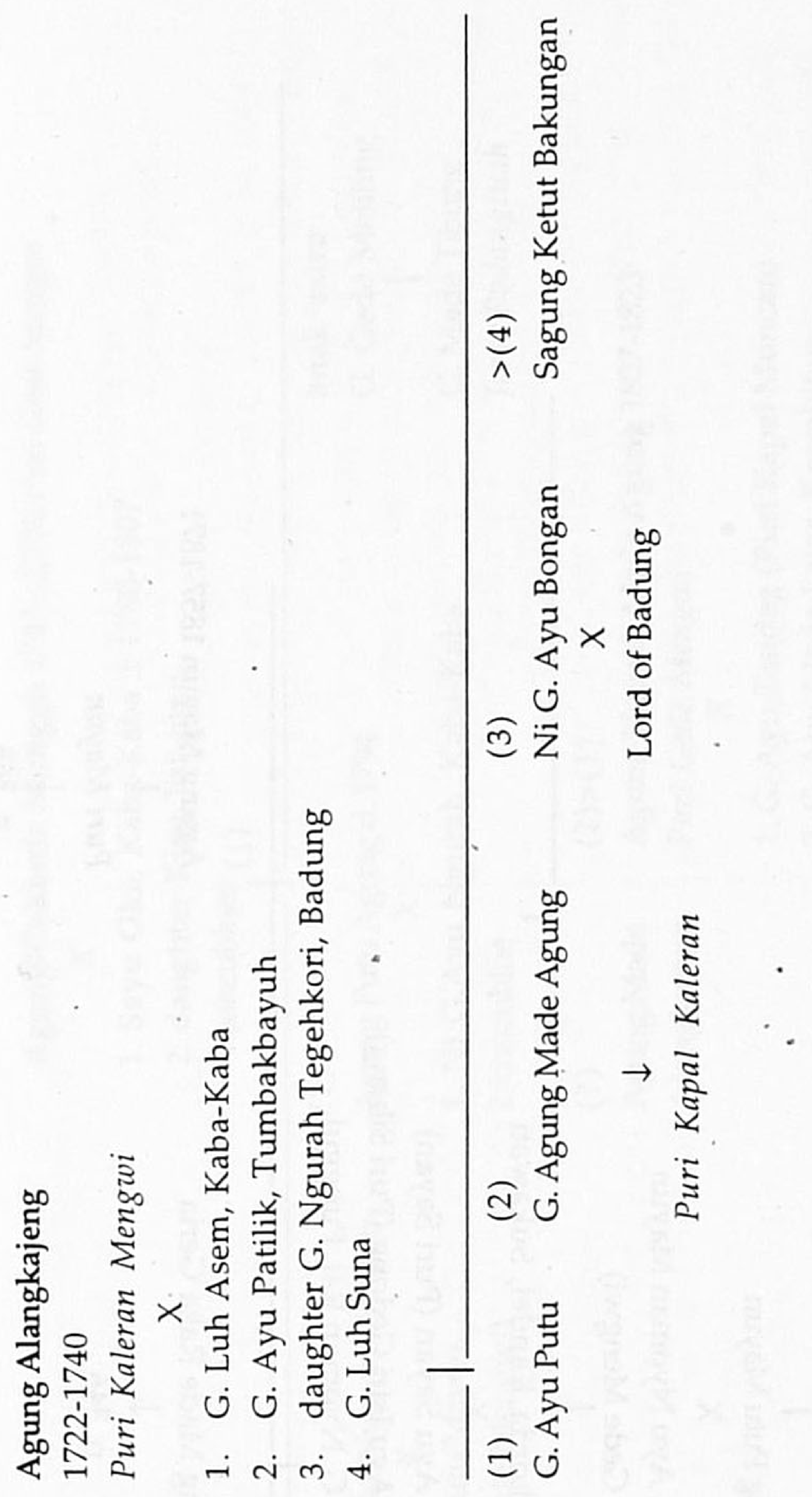




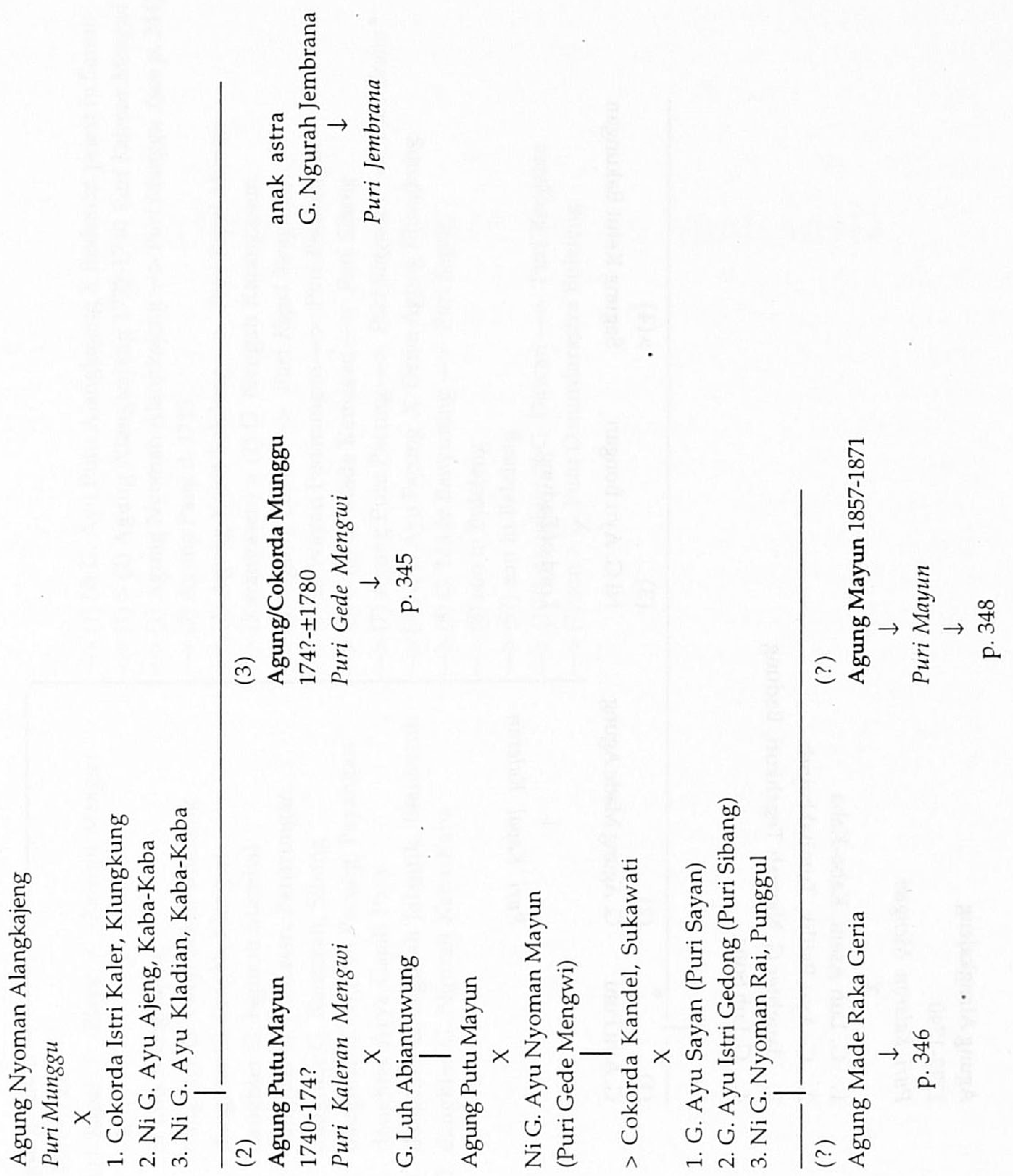




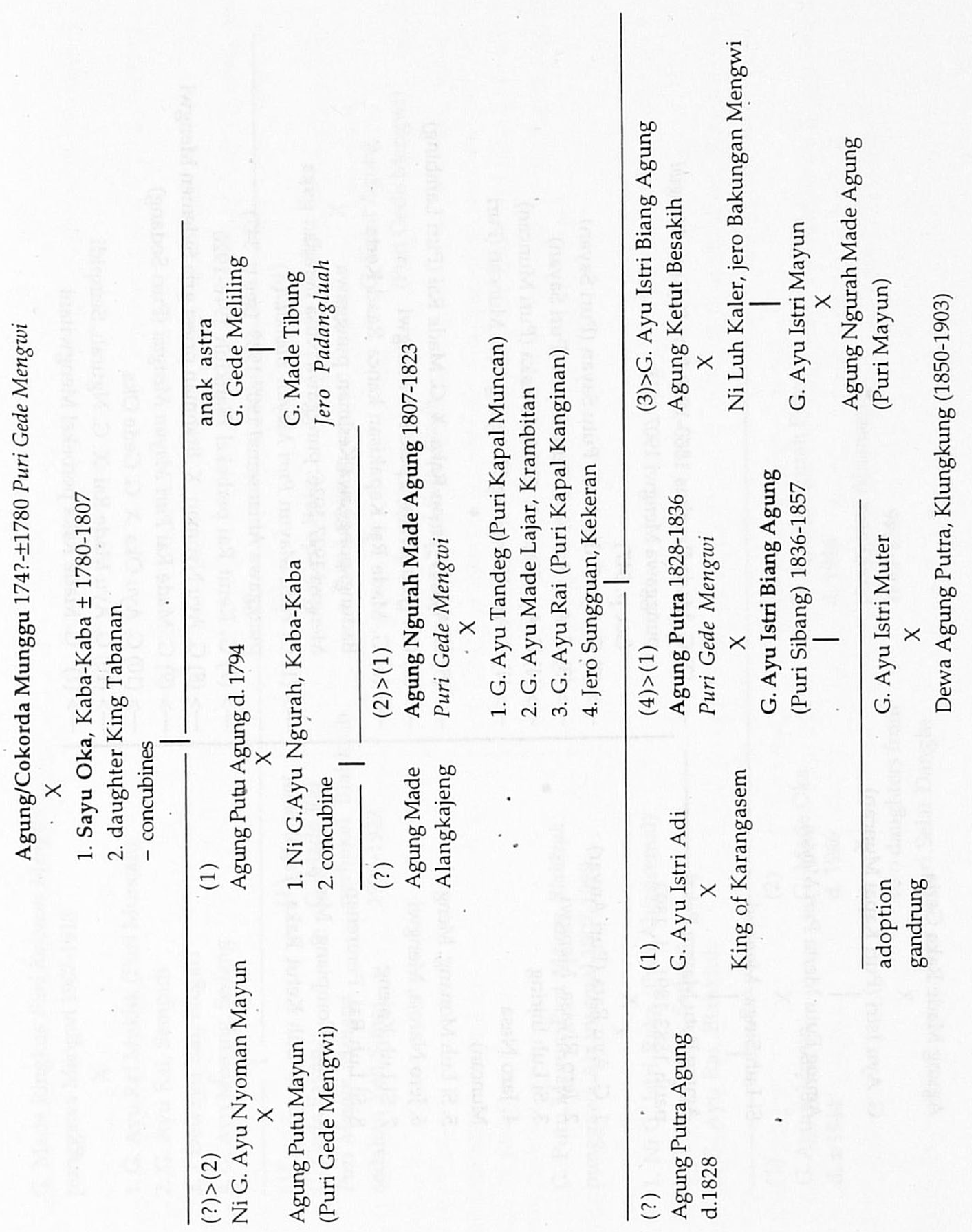




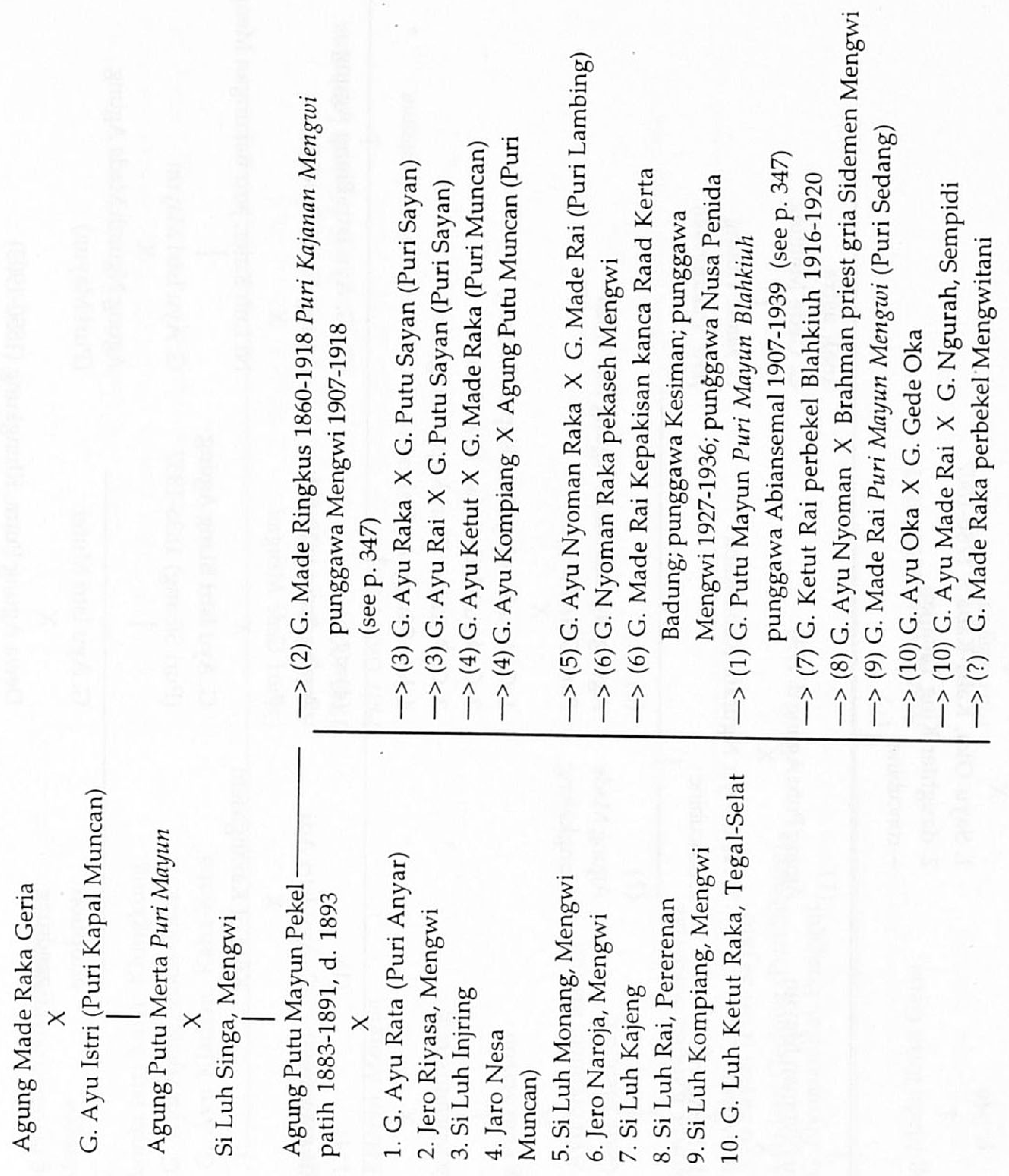




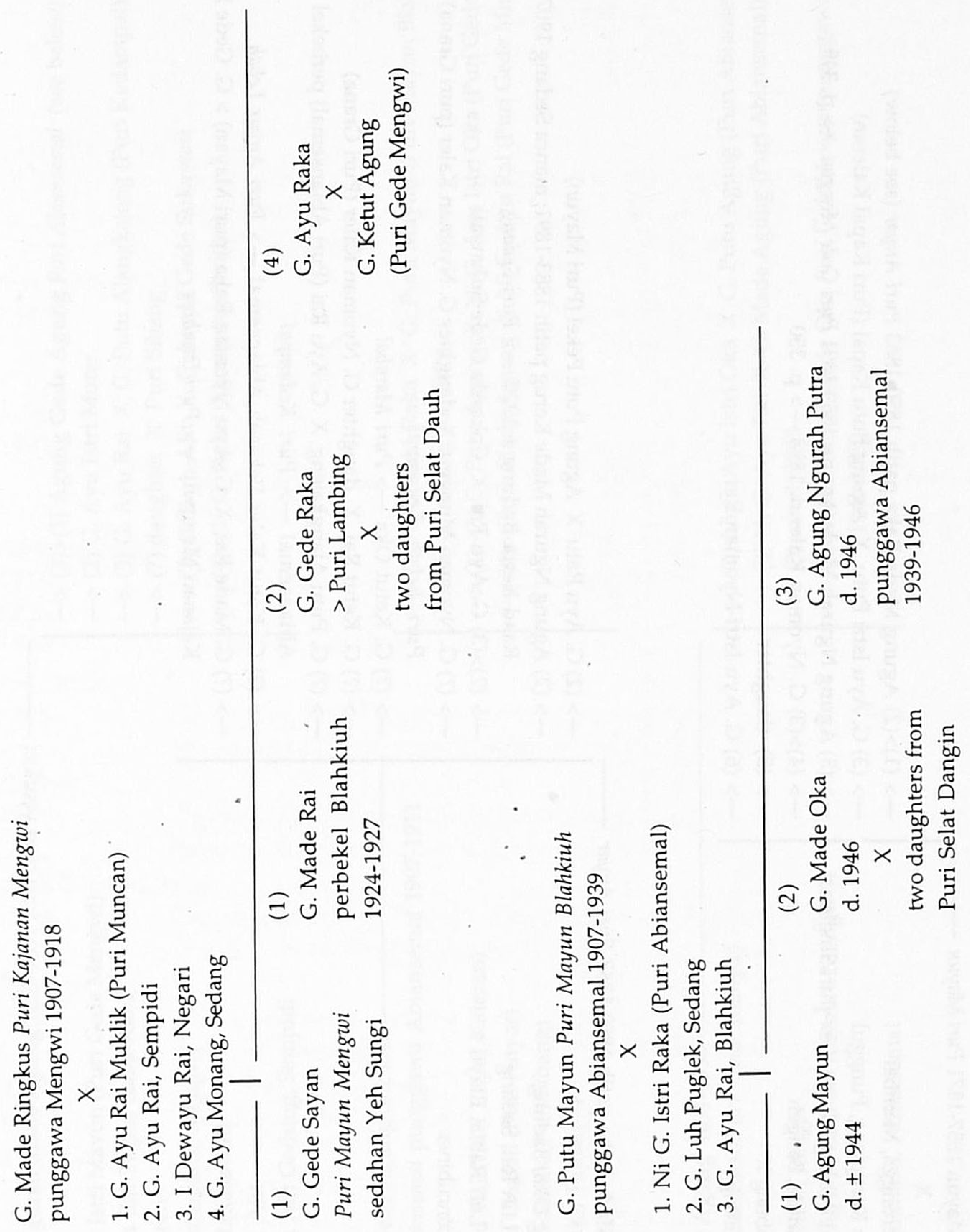




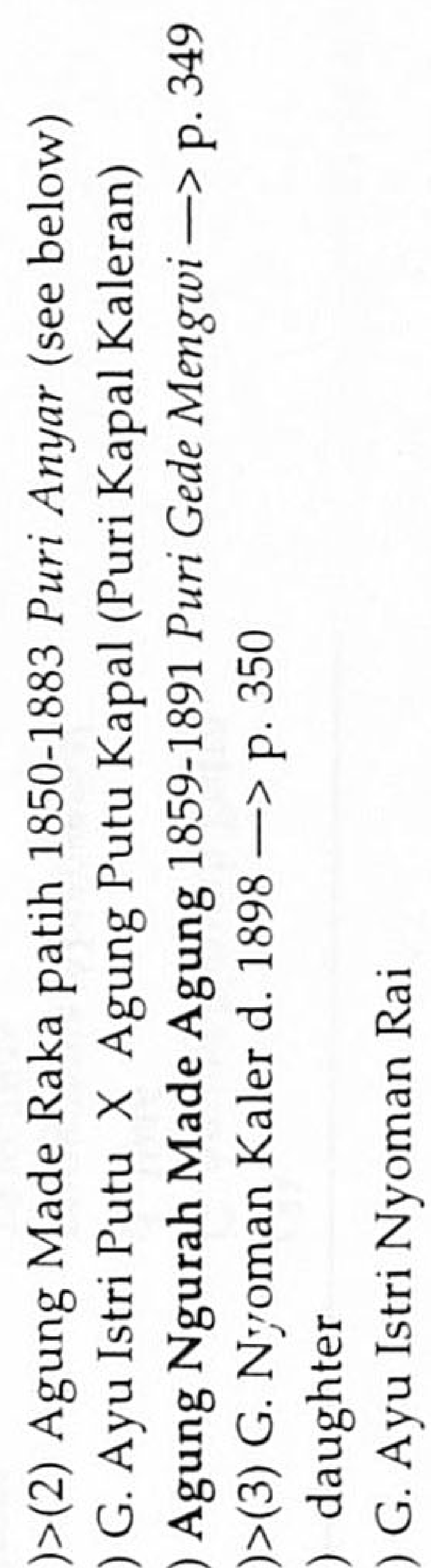

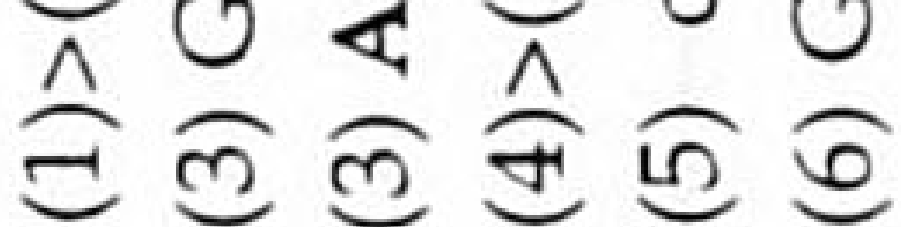

离

宁

5

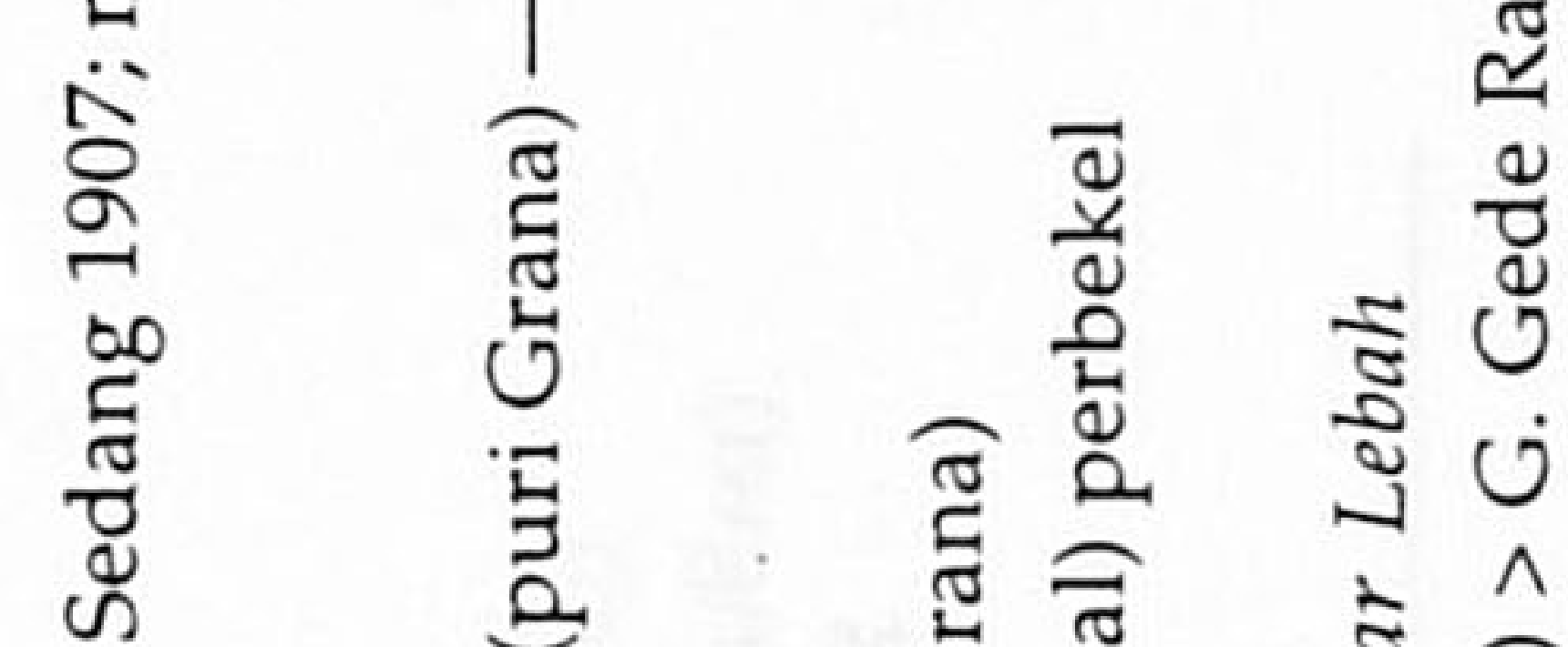

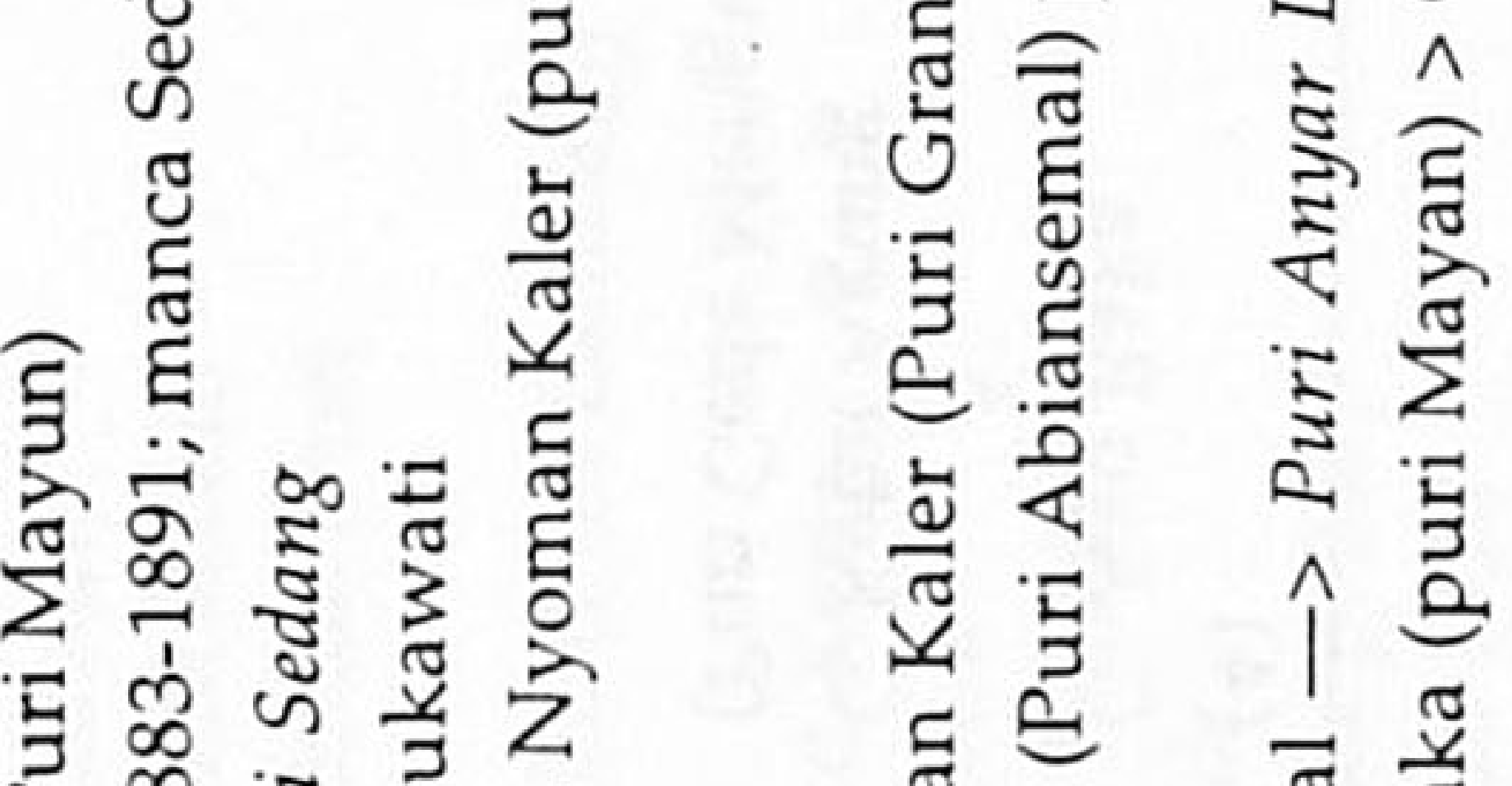

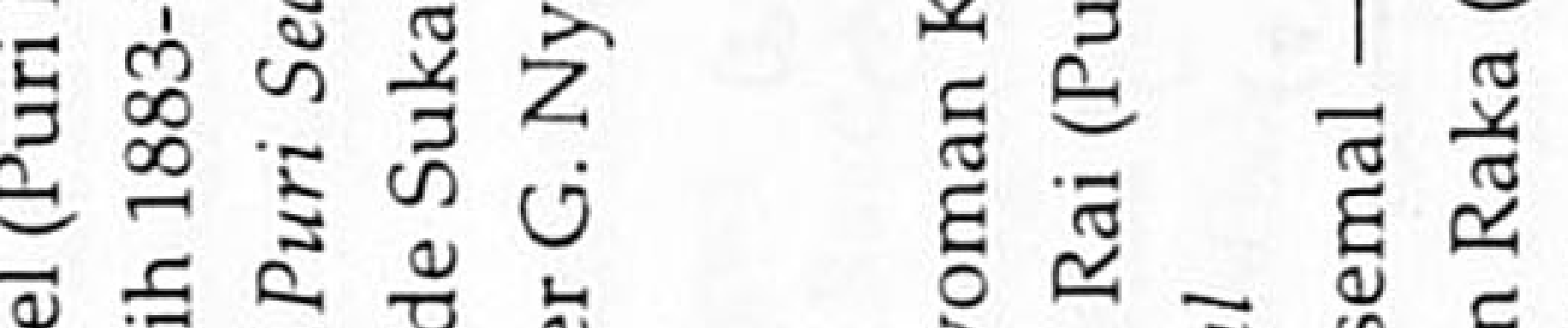

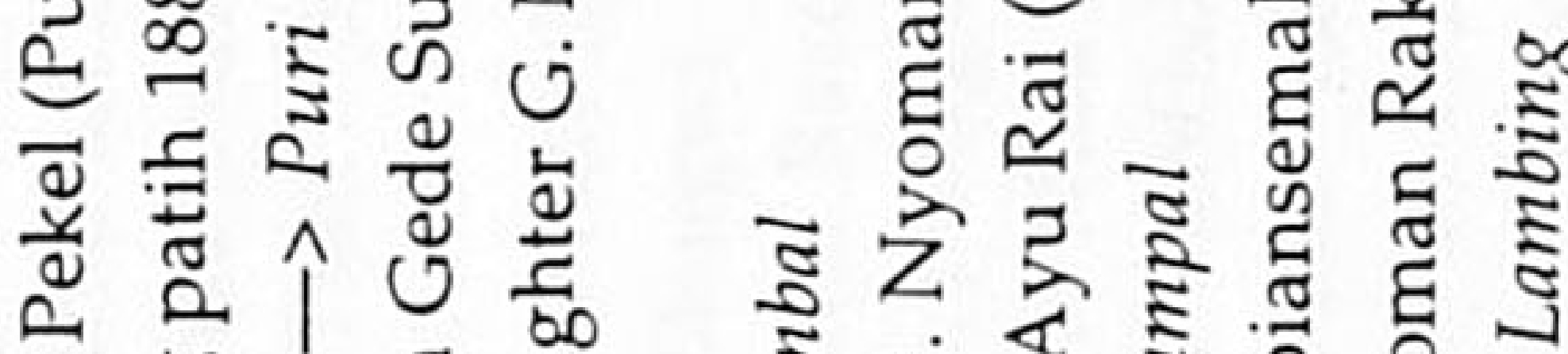

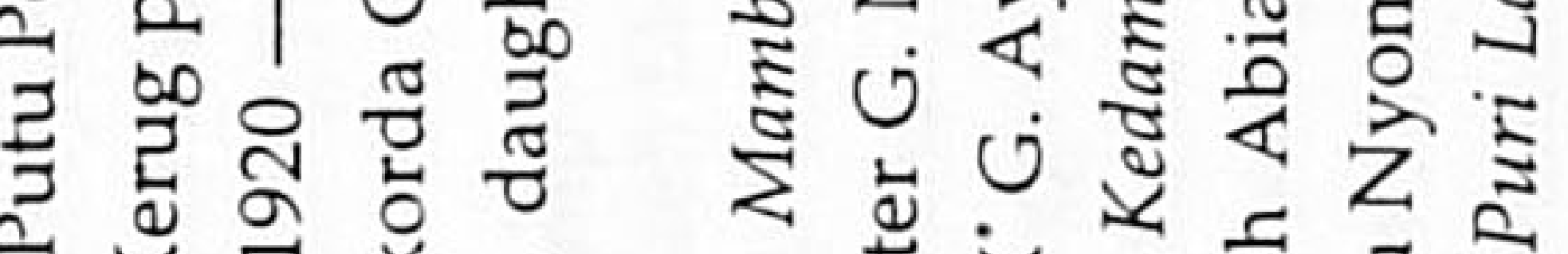
$\infty \begin{aligned} & 1 \\ & 0\end{aligned}$

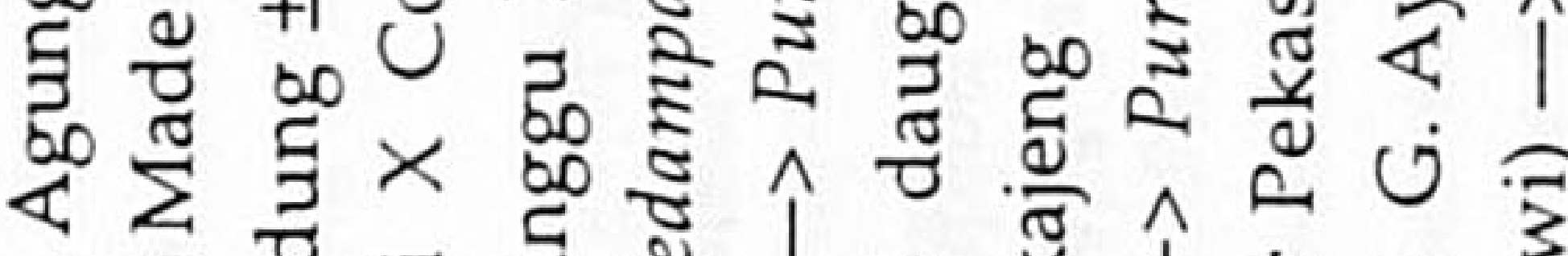

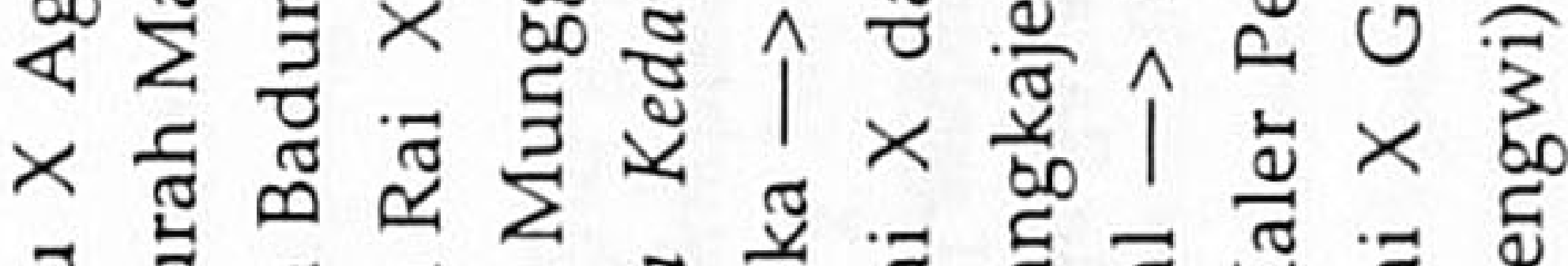

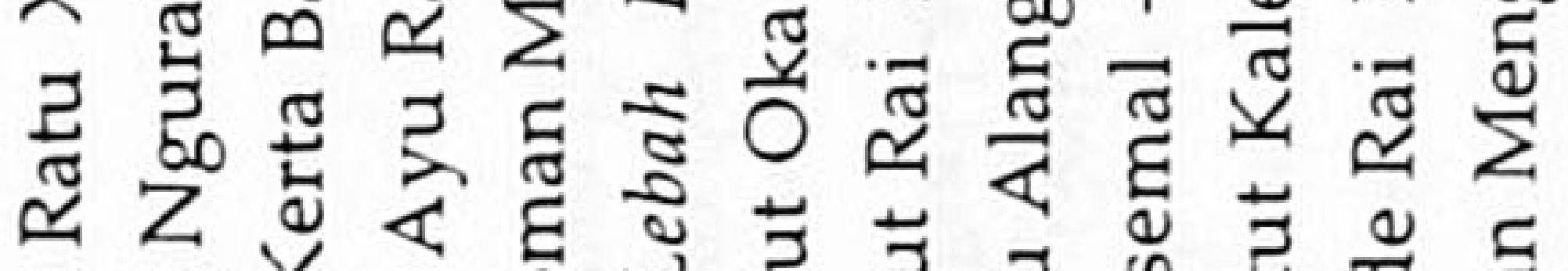

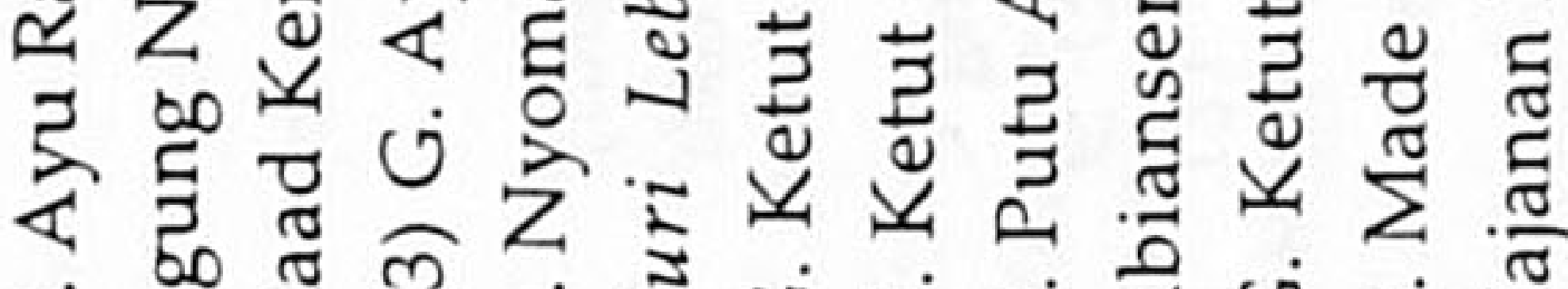

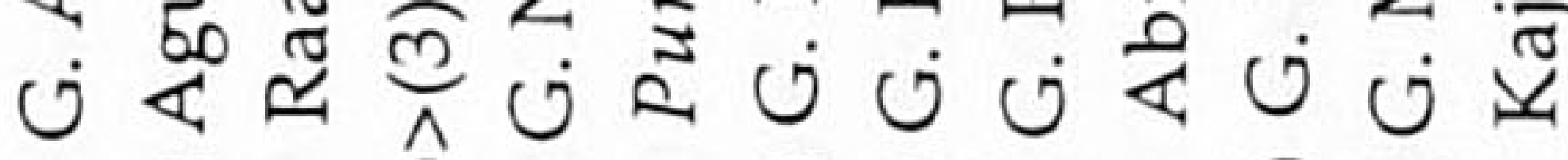

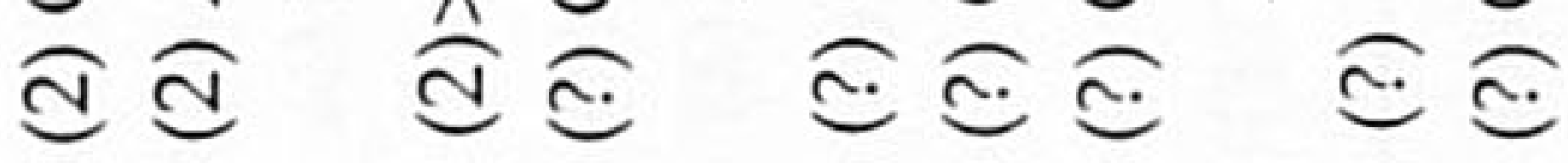
$\hat{\imath} \hat{\imath} \hat{\imath} \hat{\imath} \quad \hat{\imath} \hat{\imath} \hat{\imath} \quad \hat{\imath} \hat{\imath}$ $\hat{\imath} \hat{\imath} \hat{\imath} \hat{\imath} \hat{\imath} \hat{\imath}$

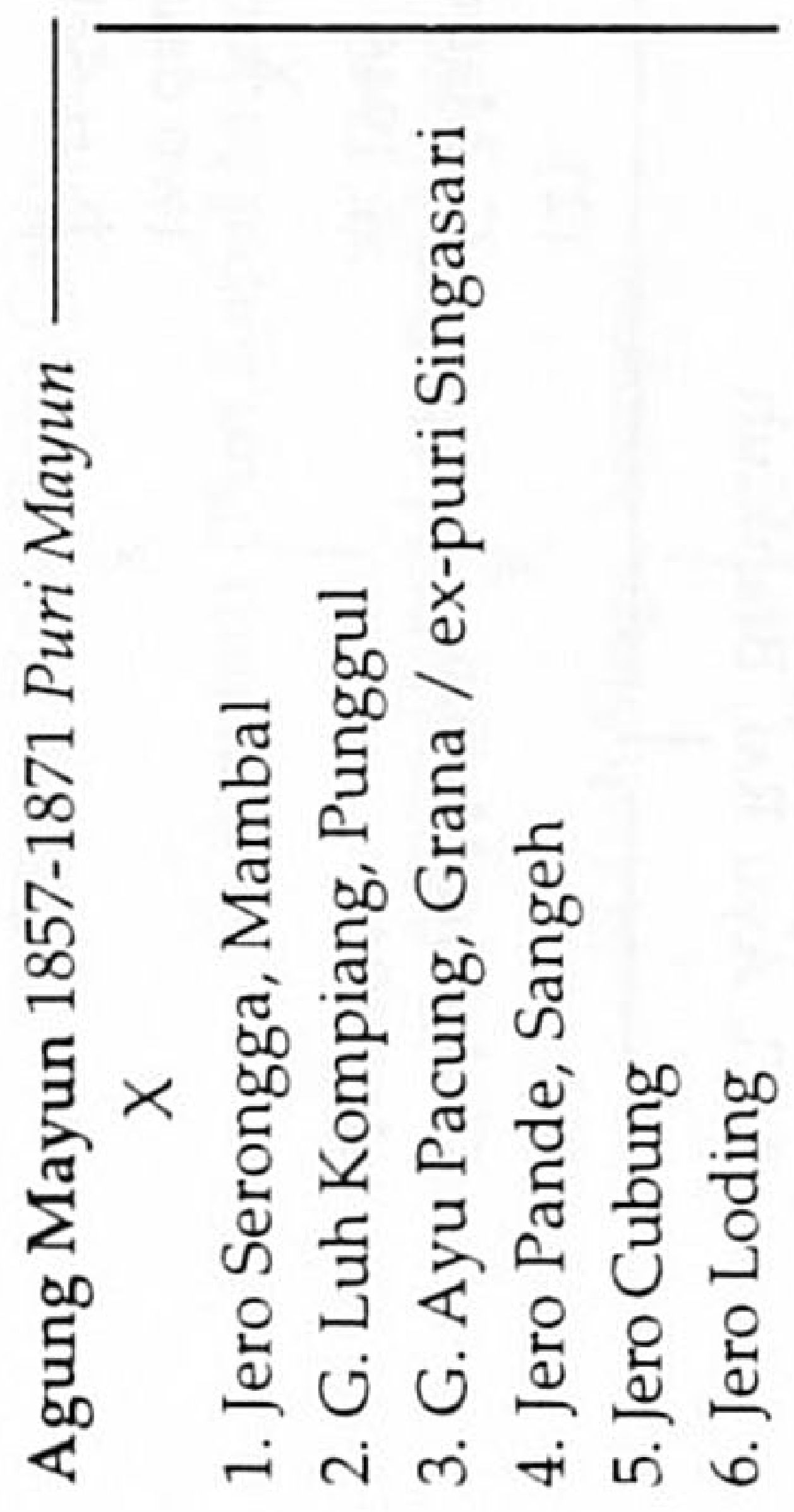

$\stackrel{3}{3}$

ב

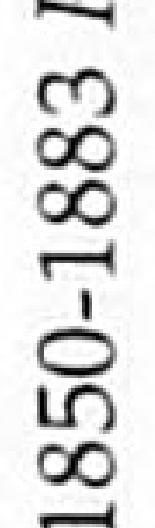

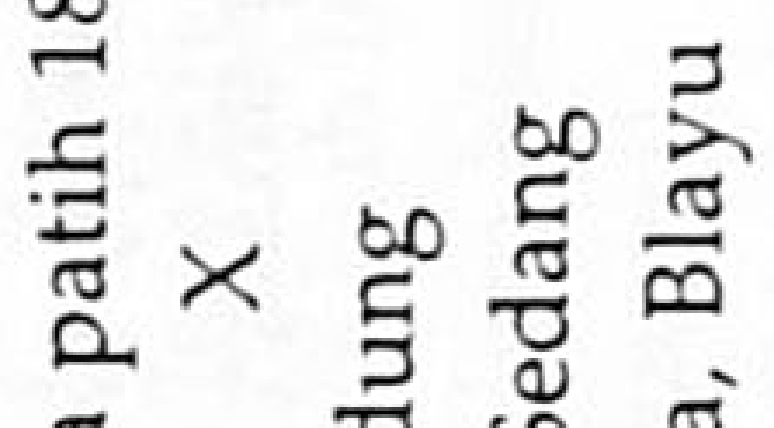

范

$\sum^{\pi} \quad 000$

$\sum_{\infty} \cong \dot{v}$

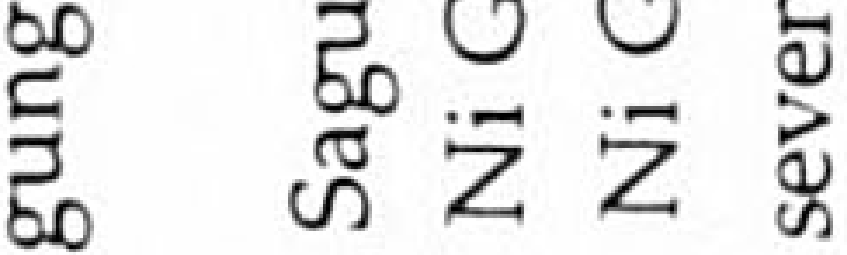



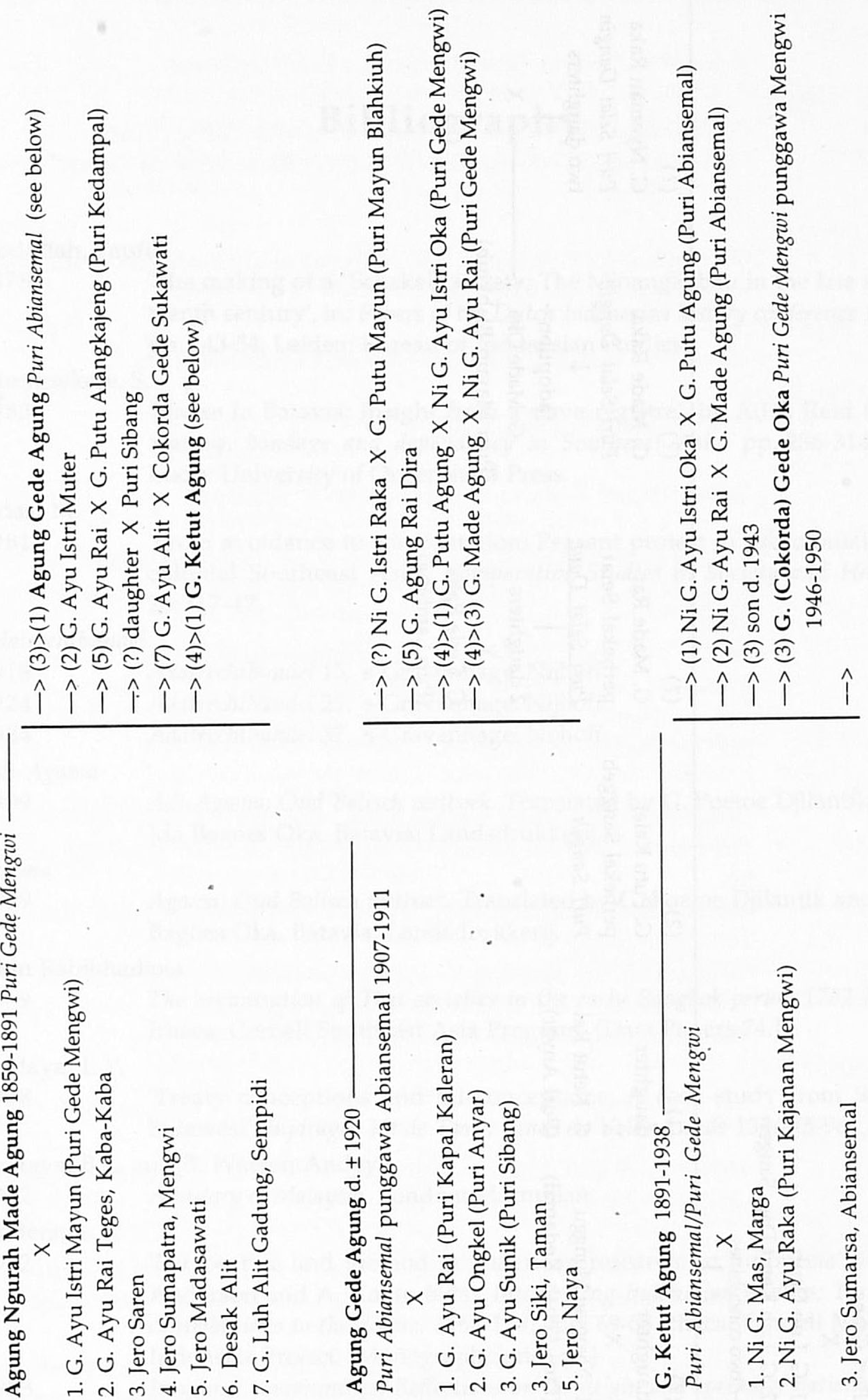


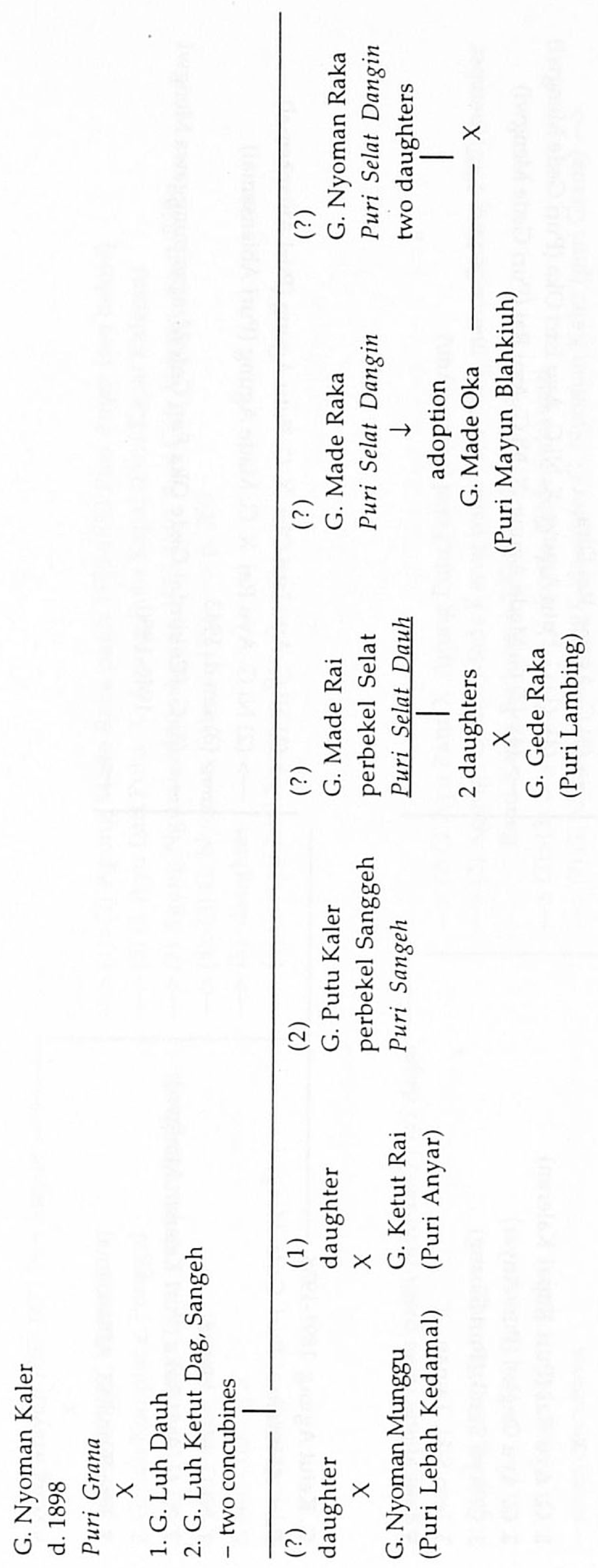




\section{Bibliography}

Abdullah, Taufik

1978

'The making of a "Schakel" society; The Minangkabau in the late nineteenth century', in: Papers of the Dutch Indonesian history conference 1976, pp. 143-54. Leiden: Bureau of Indonesian Studies.

Abeyasekere, S.

1983

'Slaves in Batavia; Insight from a slave registre', in: A.J.S. Reid (ed.), Slavery, bondage and dependency in Southeast Asia, pp. 286-314. St. Lucia: University of Queensland Press.

Adas, M.

1981

'From avoidance to confrontation; Peasant protest in precolonial and colonial Southeast Asia', Comparative Studies in Society and History 23:217-47.

Adatrechtbundel

1918

Adatrechtbundel 15. 's-Gravenhage: Nijhoff.

1924

- Adatrechtbundel 23. 's-Gravenhage: Nijhoff.

1934

Adatrechtbundel 37. 's-Gravenhage: Nijhoff.

Adi-Agama

1909 Adi-Agama; Oud Balisch wetboek. Translated by G. Poetoe Djilantik and Ida Bagoes Oka. Batavia: Landsdrukkerij.

Agama

1909

Agama; Oud Balisch wetboek. Translated by G. Poetoe Djilantik and Ida Bagoes Oka. Batavia: Landsdrukkerij.

Akin Rabibhadana

1969 The organisation of Thai societies in the early Bangkok period 1782-1873.

Ithaca: Cornell Southeast Asia Program. [Data Papers 74.]

Andaya, L.Y.

1978

'Treaty conceptions and misconceptions; A case study from South Sulawesi', Bijdragen tot de Taal-, Land-en Volkenkunde 134:275-96.

Andaya, B.L. and B. Watson Andaya

1982

A history of Malaysia. London: Macmillan.

Anderson, B.

1982

'Perspective and method in American research on Indonesia', in: B. Anderson and A. Kahin (eds), Interpreting Indonesian politics; Thirteen contributions to the debate, 1964-1981, pp. 69-83 Ithaca: Cornell Modern Indonesia Project. [Monograph Series 62.] Imagined communities; Reflections on the origin and spread of nationalism. London: Verso. 
Anderson, P.

1974 Lineages of the absolutist state. London: New Left Books.

Arifin, W.

1980 Babad Wilis. Jakarta: École Française d'Extrême Orient.

Asad, T. (ed.)

1973

1983

Anthropology and the western encounter. London: Ithaca Press.

'Anthropological conceptions of religion; Reflections on Geertz', MAN n.s. 18:237-57.

Baal, J. van

1981

Man's quest for partnership; The anthropological foundations of ethics and religion. Assen: Van Gorcum.

Babad Arya Tabanan

1974 Babad Arya Tabanan. Denpasar: Parisada Hindu Dharma.

Babad Bali Radiya

1957

Babad Bali Radiya. Klungkung.

Babad Mengwi

1974 Babad Mengwi. Denpasar: Parisada Hindu Dharma.

Bagus, I. G. Ngurah

1970 'Pertentangan kasta dalam bentuk baru pada masjarakat Bali', in: Liber Amicorum E.M.A.A.J. Allard, pp. 33-47. Nijmegen: Katholieke Universiteit.

1991 'Bali in the 1950s; The role of the pemuda pejuang in Balinese political processes', in: H. Geertz (ed.), State and society in Bali; Historical, textual and anthropological approaches, pp. 199-212. Leiden: KITLV Press. [KITLV, Verhandelingen 146.]

Bakker, J.B.

1936

$1937 a$

$1937 b$

$1937 \mathrm{c}$

$1937 d$

Bali Post

1983

Bassett, D.K.

1964

Bateson, G.

1970

Baum, V.

1949
'Structuur en bevolking van Zuid-Bali', Koloniaal Tijdschrift 25:595-602.

'Belastingheffing van gronden in Zuid-Bali', Koloniaal Tijdschrift 26:17784.

'Goederenbalans en belastingdruk van de afdeeling Zuid-Bali', Koloniaal Tijdschrift 26:287-94.

Landbouw in de afdeeling Zuid-Bali, Koloniaal Tijdschrift 26:63-73.

'Uitkomsten van een plaatselijk onderzoek gehouden in eenige dessa's van Zuid-Bali', Koloniaal Tijdschrift 26:529-48.

Bali Post. Denpasar.

'British trade and policy in Indonesia 1760-1772', Bijdragen tot de Taal-, Land-en Volkenkunde 120:197-223.

'Bali; The value system of a steady state', in: J. Belo (ed.), Traditional Balinese culture, pp. 384-401. New York: Columbia University Press.

Liefde en dood op Bali. Second edition. Utrecht: De Haan. [First edition 1937; Translation of Liebe and Tod auf Bali. Amsterdam: Querido, 1937.] 
Beeckman, D

1718

A voyage to and from the island of Borneo, in the East Indies. London: Warner and Batley.

Belo, J.

1970a

$1970 b$

(ed.) Traditional Balinese culture. New York: Columbia University Press. 'A study of customs pertaining to twins in Bali', in: J. Belo (ed.), Traditional Balinese culture, pp. 3-56. New York: Columbia University Press.

Benda, H.J.

1958

The crescent and the rising sun; Indonesian Islam under the Japanese occupation. The Hague/Bandung: Van Hoeve.

Bendix, R.

1962

Max Weber; An intellectual portrait. New York: Anchor Books.

Bentley, G.C.

1986

'Indigenous states of Southeast Asia', Annual Review of Anthropology 15:275-305.

Berg, C.C.

1927

1932

De middeljavaanse historische traditie. Santpoort: Mees.

1938 'Javaansche geschiedschrijving', in: F.W. Stapel (ed.), Geschiedenis van

Babad Bla-batuh; De geschiedenis van een tak der familie Jelantik. Santpoort: Mees. Nederlandsch-Indië, vol. 2, pp. 5-148. Amsterdam: Joost van den Vondel.

Bloch, $\mathrm{M}$.

1964 Feudal society. Chicago: University of Chicago Press. 2 vols. [Translation of La société féodale. Paris: Albin Michel, 1940.]

Bloemen Waanders, P.L. van

1856 'Aanteekeningen omtrent Bali', Tijdschrift voor Indische Taal-, Land- en Volkenkunde (TBG) 5:431-47.

1858 . 'Aanteekeningen omtrent Bali', Tijdschrift voor Indische Taal-, Land- en Volkenkunde (TBG) 7:73-7.

1859 'Aanteekeningen omtrent de zeden en gebruiken der Balinezen inzonderheid die van Boeleleng', Tijdschrift voor Indische Taal-, Land-en Volkenkunde (TBG) 8:105-279.

1868 'Bijdrage tot de kennis van het eiland Bali', Tijdschrift van NederlandschIndië 3e serie, 2-1:367-410.

1870 'Dagverhaal eener reis over Bali in Juni en Juli 1856', Tijdschrift van Nederlandsch-Indië 3e serie, 4-1:415-41, 2:12-38.

Blok, A.

1977

Blom, G.

1841

'Clio en de antropoloog', in: L. Brunt (ed.), Anders bekeken; Wet en werkelijkheid in sociaal onderzoek, pp. 65-89. Meppel/Amsterdam: Boom.

Lotgevallen op mijne reis naar Java; Het verongelukken van het fregatschip Overijssel, nabij het eiland Baliy, en de terugreis naar Nederland met het fregatschip Johanna Catharina.. N.p.: n.n. 
Boon, J.A.

1977

The anthropological romance of Bali 1597-1972Dynamic perspectives in marriage and caste, politics and religion. Cambridge: Cambridge University Press.

Bosch, F.D.K.

1932

'Een ontoelaatbaar experiment', Djawa 12:258-9.

1942

' "Local genius" en Oud-Javaanse kunst', Mededelingen Koninklijke Nederlandse Akademie van Wetenschappen, afdeling Letteren, Nieuwe Reeks 15:1-25.

1960 The golden gem; An introduction to Indian symbolism. The Hague: Mouton.

Breman, J.C. 1980

The village on Java and the early colonial state. Rotterdam: Erasmus University. [Comparative Asian Studies Programme 1.]

Brinkgreve, $\mathrm{F}$. 1981

'Maligia; Zuiveringsceremonie op Bali', Verre Naasten Naderbij 15-2:2941.

Broek, H.A. van den

'Verslag nopens het eiland Bali; De vorsten, hunne geaardheid en betrekkingen, den handel, de culture, de bevolking, hare zenden en gewoonten, godsdiensten en andere bijzonderheden', De Oosterling $1: 158-236$.

Brown, C.

1987

'The influenza pandemic of 1918', in: N. Owen (ed.), Death and disease in Southeast Asia; Explorations in social, medical and demographic history, pp. 235-56. Singapore: Oxford University Press.

Bruyn Kops, G.F. de

1915 'Het evolutietijdperk op Bali 1906-1909', Koloniaal Tijdschrift 4-1:45979.

Bijl de Vroe, C.

1980 Onder de Buitenzorgse troon; Indisch dagboek 1914-1919. Haarlem:

Fibula-van Dishoeck.

Byvanck, W.G.C.

1894 'Onze betrekkingen met Lombok', De Gids 16:134-57, 229-337.

Candrawati, Idayu

1981 'Pura Langgar dalem, pura penataran agung puri Bunutin Bangli', [Thesis University Udayana, Denpasar.]

Carey, P.

1986

'Waiting for the "Just King"; The agrarian world of South Central Java from Giyanti (1755) to the Java War', Modern Asian Studies 20:59-137.

Ceger, G.Ngurah

1973 'Monografi subak Tinjak Manjakan'. Mengwi (typescript).

Chabot, H.Th.

1950

Verwantschap, stand en sexe in Zuid-Celebes. Groningen/Djakarta: Wolters-Noordhoff. 
Coedès, G.

1968

The indianized states of Southeast Asia. Honolulu: East-West Center Press.

Cohen, A.

1969

1974

'Political anthropology; The analysis of the symbolism of power relations', MAN n.s. 4:215-35.

symbolism in complex society. Berkeley: University of California Press.

1979 'Political symbolism', Annual Review of Anthropology 8:87-113.

Cohn, B.S.

1980

'History and anthropology; The state of play', Comparative Studies in Society and History 22:198-221.

1987 'Notes on the history of the study of Indian society', in: B.S. Cohn, An anthropologist among the historians and other essays, pp. 136-71. Delhi: Oxford University Press.

Cool, W.

1896

De Lombok expeditie. Batavia: Kolff.

Covarrubias, $\mathrm{M}$.

1973

Island of Bali. New York: Knopf. [First edition 1937.]

Craandijk, $\mathrm{H}$.

1906

'Bali en imperialisme', Indische Gids 28-1:829-49.

Crawfurd, J.

1820

'On the existence of the Hindu religion in the island of Bali', Asiatick 'Researches 13:128-170.

Creese, $\mathrm{H}$.

1991

'Balinese babad as historical sources; A reinterpretation of the fall of Gelgel', Bijdragen tot de Taal-, Land-en Volkenkunde 147:236-60.

Daghregister

1887-1931

Daghregister gehouden int casteel Batavia 1624-1682. Edited by J.A. van der Chijs et al. Batavia: Kolff, 's-Gravenhage: Nijhoff. 31 vols.

Damsté, H.T.

1922

De toekomst van het Binnenlandsch Bestuur. Buitenzorg: Vereeniging van Ambtenaren bij het Binnenlandsch Bestuur in Nederlandsch-Indië.

1923

1925

'Balische bestuursproblemen', Indisch Genootschap 1923:111-41.

'Het Petjatoe- en ambtsvelden probleem', Koloniaal Tijdschrift 14:44867.

Darnton, R.

1990

De kus van Lamourette; Bespiegelingen over mentaliteitsgeschiedenis.

Amsterdam: Bakker. [Translation of The kiss of Lamourette, New York: Norton.]

Djelantik, G. Putu

$1980 \quad$ 'Catatan harian perang Badung 1906'. Singaraja (typescript).

Dove, M.

1985

'The agroecological mythology of the Javanese and the political economy of Indonesia', Indonesia 39:1-36. 
Dumont, L.

1957

1970

'For a sociology of India', Contributions to Indian Sociology 1:7-22.

' "The village community" from Munro to Maine', in: L. Dumont, Religion, politics and history in India, pp. 112-32. Paris/The Hague: Mouton.

Earl, G.W. 1850

'The trading ports of the Indian archipelago', Journal of the Indian Archipelago and Eastern Seas 4:369-99, 534-45.

Eck, R. van

$1878-80$

'Schetsen van het eiland Bali', Tijdschrift van Nederlandsch-Indië nieuwe serie 7-2, 7:85-130, 165-213, 325-56, 405-30; 8-1:36-60, 104-34, 286$305,365-87 ; 9-1: 1-39,102-32,195-221,401-29 ; 2: 1-18,81-96$.

Eerde, J.C. van

1921

'Dewa Manggis V van Gianyar', Onze Eeuw 21-1:31-56.

Elson, R.

1978 The Culture System and 'agricultural involution'. Clayton: Monash University, Centre for Southeast Asian Studies. [Working Paper 14.]

Errington, S.

1983 'The place of regalia in Luwu', in: L. Gesick (ed.), Centers, symbols, and hierarchies; Essays on the classical states of Southeast Asia, pp. 194-241. New Haven: Yale University, Southeast Asia Studies. [Monograph Series 26.]

Fabian, J.

1983 Time and the other; How anthropology makes its object. New York: Columbia University Press.

Fasseur, C.

1979

'Een koloniale paradox; De Nederlandse expansie in de Indonesische archipel in het midden van de 19e eeuw, 1830-70', Tijdschrift voor Geschiedenis 92:162-86.

Fischer, $\mathrm{H}$.

1907

'Brieven uit Bali', Berichten uit Nederlandsch Oost-Indië voor de leden van den Sint-Claverbond 19:1-39.

Flierhaar, H. te

1941

'Aanpassing van het inlandsch onderwijs op Bali aan de eigen sfeer', Koloniale Studiën 25:135-59.

Fox, J.J.

1980

(ed.) The flow of life; Essays on Eastern Indonesia. Cambridge, Mașs.: Harvard University Press.

1988 Origin, descent and precedence in the study of Austronesian societies. Leiden: Leiden University. [Public Lecture on Indonesian Studies.]

Fraser, J.J.

$1910 \quad$ 'De inheemsche rechtspraak op Bali', Indische Gids 32:865-910.

Friederich, R.H.Th.

1849-50 'Voorlopig verslag van het eiland Bali', Verhandelingen van het Bataviaasch Genootschap voor Kunsten en Wetenschappen 22:1-63, 23:1-57. 
Geertz, C.

$1973 a$

'Religion as a cultural system', in: C. Geertz, The interpretation of cultures, pp. 87-125. New York: Basic Books.

1973b 'Thick description; Toward an interpretive theory of culture', in: C. Geertz, The interpretation of cultures, pp. 3-30. New York: Basic Books.

1980 Negara; The theatre state in nineteenth century Bali. Princeton: Princeton University Press.

Geertz, H. (ed.)

1991 State and society in Bali; Historical, textual and anthropological approaches.

Leiden: KITLV Press. [KITLV, Verhandelingen 146.]

Geertz, H. and C. Geertz

1975 Kinship in Bali. Chicago: University of Chicago Press.

Gegevens

1906 Gegevens betreffende de zelfstandige rijkjes op Bali. Batavia: Landsdrukkerij.

Generale missiven

1960-79

Generale missiven van Gouverneurs Generaal en Raden aan Heren XVII der VOC, vol. I-VII (1610-1725), Edited by W.P. Coolhaas. 's-Gravenhage: Nijhoff.

Gerdin, I.

1981

'The Balinese sidikara; Ancestors, kinship and rank', Bijdragen tot de Taal-, Land-en Volkenkunde 137:17-34.

Gesick, L. (ed.)

1983 Centers, symbols, and hierarchies; Essays on the classical states of Southeast Asia. New Haven: Yale University, Southeast Asia Studies. [Monograph Series 26.]

Geuns, M. van

1906 Door Badoeng en Tabanan. Soerabaja. (Offprint Soerabajasch Handelsblad.)

Gonda, J.

1973

Sanskrit in Indonesia. Second edition. New Delhi: International Academy of Indian Culture.

Goor, J. van

1982

'The death of a middleman', in: G.J. Schutte and H.A. Sutherland (eds), Papers of the Dutch-Indonesian historical conference 1980, pp. 223-49. Leiden/Jakarta: Programme of Indonesian Studies.

Goris, R.

1937

'Overzicht van de belangrijkste literatuur betreffende de cultuur van Bali over het tijdvak 1925-1935', Mededelingen Kirtya Liefrinck-Van der Tuuk 5:15-43.

Graaf, H.J. de

1935

1941

1949

De moord op kapitein François Tack, 8 februari 1686. Amsterdam: Paris.

'Lombok in de 17e eeuw', Djawa 21:355-74.

'Gusti Pandji Sakti, vorst van Buleleng', Tijdschrift voor Indische Taal-, Land-en Volkenkunde (TBG) 83:59-82. 
Catalogus van de handschriften in westerse talen van het KITLV. 's-Gravenhage: Nijhoff.

Grader, C.J.

1960a

'The irrigation system in the region of Jembrana', in: J.L. Swellengrebel (ed.), Bali; Studies in life, thought, and ritual, pp. 267-88. The Hague: Van Hoeve.

1960b 'The state temples of Mengwi', in: J.L. Swellengrebel (ed.), Bali; Studies in life, thought, and ritual, pp. 157-86. The Hague: Van Hoeve.

1970 'Ekadacarudra; Het honderd jaarlijks landreinigings-ritueel op Bali', in: Liber amicorum E.M.A.A.J. Allard, pp. 75-104. Nijmegen: Katholieke Universiteit.

n.d. 'Abenan bikul', bijlage 27 beschrijving coll.Korn KITLV (typescript).

Graves. E. and C. Kasetsiri

1967 'A nineteenth century account of Bali', Indonesia 7:77-123.

Groothof, A.

1918 'Studie over het inlandsche waterschapswezen op Bali en Lombok', Adatrechtbundel 15:308-73.

1922 'De organisatie der inlandsche bevloeiingswaterschappen of "soebaks" op Bali en Lombok', Indisch Bouwkundig Tijdschrift 25, 9:167-70.

Guermonprez, J.-F.

1985 'Rois divins et rois guerriers; Image de la royauté à Bali', L'Homme 25, 95:39-70.

1987 Les pandé de Bali; La formation d'une 'caste' et la valeur d'un titre. Paris: École Française d'Extrême-Orient.

1989 'Dual sovereignty in nineteenth century Bali', History and Anthropology 4:189-207.

1990 'On the elusive Balinese village; Hierarchy and values versus political models', Review of Indonesian and Malaysian Affairs 24:55-89.

1991 'How Pedanda and Sengguhu were unduly indianized with considerations on the differentation of priestly roles in Bali'. Paper conference on Artistic Representation in Social Action; The Case of Bali, Princeton.

Guha, R.

1989 'Dominance without hegemony and its historiography', in: R. Guha (ed.), Subaltern studies VI; Writings on South Asian history and society, pp. 210-309. Delhi: Oxford University Press.

Gunning, H.C.J. en A.J. van der Heyden

1926 'Het petjatoe- en ambtsveldenprobleem in Zuid-Bali', Tijdschrift voor Indische Taal-, Land-en Volkenkunde (TBG) 66:319-94.

Haan, F. de

1922

Oud Batavia; Gedenkboek uitgegeven door het Bataviaasch Genootschap van Kunsten en Wetenschappen naar aanleiding van het driehonderdjarig bestaan der stad in 1919. Batavia: Kolff. 2 vols.

Haga, B.J.

1924

Indonesische en Indische democratie. Den Haag: De Ster. 
Hagesteijn, R.

1989 Circles of kings; Political dynamics in early continental Southeast Asia. Dordrecht: Foris. [KITLV, Verhandelingen 138.]

Hall, K.R.

1985

Maritime trade and state development in early Southeast Asia. Sydney: Allen and Unwin.

Hanna, W.A.

1976

Bali profile; People, events, circumstances, 1001-1976. New York: American Universities Fieldstaff.

Hanks, L.

1975

'The Thai social order as entourage and circle', in: G.W. Skinner and A.T. Kirsch (eds), Change and persistence in Thai culture; Essays in honor of Lauriston Sharp, pp. 197-218. Ithaca: Cornell University Press.

Happé, P.L.E.

1915 'Eenige bijzonderheden omtrent de inlandsche rijstcultuur in Zuid-Bali', Indisch Bouwkundig Tijdschrift 18-21:401-7.

1919 'Een beschouwing over het Zuid-Balische soebakwezen en zijne verwording in verband met de voorgenomen vorming van waterschapen in Nederlandsch-Indië', Indische Gids 41-1:183-200.

Heeres, J.E.

1894

'Onze betrekkingen met de Kleine Soenda eilanden 1640-48', in: Feestbundel van taal-, letter-, geschied-en aardrijkskundige bijdragen, ter gelegenheid van zijn tachtigsten geboortedag aan Dr. P.J. Veth, oudhoogleraar, door eenige vrienden en oud-leerlingen aangeboden pp. 178-85. Leiden: Brill.

Heine-Geldern, R.

1942 'Conceptions of state and kingship in Southeast Asia', Far Eastern Quarterly 2:15-30.

Helms, L.V.

$1882 \quad$ Pioneering in the Far East and journeys to California in 1849 and to the White Sea in 1878. London: Allen.

Helsdingen, W.H. van (ed.)

1941 Daar wèrd wat groots verricht. Amsterdam: Elsevier.

Hengeveld, G.J.N.

1920 'De mogelijkheid tot het maken van kunstwerken ten behoeve van de irrigatie op Bali', Geologische Onderzoekingen, II:87-93. Weltevreden: Landsdrukkerij.

Henige, D.P.

1974

The chronology of oral tradition; Quest for a chimera. Oxford: Clarendon Press.

Heyden, A.J. van der

1924

'Het waterschapswezen in de voormalige Zuid-Balische rijkjes Badoeng en Mengwi', Koloniale Studiën 8-2:266-75.

Heyting, L.C.

1925 a

'Een legende van het Bratanmeer (een Balisch wespenverhaal)', Nederlandsch-Indië Oud en Nieuw 9-9:275-80. 

vorst van Matjan Poetih', Koloniaal Weekblad, 25-27:3-4.

Hinzler, H.I.R.

1976

'The Balinese babad', in: Sartono Kartodirdjo (ed.), Profiles of Malay

1981 Bima Swarga in Balinese wayang. 's-Gravenhage: Nijhoff. [KITLV, Verculture, pp. 39-52. Jakarta: Ministry of Education and Culture. handelingen 90.]

1986a 'The Usana Bali as a source of history', in: Taufik Abdullah (ed.), Papers of the 4th Indonesian-Dutch history conference, vol. 2, pp. 124-62. Yogyakarta: Gadjah Mada University Press.

1986b 'In search of Balinese authors; The story of padanda Wanasara', in: C.M.S. Hellwig and S.O. Robson (eds), A man of Indonesian letters; Essays in honour of Professor A. Teeuw, pp. 216-37. Dordrecht: Foris. [KITLV, Verhandelingen 121.]

1986c 'Facts, myths, legitimation and time in Balinese historiography'. Paper workshop Balinese State and Society, KITLV, Leiden.

Hobart, M.

1978

'The path of the soul; The legitimation of nature in Balinese concepts of space', in: G.B. Milner (ed.), Natural symbols in Southeast Asia, pp. 5-28. London: SOAS.

1985 'Violence and silence; Towards a politics of action'. Paper conference on Violence as a Social Institution, St. Andrews.

Hocart, A.M.

1969

The life-giving myth and other essays. London: Tavistock/Methuen.

1970

Kings and councillors; An essay in the comparative anatomy of human society. With an introduction by R. Needham. Chicago: University of Chicago Press.

Hoeber-Rudolph, S.

1987 'Stateformation in Asia; Prolegomena to a comparative study', Journal of Asian Studies 46:731-46.

Hoëvell, W.R. van

1845 'Eenige mededeelingen omtrent het eiland Bali van Abdullah bin Mohamad el Mazrie, met eene Nederduitsche vertaling en aanteekeningen', Tijdschrift van Nederlandsch-Indië 7, 2:139-201.

1846a Nederland en Bali; Eene stem uit Indie tot het Nederlandsche volk. Groningen: n.n.

1846b 'Wetenschappelijke nasporingen op het eiland Bali', Tijdschrift van Nederlandsch-Indië 8, 3:223-43, 4:205-16.

1849-54 Reis over Java, Madura en Bali, in het midden van 1847. Amsterdam: Van Kampen. 3 vols.

Hogendorp, D. van

$1799 \quad$ Berigt van den tegenwoordigen toestand der Bataafsche bezittingen in OostIndiën en den handel op dezelve. Delft: Roelofswaert.

Hoos, A.A.

1894 'Bali en Lombok', Verslagen Algemene Vergaderingen van het Indisch Genootschap 1894:189-218. 
Hooykaas, C.

1947

'Catalogus van boeken en artikelen over Bali en Lombok 1920-1947' (typescript).

1964

Agama Tirta; Five studies in Hindu-Balinese religion. Amsterdam: NoordHollandsche Uitgevers Maatschappij. [Verhandelingen der Koninklijke Nederlandse Akademie van Wetenschappen, Afdeling Letterkunde, Nieuwe Series 70-4.]

Hooykaas-Van Leeuwen Boomkamp, J.H.

1949

De 'goddelijke gast' op Bali; I Bagoes Diarsa, Balisch gedicht en volksverhaal. Bandoeng: Nix.

Howe, L.E.A.

1983 'An introduction to the cultural study of traditional Balinese architecture', Archipel 25:137-58.

1991

'Rice, ideology and the legitimation of hierarchy in Bali', MAN n.s. 26:445-67.

Hugenholtz, W.R.

1986 'Taxes and society; Regional differences in Central Java around 1830', in: Sartono Kartodirdjo (ed.), Papers of the 4th Indonesian-Dutch history conference, vol. 1, pp. 142-73. Yogyakarta: Gadjah Mada University Press.

Hunger, W.F.T.

1932

'Adatdesa's en gouvernementsdesa's in Zuid-Bali', Koloniale Studiën 162:603-16.

1933 'Balische deelbouwcontracten gewijzigd als gevolg der huidige crisis', Koloniale Studiën 17:174-82.

1937 'Adatuitgaven in Zuid-Bali', Koloniale Studiën 21:610-40.

Ikhtisar keadaan

1973

Ikhtisar keadaan politik Hindia-Belanda tahun 1839-1848. Jakarta: Arsip National Republik Indonesia.

Inden, R.

1986

'Orientalist constructions of India', Modern Asian Studies 20:401-46.

Irwin, G.

1955

Nineteenth century Borneo; A study in diplomatic rivalry. 's-Gravenhage:

Nijhoff. [KITLV, Verhandelingen 15.]

Jacobs, J.

1883

Eenigen tijd onder de Baliërs. Batavia: Kolff.

Jaquet, F.G.P.

1983 Sources of the history of Asia and Oceania in the Netherlands, vol. 2, 17961949. München: Saur.

Java Government Gazette

1815 Java Government Gazette. Batavia.

Javasche Courant

1828 Javasche Courant. Batavia (3-7-1828).

Jonge, J.K.J. de and M.L. van Deventer (eds)

1862-1909 De opkomst van het Nederlandsch gezag in Oost-Indië. 's-Gravenhage:

Nijhoff, Amsterdam: Muller. 16 vols. 
K.

'Een bezoek bij den radja van Beliling op het eiland Bali in 1845', Tijdspiegel 1:213-26.

Kaaden, W.F. van der

1936 'Nangluk merana in Gianjar', Djawa 16:123-28.

1938 'Geschiedenis van de bestuursvoering over Bali en Lombok, 1898-1938',

Tropisch Nederland 11:203-8, 219-24, 234-40, 253-56, 265-72.

Kamar, $\mathrm{Pa}$

1926 'Geschiedenis van Madoera', Djawa 6:231-50.

Kat Angelino, P. de

1921a 'De ambtsvelden en de petjatoe-pengajah in Gianjar', Koloniaal Tijdschrift 10:225-65.

1921b 'De robans en parekans op Bali', Koloniaal Tijdschrift 10:590-608.

1921c 'De kèpèng op Bali', Koloniale Studiën 5-1:67-83.

Kats, J.

1929

'Een Balische brief uit 1768 aan den gouverneur van Java's noordkust', in: Feestbundel uitgegeven door het Koninklijk Bataviaasch Genootschap van Kunsten en Wetenschappen bij gelegenheid van zijn 150 jarig bestaan. 17781928, vol. I, pp. 291-6. Weltevreden: Kolff.

Kemmerling, G.L.L.

1918 'De aardbeving op Bali op 21-01-1917', Jaarboek van het Mijnwezen in Nederlandsch-Indië 46:1-49.

Kemp, P.H. van der

1899 'Het verblijf van commissaris Van den Broek op Bali' van 17 december 1817 tot 24 juni 1818, Bijdragen tot de Taal-, Land-en Volkenkunde 50:331-91.

Koentjaraningrat

1980 'Javanese terms for god and supernatural beings and the idea of power', in: R. Schefold et al. (eds), Man, meaning and history; Essays in honour of H.G. Schulte Nordholt, pp.127-39. 's-Gravenhage: Nijhoff. [KITLV, Verhandelingen 89.]

Kol, H. van

1903

Uit onze koloniën. Leiden: Sijthoff.

1914

Driemaal dwars door Sumatra en zwerftochten door Bali. Rotterdam: Brusse.

Koloniaal Verslag

1892

Koloniaal Verslag. Den Haag: Algemeene Landsdrukkerij.

Korn, V.E.

1917

$1922 \mathrm{a}$

'De belasting op de bedrijfs- en andere inkomsten in verband met de heffing der landelijke inkomsten op Bali', Tijdschrift van het Binnenlandsch Bestuur 53-8:472-500, 9:662-8.

$1922 b$

Balische overeenkomsten. 's-Gravenhage: Nijhoff.

1923

'De betekenis der adoptie in de Balische samenleving', Indische Gids 44, 1:297-321.

'Hoe er een nieuw licht werd geworpen op het Balische soebakwezen', Koloniaal Tijdschrift 12:324-31. 
'Bali is apart ... is fijner bezenuwd dan eenig ander deel van Indië', Koloniaal Tijdschrift 14:44-53.

1927 'Balische bevloeiingstunnels', Koloniale Studiën 11-1:351-81.

1932 Het adatrecht van Bali. Second edition. 's-Gravenhage: Naeff. [First edition 1924.]

1933 De dorpsrepubliek Tnganan Pagringsingan. Santpoort: Mees.

1955 'In memoriam Henri Titus Damsté, 28 jan. 1874-6 jan.1955', Bijdragen tot de Taal-, Land-en Volkenkunde 111:113-36, 308.

Kraemer, $\mathrm{H}$.

1933 De strijd over Bali en de zending. Amsterdam: Paris.

Krapels, C.G.P.

1939

'Het schuldenprobleem der landbouwende bevolking op Bali', Volkscredietwezen 27:249-324.

Krom, N.J.

1931

Hindoe-Javaansche geschiedenis. Second edition. 's-Gravenhage: Nijhoff. [First edition 1926.]

Kulke, $\mathrm{H}$. 1982

1986

Kumar, A.

1976

1979

'Stateformation and legitimation in early Java'. Paper 3rd Colloquium on Southeast Asia, Bielefeld.

'The early and imperial Kingdom in Southeast Asia', in: D.G. Marr and A.C. Milner (eds), Southeast Asia in the 9th to 14th centuries, pp. 1-22. Singapore: Institute of Southeast Asian Studies.

'Indian colonies, indianization or cultural convergence? Reflections on the changing image of India's role in Southeast Asia', in: H. Schulte Nordholt (ed.), Onderzoek in Zuidoost Azie; Agenda's voor de jaren negentig, pp. 8-32. Leiden: Vakgroep Talen en Culturen van Zuidoost Azië en Oceanië. [Semaian 3.]

Surapati, man and legend; A study of three babad traditions. Leiden: Brill. 'Javanese historiography in and of the "colonial period"; A case study', in: A.J.S. Reid and D. Marr (eds), Perceptions of the past in Southeast Asia, pp. 187-206. Singapore: Heinemann.

1980 'The peasantry and the state on Java; Changes of relationships, 17th to 19 th centuries', in: J. Mackie (ed.), Indonesia; The making of a nation, pp. 577-600. Canberra: Australian National Univerșity.

Kumpulan

n.d.

Kumpulan hasil penelitian sejarah pura. Denpasar: Institut Hindu Dharma.

L.

1868

'De afscheiding van het bestuur van Bali.van dat van Banjoewangi', Tijdschrift van Nederlandsch-Indië 3e serie 2-1:162-5.

Lamster, J.C. 1946

J.B. van Heutsz als Gouverneur-Generaal 1904-1909. Amsterdam: Van Kampen. 
Lane, M.

1972

'Wedastera Suyasa in Balinese politics, 1962-72; From charismatic politics to socio-educational activities'. [BA Hons. thesis University of Sydney.]

Lekkerkerker, C.

1918

1920

$1923 a$

$1923 b$

$1923 c$

1926

1933

Leupe, P.A.

1855

1856

Leur, J.C. van

1955

Lieberson, J.

1984

Liefrinck, F.A.

1877

1886-87

1890

1921

1927

Lier, H.F. van

1866

Locher, G.W.

1969
'De Baliërs van Batavia', Indische Gids 40-1:409-31.

Bali en Lombok; Overzicht der litteratuur omtrent deze eilanden tot einde 1919. Rijswijk: Blankwaardt en Schoonhoven.

'Balambangan', Indische Gids 45-2:1030-67.

'Het voorspel der vestiging van de Nederlandsche macht op Bali en Lombok', Bijdragen tot de Taal-, Land-en Volkenkunde 79:198-322.

'De tegenwoordige economische toestand van het gewest Bali en Lombok', Koloniaal Tijdschrift 12:153-210.

'Bali 1800-1814', Bijdragen tot de Taal-, Land-en Volkenkunde 82: 31538.

'Drieërlei visie op het Balische zendingsvraagstuk', Koloniaal Tijdschrift 22:343-58.

(ed.) 'Schriftelijck rapport gedaan door den predicant Justus Heurnius; aengaende de gelegentheijt van 't eijland Ende, tot het voortplanten van de Christelijcke religie, en van wegen de gelegentheijt van Bali 1638', Bijdragen tot de Taal-, Land-en Volkenkunde 3:250-62.

'Het gezantschap naar Bali, onder den Gouverneur-Generaal Hendrik Brouwer in 1633', Bijdragen tot de Taal-, Land-en Volkenkunde 5:1-71.

Indonesian trade and society; Essays in Asian social and economic history. The Hague/Bandung: Van Hoeve.

'Interpreting the interpretor', New York Review of Books, 15-3-1984.

'Nota betreffende den economischen toestand in het rijk Bangli', Tijdschrift voor Indische Taal-, Land-en Volkenkunde (TBG) 24:180-200.

'De rijstcultuur op Bali', Indische Gids 8-2:1033-59, 1213-37, 1557-68, 9-1:17-30, 182-9, 364-85, 515-52.

'Bijdrage tot de kennis van het eiland Bali', Tijdschrift voor Indische Taal, Land-en Volkenkunde (TBG) 33:233-427.

Nog eenige verordeningen en overeenkomsten van Balische vorsten. 's-Gravenhage: Nijhoff.

Bali en Lombok; Geschriften. Amsterdam: De Bussy.

'Aanteekeningen omtrent het rijk Djembrana', Tijdschrift voor Indische Taal-, Land-en Volkenkunde (TBG) 15:273-85.

'Nieuwe relaties tussen de culturele antropologie en de geschiedenis', Bijdragen en Mededelingen betreffende de Geschiedenis der Nederlanden 83:33-52. 
'Huis, macht en staat', Bijdragen tot de Taal-, Land- en Volkenkunde 141:86-102.

Locher-Scholten, E.

1981 Ethiek in fragmenten; Vijf studies over koloniaal denken en doen van Nederlanders in de Indonesische archipel 187-1942. Utrecht: Hes.

Logeman, J.H.

1955

Het staatsrecht van Indonesië. Den Haag/Bandung: Van Hoeve. [Derde herziene druk.]

Lovric, B.J.A.

1986

'The art of healing and the craft of witches in a "hot earth" village', Review of Indonesian and Malaysian Affairs 20(Summer):68-99.

1987a 'Bali; Myth, magic and morbidity', in: N. Owen (ed.), Death and disease in Southeast Asia; Explorations in social, medical and demographic history, pp. 117-41. Singapore: Oxford University Press.

$1987 b$

Rhetoric and reality; The hidden nightmare; Myth and magic as representations and reverberations of morbid realities. [PhD thesis, University of Sydney.]

Mabbett, I.W.

1977 a

"The "indianization" of Southeast Asia; Reflections on the prehistoric sources', Journal of Southeast Asian Studies 8:1-14.

$1977 b$

'The "indianization" of Southeast Asia; Reflections on the historical sources', Journal of Southeast Asian Studies 8:143-62.

Mahaudiana

1968

Babad Manggis Gianyar. Gianyar: Gde Thaman.

Mayun, I.B. et al. (eds)

1979

Ceritera rakyat (mite der legende) daerah Bali. Denpasar: Pusat Penelitian Sejarah dan Kebudayaan Departemen P. dan K.

McVey, R.

1978

'Introduction; Local voices, central power', in: R. McVey (ed.), Southeast Asian transitions; Approaches through social history, pp. 1-31. New Haven: Yale University Press.

Medhurst, W.H.

1858

'Aanteekeningen gehouden op eene reis over Bali, meer bepaald in het vorstendom Baliling', Tijdschrift van Nederlandsch-Indië 20-1:193-221.

Meilink-Roelofsz, M.A.P.

$1962 \quad$ Asian trade and European influence in the Indonesian Archipelago between 1500 and about 1630. The Hague: Nijhoff.

Mershon, K.

1971

Seven plus seven; Mysterious life rituals in Bali. New York: Vantage Press.

Mey, Th.J. van der

1986

'A Balinese account of the royal consecration ceremony of I Dewa Manggis of Gianyar in 1903', in: C.M.S. Hellwig and S.O. Robson (eds.), A man of Indonesian letters; Essays in honour of Professor A. Teeuw, pp. 257-70. Dordrecht: Foris. [KITLV, Verhandelingen 121.] 
Miller, D.B.

1984

'Hinduism in perspective; Bali and India compared', Review of Indonesian and Malaysian Affairs 18 (winter):36-63.

Monografi Desa

$1983 \quad$ Monografi Desa Sibanggede. Sibanggede (typescript).

Moojen, P.E.J.

1920 Bali; Verslag en voorstellen aan de regeering van Nederlandsch-Indie. Batavia: Bond van N.I. Kunstkringen en N.I. Heemschut.

Naerssen, E.J. van

1918 'Irrigatie en waterverdeling volgens de opvatting der Baliërs', Adatrechtbundel 15:27-39.

1975 'Tribute to the god and tribute to the king', in: C.O. Cowan and O.W. Wolters (eds), Southeast Asian history and historiography, pp. 296-303. Ithaca: Cornell University Press.

Naerssen, F.H. van, Th.G.Th. Pigeaud and P. Voorhoeve

1977 Catalogue of Indonesian manuscripts, vol. 4, part 2; Old Javanese charters, Javanese, Malay and Lampung manuscripts, Mads Lange's Balinese letters and official letters in Indonesian languages. Copenhagen: Royal Library of Copenhagen.

Nagtegaal, L.

1988 Rijden op een Hollandse tijger; De noordkust van Java en de V.O.C. 1680-

1743. [PhD thesis Rijksuniversiteit Utrecht.]

Nieuwenhuys, R.

1967 Tussen twee vaderlanden. Amsterdam: Van Oorschot.

Nieuwenkamp, W.O.J.

1906-10 Bali en Lombok. Edam: De Zwerver.

Olivier, J.

1827 Land-en zeetogten in Nederland's Indië, vol. 1. Amsterdam: Sulpke.

Onghokham

1975

1978

The residency of Madiun; Priyayi and peasant in nineteenth century Java. [PhD thesis Yale University, New Haven.]

'The inscrutable and the paranoid; An investigation into the sources of the Brotodiningrat affair', in: R. McVey (ed.), Southeast Asian transitions; Approaches through social history, pp. 112-57. New Haven: Yale University Press.

Ortner, S.B.

1984

'Theory in anthropology since the sixties', Comparative Studies in Society and History 26:126-66.

Owen, N. (ed.)

1987

Death and disease in Southeast Asia; Explorations in social, medical and demographic history. Singapore: Oxford University Press.

Panitia Peneliti

n.d. 'Panitia Peneliti Sejarah P.H. Dwijendra; Sekelumit bekal/sarana sejarah Bali dan dharma yatra D.H. Nirarta/Dwijendra abad 15-16 M.' (typescript). 
Peddemors, $\mathrm{M}$.

1933

'Balische deelbouwcontracten gewijzigd als gevolg der huidige crisis', Koloniale Studiën 17-2:689-96.

Pendit, Ny. S.

1979 Bali berjuang. Second revised edition. Jakarta: Gunung Agung. [First edition 1954.]

Philokalos

1936 'De keerzijde', Djawa 16:139.

Pigeaud, Th.G.Th.

1932

'Aanteekeningen betreffende den Javaanschen Oosthoek', Tijdschrift voor Indische Taal-, Land-en Volkenkunde (TBG) 72:215-313.

1960-63 Java in the 14th century; A study in cultural history; The Nagara-Kertagama by Rakawi Prapanca of Majapahit, 1365 A.D. The Hague: Nijhoff. 5 vols. [KITLV, Translation Series 4.]

Pleyte, C.M.

1901

'Herinneringen uit Oost-Indië', Tijdschrift van het Koninklijk Aardrijkskundig Genootschap 2e serie 18:34-66, 233-59, 584-627, 909-31.

Plumb, J.H.

1971

The death of the past. Boston: Houghton Mifflin.

Pluvier, J.M.

1953

Overzicht van de ontwikkeling der nationalistische beweging in Indonesie in de jaren 1930 tot 1942. Den Haag/Bandung: Van Hoeve.

Pollmann, T.

1990

'Margaret Mead's Balinese; The fitting symbols of the American dream', Indonesia 49:1-36.

Powell, $\mathrm{H}$.

1930

The last paradise. New York: Cape and Smith.

Putra, G. Ag. Gede

n.d. 'Pura Sada dan Pura Taman Ayun' (typescript).

n.d. . 'Pura Sada Kapal' (typescript):

n.d. 'Pura Tamau Ayun' (typescript).

Putra Agung

1974

Perobahan sosial dan pertentangan kasta di Bali Utara, 1924-1928. [Thesis Universitas Gadjah Mada, Yogyakarta.]

Raka, I. G. Gde

1955 Monografi pulau Bali. Djakarta: Pusat Djawatan Pertanian Rakjat.

Radermacher, J.C.M.

1786 'Korte beschrijving van het eiland Celebes en de eilanden Floris, Sumbawa, Lombok en Baly', Verhandelingen van het Bataviaasch Genootschap voor Kunsten en Wetenschappen 4:143-96.

Raffles, T.S.

1817 The history of Java. London: Black, Parbury and Allen. 2 vols.

Ranger, T.O.

1983

'The invention of tradition in colonial Africa', in: E.J. Hobsbawn and T.O. Ranger (eds), The invention of tradition, pp. 211-62. Cambridge: Cambridge University Press. 
Reid, A.J.S. (ed.)

1983 Slavery, bondage and dependency in Southeast Asia. St. Lucia: University of Queensland Press.

1988 Southeast Asia in the age of commerce 1450-1680, Vol I: The lands below the winds. New Haven: Yale University Press.

Reken, I. Wayan

n.d. 'Sejarah Jembranạ' (typescript).

Rhodius, $\mathrm{H}$.

[1964] Schönheit und Reichtum des Lebens; Walter Spies (Maler und Musiker auf Bali 1895-1942); Eine Autobiographie in Briefen mit ergänzenden Erinnerungen. 's-Gravenhage: Boucher.

Ricklefs, M.C.

$1981 \quad$ A history of modern Indonesia. London: Macmillan.

Rietschoten, C.H. van

1910 'Algemeen verslag van den chef staf der expeditie naar Bali, 1906', Indisch Militair Tijdschrift extra bijlage 27:1-139.

Robinson, G.

1988

'State, society and political conflict in Bali, 1945-1946', Indonesia 45:148.

1992 'The economic foundations of political conflict in Bali, 1950-1965', Indonesia 54:59-94.

Robson, S.O. 1971

Wangbang Wideya; A Javanese panji romance. The Hague: Nijhoff. [KITLV, Bibliotheca Indonesica 6.]

Roon, J. van

1916

'Enkele aanteekeningen omtrent Bali', Jaarverslag Topografische Dienst van Nederlandsch-Indië 11:213-87.

Rouffaer, G.P.

'Vorstenlanden', Adatrechtbundel 34:233-79. 's-Gravenhage: Nijhoff.

Rubinstein, R. 1991

'The Brahmana according to their babad', in: H. Geertz (ed.), State and society in Bali; Historical, textual and anthropological approaches, pp. 4384. Leiden: KITLV Press. [Verhandelingen 146.]

Rush, J.R.

1990 Opium to Java; Revenue farming and Chinese enterprise in colonial Indonesia. Ithaca/London: Cornell University Press.

Sahlins, M.

1963

'Poor man, rich man, big man, chief; Political types in Melanesia and Polynesia', Comparative Studies in Society and History 5:285-303.

1985 Islands of history. London: Tavistock.

Said, E.

1979 Orientalism. New York: Vintage Books.

Sartono Kartodirdjo,

1966 The peasants revolt of Banten in 1888; Its conditions, course and sequel; $A$ case study of social movements in Indonesia. The Hague: Nijhoff. [KITLV, Verhandelingen 50.] 
1973 Protest movements in rural Java. Singapore: Oxford University Press.

Schmidt auf Altenstadt, D. von

1920 'Bezoek van den Gouverneur-Generaal van Nederlandsch-Indië aan Bali', Nederlandsch-Indië Oud en Nieuw 5:165-87.

Schrieke, B.J.O.

1955-57 Indonesian sociological studies. The Hague: Van Hoeve. 2 vols.

Schulte Nordholt, $\mathrm{H}$.

1980 'Macht, mensen en middelen; Patronen en dynamiek in de Balische politiek ca. 1700-1840'. [Doctoraalscriptie Vrije Universiteit Amsterdam.]

1981a 'The Mads Lange connection; A Danish trader in Bali in the middle of the nineteenth century; Broker and buffer', Indonesia 32:16-47.

1981b 'Negara: A theatre state?' Bijdragen tot de Taal-, Land-en Volkenkunde 137:470-6.

1986a 'Stenen vreemdelingen op Bali', Orion 3-2:8-12.

1986b Bali; Colonial conceptions and political change, 1700-1940; From shifting hierarchies to 'fixed order'. Rotterdam: Erasmus University. [Comparative Asian Studies Programma 15.]

1987 'Dekker, Havelaar en Bali', Indische Letteren 2:149-60.

1988a Een Balische dynastie; Hiërarchie en conflict in de negara Mengwi 17001940. [PhD thesis Vrije Universiteit Amsterdam.]

1988b 'Bali; Status and ancestors', in: R. Schefold, V. Dekker and N. de Jonge (eds), Indonesia in focus, pp. 71-9. Meppel: Edu'Actief.

1991a - State, village and ritual in Bali; A historical perspective. Amsterdam: CASA/VU University Press. [Comparative Asian Studies 7.]

1991b 'Temple and authority in South Bali, 1900-1980', in: H. Geertz (ed.), State and society in Bali; Historical, textual and anthropological approaches, pp. 137-63. Leiden: KITLV Press. [Verhandelingen 146.]

1991 'Origin, descent and destruction; Text and context in Balinese representations of the past', Indonesia 54:27-58.

Schulte Nordholt, H.G.

1967 Antropologie en geschiedenis. Amsterdam: Scheltema en Holkema.

1971 The political system of the Atoni of Timor. 's-Gravenhage: Nijhoff. [KITLV, Verhandelingen 60.]

Schwartz, H.J.E.F.

1901a 'Dagverhaal van eene reis naar Tabanan en Badoeng in 1899', Tijdschrift voor Indische Taal-, Land-en Volkenkunde (TBG) 43:132-58.

1901b 'Rapport van de reis naar Bangli', Tijdschrift voor Indische Taal-, Land-en Volkenkunde (TBG) 43:124-31.

Sejarah masuknya Islam

1979 Sejarah masuknya Islam di Bali. Denpasar: Proyek Penelitian Pemda.

Shiraishi, T.

1990 An age in motion; Popular radicalism in Java, 1912-26. Ithaca/London: Cornell University Press.

Sidemen, I.B. (ed.)

$1980 \quad$ Geguritan rereg Gianyar. Jakarta: P\&K.

Sidemen, I.B. et.al.

$1983 \quad$ Sejarah Klungkung Klungkung. 
Simpen, I. Wayan

1958 Babad Mengwi. Denpasar.

Smail, J.W.R.

1961 'On the possibility of an autonomous history of modern Southeast Asia', Journal of Southeast Asian History 2:72-102.

Soemersaid Moertono

1968 State and statecraft in Old Java; A study of the later Mataram period, 16th19th centuries. Ithaca: Cornell Modern Indonesia Project. [Monograph Series 43.]

Sörensen, O.W.

1921 'Irrigatie in Zuid-Bali', De Waterstaats-ingenieur 4:116-21.

Sosrowidjojo, R.

1875 Serat poerwotjarito Bali. Batavia: Landsdrukkerij.

Southall, A.

1956

1988 'The segmentary state in Africa and Asia', Comparative Studies in Society and History 30:52-82.

Staatsblad van Nederlandsch-Indië

Staatsblad van Nederlandsch-Indië. Batavia: Landsdrukkerij.

Stein, B.

1977 'The segmentary state in South Indian history', in: R.G. Fox (ed.), Realm and region in traditional India, pp. 3-51. Delhi: Vikers.

1980 Peasant, state and society in medieval South India. Delhi: Oxford University Press.

Stuart-Fox, D.

1982 Once a century; Pura Besakih and the Ekadasa Rudra festival. Jakarta: Sinar Harapan/Citra Indonesia.

1987 Pura Besakih; A Study of Balinese religion and society. [PhD thesis, Australian National University, Canberra.]

1991 'Pura Besakih; Temple-state relations from precolonial to modern times', in: H. Geertz (ed.), State and society in Bali; Historical, textual and anthropological approaches, pp. 11-41. Leiden: KITLV Press. [Verhandelingen 146.]

1992 Bibliography of Bali; Publications from 1920 to 1990. Leiden: KITLV Press. [Bibliographical Series 19.]

Stutterheim, W.F.

1948 De kraton van Majapahit. 's-Gravenhage: Nijhoff.

Sugriwa, I.G.B.

1975 Babad Blahbatuh. Denpasar: Balimas.

Sukarto K. Atmodjo

1986 'Some short notes on agricultural data from ancient Balinese inscriptions', in: Sartono Kartodirdjo (ed.), Papers of the 4th Indonesian-Dutch history conference, vol. 1, pp. 25-62. Yogyakarta: Gadjah Mada University Press. 
Surat-surat perdjandjian

$1964 \quad$ Surat-surat perdjandjian antara keradjaan-keradjaan Bali/Lombok dengan pemerintah Hindia-Belanda 1841 s/d 1938. Djakarta: Arsip Nasional Republik Indonesia.

Sutherland, H.A.

1979 The making of a bureaucratic elite; The colonial transformation of the Javanese priyayi. Singapore: Heinemann.

1983a 'Slavery and the slave trade in South Sulawesi', in: A.J.S. Reid (ed.), Slavery, bondage and dependency in Southeast Asia, pp. 263-85. St. Lucia: University of Queensland Press.

1983b 'Power and politics in South Sulawesi 1860-1880', Review of Indonesian and Malaysian Affairs 17:161-207.

Swellengrebel, J.L.

1941 'Enkele Balische spelen (II); Het "kraaienspel" ', Tijdschrift voor Indische Taal-, Land-en Volkenkunde (TBG) 81:514-30.

1947 'Een vorstenwijding op Bali', Mededelingen Rijksmuseum voor Volkenkunde 2. Leiden.

1960a (ed.) Bali; Studies in life, thought, and ritual. The Hague: Van Hoeve.

1960b 'Introduction', in: J.L. Swellengrebel (ed.), Bal; Studies in life, thought, and ritual, pp. 1-76. The Hague/Bandung: Van Hoeve.

1969 (ed.) Bali; Further studies in life, thought, and ritual. The Hague: Van Hoeve.

Swieten, J. van

$\mathrm{T}$.

1874

Krijgsverrigtingen tegen het eiland Balie in 1848. Amsterdam: Doorman.

'Bali en Lombok', Tijdschrift van Nederlandsch-Indië, Nieuwe Serie 32:439-55.

Tambiah, S.J.

1976

World conquerer and world renouncer; A study of Buddhism and polity in

Thailand against a historical background. Cambridge: Cambridge University Press.

$1985 a$

'The galactic polity in Southeast Asia', in: S.J. Tambiah, Culture, thought, and social action; An anthropological perspective, pp. 252-86. Cambridge, Mass./London: Harvard University Press.

$1985 b$

'A reformulation of Geertz's conception of the theatre state', in: S.J. Tambiah, Culture, thought, and social action; An anthropological perspective, pp. 316-38. Cambridge, Mass./London: Harvard University Press. 'At the confluence of anthropology, history and indology', Contributions to Indian Sociology 21:187-216.

Tan, R.Y.D.

1967

'The domestic architecture of South Bali', Bijdragen tot de Taal-, Land-en Volkenkunde 123:442-76.

Tantra, G. Ag. Ketut

1980 'Monografi subak Penarungan', Penarungan (typescript).

Tarling, N.

1962

Anglo-Dutch rivalry in the Malay world 1780-1824. Cambridge: Cambridge University Press. 
Tilly, C. (ed.)

1975

The formation of national states in Western Europe. Princeton: Princeton University Press.

Tuuk, H.N. van der

1897-1912 Kawi-Balineesch-Nederlandsch woordenboek. Batavia: Landsdrukkerij. 4 vols.

Utrecht, E.

1962 Sedjarah hukum internasional di Bali dan Lombok. Bandung: Sumur Bandung.

Valentijn, F.

1726

Oud en nieuw Oost-Indiën. Dordrecht: Van Braam, Amsterdam: Onder de Linden. 5 vols.

Valeri, V.

1972

'Le système des rangs à Hawaii', L'Homme 12, 72:29-66.

Van der Kraan, A.

1980 Lombok; Conquest, colonisation and underdevelopment. Singapore: Heinemann.

1983 'Bali; Slavery and the slave trade', in: A.J.S.' Reid (ed.), Slavery, bondage and dependency in Southeast Asia, pp.315-40. St. Lucia: University of Queensland Press.

Veer, K. van der

1918 'Zuid-Bali en zijn rijstbouw', Teysmannia 29:367-88.

Verslag onderzoek belastingdruk

1929 Verslag van het onderzoek naar den belastingdruk op de inlandsche bevolking in de Buitengewesten. Weltevreden: Landsdrukkerij.

Vickers, A.

1982

'The writing of kakawin and kidung on Bali', Bijdragen tot de Taal-, Land-en Volkenkunde 138:492-3.

1986 The desiring prince; A study of the kidung Malat as text. [PhD thesis, University of Sydney.]

1987 'Hinduism and Islam in Indonesia; Bali and the Pasisir world', Indonesia 44:31-58.

1989 Bali; A paradise created. Ringwood, Vic.: Penguin.

1991 'Ritual written; The song of the ligya, or the killing of the rhinoceros', in: H. Geertz (ed.), State and society in Bali; Historical, textual and anthropological approaches, pp. 85-136. Leiden: KITLV Press. [Verhandelingen 146.]

Vink, G.J.

1929

'Over de koffiecultuur der Baliërs', Landbouw 5:1-75.

Visman, F.H.

1928 'Herstel van zelfbesturen', Koloniale Studiën 12-2:103-36.

Vlijmen, B.R.F. van

1875 Bali 1868; Eene bladzijde der Indische krijgsgeschiedenis. Amsterdam: Loman.

Vollenhoven, C. van

1928 De ontdekking van het adatrecht. Leiden: Brill. 
Vroom, J. de

1872, 1875 'Balineesche lontarbrieven met vertaling en aanteekeningen', Tijdschrift voor Indische Taal-, Land-en Volkenkunde (TBG) 18:228-39, 21:104-19.

Walters, R.

1980

'Signs of the times; Clifford Geertz and historians', Social Research 47: 537-56.

Warna, I Wayan (ed.)

1978 Kamus Bali-Indonesia. Denpasar: Dinas Pengajaran Propinsi Daerah Tingkat I Bali.

1986 Babad Dalem; Teks dan terjemahan. Denpasar: Dinas Pendidikan dan Kebudayaan Propinsi Daerah Tingkat I Bali.

Warren, C.

$1990 \quad$ Adat and dina; Village and state in contemporary Indonesia. [PhD thesis University of Western Australia, Perth.]

Warren, J.

1981

The Sulu zone 1768-1898; The dynamics of external trade, slavery, and ethnicity in the transformation of a Southeast Asian maritime state. Singapore: Singapore University Press.

Weber, M.

1925

Wirtschaft und Gesellschaft. Second edition. Tübingen: Mohr. [First edition 1922.]

Weck, W.

$1937 \quad$ Heilkunde und Volkstum auf Bali. Stuttgart: Enke.

Weede, H.M. van

1908 Indische reisherinneringen. Haarlem: Tjeenk Willink. 2 vols.

Weitzel, A.W.P.

1859 De derde militaire expeditie naar het eiland Bali in 1849. Gorinchem: Noorduyn.

Wertheim, W.F.

1950 'Een nieuwe visie op het oude Oosten; Leven en werken van wijlen Dr. van Leur', in: W.F. Wertheim, Herrijzend Azië, pp. 10-29. Arnhem: Van Loghem Slaterus.

1964 East-West Parallels; Sociological approaches to modern Asia. The Hague: Van Hoeve.

1978 Indonesië; Van vorstenrijk tot neo-kolonie. Meppel/Amsterdam: Boom.

Wessels, C.

1923

'Een Portugese missiepoging op Bali in 1635', Studiën 55:433-43.

Wiener, M. 1990

Visible and invisible realms; The royal house of Klungkung and the Dutch conquest of Bali. [PhD thesis University of Chicago.]

Wikan, U.

1990

Managing turbulent hearts; A Balinese formula for living. Chicago: University of Chicago Press.

Wiryasutha, G. Ny.

1939

Tjatoer wangsa di Bali. N.p.: n.n. 
Wittfogel, K.A.

Oriental despotism; A comparative study of total power. New Haven: Yale University Press.

Wolf, E.

1982

Europe and the people without history. Berkeley: University of California Press.

Wolters, O.W.

1970

The fall of Srivijaya in Malay history. Ithaca/London: Cornell University Press.

1982

History, culture and region in Southeast Asian perspectives. Singapore: Institute of Southeast Asian Studies.

Wong Lin Ken, 1960

'The trade of Singapore 1819-69', Journal of the Malayan Branch of the Royal Asiatic Society 33-4.

Worsley, P.J.

1972

Babad Buleleng; A Balinese dynastic genealogy. The Hague: Nijhoff. [KITLV, Bibliotheca Indonesica 8.]

IJzerman, M.J.

'Bali, een land van merkwaardige contrasten, uitwendig, oppervlakkig een en al schittering, inwendig droef heidendom', Wolanda-Hindia 4:52$5,65-7,75-80,88-92,98-102,117-8,129-32$.

Zentgraaff, H.C.J.

1933 'Het Bali reservaat', Javabode, 9-8-1933.

Zoetmulder, P.J.

1974 Kalangwan; A survey of Old-Javanese literature. The Hague: Nijhoff. [KITLV, Translation Series 16.]

1982 Old Javanese-English dictionary. The Hague: Nijhoff. 2 vols.

Zollinger, $\mathrm{H}$.

1845

1847

1849

1850

1855

'Een uitstapje naar het eiland Bali', Tijdschrift van Nederlandsch-Indië 7$4: 1-56$.

'Het eiland Lombok', Tijdschrift van Nederlandsch-Indië 9-2:177-204, 301-83.

'Verhaal eener reis over de eilanden Bali en Lombok gedurende de maanden Mei tot September 1846', Verhandelingen van het Bataviaasch Genootschap voor Kunsten en Wetenschappen 22:1-15.

'Verslag van eene reis naar Bima en Soembawa, naar eenige plaatsen op Celebes, Saleijer en Floris, gedurende de maanden Mei tot December 1847', Verhandelingen van het Bataviaasch Genootschap voor Kunsten en Wetenschappen 23:1-224.

Besteigung des Vulkanes Tambora auf der Insel Sumbawa und Schilderung der Eruption desselben im Jahr 1815. Winterthur: Wurster. 
Balinese sources

$\begin{array}{ll}\text { Or. } & : \text { Collection Oriental Manuscripts University Library, Leiden } \\ \text { HKS } & : \text { Hooykaas/Hinzler Ketut Sangka system, KITLV and University } \\ & \quad \text { Library, Leiden } \\ \text { K } & : \text { Gedong Kirtya, Singaraja } \\ \text { tr. } & : \text { Transscription from Balinese } \\ \text { transl. } & : \text { Translation in Indonesian }\end{array}$

Babad Arya Manguwi, jero Batuaya, Amlapura, \pm 1939; HKS 2930, Or. 16.047; transl. I Gede Ny. Pugeh, Tabanan, and Ida Bagus Rai Pidada, Klungkung.

Babad Arya Tabanan, I G. Ng. Oka, puri Gede Krambitan 193?; K 1792/13, Or. 12.967; transl. I G. Bagus Sugriwa, KITLV, Coll. De Graaf, H 1055:8.

Babad Badung Krambitan, I G. Ng. Oka, puri Gede Krambitan 193?; HKS 352, Or. 12.967; transl. Ida I Dewa Wy. Pucangan, Sidemen.

Babad Bakungan Blahkiuh, jeroan Bakungan Blahkiuh 193?; HKS 3820, Or. 16.965; transl. I Gede Ny. Pugeh, Tabanan.

Babad Bhoemi, KITLV, Coll. Korn, Or. 435:232.

Babad Catur Brahmana, K 273/4, Or. 9237.

Babad Dalem, K 1252; transl. I Dewa Gede Catra, Amlapura.

Babad Jero Tangeb Mengwi (Arya Kaja Kauh), HKS 3826, Or. 16.970; transl. Ida I Dewa Wy. Pucangan, Sidemen.

Babad Kaba-Kaba, tr. Coll. D. Stuart-Fox; transl. I Gede Ny. Pugeh, Tabanan.

Babad I G. Gede Meliling, jero Kajanan, Dalung; HKS 3758, Or. 16.902; transl. I Gede Ny. Pugeh, Tabanan.

Babad Mengwi-Blahkiuh, I G. Putu Mayun, 1927; a: ARA MvK V26-4-1940-9, transl. I G. Gede Raka 1938; b: transl. in: Luh Gede Putjangsri (1970), based on Fakutas Sastra Universitas Udayana, Denpasar, Krp. 129; c: K 1340/12, HKS 3892, Or. 19.036; d: shortened Indonesian version: Simpen (1958).

Babad Mengwi-Buleleng, K 1135/10, Or. 9639; transl. I Gede Ny. Pugeh, Tabanan.

Babad Mengwi-Kedampal, puri Lebah, Kedampal, Abiansemal \pm 1955 ; HKS 3870, Or. 16.925; transl. I Gede Ny. Pugeh, Tabanan.

Babad Mengwi-Lambing, I G. Ag. Made Rai, puri Anyar Lambing \pm 1955 ; HKS 3853, Or. 16.997; transl. I Gede Ny. Pugeh, Tabanan.

Babad Mengwi-Sedang, Sang Gede Resi Mayun puri Sedang $\pm 1923 ;$ KITLV, Coll. Korn, Or. 435:179; transl. I G. Alit Deli \pm 1923.

Babad Mengwi-Penarungan, HKS 3855, Or. 16.999.

Babad Sukahet, Munggu, Mengwi; Museum Bali, Denpasar, K 1921/13 (tr. 1941), Or. 10.025; transl. Ida I Dewa Wy. Pucangan, Sidemen.

Babad Sukawati, a. Babad Dalem Sukawati (Indonesian), Cokorda Agung, puri

Agung, Tegal-Lalang, 1976; b. Babad Timbul Sukawati (Indonesian), I Made Sanggra, Sukawati, 1971.

Babad Surapati, tr. Or. 10.628; transl. I Gede Ny.Pugeh, Tabanan.

Babad Patjung Getasan, HKS 178, Or. 12.750; transl. Ida I Dewa Wy. Pucangan, Sidemen.

Babad (Arya) Patjung, ms gria Gede Panarukan; HKS 341, Or. 12.912; tr. and transl. I G. Ng. Pt. Oka 193?. 
Bancangah Arya Kutawaringin, Arya Kapakisan (Babad Gusti Celuk Blayiu); HKS 3795, Or. 16.939; transl. Ida I Dewa Wy. Pucangan, Sidemen.

Bhuwana Winasa, Ida Pedanda Ngurah, gria Gede Blayu 1918; KITLV, Coll. Korn, Or. 435:270, Or.11.258, 14.870; transl. I Gede Ny. Pugeh, Tabanan.

Buku Purnatatwa Satria Dalem, Coll. M. Wiener; tr. and transl. Ida Bagus Rai Pidada, Klunkung, 1983.

Kidung Nderet, a. K 253, HKS 449, Or. 13.060; transl. I Wy. Dunia, Denpasar; b. Joeda Mengwi, K 501, Or. 9333; c. puri Gede Krambitan; HKS 1958, Or. 15.102; Dutch translation. H. Hinzler.

Pamancangah Dalem Mengwi, tr. KITLV, Coll. Korn, Or. 435:175; transl. I Gede Ny. Pugeh, Tabanan.

Pariagem Taman Bali, tr. Coll. I Kt. Rinda, Blahbatuh; transl. Ida I Dewa Wy. Pucangan, Sidemen.

Paswara Mengwi, tr. KITLV, Coll. Korn, Or. 435:175, HKS 1858, Or. 14.727; transl. I Gede Ny. Pugeh, Tabanan.

Pralambang Bhasa Wewatekan ( \pm 1850$)$, Coll. I Md. Kanta, Klungkung; HKS 3605, Or. 16.749; transl. Ida Bagus Sunu Pidada, Klungkung.

Prasasti Bendesa Tangkas Kori Agung Gerih, Abiansemal; HKS 3819, Or. 16.963; transl. Ida I Dewa Wy. Puncangan, Sidemen.

Raja Purana Pura Besakih, KITLV, Coll. Korn, Or. 435:253; tr. and transl. G. Putu Djiwa, Klungkung 1922.

Samboengan Babad Mengwi (Indonesian), G. Gede Raka 1938; ARA MvK V26-4-1940-9. Silsilah Brahmana Manuaba, Coll. gria Manuaba, Taman.

Silsilah Brahmana Mas Timbul, Coll. gria Tandeg, Lambing.

Tjatatan singkat tentang silsilah keluarga besar puri Mengwi, I G. Ag. Oka Pabean, Denpasar.

Uwug Kengetan, in: I. B. Mayun et al. (ed.) 1979, pp. 37-48.

\section{Archives}

Algemeen Rijksarchief (ARA), Den Haag

Archive VOC: brievenboek Java's Noordoostkust 1710-1735

Archive Ministerie van Koloniën (MvK) 1818-1940

Memories van Overgave (MvO)

Verbalen (V)

Besluiten Gouverneur-Generaal (Besl.)

Mailrapporten (Mr)

Separate reports

Archive Nederlandse Handel Maatschappij (NHM)

Personal collections

Ph.J. van Zuylen van Nijevelt

Van Alphen Engelhard (VROA 1916)

Schneither

A.H.W. de Kock

J.B. van Heutsz

M.Boon, memories en rapporten Bali 1930-1949 
Arsip Nasional Republik Indonesia (ANRI), Jakarta

Residentie Archief Bali 1820-1890.

Besluiten Gouverneur-Generaal 1818-1870.

Koninklijk Instituut voor Taal-, Land-en Volkenkunde (KITLV), Leiden

Western Manuscripts

Coll. H.J. de Graaf (H 1055)

Coll. P. Dubois (H 281)

Coll. Mayor-Lange (H 1177)

Coll. P.A.J. Moojen (H 1169)

Oriental Manuscripts

Coll. V.E. Korn (Or. 435).

Personal archives and collections

Bali

Archive puri Kanginan Amlapura, Karangasem.

Reports on Bali 1880-1950, private archive (anonymous), Gianyar.

Reports on Bali 1846-1902, Gedong Kirtya, Singaraja.

The Netherlands

Coll. C.J. Grader.

Coll. J.L. Swellengrebel, Zendingsverslagen Bali 1932-1939.

Coll. R. Goris, reports from the 1920s and 1930s, formerly in the possession of Professor C. Hooykaas. 



\section{Index}

abhiseka 39, 113, 151

Abianbase 187, 196

Abiansemal 56, 67, 127, 201-7, 214-5, 226, 304-5

- district 219-20, 224, 239, 243, 258, 289, 314, 336-9

lord of - 37, 64 puri - of Mengwi dynasty 201-3, $209,226,229,267,302-4,336$

Aceh War 172, 183, 211

Adas, M. 4, 9

adat 233, 242, 245, 280, 311

- head 297, 299

- law 148 280, 298, 306

- state law 308

administration of districts, colonial 219-26, 231-2, 234, 249, 255, 285, $301,313,334$

adoption in Mengwi dynasty 29-30, $37,46,52,90-1,115-6,118-9,137-$ 9, 154, 304-6, 333

Agung Alangkajeng 22, 30-5, 37, 44, 47-8, 52, 61-2, 119, 122, 139, 158

Agung Anom 26-31, 35-8, 44

Agung Besakih 115-9, 137-8, 140-41

Agung Gede Agung 193, 201-7, 219, 224,304

Agung Kerug 177-88, 193, 203, 221, 304-5

Agung Made Raka 122-6, 137, 141, $146-7,176-9,202-3$

Agung Mayun 111, 116-8, 120-2, 125$9,131-42,146,149,153,158-9,176$, 180

Agung Munggu see Cokorda Munggu

Agung Ngurah Made Agung 92, 95, $101,109,141$

Agung Nyoman Alangkajeng 52, 59,
63,66

Agung Panji 28-9, 36

Agung Pekel 176-8, 181, 185-8, 193

Agung Putra 113, 115-6, 119

Agung Putu Mayun 63-4

Agung Putu Mayun (son of Agung Putu

Mayun above) $90-1$

anak astra 65-6, 79, 88, 103

ancestor(s) 19, 45, 73, 141, 152, 155-7,

$202,274,310,339$, see also kawitan

Anggantaka 67, 187

Angkor 331

Arabs 169

Armenians 169

Arya Kepakisan 19, 38

Asia(n) 1, 2, 232

Ayu Oka 87-91, 95, 100-1, 114, 118, 137, 181

Ayung (river) 45, 51, 55, 58-9, 95, 107 , 285, 291

Ayutthya 331

Baal, J. van 11

babad 23, 32

Babad Buleleng 26, 35

Babad Dalem 23

Babad Mengwi 19, 22-6, 33, 39, 45-6, $62-4,93-4,276-7,314,320$

Babad Surapati 35

Badung (negara) 25, 48, 67, 79, 88, 95$6,99,103-8,116,120-1,132,166-7$, $170,174,177-82,185-8,192-5,201-$ 2, 206, 212-4, 220-1, 225, 255, 290 colonial conquest of - 210-6, 336 colonial subdivision of - 219, 223, 227, 238, 246-9, 252, 258, 276, $284-5,288-9,293,298,307$ king of $-87,99,109,111-3,161$, 
165, 170, 179, 188, 192, 212, 215 ruler of - 314, 322

Bakungan jeroan - 37, 117, 122, 251, 299-300 Sagung - 37, 68, 101, 127

Bangli 126, 175, 185-8, 196, 214-6, 235 king of - 167-8, 255 regent of - 255, 258-9

banjar 49, 65, 69, 149-50, 202, 209, 240-1

klian - 149, 240-2, 245, 297

Banjar 100

Banjarambengan 33, 39

Banyuwangi 162, 171

barong 259

Batavia 1, 24, 31, 41-3, 93, 106, 161-8, $171,175,198,211-3,225,282-3$, 320

Bateson, G. 280, 286

Batu Bata (soroh) 38, 40, 122

Beeuwkes, H. 287

Belo, J. 280

bendesa 47, 49, 53, 149-50, 240-2

Bendesa Mas 125-8

Benoa 281-2

Besakih 115, 259, 310, 314

Biang Agung 118-20, 137-8, 141, 165

Bima 22, 321

Binnenlandsch Bestuur (BB) 219-30, 233-4, 239-41, 245-52, 255-6, 259$60,263-9,274,277-9,284-5,289-$ $91,293,300,304,311-4,320$ director of - 309, 319

black magic 139

Blahbatuh 51, 79, 90

Blahkiuh 56, 68, 125-8, 136, 148, 203, 206-10, 213-6, 226-7, 238-39, 243-5, 250-1, 259, 263, 271-6, 282-3, 293-

$5,301-5,315,322-5,329,337$

conflict in - 297-301, 336

- district 219-20, 223, 250 subak - 250-1

Blambangan 19, 22, 27-8, 31-7, 43-4, $47-8,65,79,93-4$ lord of - 32, 326

Blayu 26-9, 37-8, 45, 51, 115-6, 187, 241

puri - 51, 58, 123-4, 145-6, 187, 253
Bloch, M. 11

Bongkasa 58, 107, 148, 196, 209 puri - 220, 337

Brahman(a) 43, 65, 69-71, 235-7, 274, $297,300-3,307,311$

- priest see pedanda and purohita - ritual 155

Brahman Manuaba 227-9

Brahman Mas 71

Bratan 73, 123, 133-5

British 93, 96, 160-6

Buduk 187

Buginese 93-6, 106-8, 166, 169, 188

Buleleng 19, 25-35, 39, 44, 47, 61, 79, $94,107,126,132,162-4,168-70$, $176,180,213,224-5,232,246,267$, 296

colonial conquest of - 164-7

colonial rule in - 168-73

king of - 161-4, 167

regent of -171

Bun 51, 64, 67, 90

lord of - 64-7

bureaucracy, colonial 217, 242, 264, $279,284,301,310,314,334$

Carangsari 147, 196, 283 puri - 124-6, 188, 205, 303, 337

- subdistrict 219, 303

Caron, L.J.J. 277

caste system, colonial 217, 233-40, $255,279,319$

China 97

Chinese 81, 93, 96, 107, 126-7, 169, $212,281-3$

- porcelain 83

cockfight $42,81,84-6,130,226,229$, 268

coffee, production and export 107-8, 125-8, 130-1, 169, 176-8, 185, 188, 251,290 , see also trade

Cokorda Bima Sakti Blambangan see Agung Alangkajeng

Cokorda Gede Oka 338

Cokorda Gede Sukawati of Ubud 183, 186, 193-6, 200, 206, 216

Cokorda (Gusti) Agung of Mengwi see Agung Anom 
Cokorda Munggu 21, 62-71, 75-6, 79-

$81,87-93,101-4,133$

commoners $7,15,40-3,53,66,85,91$ -

2, 119-21, 135, 147-8, 153-4, 175, $225,230-40,245,255,267-8,321$, 333,335 , see also Sudra

concubine 52,83

conflict $7,22,44,50-3,75,79-80,85$,

$105,109-11,151,158,183,192$,

$226,295,302,331,336$, see also

factions and violence

- in Mengwi dynasty under colonial rule $264,307,314-26,336,339$

conquest, colonial 13, 191, 206, 210,

215,234

contest state $4,7,63,149$

copra see trade

corvée labour 227, 237-42, 247, 250,

$271,281,286-7,297,328$

- and women 238-9

cosmic order $6,10,39,136,151-6$,

$230,263,332$

Covarrubias, M. 280

Crawfurd, J. 231

cremation 50, 109, 114, 119, 134, 1389, 151-3, 158, 179, 192, 211, 230, $255,300-1,304-5,323-5,336-7$

- and widow burning 170, 211-2

crop failure 97, 132-4, 151, 158-9, 179, $258,273,287,317,336$

cycle of life $136,230,263,332,335$, see also cosmic order

Damsté, H.T. 265

dance performance $85,122,148,182$, 267, 304, 322

Dang Hyang Nirarta 274-5

decolonization 2-3, 337

demons 15, 116, 133

white - 216

Den Kayu 39, 69, 195

Denpasar

puri - 109

- town 219, 278, 281-3, 296, 337

desa see village

despotism 1, 5, 55

oriental - 3, 232

Dewa Agung of Klungkung 21, 24-5,
29, 32-4, 66, 69-71, 113-6, 119-20, $132,137,140-1,161,164-8,171-6$, 179-88, 197-8, 205-6, 216, 322

Dewa Agung Rai of Klungkung 140, 185

Dewa Anom of Sukawati 29, 33

Dewa Manggis (DiMadia) $89-90$

disease see epidemics

Dubois, P. 43, 87, 92, 97-9

Dutch 93, 96

- envoys 1, 5, 160-1, 165, 170, 175, 182

- imperialism 199, 210

- mercenary 95

- military expeditions 159, 164-9, 175,238

- policy and diplomacy towards pre-colonial Bali 159-64, 168-75, 179, 182-5, 191, 198, 207

- travelers 122

treaties with the - 119,160-2, 166$7,170,199,211-4$

dynasty $9,12-3,17$

East Java(nese) $19,22,25,28,31-2$, $38,47,65,79,93,97,216,325$

economy $81,169,263,331$

economic depression of the $1930 \mathrm{~s}$ $13,280,286-97,300,307,315-8$, 335-6

world - 13, 282, 334

education, colonial 207, 224-6, 256, $264,278-9,292,302-4,309-11,318-$ 9,325

entourage $4,12,35-42,51-2,65-7,76$, $83,87,91,103,109,115,122,145$, $157,175,196,227-9,245,250,274$, 294-5, 300-2, 335, see also followers, mekel and prabali

epidemics $11,15,32,94,107,112$,

116, 131-4, 151, 158-9, 195, 258,

290,336

erosion 291

Errington, S. 152

ethical policy $170-1,198,210-1$

Europe(ans) 1, 163, 279, 284, 288, 311

export see trade 
factions in dynastic centre of Mengwi 64-5, 116-20, 139, 147, 176-82, 207

Flores 211

followers 4, 11-2, 22, 35-8, 41, 45, 49$50,61-5,68-9,76,86-7,99-106$, $109,115-8,122,125-31,145-50$, 155-7, 166, 177-8, 201-3, 209, 213, $238-40,301,333-5$, see also entourage, irrigation and warfare - under colonial rule 220, 226-8, 233-5, 250, 256, 269, 275, 295300

fragmentation see segmentary state Friederich, R.H.Th. 231-4

Galungan 158, 309 gambuh 89, 102-3, 119 gandrung 85, 115-9

Geertz, C. 5-11, 60, 76, 151, 156

Gelgel 19-26, 43, 333

Dalem of - 19, 23, 34

patih of - see Gusti Agung

genealogical narrative see babad

Gerih 195

Gianyar 89-90, 100-1, 107, 121, 165, 179-86, 193-200, 205, 214-6, 235, $242,247,288,293$ fall of - 174-5, 178 king of - 199, 255 regent of - 255, 258-9

Goa Lawah 115

Goris, R. 278

Grader, C.J. 290

Grana 127-8, 209 puri - 131, 176

gria 39-40, 69-71, 203

- Gede Den Kayu 40, 119

- Manuaba Blahkiuh 229, 274

- Pemaron 65

- Sidemen 69, 119

Guermonprez, J.-F. 157

Gumasih (dam) 59, 65, 88, 103-4, 187, 195

Gunung Agung 15, 32, 131, 263

Gunung Rinjani 32

Gusi (noble title) 37-8, 53, 122, 227

Gusti (noble title) 37, 53, 65, 79, 154, 227, 299
Gusti Agung (noble title) 53

Gusti Agung, patih of Gelgel 19-25

Gusti Agung Made Alangkajeng see Agung Alangkajeng

Gusti Agung Ngurah Made Agung (royal title) 53, 76, 91, 113, 141

Gusti Agung Ngurah Putra 325, 336

Gusti. Bagus Jelantik 256, 258-9

Gusti Gede Jelantik 186, 193-200, 206, 216

Gusti Gede Raka 305, 319-22

Gusti Kamasan 45-50

Gusti Ketut Agung 226, 257, 264, 267$8,277,307,314-20,323-6,336,338$

Gusti Ketut Jelantik 163, 166

Gusti Made Ringkus 206-10, 213-6, 219, 223-5, 250, 259

Gusti Munggu 188, 203

Gusti Ngurah (noble title) 53, 66

Gusti Ngurah Kesiman 166-7

Gusti Ngurah Ketut Sangka 323

Gusti Ngurah Made Pamecutan 112

Gusti Nyoman Wiryasutha 311

Gusti Putu Mayun 207, 215, 219, 22330, 238-9, 243-5, 250-9, 264, 268-9, 273-7, 294-307, 314-25, 334-7, see also puri Mayun Blahkiuh

Gusti Rai Kepakisan 268, 276-7, 314-5

Hanks, L. 4

Heine-Geldern, R. 6

Heutsz, J.B. van 191, 211-6

hierarchy in Mengwi 7-12, 19-22, 31-3, 39-40, 43-5, 52-3, 62, 71, 75-9, 85-7, $92,136,143-52,155,226,234,319$, 333 , see also ritual order

- and crisis 81, 100, 108-10, 182-9, 290

- and jurisdiction 154

- and ritual 155-7, 257, see also cycle of life

- and violence 125, 149, 332

restoration of- 111, 119-21, 319

Hindu(ism) 5, 32, 93, 231-4, 237, 240, 265

Hinzler, H. 23

Hirschmann, H. 314

historiography, colonial 2 
Hocart, A.M. 156

Hoëvell, W.R. van 231

holy water 151, 155, 158, 273, 317, 335

Huskus Koopman, H.J. 162

I Gusti Agung Ngurah Made Agung 19

I Ketut Widjanegara 267

Ida Bagus Ketut Kajeng 302

image, colonial 192, 217, 230-43, 246-

$50,263,269,277-81,336$

incest 180

indebtedness $42,126,288-97,304-5$, 317

India(n) 5, 8-10, 110, 332

- Ocean 15

Indianization 5, 8-9, 39, 155, 332

Indonesia(n)

- archipelago 5, 12, 41, 81, 93, 96-7, $109,166,210,333$

eastern - 331-2

- government 337-9

- revolution 336-7

- state and conflicts 338-9

western - 332

invention of tradition $13,263,280$,

334-5, see also image

irrigation 12-3, 22, 47, 55-61, 73-7, 95 , $99-103,121,127,145,148-50,331-$

3 , see also sedahan and subak

- and colonial policy 227, 246-50, 254-5, 285, 291, 335

- and colonial taxation 284-6, 295

- and followers 55, 59-60, 125, 202, 252-3

- and hierarchy 55, 61, 129, 134, 158, 254

- and Mengwi dynasty 55-61, 104, 128

- and regulations 125

- and ritual 55, 61, 73-5, 130-1, $134-5,156,254$

- and war 179, 186-8, 200

Islam 198, 231-2, 265, 277

jaba see commoners

Jacobs, J. 170

Jagapati 67
Jagaraga $165-6$

Jakarta 337

Jambi 211

Japanese 287, 336-8

Java(nese) 2, 19, 23, 31-2, 68, 86, 93, $96,112,155,159,162-4,168-9,235$,

$264,279,308,319$

- nobility 23, 34, 231, 265

Jembrana $19,65,79,93-4,267$

colonial annexation of - 167, 173

puri - 66

jero $15,36,53,79$

jeroan $37,47,122$

Jimbaran 75, 95, 133

jurisdiction $40-3,85,92,122,129,148$, $152-4,170,235,331$

colonial - 221, 235-9, 251, 279, 298-9, 305-7

Kaba-Kaba 93, 180-2, 185-7, 292 puri - 51-2, 58, 66, 87, 112, 145-6, $187,253,292$

Kalimantan 211

kaliyuga 77, 100, 111

kaja and kelod 15

Kapal 26, 29, 36-8, 45, 59-62, 136, $157,187,195-6,283,339$

- district 219-23

puri - 58

puri - Kaleran 139-41, 145-6,

177, 180, 195, 221

puri-Muncan 46, 50, 59, 195, 220

Karangasem 25, 29, 33, 41, 65, 94, $100,132,165,193,197-9,214-6$, $256-9,288$

colonial annexation of - 176, 199, 205

king of - 114, 161-4, 167, 255

puri - 308

kawitan 22, 31, 34, 136, 152, 157, 271,

$322-5,339$, see also ancestors

kelod see kaja

Kengetan 45, 107

kepeng 42-3, 96, 103, 130, 282, 284

exchange with Dutch currency 282-

$4,288,296$

kerta (judge) 154, see also jurisdiction

Ketut Sandi 225-6, 257, 266 
Kidung Nderet 102, 105, 109

kingship 5-7, 62, 71, 76, 104, 109-12, $119,137-43,226,322,331-2$

Klungkung 21-5, 29, 33, 71, 100, 114-6, $119,132,160,165-8,173-5,178$, 181-3, 186, 193-200, 205-7, 214, $235,247,255,333$

colonial conquest of - 215-6 puri - 71, 76

Kol, H. van 192

Koninklijke Paketvaart Maatschappij 282-3

Korn, V.E. $148,243,265,277-8,284$, 287

Kramas 79, 90, 101-2

Krambitan 323

kris 21-2, 33-4, 61, 69, 88, 104, 119-21, 139-40, 152-4, 156-8, 178, 193, 213, 216, 267, 304

kulkul 36, 81, 88, 188, 267, 273, 337

Kuta 166-9

Lambing 304 puri - 305, 319

land rent see (colonial) taxation landownership 13, 129, 221, 249-56, 267, 286, 289-93, 306, 329, 335

Lange, Mads 166

Leur, J.C. van 2-3

Liefrinck, F.A. 199, 211-6, 232-4, 237, 240-1, 246

Liefrinck, J.H. 182, 185, 195, 197

Lombok 32, 94, 97, 159-65, 170-5, 191 colonial conquest of - 197-200, 205 king of - 161, 167, 198-200 lords see manca (agung), nobility and satellites

Machiavelli, N. 6

McVey, R. 13

Made Tibung 103-10, 118

Madura, Madurese 28, 47

Mahabharata 22, 276

Majapahit 19, 23, 26, 31-4, 71, 231, 331

Makasar 308

malasti 134, see also (royal) ritual malelungan 136, see also (royal) ritual maligya 138, see also cremation

Mambal 47, 50, 65, 88, 104, 125-7, 241,302

mamukur 134, 337, see also cremation manca 146, 150, 186, 195, 219, 242,

303

- agung 145-6, 150, 178-81

mandala 9-10

Mandarese 93

Marga 51, 108, 115, 123, 146, 180 puri - 51, 107, 123, 253

marriages in Mengwi dynasty 30,46, $52,90-2,114,117,125,128,137$, 141, 146-7, 151-4, 203-5, 209, 256, $301,306,333$

Mas Sepuh 93-4, 326

masatia rambut 323 , see also cremation Mauritius 97

Mayor, J.F.T. 163-4

Mayun see Agung -, Agung Putu -, puri - and Gusti Putu -

Mead, M. 280

Medhurst, W.H. 160

mekel 49, 59, 79, 88, 101-3, 117-8, 145, 150, 153-4, 178, 186, 195, 201, 226, 240-2, see also entourage and followers

Mengwi (region) 13, 19-34, 56, 68, 79, $86,89,94,107,113,116,124,132$, $150,172-5,178-87,191,195,198$, 201, 213-7, 225-6, 242, 249, 256-9, $263,266-8,275-6,283,289-91,314-$ 8,337 desa - 21, 26-7, 36-7, 40, 43-4, 48, $52,58,63-9,75,87,103,116-8$, $122,136,155,182,187,192,195-$ $6,268,315,323$

- district 219-20, 223, 267, 314, 320, 338

- dynasty 12, 17-28, 34-40, 45 , 48$53,56,65-6,79-81,87,92-6,108-$ $11,115,118,121-5,130-4,143$, $147,152-7,175-6,186-8,193$, 220, 224-6, 229, 250, 267-9, 276, $302-4,314-21,326,331-3,337-9$, see also satellites

- dynasty in exile 193-7, 200-3, 206-7, 227 
fall of - 175-89, 305, 314

king of $-22-4,32-4,37,46,51,59$, 64, 79, 84-5, 102-4, 112-4, 118, $152-3,177,181,188-9,192,202$, 275

negara - 12, 21, 24-6, 34, 62, 75-9, $89,96,104-11,120,123-5,132-8$, $141-61,165,175-6,180-2,185$, 188-9, 197, 201-3, 215-6, 219, $224,268,275-7,315,320,323$, 331-3

provisional negara - 200-6

royal centre of - $6,9-12,44-5,49$ -

$55,58,61-4,69,75-6,79,86-95$, $100-11,114,117-23,127,130$, $133-6,145-9,155-9,175-82,185$, 195-7, 205, 257, 264, 268, 333

meru 73, 131-3, 135-6, see also (negara) temple

Michiels, A.V. 166

migration 4, 44, 67-9, 107, 126, 133, 195-6, 207-9

labour - 169, 290

mission, Christian 278, 290

Moll, H.J.E. 310

Moluccas 31, 41

Moojen, P.A.J. 279

Moolenburgh, P. 265

Mount Manggu 73, 134

god of - 135

mountain culture 135,148

Munggu 45-6, 65, 68, 71, 79, 87, 94, $116-8,121,125,133,177,181,195$ puri - 52, 59, 62-6, 69

nagabanda 323 , see also cremation Nagarakrtagama 23

nationalism 266, 277-8, 308, 311

natural disaster $97,112,132-3,150$, $156,257-8,263,269,273,279,336$

Nederlandsche Handel Maatschappij 160,282

Negara 183

negara $6,11-3,22,111,211,219,254$, $257,331-2$

alliances and conflicts between $12,29,87-8,99-100,110-2,124$, $137,159,164-7,170,173-6,333-4$ colonial restoration of $-263-6,276$, $279,307-14,334$

Netherlands Indies government see state (colonial)

New South Wales 97

ngluer 114 , see also cremation

ngrebeg 91, 275, see also (royal) ritual

niskala see sekala

nobility $6-7,11,22-3,43,53,77,191-2$

Mengwi - 51-2, 56, 63, 83, 92, 146-

$8,153,187,201$

Mengwi-under colonial rule 220, $235,239,243$, see also (colonial) administration and policy

Nusa Penida 116, 185, 315

nyeburin 141,306, see also marriages in

Mengwi dynasty

nyepi 134, 273

odalan $50,75,202,269,325,338$

opium 42-4, 85, 96, 102-3, 108, 113,

$126,130,165-6,169,176-8,188$,

$210,215,224,227,257$

pacatu system $60,129-30,238,252-7$,

335 , see also followers, irrigation and pengayah -

Padangluah 79, 88-90, 95, 103-6, 10811

jero -79

padmi $52,87,114,118,137,177,180-$

1,333

pajeg see taxation

palebon see cremation

pamrajan see temple

panampa see patih

Panglan 196

Panji Danurdarastra 29-30

Panji Sakti 27-8, 33

parekan 83, 102-3

Partai Indonesia Raya (Parindra) 311

Partai Komunis Indonesia (PKI) 339

Partai Nasional Indonesia (PNI) 339

Pasek, Made and Ketut 174-5

pasimpangan see (negara)temple

paswara see jurisdiction

patih $37,71,177-8,181,203,221,297$, 304 
patrimonial(ism) 2, 5, 10, 110

Payangan 124-6

pedanda $19,34,38-40,45-7,50,141$,

$154-5,181,238,263,274-5,310$

- Kamenuh 39, 69

pekandelan see roban

pekaseh see subak(head)

Penarungan 45-6, 201, 304

puri - 58, 66, 153, 220, 304

penawing see concubine

Penet (river) 55, 58, 73

pengayah pacatu 60,99 , see also irrigation, followers and pacatu system

Pengelengan see Mount Manggu

perbekel see village (head)

Pererenan 187

Petang 126, 131, 148, 188, 196, 205

Pikah 298-9

Plaga 125

policy and nobility, colonial 191, 217,

225, 230-40, 243, 248, 255-6, 263-6,

$307,314,334$, see also negara

popular chiefs see policy

population figures $143,205,290,328$

poverty $13,287-97,300,305,335$

Powell, H. 280

power 120, 124, 132, 147, 158, 176

colonial monopoly of - 245, 334, 336

royal - 11, 21-2, 35, 89, 146, 149-

$52,156,315-8,332-3$

prabali $38,47,52,65,83-5,121,235$,

see also entourage

precolonial state see state

Probolinggo 325

protectorate 199-200, 205, 214-6, 255

punggawa 219-20, 223, 225-9, 234,

239, 249, 253-6, 259, 264, 267, 273,

292, 304, 313, 335, 337-8

Punggul 209, 307

puri - 128, 147, 220

puputan 213-6, 333

pura Arantaja 131-3

pura Batu Ngaus 273, 302

pura Bukit Sari Sangeh 307

pura Giri Kusuma 271-6, 299-300, 302-

$3,307,318,335-7$

- and irrigation 273-4 pura penataran agung see.

(negara)temple

pura Sada 29, 136, 157, 202, 221, 339

pura Taman Ayun 21, 62, 71-7, 133-7,

155-7, 201, 210, 215-6, 257, 271,

$314-5,338$

puri $45,53,56,148,155,238$

- and temple 156-7

puri Anyar 177-80, 185, 203-5, 220

puri Gede Mengwi 21, 69-73, 81-3, 87-

92, 101-2, 117-9, 137-8, 141, 150,

$153,156,176-7,181,188-9,192$,

267-8, 307, 317-26, 336-8

puri Kaleran Mengwi 36, 69-71

puri Mayun Blahkiuh 203-7, 215-7,

227-9, 243-5, 253, 269, 302, 320,

$325,335-6$

centre and power of - 228-30, 239,

268-7.6, 293-307, 319

dynastic ambitions of - 228-30, $245,269,277,307,314-26,336$, 339

- and irrigation 250-1, 273-4

- and landownership 251-4, 293-4, 337

puri Mayun Mengwi 91, 117-8, 121-2, $125-9,131,137-9,141,145,148$,

$158,175-7,180,185,266$

lineage of - 219, 223-5, 249, 256, $263,268,314-26,334-6$

purohita 39-40, 69-71, 75-77, 119, 123,

135, 155, 192, 202

- and king 39

pusaka 89, 119, 152, 178-9, 192, 216,

267,304 , see also kris

Raad van Indië 211

Raden Kerta see (colonial) jurisdiction

Raffles, T.S. 213

Ramayana 276

Ratu Gede Macaling 116

rice fields see sawah

ritual 13, 50, 64, 112, 148

- order $13,49,75,96,121,133-4$, $149-57,257-60,332$

royal - 5-6, 11, 39-40, 75, 84, 91, $113-4,119,123,134-6,141,151-$ 7,266 
roban 81

Rochussen, J.J. 164

Rooseboom, W. 210-1

royal authority 21, 86, 104, 109-15,

$118-21,130-1,141,148-9,152,157-$

$8,176-8,185,319,325$

royal power see power

rule, direct colonial 12-3, 96, 112, 168,

215-6, 226

rule and disorder, colonial 259-60, 335-6

\section{Sading 187}

Sagung (noble title) $37,53,122$

Sagung Nderet 101-5, 108-10

sakti see power

Samuan 209

Sang Gede Resi Mayun see Agung Kerug

Sangeh 128, 136, 145, 305-7

subak - 250-1, 295

Sanur 213-4

Sasak revolt 197-8

satellite(s) of royal centre 9-12, 22, 44-

$5,50-5,58-65,68,75-81,87,95$, 100-1, 105-15, 137, 140-1, 145-50, $155,159,176,180-1,185,203,206-$ 7,333 , see also manca (agung) and Mengwi dynasty

Satria 188, 235, 311, 321-3

sawah $55-5,58-61,65,75,79,88,95$, $101-4,107-8,122,125-31,143,156$, $186,196,209,221,252,273,288-$ $92,295-6,305-7,317,335$

Sayan 45

$$
\text { puri - 50, 107, } 196
$$

Schrieke, B.J.O. 2

Schwartz, H.J.E.F. 246

sedahan 59-60, 79, 129-31, 145, 227, $247-9,252-3,267,285,289,302$, see also irrigation

- agung 247-9, 252, 285

- family in Blahkiuh 250-1, 294-7, 335

- gede 101-4, 110

Sedang 67, 146, 203, 304

puri - 209, 305, 319

- subdistrict 219-21

segmentary state $10,46,50,53,57,61$,
$87,105,110,133,143-51,158,182$, 217,331

geographical segmentation 15

- and local variation 148

sekala and niskala 11, 133, 149, 157

Selat 209, 305-7

jero - 147

puri - 305-7

Sembung 107, 115-6

semen $151-4,158,335$, see also cycle of life

Sempidi 132, 179, 187, 195, 202

sengguhu 49

Seseh 94-5, 133-6, 326

share-cropping 202, 209, 250, 253， $275,286,292-6,300,303,335$

Sibang 45-9, 60-1, 67-8, 99, 180-1, $187,214-5,224,305$

- district 219, 223-4

puri - 46-50, 53, 58-9, 63, 66-8, 945, 104, 114, 137-8, 141, 145-6, $180-1,185,205,209,220,253$, $303,325,337$

Sibangkaja 185

Sibetan 33

Singapore $97,165,169,282-3$

Singaraja $164,206,319$

Singasari $45,63-4,68,275$, see also Blahkiuh puri - 63-4, 67, 125, 148

sisya 40,155

slave trade $25,41-4,53-4,66,96,99$, $109,167,170,331-3$

slavery $4,12,42-3,67,210$

slaves $22,41-3,77,96$

Smeru 32-4, 119, 131

Dalem - 61

Solo 163

South Asia 8

South Sulawesi 152, 211

Southall, A. 10

Southeast Asia 1-9, 42, 111, 155, 331, 334

Srijati $47-9,53$

stadtholder 199-200, 256-9

state $111,147,332$

colonial - 13, 158-62, 176, 191-2,

$199,206,232,263,277,283,301$, 
$307-8,314,322,333-5$

pre-colonial - 1-2, 8, 11, 232, 331

status differences $7,11,50,84,137$,

$149,152-3,196$

subak 128-9, 233, 254, 274, 284, 311,

see also irrigation

colonial reorganization of -217 , 246-50, 285, 334

- head 247, 252, 295, 317

succession to the Mengwi throne 62 , 88-92, 114-8, 137-42, 146, 151, 176, $180,185,212,264$

Sudra $235,238-40,245,311$, see also commoners

Sukawati 29-32, 63, 91

lord of - 64

Sumatra 159, 164, 166, 172

Sumbawa 97

Sungi (river) 45, 55, 58, 73

Surabaya $31,282-3$

suwinih see taxation

Tabanan 26, 32-3, 45, 79, 88-9, 100, $107,115,118-9,123,132,145,164$, $172-4,179-82,185-8,195,206,215$, 255

colonial conquest of - 214-6

king of - 37, 161, 211

Taman 209, 303, 307

puri - 147, 220, 302

Taman Bali 33, 107

Tambiah, S.J. 7, 10, 53, 151,

Tambora 97

Tangeb

jero - 36-7

Gusti - 37

taxation 12, 60, 79, 84, 99-104, 109$10,122,129,145-7,178,246,274$ 281 , see also irrigation and sedahan colonial - 169, 227, 247-54, 257, 283-97, 302, 327-8, 335

colonial - and trade 283-8

Tegal Selat see Selat

temple 29

house - 15, 50

house - of nobility (pamrajan) 50,

83-4, 119, 138, 155, 229, 269, 317, 320,325 negara - 13, 62, 71-7, 95-6, 123-5, 131-7, 155-8, 201, 230, 257, 266, 307

- priest 135, 274

- shrine 29, 133, 202, 275

village - 49, 57, 135, 149, 157, 202, $273,298,317$

tenah 252

Thailand 4

The Hague 160, 164, 170-1, 210, see also (colonial) state

theatre state $5,7,149$ colonial - 263, 322, 334

Tinggan 133-6, 201, 230, 257, 307

tirta see holy water

Tjarda van Starkenborgh Stachouwer, A.W. 308

tooth filing 151

trade $12,57,95,180,213,257,282$,

296 , see also coffee and slavery

export of copra 127, 282, 286-7

export of pigs 282-3, 286-7

export of rice $97,109,164,282$, 285-6

external - 81, 93-6, 99, 102-3, 106, 109-11, 125, 130, 169, 177, 281-3, $287-8,327,331,335$

nobility and - 99, 109, 170, 213, 229, 282

- and women 282-3

triwangsa 235, 311, see also (colonial) policy

Ubud 183, 186, 197, 200-1, 267, 323, see also Cokorda Gede Sukawati

Umabian 37

University of Amsterdam 3

Valentijn, F. 56

village $1,4,13-5,56-7,69,128,143$, 148-50, 191, 199, 205, 229, 301, $311,317,338-9$

colonial reorganization of -217 , $240-3,247,255,307,334$

founding of new - 126

- head 226-7, 241-5, 253, 256, 297, $301-7,313-4,320,334,337$, see also bendesa 
- republic 4, 232, 240, 243, 246, 309, 334

- rituals 149, 245

violence $4,7,12,19,35,40,43-5,62-3$,

$76,81,124-5,130-3,140,149,157$,

$182,195-6,331-2$

VOC 23-8, 32, 42, 93

Volksraad 314, 319-20

vulcanic eruption 97 , see also natural

disaster

wantilan 81, 84, 229

warfare $4,12,29,33,41-3,50,63,66$ -

$8,77,88-9,106-7,112,116-7,123-$

4, 149-53, 158, 170, 333, 336

- in South Bali 159, 173-5, 178-93,
$197,200,206-7,333$

waringin 230

wayang performance 85,321

Weber, M. 2-3, 11, 147

Wertheim, W.F. 3

Wesya 235

Wiener, M. 132

Wilhelmina, Queen 215, 310, 314, 3201

Wirasaba 31

Wolters, O.W. $8-10$

Worsley, P. 26

Wijck, C.H.A. van der 198

yuwa raja 90, 138 